Gustavo Alares López María José Solanas Bagüés, Jorge Azorín Arroyo, Sara Martín Casamayor, Erik Zubiaga Arana, Chrystelle Ferrara Viforcos, Jon Kortazar Billelabeitia, David Parra Monserrat, Óscar González Vergara, Gustavo Hernández Sánchez, Marcos Marina Carranza, Eider de Dios Fernández, Enrique Bengochea Tirado, Sereno Orenga Caleri, Javier Contreras-Becerra, Inge Fernández Bueno, Ángela González Bellver, Miguel Ángel Melero Varga, Irene Murillo Aced, Gisela Pagès, Ricardo Torres Silva, Luis Vicente Clemente Ouijada, César Rina Simón, Giacomo Demarchi, David Mota Zurdo, Virginia López de Maturana, Juan Pedro Recio Cuesta, Colectivo Revista Ecléctica, Francisco José Fernández Andújar, María Gracia Bafalluy, Vladimir López Alcañiz, Gustavo Hernández Sánchez, Iris Pascual Gutiérrez, Nicolás Sesma Landrin, Jorge de Hoyos Puente, Cristian Ferrer Gonzàlez, Octavio V. González Robles, Vincent Marin, Marcos Marina Carranza, Esther Mora Bleda, Natalia Urigüen López de Sandaliano, Gregorio Sabater Navarro]

\section{AYER Y HOY. DEBATES, HISTORIOGRAFIA Y DIDÁCTICA DE LA HISTORIA}

Juan Carlos Colomer Rubio, Javier Esteve Martí y Mélanie Ibáñez Domingo (coord.) 



\section{AYER Y HOY. DEBATES, HISTORIOGRAFIA Y DIDÁCTICA DE LA HISTORIA}

Jorge Azorín Arroyo, Sara Martín Casamayor, Erik Zubiaga Arana, Chrystelle Ferrara Viforcos, Jon Kortazar Billelabeitia, David Parra Monserrat, Óscar

González Vergara, Gustavo Hernández Sánchez, Marcos Marina Carranza, Eider de Dios Fernández, Enrique Bengochea Tirado, Sereno Orenga Caleri, Javier Contreras-Becerra, Inge Fernández Bueno, Ángela González Bellver, Miguel Ángel Melero Varga, Irene Murillo Aced, Gisela Pagès, Ricardo Torres Silva, Luis Vicente Clemente Ouijada, César Rina Simón, Giacomo Demarchi, David Mota Zurdo,

Virginia López de Maturana, Juan Pedro Recio Cuesta, Colectivo Revista Ecléctica, Francisco José Fernández Andújar, María Gracia Bafalluy, Vladimir López Alcañiz, Gustavo Hernández Sánchez, Iris Pascual Gutiérrez, Nicolás Sesma Landrin, Jorge de Hoyos Puente, Cristian Ferrer Gonzàlez, Octavio V. González Robles, Vincent Marin, Marcos Marina Carranza, Esther Mora Bleda, Natalia Urigüen López de Sandaliano, Gregorio Sabater Navarro]

Juan Carlos Colomer Rubio, Javier Esteve Martí y Mélanie Ibáñez Domingo (coord.) 
"Ayer y hoy. Debates, historiografía y didáctica de la historia"

\section{ISBN: 978-84-606-5874-0}

DOI: $10.7203 / 10550.42836$

Coordina: Juan Carlos Colomer Rubio, Javier Esteve Martí y Mélanie Ibáñez Domingo

Edita: Universitat de València. Valencia, 2015

Asociación de Historia Contemporánea

Diseño y maquetación: Carles Rodrigo Monzó

(www.carlesrodrigo.es)

Autores: Gustavo Alares López, María José Solanas Bagüés, Jorge Azorín Arroyo, Sara Martín Casamayor, Erik Zubiaga Arana, Chrystelle Ferrara Viforcos, Jon Kortazar Billelabeitia, David

Parra Monserrat, Óscar González Vergara, Gustavo Hernández Sánchez, Marcos Marina Carranza, Eider de Dios Fernández, Enrique Bengochea Tirado, Sereno Orenga Caleri, Javier

Contreras-Becerra, Inge Fernández Bueno, Ángela González Bellver, Miguel Ángel Melero Varga, Irene Murillo Aced, Gisela Pagès, Ricardo Torres Silva, Luis Vicente Clemente Ouijada, César Rina Simón, Giacomo Demarchi, David Mota Zurdo, Virginia López de Maturana, Juan Pedro Recio Cuesta, Colectivo Revista Ecléctica, Francisco José Fernández Andújar, María Gracia Bafalluy, Vladimir López Alcañiz, Gustavo Hernández Sánchez, Iris Pascual Gutiérrez, Nicolás Sesma Landrin, Jorge de Hoyos Puente, Cristian Ferrer Gonzàlez, Octavio V. González Robles, Vincent Marin, Marcos Marina Carranza, Esther Mora Bleda,

Natalia Urigüen López de Sandaliano, Gregorio Sabater Navarro. 


\section{Historiografía española entre 1939 y 1975: Dictadura y exilio}

Gustavo Alarés López y María José Solanas Bagüés - la historiografía española entre 1939 y 1975: dictadura y exilio. Pluralidad, indefinición y estrategias divergentes. Acotaciones sobre una disciplina difusa.

Jorge Azorín Arroyo - José María Jover y la historia de las relaciones internacionales: notas para su estudio.

Sara Martín Casamayor - La influencia del país de acogida en los estudios de los historiadores exiliados en América Latina: el caso de los exiliados en México. Erik Zubiaga Arana - ¿Holocausto, genocidio, exterminio, politicidio...?

Conceptualizaciones sobre el desarrollo de la represión franquista. Especial atención al caso Vasco.

Chrystelle Ferrara Viforcos - La construcción de los orígenes del cine en España a través de la manipulación historiográfica franquista.

Jon Kortazar Billelabeitia - El poder local en el primer franquismo (1939-1945) en Bizkaia a través de sus alcaldes.

\section{Haciendo Historia. Sobre enseñanza, aprendizaje y competencias para los} historiadores del siglo XXI

David Parra Monserrat - ¿Hacia una nueva didáctica? Posibilidades y reto para la enseñanza-aprendizaje de la historia en el siglo XXI.

Óscar González Vergara - Otra forma de hacer historia. Arqueología industria y contemporánea: pasado, presente y futuro de una disciplina humanística. Gustavo Hernández Sánchez - La enseñanza de la historia en el siglo XXI: propuesta metodológica.

Marcos Marina Carranza - De democracias, dictaduras, guerras, repúblicas y monarquías: la historia reciente española en los libros de texto.

3. Los hilos de la memoria: Investigación y método a través de la Historia oral Eider de Dios Fernández - Los hilos de la memoria: investigación y método a través de la historia oral.

Enrique Bengochea Tirado - Facebook como herramienta: redes sociales y grupos diaspóricos.

Sereno Caleri - Fotografía y fuentes orales: un análisis metodológico.

Javier Contreras Becerra - EI PSA y el nuevo andalucismo. Una relectura del

proceso democratizador y autonómico a través de las fuentes orales (1973-1982).

Inge Fernández Bueno - Estudio e investigación sobre los nativos norteamericanos,

problemática, enfoque metodológico y teórico de la historia oral.

Ángela González Bellver - El recuerdo del exilio. El testimonio de un exiliado: Antonio Carmona Pinto

Miguel Ángel Melero Vargas - Voces perdidas... y recobradas. La investigación de la II República, la guerra civil y la represión a través de la Historia Oral.

El caso de una comarca andaluza: Antequera.

rene Murillo Aced - Comunidades de dolor Narrar lo ocurrido, o conservarlo en el cuerpo.
Gisela Pagès - La memoria histórica y la memoria literaria de Micaela Villegas en los siglos XIX y XX

Ricardo Torres Silva - Otras voces, otros ámbitos.

. Usos públicos de la Historia en la España Contemporánea: nacionalismos, regionalismos y modelos de Estado.

Cesar Rina Simón y Luis Vicente Clemente Quijada - Usos públicos de la historia en la España contemporánea: nacionalismos, regionalismos y modelos de estado.

Giacomo Demarchi - El Estado Integral y sus fuentes: una lectura comparada.

23 David Mota Zurdo y Virginia López de Maturana - Jesús Galíndez Suárez. Político, profesor, símbolo.

28 Juan Pedro Recio Cuesta - El ideario carlista durante la primera guerra:

el caso de la Gaceta Oficial de Oñate (1835-1837).

5. Sobre las ruinas de "ese noble sueño". Estudios "post", movimientos sociales e investigación activista en la Historia

Colectivo Revista Ecléctica - Presentación de la mesa Ecléctica del IV encuentro de jóvenes investigadores en historia contemporánea.

38 Francisco Fernández Andújar - Las negras tormentas de la historia.

María Gracia Bafalluy y Vladimir López Alcañiz - Ansiedad y repetición.

42 Patologías de la temporalidad presentista.

Gustavo Hernández Sánchez - El marxismo frente a la encrucijada posmoderna: apuntes para una historia social y cultural.

Iris Pascual Gutiérrez - El grito. Testimonios cinematográficos del 68 mexicano.

52 Los procesos de transición democrática a debate.

\section{Los procesos de transición democrática a debate}

Nicolás Sesma Landrín y Jorge de Hoyos Puente - Los Procesos de transición 57 democrática a debate.

Cristian Ferrer Gonzàlez - Los Carlismos de la Transición - las idiosincrasias

63 carlistas frente al cambio político (1963-1979).

66 Octavio V. González Robles - PSOE y PCE ante la revolución de los claveles.

Vincent Marin - La difícil puesta en marcha de la Constitución: el caso

71 paradigmático de la Ley Orgánica reguladora del Derecho a la Educación (LODE). Marcos Marina Carranza - La hora de democratizar los ayuntamientos:

$77 \quad$ las elecciones municipales de abril de 1979 en Madrid.

Esther Mora Bleda - "El sujeto femenino en Transición. Mujeres y estrategias

80 en la prensa regional murciana, año 1975".

Natalia Urigüen López de Sandaliano - Los partidos demócrata cristianos alemanes en el proceso de transición democrática española.

84 Gregorio Sabater Navarro - El proceso revolucionario portugués y la oposición Española: el PCE en la encrucijada. 
Parte 1.

HISTORIOGRAFÍA ESPAÑOLA ENTRE 1939 Y 1975: DICTADURA Y EXILIO 


\section{LA HISTORIOGRAFÍA ESPAÑOLA ENTRE 1939 Y 1975: \\ DICTADURA Y EXILIO. PLURALIDAD, INDEFINICIÓN Y \\ ESTRATEGIAS DIVERGENTES. ACOTACIONES SOBRE \\ UNA DISCIPLINA DIFUSA*}

Gustavo Alares López

European University Institute

María José Solanas Bagüés

Universidad de Zaragoza

Desde aquella sesión inaugural celebrada en Zaragoza en septiembre de 2007 lo cierto es que los Encuentros de Jóvenes Investigadores parecen haberse consolidado como referente para los principiantes del oficio de la historia, si acaso alguna vez no dejamos de serlo. $Y$ es que al margen de constituir un evidente espacio para la sociabilidad de los jóvenes historiadores, la lectura retrospectiva de los diferentes Encuentros permite avanzar algunas de las líneas que presumiblemente tomarán las investigaciones futuras o, cuanto menos, constatar tendencias, modas historiográficas, flujos y reflujos de diversos modos de hacer historia y persistencia o aparición de nuevas y viejas temáticas.

No hay duda de que la reflexión sobre la historia de la historiografía ha estado presente tanto en los Congresos de la Asociación de Historia Contemporánea desde sus orígenes,' como en los celebrados por los Jóvenes Investigadores de esta Asociación. El siguiente texto pretende trazar las líneas generales de la investigación en este terreno. Un esbozo sin ánimo de minuciosidad y necesariamente parcial, acotado a la producción generada desde comienzos del siglo XXI, y primando por razón de espacio las últimas publicaciones.

\section{Historia de la historiografía. Balance de una disciplina en construcción}

En lo que respecta a la historia de la historiografía, en 2007 Miquel Marín señalaba cómo "su estatus como disciplina se halla a gran distancia del de otros territorios de la investigación especializada, una circunstancia que en España es algo más acusada".2 Lo cierto es que algunos de los problemas e indefiniciones que afectaban a la historia de la historiografía entonces, persisten en la actualidad con absoluta vigencia.

En los albores del nuevo siglo, la disciplina encargada de historiar el oficio de historiador se muestra fragmentada, inmersa en un confusionismo conceptual evidente, y en gran medida sustituida por la proliferación de lo que Miquel Marín denominó en su momento "historiografía retrospectiva". Una manera de entender la disciplina como mero relato de tendencias, grupos y escuelas, y con unos objetivos "claramente actualizantes, es decir, la reflexión última sobre el pasado de las cosas de la historiografía actual y no la historia de la profesión".3

Pero lo que quizá resulte más preocupante sean las persistentes dificultades por entender e incluso asumir la existencia de una subdisciplina como la historia de la historiografía que, más allá del exclusivo interés por los diferentes discursos históricos o por las interferencias de la

1 Miquel À. MARíN: “Orígenes y primeros años de la Asociación de Historia Contemporánea, Ayer, 92 (2013), pp. 239-250.

2 Miquel À. MARÍN: "La historia de la historiografía en España: recepción y crisis de una disciplina 1976-2007", Teresa María ORTEGA (coord.): Por una historia global: El debate historiográfico en los últimos tiempos, Granada, Universidad de Granada, 2007, pp. 391-437.

3 Ibid.; p. 417. memoria, debería tomar como objeto de estudio la reconstrucción y el análisis de la profesión en toda su amplitud y profundidad.

En estas circunstancias se han generado una multiplicidad de propuestas -en ocasiones teórica y metodológicamente contrapuestas- que ilustran el difuso ámbito de lo que ha venido entendiéndose como "historia de la historiografía".

A este respecto cabría señalar cierta implantación de la biografía como instrumento de acercamiento a los profesionales de la historia. Así, al estudio de Vicens Vives se han venido a suma diversas aproximaciones biográficas a las figuras de Raymond Carr, Santiago Montero, Martín Almagro Basch y Julio Martínez Santa-Olalla, Bosch Gimpera, Ramón Carande, Mercedes Gaibrois, José Antonio Maravall, Pio Zabala, Fernández Almagro, José María Lacarra o José María Jover. ${ }^{4}$

De la misma manera se ha producido la re-evaluación de diversas trayectorias historiográficas muy vinculadas a escuelas históricas de larga tradición como es el caso del recientemente fallecido Vicente Palacio Atard. ${ }^{5}$ Aunque también es cierto que en ocasiones este tipo de análisis -con escaso aparato metodológico y entregados a lo memorial- no escapan a las propias limitaciones impuestas por la pertenencia de grupo y la necesidad de integrar en un relato complaciente el devenir de unos historiadores que lo fueron en dictadura y que, en muchas ocasiones, participaron en el apuntalamiento de la misma. Un ejercicio de revisión de la profesión llevado a cabo de manera natural en diversos ámbitos historiográficos europeos, pero que en gran medida se encuentra pendiente de acometer por la historiografía española.

4 Josep MUÑOZ I LLORET: Jaume Vicens i Vives. Una biografia intel.lectual, Barcelona, Edicions 62 1997; Maria Jesús GONZÁLEZ: Raymond Carr. La curiosidad del zorro. Una biografia, Madrid, Galaxia Gutenberg, 2010; Xosé-Manoel NÚÑEZ SEIXAS: La sombra del César. Santiago Montero Díaz, una biografia entre la nación y la revolución, Granada, Comares, 2012, a la que habría que sumar Antonio DUPLÁ: "Santiago Montero Díaz. Un itinerario historiográfico singular", introducción a Santiago MONTERO: De Caliclés a Trajano. Estudios sobre historia política del mundo antiguo, Pamplona, Urgoiti editores, 2004, pp. IX-XC. Respecto a Martín Almagro y Santa-Olalla, Alfredo MEDEROS: "Julio Martínez Santa-Olalla y la interpretación aria de la Prehistoria de España (1939-1949)", Boletín del Seminario de Estudios de Arte y Arqueologia, 69-70 (2003-2004), pp. 13-55; ID.: "Martín Boletín del Seminario de Estudios de Arte y Arqueología, 69-70 (2003-2004), pp. 13-55; ID.: "Martín
Almagro Basch, formación y consolidación como catedrático de prehistoria (1911-1943). Boletín del Almagro Basch, formacion y consolidacion como catedrático de prehistoria (1911-1943), Boletin del Seminario de Estudios de Arte y Arqueología, 77-78 (2011-2012), pp. 335-416. Sobre Ramón Carande,
Antonio Miguel BERNAL: "Don Ramón Carande, la proyección internacional de la historiografía española", en Esteban SARASA y Eliseo SERRANO (eds.): 15 historiadores de la España medieval y moderna, Zaragoza, Institución Fernando el Católico, 20oo, pp. 231-248; Luis PALACIOS: Ramón y moderna, Zaragoza, Institución Fernando el Católico, 2000, pp. 231-248; Luis PALACIOS: Ramón del CAMPO: "Mercedes Gaibrois de Ballesteros: del amor a la historia y de la historia al amor", del CAMPO: "Mercedes Gaibrois de Ballesteros: del amor a la historia y de la historia al amor",
prólogo a Mercedes GAIBROIS: María de Molina, Pamplona, Urgoiti editores, 2010, pp. VII-CXV. prólogo a Mercedes GAIBROIS: María de Molina, Pamplona, Urgoiti editores, 2010, pp. VII-CXV. la historiografía de su tiempo", en José Antonio MARAVALL: Teoria del saber histórico, Pamplona, Urgoiti editores, 2007, pp. XI-XVI; Ignacio IZUZQUIZA: “La estructura conceptual de la Teoría del saber histórico", en José Antonio MARAVALL: Teoría del saber histórico..., pp. CIX-CLXXVII. Para Pio Zabala, Carolina RODRÍGUEZ: "Introducción" a Pío ZABALA: España bajo los Borbones, Zaragoza, Institución Fernando el Católico, 2009, pp. IX-CXII. Melchor Fernández Almagro lo analiza Cristina Institución Fernando el Catolico, 2009, pp. IX-CXII. Melchor Fernández Almagro lo analiza Cristina
VINIES: “Melchor Fernández Almagro. Aproximación a su vida y su obra”, en Melchor FERNÁNDEZ ALMAGRO: Vida y literatura de Valle-Inclán, Pamplona, Urgoiti editores, 2007, pp. VII-LXX. Sobre José María Lacarra, Miquel MARÍN: "La formación de un medievalista: José María Lacarra, 19071940", Jerónimo Zurita, 82 (2007), pp. 39-98; Enrique PÉREZ: “José María Lacarra, un archivero en la 1940", Jerónimo Zurita, 82 (2007), pp. 39-98; Enrique PEREZ: “José María Lacarra, un archivero en la Respecto a José María Jover, y junto al análisis de Elena HERNÁNDEEZ SANDOICA realizado en "José María Jover Zamora. In memoriam", Ayer, 68 (2007), pp. 9-24, señalar Ignacio PEIRÓ: “Las metamorfosis de un historiador: el tránsito hacia el contemporaneismo de José María Jover Zamora", morfosis de un historiador: el trânsito hacia el contemporaneismo de José María Jover Zamora", en Emilio MAJUELO GIL: La idea de historia en Arturo Campión, Donostia, Eusko Ikaskuntza, 2011.

5 Luis PALACIOS, Manuel ESPADAS, Antonio FERNÁNDEZ, (eds.): Vicente Palacio Atard. Maestro de historiadores, Madrid, Akron, 2013 
Así, resulta cuanto menos desconcertante que en diversos análisis de historiadores bajo el franquismo, en unos casos -y en aras de un relato cordial y amnésico- se vea enajenada su dimensión política-ideológica, mientras que en otros, se eluda la dimensión historiográfica de unos personajes que, ante todo, fueron historiadores.

Esta pluralidad de enfoques anteriormente aludida quedó patente con ocasión de la conmemoración del "Año Vicens Vives" en 2010. Y es que el homenaje y el recuerdo de las figuras referenciales de la profesión han condicionado en muchos casos la labor investigadora. En e caso de Vicens Vives, junto al homenaje al maestro y la proliferación de numerosas y no siempre justificadas adscripciones discipulares, también hubo espacio para la investigación, los nuevos aportes documentales y la proyección de nuevas variables interpretativas. ${ }^{6}$

Menos reivindicados pero también homenajeados han sido Rafael Altamira y Joaquín Costa con ocasión del aniversario de su fallecimiento. ${ }^{7}$ Una práctica de grupo, la del homenaje, que se amplía al momento de jubilaciones o doctorados honoris causa. A este respecto queda para la memoria de la profesión los textos en torno a Juan José Carreras, y más recientemente los homenajes dispensados a Julio Aróstegui, Santos Juliá, Carlos Martínez Shaw o Eloy Fernández Clemente. ${ }^{8}$

Junto a estas aproximaciones en la esfera de lo biográfico cabe señalar la relativa proliferación de memorias y ejercicios de egohistoria -de diverso alcance y naturaleza- que, si por un lado son siempre bien acogidos como testimonios de la profesión, no dejan en ocasiones de resentirse de la natural tendencia hacia la autocomprensión y a las lecturas desde el presente. ${ }^{9}$

6 Un análisis parcial de los actos y publicaciones en torno al Año Vicens en Oscar ADELL: "El Año Vicens Vives: reflexiones en torno a una conmemoración", Historiografias, 1 (2011), pp. 95-110. No obstante, el autor alude a "la escasez de novedades investigadoras", obviando el salto cualitativo y cuantitativo producido en torno a las investigaciones sobre el historiador gerundense, como ejemplifican las diversas publicaciones a cargo de Miquel Marín Gelabert. Concretamente, Miquel MARIN: A través de la muralla. Jaume Vicens Vives y la modernización del discurso histórico, BarceIona, Ediciones Vicens Vives, 2010 y las ediciones criticas de de Jaume Vicens, Ferran II i la ciutat de Barcelona, Barcelona, Vicens Vives, 2010; Jaume VICENS: España contemporánea (1814-1953), edición a cago de Miquel Angel Marin, Barcelona, Acantilado, 2012; y Jaume VICENS: La crisis del siglo XX (1919-1945), Barcelona, Acantilado, 2013. También señalaremos Cristina GATELL, Glòria SOLER: Amb el corrent de proa. Les vides politiques de Jaume Vicens Vives, Barcelona, Quaderns Crema, 2012.

7 http://www.rafaelaltamira.es/actosrealizados.htm. Destacamos de entre la producción bibliográfica Ignacio PEIRÓ: “La educación patriótica de un historiador español: el primer viaje de estudios a París de Rafael Altamira", en María LLOMPART (ed.): Identidades de España en Francia: un siglo de exilios y migraciones, Granada, Comares, 2012, pp. 39-65.

8 Respecto a Juan José Carreras, Carlos FORCADELL (ed.): Razones de historiador. Magisterio y presencia de Juan José Carreras, Zaragoza, Institución Fernando el Católico, 2009. En 2009 la comunidad profesional tributó un homenaje a Julio Aróstegui recogido en Jesús Antonio MARTiNEZ et al. (coords.): El valor de la historia. Homenaje al profesor Julio Aróstegui, Madrid, Editorial Complutense, 2009, al que se han venido sumando nuevos trabajos a raíz de su fallecimiento, como Jesús A. MARTíNEZ y Juan A. BLANCO (coord.): "Teorizar la historia, hacer historiografia. Homenaje al profesor Julio Aróstegui", Hispania Nova, 12, (2014). El homenaje ofrecido a Santos Juliá en José profesor Julio Arostegui", Hispania Nova, 12, (2014). El homenaje ofrecido a Santos Juliá en José Santos Juliá, Madrid, Taurus, 2011. Sobre Martínez Shaw, Joan VIÑAS, Roberto FERNÁNDEZ y Carlos MARTINEEZ SHAW: Investidura como doctor Honoris Causa del senyor Carlos Martínez Shaw, Lérida, Edicions de la Universitat de Lleida, 2011, pp. 8-42. Respecto a Eloy Fernández Clemente, Pedro RÚJULA (coord.): Eloy Fernández clemente. El tiempo y la historia, Teruel, CELAN, 2010.

9 En este apartado autobiográfico podriamos consignar las memorias asistidas de Miguel BATLLORI: Recuerdos de casi un siglo. Recopilados por Cristina Gatell y Glòria Soler Barcelona El Acantilado, 2001 Julio ARÓSTEGUI: "Autorretrato en escorzo (y nada complaciente) con figuras al fondo", Cuadernos de Historia Contemporánea to en escorzo (y nada complaciente) con figuras al fondo", Cuadernos Spain. A Unique History Madison, The University of Wisconsin Press, 2008, pp. 9-39; Eloy FERNÁNDEZZ Spain. A Unique History, Madison, The University of Wisconsin Press, 2008, pp. 9-39; Eloy FERNANDEZ 2011; iD: Los años deAndalán. Memorias, 1972-1987, Zaragoza, Rolde de Estudio Aragoneses, 2013. Joa-
Frente a este relativo vigor de "la apuesta biográfica", es necesario señalar un aspecto en gran medida desatendido por la actual historia de la historiografía, como es el análisis de las instituciones y los procesos de institucionalización de la profesión durante el franquismo. Al margen de diversas obras relativas al Centro de Estudios Históricos, el CSIC y sus institutos de Historia todavía no disponen de una bibliografía reseñable, más allá de algunas aproximaciones en títulos de carácter conmemorativo..$^{\circ} \mathrm{Y}$ aún resultan escasos e irregulares los estudios sobre las instituciones locales de cultura que, articuladas en torno al Patronato "José María Quadrado" del CSIC, canalizaron no poca de la producción erudita bajo el franquismo." Por otro lado, aunque se cuenta con trabajos relevantes, el análisis de la historia generada en las universidades franquistas ha sido tratada dentro del más amplio contexto de la propia institución universitaria. ${ }^{12}$

De hecho, a fecha de hoy todavía no disponemos de un análisis riguroso sobre algo tan fundamental como los procesos de oposiciones a cátedras y las estrategias de inserción profesional durante el franquismo, y cuando se ha intentado llevarlo a cabo, los resultados han sido, en general, decepcionantes.

Por otro lado, tampoco se han prodigado los análisis sobre los instrumentos de sociabilidad utilizados por la comunidad de historiadores franquistas. Importantes citas congresuales, como los diferentes Congresos de Historia de la Corona de Aragón o los míticos Congresos de Pau en torno a Manuel Tuñón de Lara, todavía no han suscitado el interés por parte de la historia de la historiografía. Y todavía resulta muy preliminar el estudio de estructuras asociativas tan relevantes como el Comité español de la Asociación Internacional de Ciencias Históricas. ${ }^{13}$

Una situación similar se percibe en relación a las revistas profesionales, principales órganos de difusión y transferencia del conocimiento histórico. Desde el ya lejano monográfico sobre la revista Hispania publicado en 1990, las principales cabeceras de la historiografía española si-

quim NADAL: Testimoni de càrrec. Vintanys de servei al pais, Barcelona, Proa, 2014; Jaume AURELL (ed.) La historia de España en primera persona. Autobiografias de historiadores hispanistas, Barcelona, Base 2012; Bartolomé CLAVERO: El árbol y la raiz. Memoria histórica familiar, Madrid, Crítica, 2013; John H. ELLOTT: Haciendo historia, Madrid, Taurus, 2012. Ignacio PEIRO: "En el taller del historiador. La(s) biografía(s) como práctica histórica e historiográfica", Gerónimo Uztariz, 28-29 (2012-2013), pp. 8-27.

10 Respecto al CEH pueden verse José María LÓPEZ SÁNCHEZ: Heterodoxos españoles. El Centro de Estudios Históricos, 1910-1936, Madrid, Marcial Pons / CSIC, 2006, y los trabajos recogidos en, José-Carlos MAINER (ed.): El Centro de Estudios Históricos (1910) y sus vinculaciones aragonesas (con un homenaje a Rafael Lapesa), Zaragoza, Institución Fernando el Católico, 2010. Respecto el CSIC, Miguel Ángel PUIG-SAMPER (coord.): Tiempos de investigación: JAE-CSIC. Cien años de ciencia en España, Madrid, CSIC, 2007

11 Desde el estudio de Jorge URÍA:Cultura oficial e ideología en la Asturias franquistas: el I.D.E.A, Oviedo, Universidad de Oviedo, 1984, se ha generado una reducida nómina de trabajos de carácter desigual, siendo los más recientes Carlos DOMPER: Por Huesca hacia el Imperio. Cultura y poder en el franquismo oscense (1938-1965), Huesca, Instituto de Estudios Oscenses, 2010; Sobre la Institución Fernando el Católico se encuentra prevista la publicación de la monografía «Lanzas de tinta». Cultura y fascismo en la Zaragoza de posguerra a cargo de Gustavo ALARES que ya en 2008 ofreció un Diccionario biográfico de los consejeros de la Institución "Fernando el Católico". Una aproximación a las elites políticas y culturales de la Zaragoza franquista (1943-1984), Zaragoza, Institución Fernando el Católico, 2008. Esta anemia contrasta con los numerosos artículos relativos al Institut d'Estudis Catalans -sobre todo con la celebracion en 2007 de su centenario- que cuenta con los volúmenes de Albert Balcells y Enric Pujol -contando con la colaboración de Santiago Izquierdo en el último- Història de l'Institut d'Estudis Catalans, Barcelona, Institut d'estudis Catalans; 2 vols., 2002 y 2007

12 Carolina RODRÍGUEZ: La Universidad de Madrid en el primer franquismo: ruptura y continuidad (1939-1951), Dykinson, 2002; Jaume CLARET: El atroz desmoche. La destrucción de la Universidad española por el franquismo, 1936-1945, Barcelona, Crítica, 2006 y Francisco MORENTE: "La Universidad en los regímenes fascistas: la depuración del profesorado en Alemania, España e Italia", Historia Social, 54 (2005), pp. 51-72.

13 Manuel ESPADAS BURGOS: Un lugar de encuentro de historiadores. España y los Congresos Internacionales de Ciencias Históricas, Madrid, Comité español de Ciencias Históricas, 2012. 
guen todavía pendientes de un análisis en profundidad que permita ahondar en las prácticas historiográficas de los historiadores durante el franquismo. ${ }^{14} \mathrm{Y}$ aquí habría que incluir desde órganos tan sugerentes como los Estudios de Historia Moderna y el Índice Histórico Español impulsados por Vicens Vives, como otros de carácter profundamente tradicional como el Boletín de la Real Academia de la Historia, por no citar las numerosas revistas de carácter regional y departamental a través de las cuales se dio curso a un importante número de investigaciones.

Junto a estos estudios de carácter fragmentario, los pasados años han asistido a la aparición de diversas obras de síntesis entre las que cabría destacar la ambiciosa Apologia and criticism: historians and the history of Spain, 1500-2000, de Gonzalo Pasamar. Y aunque procedente del ámbito alemán, no deja de resultar saludable la feliz traducción de La ciencia histórica en la era de los extremos de Lutz Raphael. ${ }^{15}$

Por último, cabría citar varios proyectos editoriales de indudable interés como la Colección de Grandes Historiadores de la editorial Urgoiti, o la Colección Historiadores aragoneses de la Institución Fernando el Católico, ambas iniciativas sustanciadas en la reedición de obras clásicas de la historiografía española acompañadas de extensos estudios introductorios.

Así, de todo lo anteriormente reseñado, cabría señalar la existencia de una pluralidad de enfoques y prácticas que, sin embargo, no ha redundado en un deseable dinamismo, sino que más bien ha explicitado la indefinición de los objetos de estudio de una subdisciplina todavía en proceso de consolidación.

\section{Historiadores franquistas, historiadores bajo el franquismo}

Esta situación de indefinición resulta si cabe más evidente en relación al estudio de los historiadores durante el franquismo. Si bien el debate en torno al rol desempeñado por los historiadores bajo regímenes dictatoriales se ha abierto en otros ámbitos historiográficos como el alemán o el italiano, la historiografía española todavía se muestra reacia a abordarlo de manera sistemática. ${ }^{16}$ Una escasez de estudios relacionada con la lenta institucionalización de una disciplina como la historia de la historiografía, pero también a las dificultades suscitadas a la hora afrontar un pasado en el que se entrecruzan las interferencias de las redes discipulares, las solidaridades ideológicas o el asfixiante dominio de lo políticamente correcto. ${ }^{77}$

14 Nos referimos al número monográfico de Hispania que, bajo la dirección de Celso ALMUIÑA con(1940-1989): Análisis y evolución de contenidos", Hispania, Vol. 50, núm. 175, 1990.

15 Lutz RAPAHEL: La ciencia histórica en la era de los extremos. Teorías, métodos y tendencias desde 1900 hasta la actualidad, Zaragoza Institución Fernando el Católico, 2012.

16 Sobre el debate en torno a los historiadores en las dictaduras europeas, y entre una voluminosa bibliografía, sirva como ejemplo, Chris LORENZ: “Encrucijadas: reflexiones acerca del papel de los historiadores alemanes en los debates públicos recientes sobre historia nazi", en Manuel CRUZ y Daniel BRAUER (coords.): La comprensión del pasado: escritos sobre filosofia de la historia, Barcelona, Herder, 2005, pp. 335-381. Sobre las conflictivas relecturas del pasado alemán, Dirk MOSES: German Intellectuals and the Nazi Past, Cambridge, Cambridge University Press, 2007. En relación a la historiografia italiana, Gabriele TURI: Lo Stato educatore. Politica e intellectuali nell'Italia fascista, Roma-Bari, Laterza, 2002, y Eugenio di RIENZO: Un dopoguerra storiografico. Storici italiani tra guerra civile e Repubblica, Firenze, Le Lettere, 2004. La trayectoria de los intelectuales e historiadores bajo regímenes dictatoriales recogidos en P. G. ZUNNINO, (ed.): Univesità e Accademie negli anni del fascismo e del nazismo, Firenze, Leo S. Olschki Editore, 2005. En relación a la creciente bibliografía relativa a los antiguos paises del Este citamos Pavel KÔLAR, Miloš REZNIK (eds.): Historische Nationsforschung im geteilten Europa 1945-1989, Köln, Kölner Beiträge zur Nationsforschung 10, SH-Verlag, 2012.

17 Respecto a la historiografía franquista, Gonzalo PASAMAR: Historiografía e ideología en la postguerra aspañola La ruptura de la tradición liberal PASAMAR: Historiografia e ideologia en la postguerra espanola. La PEIRÓ: “Ausente no quiere decir inexistente La responsabilidad en el pasado y en presente de
Un panorama completado con la complaciente reescritura de las biografías personales y la recurrente aparición de unas filiaciones liberales que, en última instancia, nos remitirían a absurdo de un franquismo sin franquistas. ${ }^{18}$

Frente a este retraimiento, la historiografía europea ha llevado a cabo un importante esfuerzo por atender a los procesos de institucionalización y profesionalización de la disciplina histórica, pero también por rastrear la proyección social de los diferentes relatos historiográficos. A este respecto cabría señalar la importancia de las diferentes publicaciones emanadas del proyecto internacional Representations of the past: National histories in Europe, liderado por Stefan Berger, Chris Lorenz, Ilaria Porciani y Lutz Raphael. Este potente grupo de investigación ha rastreado en profundidad las historiografías de treinta países europeos desde la segunda mitad del siglo XIX hasta el presente, partiendo de la asunción de que la historia había sido uno de los más importantes elementos en la construcción de las identidades nacionales en Europa. ${ }^{19}$ De la misma manera, la historiografía italiana ha llevado a cabo un intenso análisis de los procesos de institucionalización cultural, especialmente durante el periodo de Mussolini. ${ }^{20}$ Unas reflexiones que, por lo general, están todavía pendientes de abordar por parte de la historiografía española.

De la misma manera, no deja de sorprender la recurrente exclusión de la historia -entendida como elemento básico de nacionalización- en numerosos estudios sobre la construcción de las identidades nacionales y políticas, sobre todo cuando se refieren a un régimen tan "historizante" como el franquismo. ${ }^{2}$

\section{Historia de la historiografía en el exilio: un largo camino por recorrer.}

Por lo que respecta a la historia sobre el exilio de los historiadores que generó la guerra civil española, todavía está por escribir. Una consecuencia de las rupturas historicas provocadas por guerras y dictaduras entre las comunidades profesionales de historiadores europeos a

la historiografía española", Alcores, 1, (2006), pp. 9-26. Un repaso sintético del desarrollo de la historia de los intelectuales en el franquismo en Francisco MORENTE: "Más allá del páramo. La historia de los intelectuales durante el franquismo" en, Carmen FRÍAS, Jose Luis LEDESMA y Javie RODRIGO (eds.), Reevaluaciones, Zaragoza, Institución Fernando el Católico, 2011, pp. 41- 76.

18 Sobre los giros "liberales", Ignacio PEIRÓ: “Días de ayer de la historiografía española. La Guerra de la Independencia y la "conversión liberal» de los historiadores en el franquismo", en Pedro RÚJULA y Jordi CANAL: Guerra de ideas. Politica y cultura en la España de la Guerra de la Independencia, Madrid, Marcial Pons-Institución Fernando el Católico, 2011, pp. 445-479. Hace unos pocos años el historiador Miquel Marín Gelabert se preguntaba: "¿No deberíamos simplemente asumir los distintos grados de colaboracionismo de los historiadores españoles como un objeto de análisis en lugar de -o previamente a- como un juicio moral?". La propia oportunidad de la pregunta resulta suficientemente expresiva del largo camino pendiente. Miquel Angel MARIN: "La fatiga de una generación. Jaume Vicens Vives y su Historia critica de la Vida y Reinado de Fernando II de Aragón", en Jaume VICENS Historia Critica de la Vida y Reinado de Fernando II de Aragón, Zaragoza, Institución Fernando el Católico, 2006, p. XXXVII. Un intento de disminuir la influencia del Opus Dei en el control del sistema academico universitario, mediante el uso de un aparato retorico postmodernista en, Jaume AURELL: “La formación de un gran relato sobre el Opus Dei”, Studia et Documenta, 6 (2012), pp. 235-294.

19 Stefan BERGER (ed.): Writing the nation: a global perspective, Basingstoke, Palgrave Macmillan 2007, ÍD.: "National historiographies in transnational perspective: Europe in the nineteenth and twentieth centuries", Storia della Storiografia, 50 (2006), pp. 3-26.

20 Gabriele TURI: Lo Stato educatore. Politica e intellettuali nell'Italia fascista, Bari-Roma, Laterza, 2002; Mario ISNENGHI (dir.): Gli Italiani in guerra. Conflitti, identitä, memorie dal Risorgimento ai nostri giorni, Torino, Unione Tipografio Editrice Torinese, 2009, especialmente el volumen VI. Margherita ANGELINI: "Transmitting knowledge: the professionalisation of Italian historians (1920s-1950s)", Rivista Internazionale de Storia della storiografia, 57 (2010), pp. 3-174.

21 Algo que pretendemos integrar en la tesis doctoral en curso, Gustavo ALARES: Las politicas del pasado en la España franquista (1939-1964). Historia, nacionalismo y dictadura, European University Institute. 
lo largo del siglo XX fue el exilio. ${ }^{22}$ No hace falta incidir en el hecho de que en el caso español su envergadura y prolongación temporal genera una determinada problemática a la hora de abordarlo, aunque en ningún caso con carácter único en nuestro entorno. Evidentemente, no sólo se trata de dibujar el mapa del exilio, una tarea necesaria que de manera general se ha abordado para el caso de científicos y universitarios en diversas ocasiones; ${ }^{23}$ y en el caso específico de los historiadores con actualizaciones del pionero listado de Javier Malagón en 1978 además de estudios de caso que incorporan nuevas perspectivas. ${ }^{24}$

La cartografía de la comunidad mostraría dos escenarios diferenciados: a mediados de 1940, todos los catedráticos y la mayoría de doctores y licenciados exiliados habían conseguido, con mayor o menor dificultad, alejarse de la Europa en guerra para instalarse en centros y universidades americanas donde proseguir su labor, gracias en parte a los mecanismos de solidaridad internacional entre intelectuales. Una red de relaciones tejida desde principios de siglo en la etapa de internacionalización de la historiografía española, y que sería conveniente analizar en su conjunto. ${ }^{25}$

Esta forzada segregación de la comunidad de historiadores españoles en 1936-39, durante el proceso interrumpido de la "profesionalización" de la disciplina, provocó que la continuidad de las líneas programáticas y conceptuales de la historiografía liberal se realizase a partir de ese momento por estos exiliados. Entre ellos, maestros como Pere Bosch Gimpera, Claudio Sánchez-Albornoz, Agustín Millares Carlo y Juan Manuel Aguilar y Calvo, quienes, en sus respectivas especialidades, prolongaron sus investigaciones en contextos institucionales ajenos. ${ }^{26}$

22 Renato CAMURRI (ed.): "'L'Europa in esilio. La migrazione degli intellettuali verso le Americhe tra le due guerre", monográfico de Memoria e Ricerca, 31 (2009); Mario KESSLER (ed.): Deutsche Historiker im Exil (1933-1945): Ausgewählte Studien, Berlin, Metropol, 2005; Catherine EPSTEIN: A Past Renewed. A Catalog of German-Speaking Refugee Historians in the United States after 1933, Washington, German Historical Institute, 1993; Antoon DE BAETS: "Exile and Acculturation: Refugee Historians since the Second World War", The International History Review, XXVIII, 2 (june 2006), pp. 316-349.

23 José María LÓPEZ SÁNCHEZ: Los refugios de la derrota. El exilio científico e intelectual republicano de 1939, Madrid, CSIC, 2013; Luis Enrique OTERO CARVAJAL (ed.): La destrucción de la ciencia en España. Depuración universitaria en el franquismo. Madrid, Editorial Complutense, 2006.

24 Javier MALAGÓN: "Los historiadores y la historia en el exilio" en José Luis ABELLÁN: El exilio español de 1939, Taurus, Madrid, 1978, Vol. V, pp. 245-353. Más recientemente han abordado el tema Alicia ALTED VIGIL: “Historiografía e historiadores en el exilio" en Ma Fernanda MANCEBO (ed.): Encuentros de Historia y Literatura. Max Aub y Manuel Tuñón de Lara, Valencia, Biblioteca Valenciana, Generalitat Valenciana, Conselleria de Cultura i Educació, Direcció General del Llibre, Arxius i Biblioteques, 2003; ID.: "Historiadores exiliados en América latina. El caso de Ramón Iglesia Parga" en Andrea PAGNI (ed.): El exilio republicano español en México y Argentina. Historia cultural, instituciones literarias, medios, Madrid, Iberoamericana, 2011, pp.77-92; Yolanda BLASCO: “Los costes del franquismo para la universidad española y para los profesores exiliados. El caso de Pere Bosch-Gimpera", Historiografias, 3 (Enero- Junio, 2012), pp. 45-61. Excede del objetivo glosar todas las investigaciones parciales al respecto, muchas de ellas recogidas en Actas de Congresos (GEXEL, Internacionales de la Universidad de San Sebastián, etc.) o revistas especializadas como Migraciones y Exilios o Laberintos: revista de estudios sobre los exilios culturales españoles.

25 Una de las expresiones de solidaridad académica más reconocida fue la creación de la Casa de España y el Colegio de México, instituciones estudiadas en diferentes ocasiones por Clara E Lida. Baste citar Clara E. LIDA, José Antonio MATESANZ y Josefina Zoraida VÁZOUUZZ (comps.): La Casa de España y el Colegio de México. Memoria 1938-2000, México, El Colegio de México, 2000

26 Ignacio PEIRÓ, "Historiadores en el purgatorio. Continuidades y rupturas en los años sesenta”, Cercles. Revista d'Historia Cultural, Universitat de Barcelona, 16 (2013), pp. 53-81; Germán RAMíREZ, turales españoles, 13 (2011), pp. 123-162 http://bv.gva.es/documentos/lab13.pdf
De todo ello, si bien se ha prestado una merecida atención a las figuras de primera línea, ${ }^{27}$ las aproximaciones biográficas y conmemorativas prevalecen sobre los estudios basados en categorías propias de la historia de la historiografía. Diluida su presencia entre la abundante literatura sobre el exilio intelectual surgida en los últimos tiempos, la figura del historiador exiliado no acaba de merecer una aproximación sistemática como mediador entre historiografías. Aún con todo, el relato sobre los historiadores exiliados en el continente latinoamericano se encuentra más desarrollado que el concerniente al segundo grupo: los historiadores españoles exiliados en Europa, y más concretamente en Francia. Con la excepción de la figura de Manuel Tuñón de Lara, ${ }^{28}$ que como catalizador de la historiografía francesa y debido a su influencia en la renovación del contemporaneismo español cuenta con una mayor bibliografía al respecto, sólo en la última década han merecido atención algunos de sus compañeros de viaje: Emilio Gómez Nadal, ${ }^{29}$ Teresa Andrés,30 o el que consideraban su maestro, Manuel Núñez de Arenas, mientras la figura de Francisco González Bruguera continua sin biografiar, y su influyente obra sobre la historia de España sin traducir. ${ }^{31}$

El juego de transferencias entre la historiografía liberal y obrera de principios de siglo en España, la influencia de la historiografía francesa así como su recepción y adaptación entre los jóvenes historiadores españoles de los años 70 se encuentra en este escenario del exilio. ${ }^{22}$ Pero al contrario de lo ocurrido en América, la inserción en el sistema académico francés de dichos historiadores no fue inmediata, marcadas trágicamente sus trayectorias por la Segunda Guerra Mundial. Lejos de su original grupo profesional, fue parte de la comunidad hispanista gala quién acogió sus propuestas y facilitó lo que pudo su inserción en el pétreo sistema universitario francés. Conectar a los historiadores exiliados durante la guerra civil con los exiliados posteriores, y a su vez con los hijos de exiliados formados en Francia que en ocasiones llegaron

27 Francisco GRACIA: Pere Bosch Gimpera. Universidad, politica y exilio, Madrid, Marcial Pons, 2011 pp. 395-569. Sobre Claudio Sánchez-Albornoz la bibliografía es muy abundante, citaremos aqu la tesis más reciente dedicada al medievalista: Juan Pablo DOMINGUEZ: Claudio Sánchez-Albornoz (1893-1984). Historiador, intelectual y politico, Universidad de Navarra, 2010. De la abundante bibliografía sobre el historiador canario, el artículo de Ascension HERNANDEZZ DE LEÓN: "Agustín Millares Carlo: su trabajo en La Casa de España y El Colegio de Mexico (1939-1959)", Boletín Millares Carlo, 29 (2010), pp. 11-28. Para el resto de exiliados, si bien existe bibliografia que sería imposible de citar aqui, sigue siendo una herramienta imprescindible lgnacio PERRO y Gonzano PASAMAR

28 Dossier: "Manuel Tuñón de Lara, diez años después. La huella de un legado" en Cuadernos de Historia Contemporánea, 30 (2008), pp. 185-198, donde se encuentran referencias a la bibliografía anterior. 29 La revista Laberintos: revista de estudios sobre los exilios culturales españoles le dedicó un dossier
en su número 10-11 (2008-2009), pp. 286-410; Antonio GÓMEZ ANDRÉS y Francesc PÉREZ I MORAGÓN (eds.): Emili Gómez Nadal: diaris i records, València: Universitat de València, 2008.

30 Citamos el más reciente de Romà SEGUÍ I FRANCĖS: "La etapa del exilio de Teresa Andrés Zamora (1939-1946): de la gestión bibliotecaria al espacio político" Laberintos: revista de estudios sobre los exilios culturales españoles, 14 (2012), pp. 139-150

31 Sobre este grupo de exiliados y Manuel Núñez de Arenas en particular he adelantado algunos aspectos de mi tesis en María José SOLANAS: "Manuel Núñez de Arenas, maestro de historiadores exiliados en Francia", en José Angel ASCUNCE, Mónica JATO, Ma Luisa SAN MIGUEL (coords.): Exilio y Universidad (1936-1955), Editorial Saturraran, San Sebastián, 2008, vol. 2, pp. 1225-1244; ÍD..: "Manue Núnezez de Arenas: los exilios de un historiador", Claves del mundo contemporáneo. Debate e investigación. Actas del XI Congreso de la Asociación de Historia Contemporánea, Granada, Comares, 2013.

2 Maria José SOLANAS: "Transferencias culturales e historia cruzada: orisen y desarrollo. Apuntes Maria Jose socanAs: "Transferencias culturales e historia cruzada: origen y desarrollo. Apunte sobre su aplicación al estudio de la historia de la historiografía española" en Ma Candelaria FUEN-
TES NAVARRO et al. (eds.): II Encuentro de Jóvenes Investigadores en Historia Contemporánea:celebrado en Granada los dias 22 al 25 de septiembre de 2009. Granada. Editorial Universidad de Granada, 2010. CD-ROM. 
a formar parte de esos mismos círculos hispanistas ${ }^{33}$ nos dará las claves de este escenario historiográfico, completándolo con el análisis del papel aglutinador de los seminarios de historia de Pierre Vilar en París. Y todo ello, sin olvidarnos de los espacios alternativos para la interpretación de la historia como la editorial Ruedo Ibérico, o los creados por republicanos, socialistas y anarquistas, reorganizando sus propios canales para la difusión de la denominada "historia militante". En definitiva, el estudio de las redes establecidas entre las diferentes coordenadas historiográficas que transitaron los historiadores exiliados nos permitirá reconstruir el desarrollo de la profesión fuera de las fronteras nacionales. Una tarea que, además de pugnar con la lejanía de las fuentes directas nos obliga a permanecer en constante diálogo y conocimiento de las historiografías receptoras. La publicación de epistolarios y memorias ${ }^{34}$ es un primer paso para acercarnos a las problemáticas propias de los protagonistas. Pero todavía falta la reconstrucción de los itinerarios profesionales y políticos de estos exiliados en los campos profesionales de destino: su inserción y adaptación a las respectivas instituciones, la gestión de sus relaciones y sus opciones profesionales. De la misma manera, es nuevo el circuito de publicaciones al que deben adherirse, y el acceso a los medios de producción y reproducción: bibliotecas, seminarios, transferencias, los contactos con sus antiguos discípulos y la creación de nuevos grupos de trabajo. Las aproximaciones realizadas desde la historia intelectual necesitan ser completadas con un mayor análisis de las influencias, préstamos intelectuales y relaciones que el exilio impuso a sus trayectorias académicas, así como los nuevos lugares de sociabilidad. Por supuesto, un camino investigado ha sido y debe ser el de las relaciones con la historiografía franquista en todas sus vertientes, y las distintas actitudes ante la recepción de las figuras y propuestas de estos historiadores exiliados por la comunidad del interior. ${ }^{35}$ Transitar los caminos de la lógica y legítima tarea de recuperación de una historia silenciada no nos exime de utilizar un aparato crítico que impida una deriva autocomplaciente.

\section{Grupos de investigación sobre historia de la historiografía}

Frente a esta pluralidad difusa que hemos dibujado, también convendría señalar la progresiva consolidación de algunos grupos de investigación que han venido ofreciendo propuestas más concretas.

Amparado por el magisterio de Juan José Carreras (1928-2006), desde mediados de la década de los ochenta el Departamento de Historia Contemporánea de Zaragoza se afirmó por una vocación sistemática por la historia de la historiografía, teniendo como principales referentes a Ignacio Peiró y Gonzalo Pasamar, y generando -entre diversos trabajos- el ya imprescindible Diccionario de Historiadores españoles contemporáneos.

Lo cierto es que el grupo zaragozano ha procurado articular un proyecto de investigación centrado en el análisis integral de la profesión de historiador. ${ }^{36}$ Dicha propuesta pretende tras

33 Ricardo GARCÍA CÁRCEL E Eliseo SERRANO MARTÍN (eds.): Exilio, memoria personal y memoria histórica. El hispanismo francés de raiz española en el siglo XX, Zaragoza, Institución Fernando el Católico, 2009.

34 Citaremos aquí sólo algunos ejemplos recientes: Ritama MUÑOZ ROJAS: "Poco a poco os hablaré de todo". Historia del exilio en Nueva York de la familia De los Rios, Giner, Urruti. Cartas 1936-1953, Madrid, Publicaciones de la Residencia de Estudiantes, 2009. Nicolás SÁNCHEZ-ALBORNOZ: Cárceles y exilios, Barcelona, Anagrama, 2012.

35 Javier PRADERA:“El descubrimiento del exilio en España", en Nicolás SÁNCHEZ-ALBORNOZ (comp.): El destierro español en América. Un trasvase cultural, Madrid, Sociedad Estatal Quinto Centenario, Instituto de Cooperación Iberoamericana, 1991, pp. 235-242.

36 Un grupo congregado en torno al Seminario permanente de Historia de la Historiografía Juan Uné Carreras de la institución Fernando el Católico, dirigido por Carlos Forcadell y a Proyan Jasto sado y narrativas de la nación (1808-2012)", con Ignacio Peiró como investigador principal http. historiadorescontemporaneos.wordpress.com cender el mero análisis de los discursos históricos para acometer el estudio de los procesos de institucionalización, las estrategias de sociabilidad académica, el establecimiento de redes discipulares, los procesos de transferencia, o los fenómenos de autopercepción. Los diversos trabajos de Miquel Marín Gelabert e Ignacio Peiró37 han venido completándose con las aportaciones de investigadores más jóvenes centradas sobre temáticas diversas, ya sean vinculadas al análisis de las transferencias culturales, los procesos de institucionalización, las trayectorias historiográficas de figuras relevantes de la profesión, o a los usos públicos del pasado..$^{38}$

De la misma manera, se ha procurado proporcionar un marco estable para el debate historiográfico a través de los siete cursos internacionales que, con carácter anual, han venido organizándose desde el Seminario permanente de Historia de la Historiografía Juan José Carreras.

Por otro lado, también en el seno de la Universidad de Zaragoza y partiendo desde unos inicios establecidos en el ámbito de la historia de la historiografía, el profesor Gonzalo Pasamar ha proseguido sus indagaciones dedicándose con especial atención a los efectos de la memoria, y disponiendo de un órgano de difusión propio consolidado, como es la revista digital Historiografias. 39

En este recordatorio de excepciones resulta especialmente llamativo el dinamismo de ciertos departamentos de Historia Antigua a la hora de analizar al tratamiento de la Antigüedad por parte del franquismo. $4^{\circ}$

De la misma manera es reseñable la labor realizada desde la Universidad de Navarra desde los años ochenta en torno al estudio de la historiografía. Este centro es el responsable de organizar las imprescindibles "Conversaciones Internacionales de Historia", así como de la edición de la revista Memoria y Civilización. ${ }^{4}$

37 Citamos aquí su Los historiadores españoles en el franquismo, 1948-1975, Zaragoza, Institución Fernando el Católico, 2005 y remitimos a los trabajos previamente citados. Al margen de los trabajos ya reseñados, Ignacio PEIRÓ: Historiadores en España: historia de la Historia y memoria de la profesión, Zaragoza, Prensas de la Universidad de Zaragoza, 2013; Luces de la Historia. Estudios de historiografia aragonesa, Teruel, Instituto de Estudios Turolenses, 2014.

38 María José SOLANAS: "Transferencias culturales: origen, desarrollo y aplicación al estudio de la historia de la historiografía española" en Ignacio Peiró y Pedro Rújula (coord.), La historia en el presente. V Congreso de Historia Local de Aragón, Molinos, 2005, Teruel, Instituto de Estudios Turolenses, 2007, pp. 379-392. Gustavo ALARES: Diccionario biográfico... op. cit.,; iD.: "De caudillos, mártires y patriotas. El mito de los Sitios en la Zaragoza contemporánea (1958-2008)" en Pedro RÚJULA y Jordi CANAL (eds.): Guerra de ideas..., pp. 369-396; İD.: "La conmemoración del Milenario del Castilla en 1943. Historia y espectáculo en la España franquista”, Jerónimo Zurita, 86 (2011), pp 149-180; ID.: "La génesis de un proyecto cultural fascista en la Zaragoza de posguerra: la Institución Fernando el Católico", en Ignacio PEIRÓ y Guillermo VICENTE (eds.): Estudios históricos sobre la Universidad de Zaragoza, Zaragoza, Institución Fernando el Católico, 2010, pp. 373-381; "José Navarro Latorre (1916-1986): un americanista en busca de comunidad", Teresa ORTEGA, Miguel Ángel del ARCO: Claves del mundo contemporáneo...op. cit., Eduardo ACERETE, "La historiografía en el distrito universitario de Zaragoza", Teresa ORTEGA, Miguel Ángel del ARCO:Claves del mundo contemporáneo... Raúl MAYORAL: El cinco de marzo de 1838 en Zaragoza. Aquella memorable jornada.. Zaragoza, Institución Fernando el Católico, 2014.

39 Gonzalo PASAMAR, "El recuerdo de la guerra civil española durante la transición: los editores y las colecciones históricas y de memorias, Historia social, 77, 2013, pp. 49-67.

40 De especial interés resultan los trabajos incluidos en Fernando WULFF y Manuel ÁLVAREZ (coords.): Antigüedad y franquismo (1936-1975), Málaga, CEDMA, 2003. De Antonio DUPLÁ: “Una historia de España audiovisual y joseantoniana", David ROMERO (coord.): La Historia a través del cine: memoria e historia en la España de la posquerra, Servicio Editorial de la Universidad del País Vasco, 2010, pp. 15-34. Junto a los numerosos trabajos sobre la figura de Bosch Gimpera de Francisco Gracia señalaremos La arqueología durante el primer franquismo (1939-1956), Barcelona, Edicions Bellaterra, 2009.

41 Citaremos Francisco Javier CASPISTEGUI (ed): Historiay globalización. VIIIConversaciones internacionales de Historia Universidad de Navarra Pamplona, 7-9 de octubre de 2010, Pamplona, EUNSA, 2012 
En este deambular por las geografías del difuso cultivo de la historia de la historiografía convendría no olvidar diversos equipos que mantienen actividades en este sentido: los trabajos auspiciados por Mariano Esteban desde la Universidad de Salamanca, el Seminario Rafael Altamira de la Universidad de Granada impulsado por Teresa Ortega, el Instituto de Historiografía Julio Caro Baroja de la Universidad Carlos III de Madrid y su Revista de historiografía, las propuestas enmarcadas en el análisis de la historiografía catalana, o el largo magisterio de Pedro Ruiz Torres y la sugerente labor de Anaclet Pons y Justo Serna desde la Universidad de Valencia..$^{42} Y$ con menor presencia en este terreno en la actualidad, pero activos puntales de la investigación en décadas anteriores serían los referentes de Elena Hernández Sandoica en Madrid, Pedro Carasa en Valladolid, la conexión con la historiografía anglosajona de corte postmodernista del grupo de Miguel Ángel Cabrera o el núcleo de Santiago de Compostela con Carlos Bermejo al frente

Por último, resulta necesario reseñar un intento de internacionalización de relieve como es el proyecto europeo "cultura histórica" respaldado por la Comisión Internacional History and Theory of Historiography, de la Universidad de Barcelona. 43

Después de todo, solo nos queda reproducir a modo de conclusión las palabras de Ignacio Peiró para definir las relaciones entre la Historia y su historia:

un camino seguro de la ciencia cuya cuestión esencial se centra en la investigación problemática de los estudios históricos, o sea, de su naturaleza cognitiva, de los objetos, métodos y discursos de la historia; pero también, de los historiadores, de sus formas de representación del pasado y procesos de institucionalización profesional, de sus usos y hábitos comunitarios, de sus motivos académicos y ambiciones administrativas, de sus funciones sociales y compromisos político-culturales. Y todo eso, en la interrelación establecida por la historiografía con el espacio histórico real que concreta la geografía de su producción. ${ }^{44}$

Esa es nuestra tarea.

42 Mariano ESTEBAN y Antonio MORALES (eds.): ¿Alma de España?. Castilla en las interpretaciones del pasado español, Madrid, Marcial Pons, 2005, pp. 87-140. Anaclet PONS: El desorden digital: guía para historiadores y humanistas, Madrid, Siglo XXI, 2013.

43 Puede consultarse su web en http://www.culturahistorica.es

44 Ignacio PEIRÓ: Historiadores en España...... 12 
JOSÉ MARÍA JOVER Y LA HISTORIA DE LAS RELACIONES

\section{INTERNACIONALES: NOTAS PARA SU ESTUDIO}

Jorge Azorín Arroyo

Universidad de Zaragoza

Una «relación internacional» es, ciertamente, una negociación diplomática, una contienda bélica o una convención plurinacional de carácter político. Pero también lo es un intercambio comercial, un empréstito o una inversión financiera; lo es un intercambio o un influjo cultural, intervenga o no en él la acción del Estado; lo son las corrientes migratorias, cualquiera que sea su carácter; lo son, incluso, tanto el hecho de masas constituido por la imagen que los miembros de una colectividad nacional se forman de los pertenecientes a otra, como la corriente de opinión pública que, en materia de política exterior, alimenta o es alimentada por una campaña de prensa. La posición internacional de un país en un momento dado vendría significada por el complejo de relaciones que queda aludido.

Estas palabras de José María Jover, por obvias que puedan parecer, condensan en pocas líneas el renacer de la historia de las relaciones internacionales en la historiografía española. El tradicional marco del Estado-nación como referencia histórica e historiográfica ha sido ampliamente superado, insertando el devenir histórico de los diferentes países en unas coordenadas más globales y de mayor calado para, de esta manera, lograr trazar dinámicas históricas tanto continentales como mundiales. En España, los estudios relativos a las relaciones entre Estados experimentaron una profunda renovación teórica durante las décadas de los años 1950 y 1960. Hasta ese momento, la historiografía se limitaba al análisis y relato de los hitos fundamentales propios de la vieja historia diplomática, en una concepción elitista -desde arri$b a$ - centrada en la toma de decisiones de las élites dirigentes, políticas y militares. La revolución teórico-metodológica se produjo de la mano de historiadores como Pierre Renouvin y Federico Chabod gracias al moderno enfoque sociológico establecido a partir de la introducción de nuevos factores de estudio. En este escenario, las dinámicas internas de los países, las condiciones materiales y las mentalidades comúnmente compartidas de los pueblos y sociedades se valorarán como elementos pautadores y condicionantes de las relaciones internacionales.

La penetración de esta corriente historiográfica en España pivotó en torno a José María Jover, historiador originalmente modernista responsable de la recepción y consolidación de este tipo de estudios aplicados al caso español desde los años cincuenta, y que evolucionará hacia el contemporaneismo, especialmente dedicado al siglo XIX. Por esta razón, se puede afirmar que Jover constituye uno de los pilares esenciales para la renovación y modernización de la disciplina histórica en España, no únicamente en cuanto al desarrollo de las relaciones internacionales, sino como uno de los ejes vectoriales del renacimiento de la historiografía profesional.

Para comprender dicho proceso debemos remontarnos a la primera «hora cero" que significó la Guerra Civil iniciada en 1936, una ruptura de la tradición liberal de preguerra que paralizó el

1 José María JOVER: “El siglo XIX en la historiografía española de la época de Franco (1939-1972)”, en José María JOVER: Historiadores españoles de nuestro siglo, Madrid, RAH, 1999, p. 249. proceso de profesionalización protagonizado por la comunidad de historiadores españoles a lo largo del primer tercio del siglo XX. Tras esta primera «larga travesía por el desierto» de la universidad franquista, la ciencia histórica inició un lento proceso de disciplinarización en el que comenzaron a dibujarse sus límites externos y sus márgenes internos, definiendo los objetos de estudio, los medios científicos y las pautas metodológicas. Convenientemente depurada la universidad española según unos férreos patrones nacionalcatólicos y fascistas, el nuevo contemporaneismo apareció partiendo de las escuelas disciplinares del franquismo, es decir, del medievalismo y del modernismo, gracias a una nueva generación de historiadores que, como Jover, accedieron a las cátedras entre 1940 y 1949 y desarrollaron todo su potencial investigador en una segunda fase que se sitúa en la década de 1950 y más adelante. Del mismo modo, la historiografía española, tradicionalmente anclada en los márgenes de la periferia europea, con el núcleo franco-alemán como referente teórico-metodológico por excelencia, inició lentamente su inserción en patrones y modelos europeos, a la par que el contemporaneismo se emancipó de la matriz disciplinar medievalista y modernista, siendo Jover uno de sus máximos exponentes.

La presente comunicación pretende tomar la personalidad de José María Jover como punto de partida y referencia para un estudio más global en torno a las condiciones académicas e historiográficas en las que se produjo la renovación de la ciencia histórica española durante el franquismo, tanto en lo relativo a la introducción de la historia de las relaciones internacionales como al desarrollo disciplinar del contemporaneismo. La intención es profundizar en el estudio de las condiciones académicas e historiográficas en las que se produjo dicha transferencia cultural, tomando como margen cronológico las décadas de 1950 y 1960 por dos motivos. En primer lugar, porque es éste el periodo en el que se produce la recepción de la historia de las relaciones internacionales, implantándose lenta y tímidamente en la historiografía española. $Y$ en segundo lugar, porque debe ser debidamente incardinado en el proceso de normalización de la historiografía española acontecido en esos mismos años, sobre todo en su vertiente exterior, y que le confiere unas características específicas por el hecho de lograr una cierta apertura teórico-metodológica.

\section{Estado de la cuestión}

La historia de las relaciones internacionales en España constituye una materia que ha sido ampliamente estudiada desde muy diversas ópticas pero, por lo que respecta a los enfoques historiográficos de la misma, los trabajos han sido más bien escasos. A pesar de este punto de partida un tanto desolador, debido al reducido número de referencias, hay ciertos aspectos que han sido tratados de manera específica y que guardan relación con diferentes apartados que se desarrollan a lo largo del presente trabajo.

En primer lugar, existen diversas panorámicas en torno a la evolución teórica que han experimentado este tipo de estudios. En ellos se incide fundamentalmente en los grandes vectores de renovación en los que, irremediablemente, ha de enmarcarse a Jover, transitando por una nueva metodología y práctica histórica muy distinta de la vieja historia diplomática tradicional. En este grupo se incluyen las aportaciones de Celestino del Arenal, quien aborda el desarrollo de las relaciones internacionales como disciplina científica a partir de la politología, la sociología y el derecho internacional. ${ }^{2}$ Otros autores, entre los que destacan Francisco Quintana Navarro, Juan Carlos Pereira o José Luís Neila, han contribuido a trazar una visión global de la historia de las relaciones internacionales en España desde una óptica historiográfica. ${ }^{3}$ En

Celestino del ARENAL MOYÚA: La teoría de las relaciones internacionales en España, Madrid, International Law Association, 1979; İD.: Introducción a las relaciones internacionales, Madrid, Tecnos, 1984

3 Juan C. PEREIRA: Introducción al estudio de la política exterior de España: siglos XIX y XX, Madrid, Akal, 1982. I D : Historia de las al estudio de la politica exterior de España: siglos XIX Y XX, Madrid, "Dal, 1982, L. 
estos trabajos se analizaba también la evolución de la propia disciplina a nivel internacional y se remarcaba el protagonismo que en la redirección de estas corrientes tuvieron autores como Pierre Renouvin, Jean-Baptiste Duroselle, Federico Chabod o Ludwig Dehio. En este sentido, la obra de Lutz Raphael, La ciencia histórica en la era de los extremos, ofrece una visión de conjunto de la historia de las relaciones internacionales a partir del lugar que ocupa en la propia disciplina histórica, resaltando los cambios historiográficos producidos en su seno. ${ }^{4}$

En segundo lugar, la trayectoria de José María Jover ha sido abordada desde múltiples planos. Un primer y obligado acercamiento debe realizarse a parir de la «voz» que le dedican Ignacio Peiró y Gonzalo Pasamar en su Diccionario Akal de historiadores españoles contemporáneos, monumental obra que aporta valiosa información para el investigador puesto que ofrece una radiografía completa de la vida profesional del historiador objeto de estudio. ${ }^{5}$ En cuanto a su faceta como estudioso de la historia de la historiografía, un análisis pormenorizado de su evolución profesional e historiográfica queda recogido en el ya clásico artículo de Ignacio Peiró consagrado al estudio de su metamorfosis como historiador, partiendo del modernismo imperante en la historiografía de posguerra hacia un contemporaneismo que progresivamente empezaba a perfilarse en el seno de la universidad franquista. ${ }^{6}$ En cierto sentido, este trabajo constituye el punto de partida para la investigación, puesto que en él se establecieron las líneas fundamentales relativas a la vertiente joveriana de las relaciones internacionales a partir de los contactos y transferencias culturales con las historiografías italiana, francesa y alemana.

Incluimos también aquí el homenaje que en 1988, con motivo de su jubilación en la Universidad Complutense de Madrid, discípulos y compañeros le dedicaron, junto a Vicente Palacio Atard, como reconocimiento a toda su trayectoria académica y profesional En estas páginas aparecían diversos artículos que trataban el paso del catedrático por la universidad madrileña desde diferentes perspectivas, como la impronta que dejó en sus alumnos a través de su docencia y magisterio, los caminos abiertos en torno a la historia social decimonónica, su condición prematura de historiador de la historiografía o sus aportaciones sobre las relaciones internacionales españolas contemporáneas.? En esta misma línea se sitúa el

de un término", Historia Contemporánea, 7 (1992), pp. 155-182; e ÍD.: “España en la política exterior. La obra de José María Jover", Política Exterior, 74 (marzo-abril de 2000), pp. 151-156, este último con motivo de la publicación de la recopilación de textos de Jover bajo el título, España en la Política Internacional. Siglos XVIII-XX, Madrid, Marcial Pons, 1999. Francisco QUINTANA NAVARRO: "La historia de las relaciones internacionales en España: apuntes para un balance historiográfico", en VV.AA.: La historia de las relaciones internacionales: una visión desde España, Madrid, CEHRI, 1994, pp. 9-65; José Luís NEILA: “La Historia de las Relaciones Internacionales: notas para una aproximación historiografica", Ayer, 42 (2001), pp. 17-42.

4 Lutz RAPHAEL: La ciencia histórica en la era de los extremos. Teorias, métodos y tendencias desde 1900 hasta la actualidad, Zaragoza, Institución «Fernando el Católico», 2012, especialmente el capítulo VIII, pp. 155-172.

Ignacio PEIRÓ MARTín y Gonzalo PASAMAR ALZURIA: Diccionario Akal de historiadores españoles contemporáneos (1840-1980), Madrid, Akal, 2002, pp. 337-338.

6 Ignacio PEIRÓ MARTíN: “La metamorfosis de un historiador: el tránsito hacia el contemporaneismo de José María Jover Zamora", Revista Jerónimo Zurita, 82 (2007), pp. 175-234. Este ensayo ha sido reeditado, corregido y ampliado, en el capitulo tercero del libro de ÍD.: Historiadores en España. Historia de la Historia y memoria de la profesión, Zaragoza, Prensas Universitarias de Zaragoza, 2013, pp. 119-192.

7 Todas las aportaciones quedan recogidas en el monográfico dedicado a la obra y personalidad de los historiadores Vicente Palacio Atard y José María Jover Zamora, publicado en Cuadernos de Historia Contemporánea, 9 (1988). Destacan los artículos de José CEPEDA ADÁN: "El estilo de dos historiadores", pp. 11-16; Vicente CACHO VIU:"Los supuestos del contemporaneismo en la historiografia de posguerra”, pp. 17-28; María Victoria LÓPEZ-CORDÓN: “La obra y la personalidad de Don homenaje póstumo, recientemente editado por Rosario Ruiz Franco, en el que participan muchos de sus discípulos madrileños. ${ }^{8}$

En tercer lugar, un nutrido grupo de trabajos relacionados con la historia de la historiografía a pesar de no estar directamente vinculados con José María Jover, sirven como plataforma global en la que encuadrar al autor a lo largo de la dictadura franquista. En este sentido, los estudios de Ignacio Peiró y Gonzalo Pasamar abrieron nuevos caminos desde la década de 1980, bajo e magisterio de Juan José Carreras, en el análisis del proceso de profesionalización de los historiadores españoles. ${ }^{9}$ Proceso que, como demostró Gonzalo Pasamar, quedó interrumpido a la altura de la Guerra Civil y la inmediata posguerra. ${ }^{\circ}$ Posteriormente, esta dirección fue continuada con las aportaciones de Miquel Marín Gelabert relativas a la normalización de la historiografía y la disciplinarización de la práctica histórica durante el franquismo, evoluciones entendidas como la estructuración de la actividad historiográfica, con unos márgenes cronológicos (1948-1975) coincidentes, grosso modo, con la trayectoria académica de Jover." Constituyen trabajos de gran utilidad para comprender las dinámicas que confluyen en la creación de una comunidad de historiadores con identidad propia, trazando el entramado institucional en el que se inserta la práctica histórica, así como los inicios de la posterior profesionalización acontecida a finales de los años 1970 e inicios de 1980, a partir de la segunda «hora cero» de la disciplina. ${ }^{2}$ Dentro de ese

de las Relaciones Internacionales en las últimas décadas del siglo XIX y de las primeras del XX", pp. 53-58 y José Antonio PIOUERAS ARENAS: "Treinta años de una llamada a la historia social. (Un hito historiográfico de Jover Zamora)", pp. 229-241.

Rosario RUIZ FRANCO (ed.): Pensar el pasado. José María Jover y la historiografía española, prólogo de Guadalupe Gómez-Ferrer, Madrid, Biblioteca Nueva, 2013.

9 Según ambos autores, la profesionalización es una «categoría socioprofesional que designa el proceso por el cual la escritura de la historia o historiografía se ha convertido en la definición de un grupo. Esto comporta, por una parte, una enseñanza teórica fundamentada en unas categorías generales a todo el grupo; por otra, una metodología y una deontología comunes que permiten reconocer esas categorias; y finalmente un discurso común que, ejercido por las revistas profesionales y las asociaciones, refuerzan la homogeneidad de la profesion". La cita procede de Ignacio PEIRO MARTíN y Gonzalo PASAMAR ALZURIA: "La vía española hacia la profesionalización historiográfica", Studium. Geografia. Historia. Arte. Filosofia, 3 (1991), p. 162. En este mismo sentido, ver Ignacio PEIRO MARTiN: "La aventura intelectual de los historiadores españoles", en Ignacio PEIRÓ MARTÍN y Gonzalo PASAMAR ALZURIA: Diccionario Akal de historiadores..., pp. 9-45. Sirva como ejemplo del desarrollo de este tipo de estudios, en lo que algunos autores han venido a 政 medievalismo profesional. Andrés Giménez Soler (1869-1938), tesina dirigida por Ignacio Peiró Martín, Universidad de Zaragoza, 2012.

- Gonzalo PASAMAR ALZURIA: Historiografía e ideología en la posguerra española: la ruptura de la tradición liberal, Zaragoza, Prensas Universitarias de Zaragoza, 1991.

11 La normalización implica «la creación de normas implícitas y explícitas que organizan la práctica profesional» y «la formulación paulatina de las condiciones necesarias para la estructuración de una comunidad historiográfica profesional en sus formas de sociabilidad, intercambio y reproducción, en el contexto de un entramado legal y de una geografía académica que determinaba ducción, en el contexto de un entramado legal y de una geografia académica que determinaba el desarrollo de la actividad del historiador, el despliegue de sus expectativas y la proyección de sus carreras".. La cita en Miquel MARIN GELABERT: "El aleteo del lepidoptero. La reincorporación de de Uztáriz, 19 (2003), p. 122. Un estudio en profundidad de este proceso en los trabajos de ÍD.: Los historiadores españoles en el franquismo, 1948-1975. La historia local al servicio de la patria, Zaragoza. Institución «Fernando el Católico", 2005, pp. 44-9o e í I.: La historiografía española de los años za. Institución «Fernando el Católico», 2005, pp. 44-9o e iD.: La historiografia española de los años
cincuenta. La institucionalización de las escuelas disciplinares, 1948-1965, tesis doctoral dirigida por Ignacio Peiró Martín, Universidad de Zaragoza, 2008.

12 Un estudio de la profesionalización a partir de la segunda «hora cero» en Miquel MARíN GELABERT: Los historiadores españoles en el franquismo ; e ÍD.: "Subtilitas Applicandi. El mito en la historiografí española del franquismo", Alcres, 1 (2006)...,

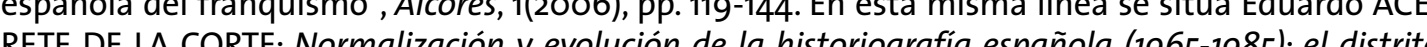


proceso de normalización, Miquel Marín se encargó igualmente de estudiar su plano exterior es decir, los contactos de la historiografía española con sus homólogas europeas en las décadas centrales del siglo XX. Estos planteamientos permiten medir el grado de internacionalización de la historiografía española, ${ }^{13}$ como también hizo Carlos Forcadell, al considerar a Jover, junto con Juan José Carreras, como uno de los nexos de unión con la historiografía alemana. ${ }^{14}$

Sobre Pierre Renouvin y su faceta como renovador de la historia de las relaciones internacionales en Francia, la primera referencia, de obligada consulta, es el Dictionnaire Biographique de Christophe Charle, gracias al cual poseemos información estructurada y clarificadora sobre la trayectoria del historiador en cuestión. ${ }^{15}$ Tras un barrido bibliográfico, y a pesar de su indiscutible trascendencia en el ámbito académico galo, no abundan las referencias sobre su persona y su obra, a pesar de algunas excepciones como las de Maurice Le Lannou, René Girault, Annette y Jean-Jacques Becker o su discípulo, Jean-Baptiste Duroselle. ${ }^{16}$ Estos trabajos profundizan específicamente en los nuevos aportes teóricos del historiador francés, tomando como punto de referencia el concepto de forces profondes. Algo similar ocurre con Federico Chabod, autor escasamente estudiado, salvando la obra de Margherita Angelini que lo sitúa en el contexto historiográfico italiano. ${ }^{17}$

Otros autores, siguiendo con la tendencia apuntada líneas arriba, han abordado de manera específica la influencia de historiografías extranjeras en España durante las décadas de los cincuenta y sesenta. Concretamente la recepción e influencia de los postulados franceses en España desde una óptica comparada y transnacional, tomando como referencia los procesos de transferencias culturales y la circulación de ideas..$^{1}$ Finalmente, algunos historiadores como Karl Dietrich Erdmann o Manuel Espadas Burgos han analizado los Congresos Internacionales de Ciencias Históricas como plataformas de mediación cultural y foros de intercambio de teorías y metodologías. ${ }^{19}$

universitario de Zaragoza, tesina dirigida por Ignacio Peiró Martín, Universidad de Zaragoza, 2011 13 Miquel MARÍN GELABERT: "Historiadores locales e historiadores universitarios. La historiografía espa-
ñola en su contexto internacional, 1948-1965", en Carlos FORCADELL ÁLVAREZ e Ignacio PEIRÓ MARTíN nola en su contexto internacional, 1948-1965", en Carlos FORCAD la Historiografia, Zaragoza, Institución
(eds.): Lecturas de la historia. Nueve reflexiones sobre Historia de la Hito (eds.): Lecturas de la historia. Nueve reflexiones sobre Historia de la Historiografia, Zaragoza, Institucion
"Fernando el Católico", 2001, pp. 97-194 y Miquel MARÍN GELABERT: "El aleteo del lepidóptero...".

14 Carlos FORCADELL:“YA NO TAN DISTANTE: recepción y presencia de la historiografía alemana en la España democrática", Jerónimo Zurita, 84 (2009), pp. 279-294.

15 Christophe CHARLE: Les Professeurs de la Faculté de Lettres de Paris. Dictionnaire Biographique, 19091939, Vol. II, Paris, Institut National de la Recherche Pédagogique, Editions du CNRS, 1986, pp. 181-183. 6 Maurice LE LANNOU: Notice sur la vie et les travaux de Pierre Renouvin: 1893-1974, Paris, Institut de France, Académie des Sciences Morales et Politiques, 1977; René GIRAULT: "Pierre Renouvin, la BDIC et l'historiographie française des relations internationales , Materiaux pour 'histoire de notre temps, 49-50 (1998), pp. 7-9; Annette BECKER y Jean-Jacques BECKER: “Pierre Renouvin” en Véronique SALES, 作, Aris, Armand Colin, 2003, pp. 104-118; Jean-Baptiste. DUROSELLE: "Pierre Renouvin et la science politique", Revue française de science politique, 3 (1975), pp. 561-574

17 Margherita ANGELINI: Fare storia. Culture e pratiche della ricerca in Italia da Gioacchino Volpe a Federico Chabod, Roma, Carocci Editore, 2012.

8 René. GIRAULT: "Reflexions sur la methodologie de l'histoire des relations internationales. L'exemple des relations franco-espagnoles", en AA.VV: Españoles y franceses en la primera mitad del siglo XX Madrid, CSIC, 1986, pp. 151-160. Julio ARÓSTEGUI: "La teoría de la historia en Francia y su glo XX, Madrid, CSIC, 1986, pp. 151-160; Julio AROSTEGUI: "La teoria de la historia en Francia y su influencia en la historiografia española" y Jordi CANAL i MORELL: "Admoniciones, mitos y crisis. siglo XX", ambos en Benoît PELLISTRANDI (ed.): La historiografia francesa del siglo XX y su acogida siglo XX", ambos en Benoit PELLISTRANDI (ed.): La historiografia fra
en España, Madrid, Casa de Velázquez, 2002, pp. 365-406 y $337-364$.

19 Karl DIETRICH ERDMANN. Toward a Global Community of Historians. The International Historical Karl DIETRICH ERDMANN: Toward a Global Community of Historians. The International Historical Congresses and the International Committee of Historical Sciences, 1898-2000, New York, Oxford, Berghahn Books, 2005; Manuel ESPADAS BURGOS: Un lugar de encuentro de historiadores. España y los Coras

\section{Planteamientos teóricos y metodológicos}

Debido a la naturaleza de la investigación, resulta imprescindible un primer acercamiento a la materia a través de las transferencias culturales y la circulación de ideas. Ambos campos proporcionan el marco teórico y conceptual de referencia, así como los recursos metodológicos y epistemológicos a partir de los cuales iniciar el estudio propiamente dicho. Puesto que el fundamento del presente trabajo gira en torno a la recepción de una serie de corrientes historiográficas por parte de José María Jover y su posterior desarrollo en España, la perspectiva comparada y la historia de tipo transnacional deben ser una constante a lo largo de la realización de la investigación. Pero, para que ésta no se limite únicamente a la relación de tipo intelectual entre los autores estudiados, las conclusiones extraídas deben extrapolarse a un marco más global, es decir, a las condiciones académicas e historiográficas de la universidad española durante el franquismo en relación con el contexto europeo. En este sentido, se observa la necesidad de combinar tanto el estudio de los elementos personales -micro- como otros de tipo ambiental, estructural e institucional.

La intención de superar el tradicional marco nacional como referencia de estudio para la historiografía ha sido una constante a lo largo de todo el siglo XX. Desde que en 1928 Marc Bloch abogara por el desarrollo de estudios históricos desde una perspectiva comparada, ${ }^{20}$ en el seno de la historiografía europea se han suscitado diversos e interesantes debates en torno al hecho transfronterizo y las transferencias culturales. Cuando a finales de la década de 1980 Michael Espagne y Michael Werner conceptualizaron la noción de «transferencia», dieron lugar a toda una corriente teórica con un utillaje propio que, desde entonces, iba a devenir crucial no sólo para los estudios de historia intelectual, sino para el conjunto de las ciencias sociales. ${ }^{21}$

Francia fue el núcleo originario de la teoría de las transferencias cultuales y, concretamente, se cimentó sobre el estudio de los intercambios culturales mutuos con Alemania en la época contemporánea. Esta nueva perspectiva pretendía romper con el hastío producido por las férreas ataduras del marco estatal como paradigma de investigación histórica pero, además, surgía de la incomodidad con la antigua historia comparada, ${ }^{22}$ acusándola de limitarse al aná-

riche (Roma 1955) cinquant'anni dopo, Atti del convegno internazionale. Roma, 21-24 settembre 2005, Unione Internazionale degli Istituti di, Archeologia, Storia e Storia dell'Arte in Roma, 2005.

20 Marc BLOCH: "Pour une histoire comparée des sociétés européennes", Revue de Synthèse Historique, 46 (1928), pp. 16-50.

21 Michael ESPAGNE y Michael WERNER: Transferts, les relations interculturelles dans l'espace franco-allemand XVIIIle et XIXe siècle, París, Recherche sur les civilisations, 1988. Un año antes, ambos autores publicaron su «manifiesto» en la revista Annales: İD.: “La construction d'une référence culturelle allemande en France: Genèse et histoire (1750-1914)", Annales Économies. Sociétés. Ci
vilisations, 4 (juillet-aout 1987), pp. 969-992. La noticia de este artículo programático procede de vilisations, 4 (juillet-août 1987), pp. 969-992. La noticia de este artículo programático procede de
María José SOLANAS BAGÜÉS: "Tranferencias culturales: origen, desarrollo y aplicación al estudio
de la historia de la historiografía española" en Ignacio PEIRÓ MARTíN y Pedro RÚJULA, (coords.): de la historia de la historiografia española" en Ignacio PEIRO MARTIN y Pedro RUUULA, (coords.);
La historia en el presente. $V$ Congreso de Historia Local de Aragón, Molinos, Instituto de Estudios La historia en el presente. V Congreso de Historia Local de Aragón, Molinos, Instituto de Estudios
Turolenses, 2007, pp. 379-392. El presente apartado metodológico es deudor de este trabajo. En Turolenses, 2007, pp. 379-392. El presente apartado metodológico es deudor de este trabajo. En
un plano más teórico, encontramos las aportaciones de Francois CHAUBET: "La notion de transun plano mas teoorico, encontramos las aportaciones de François CHAUBET: "La notion de trans-
fert culturel dans I'histoire culturelle" y Antonio NINIO RODRÍGUEZ: "Relaciones y transferencias culturales internacionales", ambos en Benoît PELLISTRANDI y Jean-François SIRINELLI: L'histoire culturales internacionales", ambos en Benoît PELLISTRANDI y Jean-François SIRINELLI: L'histoire
culturelle en France et en Espagne, Madrid, Casa de Velázquez, 2008, pp. 159-178 y 179-208. Y la obra de François CHAUBET y Laurent MARTIN: Histoire des relations culturelles dans le monde contemporain, Paris, Armand Colin, 2011

22 En este punto diversos trabajos abordan, desde una perspectiva teórica, la historia comparada: En este punto diversos trabajos abordan, desde una perspectiva teorica, la historia comparada: Peter SCHOTTLER: "Le comparatisme en histoire et ses enjeux: lexemple franco-allemand", y Thie-

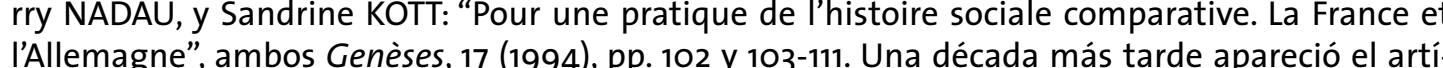
l'Allemagne", ambos Genèses, 17 (1994), pp. 102 y 103-11. Una década más tarde apareció el artíréflexivité", Annales. Histoire, Sciences Sociales, 58 (2003/1), pp. 7-36, en el que defendia la validez 
lisis mecánico de diferentes historias nacionales superpuestas, sin una verdadera vocación de conectar ambas realidades. ${ }^{23}$

En estrecha relación con lo anterior se muestran los presupuestos de la historia transnacional, en alusión al movimiento y circulación transfronterizos de personas, ideas, tecnologías e instituciones. Lo transnacional, a caballo entre el concepto francés de mondialisation y la globalización de corte anglosajón, sitúa al Estado en relación a su contexto exterior, de modo que, a diferencia de las viejas historias nacionales, no se individualiza ni se compartimentaliza su estudio. En esta concepción, lo que prima es la relación y tensión constantes con el entorno global en el que se inscribe el Estado, retroalimentándose de manera continua con todo aqueIlo que procede del exterior. La frontera pasa a un segundo plano, puesto que lo que verdaderamente importa desde esta óptica, son los espacios intermedios, las culturas y tradiciones propias de los pueblos y la evolución y desarrollo de las instituciones. ${ }^{24}$

En consecuencia, y desde la perspectiva de la historia de la historiografía española, el seguimiento retrospectivo del establecimiento de redes académicas y profesionales con otros países del entorno europeo debe hacerse a partir de la identificación de los préstamos o transferencias culturales. Las influencias, acomodaciones, recepciones o rechazos de teorías y corrientes han de ser considerados como algo propio y natural dentro de la disciplina histórica, evoluciones todas ellas enmarcadas dentro de un proceso más global como es el de la normalización externa de la historiografía en España.

Lo novedoso de la teoría de las transferencias culturales, además de tomar como referente de estudio el campo del que proviene el elemento de aculturación (es decir, la cultura originaria -siguiendo, en cierto sentido, la teoría de los campos de Pierre Bourdieu-), ${ }^{25}$ pone su enfoque en la cultura receptora. De este modo se descarta una posible relación o posición jerárquica de inferioridad por parte de la cultura que recibe la influencia, debiendo tomar las condiciones político-culturales y sociales del medio receptor como tema de análisis. Así, la reconstrucción de las redes de intercambio y el papel de los mediadores culturales se desvelan como piezas clave a lo largo de la investigación, razón por la cual se debe prestar especial interés al análisis de los documentos, así como al posterior discurso ideológico desarrollado a partir de los mismos para medir el grado y la dimensión de la recepción de la transferencia cultural, en este caso, la teoría de las relaciones internacionales.

Dentro de los fenómenos de mediación cultural aplicados al plano historiográfico, las estancias académicas en el extranjero y los desplazamientos internacionales de los historiadores constituyen elementos fundamentales para nuestro estudio. De este punto se nutren corrientes historiográficas como las historia de los intelectuales y, de manera más específica,

de la historia comparada como fundamento metodológico sin despreciar los logros de las transferencias culturales.

23 Michael ESPAGNE: "Sur les limites du comparatisme en histoire culturelle", Genèses (1994), pp. 112-121. 24 Stefan BERGER: "National Historiographies in Transnational Perspective: Europe in the Nineteenth and Twentieth Centuries", Storia della Storiografia, 50 (2006), pp. 3-26; İD.: "Introduction: Narrating the Nation: Historiography and Other Genres", en Stefan BERGER, Linas ERIKSONAS y Andrew MYCOCK (eds.): Narrating the Nation. Representations in History, Media and the Arts, New Andrew MYCOCK (eds.): Narrating the Nation. Representations in History, Media and the Arts, New
York, Oxford, Berhahn Books, 2008, pp. 1-18; Xosé Manoel NÚÑEZ SEIXAS: “History of Civilization: York, Oxford, Berhahn Books, 2008, pp. 1-18; Xosé Manoel NUNNEZ SEIXAS: "History of Civilization: Transnational or Post-Imperial? Some lberian Perspectives (1870-1930)", en Stefan BERGER y Chris Ilan, 2010, pp. 384-403 y la recopilación de trabajos en Christophe CHARLE, Jürgen SCHRIEWER y Ilan, 2010, pp. 384-403 y la recopilacion de trabajos en Christophe CHARLE, Jurgen SCHRIEWER y Search for Cultural Identities, Frankfurt, New York, Campus Verlag, 2004.

25 Pierre BOURDIEU: "Les conditions sociales de la circulation internationale des idées", Actes de la Recherche en Sciences Sociales, 145 (2002), pp. 3-8. la historia de la movilidad y de las migraciones universitarias. ${ }^{26}$ Dichos fenómenos han contribuido a conformar unas redes de intercambios que actúan a modo de complemento teórico y ayudan a desarrollar unas metodologías de trabajo y unos enfoques nuevos y originales, no importados mecánicamente sino con una adecuación a los moldes previos del núcleo receptor.

$Y$ decimos que este aspecto resulta crucial para nosotros porque Jover cumple, de manera ejemplar, con las características que se le suponen a un mediador cultural. Su asistencia al $X$ Congreso Internacional de Ciencias Históricas de Roma en 1955 y su estancia en la Universidad alemana de Friburgo de Brisgovia a principios de los años sesenta, los situaron, -máxime en un momento de autarquía cultural en el que la historiografía española había quedado relegada a los márgenes y la periferia europea-, en una posición de privilegio, como punto intermedio y nexo de unión entre diversas historiografías europeas.

\section{Hipótesis de Trabajo}

La hipótesis central de la investigación parte de la premisa previa que considera que la nueva historia de las relaciones internacionales supuso, globalmente, una profunda renovación y un aporte teórico y metodológico incuestionable respecto a las viejas formas de historiar la relación entre Estados. En este sentido, José María Jover fue el verdadero introductor de este tipo de estudios en la historiografía española desde la década de los cincuenta, poniendo punto y final a la historia diplomática que había ido desarrollándose desde el siglo XIX. Su labor contribuyó no sólo a la renovación de la historia de las relaciones internacionales en España sino de toda la historiografía española en general.

Del mismo modo, a pesar de que los primeros contactos de la historiografía española con la obra de Pierre Renouvin se produjeron con anterioridad, sobre todo a través de la sociología y la ciencia política durante la década de 1930, ${ }^{27}$ Jover fue el verdadero receptor, introductor y dinamizador de los nuevos planteamientos teóricos del historiador francés en España, madurándolos con posterioridad junto con los de procedencia italiana, como es el caso de la obra de Federico Chabod.

La trayectoria académica e intelectual de Jover evidencia una serie de características a partir de las cuales se puede afirmar que toda su labor puede ser inscrita en los procesos de cambios y las mutaciones que tuvieron lugar en la historiografía española a lo largo de las décadas de 1950 y 1960. En otras palabras, constituye uno de los más claros exponentes del proceso de normalización externa acontecido en la historiografía española durante la dictadura.

El nuevo contemporaneismo historiográfico español apareció a partir de las escuelas disciplinares del franquismo, siendo las matrices medievalista y modernista madrileñas el epicentro. Como ha demostrado Miquel Marín, la «fatiga generacional» de muchos historiadores dedicados a la Historia Moderna coadyuvó a que se abrieran nuevos caminos en la investigación histórica, aproximándose progresivamente hacia unas temáticas no exploradas y cronológicamente más cercanas. ${ }^{28}$

26 Christophe CHARLE: La République des universitaires, 1870-1940, París, Seuil, 1994; ÍD.: "Ambassadeurs ou chercheurs? Les relations internationales des professeurs de la Sorbonne sous la Ille République", Genèses, 14 (1994), pp. 42-62. Y también la obra de François DOSSE: La marche des idées. Histoire des intellectuels, histoire intellectuelle, Paris, La Découverte, 2003

27 Hemos encontrado una primera y muy temprana reseña bibliográfica de la obra de Pierre RENOUVIN: La crise européene et la Grande Guerre (1904-1918), Paris, F. Alcan, 1934, a cargo de Agusti de MONTCLAR en Criterion. Revista Trimestral de Filosofia, 35 (gener-juny de 1934), pp. 137-139. La noticia de esta mención a la obra de Renouvin ha sido posible gracias al servicio digital del Arxiu de Revistes Catalanes Antigues (ARCA).

28 Ver Miquel MARÍN GELABERT: “La fatiga de una generación. Jaume Vicens Vives y su Historia crítica vida y reinado de Fernando II de Aragón, "Colección Historiadores de Aragón», Zaragoza, Institu- 
Por esta razón, la siguiente cuestión que surge a nuestro paso es la relación que pudo darse entre el tránsito o metamorfosis, según conceptualizara Ignacio Peiró, del modernismo primigenio joveriano y su posterior contemporaneismo con el creciente interés por la historia de las relaciones internacionales. A todas luces parece evidente que la nueva concepción histórica de Renouvin jugó un papel determinante en la «mutación de identidad» de Jover como historiador, al igual que los meses que pasó en la Universidad de Friburgo en 1961. ${ }^{29}$ Estos contactos internacionales, que actuaron a modo de plataforma de intercambio de corrientes teóricas y metodológicas, permitieron que Jover diese su salto a Europa.

En consecuencia, jpodemos afirmar que José María Jover creó una escuela disciplinar en Valencia, desgajada del núcleo madrileño, tras su llegada a la cátedra en 1949?; e incluso, ¿fundó una escuela dedicada al estudio de las relaciones internacionales contemporáneas que se desarrollaría a lo largo de las dos décadas siguientes? La respuesta a las cuestiones planteadas sólo podrá hallarse teniendo en cuenta los lazos académicos y profesionales tendidos en la ciudad mediterránea -y también en Madrid-, así como la huella que pudo dejar en muchos de sus discípulos. El análisis y valoración de las tesis doctorales dirigidas por Jover, junto con los circuitos de promoción y las redes con el mundo editorial también pueden ofrecer algo de luz a tales preguntas.

De manera explícita, el estudio historiográfico de Jover debe extrapolar los resultados a un nivel más global, es decir, inscribirlos en el proceso de normalización y apertura que experimentó la historiografía española a partir de los años 1950 y 1960. Valorando la implicación y responsabilidad que José María Jover pudiera tener en dicho proceso, junto con otros autores como Jaume Vicens Vives o los historiadores españoles en el exilio -quienes establecieron sólidos contactos profesionales con los hispanistas-, se debe sopesar en qué medida la historiografía española de aquellos años inicia su despegue tomando las "coordenadas europeas» como referencia o modelo a seguir, es decir, hasta qué punto la historiografía española se internacionaliza, se homologa y estandariza con sus escuelas vecinas.

\section{Fuentes}

El desarrollo de la investigación parte de la consulta y manejo de dos tipos de fuentes primarias. Por una parte, las de tipo documental, conservadas en diversos archivos españoles, y por otra, las de tipo literario, es decir, la producción bibliográfica de José María Jover.

Las fuentes documentales se conservan en tres archivos. En primer lugar, el Archivo Genera de la Administración (AGA), sito en Alcalá de Henares, contiene el grueso de la documentación relativa a la oposición de Jover a la cátedra de «Historia Universal Moderna y Contemporánea e Historia General de la Cultura Moderna y Contemporánea» de la Universidad de Valencia en 1949. El Expediente de la oposición ${ }^{30}$ posibilita un estudio de la prueba de acceso al puesto, lo cual proporciona una primera imagen de sus conocimientos como historiador modernista. Con ello, se establece el punto de partida inicial de su posterior evolución, observando de manera progresiva los cambios y transformaciones de su práctica histórica.

Otros dos documentos conservados en el AGA son el Programa de la asignatura a la que aspiraba y la Memoria de oposición. ${ }^{31}$ El primero de los citados ofrece una propuesta de es-

ción «Fernando el Católico», 2006, pp. XIII-CXX.

29 El concepto de «mutación de identidad» de los historiadores franquistas en Miquel MARÍN GELABERT: Los historiadores españoles en el franquismo..., pp. 79-82.

30 Expediente de oposición de José María Jover Zamora (1949), AGA 31-04050.

31 José María JOVER: Programa de la asignatura de Historia Universal de las Edades Moderna y Contemporánea e Historia general de la Cultura (moderna y contemporánea) (1949) ACA $31-04052$ 1949: iD. Memoria sobre concepto, método fuentes y enseñanza de la Historia Universal Moderna y Contemporánea (1949), AGA 31-04052. tructuración de la asignatura a lo largo de casi cinco siglos de historia, con especial incidencia en aspectos artísticos, filosófico-religiosos, ideológicos y culturales. Esta información, en función del peso e importancia concedidos a cada rama, muestra en qué medida Jover, en 1949, podía ser calificado como un uhistoriador de las ideasn sin incurir respecta al segundo documento, la Memoria de oposición recoge de manera sobresaliente la concepción histórica de Jover. En sus páginas desarrolla extensamente un conjunto de consideraciones de tipo epistemológico y metodológico, así como alguna pincelada sobre la didáctica de la Historia en los niveles universitarios. La comparación de este texto con la Memoria que elaboró doce años más tarde, con motivo de su estancia en la Universidad de Friburgo de Brisgovia, ilustra la dirección que tomaron sus investigaciones, así como la evolución y variación temática, metodológica y cronológica de sus estudios.

En este mismo archivo se encuentran también dos textos del mismo autor. El primero, Tres actitudes ante la paz con Portugal, data de 1948 y constituye el texto original que, con variaciones, se publicaría dos años más tarde en la revista Hispania..$^{32} \mathrm{~A}$ modo de ensayo histórico, recoge un conjunto de reflexiones sobre las causas, pero sobre todo, las consecuencias y la trascendencia histórica de la escisión lusa de la monarquía hispánica, con especial incidencia en las corrientes de pensamiento político gestadas en España a raíz de dicho acontecimiento. En el segundo de los citados documentos, Sobre los conceptos de monarquía y de nación en el pensamiento político español del XVII,33 coincidiendo con su estancia en el Instituto "Jerónimo Zurita", dependiente del CSIC, en calidad de becario (1944-1948), el autor pretende realizar un esbozo de los desplazamientos de significado y las transformaciones conceptuales de términos como «nación española», «monarquía española», «naciones de España», «reinos de España», «monarquía católica», «España», etc., atendiendo a las connotaciones y particularidades internas de la concepción de esos elementos por el pensamiento político español del siglo XVII y cómo han sido interpretados posteriormente por la politología y la técnica jurídica.

El segundo de los fondos documentales consultados es el que se encuentra en el Archivo Histórico de la Universidad de Valencia (AHUV). El Expediente Personal que se conserva abarca la totalidad de su estancia en dicha universidad, desde 1949 hasta 1964, año de su traslado a la Universidad de Madrid. ${ }^{34}$ Sin ninguna duda, este es el documento que más y mejor contribuye a reconstruir su etapa académica en Valencia. La hoja de servicios es muy completa, tanto anterior como posteriormente a su nombramiento como catedrático. En ella figuran los cargos académicos e institucionales que ostentó, tanto en la Universidad -llegando a ser vicedecanocomo en la Institución «Alfonso el Magnánimo» de la Diputación Provincial de Valencia y en el CSIC. También aporta un listado completo de sus publicaciones durante ese período, algunas de las tesis por él dirigidas y las asignaturas y cursos monográficos impartidos en su actividad como docente. De la misma manera, recoge los permisos para sus desplazamientos internacionales (Portugal y Alemania), así como su evolución en los escalafones de catedráticos con la consiguiente dotación económica.

En tercer lugar, la Biblioteca Española de Música y Teatros Contemporáneos del Archivo de la Fundación Juan March, situado en Madrid, conserva la Memoria justificativa de las motivaciones y actividades desarrolladas por Jover en la Universidad alemana de Friburgo de Brisgo-

32 José María JOVER: Tres actitudes ante la paz con Portugal (1948), AGA 31-04051, 82 pp., publicado como "Tres actitudes ante el Portugal Restaurado", Hispania, 38 (1950), pp. 104-170.

33 José María JOVER: Sobre los conceptos de monarquía y de nación en el pensamiento político español del XVII, AGA 31-04051, sin fecha, 67 pp., publicado en Buenos Aires por Claudio Sánchez-Albornoz como "Sobre los conceptos de monarquía y de nación en el pensamiento político español del XVII", Cuadernos de historia de España, 13 (1950), pp. 101-150.

34 Expediente Personal de José María Jover Zamora, AHUV, caja 112, $n^{\circ} 7$ 
via en 1961.35 El objetivo de aquella estancia era trazar las líneas maestras por las que discurría la historiografía contemporaneísta en Alemania y ello queda brillantemente expuesto en este documento. A diferencia de las anteriores, esta pieza aporta una información crucial en lo referente a la historia de las relaciones internacionales. Gracias a ello, conocemos la evolución de la concepción joveriana de la política exterior española respecto a lo expuesto en aquella Memoria valenciana de 1949. Los nuevos referentes teóricos en los que apoyó sus investigaciones a partir de entonces -Ludwig Dehio, Geoffrey Barraclough o Herbert Butterfield- quedan plasmados en este texto de índole historiográfica.

El segundo tipo de fuentes manejadas para la consecución de este estudio son las bibliográficas derivadas de su práctica historiográfica. Mediante el análisis de las principales obras de José María Jover dedicadas a la historia de las relaciones internacionales se puede profundizar en su concepción sobre esta disciplina histórica, vislumbrando la evolución de su pensamiento. Las grandes etapas de producción bibliográfica y los momentos precisos de la recepción de los postulados internacionales constituyen los criterios básicos con los que enfrentarse a su extensa obra. Debido a sus distintas facetas como historiador, Jover abordó muchos y muy diversos temas de estudio -y varias épocas-, desde la historia de las relaciones internacionales a la historia de la historiografía, pasando por la historia social, la historia política o la historia de la cultura y de las mentalidades. Por esta razón y ante la imposibilidad de abarcar todos sus escritos, hemos de señalar que generalmente nos hemos limitado al manejo de aquellos trabajos que tienen como columna vertebral la historia de las relaciones internacionales. ${ }^{36}$

35 Memoria de becario de José María Jover Zamora de la Fundación Juan March (23 de octubre de 1961). Biblioteca Española de Música y Teatros Contemporáneos de la Fundación Juan March de Madrid. Alberga el texto de José María JOVER: "Las tendencias actuales de la historiografía alemana en el campo de la Historia Contemporánea". Descubierto por María José Solanas Bagüés, hemos consultado este documento gracias a su amabilidad.

36 Ver Jorge AZORÍN ARROYO: El salto a Europa: José María Jover Zamora y la historia de las relaciones

internacionales, tesina dirigida por Ignacio Peiró, Universidad de Zaragoza, 2013, p. 78, donde se recogen todos los trabajos de José María Jover. 


\section{LA INFLUENCIA DEL PAÍS DE ACOGIDA \\ EN LOS ESTUDIOS DE LOS HISTORIADORES \\ EXILIADOS EN AMÉRICA LATINA: EL CASO DE \\ LOS EXILIADOS EN MÉXICO}

Sara Martín Casamayor

Universitat de València

\section{Presentación de la comunicación.}

La palabra exilium, del latín, significa separar a una persona de la tierra en la que vive. Se trata del obligado abandono de lo propio, por lo que supone una condena en la medida que impone el desarraigo. ' En el caso de los exiliados republicanos, que comenzaron a emigrar de España desde poco tiempo después del inicio de la Guerra Civil, y, en concreto, en relación a los historiadores e intelectuales exiliados en México, se emplea también el término de "transterrados", el cual es opuesto a destierro y matiza el desarraigo que caracteriza la definición de exilium.

En esta comunicación, partimos de la idea de que el exilio modificó, en muchos casos, los temas de investigación de los historiadores españoles. En concreto, consideramos que fue el apoyo proporcionado por determinados países que acogieron a los intelectuales lo que propició la continuación del desarrollo de su carrera profesional, la cual no podía continuar en el país de origen.

La ayuda ofrecida a los historiadores y otros intelectuales se materializó en ciertas instituciones y disposiciones que a continuación comentaremos. Dentro del ámbito de América Latina, destino importante de exiliados españoles, trataremos específicamente el caso de México, dada la importancia singular su actuación. Haremos incidencia también en los temas de estudio a los que se dedicaron los historiadores tras el exilio y el modo en que concebían ellos su situación, más allá del ámbito puramente personal, en sentido filosófico.

\section{El camino hasta México}

El éxodo de profesores e intelectuales republicanos comenzó muy pronto. No solo se debió a su compromiso político o a su participación política directa, también se exiliaron aquellos profesionales que, a lo largo de su trayectoria investigadora y docente en las universidades españolas, habían dado muestras de su condición progresista y liberal; ${ }^{2}$ asimismo hubo quienes lo hicieron, simplemente, dada la posibilidad de la muerte. ${ }^{3}$

Desde poco tiempo después de la sublevación militar que dio paso a la Guerra Civil Española en julio de 1936, el Gobierno de la República facilitó la salida del país a diferentes intelectuales, entre los cuales se encontraban historiadores: José Ortega y Gasset, Ramón Menéndez Pidal, Juan Ramón Jiménez, Gregorio Marañón, Ramón Gómez de la Serna, Américo Castro o Azorín ${ }^{4}$

1 Silvia DUTRÉNIT BIELOUS: “Los exilios: una impronta regional”, en Joan DEL ALCÀZAR (ed.): Historia actual de América Latina, Valencia, Tirant lo Blanch, 2011, p. 129.

2 Carmen Rosa CUBAS VALENTÍN, Nuria JUANES PRIETO, Juan F. ROMÁN RODRÍGUEZ.: "Historiadores españoles exiliados en América", Boletín Millares Carlo, 13 (1994), p. 339.

3 María Fernanda MANCEBO: "Profesores universitarios en el exilio", en Ángeles EGIDO LEÓN y Matilde EIROA SAN FRANCISCO (eds.): Los grandes olvidados. Los republicanos de izquierda en el exilio, Madrid, C.I.E.R.E., 2004, p. 371.

4 Vicente LLORENS: Estudios y ensayos sobre el exilio republicano de 1939, Sevilla, Biblioteca del Exi-
Algunos de los que partieron al exilio lo hicieron hacia otros países de Europa, como la Francia del Frente Popular liderado por Léon Blum. No obstante, el estallido de la Segunda Guerra Mundial en 1939 y, en el caso de Francia, especialmente la ocupación nazi del país en 1940, agudizaron la inestabilidad de los emigrados. Aquellos que pudieron marcharse, eligieron nuevos destinos de emigración, entre los que destaca América Latina; en el caso de los intelectuales dedicados a las letras la mayoría de ellos eligió tal destino. ${ }^{5}$ Aunque hubo otros países de América Latina que contaron con la presencia más o menos prolongada de exiliados y, en concreto, de historiadores, como Cuba, República Dominicana, Panamá, Venezuela o Argentina (país este último en el que destaca la presencia de Claudio Sánchez-Albornoz, medievalista que desarrolló una actividad de gran transcendencia), el papel de México, ya desde el inicio de la Guerra Civil, no tuvo parangón.

De hecho, en el transcurso de la guerra en España, México y la Unión Soviética fueron los únicos países que brindaron ayuda a la República a nivel estatal. México la apoyó de diferentes maneras, entre las cuales cabe mencionar su defensa en la Sociedad de Naciones y el envío de armas, tras un complicado proceso de contrabando vía Holanda o Bélgica ${ }^{6}$ y en vista del flagrante incumplimiento del Acuerdo de No Intervención por parte del otro bando.

Además, el presidente mexicano Lázaro Cárdenas ofreció acoger en su país a un grupo de intelectuales. Posteriormente, dado el establecimiento en Francia del gobierno de extrema derecha del Mariscal Pétain, que, de manera legal y con la intermediación de Franco, inició una venganza de Estado contra las izquierdas, el presidente mexicano envió a Luis Íñigo Rodríguez como ministro plenipotenciario de México en Francia para ofrecer la acogida en su país a los refugiados españoles en general. ${ }^{7}$

Por otro lado, el estallido de la Segunda Guerra Mundial también provocó el traslado a México de la Junta de Cultura Española, fundada en marzo de 1939 en París por un grupo de intelectuales. Independientemente del Servicio de Evacuación de Refugiados Españoles (SERE) creado por la República, la Junta tenía como objetivo principal salvar el espíritu de la cultura española y mantener unidos a los intelectuales españoles. En México se crearon una biblioteca, un centro cultural y una revista, España peregrina, si bien la Junta desapareció un año después, debido a la algo complicada situación política de México.

Con todo, de los aproximadamente 35.000 republicanos españoles que encontraron asilo en el continente americano, unos 22.000 lo hicieron en México. ${ }^{8}$ En lo que se refiere al colectivo de los historiadores, al exilio partieron profesores universitarios, de Segunda Enseñanza docentes de las Escuelas Normales de magisterio, archiveros y bibliotecarios (poco más de un centenar). No fueron muchos, teniendo en cuenta las cifras totales del exilio, pero debido a la altura intelectual de muchos de ellos, la influencia que ejercieron en los países que les brindaron asilo fue decisiva.

lio, 2006, p. 287 .

5 Carmen Rosa CUBAS VALENTÍN, Nuria JUANES PRIETO, Juan F. ROMÁN RODRIGUEZ:: "Historiadores españoles exiliados en América", Boletín Millares Carlo, 13 (1994), p. 339.

6 Carlos BLANC AGUINAGA: "Ültimas y muy parciales meditaciones sobre el exilio en México", en Manuel AZNAR SOLER y José Ramón LóPEZ GARCíA (eds.): El exilio republicano de 1939 y la segunda generación, Sevilla, Renacimiento, 2011, p. 61.

7 Jordi GUIXÉ COROMINES: La república perseguida. Exilio y represión en la Francia de Franco, 19371951, Valencia, PUV, 2012, p. 155.

8 Alicia ALTED VIGIL: “Historiadores exiliados en América latina”, en Andrea PAGNI (ed.): El exilio re publicano español en México y Argentina. Historia cultural instituciones literarias, medios, Madrid,

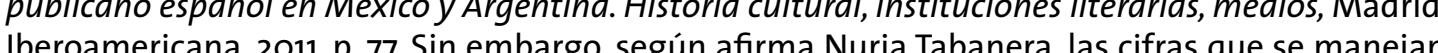
sobre los exiliados en México son variables y Clara E. Lida ha reducido en sus trabajos el número de 25000 a 1700 . Nuria TABANERA: “Presentación", en Arturo CARCIA IGUAL: Entre aquella España 


\section{Los historiadores españoles acogidos oficialmente en México.}

La ayuda de México que llegó hasta los intelectuales emigrados se debió en parte a la acción de intelectuales mexicanos, que desde 1937 pidieron al gobierno que realizara las estructuras necesarias para acoger a unos treinta intelectuales españoles de prestigio. Entre estos intelectuales mexicanos se hallaban Daniel Cosío Villegas y Alfonso Reyes. Asimismo, la iniciativa contó con la ayuda económica de varias instituciones mexicanas: la Secretaría de Educación, el Fondo de Cultura Económica, el Banco Nacional de México y la Universidad Nacional.

Entre las instituciones que se dedicaron a acoger a los intelectuales exiliados destaca especialmente La Casa de España en México, fundada en 1938 expresamente para posibilitar a estos exiliados la oportunidad de continuar sus trabajos. Tras la propuesta de Daniel Cosío Villejas, historiador, economista y diplomático, el presidente Cárdenas firmó un decreto para la creación de tal institución, autorizando finalmente una capacidad de cincuenta personas. La iniciativa del presidente Lázaro Cárdenas tenía el fin de acoger temporalmente a los científicos, académicos y artistas amenazados por la Guerra Civil. ${ }^{9}$

El primer historiador exiliado que se vinculó con La Casa de España fue José Moreno Villa y poco después lo hizo Agustín Millares Carlo, gran erudito. La Casa seleccionó a los científicos, artistas e intelectuales refugiados más distinguidos como miembros residentes, si bien buscó otro destino laboral en otras instituciones del país para aquellos que no tenían cabida en ella. También estuvieron vinculados con esta institución Ramón Iglesia Praga, el político e investigador Luis Nicolau d'Olwer, Rafael Altamira, el paleógrafo José Ignacio Mantecón, José María Miguel i Vergués, especialista en la historia de la independencia mexicana, y José Miranda, que provenía del campo del derecho político y quien aportó abundantes temas a la historiografía mexicana. Los gastos fueron financiados por el Estado mexicano y el presupuesto permitió que los refugiados recibieran desde el principio sueldos y percepciones comparables a las de sus colegas mexicanos profesores de universidad, aunque tales retribuciones no eran muy altas. ${ }^{\circ}$

Por tanto, La Casa de España en México ofreció a los intelectuales españoles un marco institucional para poder continuar con sus actividades profesionales y aportar sus conocimientos al desarrollo de las diferentes disciplinas de su especialidad en el país que los acogía. Se creó teniendo como modelo el Centro de Estudios Históricos (CEH) de Madrid y quedó ligada, desde su fundación, a instituciones mexicanas de educación superior. Alfonso Reyes fue su director a partir de marzo de 1939 y conocía bien el CEH de España, puesto que trabajó en él bajo la dirección de Menéndez Pidal debido a que entre 1914 y 1924 estuvo exiliado en España. El CEH había sido fundado en Madrid en 1910, bajo el amparo de la Junta para Ampliación de Estudios e Investigaciones científicas (JAE), dentro de un amplio proyecto de política cultural en España, cuyo principal objetivo era la reforma de la enseñanza universitaria y de la investigación, en línea con las innovaciones pedagógicas y científicas que se estaban produciendo en el resto de Europa.

A través de La Casa se desarrollaron y estrecharon lazos entre la comunidad académica, científica y artística de México y los recién llegados, por medio de exposiciones, conciertos, conferencias, cursos o seminarios." Asimismo, esta institución desarrolló una serie de actividades culturales cada vez más variadas conforme se incorporaban nuevos intelectuales e intensificó en los momentos finales de la guerra sus gestiones para recibir a más escritores, artistas y científicos que solicitaban ser acogidos en muchos casos.

Clara E. LIDA: El Colegio de México en sus 70 años: 1940-2010. Recuperado de internet (http://www. colmex.mx/index.php?.option=com content\&view=article\&id=64 \&ltemid $=54$ )

o Clara E. LIDA: “Un exilio en vilo", en Andrea PAGNI (ed.): El exilio republicano español en México y Argentina. Historia cultural, instituciones literarias, medios, Madrid, Iberoamericana, 2011, p. 25.
Lluis DE LLERA: Filosofía en el exilio: España redescubre América, Madrid, Encuentro, 2004, p. 52.

11 Clara E. LIDA: “Un exilio en vilo", en Andrea PAGNI (ed.): El exilio republicano español en México y Argentina. Historia cultural, instituciones literarias, medios, Madrid, Iberoamericana, 2011, p. 25.
Gracias a todo ello, múltiples instituciones mexicanas, como la Universidad Nacional y las de los estados o la Escuela Nacional de Antropología e Historia, entre otras, se nutrieron de las labores y enseñanzas de los exiliados. Con todo, La Casa no solo proporcionó una rica actividad intelectual y académica propias, sino que, transformada en una institución de altos estudios, funcionó como centro de irradiación o de distribución del talento de los republicanos hacia diferentes esferas profesionales mexicanas."

Tras la Guerra Civil Española, el 8 de octubre de 1940 el Patronato de la Casa de España, encabezado por Alfonso Reyes, decidió modificar el nombre del centro, ya que era percibido como demasiado ligado al grupo de los exiliados y tenía una connotación de viejo colonialismo: se transformó en el Colegio de México, cuya existencia continúa en el presente. Asimismo, el cambio se debió a la pretensión de dar estabilidad y continuidad a la institución más allá de la circunstancia que dio lugar a su origen. El nuevo Colegio dio cabida también a mexicanos, de forma explícita, y trató de hacer frente a las reacciones suscitadas en distintos medios contra la política cardenista de apoyo a los exiliados de la República.

Aparte de La Casa de España en México, hubo otras instituciones y medios en los cuales los historiadores exiliados participaron directamente y continuaron con su actividad profesional en México, entre las que cabe señalar la Universidad Nacional Autónoma de México (UNAM).

La UNAM se encontraba en esos momentos en plena etapa de expansión. A esta universidad se vinculó Rafael Altamira, uno de los historiadores que a lo largo de su carrera profesional más se preocupó por acercar y dar a conocer América Latina a los españoles y España a los latinoamericanos. Fue también de gran relevancia la aportación de Agustín Millares Carlo, que entre 1939 y 1958 impartió clases de Paleografía y Lengua y Literatura Latinas en la universidad. Su actividad como latinista fue esencial para la consolidación de la sección de Filología Clásica dentro de la Facultad de Filosofía y Letras, al igual que del Centro de Traductores, hoy en día Centro de Estudios Clásicos. A esto hay que añadir su importante labor como historiador y bibliógrafo americanista. Otros emigrados que impartieron docencia en la UNAM fueron el bibliógrafo José Ignacio Mantecón, Wenceslao Torres, traductor de gran parte de la obra de Marx, Carlos Bosch García y Juan Antonio Ortega Medina, miembro último de la Academia de la Historia Mexicana y perteneciente a una segunda generación ya formada en el exilio, al igual que Bosch García.

Otras instituciones en las que los historiadores exiliados impartieron clases fueron el Departamento de Investigaciones Históricas del Instituto Nacional de Historia y Antropología, la Escuela Normal Superior, el México City College, la Universidad de las Américas, la Escuela de Historia de la Universidad Iberoamericana y la Escuela Nacional de Bibliotecarios y Archivistas. ${ }^{13}$

Por otro lado, los exiliados en México llevaron a cabo publicaciones editoriales. Destaca e Fondo de Cultura Económica, editorial fundada por Daniel Cosío Villegas antes de la llegada de los españoles a México, en 1934. Un núcleo significativo de refugiados españoles colaboró en esta editorial. Los historiadores exiliados tradujeron obras en lengua extranjera como e alemán o el inglés, muchas de ellas fundamentales, que posteriormente se publicaban en la sección de historia del Fondo de Cultura Económica, dirigida desde 1939 conjuntamente por Agustín Millares y Silvio Zavala. También editaron otras revistas, entre las que destacan Historia Mexicana y Cuadernos Americanos. En la dirección de esta última figuró Pere Bosch Gimpera, padre de Carlos Bosch García y perteneciente a un grupo numeroso de investigadores que escribieron de historia, pero cuyo campo de especialidad era fundamentalmente la antropología.

12 Alicia ALTED VIGIL: “Historiadores exiliados en América latina. El caso de Ramón Iglesia Parga” en Andrea PAGNI (ed): El exilio republicano español en México y Argentina. Historia cultural, instituciones literarias, medios, Madrid, Iberoamericana, 2011, pp. 85 y 86.

13 Alicia ALTED VIGIL:“Historiadores exiliados en América latina. El caso de Ramón Iglesia Parga”, en ciones literarias, medios, Madrid, lberoamericana, 2011, pp. 86 y 87. 
Como última medida debida a su compromiso con la causa republicana, Cárdenas ofreció a los exiliados el derecho a la ciudadanía mexicana el 23 de enero de 1940. El gobierno de México emitió un decreto por el cual se les permitía solicitar la ciudadanía sin más condición que el requisito de firmar un documento y dar su lugar de nacimiento. ${ }^{14}$

Una enorme mayoría de los exiliados aceptó la oportunidad de convertirse en ciudadanos mexicanos, ya que tal ciudadanía significaba el fin de casi todas las restricciones formales que habían encontrado en su trabajo y en sus viajes. Sin embargo, algunos de los españoles más activos en política, empeñados en la idea de volver a España cuanto antes, es decir, en cuanto cayera Franco, concibieron como obligación moral conservar sus pasaportes originales.

\section{Los nuevos temas de estudio en los historiadores españoles.}

La oportunidad que se brindó a los intelectuales e historiadores españoles exiliados de continuar con sus estudios, contribuyó a la ampliación de sus enfoques y métodos de análisis, así como al aumento del interés por su disciplina en México. Muchos de los historiadores españoles se consagraron al americanismo, lo cual supuso un cambio en sus carreras profesionales, con la consiguiente pérdida de la experiencia concreta de las trayectorias previas.

En líneas generales, en la obra de los historiadores exiliados predominó el estudio de la época colonial española y del período de la Independencia, sobre la investigación de la historia contemporánea de los países latinoamericanos. Este hecho se vio favorecido por la necesidad que tenían los exiliados de integrarse de forma rápida en los países de acogida, por lo que evitaban entrar en disquisiciones políticas que podrían poner en peligro el buen recibimiento que les habían ofrecido.

Entre aquellos que se dedicaron a la disciplina histórica en México, cabe destacar concretamente a Agustín Millares Carlo, el cual ya hemos mencionado en diversas ocasiones. Millares Carlo llegó a México en 1939 y permaneció más de veinte años, durante los cuales no cesó de trabajar y de contribuir, con ello, al desarrollo de las humanidades en el país. Proporcionó una aportación erudita al conocimiento del México colonial. Asimismo, su contribución al conocimiento del padre Las Casas merece mención especial.

Con todo, la llegada de historiadores exiliados a México y su inserción laboral en instituciones dedicadas a su formación y carrera profesional, dio lugar a la interrelación activa entre el pensamiento de España y América, segunda etapa de un movimiento de acercamiento mutuo que se inició en 1898.

A América Latina llegó la dialéctica que existía en España entre el positivismo y una filosofía más relativista La primera tendencia estuvo representada en España por la figura de Menéndez Pidal, influente miembro del CEH de Madrid, cuya concepción filosófica de la historia se centraba en un concepto de "tradición" que encontraba su mejor expresión en la Edad Media peninsular. En cuanto a la segunda tendencia, estuvo definida por la filosofía de Ortega y Gasset, en la que destaca el concepto de "circunstancia" que implica una concepción relativista del acontecer humano y por lo tanto de la historia, ya que la persona no puede concebirse de manera independiente de las circunstancias que la rodean y en el seno de las cuales actúa.

Por otra parte, es indudable que los republicanos españoles contribuyeron a transformar la percepción que se tenía de España y lo español en determinados sectores de las sociedades latinoamericanas que les acogieron. También ellos llevaron a cabo una importante reflexión acerca del sentido de la hispanidad, cuestión que más adelante concretaremos.

Asimismo, estos historiadores dejaron en México, con toda probabilidad, una impronta permanente, ya sea temática o metodológica, en los alumnos mexicanos a los que contribuyeron a formar y que posteriormente constituirían la plana mayor de los historiadores más

14 Patricia W. FAGEN: Transterrados y ciudadanos, México, Fondo de Cultura Económica, 1975, pp. 58 y 59. representativos del país. Con todo, proporcionaron una influencia renovadora en el campo de la historiografía mexicana.

Por último, si bien el cambio temático en los estudios de los historiadores dificultó un tanto el proceso de adaptación, también se produjeron resultados positivos, ya que ello les condujo a una nueva percepción de América y de lo español, lo cual se refleja en el término de "transterrados" dado por el filósofo español exiliado en México José Gaos.

\section{¿Transterrados?}

José Gaos reflexionó profundamente acerca del significado de América y su intrínseca relación con la identidad española. El término de transterrados fue resultado de esta reflexión así como de la experiencia existencial y de la producción intelectual de Gaos en América. Consistía en la idea de que la España que tuvo que emprender el camino del éxodo se "transterraba" a una América que era parte de la misma España: la misma tierra española, el mismo mundo, la misma lengua y cultura. Por tanto, era más adecuado denominar transtierro y no destierro a este fenómeno.

Así, el transtierro significaría una continuación de lo español en México. Se trata de una idea entrañable para el emigrado, que se consideraría un "empatriado", poseedor de dos patrias: la de origen y la de destino, en la que se encuentra empatriado..$^{5}$

Con esto, el pensamiento de Gaos unió de forma ejemplar España y América, al sostener que es constitutivo del filósofo el reflexionar insertado en su contexto, fundamentación última de su planteamiento del concepto de transterrado.

Sin embargo, la idea y el término proporcionados por Gaos han sido cuestionados. En este sentido, Clara E. Lida'16 afirma que el proceso de adaptación de los refugiados españoles a México fue lento, difícil e incluso hostil, al menos en los primeros lustros; la autora se cuestiona si finalmente se realizó una adaptación plena. También en línea crítica, Francisco Caudet ${ }^{77} \mathrm{ca}-$ racteriza de falaz el término creado por Gaos y estipula que tal idea comportaba, con mayor o menor conciencia por parte de su autor, la idea de que lo mexicano y, por extensión lo latinoamericano, era una subcultura de lo español cuando salieron de España y mientras vivieron en el "destierro". Asimismo, según Caudet, se trataría de una idea ilusoria: los exiliados se hallaban, ciertamente, en tierra ajena.

Por último, la concepción ideológica de los exiliados dedicados a la historia se plasmó en algunas de sus ideas y temas de debate, entre los que destacamos la reflexión acerca del sentido de la hispanidad.

Este sería un último punto a destacar, fruto de la experiencia de los exiliados y deudor de la ayuda mexicana recibida. Aunque, en teoría, aquellos que reflexionaron sobre esta cuestión pretendian dar un significado alternativo al del bando nacional y superar los tópicos del momento, incidieron sobre la dialéctica de las dos Españas: la España roja, liberal y progresista, y la España negra de la reacción y la represión, representada por el régimen franquista.

Asimismo, tal meditación sobre España se vio completada con otra sobre América, producto de ese "segundo descubrimiento de América" que se produjo a partir de 1939 y que se hallaría un tanto en consonancia con el concepto de transtierro de Gaos. Los exiliados vieron una prolongación de la cultura española en los países de acogida. Coincidieron con los latinoamerica-

15 http://www.cialc.unam.mx/pensamientoycultura/biblioteca\%2ovirtual/diccionario/transterrados.htm

16 Clara E. LIDA: “Un exilio en vilo”, en Andrea PAGNI (ed.): El exilio republicano español en México y Argentina. Historia cultural, instituciones literarias, medios, Madrid, Iberoamericana, 2011, p. 24.

17 Francisco CAUDET: “La mitificación nacionalista de España en las revistas del exilio de 1939", en Andrea PAGNI (ed): El exilio republicano español en México y Argentina. Historia cultural instituciones literarias, medios, Madrid, Iberoamericana, 2011, p. 60. 
nos en rechazar la política de "Hispanidad", política de imperialismo cultural practicada por el Estado español surgido tras la guerra civil. Este rechazo estuvo unido a un nuevo acercamiento y conocimiento de lo americano, sentido como una prolongación de la experiencia española.

Conclusiones.

La presentación de las acciones estales de México encaminadas a acoger a los historiadores españoles y posibilitar la continuación de su carrera profesional es un ejemplo de política internacional diferente a la predominante en un momento determinado. Es, más allá de sus límites y defectos, una muestra de solidaridad, sin que ello implique que se tratara de una ayuda totalmente desinteresada. El caso de México, especialmente, posibilitó el desarrollo de una historiografía y un pensamiento que, con otra suerte, probablemente hubiera desaparecido o no hubiese evolucionado. Quizás podríamos llegar a hablar de la contribución a la salvación de una generación de historiadores, aquellos que no apoyaron al régimen franquista.

Sin embargo, más allá de esta posible salvación, es muy importante tener en cuenta que la emigración cambió el pensamiento de los historiadores, según hemos señalado. El cambio temático de sus estudios se vio acompañado de una nueva percepción de lo analizado, consecuencia del exilio y, sin duda, de la acogida concreta recibida. En definitiva, sus carreras fueron salvaguardadas, pero tomaron un nuevo rumbo de forma determinante. 


\section{¿HOLOCAUSTO, GENOCIDIO, EXTERMINIO, \\ POLITICIDIO...? CONCEPUTALIZACIONES SOBRE EL \\ DESARROLLO DE LA REPRESIÓN FRANOUUISTA. ESPECIAL \\ ATENCIÓN AL CASO VASCO.*}

Erik Zubiaga Arana

Universidad del País Vasco (UPV-EHU)

El presente artículo, por un lado, recoge las múltiples y variadas reflexiones surgidas en el ámbito académico en torno a la conceptualización de la represión del régimen franquista durante la Guerra Civil y la inmediata posguerra y, por otro lado, analiza específicamente el caso la represión insurgente en Bizkaia por medio de las interpretaciones de las dos principales narrativas, antagónicas en fines y medios, existentes en la actualidad, es decir, historiografía y literatura militante.

La naturaleza múltiple y variable de las medidas coercitivas empleadas por el Estado franquista son asumidas por la totalidad de la historiografía especializada en la cuestión. No obstante, existe un debate encendido sobre la planificación de esas medidas, y en estrecha relación, otro sobre la naturaleza de la violencia política del régimen de Franco. Aún a riesgo de reducir el debate, rico y lleno de matices, se distinguen dos grandes grupos con opiniones divergentes. Parte de la historiografía española sostiene que la represión franquista fue consecuencia de una detallada programación y que la planificación de la represión consistía en un plan de exterminio que perseguía la aniquilación absoluta del enemigo.' En relación a este debate se ha ido generando una profusa variedad de opiniones sobre la conveniencia del uso de conceptos tales como genocidio, holocausto, politicidio, etc. para los procesos de violencia efectuados tras el fallido golpe de Estado de julio de $1936 .^{2}$ La otra corriente de historiadores, sin embargo, cuestiona la operatividad de tales conceptos para describir detalladamente las distintas fases represivas empleadas por el gobierno de Franco y, por tanto, se decantan por otro tipo de sustantivos.

\section{Los estudios de genocidio, holocausto y exterminio.}

Los genocide studies agrupan una gran cantidad de análisis y formulaciones sobre el concepto genocidio. Este término fue acuñado en 1944 por el jurista y politólogo polaco Raphael Lemkin, quien lo concibió como

* Esta comunicación ha sido realizada gracias a la inclusión del autor dentro del “Programa de Formación y Perfeccionamiento del Personal Investigador" del Departamento de Educación, Universidades e Investigación del Gobierno Vasco. Asimismo, este trabajo forma parte de las investigaciones desarrolladas por el GRUPO DE INVESTIGACIÓN DEL SISTEMA UNIVERSITARIO VASCO DE HISTORIA SOCIAL Y POLITICA DEL PAÍS VASCO CONTEMPORÁNEO (IT-429-10) financiado por el Gobierno Vasco.

1 Francisco ESPINOSA MAESTRE: La columna de la muerte. El avance del ejército franquista de Sevilla Badajoz, Barcelona, Crítica, 2003; ÍD.: Violencia roja y azul, 1936-1950, Barcelona, Crítica, 2010. Julián CASANOVA, et al.: Morir. Matar, sobrevivir. La violencia en la dictadura de Franco, Barcelona, Crítica, 2002.

2 Julio AROSTEGUI, Jorge MARCO, Gutmaro GOMEZ BRAVO (coord.): "De genocidios, holocaustos, exterminios Sobre los procesos represivos en España durante la Guerra Civily la dictadura", Hispania Nova, 10 (2012), s.n. un plan coordinado de diferentes acciones cuyo objetivo es la destrucción de las bases esenciales en la vida de un grupo nacional, con el propósito de aniquilar al grupo en s mismo [...]. El genocidio se dirige contra el grupo nacional como una entidad y las acciones involucradas se dirigen contra los individuos no en su capacidad de individuos, sino como miembros del grupo nacional. ${ }^{3}$

La necesidad de delimitar el marco interpretativo propició el surgimiento de numerosas acepciones del término; éstas varían en función del perfil del agente represor (actor estatal o no-estatal), los objetivos (aniquilación parcial o total), modos represivos empleados, perfil de la víctima (nacional, étnico, religioso, racial, político, otros), etc. La comunidad científica no ha sido capaz de consensuar el significado del término, al igual que ha sucedido con la palabra holocausto. Además, las dificultades de conceptualización han facilitado la aparición de controversias y posturas enfrentadas de difícil resolución ${ }^{4}$. Cada cual desarrolla el marco interpretativo en función de diferentes perspectivas (tanto morales como históricas), hay demasiadas conceptualizaciones en disputa, con lo cual el debate no tiene visos de avanzar.

Cabe señalar que entre aquellos partidarios al uso del término genocidio coexisten diversas posturas, no todos los autores esgrimen las mismas razones. Por ejemplo, Antonio Miguez es partidario de emplear la perspectiva de estudios de genocidio para analizar los episodios de violencia de retaguardia de los franquistas, no obstante, es muy crítico con aquellos autores proclives al uso tópico del concepto. Esto es, rechaza las tesis «genocidas» carentes de dimensión interpretativa porque éstas persiguen, exclusivamente, la "equiparación de su significado con sucesos muy graves de matanzas colectivas" y, por consiguiente, se limitan a atribuir un carácter enfático al término. ${ }^{5}$

De la misma forma, tampoco existe una posición hegemónica en cuanto a la duración de la política de exterminio se refiere. Por ejemplo, tanto Matilde Eiroa como Miguez consideran que la fase de exterminio no se extiende indefinidamente en el tiempo, sino que se circunscribe a un periodo específico. Así, el genocidio o «las prácticas genocidas» se limitarían al denominado "terror caliente» desplegado durante el verano y otoño de $1936 .{ }^{6}$ Francisco Espinosa apunta en la misma dirección. En su última obra colectiva, afirma que las investigaciones realizadas hasta la fecha le permiten corroborar que "al menos en la ruta que lleva del norte de África a Madrid, cabe hablar de un plan de exterminio".? No obstante, las tesis de exterminio y genocidio que ha defendido en anteriores publicaciones no se circunscriben exclusivamente a lo acaecido en el suroeste español, sino que lo equipara con la represión sufrida en las provincias de "Castilla, Galicia, La Rioja, Navarra, Aragón, Baleares o Canarias", justamente en aquellos territorios donde el golpe de Estado triunfó. ${ }^{8}$ Al genocidio franquista le atribuye la aplicación de "métodos de eliminación masiva de personas por causas políticas y con el único objetivo de acabar con el sistema político legal, incluso con una cultura política, para imponer

3 Jorge MARCO: “Genocidio y 'Genocide Studies'. Definiciones y debates”, Hispania Nova., 10 (2012), s.n.

4 Una muestra de las discusiones del momento: Fernando DEL REY: "Revisionismos y anatemas. A vueltas con la II República", Historia Social, 72 (2012), pp. 155-172. Antonio ELORZA: “El genocidio franquista", El Pais, 23 de septiembre de 2008. Jorge MARTINEZ REVERTE: "De holocaustos y matanzas", El Pais, 11 de mayo de 2011.

5 Antonio MIGUEZ MACHO: "Nuestro pasado presente: práctica genocida y franquismo", Hispania Nova, 10 (2012), s.n.

6 Matilde EIROA: "Prácticas genocidas en guerra, represión sistémica y reeducación social en guerra", Hispania Nova, 10 (2012), s.n.

7 Francisco ESPINOSA MAESTRE et. al (coords.): Violencia roja y azul..., pp. 55-56.

8 Ibid.p. 118. 
otro más acorde con los intereses de los perdedores de las elecciones de febrero de 1936 ".9

Los autores anteriormente citados se decantan por el uso del término genocidio para des cribir y analizar la violencia franquista. Paul Preston, en cambio, considera que holocausto es el sustantivo ideal para definir el periodo de represión "en las retaguardias durante la Guerra Civil y en toda España después" porque "la guerra civil fue una gran calamidad [...], y quien piense que da igual lo que le pasó a los españoles, que no importa, que no era terrible y que eso no fue un holocausto, para mí es una persona insensata e insensible"..$^{\circ}$ Además de operatividad analítica, por lo visto, atribuye fuertes connotaciones morales al término. Igualmente, afirma que la voluntariedad de demorar el curso de la guerra con el fin de eliminar a la mayor cantidad de potenciales enemigos, revela el deseo de las autoridades franquistas de llevar cabo una actividad exterminadora sin cuartel."

Los razonamientos que demostrarían la existencia de un plan de exterminio y la designación de un sujeto identificable del enemigo y, por lo tanto, la conveniencia de sustantivar como genocida la represión franquista, se han sustentando, entre otras, en torno a las siguientes manifestaciones. Las palabras del «director» de la sublevación militar, el general Mola, son presentadas como ejemplo fehaciente del deseo de los insurgentes de imponer una violencia extrema e inmisericorde. Un día después de la sublevación militar aseveraba lo siguiente en una reunión de alcaldes en Pamplona: "es necesario propagar una atmósfera de terror [...] Cualquiera que sea abierta o secretamente defensor del Frente Popular debe ser fusilado. [...] Todo aquel que dude, ampare o oculte a alguien del Frente Popular debe ser asesinado".12 La famosa base $5^{\text {a }}$. de la Instrucción Reservada número 1 firmada el 25 de mayo de 1936 en Madrid apuntaba en la misma dirección,

se tendrá en cuenta que la acción ha de ser en extremo violenta, para reducir lo antes posible a un enemigo fuerte y bien organizado. Desde luego, serán encarcelados todos los directivos de partidos políticos, sociales o sindicatos desafectos al movimiento, aplicándose castigos ejemplares a dichos individuos para estrangular los movimientos de rebeldía o huelga."

El 28 de julio de 1936, tras el fallido golpe de estado, el general Franco, en una entrevista realizada por el estadounidense Jay Allen, se mostraba - aunque hay quien cuestiona la interpretación de las declaraciones- dispuesto a hacer desaparecer a media España. ${ }^{14}$

Por otra parte, tanto Miguez, Espinosa como Miguel Ángel Rodríguez Arias, sostienen que el ocultamiento de pruebas o la negación del ejercicio de la represión es una característica in herente a toda práctica genocida, y añaden que "en el caso español la continuidad del régimen dictatorial fue la mejor garantía de la hegemonía del negacionismo sistemático de la práctica genocida". ${ }^{5}$ La abundancia de fosas comunes dispersas por todo el territorio es, para Espinosa, el mayor exponente del deseo de ocultar los cadáveres con el fin de que nada de lo sucedido transcendiera ${ }^{16}$. En la misma dirección, Rodríguez Arias apunta que "Franco no sólo quería ga-

9 Ibid. p. 117 .

10 R. MATEOS HERRAIZ: "El holocausto español", Periodismo Humano, 8 de junio de 2011

11 Paul PRESTON: Franco. Caudillo de España, Barcelona, Grijalbo, 1994

12 J. ITURRALDE: El catolicismo y la cruzada de Franco, Vol I, Bayona, 1956, p. 89.

13 Julio PRADA RODRIGUEZ: La España masacrada. La represión franquista de guerra y posguerra, Madrid, Alianza, 2010. P.111.

14 Javier RODRIGO: Los campos de concentración franquistas. Entre la historia de la memoria, Madrid, Siete mares, 2003, p. 30

15 Antonio MIGUEZ MACHO: "Nuestro pasado presente:...", s.n.

16 Francisco ESPINOSA MAESTRE et. al (coords.): Violencia roja y azul..., p. 96. nar la guerra, quería eliminar a cualquier sector social que pudiera dar sustento a la República española. Luego hizo lo del encubrimiento, que es típico del genocidio [...] Es un genocidio en el que se intenta aniquilar intencionadamente a una parte de nuestro país, el grupo de defensores de la República española y luchadores antifascistas a los que se aniquiló, se robaron sus bienes y muchos tuvieron que exiliarse".7

No todas las tesis que resaltan la característica exterminadora de la represión franquista se refieren exclusivamente al aniquilamiento físico. La reciente obra publicada de Gutmaro Gómez y Jorge Marco, por ejemplo, estima que las autoridades militares insurgentes diseñaron, entre 1936 y 1948, diversos proyectos "con el objeto de realizar una limpieza política de la sociedad" o, lo que es lo mismo, perseguían el "exterminio político y cultural" y, a su vez la "conversión forzosa", del adversario político a través de los mecanismos de "eliminación, castigo y aislamiento del enemigo". ${ }^{18}$ La eliminación física fue un mecanismo más, "en ningún momento fue el único ni el de mayor importancia", que contribuyó a "limpiar el espacio público y privado de cualquier rastro ideológico, político y moral de la anti-España". ${ }^{9}$

\section{Los estudios críticos con las tesis de genocidio, holocausto y exterminio.}

Al igual que sucede entre los partidarios de sustantivar la represión franquista mediante los conceptos de genocidio, holocausto o exterminio, los historiadores que cuestionan dichos planteamientos sostienen sus tesis sobre distintas líneas argumentativas. Por ejemplo, Julius Ruiz considera que el significado de "limpieza" varió completamente cuando el estado franquista comenzó a consolidarse a partir del invierno de 1936-1937..$^{20}$ La burocratización o institucionalización de la represión trajo consigo un descenso de las ejecuciones (fusilados, agarrotados y «paseados»), por lo tanto, la represión sanguinaria, mayoritariamente extrajudicial, de los primeros meses de la sublevación militar fue sustituida por un nuevo modelo represor que perseguía doblegar o transformar más que aniquilar. De la misma forma, los defensores de la planificación del exterminio obvian, según el autor, el regreso a España de la mayoría de los exiliados durante la década de los años cuarenta. La vuelta de los exiliados corrobora que, a pesar de la brutalidad de la represión, el «nuevo Estado" "no produjo expulsiones, selectivas o permanentes de población". 21

El historiador José Carlos Martínez Gálvez mediante el estudio del concepto genocidio aprobado por la ONU -no olvidemos que es la que otorga validez a efectos jurídicos- recuerda que la definición excluye rotundamente la destrucción de grupos políticos y, a su vez, determina que la tipología de la represión durante "los genocidios es indiscriminada y total, abarcando al conjunto del grupo que se quiere exterminar, incluyendo hombres, mujeres y niños. De ahí su voluntad de destrucción del grupo, destrucción que no cesa en tanto en cuanto el grupo existe".2z Por lo tanto, a pesar de la retórica de enaltecimiento de la violencia extrema de los dirigentes

17 Entrevista a M.A. RODRIGUEZ ARIAS, www.nuevatribuna.es, 20 de febrero de 2010. Recuperado de internet (http://www.nuevatribuna.es/articulo/sociedad/2010-02-21/-hay-que-tomar-concieninternet (http://www.nuevatribuna.es/articulo/sociedad/2010-02-21/-hay-au
cia-de-que-venimos-de-un-genocidio-negado/2011030922432401917.html)

18 Gutmaro GOMEZ BRAVO y Jorge MARCO: La obra del miedo. Violencia y sociedad en la España fran8 Gutmaro GOMEZ BRAVO y Jorge MARCO: La obra del miedo. Viol
quista (1936-1950), Barcelona, Ediciones Península, 2011, p. 66 .

Ibídem.

20 Julius RUIZ: "A Spanish Genocide? Reflections on the Francoist Repression after the Spanish Civil War", Contemporary European History, 14 (2005), pp. 171-191; ID.: "Las metanarraciones del exterminio", Revista de libros, 172 (Abril 2011), s.n.

21 Julius RUIZ: "Las metanarraciones del exterminio", p. 10. Conxita MIR, "el sino de los vencidos: Ia represión franquista la Cataluña rural de posguerra", en Julián CASANOVA, et al.: Morir. Matar, sobrevivir..., p. 151.

22 J.C. MARTINEZ GALVEZ: "Algunas precisiones sobre la violencia franquista", en Hispania Nova, 10 (2012), pp. 7-8. 
sublevados (Queipo de Llano, Mola, Franco, etc.), habría que diferenciar las amenazas vertidas y los hechos consumados, ya que estos variaron sustancialmente en función del periodo y la zona geográfica donde se desarrollaron. El denominado terror caliente dio paso al perfeccionamiento de la maquinaría legal de la represión. De esta forma, "los centenares de miles -sino algunos millones- que en algún momento fueron identificados como «rojos" y como miembros del colectivo, que presuntamente, se persegu[ía] aniquilar, [...] no fueron exterminados". ${ }^{23}$

El profesor Enrique Moradiellos también cuestiona la validez de las "aplicaciones utilitariamente inmoderadas del conocimiento histórico [promovidas] por parte de sectores de la izquierda" que, además, "han servido de coartada justificativa para las críticas reactivas de ciertos autores del frente pseudorevisionista filofranquista". ${ }^{24}$ Estima, al igual que Javier Ugarte, que la falta de cautela a la hora de aplicar los conceptos de holocausto y genocidio para categorizar la represión franquista, ha facilitado el surgimiento de un combate de "memorias enfrentadas entre posicionamientos católico-conservadores" e izquierdistas-republicanos concretamente, un enfrentamiento dialectico que tiende cada vez más "[a consolidar]componentes políticos presentistas [...] y a perder los pocos atisbos historiográficos que la adornaban originalmente". ${ }^{25}$ Así las cosas, en palabras de Moradiellos, la ausencia de rigurosidad terminológica y el afán de enjuiciar el pasado explican la proliferación de teorías que exceden el terreno historiográfico.

\section{La represión franquista en el País Vasco, ¿genocidio?}

La historiografía del País Vasco, llamativamente, hasta tiempos recientes, ha obviado acometer estudios profundos sobre la represión franquista desplegada en el territorio vasco durante la guerra civil y la inmediata posguerra. El vacio historiográfico reinante ha sido paliado, en parte, por los trabajos académicos de Ugarte y la reciente tesis doctoral de Javier Gómez sobre Álava y Barruso sobre Gipuzkoa, a nivel provincial, y Aizpuru, a escala local (Hernani), sobre Gipuzkoa. ${ }^{26}$ Sin embargo, la provincia de Bizkaia, a pesar de la particularidad del territorio - ausencia de golpe de Estado, único territorio del País Vasco que permaneció durante un tiempo sustancial fuera del «nuevo Estado», sede del Gobierno de Euzkadi, amplia pluralidad política, la participación del Partido Nacionalista Vasco (tradicionalista y confesional) en el bando republicano, gran valor estratégico por su potencial industrial, etc.-, en opinión de los catedráticos de la Universidad del País Vasco, de la Granja y de Pablo, "sigue estando huérfana de estudios globales serios sobre la represión franquista". ${ }^{27}$

La gran mayoría, por no decir la totalidad, de los debates de cariz histórico que se plantean en el País Vasco ofrecen un mismo panorama: por un lado, las tesis académicas y, por otro, los

23 Julio PRADA RODRIGUEZ: “Entre Escila y Caribdis. Contribuciones a un debate necesario”, Hispania Nova, 10 (2012), p. 13 .

24 Enrique MORADIELLOS: "Revisión histórica crítica y pseudo-revisionismo político presentista: el caso de la guerra civil española", en Dpto. de $\mathrm{H}^{a}$ del Pensamiento y de los Movimientos Sociales y Politicos, UCM, Fundación Ortega y Gasset, curso 2009-2010, p. 12. Recuperado de internet (http:// www.ucm.es/info/historia/ortega/5-og.pdf).

25 Javier UGARTE, "iLegado del Franquismo? Tiempo de contar", en Carme MOLINERO: La Transición, treinta años después, Barcelona, Península, 2006, p. 221

26 Pedro BARRUSO: Violencia política y represión en Guipúzcoa durante la guerra civil y el primer franquismo, San Sebastián, Hiria, 2005. Javier UGARTE TELLERÍA: "Represión como instrumento de acción política del "nuevo Estado". Álava, 1936-1939", Congreso de Historia de Euskal Herria, Vol.7 (1988), pp. 275- 304. Javier GOMEZ CALVO: Matar, purgar, sanar. La represión franquista en Álava (1936-1945) UPV-EHU, (tesis doctoral), 2013. Mikel AIZPURU: El otoño de 1936 en Guipúzcoa: los fusilamientos de Hernani, Irún, Alberdania, 2007.

27 José Luis DE LA GRANJA y Santiago DE PABLO: Guía de fuentes documentales y bibliográficas sobre la Guerra Civil en el Pais Vasco (1936-1939). Eusko lkaskuntza, 2009, p. 48. planteamientos memorísticos caracterizados por una visión que persigue enjuiciar el pasado para lograr réditos políticos en el presente. ${ }^{28}$ La rigurosidad de los trabajos académicos en el terreno puramente analítico, lógicamente, es mayor. No obstante, la proyección social de las teorías carentes de diálogo crítico con las fuentes consultadas, maniqueísmo terminológico y establecimiento de perspectivas reduccionistas que flaco favor hacen al entendimiento de los complejos procesos históricos es alarmantemente superior. No en vano, como nos recuerda Antonio Rivera, "la historia militante, la historia con «voluntad constructiva de presente», tiene una abundante tradición en el País Vasco".29

De este modo, tal y como he señalado anteriormente, junto a la interpretación académica de los hechos pasados, surge una narración de la historia, caracterizada por una visión netamente presentista, ajena al rigor y método que deben guiar al historiador. Tal y como denuncia Espinosa,

en realidad se trata de una cuestión viciada por el sesgo nacionalista que todo impregna al que hay que unir eso que algunos llaman «el conflicto vasco», lo que vendría a significar que para una comunidad como Euskadi, que lleva ya décadas alimentando el victimismo, no resulta fácil asumir que, frente a lo que se les ha contado siempre, la represión franquista allí fue de las menos duras de España.

ETA, concretamente la corriente adscrita a la base lingüística de Txillardegi, de los años setenta, interiorizó el relato del genocidio cultural de los vascos y el discurso que venía alimentando el nacionalismo vasco. Por ejemplo, en uno de los boletines internos de ETA se declaraba que "la clase trabajadora española es imperialista en Euzkadi" y "consciente o inconscientemente completan actualmente el genocidio vasco comenzado durante la guerra del 36 ". ${ }^{\circ} \mathrm{El}$ término genocidio viene a representar la represión secular española, en este caso franquista, que se sucede a través de distintas manifestaciones y protagonistas contra las esencias del milenario pueblo vasco. Obviamente, las tesis lingüísticas de Txillardegi ignoran los datos referidos al origen vasco de gran parte de los miembros voluntarios de las tropas franquistas que conquistaron el País Vasco, los apoyos sociales que el bando rebelde suscitó en Euskadi y la amplia pluralidad política y, a su vez, la variedad de complejas adscripciones identitarias que caracterizaban el escenario político vasco. ${ }^{31}$ Por tanto, de la guerra civil española salió un País Vasco vencido, pero también, contrariamente a lo que se ha afirmado con frecuencia, un País Vasco vencedor.

En la actualidad, el máximo representante del victimismo secular nacionalista es Iñaki Egaña. Así lo corroboran las críticas de numerosos historiadores especializados en la represión franquista. Por ejemplo, Espinosa critica enérgicamente que Egaña, "[al] hablar de la represión en Euskal Herria y no en Euskadi" suma las víctimas navarras a las vascas y, de esta forma, "ob-

28 http://www.euskalmemoria.com/.

29 Antonio RIVERA: "Cuando la mala historia es peor que la dememoria. Acerca de los mitos de la historia contemporánea vasca", en El valor de la palabra. Hitzaren balioa, $n^{\circ} 4$ (2004), p.43.

30 En el boletín interno de Eta Kemen, n.1, 1970, en Gaizka FERNANDEZ SOLDEVILLA y Raúl LOPEZ ROMO: Sangre, votos, manifestaciones: ETA y el nacionalismo vasco radical 1958-2011, Madrid, Tecnos, 2012, p. 53 .

31 Para el origen de las tropas franquistas en el País Vasco ver Jorge MARTINEZ REVERTE: El arte de Para el origen de las tropas franquistas en el Pais Vasco ver Jorge MARTINEZ REVERTE: El arte de matar. Como se hizo la Guerra Civil española, Barcelona, RBA, 2009, p. 138. La colaboración civil de la burguesía vizcaína en J.M. GARMENDIA y M. GONZALEZ PORTILLA: "Crecimiento económico y actitudes políticas de la burguesía vasca, en la posguerra", en VV.AA., España franquista. Causa Ceneraly Acticudes Sociales ante la Dictadura, Edicions Universidad de Castilla La-Mancha, Albacete, 1993, pp. 179-195. Y la plural
Pais Vasco, Madrid, Alianza, 1990.

( 48. 
tiene una cifra más acorde con la leyenda". ${ }^{32}$ Es por todos conocida la polémica que genera la cuantificación de la represión franquista, la denominada "guerra de cifras", sobre todo porque muchos de los estudios que se presentan manipulan los datos con el fin de otorgar mayor pedigrí antifranquista a un territorio o movimiento político específico. ${ }^{33}$ El catedrático Santiago de Pablo apunta que

las obras ligadas a la izquierda abertzale, como la de Egaña, tiene un singular empeño en sumar víctimas - por ejemplo, incluyendo como fusilados a posibles muertos en el frente-, pero llegan al caso más extremo de incluir como asesinados por los franquistas en Guipúzcoa a algunos fusilados en determinados pueblos que en la fecha que señalan estaban bajo control republicano. ${ }^{34}$

No son de extrañar, por lo tanto, los enfáticos títulos de las dos últimas publicaciones de Egaña: Frankismoa Donostian. Las víctimas del genocidio franquista en Donostia y El franquismo en Euskal Herria. La solución final. Juega conscientemente de forma irresponsable con la utilización de terminología que no resulta apta para interpretar los hechos acaecidos en Euskadi. El uso frívolo del "genocidio" y la «solución final» persigue equiparar de alguna manera, el plan que la Alemania nazi ejecutó para exterminar sistemáticamente la población judía durante la II. Guerra Mundial y la represión franquista desplegada en Euskadi y Navarra.

Tiempo atrás, en el año 200o, varios historiadores de la UPV-EHU denunciaron por plagio la enciclopédica obra de historia en ocho volúmenes titulada 1936. Guerra Civil en Euskal Herrial 1936. Gerra Zibila Euskal Herrian coordinada por Egaña. Los denunciantes atestiguaron que "el libro es un auténtico "refrito" de textos ya publicados y, en determinadas partes de algunos volúmenes, un verdadero plagio, copiándose párrafos enteros sin apenas cambios respecto a los trabajos originales y sin citar las fuentes de información". Además apuntan que

todo este trabajo de collage (al que se han añadido, y es de justicia aclararlo, algunos datos nuevos de carácter local, recabados suponemos que en archivos municipales o en fuentes orales) ha dado como resultado una obra con numerosos errores y contradicciones, que no aporta prácticamente nada al conocimiento que la historiografía profesional -con sus lagunas y limitaciones- tenía ya de la Guerra Civil en Euskadi. 35

\section{Conclusiones}

La falta de consenso que generan tales términos entre los estudiosos, fundamentalmente por la variedad de definiciones que les son atribuidos, dificulta y puede llevar a equívocos la interpretación de los acontecimientos del pasado. La ausencia de unidad de criterio, en aras del desarrollo de los estudios de la represión, exige irremediablemente un uso responsable de los términos. Así las cosas, los profesionales deberán de definir rigurosamente los conceptos clave y, a su vez, las razones que motivan su utilización o rechazo.

La represión franquista no requiere de sustantivos que traten de añadir ferocidad y espectacularidad a dicha violencia, a no ser que el marketing de la editorial así lo exija, sino requiere de estudios rigurosos que profundicen en el conocimiento de una de las etapas más traumáticas de nuestra historia reciente. La no utilización o la crítica al uso del genocidio, holocausto

32 Francisco ESPINOSA MAESTRE et. al (coords.): Violencia roja y azul..., p. 50

33 Iñaki EGAÑA SEVILLA: Los crimenes de Franco en Euskal Herria 1936-1940, Tafalla, Txalaparta Altaffaylla, 2009, pp. 63-64.

34 Santiago DE PABLO: “La guerra civil en el País Vasco: ¿un conflicto diferente?”, Ayer, 50 (2003), p. 140.

35 Santiago de Pablo, Pedro Barruso, Antonio Rivera y Javier Ugarte, 2010. Recuperado en internet

(http://www.h-debate.com/listahad/19-01-00.htm) o exterminio no supone infravalorar el hecho represivo, todo lo contrario, obedece a la idea de abarcar los diferentes mecanismos represivos desplegados en su conjunto, no solo aquellos referidos a la represión física. Además, no se pueden obviar las distintas etapas de la represión ni las notables particularidades del hecho represivo en cada territorio.

Por ejemplo, el descenso de las condenas de muerte, la paulatina salida de las cárceles y la vuelta de una gran parte de los exiliados políticos no casa con la supuesta voluntad exterminadora del «nuevo Estado», ni tampoco con el «holocausto español» que describe Preston. No obstante, las teorías que destacan la disminución paulatina de la represión física no son óbice para afirmar que en la mayoría de los territorios conquistados, especialmente durante los primeros meses de la sublevación, se desató una represión feroz, organizada por la cúpula militar sediciosa, que acabó con decenas de miles de vidas por considerarlas simplemente desafectas a la causa rebelde. Por lo tanto, las teorías de la paulatina disminución de la represión franquista no tienen por qué entrar, de forma obligatoria, en contradicción con la totalidad de los planteamientos esgrimidos por los autores proclives a las tesis genocidas de la represión.

Las teorías sobre la disminución de la intensidad represiva también deben ser matizadas y estar sujetas a permanente perspectiva crítica. Pablo Gil Vico, en referencia a la teoría defendida por Ruiz, puntualiza que la disminución de la represión fue un proceso discontinuo y desigual, esto es, no se estableció de la noche a la mañana ni se extendió a todo el territorio nacional de forma simultánea. ${ }^{36}$ En primer lugar, la excarcelación, acontecida durante 1940 y 1945, "cuidadosamente desordenada" no obedecía a una amnistía, o "fruto podrido del liberalismo" en palabras de Franco, sino a un "perdón concebido como una redención y expiación de los pecados". ${ }^{37}$ El derecho penal fue concebido como un derecho divino, reflejo de la influencia religiosa del discurso legitimador del «nuevo Estado».

Las investigaciones de Javier Rodrigo constatan que las excarcelaciones se debieron, "muy a pesar de las autoridades civiles y religiosas implicadas", esencialmente, por el cúmulo de problemas que el colapso de las cárceles estaba originando a las autoridades..$^{8}$ La ingente cantidad de detenciones convirtió las prisiones en recintos sobresaturados, no habilitados e insalubres, donde las enfermedades contagiosas se propagaban a un ritmo frenético.39 "El peligro de colapso administrativo, la presión económica y la conflictividad penitenciaria motivaron la nueva estrategia de excarcelaciones", el mantenimiento de aquel sistema carcelario comportaba un elevado riesgo para el régimen..$^{\circ}$. Sin embargo, en " 1946 las prisiones aún tenían cifras de reclusos superiores en tres o cuatro veces la capacidad prevista". ${ }^{11}$

De igual forma, a pesar de que los planes de la junta militar radicada en Burgos eran de aplicación general y sus consecuencias dramáticas tuvieron un largo alcance en todos los territorios del país, la singularidad territorial de la represión es un hecho, la represión no se ejecutó, ni en forma ni en intensidad, de la misma manera en todas las regiones. Los numerosos estudios territoriales que disponemos en la actualidad nos permiten desechar las teorías generalistas que tratan de establecer un mismo patrón represivo para todo el Estado.

6 Pablo GIL VICO: La noche de los generales. Militares y represión en el régimen de franco, Barcelona, Ediciones B, 2004.

37 Gutmaro GOMEZ BRAVO: El exilio interior. Cárcel y represión de la España franquista 1939-1950, Barcelona, Taurus, 2009, p. 13.

38 Javier RODRIGO: Hasta la raíz. Violencia durante la Guerra Civil y la dictadura franquista, Madrid, Alianza editorial, 2008, p. 168.

39 MORENO, F., "La represión en la posguerra", en Santos JULIÁ: Victimas de la guerra civil, Madrid, Temas de Hoy, 1999, p. 288

40 Javier RODRIGO: Hasta la raíz. Violencia durante la Guerra Civil y la dictadura franquista, Madrid, Alianza editorial, 2008, p. 168

41 Julián CASANOVA et al: Morir Matar, sobrevivir. p. 24. 
Por ejemplo, en un trabajo sobre la represión franquista en el País Vasco, Espinosa manifiesta que "sólo en la ciudad de Sevilla el fascismo acabo con más gente (3.200) que en todo el País Vasco: sólo en una provincia como Huelva, similar a Vizcaya o Guipúzcoa en población, fueron asesinadas más del doble de personas (6.019) que en todo el País Vasco" 42 Como se observa las diferencias en cuanto al número de ejecutados son notorias. La intensidad y los métodos represivos franquistas variaron en función del tiempo y el espacio. Es por ello, que los términos "represión ejemplar", 43 "represiones",44 incluso "politicio" puedan ser algunos de los términos que mejor definan la violencia política múltiple, selectiva y dinámica empleada por el régimen franquista.

"Hoy, con la lección bien acumulada por un siglo de totalitarismos y dictaduras, es el tiempo de volver del revés la célebre frase de George Orwell, miles de veces repetida, y afirmar que quienes pretendieron controlar el pasado, perdieron el futuro, como perderán el pasado quienes pretendan controlar el presente al modo de los comisarios de la memoria". 45 Santos Juliá.

42 Francisco ESPINOSA MAESTRE. "Sobre la represión en el País Vasco", 2009, p.15. Recuperado en internet (http://dialnet.unirioja.es/servlet/articulo?codigo=2914416).

43 Julio PRADA RODRIGUEZ: “Entre Escila y Caribdis...”, p. 20.

44 Conxita MIR: "Violencia política, coacción legal y oposición interna", Ayer, 33 (1999), pp. 115-147.

45 Santos JULIÁ: Hoy no es ayer. Ensayos sobre la España del siglo XX, Barcelona, RBA, 2009, pp. $20-21$. 


\section{LA CONSTRUCCIÓN DE LOS ORÍGENES DEL CINE \\ EN ESPAÑA A TRAVÉS DE LA MANIPULACIÓN \\ HISTORIOGRÁFICA FRANQUUISTA}

Chrystelle Ferrara Viforcos

Universidad de Oviedo

La presente comunicación pretende poner de manifiesto la supuesta manipulación de datos observada en los primeros textos de la historiografía cinematográfica contemporánea a Régimen, tomando como ejemplo paradigmático el caso de Juan Antonio Cabero (1890-1962) y la información aportada acerca de la llegada del cine a España en uno de los capítulos incluidos dentro de su Historia de la Cinematografía Española.

Esta primera generación de historiadores, que se prolonga desde los años cuarenta hasta finales de los sesenta, y en las que incluyo también nombres como Carlos Fernández Cuenca (1904-1977)² o Fernando Méndez-Leite (1905-1986),3 acusan una orientación política a favor de sistema franquista, donde la españolidad y el sentimiento patriótico y nacional estaban a flor de piel. Dicha cuestión no es baladí, ya que la situación política sumerge la España posbélica en un periodo de autarquía, no sólo económica sino también cultural, donde prevalece cierto desconocimiento con respecto al exterior.

En sus textos se evidencia el interés por dignificar el cinematógrafo de los hermanos Lumière, otorgándole el mérito de constituir el primer sistema tecnológico que permitió la proyección pública de imágenes en movimiento- esto es, Cine- en España. Y no en cualquier momento sino, según informa esta primera generación historiográfica, coincidiendo con las famosas y representativas fiestas de San Isidro del 15 de Mayo. Además, observamos como también coinciden en la omisión, en unos casos, o el desprecio en otros, por el animatógrafo, un aparato muy similar al de los Lumière, presentado al público por Mr. Rousby en el Circo Price el 12 de Mayo de 1896, convirtiéndose, verdaderamente, en el primer espectáculo colectivo de imágenes en movimiento de nuestro país. 4

Comenzamos, pues, por Cabero, ${ }^{5}$ el cual sitúa la inauguración del cinematógrafo el día 15 de mayo de 1986 - aunque asegura que hubo una première para la prensa el día 13-coincidiendo con las fiestas de San Isidro, en los bajos del Hotel Rusia, situado en la Carrera de San Jerónimo $n^{\circ} 34$ :

Las sesiones se sucedian con una rapidez extraordinaria, invirtiendo en cada una de ellas de 15 a 20 minutos. La sala no tenía otra ornamentación que un empapelado en negro

1 Juan Antonio CABERO: Historia de la Cinematografia Española: once jornadas (1896-1948), Madrid, Gráficas Cinema, 1949

2 Carlos FERNÁNDEZ CUENCA: Promio, Jimeno y los primeros pasos del cine en España, Madrid, Filmoteca Nacional, 1959

3 Fernando MÉNDEZ-LEITE: Historia del Cine Español, Madrid, Rialp, 1965

4 Esta información ha quedado ya corroborada y confirmada a través de las investigaciones de diferentes autores a los que sumo mi tesina, "De la tradición de espectáculos precinematográficos en Madrid a la llegada del cinematógrafo", donde se puede observar el análisis realizado no sólo de la bibliografía precedente sino también de la hemerografia pertinente.

5 Juan Antonio CABERO: Historia de la Cinematografía..., pp. 26-28. sobre las paredes y algunas cortinas del mismo color que llegaban hasta la pequeña pantalla blanca, colocada a la espalda de la puerta de entrada. Unas 15 o 20 filas de sillas corrientes, sujetas por un larguero de madera cada fila, constituían el aforo, cuyo precio por lo general, era de dos pesetas entrada, resultando un negocio excelente, pues cada programa era pasado infinidad de veces.

Añade que el programa inaugural se componía:

De una serie de cintas de celuloide, de 17 metros de largo por 36 milímetros de ancho aproximadamente, distribuidas en varias sesiones, una de las cuales era la siguiente: ${ }^{6}$

- Batalla de nieve

- Baños de Diana

- Salida de los obreros de la fábrica Lumière en Lyon

- El cochero dormido

- Maniobras de artillería en Vicálvaro

Aporta un fragmento de un "diario matutino de la Villa y Corte" (sin especificar) del 15 de mayo (pero que hace alusión al primer pase exclusivo para la prensa y personalidades distinguidas), que nos informa de que "El programa, repetido varias veces, contenía diez números, de los que son dignos de mención especial La llegada de un tren a la estación, Un paseo por el mar, La avenida de los Campos Elíseos, El concurso hípico de Lyon y La demolición de un muro".

No se hace alusión al animatógrafo, quizás por desconocimiento, o simplemente por no considerarlo un dato a tener en cuenta, ya que resulta curioso que, habiendo consultado la prensa del momento como él mismo nos indica, no haya encontrado ninguna reseña referente al aparato inglés, las cuales, sí que aparecen en la hemerografía madrileña.

Siguiendo la estela de Cabero, analicemos brevemente el caso de Fernández Cuenca. Este investigador se halla entre los primeros autores que describen el proceso de penetración de cine en nuestro país. Cierto es que posteriormente, al igual que sucede con Cabero, sus datos han sido refutados, y así y todo suponen una fuente de incalculable valor para comenzar a elaborar textos como el presente.

Fernández Cuenca, junto con el Círculo de Escritores Cinematográficos es responsable de la creación de la placa conmemorativa situada en el número 28 de la Carrera de San Jerónimo con motivo del cincuenta aniversario de la primera proyección cinematográfica, y dice así "El día de San Isidro se celebró en esta casa la primera exhibición del cinematógrafo para los españoles. Homenaje del Círculo de Escritores Cinematográficos. 1896-15 de Mayo de 1946".

En uno de sus principales escritos, 7 encontramos un párrafo que he querido sacar a colación porque, a mi entender, encierra cierta ironía, ya que parece ocultar una afirmación implícita en sus palabras:

Una curiosa coincidencia, pues no parece lógico suponer que fuera elegida la fecha por su peculiar carácter madrileñisimo, hizo que el cine llegara a Madrid justamente en la solemne fiesta de San Isidro, celestial patrono de la ciudad. Vino así el cine a ser el más sorprendente regalo que se añadía al programa de los festejos en aquel año de 1896.

6 En este caso, he reproducido literalmente los títulos aportados por Cabero, pero debo puntualizar que estos datos no han sido corroborados de manera concluyente, ni por dicho autor, ni por otros investigadores posteriores.

7 Carlos FERNÁNDEZ CUENCA: Promio, Jimeno y los primeros pasos..., pp. 7-14. 
Desde mi punto de vista, Carlos Fernández Cuenca subraya en este fragmento una cuestión que, desde la coherencia textual que emana de la redacción, parece querer dar a entender que fue algo premeditado. Pero, conjeturas aparte, observamos como respalda la fecha cifrada en la placa conmemorativa.

Pero lo verdaderamente interesante de este capítulo de su obra, probablemente sea el comentario que encontramos unas líneas más abajo dónde nos habla de la repentina inquietud de Promio debido a la presencia en la ciudad de otro aparato, él cual temía que hiciera sombra a su espectáculo: el kinetoscopio de Edison. Por los datos que incorpora en este párrafo, entendemos que, en realidad, se refiere al animatógrafo, ya que nos indica que tuvo su presentación el 11 de mayo en el Circo de Parish, de la mano de Mr. Rousby. Y si bien al principio parece admitir cierta rivalidad entre ambos aparatos, en seguida denota cierto menosprecio por el artilugio inglés:

Pero lo que empezó con mucha brillantez dejaría pronto de apasionar a los madrileños [...] Puestos a elegir entre dos procedimientos de impresión y reproducción de escenas animadas, el público prefirió sin lugar a dudas el francés. Esta vez quedó en derrota el famoso e indiscutible individualismo del carácter español: los españoles entusiasmáronse con la visión colectiva del cinematógrafo y desdeñaron la individual del cinetoscopio.

Resulta de gran interés esta última reflexión ya que incurre en el mismo error que posteriormente reitera Méndez-Leite, no sólo en confundir el kinetoscopio de Edison con el animatógrafo, sino también en considerar este último como un aparato de visión individual, cuando la proyección de sus vistas se realizaba de manera colectiva.

Por último, nos enfrentamos al caso peculiar de Méndez-Leite, ${ }^{8}$ cuya obra, a pesar de fecharse en 1969, parece involucionar y persistir en los mismos errores de sus antecesores. Apenas hallamos en su trabajo aportaciones propias, tratándose más bien de una especie de resumen de los términos vertido por sus predecesores.

En cuanto a la llegada del cinematógrafo a España, coincide con Cabero en que fue estrenado para la prensa el día 13 de mayo de 1896, en los bajos del Hotel Rusia. Sin embargo, añade una sesión más de índole privada y exclusiva, el 15 de mayo, coincidiendo con San Isidro, retrasando hasta el día 16 la presentación del cinematógrafo ante el público madrileño en general. En la sesión del día 15, para un público selecto y distinguido, se habría presentado "El regador regado", además de "La avenida de los Campos Elíseos" " "La salida de los obreros de la fábrica Lumière". Más adelante, recoge la misma nota de prensa que Cabero, alusiva a un periódico sin identificar.

Obviamente, los tres autores aquí reseñados no conforman la totalidad de los escritos sobre el tema, pero posiblemente sean los que mejor ejemplifiquen el estilo de investigación imperante en la época, además de ser los autores de las obras más punteras del momento a respecto y las más estudiadas con posterioridad.

\section{El animatógrafo y el cinematógrafo a través de la prensa histórica.}

Una vez analizada la bibliografía, me dispuse a emprender la revisión de la prensa histórica con el propósito de corroborar la información obtenida en las fuentes. Curiosamente, lo que comenzó siendo una tarea complementaria, se convirtió en el verdadero sustento de mi hipótesis, a la luz de los descubrimientos realizados en dicho análisis. Debido a la enorme cantidad de publicaciones que coexistían en Madrid durante las fechas en las que nos movemos, y teniendo en cuenta que muchas de ellas ya habían sido sacadas a la luz por la gran mayoría de

8 Fernando MÉNDEZ-LEITE: Historia Del Cine..., pp. 15-27. los investigadores, decidí concentrar mi atención en dos diarios específicos, El País y La Época, evitando así la reiteración innecesaria e infructuosa de documentos tan manidos como El Imparcial, El Heraldo de Madrid o La Iberia.

Comenzamos, por tanto, haciendo alusión al diario El País, del cual he seleccionado los periódicos correspondientes a la semana de ambos estrenos madrileños (el del animatógrafo y el del cinematógrafo). Si bien no hace mención al aparato de los Lumière- aspecto que me resulta, cuanto menos, llamativo-, este periódico nos sirve como referencia para rastrear la llegada de Rousby a nuestro país. Encontramos publicada en su sección de "Noticias de Espectáculos" del martes 12 de mayote 1896,9 la siguiente reseña "Esta noche, debut del notable artista Mr. Rousby con su animatógrafo". Unas líneas más abajo, en "Funciones para hoy", nos informa: "Circo de Parish: compañía ecuestre, acrobática, gimnástica y cómica de Mr. Hugo Herzog. Debut de Mr. Rousby y de la graciosa bailarina española señorita Rosita Tejero, y Mr. Herzog con sus caballos amaestrados y otros números notables. Entrada general, 50 céntimos".

Veremos cómo este anuncio se repite, casi invariablemente, durante toda la semana. Parece quedar claro, pues, que el animatógrafo fue estrenado al público el 12 de mayo de 1896 en el Circo de Parish. Pero ¿se realizó una sesión privada el día anterior? Para resolver esta cuestión, debemos sacar a colación el diario La Época y su apartado de "Diversiones públicas", cuya publicación del 12 de mayo dice así:10

Anoche, después de la función, se verificó en Parish el ensayo del notable aparato titulado El Animatógrafo, mediante el cual se reproduce la fotografía de movimiento, inventada por Edison en una forma distinta de la presentada por Mr. Hugo Herzog. El nuevo aparato ofrece a la vista del espectador los movimientos del cuerpo humano, proyectados en un amplio lienzo por medio de poderosos focos eléctricos, el tamaño de las figuras adquiere grandes proporciones y los cuadros resultan de gran efecto.

Esta noticia recuerda enormemente, ya que la redacción es prácticamente idéntica, a la publicada por Seguin y Letamendi en Un Siglo de Cine Español, correspondiente al Heraldo de Madrid del 12 de mayo." Por tanto, las fechas y lugar establecidos para la première del animatógrafo, y su presentación general ante el público madrileño, parecen estar bastante claras. Lo que aún no ha sido confirmado con seguridad son las vistas que en dicha inauguración se proyectaron. Sólo he podido encontrar referencias a ello en Josefina Martínez y en el libro Madrid, figuras y sombras, cuyo autor se justifica en una noticia aparecida en el diario Nuevo Mundo, para respaldar sus palabras, pero que data del día 21 de mayo, ${ }^{12}$ nueve días después de su estreno en la capital:

Y qué decir del animatógrafo que presenta el Circo de Parish, ¿que la ilusión es completa al ver aquellos herreros golpeando en el yunque; a los chinos fumando opio y lanzando columnas de humo que se desvanecen; a la Loie Fuller en su danza serpentina; a la Bella Chiquita en su provocadora y venal danza del vientre, y en fin, viendo como se forman en el horizonte las olas...?

9 El Pais (Madrid), 12 de mayo de 1896

10 La Época (Madrid), 12 de mayo de 1896

11 Heraldo de Madrid (Madrid), 12 de mayo de 1896. En: Jean-Claude SEGUIN y Jon LETAMENDI: “Los orígenes del Cine Español” en Un siglo de Cine Español, Cuadernos de la Academia, 1 (1997), pp. $13-22$.

12 Nuevo Mundo (Madrid), 21 de mayo de 1896 . En: Fernando LÓPEZ SERRANO: Madrid figurasy som-

bra. De los teatros de títeres a los salones de cine. Madrid, Complutense, 1999, p.70. 
Volviendo a La Época, centrémonos ahora en lo referente al cinematógrafo. El caso de este periódico es paradigmático ya que se trata de la primera crónica recogida por Cabero, ${ }^{13}$ reiterada después por Fernández Cuenca y Méndez-Leite, y reproducida, a partir de estos autores, en otras fuentes bibliográficas a lo largo del tiempo. Pero lo más curioso es que en los mencionados historiadores, se presenta dicha reseña como tomada de un "diario matutino de la Villa y Corte" (sin especificar), supuestamente editado el viernes 15 de mayo de 1896. La nota dice así:

Desde anoche cuenta Madrid con un espectáculo de tanta novedad como atractivo. E Cinematógrafo, o sea la fotografía animada, es verdaderamente notable y constituye uno de los adelantos más maravillosos alcanzados por la ciencia en el siglo actual. La exhibición de cuadros y vistas panorámicas, reproducidas por medio del cinematógrafo, se hace en un espacioso local (Carrera de San Jerónimo, 34), que anoche estuvo muy concurrido por las muchas y distinguidas personas invitadas a la inauguración. La proyección de la fotografía animada sobre un telón blanco, no puede hacerse con más perfección que la que vimos anoche, estando reproducidos todos los movimientos de personas y objetos que atraviesan la escena. El programa, repetido varias veces ayer, contenía 10 números, de los que son dignos de mención especial la llegada de un tren a la estación, un paseo por el mar, la avenida de los Campos Elíseos, el concurso hípico de Lyon y la demolición de un muro. El público podrá admirar desde hoy este espectáculo, de 10 a 12 de la mañana, de 3 a 7 de la tarde y de 9 a 11 de la noche.

En primer lugar, y tras haber consultado la fuente original, se puede confirmar que dicho periódico no contó con publicación el día 15 de mayo al tratarse de un día festivo (día de San Isidro), con lo que la reseña aquí expuesta necesariamente tuvo que aparecer en otra edición. $Y$ efectivamente, rastreando los números de aquella semana de mayo de 1896 , encontramos esta nota publicada el jueves 14, es decir, un día antes de lo que aseguraba Cabero. Además, no nos encontramos ante un periódico sin identificar, sino que se trata del diario La Época, como se puede corroborar en los anexos del libro El Cinematógrafo en Madrid (1896-1960) ${ }^{14}$, y tras la verificación después de haber acudido a la fuente original.

Al consultar directamente esta misma reseña tal y como aparece en Historia de la Cinematografía Española, ${ }^{15}$ observamos cómo no está copiada literalmente de la fuente hemerográfica original, debido a que se omiten algunas palabras, precisamente aquellas que impedirían hacer coincidir los datos que nos propone Cabero; por lo que presuponemos que el autor obvió de manera consciente dicha información para que cuadrara con sus investigaciones. Comparando ambas notas de prensa (la original y la transcrita por Cabero), es preciso resaltar que mientras la primera encabeza la noticia con las siguientes palabras: "Desde anoche cuenta Madrid con un espectáculo de tanta novedad como atractivo". La segunda, es decir, en la fuente hemerográfica transcrita, se elimina la oración inicial del artículo, comenzando directamente con "El Cinematógrafo, o sea, la fotografía animada...".

Unas líneas más abajo, la nota original dice así: "La exhibición de cuadros y vistas panorámicas, reproducidas por medio del cinematógrafo, se hace en un espacioso local (Carrera de San Jerónimo, 34), que anoche estuvo muy concurrido por las muchas y distinguidas personas invitadas a la inauguración".

Sin embargo, Cabero sustituye la locución "que anoche" por la expresión "en la noche de miércoles", lo que da a entender al lector que la presentación pública del cinematógrafo habría

13 Juan Antonio CABERO: Historia de la Cinematografía.., p. 27.

14 La Época (Madrid), 14 de mayo de 1896. En: El Cinematógrafo en Madrid (1896-1960), Madrid, Ayuntamiento de Madrid, 1986, p. 45

15 Juan Antonio CABERO: Historia de la Cinematografía... p. 27. tenido lugar el viernes 15 y no el jueves 14, cuando realmente sucedió, tal y como nos indica la nota de prensa original. Pero aún hay más. La Época prosigue: "La proyección de la fotografía animada sobre un telón blanco, no puede hacerse con más perfección que la que vimos anoche".

Cabero elimina el término "anoche", cuadrando así, de nuevo, las fechas que propone. Y continúa: "El programa, repetido varias veces (ayer)", suprimiendo asimismo el adverbio temporal "ayer" que aparece en la crónica primigenia.

Y ya para terminar, observamos como el historiador finaliza la transcripción del texto periodístico con la frase: "...y la demolición de un muro".

En cambio, la fuente original incorpora una oración crucial para la correcta interpretación del artículo publicado en el diario madrileño: "El público podrá admirar desde hoy este espectáculo, de 10 a 12 de la mañana, de 3 a 7 de la tarde y de 9 a 11 de la noche".

Si realmente esta noticia hubiera sido publicada en la edición del viernes 15 , no tendría sentido el propio texto de la crónica. Por ello, resulta demasiado sospechoso que en la obra de Cabero aparezcan eliminadas, precisamente, aquellas palabras que echarían por tierra su hipótesis. Mientras que, si asumimos que la reseña pertenece al día 14 (como ya se corroboró) todo el texto cobra sentido, y nos permite deducir y confirmar la fecha de estreno del cinematógrafo en nuestro país.

En los días siguientes a esta publicación, se reiteran los anuncios referentes al nuevo espectáculo, ofreciendo la misma información acerca del local y sus horarios.

\section{Análisis comparativo entre el animatógrafo y el cinematógrafo.}

Para culminar nuestras reflexiones, procede ahora establecer una comparativa entre los dos inventos.

Si de una manera estrictamente literal entendemos "proyección cinematográfica" como e resultado obtenido por el aparato "cinematógrafo", entonces sí, España conoció dicho invento el 14 de mayo de 1896. Pero si nuestra noción de cine va ligada a la reproducción de imágenes en movimiento, proyectadas sobre una superficie, para su disfrute colectivo, entonces debemos ser honestos y puntualizar que en Madrid, dicha invención ya había sido mostrada dos días antes por cortesía del animatógrafo, aparato que, como hemos visto, ofrecía las mismas posibilidades que el artefacto de los Lumière.

Si analizamos detenidamente ambos estrenos madrileños (el del animatógrafo y el del cinematógrafo), nos encontramos con una serie de claves que pueden ayudarnos a comprender, al menos a mi juicio, por qué la historiografía del cine español mantuvo - consciente o inconscientemente- la idea de que el Cine se dio a conocer a los españoles durante las fiestas de San Isidro y mediante el cinematógrafo Lumière.

Siguiendo en esta línea, aceptemos que el Cine tuvo su nacimiento en nuestro país según nos dicen las crónicas el 15 de mayo de 1896 (cierto es, que anteriormente se presentó a la prensa, pero vamos a referirnos a su "estreno oficial"). Como hemos podido comprobar, este dato es falso y realmente el cinematógrafo realizó su primera proyección el 13 de mayo, para la prensa, y el 14 para el público general..$^{16}$ ¿Por qué entonces afanarse en dicha fecha?

En la bibliografía comentada en este texto, observamos cómo en muchas ocasiones se repite la misma frase: "coincidiendo con las fiestas de San Isidro..." o "el día 15 de mayo, coincidiendo con los festejos de San Isidro...." ${ }^{77}$ Desde el punto de vista histórico, resulta lógico pensar

16 Joaquín CÁNOVAS: "Las primeras sesiones del cinematógrafo Lumière en Madrid", en De Dalí a Hitchcock. Los caminos del Cine, Actas del V Congreso de la AEHC, A Coruña y Santiago de Compostela, AEHC, Xunta de Galicia, 1995, pp. 51-65.También en fuentes hemerográficas como La Época o El Correo.

17 Esta idea se reitera en autores como Cabero, Fernández Cuenca, Méndez-Leite o Josefina Martínez. 
que tal novedad como la que suponía el cinematógrafo, resaltaría mucho más su importancia e incluso su legitimación como una nueva maravilla de la tecnología, al ser presentada como un gran espectáculo, en el marco de las fiestas patronales de la capital de un país, donde la ciudad se engalanaba como nunca y tenía la oportunidad de demostrar a la nación española sus más preciados tesoros. Probablemente, no hubiera tenido el mismo alcance situar la primera proyección cinematográfica un día antes de las grandes fiestas madrileñas. Por no hablar de la presencia previa del animatógrafo, un aparato que, aunque ofrecía las mismas posibilidades que el artilugio francés, no era tan conocido, no contaba con el mismo prestigio y desde luego no presentaba el mismo impacto mediático que el causado por el cinematógrafo, del cual se conocía ya su existencia en toda Europa antes de ser presentado en nuestro país. Debemos tener en cuenta, asimismo, que el local seleccionado para estrenar el aparato de Mr. Rousby fue un circo, insertado, además, entre el resto de espectáculos que se ofrecían en el Parish. Recordemos cómo se anunciaba su première en la prensa: "Compañía ecuestre, acrobática, gimnástica y cómica de Mr. Hugo Herzog. Debut de Mr. Rousby y de la graciosa bailarina española señorita Rosita Tejero, y Mr. Herzog con sus caballos amaestrados y otros números notables".18 Por su parte, el cinematógrafo contó con los bajos de un hotel, con unas condiciones de mayor calidad para su exhibición, en una de las calles más céntricas, elegantes y concurridas de $\mathrm{Ma}$ drid, ${ }^{19}$ y gozó de exclusividad absoluta para su estreno.

Por otro lado, detengámonos unos instantes en el público que debió asistir a ambos espectáculos. El Circo de Parish, suponemos, contaría con la presencia de un aforo popular, abierto a todo aquel que quisiera disfrutar de una tarde de diversión. Además de que, al tratarse de un circo y al ser más barato (50 céntimos la entrada general ${ }^{20}$ frente al precio de una peseta por sesión de cinematógrafo ${ }^{21}$ debemos presuponer una condición social más baja que la de los asistentes a la Carrera de San Jerónimo, que si bien estaba abierta al público en general, se reitera sin cesar en las crónicas "las muchas y distinguidas personalidades" 22 que acudieron a su estreno, dignificando, así, la première de dicho invento.

Por último, tengamos en cuenta las cintas, esto es, las vistas proyectadas en ambas sesiones. El debut de Rousby en el Circo de Parish contó, como nos señala Josefina Martínez, con las siguientes imágenes "Una herrería, el puente de Black Frias de Londres, también un rompimiento de olas, unos herreros golpeando un yunque, chinos fumando opio y Loie Fuller realizando la danza del vientre"..23

Habría que añadir, también, la pequeña reseña que se nos ofrece en Madrid, figuras y sombras: "Componían el repertorio "la bella Chiquita con sus danzas obscenas", "bailes cingaleses" y "la bayadera Serpentina", entre otras vistas. Dominaban las escenas de danza y no faltaba el oleaje del mar y la llegada de algún tren, tema que sería muy utilizado por los Lumière en sus cintas". 24

18 El Pais (Madrid), 12 de mayo de 1896

19 Carlos FERNÁNDEZ CUENCA: Promio, Jimeno y los primeros pasos..., p. 9.

20 El Pais, (Madrid), 12 de mayo de 1896

21 Josefina MARTÍNEZ: Los primeros veinticinco años de cine en Madrid (1896-1920). Madrid, Filmoteca Española/ICAA, 1992.

22 La Época (Madrid), 14 de mayo de 1896. Recordemos, también, la descripción de Azorín, presente en su libro Madrid, en: Carlos FERNÁNDEZ CUENCA: Promio, Jimeno y los primeros pasos..., p. 9: "a esa hora del anochecer es cuando la acera de la Carrera de San Jerónimo cobra su animación selecta. En un breve trecho se congrega lo más conocido de España."

23 Josefina MARTíNEZ: Los primeros veinticinco años..., pp. 25-28.

24 Nuevo Mundo (Madrid), 21 de mayo de 1896, en: Fernando LÓPEZ SERRANO: Madrid, figuras y sombras...p. 70 .
Si esta información es totalmente verídica, ${ }^{25}$ nos encontraríamos ante un conjunto de vistas que, si bien es cierto se encuentran en la línea de las ofrecidas por los hermanos Lumière también es preciso señalar que, en su conjunto, la sesión es más del gusto digamos popular, ya que se trata de imágenes de un atractivo visual muy potente que despiertan, ante todo, la sorpresa, el exotismo y la excitación del público, máxime con las escenas de baile o con los chinos fumando opio. Mientras que las vistas del catálogo Lumière ofrecidas en España, podrían tildarse de un tanto más "finas" o"sofisticadas", con un afán un poco más documentalista que sensacionalista; y así nos encontramos con imágenes como "la llegada de un tren a la estación", "un paseo por el mar", "la avenida de los Campos Elíseos", "el concurso hípico de Lyon" y "la demolición de un muro".

Lo cierto es que, a la luz de las crónicas periodísticas, desde la misma presentación de los dos ingenios visuales, se detecta una segregación del público popular y burgués, privilegiándose finalmente la asistencia del cinematógrafo frente a la concurrencia del animatógrafo.

Observamos cómo, a la hora de abordar una historia de los inicios del cine en España los investigadores de nuestra historiografía pioneros en la materia, intentaron dignificar por todos los medios los comienzos del todavía joven arte cinematográfico. Por ello, analizando y comparando el contexto en el que el cinematógrafo es presentado con el resto de sus competidores y precedentes, nos encontramos con una serie de aspectos que, observados desde la distancia, dejan a estos aparatos en desventaja con respecto a su competidor francés. Poniendo como ejemplo concreto el caso del animatógrafo- el más parecido y próximo al cinematógrafo-, existen diversos aspectos en contra del artefacto creado por William Paul, como acabamos de analizar en el capítulo que precede a estas líneas: diferencias del local de estreno de ambos aparatos, el público asistente...- que pueden explicar, al menos parcialmente, el éxito obtenido por el cinematógrafo y la defensa y reconocimiento del mismo por parte de la mayoría de los investigadores.

Por otro lado, no es de extrañar que se haya tomado como hito la llegada a Madrid de aparato Lumière, a partir del cual poder construir toda la historia posterior de nuestro cine, en un acto de dignificación del propio medio cinematográfico. Sería lógico pensar, pues, que a la hora de marcar un comienzo, se eligiera dicho artilugio al cual, por aquel entonces, se le daba un mayor protagonismo, y contaba ya con un mayor reconocimiento internacional y con una proyección comercial muy superior con respecto a sus competidores, los cuales, como el animatógrafo, debido al éxito de éste, acabaron cayendo en el olvido.

Como última reflexión, me gustaría apuntar que, en el caso particular de nuestra cinematografía, debemos tener siempre presente la influencia política del Régimen en el ámbito cultural y académico. No es de extrañar, pues, el intento de relacionar el estreno del Cine en nuestro país, símbolo de modernidad y progreso a la par de otras potencias europeas como Francia, con elementos representativos de España y su capital, en este caso, una fecha, la de las fiestas con elementos representativos de España y su capital, en este caso, una fecha, la de las fiestas
de San Isidro, y unas condiciones específicas de estreno (en la Carrera de San Jerónimo, protagonizado por la aristocracia madrileña...). Días señalados y peculiaridades concretas que encierran una simbología nacionalista y un sentimiento patriótico latente, inherente a los años a los que pertenecen los textos de los investigadores aquí reseñados.

25 Recordemos que López Serrano, se justifica en una noticia aparecida en el diario Nuevo Mundo pero que, como ya comentamos en el apartado de las fuentes hemerográficas, data del 21de mayo de 1896 , con lo que las vistas proyectadas en la inauguración pudieron haber sido otras.

26 La Época (Madrid), 14 de mayo de 1896 


\section{EL PODER LOCAL EN EL PRIMER FRANOUUISMO}

\section{(1939-1945) EN BIZKAIA A TRAVÉS DE SUS ALCALDES}

Jon Kortazar Billelabeitia

Euskal Herriko Unibertsitatea/Universidad del País Vasco

\section{Introducción}

El objetivo de esta comunicación es contribuir al conocimiento de dos aspectos concretos del franquismo cuya investigación está todavía en ciernes, nos referimos a la institucionalización del poder local y las características de los cuadros intermedios que ocupaban los puestos de responsabilidad a ese nivel. En esta comunicación me referiré al caso de Bizkaia, en detalle a algunos alcaldes de sus Ayuntamientos más importantes en las fechas posteriores al fin de la conflagración civil, en concreto al lapso 1939-1945.

La lucha entre distintos sectores del franquismo por los cargos administrativos y políticos y por el ejercicio del poder, y derivando de esto, por la hegemonía del proyecto político de cada sector que apoyo al régimen nacido del golpe de Estado del 18-VII-1936; es un enfrentamiento que tuvo su reflejo a todos los niveles de la estructura del Estado. El nivel local reviste importancia por el hecho de ser "la cara del poder" con la que se relacionan en su vida diaria los ciudadanos.

Cuando hablamos de la interactuación de los ciudadanos con el poder local, entroncamos con otro debate sobre el franquismo abierto en las últimas décadas, el debate sobre el "consenso", la "aceptación" o el "consentimiento" del régimen en el seno de la población; ya que los que ocupaban el poder local solían ser las personas que debían gestionar los mecanismos del régimen para conseguir que éste fuese "aceptado".

En el caso de Bizkaia, la existencia de un escenario de guerra "sui generis", con la fuerza de un partido político de ideología conservadora (demo-cristiana, para ser exactos) que se alineó con las fuerzas de la República planteó una actuación diferente en los mecanismos de la represión y aceptación del régimen, ya que este debía de moverse en unos parámetros sociales diferentes al del resto de las zonas (los mecanismos de cooptación-hostilidad no funcionan igual con un partido opositor pero conservador que con un partido socialista). Sin embargo, este es un aspecto muy tangencial del asunto que nos ocupa; es materia de otro debate, $s$ bien es cierto que el debate que es materia de esta comunicación, es decir la institucionalización del poder local del franquismo en Bizkaia, puede contribuir a esclarecer este otro aspecto.

Para esta comunicación he decidido hacer un muestreo de los Ayuntamientos más importantes de cada comarca de la provincia, para diferenciar en ese sentido entre los Ayuntamientos más industriales y más rurales.

En esta comunicación estudiaremos sobre todo el franquismo en sus primeros años, precisamente la etapa con más carga totalitaria del franquismo y de más presencia de Falange Española; y también la época más convulsa y represiva del franquismo; en concreto el intervalo que va del año 1939 al 1945. En esta comunicación observaremos si el declive de la influencia de la organización fascista hacia el final de la guerra es concomitante con un proceso semejante en la provincia de Bizkaia, así como si "otras" familias franquistas experimentan un proceso idéntico durante la evolución del régimen. De la misma manera, se intentará dilucidar e grado de integración de personas conservadoras en principio alejadas del régimen.

\section{Sobre los cuadros y administración en el régimen franquista}

Antonio Canales establece una distinción entre las diferentes lógicas según las cuales un partidario del régimen pudo ocupar puestos de responsabilidad en el aparato; lo que él llama "las lógicas de la victoria". Según Antonio Canales existen la "lógica de la victoria social" y la "lógica de la victoria política": la primera de ellas sería tendente a restablecer en el poder a las antiguas élites derechistas y conservadoras, que no se olvide, formaron la base del apoyo social y económico al bando que dio el golpe de Estado;' y la segunda de ellas más concordanascendieron debido a su militancia política falangista o tradicionalista. ${ }^{2}$

Antes hemos aludido a la existencia de una Guerra Civil en la gestación del franquismo. Esta variable también tendría su propio papel en la composición del mapa local, tanto a nive institucional como a nivel interior del partido. Uno de los más intransigentes (y más ideologizados) partidarios iniciales del régimen franquista, Dionisio Ridruejo ya advertía del mismo hecho: lo que ocurrió fue un "golpe de Estado" a la inversa, en la cual el Estado tomó el partido. ${ }^{3}$ Pero no sólo eso, sino que el partido único iba a estar cerrado para todo tipo de personas marcadas como "perdedoras". Iba a ser un partido sólo para los que ganaron la guerra civil. ${ }^{4}$ Esta apreciación no es baladí, no sólo debido a la dificultad de conseguir la "integración" necesaria para crear la comunidad nacional única proyectada por los fascistas; sino porque en el hecho de aceptación de los militantes iba a figurar los méritos adquiridos en la guerra como una puerta de entrada para el partido único así como para los cargos que deparaba la militancia en FET-JONS. Se daba así una peculiar "jerarquización política" que iba a yuxtaponerse a la jerarquización por "méritos ideológicos". El partido único fue hijo de la Guerra Civil, a ella le debió su importancia y posición de predominio, pero también ella "hizo el partido", así como lo moldeó impidiendo una fascistización total del partido; máxime cuando le puso un techo.

Los cuadros a nivel local han sido profusamente estudiados por el profesor Glicerio Sánchez Recio. Según el profesor Sánchez Recio la composición de los cuadros medios del franquismo se identificaba por sus intereses, más que por su procedencia política (diversidad de origen, identidad de intereses es la fórmula utilizada por Sánchez Recio). El amplio porcentaje de afiliados a la FET-JONS que encontramos en los cuadros de la Administración no debe interpretarse como un predominio representativo de la Falange de "camisa vieja", ya que en la posguerra mucha gente no precisamente falangista se afilió al partido único. El viraje hacia un mayor porcentaje de afiliados a FET-JONS se daría sobre todo a mediados de los años 40, cuando en las altas esferas e proyecto falangista estaba dando marcha atrás. Por tanto, no debemos hacer una equivalencia simple, por lo menos a partir de 1942 (ya una vez iniciada la marcha atrás del proyecto falangista dentro del régimen) entre el alto número de afiliados a FET-JONS y "predominio de la ideología falangista". Según Sánchez Recio, en la base de los cuadros del régimen se establecería una especie de "sincretismo doctrinal" en base (pero no exclusivamente) a la ideología falangista, pese a los diversos intentos (fracasados) de los "camisas viejas" para establecer una orientación más

Sin embargo, por tratarse de un régimen en gran medida totalitario (por lo menos en los primeros variable: la existencia de un poder central poco dispuesto a compartir cuotas de poder o de tolerar "jeques" locales y muy propenso a establecer una jerarquía de arriba abajo.

2 Antonio CANALES SERRANO: "Las lógicas de la victoria. Modelos de funcionamiento político local bajo el primer franquismo", Historia Social, núm. 56 (2006), pp. 111-130.

3 Dionisio RIDRUEJO: Casi unas memorias. Barcelona, Planeta, 1976. No es de extrañar que Ridruejo fuese uno de los primeros falangistas en irse del partido único, debido a su supuesta debilidad en la fascistización.

4 Ricardo CHUECA: El fascismo en los comienzos del régimen de Franco, Un estudio sobre FET-JONS. Madrid, CIS, 1983, pp. 173-177. 
decididamente falangista en el régimen; citando a los propios falangistas, sería la "apatía"s o la "vieja política" los más graves obstáculos para dichos propósitos. ${ }^{6}$

Como bien queda dicho, el régimen y sus cuadros carecerían de una ideología común, debido al fracaso de los falangistas en imponerla. Sin embargo, siguiendo la línea de Sánchez Recio de "Intereses comunes", eso no excluye que existiese un cúmulo de creencias comunes a todo eso que Sánchez Recio llamaba "coalición reaccionaria": anticomunismo, nacionalismo español, odio a la II República y/o a la democracia, religión, estima por la jerarquía, etcétera.?

El declive de la Falange (esto es, la conversión del partido fascista en una fuerza subordinada dentro del régimen, sin posibilidades de crear una hegemonía), se dio según muchos autores a partir de 19410 1942, concordando con la caída de Ramón Serrano Suñer ${ }^{8}$ (Glicerio Sánchez Recio apunta a 1937, cuando según su expresión Falange pasó a ser un "Partido de orden")..${ }^{9}$ Este hombre, abogado ex-cedista reconvertido en falangista, fue pieza clave en el entramado de gobierno del Estado franquista en los primeros años de la andadura de éste, pero también se convirtió en el símbolo de todo lo odioso que el régimen tenía a los ojos de las masas. El declive de la Falange sería anterior a la II Guerra Mundial, incluso anterior a la Batalla de Stalingrado (1943). ${ }^{10}$

Las razones para esta caída, pueden ser las siguientes: primacía de "lo técnico" sobre "lo político" en la administración franquista, resistencia por parte tanto de la Iglesia (importante factor de legitimación del régimen) como entre los militares (la Falange jamás tuvo nunca la hegemonía total en el poder) y la escasez de medios con los que contaba el partido único. Por tanto, tenemos un partido incapaz de "totalizar el Estado"; más allá de "totalizar" la acción pública propagandística por encargo del mismo Estado. En cuanto al Estado se le hizo más inconveniente utilizar este instrumento, FET-JONS perdió protagonismo, y esto sí que puede ser consecuencia de la derrota del Eje en la ll Guerra Mundial, pero no lo es que FET-JONS estuviese en una posición subordinada (instrumento del Estado). En el contexto que nos ocupa, en Bizkaia se da un caso paradigmático del mismo, en el cual los hombres que iban a ocupar las más altas instancias de las instituciones iban a ser carlistas (hasta el año 1941, años del atentado de Begoña) o miembros procedentes de la antigua oligarquía, que si bien tenían contactos financieros y hasta ideológicos o intelectuales en la Falange, provenían de un mundo distinto un mundo oligárquico que perfectamente podía prescindir del partido único. A esto debemos sumar el languidecimiento de la organización de FET-JONS en Bizkaia en los primeros años (1937-1941), siendo su Jefe Provincial el carlista José María Oriol."

Glicerio SÁNCHEZ RECIO: Los cuadros intermedios del franquismo. Alicante, Instituto Juan Gil-Albert, Diputación de Alicante y Generalitat de Valencia, 1996, pp 50-59, 76-80 y 83-116

6 Glicerio Sánchez Recio cita el caso del Jefe Provincial de Zaragoza de FET-JONS, Pío Altolaguirre (principios de los 40) y sus continúen enfrentamientos con el Gobernador Civil. Ángela CENARRO LAGUNAS: Los orígenes y la naturaleza del franquismo en Aragón, 1936-1945. tesis doctoral, Universidad de Zaragoza, 1994, Glicerio SANCHEZ RECIO: Los cuadros intermedios..., pp. 84-85. No obstante, debe ser tenido en cuenta que la "vieja politica", que muchas veces venia aparejada con la acusa-

7 Glicerio SÁNCHEZ RECIO: Los cuadros intermedios..., p. 119.

8 Entre otros, Borja de Riquer o Ismael Saz. Seguidamente desgranaremos las razones que ambos autores apuntan.

9 Glicerio SÁNCHEZ RECIO: Los cuadros intermedios..., p. 37.

10 Según Ismael Saz, la única ofensiva política falangista digna de mención ocurrió en mayo de 1941, con una fuerte presión sobre las instituciones, ayudados por Serrano Suñer. Sin embargo los cambios que Franco hizo en el Gobierno, a pesar de que aparentemente daban más poder a los falangistas en la práctica limitaban la influencia de éstos. Eso hizo que la única esperanza de los falangistas para conseguir todo el poder fuese la entrada en la contienda úclica mundial. Ismael SAZ CAMPOS: Fascismo y franquismo. Valencia, Universidad de Valencia, 2004, Pp. 163-164.

11 Joseba AGIRREAZKUENAGA y Mikel UROUIJO (dir.): Bilbao desde sus alcaldes (vol. III): Diccionario

biográfico de los alcaldes de Bilbaoy gestión Municipal durante la dictadura. Bilbao, Ayuntamien

\section{El ámbito municipal}

Los municipios españoles en el régimen franquista tenían una autonomía ínfima, ya desde la guerra civil, donde estaban sujetos a la voluntad de los comandantes militares. ${ }^{12}$ Esta situación de provisionalidad, teóricamente iba a prolongarse hasta La Ley de Bases Municipales aprobada en $1945 \cdot{ }^{13}$ Este texto, basado en la Ley municipal italiana de $1937 ;^{14}$ preveía que e Alcalde fuese, según palabras de la propia Ley, "Delegado del Gobierno en el término local", entre otras características. Esta misma ley facultaba al Ministerio de la Gobernación el nombramiento de los alcaldes de las capitales de provincia y en los municipios mayores de 10.000 habitantes, mientras que reservaba al Gobernador Civil la posibilidad de nombrar a los alcaldes de los pueblos menores a esa cifra. Las competencias de los alcaldes eran reducidas, más bien simbólicas y "vigilantes", que legislativas en el término municipal.

La Ley de Bases establecía la diferencia entre "vecino", "domiciliado" " "transeúnte"; siendo sujeto de derechos plenos el primero de ellos, para el cual se requería ser ciudadano español y emancipado (sólo los vecinos pudieron votar en las elecciones municipales de 1948). Por otra parte, reservaba al Gobernador Civil el puesto de "presidente nato de la Diputación provincial", además de amplísimas atribuciones en la vida política de la provincia, siendo el Gobernador Civil el alfa y omega de la misma. Entre esas mismas atribuciones encontramos la responsabilidad del orden público (sanciones y responsabilidad civil de las fuerzas públicas), la más alta responsabilidad política en la provincia correspondiente, concesión de permisos para actos públicos, ser la más alta responsabilidad social de la provincia (beneficencia, hospitales y etcétera) y promover cuestiones de competencia a los jueces y tribunales de la provincial. El Gobernador era además el enlace entre la provincia y la alta política estatal, siendo el representante del Gobierno en la provincia; investido además de amplios poderes políticos. Por otra parte, el Gobernador Civil podía presidir con voto las reuniones de la Diputación provincial tanto como convocar plenos extraordinarios; así como suspender las reuniones de esta (o de los Ayuntamientos) si los estimase contrarios a la ley. ${ }^{5}$ La Diputación, en la práctica, era un auxiliar de Gobernador Civil, máxime cuando en Bizkaia fue suspendido el Concierto Económico.

El Gobernador Civil, a partir del año 1940 iba a fusionarse en la misma persona con el cargo de Jefe Provincial de FET-JONS, lo que en la práctica significaba la supeditación total de los falangistas al Estado, ya que la escasez de fondos del partido único iba a hacerles depender totalmente de la institución estatal. ${ }^{16}$

En definitiva, la nueva ley municipal, si bien estableció un reglamento concreto del funcionamiento de la vida municipal y provincial, sancionó una pérdida competencial de los mismos en virtud de la orden jerárquica que quiso establecer el franquismo, convirtiendo a los Ayuntamientos en entes totalmente dependientes de instancias superiores y sin margen de maniobra competencial y presupuestaria.

de Bilbao, 2008, p. 250

12 Glicerio SÁNCHEZ RECIO: Los cuadros intermedios..., p. 36.

13 Borja DE RIQUER I PERMANYER: La dictadura de Franco. Sabadell (Barcelona), Crítica y Marcia Pons, 2010, p. 66.

14 Marti MARINI CORBERA: "Franquisme i poder local. Construcció i consolidació dels ajuntaments feixistes a Catalunya, 1938-1949", Recerques, núm. 31 (1995), pp. 37-52.

15 Información sobre competencias municipales en: Ley de Bases de Régimen Local (1944-VII-17), in Local. lustel y Madrid, Fundación Democracia y Gobierno Local, 2008 pp. 1632-1644 (en concreto Bases $5,6,13,14,36$ y 37 ).

16 Borja DE RIOUER I PERMANYER: La dictadura..., p. 39 


\section{Ayuntamientos en Bizkaia 1939-1945}

Como se ha señalado en la introducción, en este trabajo se analizarán los alcaldes de las corporaciones más importantes de Bizkaia: la capital, Bilbao más los pueblos más importantes de cada comarca: Barakaldo (Margen Izquierda), Getxo (Margen Derecha y Uribe-Kosta), Balmaseda (Enkarterri), Galdakao (Arratia-Ibaialdeak), Durango (Durangaldea), Ondarroa (Lea-Artibai), Gernika (Busturialdea/Urdaibai) y Mungia (Uribe-Butroi/Mungialdea). El espacio cronológico analizado es el del primer franquismo, de 1939 a 1945.

Lo primero que llama la atención en este análisis es la poca estabilidad de los equipos consistoriales reseñados. A excepción de Barakaldo, en el cual el alcalde José María Llaneza Zabaleta iba asumir el cargo en 1937 e iba a durar en el mismo hasta la década de los sesenta; los demás ayuntamientos iban a ser muy proclives a los cambios de regidor. En Bilbao en este lapso de tiempo fueron cuatro los alcaldes que pasaron por el máximo puesto consistorial: José Félix Lequerica, José María Oriol, Tomas Pero-Sanz y Joaquín Zuazagoitia. A estos deben ser sumados José María Areilza y José María González de Careaga que desempeñaron el cargo entre 1937 y 1938. ${ }^{17}$ Tres de estos alcaldes (Areilza, Gonzalez de Careaga y Lequerica) iban a estar entre 6 y 8 meses en el cargo solamente. Oriol cubriría casi dos años (22 meses y medio) y Pero-Sanz algo más de un años (20 meses y medio). El único longevo sería Zuazagoitia, que estaría en su puesto hasta 1959, cumpliendo casi diecisiete años en el poder. En total, el alcalde bilbaíno iba a pasar de media 40 meses en el poder; poco más de tres años. En otros pueblos, a excepción de Barakaldo y Ondarroa (donde José Ramón Osa Carril iba a estar en el cargo hasta 1948), ${ }^{18}$ la situación no iba a ser mucho más estable. En Gernika, el primer alcalde en posesión, Juan Bilbao Monasterio, iba a estar tres años en el poder (1938-41). Su sustituto, Enrique Amurrio iba a estar algo más tres años y medio (de octubre de 1941 a Marzo de 1945).19 Uno de ellos dos, Juan Bilbao, iba a ser víctima de una intentona fracasada para quitarlo del poder en otoño de 1938, en la cual van a estar implicados casi todos los concejales, menos dos de ellos. ${ }^{20}$ Los demás pueblos irían en este sentido. Balmaseda iba a tener tres alcaldes en el lapso analizado, Fabián González (1938-1940), Manuel Braceras (1940-1943) y Anastasio Agustino (1943 en adelante). ${ }^{21}$ El caso de Durango sería parecido al de otros casos, sin embargo tendría la pe-

17 Información sobre estos ediles se encuentra en Joseba AGIRREAZKUENAGA y Mikel UROUIJO (dir.): Bilbao desde sus alcaldes (vol. III): Diccionario biográfico de los alcaldes de Bilbao y gestión Municipal durante la dictadura. Bilbao, Ayuntamiento de Bilbao, 2008

18 La información sobre José Ramón Osa Carril se puede encontrar en los Boletines Históricos de la Provincia de Vizcaya editados entre los años 1937 y 1948, en el Archivo Municipal de Ondarroa y en los documentos del Archivo General de la Administración AGA, sección (8) Gobernación, fondo antiguo 025, caja 025 44/02553, expediente "Ondárroa" y AGA (8) Gobernación, fondo antiguo 025, caja 44/O2912 expediente "Ondárroa".

19 Iba a ser sustituido por el jefe local de FET-JONS, Vicente Rojo Cubillo, quien iba a compaginar el puesto de alcalde de Gernika con su puesto en la Diputación de Bizkaia. Rojo Cubillo iba a tener una dilatada experiencia en la derecha local; siendo uno de los dirigentes monárquicos locales iba a participar en una conspiración monárquica en 1931, siendo desterrado por Casares Ouiroga a Cáceres. Información sobre Rojo Cubillo se encuentra en: AGA sección (8) Gobernación, fondo antiguo 025, caja 44/02553, expediente "Guernica" (sobre su nombramiento como vicealcalde en 1943) y AGA sección Gobernación (8), fondo antiguo 025, caja 44/02768, carpeta 1, expediente "Diputación": (sobre su nombramiento en la Diputación en 1944). Su participación en la conspiración monárquica es mencionada en Eduardo GONZALEZ CALLEJA: Contrerravolucionarios. Madrid , Alianza Editorial, 2001, p. 48.

20 Estos dos concejales iban ser Florencio Amador Carrandi y Leandro Omaechevarria Basabe; los únicos que iban a seguir en el próximo equipo de Gobierno. Información en AGA sección Gobernación (8), fondo antiguo 025, caja 44/02604, carpeta 1, expediente "Guernica".

21 Sin contar con el alcalde durante los seis meses de julio de 1937 a enero de 1938. Escolástico Zulaica Arás. Zulaica y su equipo de Gobierno fueron destituidos debido a que se encontraron elementos culiaridad del color carlista. Entre 1939 y 1945 pasarían tres alcaldes: José María Arce, Leonardo Tristán y Justo Uribarrena (anteriormente, entre 1937 y principios de 1938 ejercería Adolfo Uribasterra). Sin embargo, el último de estos tres, Uribarrena, no sería muy bien visto por "Ia masa tradicionalista" debido a que no se le consideraba como suficientemente carlista o que anteponía las jerarquías del régimen a las del movimiento dinástico. ${ }^{22}$ Otro Ayuntamiento de color carlista iba a ser Galdakao, donde iban a estar dos alcaldes: Martín Ibarreche (1943-1948) y Braulio lbarreche (1943 en adelante). ${ }^{23}$

En el extremo de la inestabilidad, tenemos los casos de Mungia y Getxo. En Mungia encontramos el ayuntamiento hecho un caos, a la dimisión de Juan Ramón del Barco Oñate en mayo de 1938, sigue un periodo de seis meses a cargo de Teodoro Urrutia, que sale del cargo en diciembre de 1938. A esto seguiría un periodo de cinco años de interinidad, hasta 1943, cuando Del Barco se vuelva a hacerse cargo del Ayuntamiento. ${ }^{24}$ Sin embargo, el pueblo más inestable en este lapso, fue claramente Getxo, que conoció oficialmente cuatro alcaldes: Salvador Basagoiti Ruiz (nombrado a mediados de 1938 y sustituido en 1939), Cándido Bilbao Basterra (1939-1944), Joaquín Ibargüengoitia Cortázar (1944-1945) y Juan Bautista Merino Urrutia (a partir de 1945$)^{25}$. Sin embargo, Cándido Bilbao dimitiría a mitad de su mandato, lo que haría que el concejal Jesús Baillo se hiciese cargo del Ayuntamiento de manera interina, a la manera de Ciriaco Basozabal en Mungia. En este pueblo no fue hasta 1945, al hacerse cargo del ayuntamiento Juan Bautista Merino Urrutia, cuando se conoció algo de continuidad. Por tanto, la nota dominante durante estos años en los Ayuntamientos vizcaínos iba a ser la inestabilidad: entre el caso extremo de Bilbao (cuatro alcaldes para el lapso 1939-45 y seis si contamos el lapso 1937-45), Getxo o Mungia; y las excepciones estables de Barakaldo y Ondarroa; lo norma iba a ser conocer tres alcaldes en el lapso analizado.

La inestabilidad iba a ser palpable también si analizamos los porqués de los cambios de alcalde. Si bien en el caso bilbaíno de los cinco relevos que se dieron tan sólo uno puede imputarse a una cuestión "política", cuando el carlista Pero-Sanz, desprestigiado por los atentados de Begoña en el marco de un enfrentamiento entre falangistas y carlistas fue sustituido por Joaquín Zuazagoitia ${ }^{26}$ (estos atentados marcarían la pérdida del poder carlista en la provincia,

"indeseables" en ese equipo de Gobierno, Sin embargo el propio Zulaica fue recuperado como suplente del juez municipal en 1946, según Boletín Oficial de la Provincia de Vizcaya. La mención sobre los "elementos indeseables", aunque no se cite a Zulaica está en AGA sección Gobernación (8), fondo antiguo 025 , caja 44/02604, carpeta 1, expediente "Valmaseda". Por otra parte, el citado Anastasio Agustino tambien serímiembios de la diputación de Bizkaia.

22 AGA sección Gobernación (8), fondo antiguo 025, caja 44/02534, carpeta 1, expediente "Durango". Uribarrena sería sustituido en 1947, ocupando su puesto José Julián Zabala Mintegui.

23 No habría relación familiar entre ambos. Martín Ibarreche iba a ser visto en 1940 repartiendo pasquines de signo tradicionalista, según la denuncia de un cierto José María Aibar; dicha información se puede ver AGA sección Presidencia (9), fondo 17.10, caja 51/20517, expediente 20. Por su parte, Braulio Ibarreche fue miembro de la Diputación, nombrado en 1949.

24 El vicealcalde Ciriaco Basozabal iba a ser la persona encargada de estar al frente del Ayuntamiento en ese lapso de cinco años. Sin embargo, debido a que era funcionario en el Ayuntamiento de Bilbao, habría quejas debido a su proceder, en el sentido de que "no se implicaba demasiado en el Ayuntamiento", que le constaría la destitución en 1943. Datos sobre Ciriaco Basozabal en AGA sección Gobernación (8), fondo antiguo 025, caja 44/02553, expediente "Munguía".

25 Antes estuvieron de alcaldes Ramón Churruca Arellano (1937), quien luego fue concejal en Bilbao y José María Oriol, quien luego fue alcalde de Bilbao (primeros meses de 1938). Sobre el nombramiento de Joaquín Ibargüengoitia, que iba a comportar un cambio en el equipo de Gobierno puede verse to de Joaquin Ibarguengoitia, que iba a comportar un cambio en el equipo de Gobierno puede verse"

26 Jobacion Joseba AGIRREAZKUENAGA y Mikel UROUIJO (dir.): Bilbao desde sus alcaldes (vol. III)..., pp. 236-239.
Todos los demás alcaldes vendrían de un mismo ambiente, el ambiente monárquico "fascistizaTodos los demás alcaldes vendrian de un mismo ambiente, el ambiente monárquico fascistizaaltos de la Administración tras su relevo. 
salvo en sus reductos más fuertes como Barakaldo). ${ }^{27}$ Además del ya comentado caso de rebelión de los concejales contra el alcalde Juan Bilbao en Gernika; tenemos el relevo de Escolástico Zulaica (Balmaseda) en 1938 por "infiltración de «elementos indeseables»", el cambio de equipo gobernante de Getxo en 1938 por la misma razón ${ }^{28}$ e incluso los ya citados problemas en Durango con Justo Uribarrena Erdoiza. En Gernika en 1945 también se da una sustitución política, pero en este caso no es debido a "precauciones" con la gente que había entrado en el Ayuntamiento, sino con el objeto de premiar al jefe local de FET-JONS, José Luis Unceta Aizpiri, que fue nombrado teniente de alcalde. ${ }^{29}$ En el caso de Galdakao, a pesar de que la razón oficial para el cambio propuesto en 1943 fuese el "cansancio" de los corporativos establecidos, el recuerdo del alcalde Martín Ibarreche repartiendo panfletos tradicionalistas años atrás tuvo su peso, dado el perfil político del sucesor, Braulio lbarreche..$^{30}$ Incluso en la muy estable Baracaldo se iban a dar casos de reajustes políticos, aunque a menor escala, en septiembre de 1938 un concejal iba a ser destituido debido a razones políticas. ${ }^{31}$ Otra razón para el cambio de Ayuntamiento iba a ser la "desidia" o "falta de efectividad", como iba a ocurrir en Mungia en 1943, en el caso de la citada vuelta al poder de Juan Ramón del Barco o en Bilbao donde pese a que no propició ningún cambio de alcalde, si provocó sustituciones en los concejales. ${ }^{32}$ Sin embargo, la razón más citada para los cambios consistoriales iba a ser el "cansancio" de los corporativos. ${ }^{33}$ Cabe poner en duda si esta razón se esgrimía honestamente; ya que en un contexto como el nuestro, con cambios con aproximadamente tres años de media (en la mayoría de los casos) que excluyen una continuidad en el cargo por un espacio largo de tiempo, es bastante difícil que apareciese esa circunstancia. ${ }^{34}$

Respecto a la clase social de los alcaldes; es menester diferenciar Bilbao e incluso tal vez Getxo y Barakaldo (los mayores pueblos de Bizkaia, aparte de la capital) del resto de los pueblos analizados. En estos ultimos, los alcaldes provenian de un mundo de la éite local una especie de "fuer-

27 La Gobernación Civil, otro reducto carlista, iba a ser también escenario de cambios: el carlista Almería). BOE 4-IX-1942. Vivar Téllez iba a ser muy crítico con la gestión que se llevaba a cabo en Almeria). BOE 4-IX-1942. Vivar Téllez iba a ser muy critico con la gestión que se llevaba a cabo en
el Ayuntamiento de Bilbao (Joseba AGIRREAZKUENAGA y Mikel UROUIJO (dir.): Bilbao desde sus alcaldes (vol. III)..., p. 250).

28 En Getxo debemos sumar el caso del vicejefe provincial de FET-JONS, Rafael Vierna Arana, que fue En Getxo debemos sumar el caso del vicejefe provincial de FET-JONS, Rafael Vierna Arana, que fue
ofrecido el cargo de alcalde en 1945, pero no lo aceptó. AGA sección Gobernacion (8), fondo antiofrecido el cargo de alcalde en 1945, pero no lo aceptó.

29 AGA sección Gobernación (8), fondo antiguo 025, caja 44/02534, carpeta 1, expediente "Guernica".

30 No podemos afirmar que la razón principal para la sustitución de Martín lbarreche fuese ésta, máxime cuando el cambio se da tres años después, pero sí podemos aventurar que pesó sobre todo para elegir el perfil del sucesor. Braulio Ibarreche, había militado durante la II República tanto con los tradicionalistas como con los falangistas (sobre todo a raíz del cambio de domicilio a Bilbao en 1935), y es de suponer que era una persona que anteponía a los valores comunes del régimen al faccionalismo. Sobre Braulio Ibarreche puede ser consultado en AGA sección Gobernación (8), fondo antiguo 025, caja 44/02553, expediente "Galdácano" y AGA sección Gobernación (8), fondo antiguo 025, caja 44/02604, carpeta 1, expediente "Galdácano".

31 Dicho concejal se llamaba Benito López. Información en AGA sección Gobernacion (8), fondo antiguo 025, caja 44/02604, carpeta 1, expediente "Baracaldo".

32 Joseba AGIRREAZKUENAGA y Mikel UROUIJO (dir.): Bilbao desde sus alcaldes (vol. III)..., p. 199.

33 En Gernika en el año 1941, se da una sustitución en el puesto de alcalde debido al fallecimiento mientras estaba en el cargo de Juan Bilbao Monasterio. 34 Sin embargo es difícil aventurar qué puede encontrarse detrás de dichas razones: puede ser cierta que podi servisto como un frosco por un Estado en plena etapa “movilizadora”: cabe reseñar aqu que el Gobernador Civil Genaro Riestra adujo esta misma razón para promover el cambio al frente de la diputación en 1946, al sustituir a Jose luis Coyoga Escario (que había sido fulminantemente destituido por firmar una carta exigiendo el retorno de la monarquía) por Javier Ybarra Bergé. zas vivas locales". Tenemos el caso de Durango, donde el alcalde Uribarrena era comisionista in dustrial, el ejemplo de Gernika, con Enrique Amurrio como empresario industrial y Vicente Rojo como director de una fábrica,35 Galdakao, donde el empleado Braulio Ibarreche llegó a ocupar la alcaldía, Mungia, con el caso del ya comentado Ciriaco Basozabal (funcionario del Ayuntamiento de Bilbao) o Balmaseda, donde Anastasio Agustino era Maestro Nacional. Sin embargo en poblaciones más grandes la cosa cambiaba. En Barakaldo, feudo de José María Llaneza, este mismo no era de por sí un elemento de la oligarquía (puede clasificarse como profesional liberal, ya que era facultativo de minas), pero debido a su trabajo en Altos Hornos de Vizcaya, donde estaba empleado, tenía un estrecho contacto; político y social con la oligarquía vizcaína, haciendo en muchas ocasiones una labor de puente..$^{36}$ Totalmente diferente fue la situación de los municipios de Bilbao y Getxo, sobre todo en la capital de la provincia. De los seis alcaldes que hubo hasta 1945, sólo Tomás Pero-Sanz (curiosamente el único de ellos que era tradicionalista) pertenecía a la pequeña-burguesía o burguesía media (era dueño, junto a sus hermanos, de un taller relacionado con actividades navieras: Pero-Sanz Hermanos), y hasta cierto punto el farmacéutico y articulista Joaquín Zuazagoitia, quien fue sin embargo presidente del Colegio de Farmacéuticos de Bizkaia y vicepresidente de la organización homónima en España; y por sus actividades periodístico-literarios muy cercano al grupo (tanto por los ambientes que frecuentaba como por la ideología que compartía) de los oligarcas-políticos de Neguri. ${ }^{37}$ En cambio, los demás regidores de la Villa: todos ellos ligados a familias de la oligarquía vizcaína y con importantes participaciones en las empresas españolas, e ideológicamente, un bastión de la clásica derecha "fascistizada" que alude Ismael Saz en sus obras..$^{8}$ En el caso de Getxo, además de ser lugar de residencia de dicha oligarquía mencionada en éste párrafo, ${ }^{39}$ encontramos también gente bien posicionada: el abogado Joaquín Ibargüengoitia (también ejercería esta profesión el vicealcalde José María Conde, alguien que ejercería también de alcalde en funciones a partir de 1945), el comerciante Juan Bautista Merino Urrutia, el vicealcalde (también posteriormente concejal en Bilbao además de miembro de la Diputación) Ramón Real de Asúa era ingeniero industrial, etcétera.

Hemos hecho referencia a dos grupos ideológicos en la derecha vizcaína de ésta época: por un lado los carlistas, más presentes en la Bizkaia oriental, más rural, y por otro lado, en la Bizkaia occidental, más industrial, un amplio peso del partido conservador de extrema derecha Renovación Española. Estos últimos habían absorbido en gran parte la ideología fascista. ${ }^{40}$ El origen de esta división por zonas la podemos encontrar en la última Guerra Carlista, terminada en 1876. La triunfante burguesía había conseguido emerger como la clase hegemónica en Bizkaia, y había conseguido el predominio político en las instituciones así como el cultural en lo que se refiere a las publicaciones. Sin embargo, tenemos ahí la excepción de Barakaldo, con el alcalde Llaneza, o incluso la existencia de un alcalde carlista en Bilbao (Pero-Sanz). Por otra parte, hubo pueblos en la Bizkaia oriental, como Mungia o Gernika, no proclives al tradicionalismo. La pervivencia del carlismo en Bizkaia, obviamente mayor en el mundo rural, puede entenderse si se entiende este

35 Fue apartado de su trabajo durante la guerra Civil por las tropas republicanas.

36 Datos citados en Antonio Francisco CANALES SERRANO: Las otras derechas. Derechas y poder local en el País Vasco y Cataluña en el siglo XX. Madrid, Marcial Pons Historia, 2006.

37 Pero-Sanz y Zuazagoitia serían los únicos que no tuvieron una proyección importante en su carrera tras dejar la alcaldía (aunque Zuazagoitia estuvo 17 años en la misma comparando con exiguo lapso de Pero-Sanz). Los demás alcaldes siempre consiguieron un puesto más importante en su carrera tras dejar la alcaldí.

38 Ismael SAZ CAMPOS: Fascismo y franquismo. Valencia, Universidad de Valencia, 2004 y Ismael SAZ CAMPOS: España contra España. Madrid, Marcial Pons, 2003.

39 José María Oriol, antes de ser alcalde de Bilbao, fue alcalde de Getxo entre 1937 y 1938.

40 En este punto conviene recordar las grandes relaciones, politicas, intelectuales y financieras que tuvieron los hombres de la oligarquía de Neguri con los fundadores del fascismo español. Ver en Eduardo GONZALEZ CALLEJA: Contrarrevolucionarios. Madrid, Alianza Editorial, 2011. 
términos relativos, comparando con otras fuerzas de derecha), donde echó raíces como un modo de resistencia al caciquismo liberal de principios de siglo en clave de vuelta al pasado. ${ }^{41}$

Así pues, la derecha conservadora extrema (antigua Renovación) y los carlistas serían las fuerzas predominantes en la política derechista vizcaína, ya en los tiempos de la II República, mientras que CEDA-Acción Popular y Falange tendrían un peso relativamente pequeño; sin embargo, la constitución del partido único como base falangista ayudaría, por lo menos en esta época del primer franquismo al proceso de "fascistización" que ya se estaba dando en la derecha no falangista, que se mimetizaría hasta cierto grado con la doctrina falangista.

Por último, en torno a otras características claves de los alcaldes sería su relación con las jefaturas locales. En realidad, la unificación entre Jefe Local y alcalde sería bastante tardía en una provincia como Bizkaia. En el año 1943, sólo dos de los pueblos estudiados tendrían ambos puestos unificados (Barakaldo y Balmaseda). ${ }^{42}$ En Gernika si bien es cierto que en el lapso $1941-$ 43 esos dos cargos estaban unidos en persona de Enrique Amurrio, esta unificación se rompió en 1943, recuperándose en 1945, en la persona de Vicente Rojo. ${ }^{43}$ Respecto a la implicación que tuvieron este tipo de personal en la guerra, podemos decir que fue en términos porcentuales fue bastante bajo. De los 26 alcaldes estudiados, tan sólo tres figuran como excautivos: Juan Ramón Del Barco (Mungia), José Ramón Osa (Ondarroa) y Braulio lbarreche (Galdakao). Mientras que como excombatientes figuran tres alcaldes: el mismo Braulio lbarreche (se alistó una vez el bando golpista hubo capturado Bizkaia), el bilbaíno José María Oriol quien combatió con los requetés y Manuel Braceras (Balmaseda). ${ }^{44}$ No es fácil encontrar una explicación a este he cho, una explicación plausible puede ser la que aporta Antonio Canales en su artículo sobre las lógicas de la victoria; 45 aplicado en este caso podemos decir que la lógica de la victoria social se impuso a la lógica de la victoria política. Otra razón puede ser la escasez de los cargos "ideologizados" disponibles debido a la represión republicana en Bizkaia, que se cobró alrededor de 400 vidas, diezmando así el número de los posibles candidatos "ideologizados" que podría proveer una "lógica política" al reparto de cargos..$^{46}$

41 Este tema ha sido estudiado entre otros por Ander Delgado: Ander DELGADO CENDAGORTAGALARZA: La otra Bizkaia. Política en un medio rural durante la restauración. (1890-1923). Bilbao, Universidad del Pais Vasco, 2008. Para el caso concreto de Barakaldo, Antonio Francisco CANALES SERRANO: Las otras derechas. Derechasy poder local en el Pais Vascoy Cataluña en el siglo XX. Madrid, Marcial Pons Historia, 2006. Sin embargo, tambien hay que tener en cuenta la entrada en escena de otro mov vasco, el cual arrebataria una gran parte de su base social al tradicionalismo, que una vez entrada la repúba optaria con alia con la derecha oligárquica. No es objeto de este estudo analizar

la corelacon entre

42 De esta relación hay que excluir Bilbao, ya que en la capital de la provincia no habrá Jefe Local de Falange (este puesto estaría cubierto por el jefe Provincial). La unificación de los puestos entre Jefe Provincial y Gobernador Civil se daría a principios de 1941, siendo Juan Granell Pascual el ocupante de ambos puestos (José María Oriol dimitiría como Jefe Provincial).

izkaia a fecha de Noviembre de 1943 en AGA, sección Presidencia (9), fondo 17.10, caja 51/20632.

44 Podemos sumar a José Maria Llaneza, que estuvo como vocal en una comisión para preparar el golpe de estado en Bizkaia.

45 Antonio Francisco CANALES SERRANO: "Las lógicas de la victoria. Modelos de funcionamiento político local bajo el primer franquismo", Historia Social, núm. 56 (2006), pp. 111-130

46 Debe reseñarse que la inmensa mayoría de estas muertes se produjeron a raíz de las ejecuciones ilegas debido a " tuna-mendi". Las ejecuciones ordenadas por la autoridades fueron muy pocas. 
Parte 2.

HACIENDO HISTORIA. SOBRE ENSEÑANZA,

APRENDIZAJE Y COMPETENCIAS PARA LOS

HISTORIADORES DEL SIGLO XXI 


\section{¿HACIA UNA NUEVA DIDÁCTICA? POSIBILIDADES $Y$ RETOS PARA LA ENSEÑANZA-APRENDIZAJE DE LA HISTORIA EN EL SIGLO XXI}

David Parra Monserrat

Universitat de València

La necesidad de analizar la construcción académica y escolar del conocimiento histórico, los problemas relacionados con su aprendizaje o la influencia que los distintos curricula, las finalidades educativas, los enfoques psicopedagógicos y las rutinas diarias han tenido y tienen en la configuración y representación social de una disciplina como la Historia, explica la presencia cada vez mayor de mesas o talleres de didáctica en eventos como el IV Encuentro de Jóvenes Investigadores en Historia Contemporánea; una presencia que pone de manifiesto el interés creciente de la profesión por el proceso de enseñanza-aprendizaje de la Historia y su dimensión social.

A lo largo de las próximas páginas se presenta un balance del contenido de las principales discusiones y debates mantenidos durante el transcurso de la mesa-taller "Haciendo historia: sobre enseñanza, aprendizaje y competencias para los historiadores del siglo XXI"; unos debates que evidenciaron, por un lado, la vitalidad y actualidad de los problemas relacionados con la enseñanza de la Historia y, por otro, la conveniencia de una mayor reflexión por parte de los profesionales (investigadores y docentes) para poder abordar dichos problemas con una mayor solidez. A pesar de la heterogeneidad de las comunicaciones presentadas, centradas en problemáticas dispares y no siempre conectadas, los distintos trabajos presentaron algunas líneas o ejes compartidos que, desde hace años, vienen siendo objeto de estudio de los especialistas en didáctica. De algunas de estas cuestiones analizadas durante el Encuentro daremos cuenta en los sucesivos apartados.

\section{La representación de la disciplina histórica y su impacto en la didáctica}

Intentar cambiar los modelos de enseñanza-aprendizaje y las rutinas diarias del aula es esencial para favorecer una transformación en el ámbito de cualquier disciplina escolar. Ahora bien, en el caso de materias como la que nos ocupa, resulta también de gran importancia comprende los mecanismos culturales que han conducido a determinadas representaciones que impiden avanzar en la construcción de otra Historia escolar; una Historia que fomente la confrontación de informaciones, el análisis reflexivo y el desarrollo de un pensamiento más crítico y abierto.

* El autor forma parte del proyecto de investigación "De la dictadura nacionalista a la democracia de las autonomias: política, cultura, identidades colectivas" (HAR 2011-27392), financiado por el Ministerio de Economía y Competitividad.

1 Son muchos los historiadores y los especialistas en didáctica que, en los últimos tiempos, han reivindicado una Historia escolar más critica y comprometida con problemas a tuales. Vénse, por ejemplo

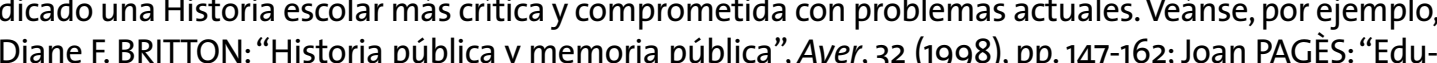

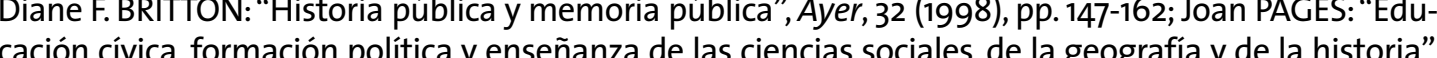
íber Didáctica de las Ciencias Sociales, Geografia e Historias sociales, de la geografia y de la historia", y memoria escolar Segunda República, Guerra Civil y dictadura franquista en las auael VALLS: Historia

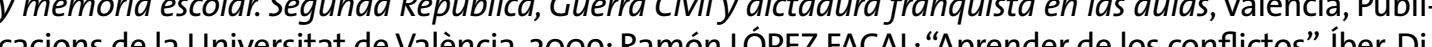

La constitución de la Historia como saber escolar no fue consecuencia de la institucionalización de la comunidad científica de historiadores; no obstante, las distintas concepciones de la historiografía académica no han estado al margen de la configuración del código disciplinar de la Historia ni de las representaciones más o menos simples, más o menos populares, que, de la misma, se han ido conformando con el paso del tiempo. ${ }^{2}$ No lo estuvieron en el siglo XIX, cuando el historicismo y el positivismo eran las tendencias hegemónicas en el campo de la historiografía; pero tampoco en la actualidad, pese a tener que convivir con otros enfoques epistemológicos preconizadores de un tipo de Historia y de unos usos públicos generalmente distintos.

A lo largo de las últimas décadas, numerosos estudios han destacado la relevancia de analizar las representaciones socioculturales que estudiantes y profesores tienen de la Historia ya que, por un lado, influyen directamente en las prácticas docentes y, por otro, inciden en la configuración de marcos interpretativos que permitan a los estudiantes de los distintos niveles educativos desarrollar un pensamiento histórico complejo y alejado de las rigideces de determinadas perspectivas historiográficas. ${ }^{3}$

En esta línea, todas las comunicaciones presentadas y no pocas de las voces que participaron en el debate durante el transcurso de la sesión de didáctica del IV Encuentro de Jóvenes Investigadores en Historia Contemporánea destacaron la importancia que la naturaleza de conocimiento histórico, así como su conceptualización y representación, tiene en el proceso de enseñanza-aprendizaje de esta disciplina. La mayoría de intervenciones pusieron sobre la mesa el reto que plantean las posturas neopositivistas y neohistoricistas, tan fuertes aún en el ámbito educativo, a la hora de desarrollar otro tipo de conocimiento histórico. ${ }^{4}$ En este sentido, se destacó en diversas ocasiones que aún son muchos los profesores y estudiantes que consideran que la Historia debería limitarse a contar los hechos "tal y como sucedieron", como si esto fuera posible (algo que la historiografía contemporánea ya ha discutido largamente) o como si la propia selección de los mismos no tuviese una elevada carga de subjetividad. ${ }^{5}$

Gustavo Hernández, por ejemplo, introducía un interesante debate al hablar del corsé que, según él, representan las disciplinas escolares en contraste con la interdisciplinariedad o la

dáctica de las Ciencias Sociales, Geografía e Historia, 69 (2011), pp. 5-7; Carlos LOMAS (coord.): Lecciones contra el olvido. Memoria de la educación y educación de la memoria, Barcelona, Octaedro, 2011

2 Para más información sobre el concepto de código disciplinar de la Historia, véase Raimundo CUESTA: Sociogénesis de una disciplina escolar: la Historia, Barcelona, Ediciones Pomares-Corredor, 1997.

3 A nivel internacional podemos señalar los trabajos de Peter Seixas, director del Centre for the Study of Historical Consciousness de la Universidad de British Columbia (Vancouver): Peter SEIXAS: "Historical understanding among adolescents in a multicultural setting", Curriculum Inquiry, 23 (3) (1993), pp. 301-325; Peter SEIXAS: "Assesment of Historical Thinking", en Penney CLARK (ed.): New possibilities for the past. Shaping history education in Canada, Vancouver-Toronto, UBC Press, 2011, pp. 139-153. En España, destacan las aportaciones de algunos grupos de investigación que, como los dirigidos por Joaquim Prats o Mario Carretero, se han centrado en el análisis de concepciones y representaciones del alumnado en relación con la Historia escolar.

4 Sobre la pervivencia e influencia de determinados enfoques epistemológicos en la conceptualización de la Historia escolar véanse, por ejemplo, Pilar MAESTRO: Historiografía y enseñanza de la Historia, Tesis doctoral, Universidad de Alicante, 1997; David PARRA: “La conceptualización de la Historia, Tesis doctoral, Universidad de Alicante, 1997; David PARRA: "La conceptualización de la
Historia escolar y sus implicaciones didácticas. Un estudio a partir del recuerdo de estudiantes de Historia escolar y sus implicaciones didacticas. Un estudio a partir del recuerdo de estudiantes de
BUP", Didáctica de las Ciencias Experimentales y Sociales, 27 (2013), pp. 3-22. Sobre las concepciones que los estudiantes tienen de la Historia escolar, consúltense también Concha FUENTES MOREque "cos estudiantes tienen de la Historia escolar, consúltense tambièn Concha FUENTES los alumnos sobre la Historia", Enseñanza de las Ciencias Sociales, 3 (2004), pp. 75-83; Nicolás MARTíNEZ VALCÁRCEL, Xosé Manuel SOUTO y José BELTRÁN: “Los profesores de Historia y la enseñanza de la Historia en España. Una investigación a partir de los recuerdos de los alumnos", Enseñanza de las Ciencias Sociales, 5 (2006), pp. 55-71.

5 Georg G. IGGERS: La ciencia histórica en el siglo XX, Barcelona, Idea Universitaria, 1998; Juan José CARRERAS: Razón de Historia. Estudios de historiografia, Madrid, Marcial Pons, 2000; Keith JENKINS: Repensar la historia, Madrid, Siglo XXI, 2009. 
pluralidad de métodos y tendencias que caracterizan hoy a la historiografía. El autor, así, reivindicaba una Historia escolar que adoptase los nuevos enfoques posestructuralistas, dando lugar a un conocimiento histórico complejo, abierto y no determinista. ${ }^{6}$

En una línea similar, Óscar González reflexionaba en su comunicación acerca de las potencialidades de la Arqueología industrial y contemporánea, una disciplina que nació con un afán conservacionista y monumental y que, en las últimas décadas, ha iniciado una transición desde una perspectiva profundamente descriptiva y basada en el documento hacia otra más interpretativa y abierta a fuentes mucho más diversas y subjetivas (alejadas de lo que tradicionalmente, desde una óptica positivista, se ha considerado patrimonio material).?

Carlos Moreno, por su parte, planteaba una nueva forma de hacer historia al reivindicar el uso de recursos como el cómic no sólo para enseñar, sino también para construir un relato histórico diferente, más centrado en las emociones y las experiencias de los protagonistas que en frías estructuras o procesos impersonales. Una vez más, era el célebre debate objetividad/ subjetividad (aunque también individuo/estructura) el que estaba sobre la mesa; un debate que, en el caso concreto del cómic, se entrelazaba con otras cuestiones como el uso de la ficción para tratar la no ficción o el papel del arte en la cultura de masas. ${ }^{8}$

La necesidad de incorporar esta pluralidad de visiones y de enfoques historiográficos al ámbito escolar para favorecer una transformación en el código disciplinar de la Historia contó con un elevado grado de consenso, aunque también hubo algunas intervenciones discrepantes que enriquecieron la discusión. Para algunos de los participantes, la existencia de diversos paradigmas podía implicar la ausencia de unas bases teóricas sólidas y generar un constante debate acerca de la definición y naturaleza de una disciplina cada vez más desdibujada y diluida dentro de las Ciencias Sociales. ${ }^{9}$ Este punto de vista conectaba directamente con el de aquellos historiadores que, desde hace años, vienen hablando de "tiempo de incertidumbre","crisis epistemológica" o, incluso, "descomposición de la Historia" por la inexistencia de un modelo claro y/o hegemónico que delimite las fronteras y la identidad de la disciplina histórica. ${ }^{10}$

Durante el debate se puso de manifiesto la complejidad de la actual situación de la Historia; una situación que ha generado respuestas muy diversas y que, en opinión de no pocos expertos, difícilmente podrá dar lugar a la configuración de un nuevo paradigma aceptado mayoritariamente por los historiadores. La postura predominante, no obstante, fue la que apostaba por la introducción de unas nuevas tendencias consideradas más aptas para unos

6 Gustavo Hernández Sánchez: "La enseñanza de la historia en el siglo XXI: propuesta metodológica", comunicación presentada al IV Encuentro de Jóvenes Investigadores en Historia Contemporánea, Valencia, 2013

7 Óscar GONZÁLEZ VERGARA: "Otra forma de hacer Historia. Arqueología industrial y contemporánea: pasado, presente y futuro de una disciplina humanistica", comunicación presentada al IV Encuentro de Jóvenes Investigadores en Historia Contemporánea, Valencia, 2013.

8 Carlos MORENO TENAS: "El arte secuencial como un lenguaje para la historiografia", comunicación presentada al IV Encuentro de Jóvenes Investigadores en Historia Contemporánea, Valencia, 2013. Resultan especialmente interesantes las reflexiones que, al hilo de todas estas cuestiones, planteó Andreas Huyssen para analizar, entre otras, la célebre obra Maus, de Art Spiegelman. Andreas HUYSSEN: “Holocausto: Imagen, Cómic, Monumento", en En busca del futuro perdido. Cultura y memoria en tiempos de la globalización, México, Instituto Goethe-Fondo de Cultura Económica, 2002, pp. 75-160.

9 Esta cuestión generó, incluso, una acalorada discusión durante la denominada "Guerra de las Humanidades". Consúltense, al respecto, Pedro RUIZ: "La historia en el debate político sobre la enseñanza de las humanidades", Ayer, 30 (1998), pp. 63-100; Rafael VALLS: "Los usos de la historia enseñada y la reciente polémica en España: un enfoque didáctico", Ayer, 30 (1998), pp. 221-240.

10 Véanse, en este sentido Roger CHARTIER. “'Histoire aujourd'hui. doutes, défis, propositions", Eutopias 42 (1994) 24 P. Miguel Ángl CABRERA: "La crisis de la historia social y el surgimiento de una historia postsocial", Ayer, 51 (2003), pp. 201-224. nuevos usos públicos. La pluralidad de enfoques o propuestas científicas, en opinión de la mayoría, no debilitaba a la Historia, sino que la enriquecía dotándola de más significados, lo cual, desde la perspectiva de la didáctica, puede contribuir a la aparición de un conocimiento más abierto, complejo y democrático.

Si el aula, como defienden numerosos especialistas, debe ser un espacio privilegiado para el desarrollo de un pensamiento más crítico, parece conveniente que los nuevos enfoques, las otras Historias, entren en las clases para ir más allá del simple relato de hechos y personajes." Una Historia crítica, en este sentido, debería estimular el debate en la esfera pública, ajustar cuentas con el pasado y, si es necesario, dar lugar a contramemorias encargadas de resaltar discontinuidades, contradicciones y cambios para desplazar aquello que, con tanto acierto, Nietzsche denominó historia monumental e historia anticuaria, tan presentes aún en nuestro sistema educativo. Para conseguirlo, es necesario que los docentes, como apunta Giroux, se vean y actúen como intelectuales transformadores, ya que sólo así darán lugar a una historia liberadora, útil para el presente y para la formación crítica de personas autónomas. ${ }^{12}$

En general, durante el debate se valoró positivamente este giro crítico que han experimentado las Ciencias Humanas y Sociales en los últimos tiempos. No obstante, también hubo quien planteó hasta qué punto era conveniente que la Historia escolar persiguiera la desestabilización o el cuestionamiento de lo que nos rodea en el caso de unas edades (niñez y adolescencia) ya de por sí caracterizadas por una cierta inestabilidad. La visión mayoritaria, sustentada en posturas propias de la sociología y la pedagogía críticas, fue que la Historia ni podía ni debía renunciar a ese componente transformador, aunque ello supusiera acabar con determinadas certezas que, en opinión de muchos de los presentes, llegarían igualmente por otras vías. Por otro lado, hubo también quien apuntó que una educación en la incertidumbre parecía adecuada, e incluso conveniente, si el objetivo es formar a personas que vivirán en un mundo inestable y en constante cambio.

Pese a la riqueza del debate, se echó en falta una mayor conexión entre todas estas reflexiones y la práctica docente, ya que no se habló en profundidad de los posibles usos didácticos de los nuevos enfoques historiográficos ni del modo en que nuestra identidad profesional como historiadores puede influir (e influye) en nuestra identidad como profesores. La discusión sí sirvió, sin embargo, para evidenciar que la escuela no ha sido un espacio pasivo de recepción de discursos elaborados por la Academia (la historiografía en el caso que nos ocupa), por lo que, como señalaba Marcos Marina en su comunicación, no podemos desdeñar la importancia de la Historia escolar en la configuración de una representación pública/colectiva de la Historia. ${ }^{3}$

\section{Una Historia útil, una Historia significativa}

El conocimiento histórico y la interpretación del pasado responden a las necesidades, prioridades, intereses y formación de aquéllos que lo construyen. La ciencia no es algo cerrado e incuestionable, sino una construcción sociocultural condicionada por las herencias o tradiciones, el contexto presente y las expectativas de futuro. Esto sirve tanto para entender cómo se elabora el discurso histórico a nivel académico como a nivel escolar, ya que explica también el porqué de determinados recuerdos, olvidos o silencios en relación con el aprendizaje de la Historia.

11 Raimundo CUESTA, Juan MAINER y Julio MATEOS: "La genealogía, historia del presente y didáctica crítica", en Juan MAINER (coord.), Pensar críticamente la educación escolar. Perspectivas y controversias historiográficas, Zaragoza, Publicaciones de la Universidad de Zaragoza, 2008, pp. 51-82.

12 Henry A. GIROUX: Cultura, política y práctica educativa, Barcelona, Graó, 2001.

13 Marcos MARINA CARRANZA: "De democracias, dictaduras, guerras, repúblicas y monarquías: la historia reciente española en los libros de texto", comunicación presentada al IV Encuentro de Jóvenes Investigadores en Historia Contemporánea, Valencia, 2013. 
Desde hace décadas, las ciencias de la educación reclaman la necesidad de que el aprendizaje de cualquier disciplina sea significativo; es decir, que se tenga en cuenta el contexto en el que se produce, así como las concepciones previas, los valores socioculturales o los intereses de aquéllos que van a aprender. El profesorado debe ser capaz de establecer comunicación con el alumnado para que éste, a partir de su experiencia, pueda construir e integrar unos significados cada vez más formales y complejos.

Tres de los cuatro trabajos defendidos reivindicaban la necesidad de unas clases de Historia que tuviesen en cuenta las opiniones de los alumnos (sus historias personales) para su uso e incorporación durante el proceso de enseñanza-aprendizaje. Esas clases, además, debían conectar la actualidad con el pasado a partir de problemas sociales relevantes y relacionar presente, pasado y futuro para enseñar a pensar históricamente y poder, así, desarrollar una conciencia histórica. ${ }^{14}$

Con relación al primer punto, debemos tener en cuenta que, diariamente, el alumnado entra en contacto con cuestiones históricas en contextos que poco o nada tienen que ver con la educación formal, es decir, escuchando las historias de familiares, mirando series o documentales en la televisión, visitando una exposición de un museo, asistiendo a un acontecimiento conmemorativo, etc. Tal y como señala Keith C. Barton, sabemos poco acerca de cómo los niños y adolescentes captan el pasado y construyen un relato sobre el mismo; lo que sí sabemos es que éste entrará en contacto con el discurso escolar, generando distorsiones, conflictos cognitivos e incluso rechazos que, si no son abordados de forma adecuada, dificultarán la incorporación de la nueva información. ${ }^{15}$

Gustavo Hernández, en esta línea, señalaba en su comunicación que la Historia escolar “llega a los alumnos sin adaptarse a nuevos contextos ni conectar con sus experiencias", puesto que docentes y legisladores están más preocupados por el currículum "académico-cognitivo" que por el currículum "vital-emocional". ${ }^{6}$ El profesorado de Historia, por tanto, debería intentar establecer esa conexión entre esos dos currículos para promover un aprendizaje verdaderamente significativo.

Para lograrlo, las distintas comunicaciones reivindicaban un papel más activo del alumnado y un abandono de lo que suelen denominarse "clases tradicionales"; clases en las que predominan la exposición narrativa cronológica, la transmisión de saberes enciclopédicos por parte de profesor, una escasa utilización de la metodología de resolución de problemas y, sobre todo, una preeminencia del libro de texto, convertido en la herramienta fundamental de enseñanza. ${ }^{17}$

14 Durante el debate se insistió en la diferencia entre conocer y pensar históricamente. El pensamiento histórico no sólo requiere un buen conocimiento de los conceptos y del contexto a estudiar, sino también el desarrollo de toda una serie de competencias que, como la empatía histórica, implican un mayor grado de profundizacion. Diversos investigadores españoles han abordado estas cuestiones en las últimas décadas. Podemos destacar los trabajos clásicos de Jesús DOMíNGUEZ: “Enseñar a comprender el pasado histórico: conceptos y empatía", Infancia y Aprendizaje, 34 (1986), pp. 1-21; o los más recientes de Ramón LóPEZ FACAL: "Pensar históricamente (una reflexión crítica sobre la enseñanza de la Historia)", íber. Didáctica de las Ciencias Sociales, Geografía e Historia, 24 (2000), pp. 46-56; Neus GONZÁLEZ, Rodrigo HENRíQUEZ, Joan PAGĖS y Antoni SANTIESTEBAN: “Empatía histórica para un presente cambiante. La enseñanza y el aprendizaje de la comprensión histórica a través de una experiencia didáctica", en Joan PAGĖs y Neus GONZÁLEZ (coords.): La construcció de les identitats i l'ensenyament de les Ciències Socials, de la Geografia i de la Historia, Bellaterra, Universitat Autònoma de Barcelona, 2010, pp. 145-157; Jorge SÁIZ: “Empatía histórica, historia social e identidades: pensar históricamente la conquista cristiana de la Valencia musulmana con estudiantes de $2^{\circ}$ ESO", Clio, 39 (2013), http://clio.rediris.es/n39/articulos/historiasocial/saiz.pdf.

15 Keith C. BARTON: "Investigación sobre las ideas de los estudiantes acerca de la Historia", Enseñanza de las Ciencias Sociales, 9 (2010), pp. 97-114.

6 Gustavo Hernández Sánchez: "La enseñanza de la historia en el siglo XXI..."

17 Nicolás MARTínEZ VALCÁRCEL, Xosé Manuel SOUTO y José BELTRÁN: “Los profesores de Historia...”.
Todo esto condujo al clásico debate sobre el uso de los manuales o sobre la visión de los mismos como un compendio cerrado y supuestamente objetivo del saber, lo que conecta con las cuestiones anteriormente tratadas..$^{18} \mathrm{El}$ saber académico, generalmente, se asocia con conocimientos de tipo conceptual, algo que, en opinión de Marcos Marina, sigue siendo lo que más abunda en unos textos escolares preocupados porque el alumnado aprenda qué sucedió o cuándo se dio un determinado hecho y no tanto por el desarrollo de habilidades o por el fomento de valores o actitudes. ${ }^{9}$

Una vez más, hubo una cierta unanimidad a la hora de señalar que los estudiantes debían dejar de ser meros consumidores para pasar a colaborar en la construcción de su conocimiento histórico. Se reclamaron, así, unas clases de Historia que se estructurasen a partir de recursos que fueran más allá de los manuales y que permitiesen aprender a buscar, analizar, interpretar y criticar fuentes primarias y secundarias de muy diverso tipo.

Lucía Montejo, por ejemplo, proponía en su comunicación la introducción de las Tecnologías de la Información y la Comunicación (TIC) en el aula. Óscar González reivindicaba la necesidad de incorporar el estudio del patrimonio material, pero también del inmaterial y el paisajístico, para hacer otro tipo de Historia. Carlos Moreno, por su parte, sugería el uso del cómic para construir un relato historiográfico diferente aprovechando un lenguaje que, en su opinión facilita la proximidad, la comprensión y la empatía por las potencialidades de la imagen. ${ }^{20}$

Como consecuencia de estas intervenciones, se generó una interesante discusión sobre la relación entre innovación e incorporación de nuevos recursos. Algunos de los presentes señalaron que la utilización de determinados materiales o herramientas no provoca per se un cambio de modelo de currículum. Así, por ejemplo, se apuntó que los cómics, aparentemente innovadores, pueden suponer un cambio de discurso que facilite el aprendizaje significativo por su elevada carga emotiva, pero también pueden ser utilizados para reproducir un relato tradicional y profundamente conformista basado en los grandes personajes y mitos de siempre.

En la misma dirección, se recordó que las TIC no suelen usarse como una herramienta que desarrolle una competencia digital plena (lo que debería implicar un uso responsable, constructivo y crítico de la información procedente de la red y de los distintos medios de comunicación). Con frecuencia, su uso se limita a un cambio de soporte, ya que lo que antes se hacía con el libro de texto o con diapositivas, ahora se hace con Prezi o PowerPoint Un ejemplo más de que lo importante no es el recurso, sino la finalidad que guiará su uso.21

\section{Conclusiones}

La enseñanza de la Historia, como hemos visto a lo largo de estas páginas, se ve condicionada por el peso de determinados enfoques, hábitos, rutinas y prácticas docentes que, en ocasiones, proceden del siglo XIX y han contribuido a construir y legitimar una determinada representación de la Historia escolar compartida por buena parte del alumnado, del profesorado y de la sociedad en general.

18 Con relación a los libros de texto son de enorme relevancia los trabajos realizados por el Centro de Investigación interuniversitario MANES sobre manuales escolares de España, Portugal y América Latina. Vease, por ejemplo, la obra de Rafael VALLS: Historiografia escolar española: siglos XIX-XXI, Madrid, UNED Ediciones, 2007.

19 Marcos MARINA CARRANZA: "De democracias, dictaduras...".

20 Lucía MONTEJO ARNÁlZ: "La inclusión de las TIC en los currículos de Ciencias Sociales en el BachiIlerato. Una propuesta de proyecto interdisciplinar", comunicación presentada al IV Encuentro de Jóvenes Investigadores en Historia Contemporánea, Valencia, 2013; Óscar GONZÁLEZ VERGARA "Otra forma de hacer Historia...."; Carlos MORENO TENAS: "El arte secuencial como un lenguaje..."

"En el caso de las TIC, la denominada alfabetización digital debería ir acompañada de una eduEn éón mediática que haga de las nuevas tenoción digital debería ir acompañada de una educación mediática que haga de las nuevas tecnologias un instrumento verdaderamente útil para
lograr objetivos propios de un currículum crítico. 
Cambiar esas prácticas y rutinas, pero también esa representación de la disciplina, resulta esencial para romper con viejos esquemas y promover un tipo de aprendizaje que supere los planteamientos tecnocraticos y se inserte claramente en un modelo de curriculum socio-criti-

co. Para conseguirlo, no basta con un cambio de recursos o estrategias metodológicas: hay que repensar y redefinir las finalidades que tradicionalmente han dado cuerpo al código disciplinar de la Historia y han condicionado su enseñanza. Ello implica que, más allá de la adquisición de conocimientos conceptuales, se debe fomentar un tipo de formación actitudinal y ética, algo que sólo es posible si se abordan determinados problemas, si se utilizan diversos enfoques y si se persigue un aprendizaje verdaderamente significativo. Sólo así se podrá lograr una Historia escolar que responda a nuevos usos y que contribuya a formar ciudadanos reflexivos, activos y críticos que participen y actúen con conciencia en el espacio público democrático. 
OTRA FORMA DE HACER HISTORIA. AROUEOLOGÍA

INDUSTRIAL Y CONTEMPORÁNEA: PASADO, PRESENTE

Y FUTURO DE UNA DISCIPLINA HUMANISTICA*

Óscar González Vergara'

Universidad de Murcia

\section{Introducción y consideraciones previas}

En este trabajo queremos presentar una disciplina, la Arqueología Industrial y Contemporánea que, a pesar de su ya dilatada existencia, todavía carece de uniformidad teórica y práctica que hagan de ella una disciplina lo suficientemente sólida, homogénea, y con unas bases, medios y metas sólidos, el menos con la solidez de otras disciplinas que versan sobre lo humano y su pasado, tanto desde el campo de la propia Historia, como también dentro de la Arqueología. Pretendemos, con este breve trabajo, mostrar una alternativa para la documentación, análisis, interpretación y puesta en valor del patrimonio contemporáneo; una metodología, si se quiere, que ayude a hacer Historia. Pero antes, hemos de tener claros algunos conceptos.

Como más adelante veremos, gran parte de los problemas teóricos y metodológicos de esta disciplina, relativamente joven, es que, desde el principio, nació sin unas ideas precisas acerca de qué entender por arqueología, patrimonio, historia, industria o contemporáneo. Sin tener esto claro, no ha de extrañarnos que prácticamente desde sus comienzos esta disciplina sólo estuviera relacionada con los grandes monumentos de la industria moderna y contemporánea, terreno casi monopolizado por arquitectos e ingenieros que dedicaron sendos trabajos al catálogo, descripción y puesta en valor de maquinarias industriales, complejos fabriles, minas, estaciones ferroviarias, puentes, etc., que hicieron de ellos "arqueólogos" de un mundo de cemento, ladrillo, hierro y cristal que empezaba a abrirse al mundo del patrimonio. Pero e arqueólogo no sólo documenta, cataloga, describe y pone en valor, y es por eso que la Arqueología de los tiempos industriales y contemporáneos necesitará de algunas décadas más para poder ser verdaderamente arqueológica, sin despreciar la labor que de urgencia hicieron estos "aprendices de arqueólogos" cuando la Arqueología parece que no tenía interés por un patrimonio que no precisaba de su metodología estrella: la excavación.

Sin dilatarnos demasiado en ello, pues tendremos ocasión de volver a retomarlos más adelante, sólo nos dedicaremos, en los espacios que siguen y que finalizan este apartado, en definir qué vamos a entender aquí por Arqueología Industrial y Contemporánea. Compartiremos en parte las definiciones recogidas en documentos internacionales y nacionales como la Carta de Nizhny-Tagil (de julio de 2003) ${ }^{2}$ y el Plan de Patrimonio Industrial (de marzo de 2011). ${ }^{3}$ Así, la Arqueología Industrial y Contemporánea será la disciplina humanística que estudie, teniendo

* Este texto se encuadra dentro del trabajo de investigación doctoral en la Universidad de Murcia, y agradezco a mis directores, el Dr. S. F. Ramallo Asensio y P. M. Egea Bruno, su ayuda y consejo.

Becario Predoctoral FPU-Universidad de Murcia. Departamento de Prehistoria, Arqueología, Historia Antigua, Historia Medieval y Ciencias y Técnicas Historiográficas.

2 Ver la Carta en: http://ge-iic.com/files/Cartasydocumentos/Carta_de Nizhny Tagil.pdf

3 PLAN NACIONAL DE PATRIMONIO INDUSTRIAL, marzo de 2011, http.//ipce mcu.es/pdfs/PN PATRLMONIO INDUSTRIAL.pdf como base la metodología arqueológica (pero con una importante influencia y contacto con el resto de disciplinas y metodologías al servicio de la investigación de las sociedades contem poráneas), el patrimonio industrial-contemporáneo ligado cronológicamente (grosso modo) ticos. Será así una disciplina que beba mucho de la Historia, la Historia del Arte, la Geografía, la Arquitectura, la Ingeniería, la Antropología Sociocultural y otras más, pero distinguiéndose de ellas en la forma global de documentar, describir, analizar, interpretar y poner en valor e patrimonio cultural contemporáneo, desde una perspectiva holística y completa.

Ouizá, y he aquí parte del problema de esta disciplina, el "error" o lo "matizable" no sean los medios y metas de esta disciplina sino el nombre, pero consideramos que, por tradición historiográfica y por ser la Arqueología el grueso metodológico de esta disciplina, ha de permanecer con ese nombre. Pero no podemos mantener un debate, en una disciplina, solo por el nombre, ni mucho menos usar el factor del nombre para desacreditarla, prejuzgarla o limitarle. Sólo las generaciones futuras, con el tiempo suficiente para ver los procesos de lo que hoy es nuestro tiempo contemporáneo, sabrá valorar quizás si la disciplina responde a su tiempo, si es intrusa, o lo que sea. Nuestra labor aquí no será esta, sino la de presentar esta disciplina, como se ha dicho, compañera y alternativa a los clásicos estudios de Historia Contemporánea. Sigamos.

\section{La arqueología industrial y contemporánea: breve historia}

Afortunadamente son muchos ya los textos y debates que, en artículos, actas de congresos y hasta manuales de índole didáctica, analizan la historia de esta disciplina, la evolución de sus herramientas y fuentes de estudio, etc., y a cuyos autores me remito (AGUILAR CIVERA 1998; CANO SANCHIS, 2007, 53-68; CERDÂ PÉREZ, 2008; ROJAS SANDOVAL, 2005, 26-35; VICENTI PARTEARROYO, 2007, 1-49; GUTIÉRREZ LLORET, 1995, 51-59, y 2001; LOPEZ CIDAD y GREGORA$\mathrm{Cl}, 2006,1-5 ;$ RAMOS, CAMPOS y MARTíN, 1991). Pero no está de más recordar algunos hitos, algunos procesos de génesis y evolución para entender cómo nació esta disciplina, ante qué premisas y necesidades, cómo ha ido cambiando a lo largo del tiempo para ser, como es, una de las vanguardias metodológicas en Arqueología, y en general en los estudios humanísticos y sociales, en mi opinión con más futuro y más trabajo.

En general, se puede decir que la necesidad de documentación y protección del patrimonio industrial británico, ligado a la Era Industrial e Imperial, un patrimonio que estaba viéndose perjudicado, relegado y destruido ante los avances tecnológicos tras las Guerras Mundiales, dio como resultado la necesidad, también, de una disciplina encargada de ello. Se creó una Arqueología Industrial, en los años 50 y 60 del siglo XX que, teniendo en la descripción arquitectónica y técnica, así como en los valores artísticos y de conservación, sin olvidar la contextualización socio-económica e histórica, su centro, pretendía salvar a los "Monumentos de la Industrialización y la Era Colonial británicas". Era una Arqueología centrada sobre todo en la descripción y la conservación, y no tanto al análisis e interpretación. Era una Arqueología que tenía de Arqueología prácticamente sólo el nombre. Era una Arqueología del Monumento Industrial, sin tener propiamente metodología arqueológica. También era una Arqueología trabajada a menudo por arquitectos, ingenieros e historiadores de diversas disciplinas (del arte, de la ciencia, de la técnica, etc.), y no por arqueólogos.

Los investigadores a quienes debemos el surgimiento y consolidación de esta disciplina, dentro del entorno británico, son Rix (RIX, 1955, 225-229, y 1967). Hudson (HUDSON, 1963, 1976, 1978, 1979 y 1983), Buchanan (BUCHANAN, 1972), Palmer y Neaverson (PALMER y NEAVERSON, 1994 y 1998). Ellos fueron los primeros en definir esta disciplina, los conceptos relacionados con ella, las metodologías de investigación del patrimonio industrial, etc. Sobre todo los primeros, Rix, Hudson y Buchanan, conceptualizaron esta disciplina como una especia de Arqueología del Monumento industrial, tal y como se decía antes. La labor del arqueólogo industrial, según esta concepción, era documentar, describir, conservar y poner en valor los monumentos industriales. La 
interpretación del patrimonio, y su inclusión dentro del debate histórico, quedaba en un segundo plano. Es por esto, y por centrarse en un aspecto muy reducido del patrimonio industrial como e representado por la arquitectura productiva industrial y sus máquinas, por lo que no ha de considerarse a estos inicios de la disciplina como "arqueológicos". Con ello, sin embargo, no restamos el valor de estos primeros intentos de teorización sobre una disciplina nueva. Vista desde hoy, estos inicios permitieron aunar las necesidades sociales de protección del patrimonio con los primeros intentos, también, de su investigación, así como la elaboración del os primeros catálogos de patrimonio industrial y de técnicas especializadas. Faltarán unos años para que esta disciplina y sus especialistas puedan ser considerados Arqueología y arqueólogos respectivamente.

Con el paso del tiempo, esta Arqueología Industrial vista como Arqueología del Monumento Industrial, a la par de una evolución conceptual y metodológica de la Arqueología en general, se fue haciendo más "arqueológica". Ante una Arqueología Industrial a la que no se consideraba Arqueología por no aplicar el método arqueológico centrado en la excavación, se enfrenta, en las últimas décadas del siglo XX y comienzos del XXI, una Arqueología Industrial que se beneficia de alternativas arqueológicas como la Arqueología de la Arquitectura (estratigrafía muraria) y la Arqueología del Paisaje (prospección y análisis arqueológico del territorio) que permiten "excavar" estos monumentos y espacios erigidos. De esta forma, lo que en origen pudieran ser recelos para reconocer a esta disciplina como arqueológica, se convirtió en la necesidad de incorporar a los arqueólogos en el estudio del patrimonio industrial, siendo el método arqueológico el centro. Con ello, junto a la documentación, descripción y conservación/puesta en valor del patrimonio industrial, se añadió la interpretación, base de toda disciplina, también la arqueológica.

Vemos así que, frente a unos inicios monumentales, artísticos, arquitectónicos, técnicos, económicos, y muy poco "arqueológicos", la "vieja" disciplina arqueológica industrial diventa Arqueología Contemporánea, una nueva revolución metodológica y conceptual aún sin explotar en su totalidad, capaz de documentar, describir, analizar, interpretar, conservar y poner en valor el patrimonio industrial, atendiendo a sus elementos materiales (edificios industriales o no, herramientas, maquinaria, cultura material en general, etc.), paisajísticos (entornos explotación, de hábitat, de comunicación, etc.) e inmateriales (representados por elementos como la música, la historia oral y el folklore en general), que hace a la Arqueología Contemporánea integrar elementos procedentes de la Historia Social, de las Mentalidades, de la Cultura y, sobre todo, de la Antropología Sociocultural.

Como resultado, las reivindicaciones antiguas para hacer arqueológica una disciplina que tenía la Arqueología como nombre fueran inútiles. Ouizás deba la Arqueología Industrial y Contemporánea evolucionar y convertirse en otra cosa, una disciplina que, aún teniendo lo arqueológico como centro, deba pensarse desde otras tantas disciplinas (Arquitectura, Ingeniería, Historia, Antropología, Geografía, etc.), quede poco claro cuáles son sus métodos ni sus presupuestos teóricos. Lo único firme que le resta es su deber y compromiso por el estudio completo, holístico y multidisciplinario del patrimonio cultural contemporáneo y la sociedad con que relaciones. Siendo así, mantiene y mantendría el nombre de Arqueología más por tradición historiográfica que por ser exclusividad arqueológica.

\section{Metodologías, fuentes y paradigmas de la arqueología industrial y contemporánea ${ }^{4}$}

Aunque hay discrepancias entre los autores, corrientes y momentos históricos en lo concerniente a qué considerar materia de estudio de la Arqueología Industrial y Contemporánea, en este apartado señalaré lo que considero que son los pilares que conforman el edificio metodotodológica en Arqueología industrial. Aquí se tomará esta bibliografía de base pero consideramos trial-contempoŕneo, por lo que añdiremos unos maticesy algunas interpretaciones personales. lógico, teórico y práctico de esta disciplina, aunque según consideremos que sea el objeto de esta disciplina encontraremos fuentes y metodologías diversas para estudiar ese patrimonio. Emplazo para otra ocasión el debate, sin duda interesante, de qué considerar que ha de ser hoy la Arqueología Industrial, si precisa cambiar de nombre (y de ser así, cuál), su relación con las disciplinas afines (Arquitectura, Ingenierías, Historias, Geografía o Antropología Sociocultural por señalar unas cuantas), etc.

La Arqueología Industrial y Contemporánea tiene en el método arqueológico su centro, aunque se ha visto, tanto en los orígenes de la misma como en su evolución, impregnada de los vicios y vanguardias de la Arqueología. Los principios están llenos de vicios como la tendencia, tan arqueológica, de tender a los monumentos arquitectónicos, aspecto que ya se ha señalado anteriormente. En el caso industrial, estos monumentos fueron los puentes, las fábricas abandonadas, los entornos mineros o las estaciones ferroviarias. Es una metodología arqueológica, sí, pero donde priman los elementos descriptivos (arquitectónicos, decorativos y funcionales) y de conservación, sobre los de análisis e interpretación histórica. Se sirvieron de la historia oral, de planos de arquitectos e ingenieros para describir y conservar estos monumentos que formaban parte de la memoria del lugar y de las gentes que vivieron en ese entorno e incluso trabajaron y transitaron por estos monumentos. Era una Arqueología trabajada por historiadores del arte, arquitectos e ingenieros mayoritariamente, una Arqueología cas sin metodología arqueológica, repetimos.

Conforme la Arqueología de la segunda mitad del siglo XX, va cambiando la concepción de la propia Arqueología, también cambiará el concepto de Arqueología Industrial, así como el modo de investigar el patrimonio. Por ello, al día de hoy, considero que estas son las fuentes básicas de la Arqueología Industrial, en la mayoría de los casos, muy entrelazadas entre sí y sin casi posibilidad de establecer límites fuertes:

- Fuentes Materiales.

- Fuentes Escritas.

- Fuentes Audiovisuales.

- Fuentes Orales.

- Fuentes Inmateriales.

- Fuentes Paisajísticas.

Con respecto a las fuentes materiales, vemos que es, según la tradición arqueológica, el grueso de todo estudio sobre las sociedades pretéritas desde la Arqueología. Vemos que en un principio, la Arqueología Industrial se centraba sólo en esta fuente. Las fuentes materiales se refieren directamente a la realidad material de la sociedad, una realidad que puede estar formada de edificios, maquinaria y herramientas, producciones industriales, etc. A la Arqueología Industrial le interesó, sobre todo en los primeros años de su existencia, los edificios, máquinas y herramientas que hacían referencia a la producción industrial, la obtención y canalización de materias primas y energía, los espacios productivos, etc. Se interesó por fábricas, casas de máquinas de vapor, estaciones de ferrocarril, obra pública, etc., olvidando que hay mucho más patrimonio industrial y contemporáneo documentado por las fuentes materiales. Como se decía anteriormente, cuando se incorporó en la Arqueología industrial el método del a Arqueología de la Arquitectura, se incluyeron, por ejemplo, el resto de edificios, tuvieran o no un carácter industrial. Asumió las herramientas y procedimientos mediante los cuales el arqueólogo extraía información sobre la evolución de los edificios, sus usos, sus materiales, sus técnicas constructivas, la procedencia de los materiales y la mano de obra, las fuentes de energía utilizadas, etc., teniendo en la estratigrafía muraria, o excavación de elementos emergentes, su propuesta estrella a la hora de analizar arqueológicamente los edificios. Se empezó a estudiar mercados, las sedes de las instituciones públicas, colegios, iglesias, cementerios, las oficinas de las empresas, etc. A esta labor se unió, o aprovechó el empuje por parte de los investigadores de la 
historia de la arquitectura contemporánea, teniendo en el eclecticismo y el modernismo un motivo para hacer Arqueología de los edificios contemporáneos no industriales. Todavía queda mucho por hacer, por ejemplo, en sistematizaciones y trabajos de carácter global acerca de la cerámica moderna y contemporánea, las producciones de envases, vestidos, etc., sobre todo para equiparar en este nivel la Arqueología Contemporánea a las de más tradición historiográfica. Vemos que, con el dominio de esta fuente, el arqueólogo contemporáneo se relaciona con el trabajo del arquitecto, del ingeniero y del historiador del arte.

Una de las diferencias más evidentes entre la Arqueología Industrial y las anteriores es que la conservación y abundancia de fuentes escritas son mayores que nunca. Lo primero porque no ha dado tiempo a que se empiece si quiera su degradación, y en otra, porque nuevos soportes, nuevos métodos de conservación, nuevos tipos documentales, etc., han dado lugar a una abundancia de documentos, de diversa índole y conservadas en distintos lugares, que nos revelan muchos, sino todos, los aspectos de la vida social, religiosa, económica, política e ideológica de la sociedad contemporánea. Y es una obligación del arqueólogo industrial el hacer uso de esas fuentes, sean públicas o privadas, y extraer de ello información sobre censos de población, planos de edificios y sus reparaciones, niveles de producción y venta, precios, etc. Esta, obviamente, es una labor ingente que precisará que el arqueólogo contemporáneo tenga, a diferencia de los pretéritos, una buena formación y destreza en archivística e historia, labor que ha de compartir con los profesionales de la investigación histórica que tengan en las fuentes escritas, su principal elemento de estudio. Por lo tanto, en este aspecto, el trabajo de arqueólogo contemporáneo se relaciona con el del historiador contemporáneo.

Otra diferencia abismal con respecto a la Arqueología de otros momentos del pasado es que la tecnología ha permitido conservar registros audiovisuales del patrimonio industrial y de la vida cotidiana. Me refiero a fotografías, documentos gráficos y sonoros que, frente a otras formas de "materialización" (pintura, escultura, música, etc.), se caracteriza por su menor tendencia y posibilidad de manipulación. Una filmación, con o sin audio, por ejemplo, de la llegada de un barco a un puerto, o fotografías de edificios emblemáticos y espacios de trabajo y ocio, son una fuente privilegiada para el arqueólogo industrial, que tendrá información de edificios, espacios y maquinaria que quizás ya no se conserve, o del uso de esos espacios. Un ejemplo muy bueno de su utilidad es la filmación de labores que están en desuso o al borde de desaparecer, tales como el trabajo del esparto, la cetrería, el esquilado, etc. La conservación de los registros audiovisuales de estas laboesparto, la cetrería, el esquilado, etc. La conservación de los registros audiovisuales de estas labo-
res ayuda a la investigación realizada ahora, y sin duda también a la realizada con posterioridad, cuando quizás ya no existan las personas que hagan esos trabajos no que los recuerden.

Unido con esto último, tenemos las fuentes orales, tan usadas por historiadores contemporáneos y antropólogos socioculturales y que tratan de registrar, por escrito, en audio o en formato vídeo, entrevistas a personas que hablan de sus experiencias, recuerdos, etc. Para tiempos contemporáneos es de gran utilidad contar con las personas que vivieron, trabajaron y usaron ciertos espacios y ciertos momentos cronológicos, y contar con su testimonio no sólo aporta información (toponimia, antroponimia, etc.), sino que ayuda a contextualizar y a humanizar el a menudo frío y distante testimonio material o escrito. De igual forma, el arqueólogo contemporáneo ha de ser sensible al patrimonio inmaterial, como las tradiciones folklóricas, la música, los refranes, la antroponimia, la toponimia, etc. Se conforma así una necesidad de que el arqueólogo contemporáneo sea también un poco historiador social y antropólogo. Ha de ser capaz de analizar la sociedad presente, de entrevistar a sus habitantes, a registrar la memoria de los espacios de trabajo, hábitat, etc., y hacer de ello un modo de enriquecer su trabajo arqueológico.

Para finalizar, la otra gran fuente de documentación del pasado industrial y contemporáneo lo conforma la documentación que alude a elementos del paisaje. Aunque elementos paisajísticos se conservan en fuentes escritas (ejemplo, lindes, explotaciones mineras, trazados de vías de comunicación, etc.) e iconográficas (fotografías y filmaciones, por ejemplo), no hemos de olvidar que el paisaje, con alteraciones o no, sigue siendo paisaje, y que a menudo se han realizado mapas al respecto. Por lo tanto, la Arqueología Industrial y Contemporánea ha de asumir los discursos de la Arqueología del Paisaje en cuento a las herramientas de prospección, documentación, análisis e interpretación del territorio, de la toponimia, de los medios de transporte, de las relaciones entre el hombre y la naturaleza, paisajes urbanos, etc. También ha de ser capaz de "excavar" el paisaje, es decir, teniendo el paisaje como elemento material y la documentación escrita, iconográfica, audiovisual, cartográfica, etc., ser capaz de vertebrar cómo eran los paisajes en el pasado, su orografía, sus usos, su evolución, etc. El arqueólogo industrial se hace también con ello, un poco geógrafo, teniendo que ser diestro en cartografía, programas de SIG, urbanismo, etc.

Vemos que a nivel metodológico, la Arqueología Industrial y Contemporánea es hoy mucho más precisa y está mucho más consolidada que hace unas décadas. De un pasado donde estos aspectos brillaban más por su ausencia, se ha pasado a un presente donde al menos hay cierto interés por teorizar acerca de esta disciplina, y en lo que aquí respecta, a su metodología y de las fuentes de las que se sirve. El futuro, de seguir esta línea, debiera pasar por el debate, la mejora de la teoría tras décadas de trabajo práctico y de investigación, y por tanto, "avanzar" en la mejora de esta disciplina, y no caer en estancamiento y desaceleración, como parece que ocurre en Europa, sobre todo en los países que vieron nacer esta disciplina (Reino Unido, Alemania y Francia, por poner un ejemplo), aspectos estos que se deben, en mi opinión, al no haberse teorizado lo suficiente acerca de una disciplina que se alzó muy rápido, pero con pocas (o ninguna) bases sólidas. Otra posibilidad de explicación es que, como está ocurriendo también en España, se ha abandonado en cierta forma la reflexión entorno a la Arqueología industrial, sus fuentes, sus metodologías, etc., para pasar a reflexionar sobre el patrimonio industrial, algo más material, físico. Pero qué duda cabe que si la reflexión no va por caminar de la mano de ambas realidades, el resultado será una desvirtualización de la Arqueología Industrial como disciplina que no se sabe qué estudia, de qué manera, etc., o un objeto, el patrimonio industrial, que parece como caído del cielo, y sin más teoría sobre él que las necesarias y útiles habilidades prácticas de quien, por investigación o urgencia, se ocupe de este patrimonio.

Este trabajo, en este punto, queda sin concluir pues está en continuo debate.

\section{Un ejemplo práctico murciano}

Con el fin de poder mostrar las amplias posibilidades de esta disciplina a la hora de documentar, interpretar y poner el valor el patrimonio industrial y su relación con la sociedad contemporánea, sirva el ejemplo de los cantes mineros. Estos cantes, nacidos del folklore tradicional precontemporáneo, vieron en los entornos mineros escenarios de experiencias de vida traumáticas y de ocio. En las cuencas mineras de Jaén, Almería y Murcia, sobretodo, conforme las labores mineras y la inmigración a ellas asociadas fueron siendo cada vez más cotidianas, se creó un tipo de flamenco, los cantes mineros, compuestos de tarantas, tarantos, mineras, cartageneras, levanticas y algunas más donde es usual encontrar alusiones a la vida del minero, de cómo eran las minas, de qué tácticas se servían, de los sistemas de transporte e iluminación, etc. Hablan también de la vida fuera de la mina (juego, alcohol y prostitución), de conflicto social (sistema de vales), de los accidentes ocurridos dentro de la mina, de los dramas de la minería (viudas, huérfanos, mineros ciegos o amputados), etc. Es por ello que, si bien toda música de forma directa e indirecta alude a las consideraciones de la sociedad, satirizándola haciendo utopía o reflejo social real, estos cantes mineros, ayudan a contextualizar toponimia, antroponimia, restos materiales, restos paisajísticos, con los sentimientos más humanos.

Uno de los entornos industriales más importantes de la Región de Murcia es la Sierra de Cartagena-La Unión, un espacio donde los cantes mineros fueron muy populares a mediados finales del s. XIX, gracias a la explotación minera de sus relieves y de la abundante mano de obra andaluza que llegó portando sus cantes. Se creó una forma singular de cantes mineros que ha sido muy bien puesta en valor, pues ya cuenta con un consolidado Festival Interna- 
cional del Cante de las Minas que en más de 50 años ha rescatado esta inmaterialidad y ha sabido unirla al resto del patrimonio industrial. Efectivamente, se ha creado un Parque Minero, se han acondicionado viejos caminos mineros, lavaderos de mineral, hornos de concentración y hasta minas, siendo una fusión entre patrimonio material, inmaterial y paisajístico cuando se organizan actuaciones flamencas dentro de la propia mina. Ello se complementa con el ya tradicional Museo Minero de La Unión, la arquitectura ecléctico-modernista, un Museo del Cante de las Minas y otro de la Semana Santa minera.

Quizás, como vemos, es posible y beneficioso que a la hora de estudiar y poner en valor los entornos industriales y contemporáneos, se pongan en relación todos los elementos existentes. En el caso de La Unión, un elemento, el musical, ha servido de excusa para unir otros patrimonios y otros espacios de difusión y puesta en valor ya existentes, dejando una visión de conjunto bastante decente.

\section{Consideraciones finales}

Como resultado vemos que, al día de hoy, la metodología y las fuentes a disposición del arqueólogo contemporáneo son variadas y de distinta procedencia. La cuestión no es discerni entre si seguir plenamente el método arqueológico, basado en al excavación y la prospección o acercarse a otras disciplinas. El objetivo para definir la Arqueología Industrial y Contemporánea no ha de ser el de una especialidad en un tipo de documentación específica. Para tiempos contemporáneos, y más para temas patrimoniales, escindir disciplinas atendiendo al criterio metodológico es no considerar de forma suficiente a la ciencia, los objetos estudiados por la ciencia y la divulgación de ese conocimiento, bien sea a otros investigadores, en la educación o a la sociedad en general. Hemos de ser conscientes que la Arqueología Industrial y Contemporánea pretende estudiar la sociedad contemporánea, o mejor dicho, las sociedades contemporáneas, usando todas las fuentes y metodologías existentes y que permitan documentar, analizar, describir, interpretar, conservar y poner en valor espacios de trabajo, de hábitat, edificios, elementos inmateriales, paisajísticos, experiencias personales, etc., del mundo contemporáneo, grosso modo, desde la caída del feudalismo, el advenimiento de los liberalismos, la llegada de la llustración, el capitalismo y de la Industrialización, hasta el día de hoy. Se mantendrán, cómo no, presentes los precedentes industriales, tales como la industria textil medieval, o la evolución del artesanado desde la prehistoria, pero no tendrá en la Industria (como elemento económico, social) su centro. De ser así, la Arqueología Industrial sería una Arqueología de una temática, y considero más enriquecedor añadir este discurso en una concepción de una Arqueología Contemporánea, que tenga en lo industrial, lo no industrial, en la vida cotidiana en lo inmaterial, en lo paisajístico de los mundos contemporáneos, su centro. De no ser así, de considerar una Arqueología Industrial centrada en las Revoluciones Industriales y considerar otra Arqueología (¿Contemporánea?) para los tiempos presentes es caer en una incongruencia de tipo filosófico que demuestra, de partida, más criterios ideológicos que científicos.

Por lo tanto, y dicho esto, considero que la Arqueología Industrial y Contemporánea, o Contemporánea a secas si se añaden los discursos de la Arqueología Industrial, se convierte, al día de hoy, en una disciplina plural, multidisciplinar, holística, etc., que estudia el patrimonio cultural contemporáneo desde diversas ópticas y desde diversos discursos, razón por lo que ha de convertirse en una forma más de hacer historia o de contextualizar lo histórico. Es una disciplina que sin duda tiene mucho que decir en los discursos contemporáneos. Es una disciplina que ya juega un papel importante entre las disciplinas y herramientas que conforman el historiador o investigador contemporáneo, pero este papel ha de verse fomentado, integrado y ampliado. Como pone de manifiesto la Carta de Nizhny-Tagil's, se ha de crear, dentro de la Universidad, Centros de Investigación, etc., programas de formación e investigación en esta disciplina. Si se quiere hacer una Arqueología Contemporánea de calidad, y no repetir los vicios del pasado (Arqueología del Monumento Industrial, Arqueología de un Periodo Económico, etc.), se ha de formar de forma plural y completa. Se ha de crear la posibilidad de que el arqueólogo pueda aprender y poner en práctica herramientas y metodologías arqueológicas como la Arqueología de la Arquitectura y la del Paisaje, además de destreza para la búsqueda y análisis de documentos archivísticos. Debe aprender los conceptos básicos de la geografía física, humana, urbana y económica, así como usar herramientas como el SIG y saber interpretar y crear mapas (cartografía). Debe tener una rica formación en antropología sociocultural para investigar e interpretar testimonios y elementos del mundo cotidiano actual. Debe tener una mínima noción de Arquitectura e Ingeniería, que le permitan al menos mantener un cierto diálogo con estos especialistas a la hora de investigar, describir y poner en valor, por ejemplo, maquinarias industriales y elementos arquitectónicos. Ha de ser sensible al arte, saber interpretarlo y dialogar con él. También es labor suya participar y coordinar actividades de conservación y puesta en valor del patrimonio contemporáneo, por ejemplo, en exposiciones, museos, etc.

$Y$ todo ello se consigue asumiendo, de una vez por todas, la calidad y validez teórico-práctica de la Arqueología Contemporánea, integrarla dentro del resto de arqueologías y ciencias históricas, y facilitar discursos y debates que den sentido y oportunidad a esta disciplina de dialogar con el resto de disciplinas e investigadores que tienen en lo contemporáneo su objeto de estudio.

\section{Bibliografía}

Inmaculada AGUILAR CIVERA: Arquitectura industrial: concepto, método, fuentes, Valencia, Museu d'Etnologia de València, 1998.

Robert Angus BUCHANAN: Industrial archaeology in Britain, Harmondsworth, Penguin, 1972.

Juan Manuel CANO SANCHÍZ: "Arqueólogos en la fábrica. Breve recorrido por la historiografía de la arqueología industrial", SPAL. Revista de Prehistoria y Arqueología de la Universidad de Sevilla, 16 (2007), pp. 53-68.

Ignacio CASADO GALVÁN: "Introducción a la arqueología industrial: origen de la disciplina y metodología”, Contribuciones a las Ciencias Sociales, diciembre de 2009, http://www.eumed. net/rev/cccss/o6/icg12.htm.

Ignacio CASADO GALVÁN: "Fuentes escritas, orales e iconográficas de la arqueología industrial", Contribuciones a las Ciencias Sociales, diciembre de 2009, www.eumed.net/rev/cccss/ 06/icg11.htm.

Ignacio CASADO GALVÁN: "Las fuentes materiales de la arqueología industrial", Contribuciones a las Ciencias Sociales, diciembre de 2009, www.eumed.net/rev/cccss/06/icg13.htm.

Ignacio CASADO GALVÁN: "La arquitectura de la Industrialización", Contribuciones a las Ciencias Sociales, diciembre de 2009, http://www.eumed.net/rev/cccss/06/icg9.htm.

Ignacio CASADO GALVÁN: "La Arqueología Industrial: una investigación multidisciplinar", Contribuciones a las Ciencias Sociales, diciembre de 2009, http://www.eumed.net/rev/ cccss/o6/icg18.htm.

Ignacio CASADO GALVÁN: "Caracterización histórica del concepto de industrial”, Contribuciones a las Ciencias Sociales, diciembre de 2009 [http://www.eumed.net/rev/cccss/06/icg27. htm].

todo el punto 6 . 
Carta de Nizhny-Tagil, 17 de julio de 2003, http://ge-iic.com/files/Cartasydocumentos/Carta_de_Nizhny_Tagil.pdf

Manuel CERDÀ PÉREZ: Arqueología industrial: teoría y práctica, Valencia, Universidad Politécnica de Valencia, 2008

Jesús Fernando LÓPEZ CIDAD y Franca GREGORACI: "El nacimiento de la Arqueología Indus trial", GAZSEHA. Gaceta de la Sociedad Española de Historia de la Arqueología, 1 (2006), pp. 1-5.

Salvador FORNER MUÑOZ: "Arqueología industrial: concepto, teoría y métodos", en María Dolores RAMOS, Concepción CAMPOS y Miguel Ángel MARTíN (eds.): Arqueología industrial: notas para un debate, Málaga, Universidad de Málaga, 1991.

Óscar GONZÁLEZ VERGARA: "Conociendo el pasado industrial. Perspectivas desde la arqueología", Ab Initio. Revista digital para estudiantes de Historia, 3 (2011), pp. 165-197.

Óscar GONZÁLEZ VERGARA: Patrimonio minero e industrial en la Sierra de Cartagena-La Unión. Introducción a su estudio y puesta en valor desde la Arqueología Industrial, Trabajo Fin de Máster, Murcia, Universidad de Murcia, 2011.

Óscar GONZÁLEZ VERGARA: "Arqueología Industrial. Un comentario bibliográfico tras medio siglo de historiografía", Anales de Prehistoria y Arqueología de la Universidad de Murcia, 25-26 (2009-2010), pp. 275-300.

Óscar GONZÁLEZ VERGARA: Arqueología Industrial en La Unión (Murcia). Patrimonio y paisaje de una ciudad minera, Tesina de Licenciatura, Murcia, Universidad de Murcia, 2012.

Sonia GUTIERREZ LLORET: "La arqueología después de la Edad Media: el registro arqueológico en la historia moderna y contemporánea", en VV.AA.: Actes de les Jornades d'Arqueologia (Alfàs del Pi, 1994), Valencia, 1995, pp. 237-253.

SOnia GUTIERREZ LLORET: Arqueología. Introducción a la historia material de las sociedades del pasado, Alicante, Universidad de Alicante, 2001.

Kenneth HUDSON: Industrial Archaeology: An Introduction, Londres, J. Baker, 1963. Kenneth HUDSON: The Archaeology of Industry, Londres, Scribner, 1976.

Kenneth HUDSON: Food, Clothes and Shelter: twentieth century industrial archaeology, Londres, J. Baker, 1978.

Kenneth HUDSON: Wold Industrial Archaeology, Cambridge, Universidad de Cambridge, 1979. Kenneth HUDSON: The Archaeology of Consumer Society: the second industrial revolution in Britain, Londres, Universidad de Fairleigh Dickinson, 1983.

Jordi NADAL OLLER: Moler, tejery fundir: estudios de historia industrial, Barcelona, Ariel, 1992. Jordi NADAL OLLER: Atlas de la industrialización de España, 1750-2000, Barcelona, Crítica, 2003.

Marilyn PALMER y Peter NEAVERSON, P: Industry in the Landscape (1700-1900), Nueva York, Routledge, 1994.

Marilyn PALMER y Peter NEAVERSON, P: Industrial Archaeology: principles and practice, Nueva York, Routledge, 1998.

PLAN NACIONAL DE PATRIMONIO INDUSTRIAL, marzo de 2011, http://ipce.mcu.es/pdfs/PN PATRIMONIO INDUSTRIAL.pdf

María Dolores RAMOS, Concepción CAMPOS y Miguel Ángel MARTíN (eds.): Arqueología industrial: notas para un debate, Málaga, Universidad de Málaga, 1991.

Michael RIX: "Industrial Archaeology", The Amateur Historian, 2/8 (1955), pp. 225-229.

Michael RIX: Industrial Archaeology, Londres, Historical Association, 1967.
Javier ROJAS SANDOVAL: "Introducción a la arqueología industrial: una visión desde las humanidades", Ingenierias, 10/35 (2007), pp. 26-35.

Ana VICENTI PARTEARROYO: "Perspectivas en arqueología industrial”, Arqueweb. Revista sobre Arqueología en Internet, 9/1 (2007), pp. 1-49. 


\section{LA ENSEÑANZA DE LA HISTORIA EN EL SIGLO XXI:}

\section{PROPUESTA METODOLÓGICA}

Gustavo Hernández Sánchez

Investigador Predoctoral FPU. Departamento de Historia Medieval Moderna

y Contemporánea. Universidad de Salamanca

El siguiente texto tratará de presentar brevemente una propuesta metodológica para la enseñanza de la historia en el presente siglo de acuerdo con las nuevas perspectivas historiográficas abiertas en el terreno de la epistemología y de la filosofía de la historia. Supone, por ello, tanto un reto como la apertura de una vereda por la que damos nuestros primeros pasos. Oueremos decir con esto, que el texto no pretende más que mostrar una reflexión personal compartida.

Nuestra hipótesis de trabajo es la siguiente: la enseñanza de la historia, después del denominado "fin de la historia", e incluso del fin de los historiadores, tema sobre el que tratan algunas obras actuales como la coordinada por Pablo Sánchez León y Jesús Izquierdo Martín El fin de los historiadores (2008), ' sería capaz de lograr un aprendizaje más completo desde los planteamientos que propone el pensamiento complejo, frente a la tradicional explicación causal, que nosotros definiremos como pensamiento simple.

En este sentido, el sistema educativo actual, según organiza los planteamientos curriculares, encorseta la disciplina de la historia, cuando no la margina o reduce directamente a un segundo plano, alejándola de la forma en que los alumnos y alumnas, y nosotros mismos -como historiadores e historiadoras-, interpretamos el mundo.

Estamos de acuerdo con Silvia Santarelli y Marta Campos cuando afirman que:

El impacto derivado del avance tecnológico en las ciencias y en la educación se manifiesta en el acceso o no a un mundo donde el poder depende del saber y de la información. En este contexto, son objetivos fundamentales de la educación impartir el saber formal, cuya prioridad es adquirir, interpretar y utilizar distintos lenguajes, tanto los sociales como los científicos y tecnológicos y el experiencial que, ante la pluralidad cultural que plantea el escenario posmoderno, se fundamenta en la experiencia, la participación y el comprender al "otro" en su identidad. 2

No se trata, pues, de presentar ningún método cerrado, sino simplemente una reflexión que profundice en la situación de la historia y de los historiadores en la educación después de hipotético fin de la historia, también del hipotético fin de los historiadores, tratando de orientar la enseñanza de la historia hacia una sociedad postindustrial y comunicacional que forma parte de un mundo globalizado. ${ }^{3}$

Véase Pablo SÁNCHEZ LEÓN y Jesús IZOUIERDO MARTíN: El fin de los historiadores. Pensar históricamente en el siglo XXI, Madrid, Siglo XXI, 2008.

Silvia SANTARELLI y Marta CAMPOS: Corrientes epistemológicas. Metodología y prácticas en geografia: propuestas de estudio en el espacio local, Bahía Blanca (Argentina), Universidad Nacional del Sur, 2002, p. 77

3 Así lo define Francisco VEIGA: El desequilibrio como orden: una historia de la posguerra fría, 199o2008, Madrid: Alianza, 2006, p. 40
El corsé de las disciplinas y los límites del currículum académico. La explicación causal. Afirmaba Michel Foucault que:

En el taller, en la escuela, en el ejército, reina una verdadera micropenalidad del tiempo (...) de la actividad (...) de la manera de ser (...) de la palabra (...) del cuerpo (...) de la sexualidad (...) Al mismo tiempo, se utiliza, a título de castigos, una serie de procedimientos (...) Se trata a la vez de hacer penables las fracciones más pequeñas de la conducta y de da una función punitiva a los elementos en apariencia independientes del aparato disciplinario: que todo pueda servir para castigar la menor costa; que todo individuo se encuentre prendido en una universalidad castigable-castigante. ${ }^{4}$

Uno de los puntos en los que redunda la crítica pedagógica del actual sistema educativo es, en efecto, el corsé que representan las disciplinas. Autores como Raimundo Cuesta han tratado ampliamente el tema. ${ }^{5}$ La misma historia se ha visto cuestionada en este sentido y ha visto en la interdesciplinariedad y la pluralidad de métodos una manera de hacerle frente. Pero este no es el tema de nuestro trabajo, que, en cierto, modo parte de este punto pero pretende ir un poco más allá. Lo mismo que el poder disciplinario, representado en los currículos académicos, simboliza la presión de una microfísica del poder normalizadora, la concepción de la historia desde un punto de vista estrictamente causal, representa un corsé difícil de salvar para el alumnado. La forma en que a éste le es presentada la historia contiene disfunciones con la realidad que vive y experimenta, y este hecho, dificulta el aprendizaje.

Reconocemos que esta afirmación resulta un tanto controvertida, ya que representa la encrucijada en la que hoy se ve inmersa tanto la responsabilidad social del historiador como, y por ello, la responsabilidad social del profesorado. No pocos de a los que propusimos las ventajas de una explicación compleja frente a una explicación causal, como el propio Raimundo Cuesta, a quién agradecemos su crítica en la elaboración de este texto, convinieron en la necesidad de presentar al alumnado cuestiones simplificadas como forma de que lo entienda mejor. Algo difíil de aceptar en un momento en que autores como Josep Fontana afirman que vivimos un periodo histórico de "crisis social" y "regresión"6. La linealidad del progreso, en este sentido, se ha visto seriamente cuestionada, cuando no absolutamente refutada, ${ }^{7}$ especialmente después de la publicación por Max Horckheimer y Theodor Adorno de la Dialéctica de la llustración en $1947 .^{8}$ Estamos de acuerdo con la profesora Amelia Álvarez cuando afirma que la actual educación está:

casi exclusivamente identificada con el hecho escolar y no con la globalidad de la acción cultural, una educación cerrada casi exclusivamente en conocimientos disciplinares y no en la globalidad del conocimiento humano (...) Una educación, en suma, demasiado preocupada por el currículum académico-cognitivo y poco preocupada por el currículum vital-emocional.9

4 Michelle FOUCAULT: Vigilar y castigar. Nacimiento de la prisión. Madrid, Siglo XXI, 2005, p. 183

5 Véase Raimundo CUESTA FERNÁNDEZ: Felices y escolarizados: crítica de la escuela en la era del capitaismo. Barcelona, Octaedro, 2005; o Raimundo CUESTA FERNÁNDEZ: Los deberes de la memoria en la educación, Barcelona: Octaedro, 2007.

6 Josep FONTANA: El futuro es un país extraño: una reflexión social sobre la crisis del siglo XXI, BarceIona, Pasado\&Presente, 2013, p. 19.

Véase Enrique CARRETERO, "Reacciones a la modernidad: una lectura de las respuestas de lo social al ejercicio del poder", Nómadas 7 (2003). http://pendientedemigracion.ucm.es/info/nomadas/7/ ecarretero.htm

8 Max HORCKHEIMER y Theodor ADORNO: Dialéctica de la llustración: fragmentos filosóficos, Obra completa, 3, Madrid, Akal, 2007.

9 Amelia ÁLVAREZ, “Los desafíos de una educación basada en la cultura” en Amelia ÁLVAREZ (ed.): Hacia un currículum cultural. La vigencia de Vigotski en la educación. Madrid, Fundación Infancia y 
Entendemos, como consecuencia, que una explicación causal (o multicausal) se presenta ante el alumnado como algo demasiado simple, difícilmente asimilable a la experiencia cotidiana. Detengámonos un momento en las características de lo que sería una explicación causal para ilustrar nuestro planteamiento (Mapa conceptual 1).

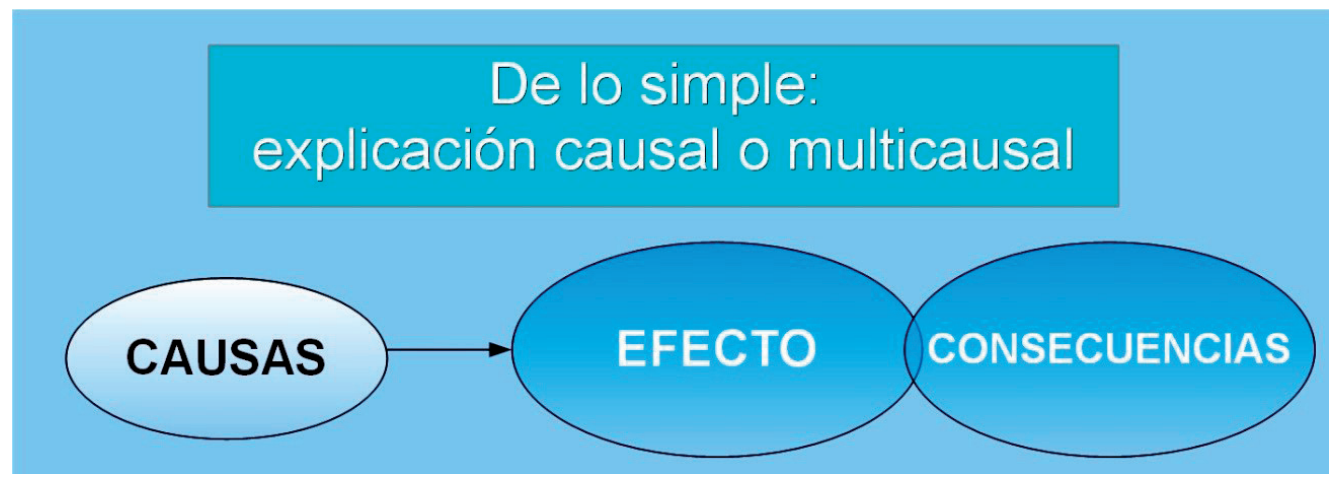

Map. 01 Esquema de explicación simple (Fuente, elaboración propia).

Siguiendo el esquema propuesto, la explicación simple se corresponde con el análisis de causa-efecto, que en enseguida explicaremos brevemente.

Diremos antes que, una de las características fundamentales de la historia, hasta el momento, fue la de darle sentido al acontecimiento o proceso -ya fuese pasado o histórico (s tenemos en cuenta la categoría "historia vivida" en su relación con la conceptualización dada por Julio Aróstegui sobre la "historia del tiempo presente")-10

Según el esquema de explicación causal, un suceso histórico o proceso determinado está generado por unas causas que, a su vez, generan unas consecuencias, las cuales, desde la perspectiva del tiempo, proporcionan un sentido, esto es, nos hacen entender la historia y, además, situarnos mentalmente en ella como agentes o sujetos históricos.

"Pensar históricamente"," como reclama Josep Fontana en su obra Introducción al estudio de la historia (2007), da, en cierto modo, sentido a nuestra existencia como agentes o sujetos históricos. Y ésta es la forma de entender y explicar la historia con la que nos hemos formado y siguen formándose los estudiantes de las enseñanzas medias y superiores.

llustraremos la idea de explicación causal con un supuesto práctico, y emplearemos como ejemplo la revolución francesa (Mapa conceptual 2).

En este ejemplo que proponemos partimos de un suceso histórico concreto: la revolución francesa. A partir de aquí, nuestra función es dotarle de un sentido, al mismo tiempo que el alumnado encuentra el mismo sentido, es decir, es capaz de comprender y conocer la historia.

Y para ello establecemos unas causas. En este punto, la explicación debería ser multicausal en tanto que en muy pocas o casi ninguna ocasión un solo factor es capaz de desencadenar el acontecimiento (o los acontecimientos). Los puntos de explicación más empleados serían el económico, el político, el social y el cultural. Elementos que podemos identificar en el periodo inmediatamente anterior, en este caso, el denominado Antiguo Régimen -proceso, a su vez que podemos acotar al siglo XVIII o extender a los inicios de la Edad Moderna (o Modernidad) e incluso antes. Vemos como la explicación simple se comienza a desbordar por los caudales de la explicación compleja-. Pues bien, estos elementos explican no solo el acontecimiento sino también su desarrollo posterior: el liberalismo. La explicación, desde este punto de vista, dota de sentido: ilustra en el sentido más pedagógico del término.

Aprendizaje, 1997, pp. 9-21, p. 9

- Julio ARÓSTEGUI: La historia vivida. Sobre la historia del presente, Madrid, Alianza, 2004

11 Josep FONTANA: Introducció a l'estudi de la historia. Barcelona, Crítica, 2007.

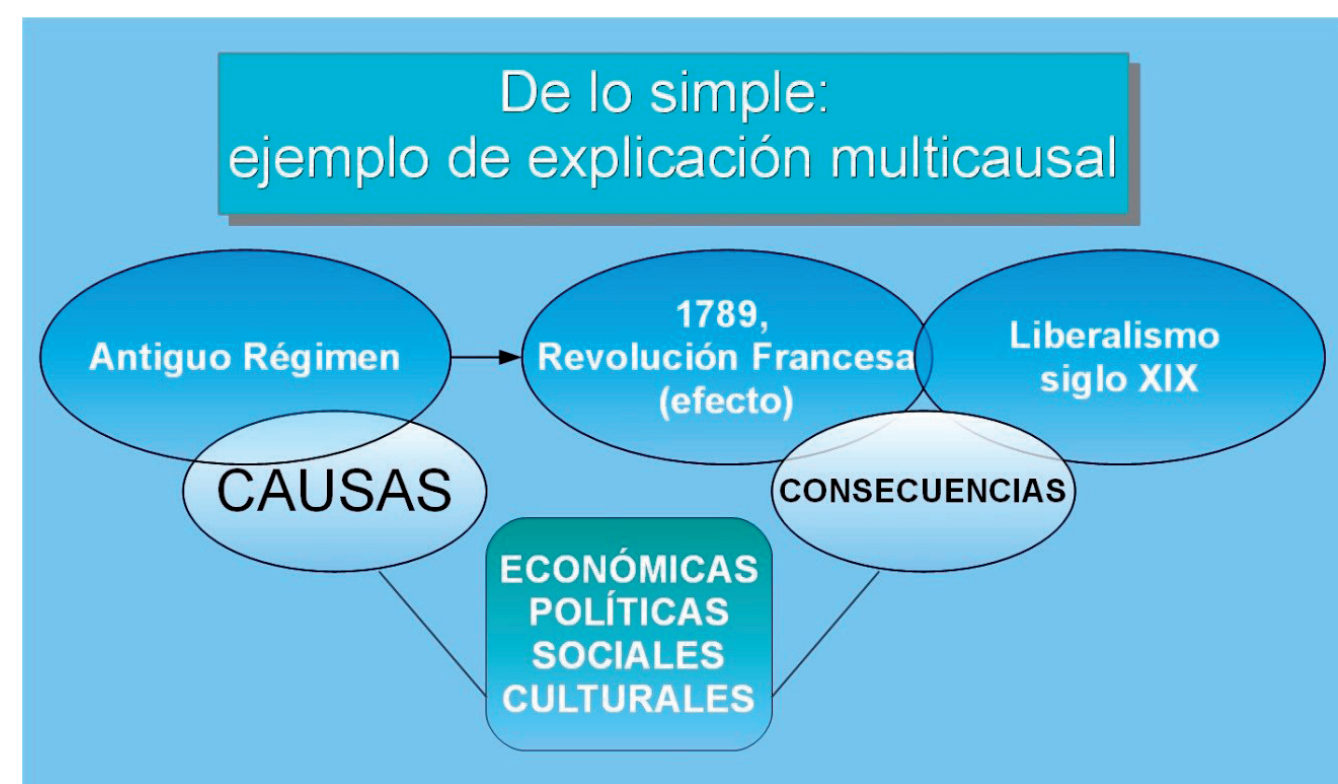

Map. 02 Ejemplo de explicación simple (Fuente, elaboración propia).

Pero en este punto podemos establecer una crítica: se trata de un esquema demasiado estructural y simple para el periodo en que vivimos, en el que la información de la que disponemos obliga a darle un enfoque distinto, un enfoque complejo.

\section{Complejidad y caos. La explicación compleja}

En sintonía con los planteamientos que introdujeron llya Prigogine e Isabelle Stengers en su obra Entre el tiempo y la eternidad, publicada en 1990, el universo "tiene una historia a la que remiten las partículas elementales que no dejan de crearse, desaparecer y transformar$\mathrm{se}^{12}$ ", como podrían demostrar los avances recientes sobre la demostración de la existencia del bosón de Higgins. El universo es más complejo de lo que parece, la vida en un mundo globalizado e informacional también. Por ello, frente a la explicación que hemos definido como simple, proponemos una explicación compleja, que no es sinónimo de complicada.

Y la defenderemos en base a que la historia no es, ni debiera aspirar a ser, un conocimiento objetivo, verdadero ni acabado. Sobre estos temas se centran los debates más polémicos entre académicos en la actualidad, introducidos, en buena medida, por la crítica posmoderna y tratados en la obra antes mencionada de Pablo Sánchez León y Jesús Izquierdo Martín. Detengámonos en el análisis complejo, haciendo antes unas pequeñas aclaraciones que consideramos oportunas.

En primer lugar, declarar la simplificación consciente de los análisis presentados (tanto del simple como del complejo) y de la necesidad de hacernos entender de la manera más sencilla (que no simple). En segundo lugar, la necesidad de definir previamente el fenómeno de la complejidad.

Edgar Morín, su impulsor, define la complejidad como la "paradoja de lo uno y lo múltiple". El pensamiento complejo trata de evitar la orientación unidimensional del conocimiento. Debe observarse la complejidad en lo cotidiano ya que el ser humano, como ser biológico y cultural, no distingue ambas realidades. Pretende, en definitiva, la autonomía en el sentido kantiano del término, yendo incluso más allá: pretendiendo la comprensión del sujeto, que ocupa el lugar del yo (autónomo) en una subjetividad comunitaria más amplia (dependiente). Aspira a la completud (unidimensionalidad) y logra lo multidimensional'3. Edgar Morín llega

12 Ilya PRIGOGINE e Isabelle STENGERS: Entre el tiempo y la eternidad, Madrid, Alianza, 1991. p. 51.

13 Vid. Edgar MORÍN: Introducción al pensamiento complejo, Barcelona, Gedisa, 2001. 
incluso a denunciar que "mientras los medios producen la cretinización vulgar, la Universidad produce cretinización de alto nivel". ${ }^{4}$ Para más información, sirva el Manual de iniciación pedagógica del pensamiento complejo, compilado por Marco Antonio Velilla, y publicado en 2002 por la el Instituto Colombiano de Fomento de la Educación Superior y la UNESCO. ${ }^{15}$

En tercer lugar, la contextualización de la historia en una suerte de evolución (desde el punto de vista estrictamente temporal) que considera unas exigencias mínimas necesarias para que se genere la historia. Según llya Prigogine e Isabelle Stengers estas exigencias mínimas son, en primer lugar, la irreversibilidad, es decir, la ruptura de la simetría entre el antes y e después. En segundo lugar el suceso; suceso, como decíamos en el epígrafe anterior, portador de sentido. El suceso no puede ser deducido de ninguna ley determinista. Introducen también la idea de que la historia no sigue un patrón-fin determinado. La tercera y última exigencia mínima necesaria sería la coherencia. De ahí que algunos sucesos históricos sean susceptibles de transformar el sentido de la evolución que desencadenan, haciendo posible, en última instancia, la actividad de historiar, esto es, construir conocimiento histórico y, en este caso, enseñarlo. Afirman los autores que:

Comprender la historia no es reducirla a regularidades subyacentes ni a un caos de sucesos arbitrarios; es comprender a la vez coherencia y sucesos: las coherencias en tanto que pueden resistir a los sucesos y condenarlos a la insignificancia; o, por el contrario, el ser destruidas o transformadas por algunos de ellos; los sucesos en tanto que pueden o no hacer surgir nuevas posibilidades de historia. ${ }^{16}$

El siguiente mapa sería la ilustración conceptual de lo que acabamos de exponer (Mapa conceptual 3).

Según esta propuesta, la historia ha de insertarse dentro de la "flecha del tiempo". Aceptaremos, de momento, la validez conceptual de esta "flecha del tiempo" que parece corroborarse de acuerdo con las últimas investigaciones acerca de la existencia del bosón de Higgis, como ya citamos anteriormente. Los autores tienden, de este modo, un puente entre la física y la historia. Dentro de la "flecha del tiempo", el suceso (portador de sentido) abre paso a lo irreversible -lo que supone algo a simple vista tan evidente como afirmar que, una vez que algo sucede, es imposible dar marcha atrás-. Pero éste suceso tiene una razón, que a su vez es la que aporta coherencia a la historia. No obstante, esta razón ya no se puede medir solamente en términos causales, sino de sensibilidad. La idea de causalidad se difumina de esta forma en una conceptualización mucho más compleja, en tanto que el estudio de las causas puede ser todo lo extenso que consideremos oportuno -todo lo extenso que pueda llegar a ser tanto nuestro conocimiento como la potencialidad del alumnado- en última instancia, tanto como lo permitan las fuentes o información disponible.

Aparece así una historia, desde nuestro punto de vista, conectada con la manera en cómo percibimos el mundo que nos rodea, en sintonía también con otras ciencias naturales (en este caso la física). Pero el planteamiento complejo no termina aquí. El suceso deviene en inestabilidad. Ilya Prigogine e Isabelle Stengers emplean en este punto la "teoría de bifurcaciones", momentos en los que el comportamiento de las sociedades o la sociedad en cuestión se hace inestable y puede evolucionar hacia varios regímenes de funcionamiento estable. Autores como Immanuel Wallerstein ya han aplicado a la sociología y a la historia la "teoría de bifurcaciones".

14 Ibíd., p. 31.

15 Marco Antonio VELILLA (comp.).: Manual de iniciación pedagógica al pensamiento complejo, Instituto Colombiano de Fomento de la Educación Superior-UNESCO, 2002. http://www pensamientocomplejo.com.ar/docs/files/Vilella Manual pedagogia pc.pdf

16 Ilya PRIGOGINE e Isabelle STENGERS: Entre el tiempo y..., p. 54

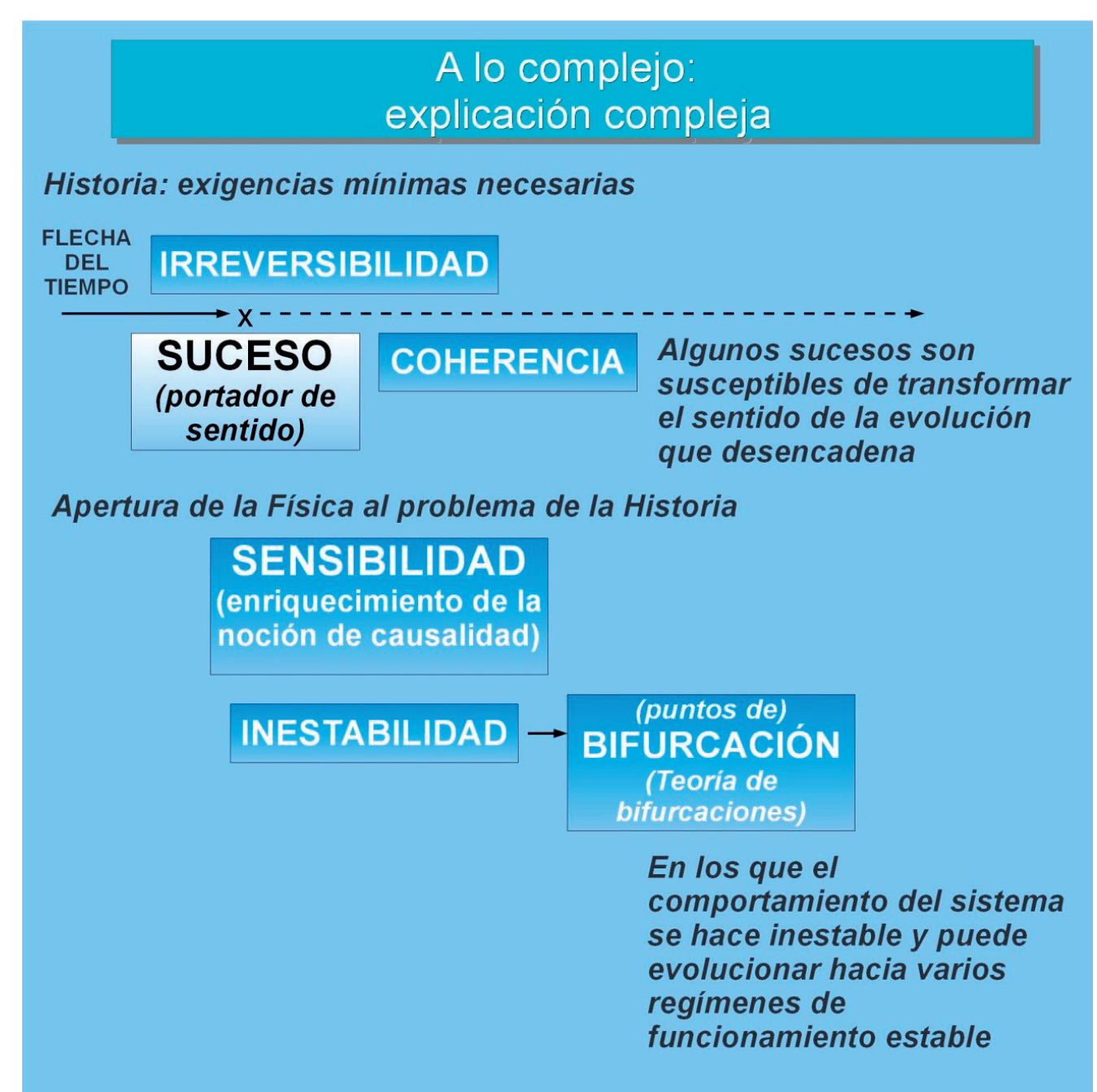

Map. 03 Esquema de explicación compleja (Fuente, elaboración propia).

Según su planteamiento en El análisis del sistema-mundo, publicado en $2004,{ }^{17}$ la hegemonía estadounidense se encontraría en esta situación desde la crisis económica de los setenta, fecha a la que se remontan numerosos estudios actuales, como el citado de Josep Fontana al inicio de la ponencia, para estudiar las causas de la "crisis de la sociedad" actual..$^{8}$ Tal vez se entienda mejor con un caso práctico. Tomemos el mismo ejemplo que antes (Mapa conceptual 4).

El suceso histórico (la revolución francesa) aparece dentro de la flecha del tiempo. Y podemos explicar este concepto de forma tan compleja como queramos; del mismo modo que antes, podremos aportar la sensibilidad que creamos oportuna. Pero el conocimiento histórico no debe terminar aquí. Como muestra el esquema, después del suceso, que vino precedido a su vez por un periodo de inestabilidad o desorden del anterior sistema, el proceso histórico en transformación continúa, podríamos decir que se bifurca y, mientras unos pretenden volve al pasado, otros mirarán hacia el futuro. Introduciríamos en esta explicación la importancia de otros sucesos que también tienen que ver con el acontecimiento central de la revolución francesa, como la crisis del Antiguo Régimen, restauraciones, revoluciones liberales y los otros y particulares conflictos que cada uno de ellos genera. Ante la irreversibilidad de la historia y sus posibilidades, el establecimiento del liberalismo en el siglo XIX aportaría la coherencia necesaria a la explicación. En este otro ejemplo hemos podido observar cómo se amplió la pers-

17 Véase Immanuel WALLERSTEIN: Análisis del sistema-mundo, México D.F., Siglo XXI, 2005.

18 Josep FONTANA: El futuro..., p. 18 


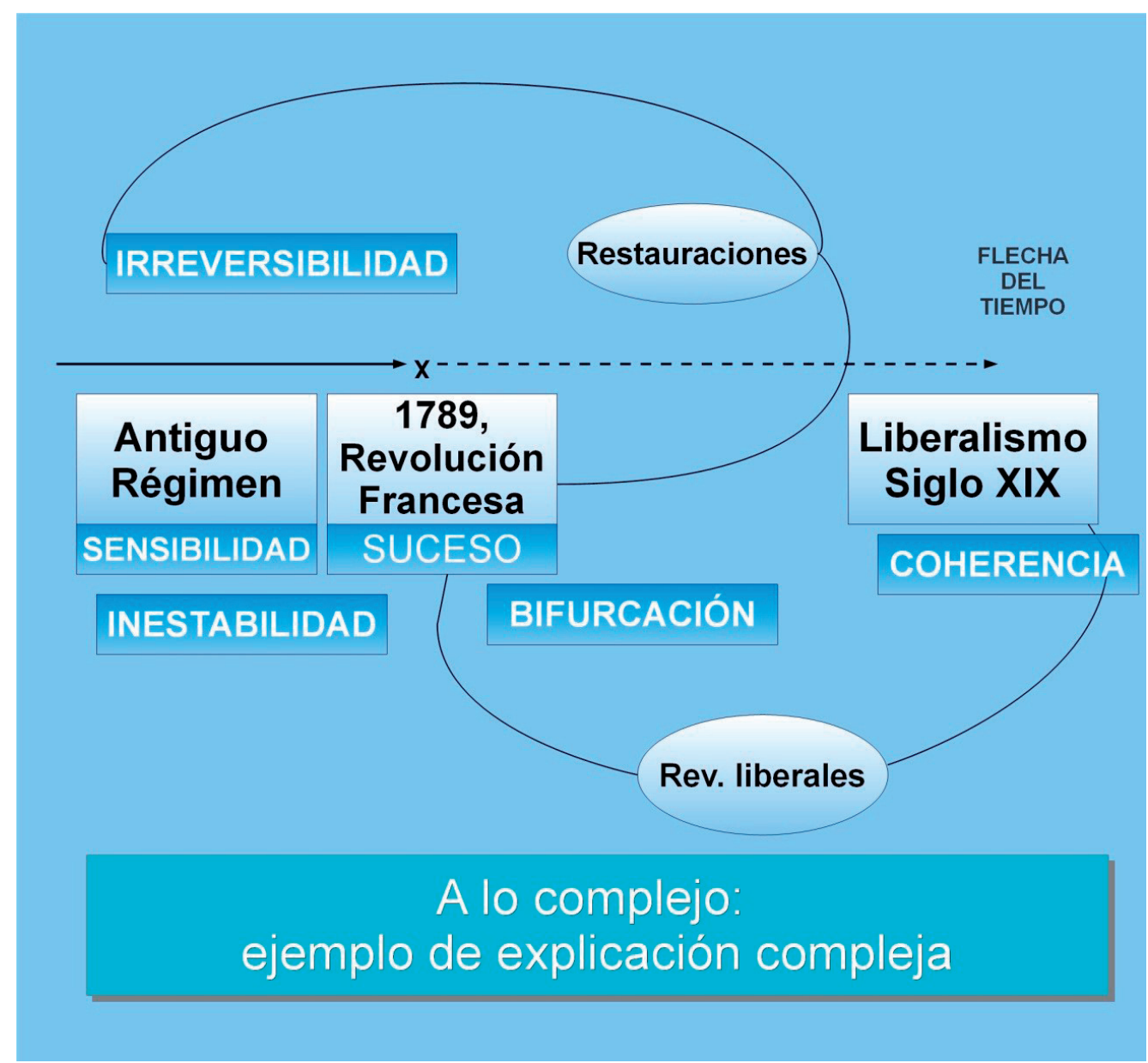

Map. 04 Ejemplo de explicación compleja (Fuente, elaboración propia).

pectiva de nuestra explicación así como los nuevos matices que tomó a pesar de que siguiese tratándose de un esquema sencillo.

\section{La educación: entre lo informacional, lo crítico y lo social y emocional}

Frente al reto de la complejidad de la sociedad actual, la cual requiere el enfoque de una educación compleja, asistimos a una grave contradicción, generada por el fenómeno de la "mercantilización del saber". La primera referencia a este proceso la hemos encontrado en el informe sobre el saber que elaboró Jean François Lyotar para el estado de Ouebec a finales de los ochenta, y que el autor sacó a la luz con el sugerente título de La condición posmoderna ${ }^{19}$. Las últimas reformas educativas en el estado español, Ley Orgánica de Educación (LOE, 2006) y Ley Orgánica para la Mejora de la Calidad Educativa (LOMCE, 2013) vienen a ratificar, dentro y Ley Orgánica para la Mejor.

En ellas se destaca un currículo eminentemente tecnocrático, el cual valora las competencias y habilidades prácticas (skills) por encima de la reflexión o pensamiento crítico-humanista. La razón técnica o razón instrumental, viene a sustituir a las ciencias sociales y humanidades, especialmente a la filosofía. Las consecuencias las describen Pablo del Río y Amelia Álvarez cuando afirman que:

19 Jean Franç̧ois LYOTARD: La condición posmoderna. Informe sobre el saber, Madrid, Cátedra, 1984, p. 17. pdfs/A17158-17207.pdf/Anteproyecto de Ley Orgánica para la Mejora de la Calidad Educativa4/ ciembre 2012) http://www.fremccoo.com/hojadellunes/BORRADORLOMCEDICIEMBRE.pdf el énfasis en lo cognitivo y el paradigma informacional ha llevado a un cierto olvido de las funciones directivas enviándolas a la periferia de la ciencia o, -lo que es más habitual- a incorporarlas a las cognitivas como funciones subsidiarias de éstas en cuanto tendrían la misma naturaleza informacional. ${ }^{2}$

Muy a menudo se olvida que una educación social y emocional, ética, también implica e conocimiento de competencias y habilidades prácticas y útiles en el día a día de los adolescentes a pesar de que no sean tan fáciles de evaluar. En este sentido, Margarita Limón considera que cuestiones como la empatía, serían fácilmente abordables desde la asignatura de historia en la enseñanza obligatoria ${ }^{22}$. De este modo, la historia estaría contribuyendo como reclama la autora, en el "desarrollo intelectual y afectivo-emocional del individuo". ${ }^{23}$

Una educación que bascule entre lo informacional, lo crítico, y lo social y emocional, dándole la misma importancia a las competencias y habilidades prácticas (saber hacer), críticas (de reflexión o saber pensar), sociales (de empatía: saber conocer al otro) y emocionales (saber conocerse) debe tener un carácter hermenéutico y crítico.

El propio Hans Georg Gadamer definía la hermenéutica como un proceso más que cómo un método, la definía -cito- como "la actitud del ser humano que quiere entender a otro". ${ }^{24} \mathrm{En}$ ello consistiría el proceso de aprendizaje en historia o el pensar históricamente que reclamábamos en otro apartado junto a autores como Josep Fontana.

En cuanto al carácter reflexivo de nuestra propuesta, serían los filósofos de la Teoría Crítica de la Sociedad, o Escuela de Frankfurt, quienes nos ofrecieran las claves interpretativas. Pertenecen a ella, entre otros, Walter Benjamin, quien inspira algunos de los problemas fundacionales o matriciales, Theodor Adorno y Max Horkheimer, de los que ya hemos hablado, Jürgen Habermas o Herbert Marcuse.

Fue Herbert Marcuse, en fecha tan temprana como 1964, quien definió la "teoría social como teoría histórica", y la historia como "reino de la posibilidad en el reino de la necesidad".25 No obstante fue Jürgen Habermas quien mejor expuso, desde nuestro punto de vista, la necesidad de una historia-reflexión. George Iggers lo resume de esta forma:

La responsabilidad política se basa en el compromiso con las categorías de una Teoría Crítica en el sentido de Max Horkheimer o de Jürgen Habermas, la cual insertándose en una sociedad futura racionalmente organizada examine con ánimo critico a la sociedad pasada y la presente. ${ }^{26}$

La enseñanza de la historia, tendría, para concluir, según nuestro punto de vista, dos finalidades fundamentales:

1. Dar a conocer el pasado en toda su complejidad, esto es, explicar cómo se construye el relato o discurso historiográfico y a qué motivos ideológicos atiende esta construcción para que

21 Pablo DEL RíO y Amelia ÁLVAREZ: "¿Saber o comportarse? El desarrollo de la construcción de la directividad", en Amelia ÁLVAREZ (ed.): Hacia un currículum..., pp. 101-133, p. 108.

22 Margarita LIMÓN LUOUE: “El fin de la historia en la enseñanza obligatoria”, en Pablo SÁNCHEZ LEÓN y Jesús IZQUUIERDO MARTíN (eds.): El fin de..., pp. 87-111, pp. 102 y ss.

23 Ibídem, p. 107.

24 Hans-Georg GADAMER: ¿Quién soy yo y quién eres tú? Comentario a Cristal de aliento de Paul CeIan. Barcelona, Herder, 1999. p. 148.

25 Herbert MARCUSE: El hombre unidimensional. Ensayo sobre la ideología de la sociedad industrial avanzada, Barcelona, Ariel, 2010. p. 33 .

26 George G. IGGERS: La ciencia histórica en el siglo XX. Las tendencias actuales: una visión panorámica y critica del debate internacional, Barcelona, Idea Universitaria, 1998. p. 66. 
el alumno pueda elaborar de forma crítica su propio discurso. Teoría Crítica de la Sociedad.

2. Contribuir al desarrollo intelectual y afectivo-emocional del individuo en un mundo globalizado donde la razón técnica o razón instrumental es predominante, utilizando toda su potencialidad (tanto en el manejo de estas técnicas e instrumentos, como de su capacidad de relacionarse con ellos y con su entorno de forma racional). Hermenéutica.

Dentro del marco general de la necesidad de, como recuerda Ramón López Facal, situar a la enseñanza de la historia en un "campo de confrontación ideológica" que "habitualmente ha estado al servicio del poder, pero" que "puede servir para cuestionar el pensamiento dominante". ${ }^{27}$ 
DE DEMOCRACIAS, DICTADURAS, GUERRAS,

\section{REPÚBLICAS Y MONAROUÍAS: LA HISTORIA RECIENTE}

ESPAÑOLA EN LOS LIBROS DE TEXTO

Marcos Marina Carranza

Universidad Autónoma de Madrid
La práctica totalidad de los libros de texto manejados define explícitamente a la Segunda República como un sistema democrático. Este rasgo queda patente en la redacción de la Constitución de 1931, ampliamente diseccionada por sus autores, y en los derechos que consagró. Al hace esta identificación algunos de ellos van más allá señalando que "la república era el símbolo de las reformas políticas y sociales que necesitaba el pais" 4 o que "ofrecía la oportunidad histórica de resolver los graves problemas"s de España. De esta línea se desmarcan algunos manuales que se limitan a apuntar el carácter "progresista e izquierdista" del texto constitucional. ${ }^{6}$

El programa de reformas que puso en práctica el gobierno presidido por Manuel Azaña aparece detallado en todos los libros de texto, que señalan los variados campos sobre los que actuó: el agrario, el educativo, el militar, el religioso, el socio-laboral o el territorial. Del mis actuo: el agrario, el educativo, el militar, el religioso, el socio-laboral o el territorial. Del misrechazaron las reformas, bien por lesionar privilegios adquiridos a lo largo del tiempo (caso de la Iglesia católica, los terratenientes o el ejército) o bien por su timidez (como esgrimían obreros, jornaleros y anarquistas). Llama la atención, en ese sentido, que uno de los manuales omita el golpe de Estado fracasado liderado por el general Sanjurjo en 1932,7 una excepción frente al panorama predominante.

La entrada en el gobierno de varios ministros de la CEDA provocó una insurrección protagonizada por los partidos y sindicatos de izquierda, la denominada Revolución de 1934. La totalidad de los libros consultados establecen ese vínculo causal, al que muchos añaden además la paralización de las reformas impulsadas en los años previos o el temor a repetir la situación alemana, con la llegada del fascismo al poder a través de las urnas. Uno de ellos apunta un motivo adicional al afirmar que "la dirección del PSOE, desde la primavera de 1934, se mostraba decidida a tomar el poder por la fuerza, rompiendo con la legalidad republicana, y a practica una política abiertamente revolucionaria". ${ }^{8} \mathrm{~A}$ su vez, hacen referencia a sus dos grandes polos, Asturias y Barcelona, aunque solo algunos enumeran la represión posterior. El aspecto más destacado afecta a la terminología, pues dos de los manuales consultados optan por calificar este movimiento como una simple revuelta, ${ }^{9}$ no una revolución.

Las explicaciones acerca de la Segunda República comúnmente concluyen con lo acontecido en la primavera de 1936, presentada habitualmente como antesala de la Guerra Civil. Los autores describen una situación protagonizada por dos bandos enfrentados (de un lado falangistas apoyados por algunos miembros del ejército y empresarios; del otro, militantes obreros radicales) que se relacionaban entre sí mediante actos violentos como los atentados, los ataques contra edificios religiosos, las huelgas o las ocupaciones de tierras por parte de los jornaleros. Hay diferencias a la hora de señalar los culpables de la situación, pues algunos manuales afirman que la vida política española se vio "asfixiada por el radicalismo proletario tes en los manuales escolares, véanse José Antonio Álvarez Osés et al:: La guerra que aprendieron los españoles. Republica y Guerra Civil en los textos de Bachillerato (1938-1983), Madrid, Los libros de la cata frana, 2000; y Rafael Valls: Historiay memoria escolar. Segunda Repülica, Guerra Civily dicta-

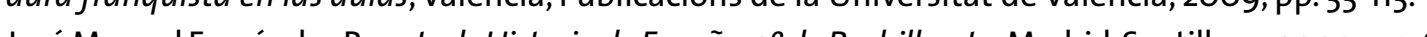

4 JoséManuelernandez Roset. 5 . Historiade España $2^{\circ}$ da Bach 5 Manuel Ángel García Parody et. al.: Historia de España. $2^{\circ}$ de Bachillerato, Zaragoza, Edelvives, 2009, p. 226.

6 Virgilio Fernández Bulete: Ciencias Sociales. Historia 4, Madrid, SM, 2011, p. 180. En una línea similar, Manuel Burgos y María Concepción Muñoz-Delgado: Historia 4. Ciencias Sociales. Educación Secundaria, Madrid, Anaya, 2008, p. 146.

7 Marianne Krause (coord.): Ciencias sociales, geografía e historia $4^{\circ}$ curso, Zaragoza, Edelvives, 2008.

8 Fernando García de Cortázar et. al.: Historia. $2^{\circ}$ de Bachillerato, Madrid, Anaya, 2009, p. 289.

9 Se trata de Virgilio Fernández Bulete: Ciencias Sociales. Historia..., p. 182; y Margarita García Sebastián y Cristina Gatell: Demos. Ciencias Sociales. Historia 4, Barcelona, Vicens Vives, 2009, p. 174.
De hecho, no se ha encontrado ninguna publicación que analice conjuntamente los cuatro perio-

Los manuales escogidos son los editados en la Comunidad de Madrid, obviando un análisis comparado del tratamiento del pasado en los libros de las diferentes autonomías.

3 Para contar con una visión de la evolución de las explicaciones sobre la Segunda República presende un gran fervor popular, que aspiraba a transformar profundamente la realidad socio-económica del país y que sucumbió a la fuerza de las armas. ${ }^{3}$ 
y la degradación del orden público"10 y otros, en cambio, sostienen que fue la derecha (englobando a industriales, terratenientes, jerarquía eclesiástica y falangistas) quien originó el caos, oponiéndose frontalmente a la victoria electoral del Frente Popular, actitud a la que respondieron "los militantes más radicales de la izquierda" con enfrentamientos callejeros cada vez más frecuentes." Tampoco sale indemne la clase política, cuyo "discurso incendiario [...] tuvo su reflejo en una creciente confrontación social", ${ }^{2}$ y más específicamente el PSOE y la CEDA partidos que "contribuyeron también, en estos meses, a la inestabilidad de la república".13

\section{La Guerra Civil}

El estallido del golpe de Estado de julio de 1936 y su doble fracaso, el del gobierno en su intento por abortar la sublevación y el de los propios rebeldes a la hora de hacerse con el poder, condujo a la Guerra Civil. Casi tres años de conflicto que significaron, por un lado, el final del régimen republicano y, por otro, el encumbramiento de un nuevo sistema político, la dictadura franquista. ${ }^{14}$

La totalidad de los libros de texto consultados sitúan al golpe de Estado ejecutado por parte del ejército, con apoyo de sectores civiles, como detonante directo de la Guerra Civil. Ahora bien, en la exposición de los motivos que llevaron al estallido del pronunciamiento pueden diferenciarse dos posturas. La mayoría de los autores perpetúan la imagen de conflicto como una lucha fratricida y una locura colectiva, haciendo un reparto equitativo de culpas entre izquierdas y derechas, reproduciendo así el esquema binario con el que se explicó la escalada de la violencia durante los meses anteriores. Solamente algunos van más allá, introduciendo una mayor profundidad analítica, apostando por causas como las des igualdades socioeconómicas o la oposición de las clases tradicionales (oligarquías, jerarquía eclesiástica y militares) a las reformas republicanas. ${ }^{15}$

En cuanto a los apoyos exteriores, los manuales escolares señalan los países que colaboraron con cada uno de los bandos y la desigual ayuda recibida por republicanos y rebeldes. Son varios los que inciden en la existencia del Comité de No Intervención, en sus nulos resultados (incluso, calificándolo como "farsa" ${ }^{16}$ ) y en el efecto perjudicial que tuvo para los intereses de bando republicano. A su vez, otros destacan el significado dado a la guerra por sus contemporáneos como una lucha entre la democracia y el fascismo.

10 Fernando García de Cortázar et. al.: Historia. $2^{\circ}$ de Bachillerato..., p. 293

11. Julio Aróstegui et. al: Hispania. Historia de España, Barcelona, Vicens Vives, 2010, p. 339

12 Ángel Bahamonde y Luis Enrique Otero Carvajal: Historia de España. $2^{\circ}$ de Bachillerato, Boadilla del Monte, SM, 2009, p. 205

13 José Manuel Fernández Ros et. al.: Historia de España..., p. 336.

14 El estudio de las transformaciones en las explicaciones sobre la contienda aparecidas en los libros de texto posiblemente sea el que cuente con mayor número de trabajos. En ese sentido, cabe mencionar José Antonio Álvarez Osés et al.: La guerra que aprendieron...; Carolyn Boyd: "De la memoria oficial a la memoria histórica: la Guerra Civil y la Dictadura en los textos escolares de 1939 al presente", en Santos Juliá (dir.): Memoria de la guerra y del franquismo, Madrid, Taurus, 2006, pp. 79-99; Rafael Valls: Historia y memoria escolar..., pp. 33-113. Puede resultar de interés también una aportación del autor de esta comunicación, Marcos Marina Carranza: "¿Qué guerra nos han explicado? La Guerra Civil en los libros de texto", en Aldea Celada, José Manuel et al.: Historia, identidad y alteridad. Actas del III Congreso Interdisciplinar de Jóvenes Historiadores, Salamanca, Hergar ediciones Antema, 2012, pp. 713-731.

15 En esa línea cabe situar, fundamentalmente, a Julio Aróstegui et. al.: Hispania. Historia de... Tímidamente, también a Virgilio Fernández Bulete: Ciencias Sociales. Historia . a Fernando García de Cortázar et. al.: Historia. $2^{\circ}$ de Bachillerato...; y a Ángel Bahamonde y Luis Enrique Otero Carvajal: Historia de España.

16 La cita, en José Manuel Fernández Ros et. al.: Historia de España..., p. 348.
La violencia ocurrida en las retaguardias es presentada, por norma general, de manera binaria, distinguiendo los actos cometidos por cada uno de los bandos. Fundamentalmente, se analiza la naturaleza de esa violencia, definiendo la republicana como espontánea y la sublevada como institucionalizada, y se describen sus manifestaciones y las víctimas que la padecieron. Además, resulta sencillo percibir el acento ideológico de las editoriales al tratar esta cuestión. Basta citar tres ejemplos: dos de los libros de texto consultados se limitaron a dar una cifra de víctimas, sin mayor explicación; ${ }^{17}$ hay manuales que prestaron mayor atención a la violencia ejercida por uno de los bandos; ${ }^{18}$ y la especial incidencia que hacen las editoriales católicas acerca de las víctimas eclesiásticas, aunque solo a aquellas asesinadas por los republicanos.

\section{La dictadura franquista}

La victoria de los sublevados en la Guerra Civil condujo al establecimiento de un régimen dictatorial que lideró el general Franco durante cerca de cuatro décadas. Un periodo de tiempo muy prolongado, con multitud de ingredientes y plagado de contrastes. ${ }^{19}$

Uno de los debates historiográficos más prolíficos del contemporaneísmo español, el referido a la naturaleza del régimen franquista, tiene su pequeño correlato en los libros de texto. Todos los manuales consultados califican al sistema político surgido de la Guerra Civil como una dictadura. A esa caracterización común se añaden una serie de elementos esenciales que representarían sus rasgos definitorios: la concentración de poderes en torno a Franco, la negación de la democracia, la influencia fascista, el rechazo del comunismo, el militarismo, e patriotismo y la impronta católica. Las dos posturas principales que ese debate que se mencionaba anteriormente también aparecen en algunos libros. De un lado estaría la editorial Vicens Vives, que asocia a la dictadura con el totalitarismo, mientras que, del otro, el manual de Anaya para Bachillerato la identifica como un régimen autoritario.

El ejercicio de la violencia fue una nota característica del régimen franquista. Los libros de texto la asocian, fundamentalmente, con los años de posguerra, llegando algunos incluso a afirmar que fue la "base sobre la que se asentó la dictadura" ${ }^{\circ}$ y que "favoreció la larga duración" ${ }^{21}$ de la misma. Dirigida contra todo aquel sospechoso de simpatizar con la Segunda República, las ejecuciones y el encarcelamiento fueron las fórmulas más habituales, conviviendo con otras como las depuraciones o la confiscación de bienes. Varios manuales desgranan el aparato legal que institucionalizó esta violencia, especialmente los pertenecientes a las editoriales Santillana y Vicens Vives, que hacen un profundo tratamiento de la cuestión, situación que contrastó con las nulas o escasas menciones hechas por otros. ${ }^{22}$

La violencia no solo tuvo lugar durante la posguerra, sino que fue la respuesta dada en todo momento por las autoridades para hacer frente a cualquier manifestación de disidencia al régimen franquista. El panorama presentado por los manuales escolares acerca de las

17 Concretamente, Manuel Burgos y Maria Concepción Muñoz-Delgado: Historia 4 Ciencias Sociales...; y Marianne Krause (coord.): Ciencias sociales, geografia

18 En Fernando García de Cortázar et. al.: Historia. $2^{\circ}$ de Bachillerato..., p. 306 se hace un análisis más amplio de la violencia republicana, deteniéndose especialmente en los sucesos de Paracuellos. Mientras tanto, en Julio Aróstegui et. al.: Hispania. Historia de..., p. 355 el tratamiento de la violencia cometida por los sublevados es más extenso, dedicando a esta cuestión un epígrafe completo en lugar del párrafo en el que sintetiza la llevada a cabo por los republicanos.

19 Para un recorrido por las explicaciones ofrecidas por los libros de texto sobre la dictadura, acudir a Rafael Valls: Historia y memoria escolar..., pp. 33-113.

20 Ángel Bahamonde y Luis Enrique Otero Carvajal: Historia de España..., p. 236.

21 Teresa Grence Ruiz et. al.: Historia. $4^{\circ}$ ESO..., p. 276.

22 Caso de Manuel Burgos y María Concepción Muñoz-Delgado: Historia 4. Ciencias Sociales...; y Virgilio Fernández Bulete: Ciencias Sociales. Historia que la mencionan como un compon..., y Virgilo Fernandez Bula Ciencias Sociales. Histora..., que la mencionan como un componente más 
distintas formas de oposición es bastante homogéneo, desde el maquis hasta los movimientos de los años finales de la dictadura. Son estos los que mayor atención reciben de manera global, incidiendo en los colectivos que se fueron distanciando del régimen y mostrando su rechazo al mismo. No obstante, solo en uno de los libros se apunta tímidamente que, pese a no lograr acabar con el régimen franquista, esta oleada de movilizaciones contribuyó a erosionar sus bases y su legitimidad. ${ }^{23}$

La imagen de la evolución política es bastante homogénea, incidiendo en las Leyes Fundamentales, la progresiva preeminencia de los católicos frente a los falangistas, las operaciones de maquillaje institucional intentando asemejarse a los regímenes democráticos occidentales o el inmovilismo característico de los años finales de la dictadura. Por su parte, dentro de la política exterior cabría destacar dos momentos, la posguerra mundial y la década de 1950. La conclusión de la Segunda Guerra Mundial significó el aislamiento internacional de España por su apoyo a las potencias fascistas, aunque solo un manual menciona la condena de la ONU al régimen franquista. ${ }^{24} \mathrm{El}$ comienzo de la Guerra Fría provocó cambios importantes puesto que en 1953 con la firma del Concordato con la Santa Sede y de los acuerdos con Estados Unidos, se logró la "aceptación internacional del régimen", ${ }^{25}$ garantizando asi "la supervivencia de la dictadura". ${ }^{26}$

Dentro de la política económica también puede apreciarse esta óptica binaria, centrada en dos grandes actuaciones. La primera de ellas es la adopción de la autarquía como principio económico en los años iniciales de la dictadura. Cabe resaltar la justificación dada por algunos manuales, motivando su puesta en práctica por influencia del aislamiento internacional que padecía la dictadura y no como una decisión voluntaria de las autoridades franquistas. ${ }^{27}$ Pese a ello, hay una gran coincidencia en la descripción de sus rasgos esenciales y de sus negativos resultados. Para salir de esa mala situación se impulsó el Plan de Estabilización, la segunda gran decisión a la que se hará referencia, aunque en esta ocasión existe una mayor homogeneidad en las explicaciones a la hora de abordar los objetivos, las realizaciones y sus resultados. Sin embargo, no son muchos los libros de texto que señalaron la influencia de las recomendaciones de los organismos económicos internacionales. ${ }^{28}$ Su éxito se vio beneficiado por una coyuntura internacional favorable y, como indican todos los autores, propició una profunda transformación de la sociedad española durante las décadas de 1960 y 1970.

\section{El proceso de democratización y la España actual}

La muerte de Franco en 1975 trajo consigo el agotamiento de cualquier intento por perpetuar la dictadura, que no fue capaz de sobrevivirle Se abrio entonces un proceso de transición política que culminó con el establecimiento del régimen democrático que sigue vigente en la actualidad. ${ }^{29}$

23 Se trata de Julio Aróstegui et. al.: Hispania. Historia de..., p. 412.

24 Margarita García Sebastián y Cristina Gatell: Demos. Ciencias Sociales..., p. 231.

25 Julio Aróstegui et. al.: Hispania. Historia de..., p. 380

26 Virgilio Fernández Bulete: Ciencias Sociales. Historia..., p. 241

27 En esa línea cabría inscribir a Manuel Burgos y María Concepción Muñoz-Delgado: Historia 4. Ciencias Sociales...; Virgilio Fernández Bulete: Ciencias Sociales. Historia...; y Marianne Krause (coord.) Ciencias sociales, geografia... En Ángel Bahamonde y Luis Enrique Otero Carvajal: Historia de Espa$\tilde{n} a \ldots . .$, p. 240 se combinan los factores coyunturales con los ideológicos.

28 Concretamente, Julio Aróstegui et. al.: Hispania. Historia de..., p. 398; Ángel Bahamonde y Luis Enrique Otero Carvajal: Historia de España..., p. 256; José Manuel Fernández Ros et. al. Historia de España..., p. 396; y Manuel Ángel García Parody et. al.: Historia de España..., p. 268.

29 No se han encontrado estudios que aborden el tratamiento en los manuales escolares del proceso de se han encontrado estudios que aborden el tratamiento en los manuales escolares del proceso de cambio politico y de los sucesivos gobiernos democráticos. Una aporarcial para el primexlicada a los estudiantes: la transición español en los libros de texto", en Claves del mundo
Los manuales escolares periodizan el cambio político de dos formas, básicamente. La primera de ellas comprende el arco cronológico entre 1975 y 1978, finalizando tras la aprobación de la Constitución. Es la que predomina en los libros editados para la ESO, aunque además es compartida por el de SM para Bachillerato. La segunda retrasa su conclusión hasta 1982, año en que se produjo la victoria electoral del PSOE. Esta opción es la mayoritaria en los manuales de Bachillerato, y es la manejada también en el de Santillana para la ESO. La excepción a este panorama viene de la mano del libro de Edelvives para Bachillerato, donde se adelanta el comienzo de este proceso a 1973, coincidiendo con la muerte de Carrero Blanco.

La clase política es la principal protagonista de la democratización, especialmente las figuras de Adolfo Suárez y Juan Carlos I. Perpetuando la imagen proyectada por el relato canónico de la transición, según el cual este proceso fue orquestado en exclusiva por las élites políticas, algunos autores incorporan al mismo a otros miembros de la escena política, fundamentalmente del ámbito de la izquierda, y, en menor medida, a la sociedad civil. Eso sí, cuando esta presente, la movilización ciudadana no se relaciona en ningún momento con los núcleos de oposición a la dictadura, especialmente activos durante el tardofranquismo, perdiendo as parte de su significado. Pese a ello, los rasgos definitorios de esa visión convencional siguen presentes, oportunamente sintetizados en la siguiente cita: "[el proceso de transición a la democracia] se realizó de forma pacífica y en un ambiente de tolerancia y de consenso entre las distintas fuerzas políticas, por lo que suscitó la admiración fuera de nuestras fronteras y se convirtió en un modelo a seguir para otros países". ${ }^{\circ}$ De ahí se infieren los cuatro elementos que caracterizan la mayoría de las explicaciones, identificando el cambio político como un proceso planificado, consensuado, pacífico y modélico.

Los libros de texto abordan también aquellos factores que dificultaron la llegada de la democracia, calificándoles de manera casi generalizada como sus "enemigos". Se tratarían del terrorismo, procedente tanto de ETA como de otras organizaciones extremistas (véanse el GRAPO o las bandas ultraderechistas, por citar los dos ejemplos principales), la amenaza golpista y la crisis económica. Todos ellos se situaron convenientemente como elementos de amenaza o distorsión del proceso de cambio político.

Pasando a la valoración hecha de los tres gobiernos democráticos, ${ }^{31}$ los gabinetes de UCD aparecen muy desdibujados. Mientras que los dos primeros ejecutivos encabezados por Suárez se consagran prácticamente en exclusiva al desarrollo de la reforma política, el tercero se presenta asolado por una serie de problemas y dificultades (el recrudecimiento del terrorismo, e agravamiento de la situación económica, el peligro involucionista, la división en el seno de partido centrista o el fortalecimiento de la oposición) que acabarían forzando su dimisión. Esta imagen la comparte el gabinete de Calvo Sotelo, aunque se destacan algunas decisiones como la entrada en la OTAN, la promulgación de la LOAPA o la aprobación de la Ley de Divorcio.

Respecto a la época socialista, los manuales escolares resaltan la puesta en marcha de un conjunto de medidas de "supusieron la transformación y la modernización de España". ${ }^{2}$ Los autores hacen referencia, fundamentalmente, a la reactivación económica, a la implantación de Estado del bienestar y al ingreso en la CEE, aunque los libros de texto de Bachillerato hacen un recorrido más profundo por los distintos ámbitos de actuación. Sin embargo, en la visión dada acerca de los gobiernos presididos por Felipe González también se tienen en cuenta los elemen-

contemporáneo: debate e investigación. Actas del XI Congreso de la Asociación de Historia Contem poránea, Granada, Asociación de Historia Contemporánea-Editorial Comares.

3o Manuel Burgos y María Concepción Muñoz-Delgado: Historia 4. Ciencias Sociales..., p. 270

31 Por razones cronológicas quedan excluidos el presidido por el socialista Rodríguez Zapatero (2004-2011), pues solo aparecen los primeros años de mandato, y el del popular Rajoy (desde 2011) que ni siquiera es mencionado por los manuales.

32 José Manuel Fernández Ros et. al.: Historia de España..., p. 428 
tos menos beneficiosos, como los escándalos de corrupción o la recesión de los años finales, que provocaron un paulatino descenso de votos que desembocó en la derrota electoral de 1996

Por último, en relación con los ejecutivos liderados por José María Aznar, se diferencian claramente sus dos legislaturas, la primera gobernando con mayoría simple y la segunda con mayoría absoluta. Todos los autores hacen especial hincapié en los éxitos registrados en materia económica, materializados en el crecimiento registrado tras la recesión de comienzos de la década de 1990 y la adopción del euro. Durante la segunda legislatura, una serie de fenómenos hicieron aumentar el descontento social, hecho que junto a lo atentados del 11 de marzo de 2004 propiciaron un nuevo cambio de gobierno. Debe puntualizarse que solamente uno de los manuales consultados establece una relación directa entre dichos actos terroristas y la participación española en la Guerra de Irak. ${ }^{33}$

\section{Conocimiento historiográfico e historia enseñada}

A través de los apartados precedentes se ha buscado ofrecer el tratamiento que reciben los diversos procesos que conforman la historia reciente de España en los libros de texto. En ellos se aborda, sintéticamente, una Segunda República de bases democráticas pero incapaz de hacer frente a una creciente polarización política y social; una Guerra Civil presentada como una locura colectiva y una lucha fratricida; una dictadura sustentada en la violencia que propició el desarrollo económico y la modernización social del país; un proceso de cambio político que desembocó en un régimen democrático de manera pacífica gracias a la labor de una clase política que priorizó el consenso frente al disenso; $y$ un final de siglo XX que proporcionó una estabilidad en todos los órdenes no conocida hasta entonces. Sobre este tapiz despuntan además, las distintas ópticas que aplican las editoriales, por lo que el tratamiento de estos acontecimientos no resulta completamente homogéneo.

Como puede comprobarse, esta imagen presenta algunas diferencias con el conocimiento generado por la investigación histórica más reciente. La historia enseñada, aquella que se trabaja en el sistema educativo, constituye un discurso reacio al cambio y muy sujeto a convenciones académicas, a pesar de que poco a poco van introduciéndose algunas novedades. El fracaso de la democracia republicana, la identificación de la Guerra Civil como una tragedia colectiva en la que todos fuimos culpables y el arraigo del relato canónico sobre el proceso de democratización son dos buenos ejemplos al respecto. Las limitaciones de espacio han impedido efectuar un estudio que atienda a la evolución de estos temas en los manuales escolares, pero se trata de una cuestión de suma importancia y que, por tanto, ha de tenerse en cuenta. En paralelo, en los acontecimientos abordados se ha detectado un fuerte predominio de los contenidos de tipo conceptual, aquellos que buscan que el alumno aprenda qué sucedió y por qué (sucesos, causas, consecuencias, fechas, etc.) y relacionándose, por tanto, con la concepción tradicional de la escolarización. Sin embargo, en muy pocas ocasiones existen en los libros de texto herramientas para el desarrollo de procedimientos, y menos aún para fomentar valores y actitudes. Una muestra, nuevamente, del estatismo de los manuales escolares, anclando el tipo de explicaciones incluidas en sus páginas.

La existencia de esta visión de la historia reciente española, con las deficiencias señaladas, debe convertirse en preocupación no solo de aquellos historiadores dedicados a la docencia en enseñanzas medias sino a todos los que investigan estos procesos históricos. Como constructores del relato sobre el pasado, los integrantes de la disciplina deben estar al tanto del tipo de conocimiento que se transmite al alumnado y participar en el proceso de elaboración de los materiales didácticos. Algunos reconocidos especialistas en los casos estudiados en esta comunicación son autores de manuales escolares, como por ejemplo Julio Aróstegui,
Ángel Bahamonde, Javier Donézar, Fernando García de Cortázar o Jordi Palafox, entre otros. Por tanto, esta reflexión no carece de sentido ni debe ser considerada de segundo nivel dentro de las tareas que debe llevar a cabo un historiador. De lo contrario se obviaría uno de los canales básicos de transmisión del conocimiento histórico, el sistema educativo, redundando en la separación existente hoy en día entre la ciudadanía y la disciplina historiográfica.

Muy vinculadas al tipo de enseñanzas sobre el pasado que llegan a los estudiantes se encuentran las utilidades de aquellas. En este punto, cobra especial relevancia el desarrollo de valores y actitudes a través del conocimiento histórico. Otra posible potencialidad debe enfocarse hacia la consolidación de identidades personales y colectivas, de la mano de la relación que se establezca entre los alumnos y su pasado. Para ello, debe tenerse en cuenta que los procesos históricos tratados en esta comunicación se imparten en la recta final de su adolescencia y, por tanto, cuando están a un paso de entrar en la edad adulta. Son, además, los que tienen un mayor impacto social debido a su fuerte carga mediática y simbólica. Como consecuencia, su aprovechamiento didáctico es todavía mayor, añadiendo valor a este tipo de docencia.

A lo largo de este texto ha podido verse la insuficiencia de los libros de texto para hacer frente a un modelo educativo que potencie los contenidos actitudinales y que forje identidades colectivas en el alumnado. Este recurso didáctico demuestra sus limitaciones para responder a este reto, fundamentalmente en la gran relevancia dada a los aspectos conceptuales y al estatismo que caracteriza las explicaciones que ofrecen sobre el pasado. En consecuencia debe ser el docente quien impulse una enseñanza que pivote en torno a esos dos ejes, diseñando unas programaciones donde estas cuestiones tengan un gran peso.

Además, ambas vías pueden permitir la extensión de una educación instrumental, que no solo se dedique a transmitir conocimiento a los estudiantes sino que les forme como futuros ciudadanos. La implicación de los historiadores en esta tarea es crucial, estableciendo una continua y fructífera interacción con un profesorado que ha de convencerse de las ventajas que proporciona apostar por este modelo didáctico. Gracias a ello, la enseñanza de la historia adquiriría un sentido mucho mayor dentro del sistema educativo y, muy posiblemente, una más alta valoración social. Solo queda que los profesionales de la disciplina se afanen en esta labor y revaloricen el trabajo que llevan a cabo, contribuyendo no solo a proporcionar interpretaciones acerca del pasado sino a construir una comunidad ciudadana más sólida. 
Parte 3.

LOS HILOS DE LA MEMORIA:

INVESTIGACIÓN Y MÉTODO A TRAVÉS DE

$$
\text { LA HISTORIA ORAL }
$$




\section{LOS HILOS DE LA MEMORIA: INVESTIGACIÓN Y}

\section{MÉTODO A TRAVÉS DE LA HISTORIA ORAL}

Eider de Dios Fernández

Universidad del País Vasco / Euskal Herriko Unibertsitatea

\section{Introducción a la mesa}

Desde los años setenta, la Historia Oral se ha venido consagrando no sólo como método, también como fin en sí misma. Son numerosas las universidades que cuentan con programas y asignaturas específicas de historia oral. Asimismo, hoy en día coexisten asociaciones internacionales como la IOHA y nacionales como el Seminario de Fuentes Orales y AHOA, dedicadas al estudio y conservación de la fuente oral. Igualmente, contamos con proyectos sumamente interesantes en los cuales la fuente oral es recogida con celo y preservada con sumo cuidado interesantes en los cuales la fuente oral es recogida con celo y preservada con sumo cuidado
a través de plataformas digitales como es el caso de Mujer y Memoria y el Arxiu de la Memòria Oral Valenciana. No obstante, ni en los anteriores Encuentros de Jóvenes Investigadores de la Asociación de Historia Contemporánea ni tampoco en los congresos de la propia AHC han existido espacios específicos dedicados a la historia oral.

Fue este el motivo el que nos impulsó, a Sescún Marías y a la que firma, a proponer una mesa que versara sobre memoria e historia oral, sobre todo, teniendo en cuenta la multitud de estudios y especialistas con los que contamos en nuestro país. La historia oral es una herramienta o metodología concreta que muchos investigadores utilizamos en nuestros trabajos aunque éstos no traten exclusivamente sobre fuentes orales. ¿Cuántas investigaciones sobre la historia más reciente han podido prescindir de las fuentes orales? Aunque hayamos hecho un par de entrevistas, quizá una decena, es frecuente que consultemos a testigos privilegiados o actores secundarios de nuestro objeto de estudio. Sin quererlo, la historia oral se ha hecho obligatoria para el avance de ciertas investigaciones, y quizá no hemos reparado lo suficiente en ella, en sus procesos, sus técnicas, sus resultados ni en su compleja metodología. "Los hilos de la memoria" nos brindó un espacio donde reflexionar sobre estas cuestiones y poder intuir las nuevas vías por las que pueden evolucionar los estudios de historia oral. Nos condujo también a replantar la historia oral no sólo como herramienta sino como fin en sí mismo, como medio de conocimiento de las identidades, subjetividades y experiencias de las sociedades o grupos que estudiamos.

A través de esta mesa y entre todos pudimos apreciar que en historia oral es tan importante lo que se cuenta como el cómo se cuenta, y exploramos así los hilos que forman la memoria. Quisimos plantear la mesa desde una perspectiva amplia y plural y la verdad es que ése fue el resultado: tuvimos la suerte de contar con profesionales con gran trayectoria en historia oral historiadores que nos introdujeron en importantes novedades metodológicas; investigadores que estaban iniciando su trayectoria y querían compartir con todos nosotros sus dudas autores que nos condujeron a replantearnos los usos de la memoria de sucesos acontecidos incluso en época moderna e historiadores que nos llevaron a comunidades inusitadas. Gracias a ellos contamos con una plataforma dinámica en la que pudimos intercambiar métodos y experiencias con memoria y fuente oral y así enriquecernos como investigadores.
En las líneas que siguen no esperéis encontraros con un balance al uso, se trata más bien de una explicación de nuestra manera de proceder a la hora de desarrollar una mesa de historia oral de modo que pueda servir de guía para futuros coordinadores. Muchos aspectos para la confluencia de historiadores en un congreso como este de "Jóvenes Investigadores". Al tratarse de "jóvenes", el arroje era necesario, y la innovación de obligado cumplimiento, no sé si lo conseguimos pero por lo menos entre todos pudimos llegar a un modo de relacionarnos totalmente opuesto a la verticalidad imperante en otros congresos. Aun así, después de esta explicación, y como no podía ser de otro modo, procederemos a exponer el trabajo de los participantes de la mesa, los que hicieron de "los hilos de la memoria" un verdadero espacio de ticipantes de la mesa, los que hicieron de "los hilos de la memoria" un verdadero espacio de ciones a partir del eje temático que seguimos en el propio congreso ya que nos parece el que mejor aglutina las diferentes comunicaciones.

\section{Organización de la mesa}

Una de las mayores preocupaciones que tuvimos fue inscribirnos en el universo relacional en el que nos movemos los jóvenes de hoy aprovechando los recursos que la era digital nos brinda. Con ese fin y con la intención de "captar" posibles comunicantes creamos un perfil de Facebook. Éramos sabedoras de que se trata de una empresa con fines lucrativos y que comercia con la información de sus usuarios, no obstante, cuenta con varios puntos fuertes para su utilización tanto de herramienta como de pantalla de las ciencias sociales. Uno de sus beneficios lo encontramos en su propia visualidad, ya que recordamos a través de emociones y el estímulo visual que puede brindarnos Facebook resulta muy atrayente. Por otra parte, encon tramos la inmediatez, universalidad, "gratuidad" y facilidad en su uso. Nuestro perfil, https:// www facebook.com/loshilos delamemoria nos sirvió para difundir los propósitos de la mesa pero está abierto a vuestra disposición para colgar cualquier tipo de información sobre investigaciones, publicaciones o eventos relacionados con la memoria e historia oral. Contamos en el momento de escribir este texto con casi 5000 amigos repartidos fundamentalmente entre Europa y América Latina y nos gustaría que pudiera serviros como una forma de diálogo o plataforma para conseguir o depositar informaciones de todo tipo. Nos permite conocer actividades que se hacen fuera de la academia y acercar la academia a la sociedad lo que en definitiva ha de ser el objetivo último de cualquier investigador.

Una vez recibidas las propuestas y las comunicaciones, procedimos a realizar una lectura pormenorizada de todas ellas y a buscar puntos comunes. De este modo, generamos una serie de preguntas de reflexión que impedian responder tácitamente y que a su vez invitaba a los comunicantes a que se leyeran las comunicaciones de sus compañeros. La forma de ponernos a dialogar entre todos, desde la horizontalidad, fue la creación de un grupo privado y secreto en nuestro perfil de Facebook. A modo de foro y de forma periódica planteamos dichas preguntas y dimos la oportunidad a que comunicantes y coordinadoras dieran respuesta a través de sus experiencias. Todos podíamos ver todas las contestaciones y a su vez interactuar con ellas, podíamos colgar vídeos o informaciones que creyéramos que daban respuesta a las preguntas, o que nos podrían brindar una perspectiva diferente (Img. o1).

El resultado fue sumamente positivo ya que de los 11 participantes que éramos, contando a las coordinadoras, 10 formamos parte de un activo debate. De esta manera, antes de que comenzara el congreso ya nos conocíamos y habíamos generado un clima de confianza en el que dudas metodológicas se entremezclaban con recomendaciones y nuevas propuestas. 6 fueron las preguntas principales propuestas por nosotras (hubo también una serie de preguntas secundarias) pero en el foro los propios comunicantes generaron sus propios interrogantes y se dieron respuesta entre ellos. Llegamos al congreso empoderados, nos habíamos tenido que leer todas las comunicaciones, nos habíamos recomendado bibliografía, conocíamos el 


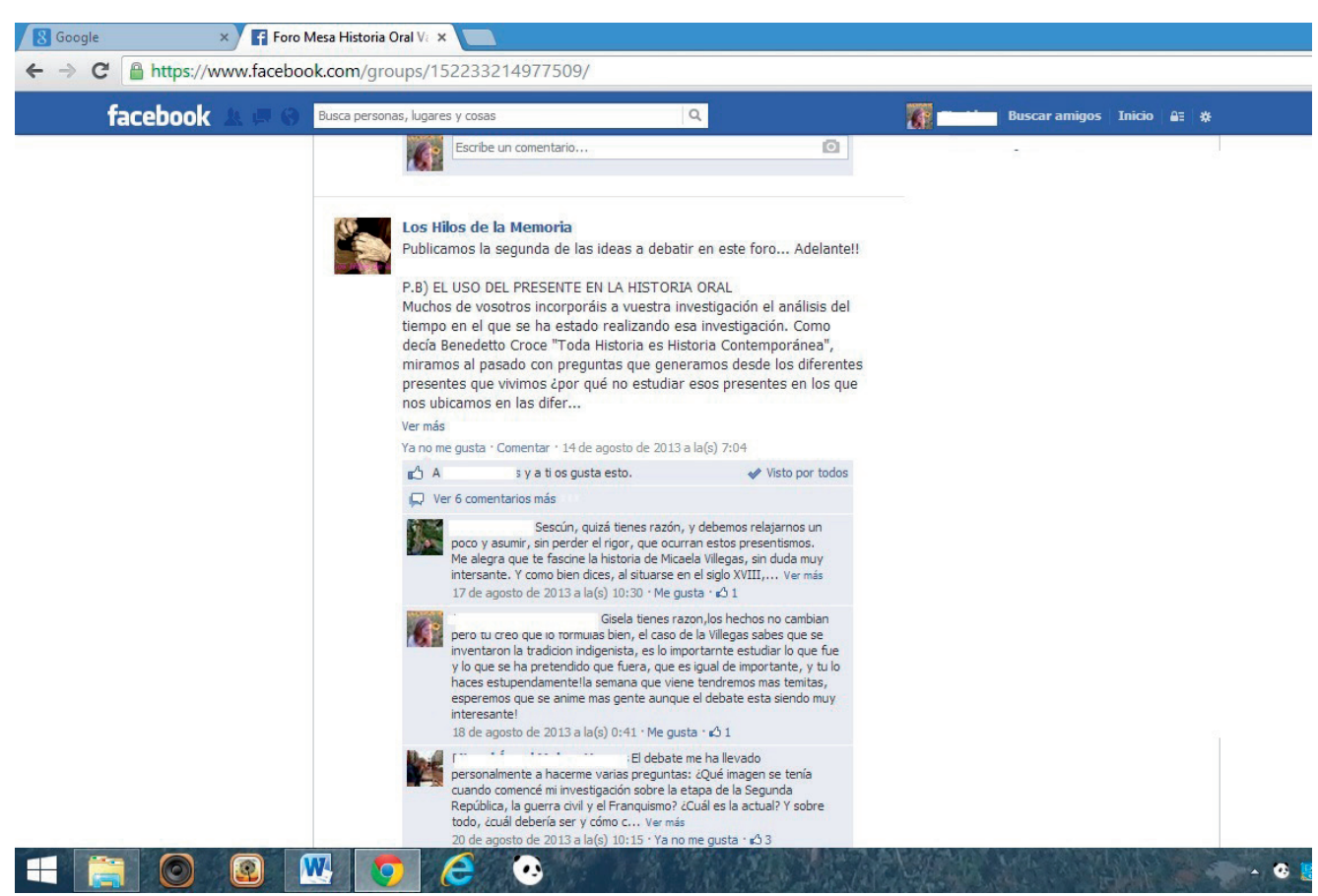

Img. 01 Foro secreto de "Los Hilos de la Memoria" en Facebook (fuente: https://www.facebook. com/groups/152233214977509, 2013)

trabajo de los compañeros, asociábamos una imagen a un nombre y finalmente, nos habíamos preparado a conciencia para el posible debate que pudiera darse en el propio congreso Éramos ya un grupo, con la sensación de seguridad que ello conlleva. No debemos olvidarnos de que el encuentro estaba dedicado a investigadores noveles y aunque contábamos con doctores entre los comunicantes, para muchos otros ésta se trataba de su primera comunicación y de su primer congreso, el sentirse apoyado era muy importante. Para nosotras, coordinadoras noveles también, tener un grupo que había generado tal identidad fue un verdadero privilegio que facilitó muchísimo la propia coordinación. Como se ha dicho con anterioridad, la razón de explicar nuestra metodología es la de poder dar alguna idea a futuros coordinadores que pretendan hacer de su mesa algo dinámico e interactivo que pueda romper con las barreras verticales que nos impone la academia.

\section{La utilización de medios audiovisuales en historia ora}

Qué duda cabe que los medios audiovisuales cada vez ocupan un mayor espacio no ya sólo en nuestro tiempo de ocio, sino que también se han convertido en una de las formas más comunes de relacionarnos con nuestro propio trabajo. Archivos digitales, archivos orales, hemerotecas y bibliotecas digitales han sido incorporadas en nuestro día a día. El correo electrónico, las redes sociales telefónicas e informáticas permiten en muchas ocasiones el acceso a la información sobre las novedades editoriales de nuestros compañeros, la divulgación con nuestros trabajos y el contacto con diferentes autores.

Pero las redes sociales pueden incluso aproximarnos a agentes históricos, a informantes, a comunidades remotas. Sobre este último aspecto reflexiona la comunicación de Enrique Bengochea, que se adentró en el congreso a través de una interesante propuesta "Facebook como herramienta: redes sociales y grupos diaspóricos". En su caso concreto estudia la última fase colonial española en la provincia de Sáhara y especialmente la actuación de la Sección Femenina en dicho territorio. Según el autor, se puede acceder con facilidad a los nombres de las falangistas que formaron parte del proyecto educativo, sin embargo, el acceso a los alumnos y antiguos habitantes se torna mucho más difícil. A falta de otro tipo de fuentes, Enrique Bengochea reflexiona acerca de la utilización de algunos blogs, páginas web y grupos en redes sociales dedicados a la memoria de los antiguos colonos que puedan dar cuenta de parte de la sociedad colonial.' Este tipo de medios digitales facilitan el acceso a gran cantidad de testimonios, no solo a través del contacto personal, sino a través de la rememoración que hacen de su experiencia en diferentes textos e imágenes. Además, pueden funcionar como repositorios de imágenes. ${ }^{2}$ La intención de estos Facebook organizativos o este tipo de blogs es compartir fotografías de conjunto, fotografías que son acompañadas por una explicación o identificación de los miembros que aparecen y una descripción del lugar o las condiciones en la que fue tomada. Y como gran parte de las comunidades digitales de la diáspora del Sáhara son antiguos militares y hombres (lo que limita el acercamiento de diversos campos de estudio), a través de este tipo de fotos se podrían intuir las relaciones entre "saharauis" y "españoles"; "hombres" y "mujeres" e, incluso, indagando en los perfiles de estas personas, entre los diferentes grupos sociales.

La propuesta de Enrique Bengochea nos introduce de lleno en la historia digital, que guarda similitudes con la historia oral tanto por la oralidad de sus fuentes, como por la naturaleza de su creación "desde abajo", y también porque ambas aumentan el archivo de fuentes disponibles y aportan nuevos abanicos de sujetos y problemáticas. Podríamos entenderlas como metodologías paralelas que incluso podrían retroalimentarse ya que a partir de la utilización de una plataforma digital podríamos llegar a una entrevista oral vía Skype o incluso con mensajes de texto como han propuesto algunos autores ${ }^{3}$. La historia digital pese a depender de un contexto globalizado, al igual que hace la historia oral, propone una multitud de historias locales y experiencias particulares que se enfrentan a la historia global. Por todas las posibilidades que ofrece el uso de Facebook para la construcción de fuente histórica y sus múltiples peligros, el autor hace un llamamiento a que reflexionemos sobre una metodología concreta que permita crear historia salvaguardando la intimidad de los informantes o de las personas a las que se refieren los informantes. Como ocurre con la historia oral, el enfoque multidisciplinar resulta necesario para conocer incluso el ámbito legal de cada investigación.

En esta línea enclavamos la comunicación del fotógrafo e historiador Sereno Caleri con "Fotografía y Fuentes orales: un análisis metodológico". Dicho autor realiza un acertado resumen

1 El autor analiza esta cuestión a partir de la lectura de Elena FIDDIAN-OASMIYEH: "Histories of displacement: intersections between ethnicity, gender and class", The Journal of North African Studies, 16-1 (2011), pp. 31-48. En este artículo, la investigadora trata de analizar el discurso producido por el encuentro colonial a través del testimonio de una serie de españoles que vivieron en la antigua colonia. El acceso a estos informantes se hizo a través de un foro de Internet en el que se ponían en contacto antiguos militares destinados al Sáhara y utilizando cuestionarios semi-estructurados.

2 Sobre la necesidad del ser humano por compartir imágenes recomendamos en cortometraje de ficción I am not here now de los directores Zisis Kokkinidis y lon Papaspyrou, Grecia 2013. Este film constituye una mezcla entre una recopilación de obras de videoaficionados, documental posmoconstituye una mezcla entre una recopilación de obras de videoaficionados, documental posmo-
derno, arte povera y cinema verité, realizado completamente con vídeos subidos a la web por diderno, arte povera y cinema verite, realizado completamente con videos subidos a la web por disu vida mediante las redes sociales y youtube. Esta película fue presentada en el $55^{\circ}$ Zinebi, el su vida mediante las redes sociales y youtu
domingo 17 de noviembre de 2013 en Bilbao. 3 La Universidad de California a través de "Berkeley's Regional Oral History Office's Artist with Disabilities Oral History Proyject" está mostrando alguno de los puntos fuertes en la utilización BOYD y Horacio ROQUE RAMíREZ. Bodies of Evidence. The Practice of Queer Oral History, Nueva York Oxford University Press, 2012, pp. 8-9. Reseña disponible en Eider DE DIOS FERNÁNDEZ: “BoYork, Oxford University Press, 2012, pp. 8-9. Reseña disponible en Eider DE DIOS FERNANDEZ: "BOdies of evidence. The practice of Queer Oral History", Boletin de la Asociación Internacional de res/64-volume-221/168-from-mouth-to-page (última consulta 11-02-2014). 
historiográfico sobre la historia de la fotografía, sobre la fotografía como fuente histórica, los estudios con fuentes orales y el análisis de la memoria colectiva. Destaca tres principales pilares en la utilización de la fotografía y de las fuentes orales en el ejercicio de la historia: el hecho histórico en sí, condicionado por el tiempo/espacio en que se produce; la interpretación del receptor de estas informaciones históricas; $y$ la memoria producida a través del distanciamiento temporal.

Al igual que nos indica el reciente Premio Internacional de Fotografía de la Fundación Hasselblad, Joan Fontcuberta, la fotografía es una interpretación, interpretación que es sometida desde su origen a varios filtros culturales. Sereno Caleri insiste en que hay que considerar la fotografía tanto en el sentido de imagen/documento como de imagen/monumento. Es decir, por una parte la fotografía ha de entenderse como una materialidad pasada en el cual objetos, personas, lugares nos informan sobre determinadas condiciones de vida en el pasado. Por otra parte, la fotografía es un símbolo, o sea, ya que es aquello que en el pasado una sociedad estableció como única imagen a ser recordada en el futuro. De tal manera que si la fotografía informa, también conforma una determinada visión del mundo. Esperamos que siguiendo con esta línea en el proceso de creación de su tesis, "La Fotografía como el espejo de la Historia: dictadura y transición en Brasil y España", el autor pueda incidir más en las vinculaciones entre historia oral y la fotografía y la posible utilización simultánea de ambos tipos de fuentes.

\section{Comunidades inusitadas}

Decidimos darle este curioso nombre a este bloque porque contamos con temáticas comúnmente ajenas en las cátedras de historia de las universidades, donde por desgracia las asignaturas a las que se las acompaña el adjetivo "universal" suelen quedarse, por falta de tiempo o de medios, en "historia de occidente y del Catón moderno". En nuestra mesa tuvimos la suerte de contar con tres investigadores que pudieron abrir nuestros horizontes historiográficos e introducirnos en comunidades desconocidas, inusitadas y no escuchadas.

Comencemos cronológicamente con la propuesta más remota en el tiempo de la mano de la doctora en historia moderna Gisela Pagès Cruz titulada "La histórica y la memoria literaria de Micaela Villegas en los siglos XIX y XX". La autora comienza analizando la figura de Micaela Villegas "La Perricholi", actriz y productora de teatro limeña de origen criollo nacida en 1748 y fallecida en 1807 que mantuvo una relación sentimental con el virrey Amat. Micaela Villegas y Santa Rosa de Lima, patrona de Perú, constituyen prácticamente las únicas mujeres que han llegado a convertirse en emblemas nacionales. Gisela Pagés estudia a la actriz por la excepcionalidad de su persona y porque se trató de un personaje que vivió en un período que funcionó como bisagra entre la última etapa del virreinato y la independencia peruana. Por todas estas circunstancias, el personaje de "La Perricholi" ha servido de base para la construcción de varias identidades nacionales a Perú y es éste el ingrediente más atractivo de dicha comunicación: la formación de la identidad hispanista y la identidad indigenista.

La identidad hispanista tuvo dos puntos de origen, el propio Perú y el romanticismo europeo. El movimiento hispanista peruano defendía el "esplendoroso" pasado hispánico de la época virreinal como definitorio en la formación de la identidad nacional peruana. ¿Qué mejor icono para esta corriente que la Perricholi? Al fin y al cabo, se trataba de una criolla exitosa durante la etapa más brillante de la era virreinal. Por otra parte, España y sus antiguas colonias se convirtieron en el foco principal de las miradas de numerosos románticos europeos. Los románticos europeos buscaban en España una naturaleza salvaje, llena de peligros y emociones para poner a prueba su masculinidad, las mujeres hispánicas se convirtieron en un objeto de deseo. Este último punto puede contrastarse en dos obras de Merimée en Carmen y en Le Carrosse que tenía como protagonista a Micaela Villegas, máximo exponente para ellos de la sensualidad limeña y de las exóticas "tapadas" (mujeres capitolinas que dejaban al descubierto solo uno de sus ojos). La otra identidad que encontramos es la indigenista, la cual tuvo lugar mayoritariamente en el siglo XX cuando los intelectuales peruanos volvieron la vista hacia los Andes para buscar la esencia de la identidad naciona peruana. A pesar de que la actriz había nacido en Lima y no era de origen indígena, se subrayaron aspectos de su persona que enlazaban con la independencia peruana como su propia actitud altiva ante el virrey, su papel en el mestizaje de culturas, o la vinculación personal con varios de los artífices del acta de independencia.

Continuando con la memoria indigenista nos encontramos con la propuesta de Inge Fernández Bueno con "Estudio e investigación sobre los nativos norteamericanos, problemática, enfoque metodológico y teórico de la historia oral". La autora critica el enfoque eurocéntrico que suele operar en las investigaciones sobre nativos norteamericanos y exige la incorporación en la práctica del historiador cierta metodología indígena. De lo contrario, en lugar de comprender las sociedades indígenas, les estaremos "robando información", lo que generará una sensación de pérdida de poder en los propios indígenas. Inge Fernández expone tres requisitos mínimos a la hora de plantear una investigación de esta naturaleza: la definición de la agenda y las temáticas del proyecto de investigación con los propios indígenas, la teorización desde una perspectiva indígena y la inclusión de los nativos no tanto como objetos de estudio sino como integrantes de la investigación.

Es fundamental conocer la lengua del grupo que estamos estudiando y los protocolos tribales, las dificultades de la historia oral con indígenas además pueden devenir de la incomprensión o el desconocimiento de la cosmovisión de la comunidad nativa norteamericana. Las características de la tradición oral indígena a la par que buena es inherente a su propia condición, por esta misma razón, a la hora de recoger la tradición oral indígena, no podemos imponer nuestra estructura del pensar. Debemos entender sus textos orales como productos de gran valor cultural sin invalidarlas a causa de la práctica inexistencia de exactitudes.

Así como Inge Fernández nos describe los elementos ideales para el estudio de los grupos de nativos pero reconocemos la dificultad de llevarlas a cabo en su totalidad, Ricardo Torres Silva nos brinda la oportunidad de adentrarnos en una comunidad coexistente pero a la vez ajena y extraña para la sociedad occidental. "Otras voces, otros ámbitos" nos acerca en la historiografía del pueblo gitano a través del análisis de dos artículos. Uno de los artículos versaba sobre los gitanos manouches de la región de Pao y abordaba la dificultad delegar su conocimiento debido a problemas como el silencio entendido como respeto a la comunidad y la indivisión del tiempo presente y pasado. Sin embargo, Ricardo Torres que comenzó su exposición a través de un ejercicio de egohistoria, "soy gitano", insiste en que no es que no haya ruptura entre pasado y presente, lo que no existe es la dicotomía sobre la cual dividir el tiempo. Otro de los artículos que recoge el autor es el de Juan Carlos Barranco Nadal, sobre las estrategias económicas de los gitanos valencianos. En este caso, el artículo está escrito bajo una atmósfera mucho más positiva que el anterior. El investigador accede al relato sin problemas, los interlocutores son plenamente conscientes de la información que transmiten y lo realizan sin pudor a la hora de una posible reprimenda ética o prejuicios morales añadidos. El tiempo histórico es parejo al tiempo emocional o vivido de los entrevistados.

Ricardo Torres nos indica que en una investigación con el pueblo caló es muy fácil encontrase con estas dos posturas enfrentadas. En los casos que el testimonio se nos presente de forma clara, fluida, coherente y cohesionada debemos aprovechar ese acceso. Sin embargo, en aquellos casos donde dichos testimonios se nos presenten de forma oblicua, fragmentada, no tiene que frustrar la investigación y tampoco tiene por qué invalidar la fuente oral. Lo que habrá que aplicar, según el autor, es otro método: "el desvelamiento del misterio del grupo pasa por adecuar, modular y ampliar nuestro propio campo de visión como historiadores". Desde aquí pretendemos incitar a Ricardo Torres a que siga esta línea de investigación tan necesaria en nuestro país. Cuenta además con instrumentos interpretativos que lo relacionan con ambos "mundos", lo que asegura una mayor fidelidad a la fuente. 


\section{Silencios, represión y agentes de cambio en el franquismo y la transición}

En la década que se inicia en el año 2000 , diferentes asociaciones para la recuperación de la memoria histórica comenzaron a generar un gran impacto social a través de actuaciones como la localización de fosas, exhumación de cadáveres, iniciativas para la eliminación de los símbolos franquistas así como la difusión de los diferentes actos de homenaje a los republicanos españoles. Esta agitación indicaba, que una de las memorias colectivas de este país, la que había quedado sometida por el pacto de reconciliación sobre el que se fundó la Transición se encontraba en disposición de contribuir a la redefinición de la memoria histórica de los últimos tres cuartos del siglo XX. Por parte de los organismos públicos también se dio cierta voluntad institucionalizadora de la memoria. La declaración del año 2006 en España como el Año de la Memoria Histórica constituye el eslabón más visible de la cadena de recuperación de la memoria histórica que hemos descrito. Todas las medidas y movimientos que se dieron en esta década significaron el fin de la hegemonía de la memoria de la reconciliación, y el despegue de lo que Julio Aróstegui denominó la memoria de la restitución. Esta nueva forma de memoria colectiva exige la revisión del pasado desde planteamientos éticos, más que desde discursos y argumentaciones que responden a la lógica puramente política. ${ }^{4}$ De esta manera, los estudios que versaban sobre la memoria de la República, los cuarenta años de dictadura o la transición a la democracia se revitalizaron y se crearon novedosos proyectos como Amarga Memoria, Todos los Nombres y Nomes y Voces, entre otros.

En esta revitalización, en esta emergencia de la memoria de la restitución encontramos las comunicaciones de este bloque. Comencemos pues, con la propuesta metodológica que nos ofrece Irene Murillo Aced con "Comunidades de dolor: narrar lo ocurrido, o conservarlo en el cuerpo". La idea central de esta motivadora comunicación se basa en reivindicar el estudio de las maneras de vivir, de disfrutar o padecer el franquismo por parte de la sociedad. En relación a esto, encontramos lo que la autora ha denominado "el problema de la victimización", es decir, la tendencia a concebir a la sociedad franquista exclusivamente como víctima reduciendo al mínimo su capacidad de agencia. Era comúnmente asumido que la sociedad se limitó a recibir de forma pasiva la represión, la definición jurídica de víctima contagió íntegramente el significado global de la palabra reduciendo así la capacidad de las personas para apropiarse de las condiciones de dominación. Todo ello conllevó la construcción de un imaginario colectivo pobre y la despreocupación por conocer la manera en que el sufrimiento social se integró en la vida cotidiana.

Debemos preocuparnos por la manera por la que las personas particulares se enfrentaron al sufrimiento y sobre si es posible transformar el lenguaje del cuerpo en un lenguaje que trascienda del dolor individual a un dolor colectivo. De esta manera superaremos esa memoria usurera ${ }^{5}$ que instauró el régimen, esa memoria hegemónica que desterró el relato de otros testimonios que ejerció la violencia sobre el recuerdo disonante. Hay que reencontrase con e recuerdo para así dar lugar a un re-agenciamiento del sufriente. La autora expone dos principales formas de enfrentarse al recuerdo y re-agenciarse de él. Una implica su comunicación y otra su silencio. Si bien en ambas situaciones el cuerpo se sitúa como un médium principal, para Irene Murillo en el segundo caso el cuerpo toma especial importancia. Nos presenta el ejemplo de una mujer que nunca habló del asesinato de su marido y, en cambio, mantuvo siempre su melena larga como le gustaba al mismo, era una manera silenciosa de reivindica la muerte de su pareja y mantenerlo vivo. Una segunda vía para re-agenciarse del recuerdo es enfrentarse a los hechos sucedidos, algo que puede recogerse también en fuente escrita ya que fueron muchas las mujeres, madres, hijas y hermanas de republicanos las que ya en el

4 Miren LLONA: "Balance y perspectivas de un nuevo enfoque historiográfico", en Cristina BORDERÍAS (ed.): La historia de las mujeres: perspectivas actuales, Barcelona, Icaria, 2009, pp. 374-376.

Expresión tomada de Jordi IBÁÑEZ FANÉS: Antígona y el duelo. Una reflexión moral sobre la memo-

ria histórica, Barcelona, Tusquets, 2009, p. 66 primer franquismo desvelaron los fusilamientos y las fosas. Su voz se enfrentaba a la negación del luto republicano impuesto por la dictadura, recuperando así la memoria silenciada, constituyéndose a sí mismas como sujetos políticos y sujetos de la resistencia. ${ }^{6}$

La comunicación de Miguel Ángel Melero Vargas, "Voces perdidas... y recobradas. La investigación de la II República, la guerra civil y la Represión a través de la Historia Oral. El caso de una comarca andaluza: Antequera", nos brinda la oportunidad de acercarnos a la memoria del segundo tercio de la historia de España a través de un ejercicio de historia local.7 El autor se basa en que la historia, es de pertenencia compartida y son las fuentes orales quienes en mayor medida pueden hacer visible ese acto de compartir ya que tratan de hacer "una cata en el presente del pasado" y establecen un diálogo entre la experiencia y la construcción de la memoria. Miguel Ángel Melero comienza la comunicación con un repaso de la historiografía de la República y de la dictadura, y sobre la relación entre historia oral y la Guerra Civil española. Analiza la subjetividad en la historia oral como maldición y bendición al mismo tiempo y, por eso, cree preciso la búsqueda de puntos de saturación de tal manera que se puedan establecer coincidencias repetitivas, es decir, convertir en objetividad múltiples subjetividades coincidentes. Por ello, el autor recuerda que la subjetividad no debe ser óbice para la inutilización de las fuentes orales ya que toda fuente está bañada de subjetividad.

El autor aporta una idea muy interesante ya que, sin dejar de apoyar que la historia oral sirve para recuperar voces perdidas, defiende que puede aplicarse también a colectivos que tuvieron oportunidad de ser escuchados pero que ahora pueden ofrecer una visión más completa de su propia historia. En el caso concreto de su marco de estudio, analiza las esperanzas depositadas por la población con la declaración de la II República, la radicalización de la sociedad, la generalización de la violencia y el silencio institucionalizado desde la victoria del bando nacional. En este sentido, enlaza con la comunicación de Irene Murillo en cómo la transmisión del recuerdo traumático, durante décadas silenciado, puede resultar una experiencia liberadora para el entrevistado.

Del recuerdo pasamos a la omisión voluntaria con Ángela González Bellver ya que comien za reflexionando sobre su interés por la contienda española y concluye que el silencio de sus familiares directos, represaliados, la empujó a buscar los porqués de esa amnesia colectiva. Su comunicación "El recuerdo del exilio. El testimonio de un exiliado: Antonio Carmona Pinto" transmite el testimonio de uno de los miles de exiliados a Francia. El recuerdo de Antonio Carmona recoge el terror de familias republicanas cuando se estaba vislumbrando el triunfo de los golpistas, la emigración y la desesperación generalizada. La migración dentro de España y fuera de ella se convirtió en un recurso para la supervivencia, sin embargo, a diferencia de muchos otros refugiados la huida a otro país, como Francia, es para Antonio Carmona una experiencia totalmente positiva ya que en lugar de acabar en campos de reclutamiento como muchos españoles, él y su familia pudieron integrase en su aldea de acogida. Una vez acabada la contienda, cuando los padres de Antonio Carmona decidieron regresar a España y son sometidos a un proceso de depuramiento y marginación, la emigración, esta vez en el propio país, se torna necesaria para la conseguir la desestigmatización. La idea más interesante que nos aporta Ángela González es que el movimiento, la emigración, la huida forzada por un sistema carnívoro y represivo puede reportar a los exiliados nuevos y positivos comienzos.

6 Para una ampliación del tema MURILLO ACED, Irene, En defensa de mi hogary mi pan. Estrategias femeninas de resistencia civil y cotidiana en la Zaragoza de posguerra, 1936-1945, Zaragoza, Prensas Universitarias de Zaragoza, 2013

7 De hecho, el doctor en Historia Contemporánea Miguel Ángel Melero es especialista en historia local y por ello co-coordina la mesa "Una necesaria herramienta de construcción metodológica: microhistoria, historia local y su importancia para la investigación histórica" en el XII Congreso de la AHC. 
Siguiendo el tiempo llegamos al texto de Javier Contreras Becerra "El PSA y el Nuevo Andalucismo. Una relectura del proceso democratizador y autonómico a través de las fuentes orales". La línea de investigación del autor se centra en la construcción de la ciudadanía y el aprendizaje democrático en Andalucía a través de las principales culturas políticas de la izquierda andaluza: el andalucismo, el comunismo y el socialismo.

Esta comunicación resulta muy acertada por dos cuestiones que me parecen fundamentales en el ejercicio del historiador. Por una parte, Javier Contreras es capaz de eliminar clichés a través del análisis pormenorizado y sistemático de un tema que en este caso concreto es el Partido Socialista de Andalucía (no PSOE). El autor analiza a través del imaginario colectivo cómo hoy, en parte impulsado por las decisiones de sus dirigentes actuales, se entiende el PSA como un partido de derechas, pero constata que durante la Transición fue un partido innovador: abogó por el regionalismo socialista, apostó después por un nacionalismo popular y solidario y recogió en sus planteamientos y en prensa demandas socio-ambientales y feministas que eran ajenas a las agendas de otros partidos de la izquierda. Por otra parte, el historiador explica el aparato crítico y las formas de proceder en historia oral. Muchos son los que creen manejar fuentes orales pero lamentablemente es escaso el número de investigadores que tratan dicha fuente con la disciplina que es necesaria y que son capaces de zafarse del "asalto a ancianos con grabadora cargada". El autor comparte con nosotras la forma que tuvo de acceder a los informantes a través de determinadas redes de confianza y expone los rasgos comunes de los testimonios que ha elegido para el texto, presenta a los entrevistados y cita debidamente la entrevista. Desde luego, creo que esta constituye la manera a seguir en los textos que conlleven la utilización de fuentes orales, fuente que desde luego implica método y profesionalidad.

\section{Conclusiones}

A lo largo de la lectura de esta serie de comunicaciones fueron muchas los interrogantes que nos asaltaron y que intentamos compartir en el debate en Facebook y en el propio congreso. En las siguientes líneas intentaré resumir cuáles fueron las principales conclusiones a las que llegamos en conjunto.

Alguno de los comunicantes reflexionó sobre su figura como historiadores ante los motivos que le llevaron a investigar su tema de estudio, Ángela González lo mostró en el texto y Ricardo Torres lo expuso de forma oral. Ya que investigando concurrimos una gran parte de nuestro tiempo inmersos en nuestro objeto de estudio, conociéndolo, interactuando con él, nos resultó necesario el análisis de nuestro punto de acercamiento hacia nuestro tema de estudio. En e caso de utilizar fuente oral donde la investigación se torna aún más personal, esta premisa se vuelve prácticamente ineludible. Pero es cierto que numerosos historiadores denuncian este tipo de ejercicios porque declaran que invalida cualquier ejercicio de objetividad. Historiadoras como Mercedes Arbaiza, Pilar Pérez-Fuentes o Cristina Borderías comprobaron que ni siquiera la fuente más impersonal, la estadística, es objetiva. Toda fuente por tanto, implica subjetividad. Incluso las denominadas ciencias naturales también son subjetivas tanto en cuanto responden a las necesidades de unas sociedades concretas, sus investigaciones son producto de estas sociedades y por lo tanto son subjetivas e históricas. Otra cosa es que ante la imposibilidad de objetivación podamos hacer declaraciones infundamentadas o que en busca de unos mar hallar tales presupuestos. Aun asi, consideramos constructivo explicar los presupuestos o premisas que tenemos y los intereses que nos llevan a investigar lo que investigamos. ${ }^{8}$ Intentar obviar nuestra propia subjetividad

En este sentido, me acuerdo una brillante exposición de Raquel (Lucas) Platero con motivo de las Jornadas Feministas Estatales de Granada acontecidas del 5-7 de diciembre de 2009 donde expuso los motivos que le habían llevado a investigar la homofobia y la represión sexual en el franquis- y por tanto personalidad en el proceso investigador sería un tanto ilusorio. Declarar nuestras subjetividades al menos implica un intento de objetivación de nuestra investigación, asumir para objetivar. A pesar de que consideramos necesarios la práctica egohistórica reconocimos que este tipo de prácticas no han de confundirse con ejercicios de egolatría.

Siguiendo con "declaración de intenciones" nos encontramos con que los comunicantes incorporaban a su investigación el análisis del tiempo en el que se estaba llevando a cabo la misma y el estudio de la memoria colectiva en torno a ese objeto en el tiempo presente. Esto resulta evidente en la comunicación de Enrique Bengochea y de Javier Contreras y en la exposición de Gisela Pagès a partir del análisis de las telenovelas de la Perricholi. Como defendía Benedetto Croce "toda historia es historia contemporánea", miramos al pasado desde los diferentes presentes que vivimos, ¿por qué no estudiar entonces esos presentes? Esta forma de trabajar resulta completa a la par que reflexiva pero puede conllevar lo que Lucien Febvre denominaba anacronismos psicológicos al no saber distanciar un tiempo de otro y al trasvasar conceptos de una época a otra. Aunque no hallamos fórmulas magistrales, sí que confluimos en la necesidad de estudiar ambos tiempos de manera separada para distinguir cómo se ajusta el pasado al presente, qué adapta el imaginario del tiempo pretérito y bajo qué presupuestos lo hace.

La manera en la que se forman las comunidades adquirió una gran relevancia en nuestro debate, y la manera por la que el ejercicio de la memoria puede ser inherente a la identidad de grupo o de comunidad, bien sea nativos americanos, gitanos, indigenas o comunidades digitales. También nos planteamos si como decía Joan Scott la identidad surge por oposición a otro grupo y de qué forma puede percibirse en las fuentes orales, o si incluso las fotografías como fuente histórica, que nos mostraba Sereno Caleri, pueden llegar a reforzar tales identidades en los sujetos entrevistados. En este sentido, muchos coincidimos en que la oposición de comunidades a menudo es un elemento aglutinante y que memoria e identidad se retroalimentan y se construyen mutuamente. 9

En todas las comunicaciones subyace la contraposición de la memoria vivida o transmitida, como una alternativa, más o menos contrapuesta, al discurso hegemónico. De este modo nos preguntamos de qué modo las fuentes orales venían a disentir con las versiones oficiales de la historia, a complementarlas o a replantearlas. Al hilo del concepto de memoria usurera analizamos hasta qué punto en nuestras investigaciones se producía una "contaminación" en la memoria, sobre si el discurso hegemónico llegaba a colonizar algún episodio de nuestros entrevistados; o por si el contrario la imposición de la "memoria oficial" había hecho que tomasen distanciamiento respecto a la misma y se concienciaran del valor intrínseco de su memoria disonante. Pudimos comprobar cómo ambas posiciones pueden encontrarse a través de la utilización de fuentes orales incluso en un mismo entrevistado. Un informante puede subrayar el valor de su memoria por no haberse sometido al control de la memoria oficial, y en cambio alguno de los pasajes de su recuerdo pueden confluir completamente con el discurso dominante sin cuestionar su veracidad o incluso pueden llegar a naturalizar dicho discurso $Y$ es que en historia oral se hacen evidentes los tejidos identitarios, las marañas que forman nuestra identidad como personas que implica que aparentes contradicciones convivan en nuestro ser de una manera más o menos amigable.

mo y en concreto la historia de María Helena N.G. La psicóloga describió como había llegado a su objeto de estudio a partir de la investigación de su propia sexualidad y cómo podía en ocasiones verse reflejada en la mujer a la que estaba estudiando. Un resumen sobre la investigación puede encontrarse en http://www.feministas.org/IMG/pdf/Mesa_memoria franquismo-_R-platero. pdf (última consulta 22-01-2014)

9 Sobre la intervención de la memoria en la creación del sujeto, Miren LLONA: "Historia Oral: la explo-

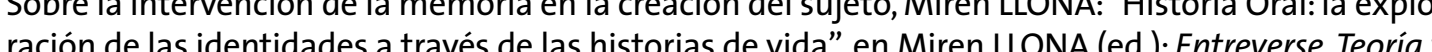
metodología práctica de las fuentes orales, Bilbao, Euskal Herriko Unibertsitatea, 2012, pp. 22-24. 
Por último, me gustaría concluir con otra de las cuestiones subyacentes en las comunicaciones, la idea de que la historia oral permite la construcción de una memoria alternativa, una especie de "historia desde abajo" que podría sustituir a la historia institucional, a la "historia desde arriba". Aunque todos apoyamos esta afirmación, creímos que en parte se trataba de una categoría a superar. Claro que la entrevista en historia oral, las historias de vida pueden hacer audibles los testimonios de gente anónima que son y han sido también agentes históricos. Pero la fuente oral igualmente nos permite entrevistar a los que fueron "protagonistas" de la historia para así poder acceder a versiones diferentes de la misma o a una comprensión más global o poliédrica como proponen Javier Contreras y Miguel Ángel Melero. Por otra parte, esta idea de "arriba" y "abajo" no debe llevarnos a un análisis desde categorías como "dominados" y "dominantes" ya que acaba limitando a nuestro objeto de estudio a través de la etiquetación. Es aquí donde debemos enclavar la tesis de Irene Murillo de deshacernos de la categoría jurídica de víctima para incorporar las experiencias plurales y heterodoxas de los entrevistados a nuestros trabajos y asi poder limpiar nuestra mirada como historiadores.

Si la historia oral es capaz de abrir campos de estudio, acceder a diferentes protagonistas

y a nuevas interpretaciones, no es de recibo empobrecerla a través del etiquetado. La historia oral bien llevada a cabo ha de dotarnos de amplitud de miras, capacidad de comprensión y una visión más compleja y dinámica de la sociedad y de sus personajes. Si conseguimos esas premisas sabremos que hemos llegado a un buen ejercicio de historia oral.

Para Sescún Marías, gracias por habernos acompañado en este viaje. 


\section{FACEBOOK COMO HERRAMIENTA: REDES SOCIALES Y}

\section{GRUPOS DIASPÓRICOS}

Enrique Bengochea Tirado

Universidad de Valencia

\section{Una oportunidad}

Este texto surge como una propuesta para reflexionar sobre las posibilidades y los límites que nos ofrecen las redes sociales como fuentes para el trabajo del historiador. Más precisamente me intereso en las páginas de Facebook como lugares de encuentro de grupos diaspóricos. Se trata de una invitación a reflexionar juntos previa a empezar a utilizar este tipo de fuentes en mi investigación.

En mi caso me enfrento con la última fase de la historia colonial' española, la provincialización de Sáhara, Ifni, Fernando Poo y Rio Muni. Más concretamente, me intereso en la Sección Femenina en la provincia de Sáhara, su desarrollo y su relación con la sociedad saharaui y metropolitana. Debido a la cercanía temporal con el presente de los fenómenos que estudio (la Sección Femenina se asentó en el territorio en 1964 y España se retiró en 1975) puedo contar entre mis fuentes los testimonios de las falangistas y de sus alumnas. No obstante, resulta difícil acceder al testimonio de aquellas personas que estuvieron en contacto con la organización ya que, tras el abandono del territorio, la mayor parte de sus habitantes metropolitanos la abandonaron.2

Conseguir el listado de mujeres que formaron parte de la institución resulta relativamente sencillo ya que muchos de los nombres se encuentran en la documentación que se puede consultar en el Archivo General de la Administración o en la Real Academia de la Historia No obstante, la información de quienes participaron como alumnos en la misma está restringida. Es en este momento en el que el acceso a otro tipo de archivos se hace necesario. Existen algunos blogs, páginas web y grupos en redes sociales dedicados a la memoria de los antiguos colonos que pueden dar cuenta de parte de la sociedad colonial.

Atendiendo a esta problemática, voy a organizar la comunicación de la siguiente manera: en un primer momento desarrollaré un estado de la cuestión de la investigación de la colonización española del Sáhara a través de los grupos virtuales. Tras este necesariamente corto apartado haré un recorrido por los diferentes lugares virtuales de encuentro de antiguos colonos para finalizar recorriendo los grupos de Facebook que me interesan específicamente. En un segundo bloque enfocaré la reflexión teórica sobre el trabajo de estos grupos para finalizar apuntando algunas de sus oportunidades y límites.

1 Con este concepto quiero referirme estrictamente al colonialismo en el sentido de control de Territorios No Autónomos, como los definió las Naciones Unidas en 1961

Vicente GOZÁLVEZ PÉREZ: "Descolonización y migraciones", Investigaciones Geográficas, no 12 (1994), pp. 45-84

\section{Rememorando juntos}

El punto de partida de esta investigación es el artículo de Elena Fiddian-Oasmiyeh Histories of Displacement: Intersections Between Ethnicity, Gender and Class. ${ }^{3}$ En éste la investigadora trata de analizar el discurso producido por el encuentro colonial a través del testimonio de una serie de españoles que vivieron en el territorio. El acceso a estos informantes se hizo a través de un foro de internet en el que se ponían en contacto antiguos militares destinados al Sáhara. Esta investigación se realizó en 2005 con cuestionarios semi-estructurados y se planteó como un punto de partida a investigaciones cualitativas más amplias.

A partir de estas propuestas me interesé por encontrar estos lugares virtuales de encuentro entre antiguos colonos. Así, es posible acceder a varias páginas donde gente que hizo el servicio militar en Sáhara tratan de mantenerse en contacto. ${ }^{4}$ Estas tienen diferentes naturalezas (una, Hermandad de Tropas nómadas, es la página web de una asociación de veteranos de las tropas nómadas; otra, Milisáhara, es un blog donde se pretende facilitar el contacto entre gente que hizo el servicio militar en el territorio entre la población que actualmente vive en Cataluña y, la tercera, Sáhara-mili, tiene forma de foro).

Pese a esta diferencia de entrada las tres páginas ofrecen posibilidades interesantes para escribir historia. Estas plataformas facilitan el acceso a gran cantidad de testimonios, no solo a través del contacto personal, sino a través de la rememoración que hacen de su experiencia en diferentes textos e imágenes. No obstante, los informantes a los que se tienen contacto son todos antiguos militares y hombres, por lo que su utilidad se limita a ciertos campos de investigación. Civiles, mujeres y saharauis quedan fuera de la participación en estos grupos (aunque no así la producción textual sobre los mismos).

El conocimiento de páginas de Facebook donde se agrupaban antiguos habitantes del territorio me lo facilitó M.P., una de mis informantes. Ella estudió en el instituto Diaz de Villegas del Aaiún a mediados de los años 60 y se mantenía en contacto con antiguos compañeros de estudio gracias a una página de Facebook. ${ }^{5}$ La búsqueda en esta red social de otras páginas similares nos facilita el acceso a otros tipos de sujetos, así, podemos encontrar un grupo de saharauis que estudiaron en español. ${ }^{6}$ Son estos grupos los que considero interesantes para el estudio de los cambios sociales ocurridos en la provincia especialmente enfocado a identidades y a lo relativo a los modelos de género.

\section{Historia digital e historia oral}

Al proponer Facebook como fuente historiográfica nos adentramos en un campo nuevo, la historia digital, definida como "the process by which historians are able to use computers to do history in ways impossible without the computer". " En este sentido es la naturaleza digital de las fuentes propuestas (grupos de facebook) y la interacción con las mismas (Comunicación

3 Elena FIDDIAN-OASMIYEH: "Histories of displacement: intersections between ethnicity, gender and class", The Journal of North African Studies, $n^{\circ} 16: 1$ (2011), pp. 31-48

4 Por ejemplo: Hermandad de Tropas nómadas, http://www.hermandadtropasnomadas.com; Milisáhara, http://milisahara.wordpress.com y Sáhara-mili, http://www.sahara-mili.net.

5 La página Yo también estudié en el Instituto General Alonso https://www.facebook.com/pages/ Yo-Tambi\%C3\%Agn-Estudi\%C3\%A9-en-el-Instituto-General-Alonso-AAIUN/155385167816930?fref=ts, también podemos una página similar relativa a Ifni: Antiguos alumnos del instituto General Diaz de Villegas Sidi Ifni AOE, https://www.facebook.com/pages/Antiguos-Alumnos-del-Instituto-General-Diaz-de-Villegas-de-Sidi-Ifni-AOE/103015533098469?fref=ts.

6 La Asociación Generaciones de La Paz https://www.facebook.com/pages/Asociaci\%C3\%Bzn-Generaciones-De-La-Paz/469692546419219?fref=ts.

7 Orville VERNON BURTON: “American Digital History”, Social Science Computer Review, Vol. 23 No. 2 summer (2005), http://chnm.gmu.edu/essays-on-history-new-media/essays/?essayid=30. 
Mediada por Computadora ${ }^{8}$ ) las que definen el tipo de historia. Por su parte, en palabras de Laura Benadiba la Historia Oral sería "un procedimiento establecido para la construcción de nuevas fuentes para la investigación histórica, con base en testimonios orales recogidos sistemáticamente bajo métodos, problemas y puntos de partida teóricos explícitos. Su análisis supone la existencia de un cuerpo teórico que se organiza a partir de la instrumentación de una metodología y un conjunto de técnicas específicas, entre las que ocupa un lugar fundamental la entrevista grabada". 9 Desde cierto punto de vista, la Historia Digital sería a las fuentes digitales lo que la Historia Oral a las orales, dos metodologías paralelas que buscarían aumentar el archivo disponible para las investigaciones históricas.

No obstante, esta forma de crear archivo tiene más implicaciones que las mera disponibilidad de fuentes, ya que, a diferencia de los archivos de documentos escritos los digitales y los orales son creados "desde abajo", abriendo las posibilidades de investigación histórica a todo un nuevo abanico de sujetos y problemáticas. "La palabra codificada 'historia oral', tomada de método americano, se utiliza - en contra de su significado literal - no para un determinado tipo de historia que se basase en la tradición oral, sino para una técnica específica de investigación contemporánea. Es adecuada, por un lado, para la exploración de determinados campos fragmentarios para los que no hay o a los que no es accesible otro tipo de documentos de transmisión y, en este sentido, representa un instrumento de heurística contemporánea. Pero, por otro lado, permite una concepción más amplia del pasado inmediato y de su elaboración sociocultural como historia, y así su práctica revierte sobre la comprensión de la historia en general."10

Esta nueva posibilidad de problemáticas y perspectivas abierta gracias a las fuentes orales y digitales tiene una concreción particular en lo que a la historia digital se refiere. Esta, pese a ser una historia global (ya que depende de un contexto globalizado) "es una acumulación de historias locales que se enfrentan a lo global; al contrario de lo esperado, son historias subalternas, las memorias ocultas y ocultadas las que se han visto emerger en el marco de la historia digital." "No obstante, las posibilidades de uno de estos grupos de crear memoria en un espacio virtual depende de varios factores, entre otros el acceso a internet y la alfabetización digital. Ambos factores deben ser tenidos en cuenta, aunque, si bien es verdad que sobre el primero pocas son las posibilidades que tenemos para actuar; se puede hacer sobre el segundo.

\section{Las páginas de Facebook}

La elección de el medio por el que se piensa trabajar influirá en los individuos a los que se tiene acceso, es aquí donde entra las posibilidades que ofrece Facebook, ya que tiene una serie de características que lo hacen óptimo. En primer lugar se trata de una herramienta en cuya alfabetización el costo cognitivo es cercano a $0,{ }^{12}$ lo que quiere decir que su acceso resulta relativamente fácil incluso para aquellas personas con pocos o ningún conocimiento de informática o internet. En segundo lugar, el crecimiento exponencial del número de usuarios de la red social ${ }^{13}$

8 Al respecto podemos ver el trabajo de Tanya IMAÑA: “Facebook, tejiendo la telaraña de las redes sociales", Razón y Palabra, 16 (2013), http://www.razonypalabra.org.mx/n62/bolivia/timana.html. 9 Laura BENADIBA y Daniel PLONTINSKY: Historia Oral. Construcción del archivo histórico escolar. Una herramienta para la enseñanza de las ciencias sociales, Buenos Aires, Novedades Educativas, 2001, p. 21

o Lutz NIETHAMMER: “'Para qué sirve la Historia Oral?", en Jorge ACEVES LOZANO (comp.): Historia Oral, Instituto Mora, México, 1997. pp. 32 y 33

Jairo Antonio MELO FLOREZ: "Historia digital: la memoria en el archivo infinito", Historia critica, ${ }^{\circ}$ 43, enero-abril 2011, DOI: 10.7440/histcrit43.2011.06, p. 84

12 Alejandro Gustavo PISCITELLI: "Facebook. Esa reiterada tensión entre sobrepromesa y la invención de nuevos mundos", Rusc, vol. 6 no 1 (2009), p. 44

13 En Octubre de 2012 se llegó a la cifra de más de 1000 millones de perfiles activos, dato consultado en: http://newsroom.fb.com/Timeline hace que se pueda considerar como una muestra representativa de la sociedad. Hecho al que hay que sumar la porosidad existente entre este entorno virtual y el social ya que cada perfil de Facebook, en principio y por su propia constitución, aspira a corresponder con perfiles equivalentes en el mundo real. El desfase entre los perfiles de la red social y los "reales" es mínimo si lo comparamos con otras experiencias como son los MMORPGS, ${ }^{14}$ por ejemplo, el Second Life. ${ }^{5}$

En este sentido, Facebook nos permitiría tener la posibilidad de contactar con personas mayores, cuya alfabetización digital es costosa pero que pueden encontrar en la red socia cierta facilidad para interactuar con otras personas. A su vez, cabía la posibilidad, como así ha sido, que consideraran que su experiencia en la colonia fuera un vínculo específico para encontrar a más personas con quien lo compartieran. Por otra parte, es de esperar que, una gran parte de los perfiles que se pusieran en contacto correspondiesen a personas que realmente hubiesen vivido en la colonia.

Dentro de Facebook se puede interactuar de varias formas: entre perfiles individuales; a través de páginas o, finalmente, en grupos. La primera corresponde a una comunicación directa entre dos perfiles, bien dejando un post en el muro, con un like, con un mensaje privado, comentando o poniendo un tag en una fotografía... La segunda está mediada por alguien que controla la página, son los administradores quienes pueden poner nuevos posts, aunque toda la comunidad puede comentarlos y ponerles like, la gente ajena puede dejar comentarios en una barra lateral. En tercer lugar en Facebook encontramos grupos, con un formato similar a los clásicos foros de internet. Estos espacios de comunicación son más horizontales ya que cualquier miembro de la comunidad puede insertar un comentario nuevo y a su vez puede ser respondido por cualquier otro, no obstante, puede que se tenga que ser miembro del grupo para poder hacerlo.

La estructura de los grupos y de las páginas permite que se puedan transformar en una especie de archivos colaborativos en los que sus miembros van aportando imágenes. Esta forma de aportación puede facilitar el acceso a materiales privados a los que sería imposible o muy difícil acceder de otra forma. También permite reconstruir colaborativamente el contexto de las imágenes expuestas, poniendo nombres y relaciones a los rostros. También debemos tener en cuenta que en Facebook "usar es comunicar", ${ }^{6}$ cada una de las posibles acciones que se desarrollan en la red social pueden traducirse a una oración declarativa (como de hecho ya hace el sistema), por ejemplo: "te has hecho amigo de tal persona" o "a esta persona le gusta eso". Ambas dimensiones (los grupos como repositorios y los grupos como lugares de comunicación en todas sus facetas) deben ser tenidas en cuenta para analizarlos.

\section{Algunas propuestas}

Teniendo esto en cuenta podemos proponer diferentes formas de trabajar estos grupos y páginas. La primera sería la más cuantitativa y consiste en dar cuenta de las interacciones que se dan en el grupo identificando de qué tipo se trata. Las diferentes formas de comunicación que se dan en un grupo de Facebook van siendo registradas por el sistema y son accesibles para cualquier persona mientras el este siga existiendo. De las mismas se puede hacer un estudio como el realizado en Academic Libraries on Facebook: An Analysis of Users' Comments, ${ }^{77}$ se trata del análisis de algunas páginas de bibliotecas estadounidenses en el que se realiza un análisis en este sentido. Una de las limitaciones que nos encontramos es la dificultad de ex-

14 Siglas en inglés para Massively Multiplayer Online Role-Playing Game, es decir, juego masivo de roles online. Son aquellos juegos online en los que, a través de un avatar se interactúa con otras personas en mundos virtuales a los cuales acceden gran cantidad de usuarios.

15 Alejandro Gustavo PISCITELLI: “Facebook. Esa reiterada tensión...” p. 45

16 Ibid., p. 46

7 Gerolimos MICHALS: "Academic Libraries on Facebook: An Analysis of Users' Comments", D-lib

Magazine, Volumen 17, $\mathrm{n}^{\circ}$ 11/12 (2011), DOI: 10.1045/november2011-gerolimos. 
traer información histórica más allá de las interacciones que se dan dentro de estos contextos. Otra posible metodología con la que abordar la información que nos pueden aportar estos grupos es la de usarlos como repositorios de imágenes. Un uso común en los grupos que se pretenden analizar es el de postear fotografías de conjunto las cuales son comentadas por los miembros identificándose entre ellos en las mismas y la situación en la que fue tomada. Esta práctica puede ser muy útil para poder conocer las relaciones interpersonales que se daban en la colonia, permite conocer cómo eran las relaciones entre "saharauis" y "españoles"; "hombres" y "mujeres" e, incluso, indagando en los perfiles de estas personas, entre los diferentes grupos sociales. Esta forma de utilizar el archivo digital permite indagar en las dimensiones afectivas de los documentos expuestos.

Siguiendo esta línea, podemos considerar los grupos como repositorios de posibles testimonios. Las personas interesadas en la participación en estos grupos pueden ser el tipo de persona que busquemos para realizar entrevistas. Así, podemos entrar en contacto con sujetos a los que después podemos entrevistar, bien en vivo, bien a través de algún dispositivo (programas de videoconferencia, por ejemplo), o, como en el ya citado artículo de Elena Fiddan-Oasmiyeh, a través de cuestionarios semiestructurados.

Una última posibilidad es la de interactuar directamente con la comunidad a través de los medios que nos ofrece la red social. Este terreno se plantea más problemático ya que la información que recibimos puede ser de diferentes tipos: likes, posts, respuestas privadas... Su naturaleza puede ser la más parecida a la fuente oral convencional ya que hace posible la interacción inmediata con "la fuente", no obstante debemos tener en cuenta las barreras que crea el que esté mediada por la computadora..$^{18} \mathrm{Un}$ ejercicio interesante podría ser el de compartir en estas páginas las entrevistas, una vez transcritas o grabadas para poder analizar las reacciones que suscitan.

\section{Algunas reflexiones}

Esta comunicación ha pretendido ser simplemente un punto de partida para empezar a considerar las posibilidades que nos ofrecen las redes sociales como fuente a la hora de realizar nuestras investigaciones. La naturaleza del archivo creado a partir de las mismas las hacen similares a las de la historia oral, permitiendo el acceso a experiencias lejanas a las instituciones. Sin embargo, ofrecen una serie de posibilidades que las hacen muy atractivas para analizar según qué tipos de sujetos. Sería este el caso de sujetos diaspóricos (como, por ejemplo, los antiguos habitantes de las colonias españolas, en este caso Sáhara) que tuvieran algún elemento memorialístico común (en este caso, antiguos estudiantes de instituto).

Más allá de las posibilidades que ofrece este tipo de fuentes, hace falta una seria reflexión metodológica sobre cómo abordar problemáticas concretas a partir de estas fuentes. En este sentido, no debemos olvidar que los grupos de Facebook son un lugar donde rememorar experiencias pasadas. También debemos tener en cuenta las ambigüedades de los diferentes códigos que se pueden usar en la plataforma. La puesta en marcha de una estrategia de investigación sobre estas fuentes debe tener en cuenta estos factores.

Un último punto a tener en cuenta con el uso específicamente de Facebook es la problemática que se da con la identidad. Como ya se ha remarcado, cada perfil en la red social aspira a corresponder con una personalidad real, si unimos este hecho con el que en Facebook "utilizar es comunicar" nos encontramos con una problemática sobre-exposición del investigador. A respecto se pueden desarrollar estrategias como la creación de perfiles específicos para reali-

18 En este sentido podemos Nan Alamilla BOYD y Horacio ROOUE RAMÍREZ: Bodies of Evidence. The Practice of Queer Oral History, Nueva York, Oxford University Press, 2012, pp. 8-9 donde se descriPractice of Queer Oras

métodos de comunicación, mensajes instantáneos entre dos computadoras. zar este tipo de trabajo y que permitan salvaguardad su intimidad a costa de consistir en un juego de información desigual entre el historiador y los informantes. 


\section{FOTOGRAFÍA Y FUENTES ORALES: UN ANÁLISIS}

\section{METODOLÓGICO}

Sereno Orenga Caleri

CAPES Foundation Ministry of Education of Brazil y

Universidad Autónoma de Madrid En esta comunicación proponemos analizar, de una manera sintética, el uso de la fotografía
y de las fuentes orales como documento histórico y elecciones metodológicas al estudio en el y de las fuentes orales como documento histórico y elecciones metodológicas al estudio en el tancia para analizar las percepciones y la memoria creadas acerca de un determinado periodo histórico. El uso de estas herramientas por el historiador es relativamente reciente, teniendo su mayor producción a partir de los años setenta y ochenta del siglo pasado. Desde nuestro punto de vista los tres principales pilares de la utilización de la fotografía y de las fuentes orales en el estudio de la historia son: el hecho histórico, condicionado por tiempo/espacio en que se produce; la interpretación del receptor de estas informaciones históricas; y la memoria producida a través del distanciamiento temporal a la hora de reconstruir el recuerdo y la memoria acerca de tal hecho histórico.

El valor de una fotografía le he atribuido después de la toma fotográfica, o sea, las informaciones contenidas en una fotografía sólo son posibles de sacar se hacemos las "preguntas" ciertas a la imagen. En otras palabras, la imagen fotográfica, como veremos más adelante en este trabajo, en cuanto documento histórico está condicionada a la interpretación del receptor acerca de la "realidad plasmada" en la foto, ella no es interpretativamente infinita. La fotografía es la base de todos los mecanismos, en gran escala, de comunicación visual modernos, como la cinematografía y la televisión (además de cambiar definitivamente la manera de los periódicos construyen la información). El primer invento fotográfico salió en el año 1839, en la Academia de las Ciencias de Paris y fue presentado por Daguerre. Desde entonces la imagen fotosensible acompaña las transformaciones sociales de todo el mundo, de la manera más "verdadera y precisa" en aquél entonces. El daguerrotipo, fue el primer aparato de captación de la imagen a través de la luz externa capaz de reflejar con precisión de líneas y contornos inalcanzables por cualquier otro tipo de intento de expresar la realidad.

Al largo de los años la "cámara oscura" fue sufriendo cambios en el campo tecnológico, en el campo estilística y también en su utilización como registro de una época. El valor atribuido a la fotografía es, y siempre fue, relativo, pero es innegable su capacidad de capturar fragmentos de una realidad que jamás se repetirá. Ella estaba presente en los hechos y eventos más relevantes de la historia desde su creación (1839), como en las guerras de Marruecos, al inicio del siglo XX, hasta las dos grandes guerras mundiales, sin hablar de la guerra civil española, y diversos otros sucedidos de la civilización moderna. La fotografía sirvió también como la memoria del viajero cuando este quería contar lo que había visto en mundos lejanos.

La producción fotográfica sigue siendo ingente en nuestros días y la fotografía continúa siendo una fuente básica para reflejar y captar el pulso de las sociedades. La tecnología digital está reforzando ciertos usos de la fotografía, aunque también es cierto que ha de convivi con otros procedimientos de captación de imágenes - fundamentalmente en movimiento - y compartir un mismo soporte digital. El hecho de captar el tiempo y reflejar la realidad, organi- zando el espacio en una imagen, todavía hace de la fotografía un soporte de extrema validez para los estudios históricos. Por eso, una vez que se trabaja con fotografía, y una vez que es posible someter todo el acervo fotográfico a los nuevos soportes digitales, no importa la distancia temporalo el contexto en el que se produce la imagen, porque el producto será siempre el mismo y estará sometido a criterios de lectura visual muy generalizados y asumidos socialmente. La clave para el uso de la fotografía por el historiador, sobre todo si quiere conformar a través de ella la memoria social, es intentar articular un discurso que resulte coherente y adecuado para la interpretación del pasado y su influencia en el presente. Además de llevar a cabo un análisis crítico imprescindible en la tarea científica de todo historiador.

La fotografía como documento fue analizada, con énfasis desde el campo sociológico, por Gisèle Freund en su libro La fotografía como documento social en el cual se ocupa de la historia de la fotografía y sus distintos usos.' Las fotografías de guerra, de prensa y política sirven para el trabajo del historiador como un documento más en su análisis. El fotohistoriador españo Publio López Mondejar también analiza en ensayos y discursos ideas muy interesantes acerca de la fotografía como fuente de memoria. ${ }^{2}$

Pero la utilización de la fotografía como documento histórico se supone también arriesgarse una vez que las interpretaciones son múltiples pero finitas. Todo historiador que se propone analizar la imagen fotográfica lo hará a partir de aspectos socio/culturales propios y distintos de otros historiadores. Desde el punto de vista metodológico nos conviene aclarar algunos aspectos interpretativos, ya que el hecho de analizar una fotografía presupone una serie de riesgos interpretativos (como ya hemos dicho). Javier Marzal Felici señaló en su libro Cómo se lee una fotografia; interpretaciones de la mirada ${ }^{3}$ un riesgo que consideramos importantísimo a tener en cuenta en el trabajo de análisis de la imagen fotográfica: es la llamada deriva interpretativa y que puede conducir al crítico a transcender la materialidad del texto icónico. Umberto Eco también ha descrito en su estudio sobre la interpretación el riesgo interpretativo que lo denomina como fanatismo epistemológico. ${ }^{4}$ La expresión de la deriva interpretativa no debe confundirse con el anarquismo epistemológico, o sea, una libre y frenética interpretación icónica que Pau Feyerabend señalaba cuando cuestionaba la infalibilidad del positivismo lógico. El crítico fotográfico debe detenerse en la información, en nuestro caso la histórica, que la imagen proporciona, pero no traspasar a una interpretación desenfrenada y que acabe por transcender lo que la fotografía es capaz de ofrecer, y acabar por tomar rumbos aleatorios y lejanos al que de hecho es posible "sacar" de una imagen fotográfica. El término deriva, al que se refiere Javier Marzal, es especialmente gráfico para describir esta posible ausencia de dirección en el trayecto analítico que exhibe un buen número de análisis críticos del texto audiovisual, hasta el punto de que parecería que el objeto estudiado carece de sentido, puesto que todo es interpretable ad nauseam.

Susan Sontag, en su libro Contra la interpretación, 5 también nos ha advertido sobre otro riesgo que afrontaremos al hablar de la "arrogancia de la interpretación" por excesiva atención a contenido, y al proponer la descripción rigurosa de la forma como antídoto necesario. En efecto son numerosos los críticos que, fascinados por la escrita derridiana basada en la deconstrucción, apelan a la inexistencia de límites en la interpretación del texto icónico, una vez ha quedado despojado el signo de su referente al carecer el texto escrito de márgenes o límites. Buena parte de estos ejercicios de análisis, autodenominados "derridianos", poco tienen que ver con el

Gisèle FREUND: La fotografia como documento social, Barcelona, Editorial Gustavo Gili, 2008

2 Publio LÓPEZ MONDEJAR: La Fotografía como fuente de memoria. Discurso del académico electo leído en el Acto de su Recepción Pública el día 30 de marzo de 2008, Madrid, Lunwerg Editores, pp. 24-25.

3 Javier Marzal FELICI: Cómo se lee una fotografia: Interpretaciones de la mirada, Madrid, Ediciones Cátedra, 2009.

4 Umberto ECO: Los límites de la interpretación, Barcelona, Lumen, 199o, p. 357.

5 Susan SONTAG: Contra la interpretación y otro ensayos, Barcelona, Debolsillo, 2007. 
sentido original de la propuesta filosófica de Jacques Derrida. El psicoanálisis postlacaniano y los estudios culturales constituyen perspectiva de trabajo que comparten la seducción por los discursos deconstructivos y posestructuralistas al tratar de "decir cosas que el texto no dice", bajo la coartada de la intertextualidad del texto icónico o del horizonte de competencia lectora como principales parámetros para indagar en el sentido del texto audiovisual. Roland Barthes y Umberto Eco también contribuyeron con amplios estudios dedicados a la desconstrucción icónica mirándola desde el campo de la semiótica/semiología (que veremos más adelante). De acuerdo con Eco a menudo, los textos dicen más de lo que sus autores querían decir, pero menos de lo que muchos lectores incontinentes quisieran que dijeran. La imagen fotográfica la representación de una realidad pasada y cabe a su interpretación el sentido que una fotografía pueda hacer. Esto nos lleva a la cuestión puesta inicialmente, donde las fotografías son "objetos" interpretativos y siendo así, las preguntas que hacemos a la imagen son fundamentales para saber las informaciones que tal imagen fotográfica nos puede ofrecer.

Roland Barthes destaca los dos principales campos de análisis dedicados al estudio de la Fotografía y sus dificultades o particularidades: "Los libros que tratan del tema. [...] Los unos son técnicos; para «ver» el significante fotográfico están obligados a enfocar de muy cerca. Los otros son históricos o sociológicos; para observar el fenómeno global de la Fotografía éstos están obligados a enfocar de muy lejos". ${ }^{6}$

Así, los estudios históricos acerca de la Fotografía tienen que ser vistos como amplios e interdisciplinares, como veremos más adelante, contribuyendo para su mejor aplicación al tema una serie de otros estudios, como la semiótica o semiología, estudios sobre la memoria desde su concepto histórico hasta el psicoanalítico, y los estudios culturales, económicos y políticos de un modo general.

La utilización de la fotografía y de las fuentes orales en el estudio de la historia atraviesa una serie de filtros culturales que hay que tener en cuenta a la hora de proceder la investigación historiográfica. En el caso de la fotografía, los filtros son un poco más amplios. Existe el filtro cultural perteneciente al fotógrafo, que lo deja claro en la manera en que recorta determinado fragmente de la realidad. La imagen que queda plasmada en la fotografía es el producto de diversas elecciones, desde lo qué captar hasta el cómo captar. Luego existe el filtro cultural del receptor de esta imagen, que también presentan miles de posibilidades, pues cada persona que la mire lo hará a partir de su percepción particular, por eso, cada fotografía puede obtener un significado diferente para cada uno que la mire. Estos riesgos, los asumimos y hacemos nuestro análisis a partir de nuestro propio filtro cultural.

En las fuentes orales estos filtros también están presentes, porque como hemos visto, la construcción de la memoria es influenciada por diversos factores y con eso la percepción del pasado se hace a partir de experiencias personales e individuales, aunque como hemos visto, puede compartir aspectos parecidos en determinados grupos sociales. El entrevistado habla a partir de su análisis, a partir de la construcción de una memoria selectiva en que muchas veces interfieren en la manera de recordar hechos históricos.

Lo que la Fotografía reproduce al infinito únicamente ha tenido lugar una sola vez; la Fotografía repite mecánicamente lo que nunca más podrá repetirse existencialmente. En ella el acontecimiento no se sobrepasa jamás para acceder a otra cosa: la Fotografía remite siempre el corpus que necesito al cuerpo que veo, es el Particular absoluto, la Contingencia soberana, mate y elemental, el Tal (tal foto, y no la Foto), en resumidas cuentas, la Tuché, la Ocasión, el Encuentro, lo Real en su expresión infatigable.7

6 Roland BARTHES: La cámara lúcida, Barcelona, Paidós, 2011, p. 28.

7 lbid., p. 26.

., p. 26.
Creemos que el punto principal de convergencia entre la fotografía y las fuentes orales, está en la construcción de la memoria, y esta memoria puede ser de cuño social y colectivo bien individual y particular, como veremos más adelante, pero son siempre interpretativas.

\section{Por un análisis histórico-semiótico de la Fotografía}

La Fotografía es un producto cultural, y como tal está condicionada a los códigos y signos inherentes al lenguaje visual socialmente construidos durante las décadas anteriores. Esto códigos y signos deben ser analizados a partir de una perspectiva semiótica, o para ser más precisos desde una perspectiva histórico-semiótica.

Las raíces de la semiótica parten del campo filosófico, aunque Umberto Eco ${ }^{8}$ señala que fue a partir del siglo XX que el estudio de los signos y de los códigos en la comunicación empezó a tener un carácter más sistemático, se encuadrando a los parámetros de una disciplina de estudio. Eco señala también las dos principales líneas de abordaje en este proceso de decodificación: una es más volcada a un análisis lingüista estructural encabezada por Ferdinand Saussure (1859-1913); la otra es la realizada por Charles Sanders Peirce (1839-1914) con una fuerte influencia de la lógica matemática. ${ }^{9}$ La principal diferencia entre estas dos líneas de análisis es en la manera de su articulación con la sociedad.

Para Saussure a lingua teria o lugar de excelencia no sistema de signos e a semiología preocupada com a produção de tais signos "no seio da vida social”, procuraría estudá-la através da relação estabelecida entre significado e significante, numa composição de dupla referência. [...] a semiología, mesmo tendo como objeto o estudo la lingua, não a entedem como um elemento histórico, fruto de um trabalho social, inmerso em uma ideología. [...] Na definição de Peirce a semiótica seria o sinónimo da lógica podendo ser definida como uma doutrina formal de signos, resultante da observação e posterior generalização por abstração das características deste signo. Peirce explica a produção sígni$\mathrm{ca}$ a partir do conceito por ele denominado de semiose, entendendo este conceito como

um processo de cooperação entre três sujeitos: um signo, o objeto e seu interpretante

Esta diferencia en relación a la doble articulación propuesta por la semiología de Saussare y los tres elementos de articulación añadido por la semiótica de Peirce es fundamental para comprender la imagen fotográfica como un agente importante en la comunicación visual organizada pory para las sociedades modernas. El objetivo de análisis de la semiótica es justamente esta semiosis peirciana, o sea, la triple articulación. En el análisis semiótico de Peirce en que va proponer la existencia de tres pilares (signo, objeto y el interpretante o receptor) para la construcción de sentido del lenguaje visual es donde la fotografía se articula en este proceso. La fotografía se presenta como el objeto, organizado visualmente de una manera codificada, interpretable a partir de la comprensión de los signos y los códigos socialmente pactados por parte de un tercer elemento, fundamental y cambiante que interpretará la imagen plasmada en la fotografía. En este contexto parece imposible comprender esta triple articulación el lenguaje visual sin tener en cuenta los aspectos históricos, culturales y sociales de estas articulaciones.

La semiótica se presenta como un análisis más amplio de los códigos y los signos del lenguaje do que la semiología, que se dedica, como hemos visto, a las articulaciones del lenguaje verbal y textual. O sea, la semiótica abarca la semiología en su campo de análisis. De

8 Umberto ECO: Tratado de Semiotica General, Barcelona, Lumen, 2000

9 Ibid.

o Ana María MAUAD: Sob o signo da imagen. Trabajo fin de Máster, Universidade Federal Fluminen

se, 1990 
acuerdo con Eco, la semiótica colocase como una teoría capaz de explicar cualquier caso de función de signos en sistemas de uno o más códigos." Roland Barthes identifica tres prácticas actuantes en una fotografía.

Observé que una foto puede ser objeto de tres prácticas (o de tres emociones, o de tres intenciones): hacer, experimentar, mirar. El Operator es el Fotógrafo. Spectator somos los que compulsamos en los periódicos, libros, álbumes o archivos, colecciones de fotos. Y aquél o aquello que es fotografiado es el blanco, el referente, una especie de pequeño simulacro, de eidólon emitido por el objeto, que yo llamaría de buen grado el Spectrum de la Fotografía porque esta palabra mantiene a través de su raíz una relación con "espectáculo" y le añade ese algo terrible que hay en toda fotografía: el retorno de lo muerto. ${ }^{2}$

En esta triple articulación propuesta por Barthes, él acredita en la imagen fotográfica como portadora de un mensaje visual ya determinado socialmente e inherente a este aparato, y que la gran "magia" de este mensaje codificado es la relación entre el fragmento de realidad capturado y su receptor. Es la manera en que cada foto se articula en forma de información con quien la observa. Este comportamiento social observado por Barthes tiene una doble articulación que los denomina de punctum y Studium..$^{13}$ En este sentido el punctum es el detalle de cada foto (a nive personal, lo que prende la atención de algunos pero no de otros), y su presencia es explicada a través de una serie de causalidad que componen la imagen retratada. Esto es particular de cada imagen y relativa al Operator fotógrafo. Ya el studium es determinado por la construcción social y cultural del sujeto que es receptor del mensaje fotográfico. El ejemplo de esta articulación utilizado por Barthes es de su perspectiva delante de una fotografía de James Van der Zee:

He aquí una familia negra norteamericana, fotografiada en 1926 por James Van der Zee. El studium es claro: me intereso con simpatía, como buen sujeto cultural, por lo que dice la foto, pues habla (se trata de una "buena" foto): expresa la respetabilidad, el familiarismo, el conformismo, el endomingamiento, un esfurzo de promoción social para engalanarse con los atributos del blanco [...] El espectáculo me interesa, pero no me "punza". Lo que me punza, es curioso decirlo, es el enorme cinturón de la hermana (o de la hija) - oh negra nodriza -, sus brazos cruzados detrás de la espalda a la manera de las escolares, y sobre todo sus zapatos con tiras. [...] Ese punctum mueve en mí una gran benevolencia, casi ternura. No obstante, el punctum no hace acepción de moral o de buen gusto; el punctum puede ser maleducado. ${ }^{14}$

En esta doble articulación propuesta por Barthes podemos observar el studium de una foto es el resultado de una perspectiva del observador como sujeto histórico, inserto en una sociedad y en una relación de espacio/tiempo determinada. De esta manera, se hará en un análisis a partir de los códigos y signos construidos culturalmente e históricamente en tal sociedad. Podríamos entender también el studium como un mecanismo de construcción y perpetuación de la memoria social colectiva, que veremos más adelante.

Analizar el punctum de una fotografía para Barthes es lo mismo que "entregarse", pues revela la percepción personal e individual del observador y que muchas veces hay fotografías que no "dicen nada" a un receptor de tal imagen. O sea, el punctum y el studium ni siempre coexisten en una misma foto.

11 Umberto ECO: Tratado de..., pp. 17-20

12 Roland BARTHES, La cámara lúcida..., p. 30.

13 Ibid., p. 60.

14 lbid., pp. 6o-63.

\section{Fotografía y Memoria}

La fotografía es el soporte del recuerdo por excelencia, a través de la imagen fotográfica se acciona el sentimiento de la fracción de realidad capturada de un determinado momento pasado (histórico). De acuerdo con Publio López Mondejar "lo que la fotografía muestra ha sido rescatado de la devastación del tiempo, mientras que lo que escapó a su mirada, se ha perdido para siempre en el vértigo del olvido. ${ }^{15}$

Para intentar entender la relación de la fotografía con la construcción de la memoria, primeramente tendremos que intentar definir este concepto inconstante que es la memoria en el campo de los estudios históricos.

El concepto de memoria como objeto de estudio en el campo de la Historia, como el uso de la fotografía, es relativamente reciente, propuesto por primera vez por la escuela francesa de los Annales en los años de 1970. El movimiento de algunos historiadores denominado de Historia Nueva propone un análisis historiográfico a partir de los vencidos o olvidados, o sea una individualización de la historia contra una historia generalista y que presenta la visión de los vencedores. En este movimiento el foco del estudio histórico se ocupa de la historia a largo plazo, o sea, una historia en que la duración del período analizado extrapola en factual, es un proceso lento y continuo, como los estudios de la historia social, económica, política y cultural. En Italia y principalmente en Francia, donde empezó este movimiento, fue denominado como microhistoria. Esta corriente historiográfica fue representada principalmente por los trabajos de Jacques Le Goff, o Georges Duby entre los medievalistas y por el italiano Carlo Ginzburg.

Para Jacques Le Goff, la memoria es la propiedad de conservar ciertas informaciones, propiedad que se refiere a un conjunto de funciones psíquicas que permite al individuo actualizar impresiones o informaciones pasadas, o reinterpretadas como pasadas. ${ }^{16}$ El estudio de la memoria pasa por la Psicología hasta la Neurofisiología, con cada aspecto suyo interesando a una ciencia distinta, siendo la memoria social uno de los medios fundamentales para si abordar los problemas del tiempo y de la Historia.

La memoria está en los propios pilares de la Historia, confundiéndose con el documento, e monumento y la oralidad. En el campo de Filosofía, de la Sociología y Antropología, pero principalmente en el Psicoanálisis, los estudios sobre la memoria individual y colectiva ya estaban avanzados cuando los historiadores empezaron a utilizar la memoria como objeto de estudio. Fue el fundador de la Psicoanálisis y uno de los iconos de la modernidad, Sigmund Freud, quien en el siglo XIX inició amplios debates sobre la memoria humana, señalando su carácter selectivo, o sea, la idea de que recordamos de cosas de forma parcial y a partir de estímulos externos, y con eso escogemos el qué y el cómo recordar. Freud distinguió la memoria de una simple acumulación de recuerdos: para él, nuestra mente no es un museo. En este punto él vuelve a Platón, que ya en la Antigüedad presentaba la memoria como un bloque de cera, donde los recuerdos quedaban impresos.

Susan Sontag afirma que recordar es ser capaz de evocar una imagen y que la imagen fija de la fotografía tiene mayor fuerza como recordatorio que la continuidad de la televisión, porque nuestra memoria se condensa en un solo marco referente. ${ }^{17}$ Los momentos más importan tes de la historia contemporánea se puede identificar con imágenes concretas, como el miliciano de Robert Capa durante la guerra civil española, o el beso de Doisneau al término de la segunda guerra mundial, la madre con sus dos hijos en Estados Unidos de Dorothea Lange, los soldados americanos y la bandera en I wo Jima y más recientemente el impacto de los aviones contra las torres gemelas de Nueva York. Estas imágenes fotostáticas son instantes con que

15 Publio LÓPEZ MONDEJAR: La Fotografia..., pp. 24-25.

16 Jacques LE GOFF: Historia e memória, Campinas, Editora Unicamp, 1994

17 Susan SONTAG: Sobre la Fotografía, Barcelona, Debolsillo, 2010. 
resumimos un periodo de tiempo, un cambio social o un suceso histórico. Recordamos a partir de las fotografías, pero también en muchos casos recordamos las propias fotografías, como la fotografía de Manuel Barriopedro del intento del golpe de Estado del guardia civil Antonio Tejero en febrero de 1981 subido al estrado de la presidencia en Madrid con una mano en alto y la otra sujetando una pistola, es un recuerdo preciso de la Transición española.

Desde 1839 , gran parte de la memoria del mundo se encuentra en las fotografías, en los documentos fotográficos. Treinta años después de su invención, su función ya era absolutamente documental y en la década de 1870 era empleada como referencia en investigación policial, militar, edición, antropológica, etnográica, arqueológica, etcétera. En los primeros años de desarrollo fotográfico, el valor documental se consideró implícito a la imagen, no así el artístico, porque el debate se planteó desde la imitación a la realidad (reproducción de la naturaleza) y no desde la creatividad. El poeta Charles Baudelaire resaltó los valores documentales en su afán por negar el carácter artístico:

[La fotografía] debe, por lo tanto, regresar a su auténtico deber, que es el sirviente de las ciencias y de las artes, pero una sirvienta muy humilde, como la imprenta y la estenografía, que ni han creado ni sustituido a la literatura. Que enriquezca con rapidez el álbum del viajero y ofrezca a sus ojos la precisión que le fálte a su memoria, que adorne la biblioteca del naturalista, que aumente a los animales microscópicos, que reafirme incluso con algunas muestras las hipótesis del astrónomo; que sea, finalmente, la secretaria y el archivo de cualquiera que necesite en su profesión una exactitud material absoluta: hasta aquí, nada mejor puede decirse. Que salve del olvido las ruinas amenazadas, los libros, los grabados y los manuscritos que el tiempo devora, las cosas preciosas cuya forma va a desaparecer y que requieren un espacio en el archivo de nuestra memoria: por ello será agradecida y aplaudida..$^{8}$

La fotografía proporciona, desde su origen, documentos fidedignos. Los trabajos realizados con la cámara oscura fueron pensados como experimentos científicos, negocios y documentos en el deseo de reproducir la realidad, de querer mostrar, como hicieron pintores y grabadores, los fragmentos de la vida y del mundo. Se pretendió, entre otras cosas, la recuperación de instantes pasados, y la captación de la realidad fue uno de los principales valores del daguerrotipo. Así, al conservar una fotografía, se conserva también la memoria, pues se rescata un fragmento de una realidad pasada capturada en un instante único e irrepetible.

La relación de la fotografía con la historia y la memoria ya había sido profetizada por Ernest Lacan, que intuyó en 1856 que la futura tarea de los fotógrafos iba a ser la de documentar exhaustivamente el universo y los sucesos más importantes y dignos de perpetuación y de memoria.

\section{Las Fuentes orales y la Memoria}

Cuando trabajamos con las fuentes orales desde el campo de la Historia, hacemos a través de entrevistas personales. Lo que buscamos es un análisis particular de hechos o eventos históricos, lo que actúa es la memoria del entrevistado. Esta memoria es producto y documento histórico. Por eso la memoria es punto clave para la investigación desde el campo de la Historia y, a la vez que es individual también se puede transformar en memoria colectiva, como analizaremos en esta parte de la comunicación.

Cuando los historiadores comenzaron a utilizar la memoria como objeto de estudio, el principal campo trabajado era el de la Historia Oral. En esta área, muchos estudiosos se preocuparon en ver las formas de la memoria y cómo esta actúa sobre nuestra comprensión del pasado

18 Charles BAUDELAIRE: Salones y otros escritos sobre arte, Madrid, Visor, 200o, p. 256 y del presente. Para teóricos como Maurice Halbawchs, ${ }^{19}$ existe incluso una clara distinción entre la memoria colectiva y la memoria histórica: pues, mientras existe una Historia, existen muchas memorias. Mientras que la Historia representa hechos distantes, la memoria actúa sobre los que fue vivido. En este sentido, se limita el uso de la memoria como documento histórico. Esta posición todavía es muy contestada hoy en día. Antonio Montenegro, ${ }^{20}$ por ejemplo, considera que a pesar de haber una distinción entre Historia y memoria, estas son inseparables, pues si la Historia es una construcción que rescata el pasado desde el punto de vista social, es también un proceso que encuentra paralelos en cada individuo por medio de la memoria.

La memoria colectiva está compuesta por los recuerdos vividos por el individuo, o que le fueron repasados, pero que no pertenece solamente a él, sino que son entendidas como propiedad de una comunidad, o un grupo. El estudio histórico de la memoria colectiva empezó a desarrollarse con la investigación oral. Este tipo de memoria, en pequeños grupos, tiene algunas características bien específicas: primero, gira casi siempre en torno a recuerdos de la vida cotidiana del grupo, como catástrofes naturales, fuertes lluvias, buena o mala cosecha, casi nunca haciendo referencias a hechos históricos valorados por la historiografía, y tiende a idealizar el pasado. En grandes sociedades o colectivos los hechos históricos, como guerras, manifestaciones y eventos, muchas veces se mezclan entre memoria social colectiva e individual, y las comunicaciones visuales juegan un papel importantísimo en esta construcción. En segundo lugar, la memoria colectiva fundamenta la propia identidad del grupo o la comunidad, pero suelen apoyarse en un sucedido considerado fundador, simplificando todo el resto del pasado. Por otro lado, ella simplifica también la noción del tiempo, haciendo solamente grandes diferenciaciones entre el presente ("nuestros días") y el pasado ("antiguamente", por ejemplo). El propio olvido es también un aspecto relevante para la comprensión de la memoria de grupos y comunidades, pues muchas veces es voluntario, señalando la voluntad del grupo de ocultar determinados hechos. Así, la memoria colectiva reelabora constantemente los hechos.

Materiales de la memoria colectiva, los documentos son monumentos en la medida en que, además de simple descripción traducen valores, ideas, tradiciones y comportamientos que permiten tanto recuperar formas de ser y de actuar de los distintos grupos sociales, en diversas épocas históricas. Asi como también opera sobre las representaciones que de ellos, todavía en los días actuales, perduran y actúan como elemento de cohesión social para sus descendientes. A partir de esta perspectiva, entendemos la memoria colectiva como el pasado que se perpetuo y todavía vive en la consciencia colectiva.

Otro aspecto importante en nuestra investigación sobre distinción entre la memoria y la Historia, está en el hecho de que ésta trabaja con el hecho colocado para y por la sociedad, mientras que para la memoria el principal es la reacción que el hecho causa en el individuo. La memoria rescata lo que está sumergido, sea del individuo, o sea del grupo, y la Historia trabaja con lo que la sociedad trajo al público. Para Montenegro la dificultad de utilizar los testimonios orales como fuente de Historia está en el hecho de que son fuentes construidas por la memoria, y ésta reelabora la realidad vivida por la imaginación, por eso, otra vez las preguntas, como en el análisis fotográfico, realizadas por el historiador en las entrevistas pueden variar de acuerdo con la intención a la hora de obtener informaciones para su trabajo, conduciendo así la respuesta del entrevistado.

En las sociedades sin la cultura de la escrita, la actitud de recordar es constante, y la memoria colectiva se confunde entre historia y mito. En tales sociedades existen miembros que son especialistas en la memoria social y que tienen el importante papel de mantener la cohesión del grupo. Un ejemplo de lo que representa la memoria colectiva de un grupo, puede ser anali-

19 Maurice HALBAWCHS: La memoria colectiva, Zaragoza, Prensas Universitarias de Zaragoza, 2004 20 Antonio MONTENEGRO: “Memória”, en Kalina Vanderlei SILVA y Maciel Henrique SILVA (coord.) Dicionário de conceitos históricos, São Paulo, Editora Contexto, 2005. 
zado en los griots de África Occidental, entre ciudadanos de países como Gambia, por ejemplo. Los griots son los especialistas responsables por transmitir la memoria colectiva de sus tribus y comunidades. Ellos conocen las crónicas de su pasado, y tienen la capacidad de narrar hechos hasta tres días seguidos sin repetirse. Cuando los griots recitan la historia ancestral de su grupo, la comunidad escucha con formalidad. Las tribus indígenas de Brasil, y de Suramérica de un modo general, también presentan en su jerarquía el miembro responsable por transmitir el conocimiento de su cultura ancestral, normalmente son los miembros más antiguos que tienen esta responsabilidad. Tales maestros de la narrativa son ejemplos de cómo la tradición oral y la memoria pueden enriquecer el estudio de la Historia. Los procesos de construcción de la memoria colectiva de un grupo muchas veces pueden ser un poco distintas de la construcción de su Historia "oficial" una vez que pasa por filtros culturales que interfieren directamente en la percepción del pasado, principalmente en el pasado no vivido.

La interdisciplinariedad en las ciencias sociales cambió la percepción de la memoria colectiva, ya a partir de Halbawchs en 1950. El estudio de la memoria colectiva pasó a interconectar la Psicología Social, la Antropología y la Etno-historia. Además de eso, fue a partir de este periodo, cuando la Nueva Historia buscó crear una Historia científica con base en la memoria colectiva, considerando también la importancia de la memoria para la definición de identidad.

El escritor afro-americano Alex Haley ${ }^{21}$ dedicó su monumental investigación en tres continentes a buscar el pasado de su familia a partir de memorias repasadas de generación a generación, desde el primer miembro de su familia que llegó a América como esclavo. Lo más relevante para nuestro análisis es que Haley trabajo con los griots en Gambia y difundió en el Occidente un ejemplo de cómo una sociedad sin escritura piensa su memoria. Las comunidades tradicionales de Gambia, los "hombres sabios", afirmaban que la ascendencia de todas las personas remontaba necesariamente a un tiempo en que no existía la escritura. En aqué entonces la memoria humana se tornaba la única forma de conseguir informaciones sobre el pasado. La oralidad del pasado a través de la memoria colectiva es una actitud delante de la realidad, y no la ausencia de una habilidad, en este caso la de escribir.

\section{Conclusiones}

En la fotografía (así como los filtros culturales impuestos en las fuentes orales, como ya hemos visto) está presente una serie de significados y códigos sociales que los estudios realizados en el campo de la semiótica nos ofrece herramientas capaces de comprehender la producción de sentido en las sociedades humanas, como una totalidad. Las imágenes fotográficas asumen el papel de documento/monumento. Para Le Goff hay que considerar la fotografía tanto en el sentido de imagen/documento y como imagen/monumento. ${ }^{22}$ En el primer caso, se considera la fotografía como índice, como una materialidad pasada en el cual objetos, personas, lugares nos informan sobre determinados aspectos de este pasado - condiciones de vida, organización urbana o rural, condiciones de trabajo, moda, etcétera. En el segundo caso, la fotografía es un símbolo, o sea, aquello que en el pasado la sociedad estableció como única imagen a ser recordada en el futuro. La historiadora brasileña Ana Maria Maud también señala que no se puede olvidar jamás que todo documento es monumento, y que si la fotografía informa, ella también conforma una determinada visión del mundo ${ }^{23}$. La recepción de la fotografía y su comprensión presupone un aprendizaje, relacionada a la interacción de los códigos de lectura propios a la imagen fotográfica. Estos códigos son convencionalizados culturalmente y históricamente.

21 Alex HALEY: Negras raizes, Circulo do Livro, São Paulo, s.a.

22 Jacques LE GOFF: "Documento/monumento", en Memoria-História, Enciclopédia Einaudi, vol. I. Lisboa Imprensa Nacional - Casa da Moeda, 1985

23 Ana Maria MAUAD: "Através da Imagen: Fotografia e História Interfaces", Revista Tempo, vol. 1, nº 2 (1996), Rio de Janeiro, pp. $73-98$
La fotografía debe de ser, como las fuentes orales, considerada un producto cultural, fruto del trabajo social de producción de significados. En este sentido, toda la producción de la mensaje fotográfica está asociada a los medios de producción cultural, o sea, debe de ser comprehendido a partir del contexto histórico-social limitado por la relación tiempo/espacio presentes en la investigación histórica. Dentro de esta perspectiva, la fotografía puede, por un lado, contribuir para la transmisión de nuevos comportamientos y representaciones de la clase que posé el control de tales medios de comunicación, y por otro actuar como eficiente medio de control social, a través de la educación de la mirada hacia la imagen fotográfica.

Las articulaciones de sentido propuesta por la imagen fotográfica, como hemos observado, son resultado de la construcción histórico-social en que se producen. La idea de Bresson en la apertura de este apartado inicial, releva la triple articulación temporal propuesta por la fotografía de "capturar y preservar la vida en acto de vivir" revela la articulación de esta entre el presente (la toma fotográfica, el momento del click), el pasado (la imagen fotografiada es irrepetible y queda "archivada" como parte de un pasado) y el futuro, pues igual que su reproducción, la interpretación fotográfica es múltiple, aunque finita, una vez que depende de un observador o receptor de este mensaje codificado y que el valor de una fotografía es atribuido muchas veces después de la toma fotográfica, el studium y el punctum pueden articularse de tantas maneras como el número de observadores de tales imágenes.

La Fotografía registra el presente y alimenta el recuerdo del pasado, actualizando la memoria. Esta dualidad entre presente y pasado es inherente al registro fotográfico, y de gran valor para el análisis del pasado a través de las imágenes fotográficas por parte del historiador social y cultural.

A partir de la perspectiva del análisis histórico-semiótico de la fotografía, ella se presenta también como una herramienta social y política, principalmente en regímenes poco democráticos o dictatoriales. Aunque muchas veces también el mensaje visual de una época es determinante para la elaboración y la actualización de la memoria de este pasado. Entendiendo los mecanismos y sistemas de construcción de sentido social en los mensajes fotográficos, como su uso de articulación ideológica y política del mensaje, o la construcción y afirmación de las identidades nacionales en el siglo XX.

La asociación de la imagen fotográfica en los medios de comunicación de masa, como las revistas especializadas y los periódicos de gran distribución (como analizaremos más adelante), fue fundamental para el desarrollo de la fotografía como mensaje y portadora de un nuevo y eficaz lenguaje social.

El studium de Barthes y la semiosis de Peirce son las dos articulaciones que nos ocuparemos en nuestros análisis posteriores en este trabajo, pues cobran sentido a partir del análisis historiográfico de la fotografía como lenguaje y la sociedad como observador y receptor de este mensaje. Y dentro de este contexto también tenemos que tener en cuenta, siempre, la triple articulación existente entre el Operator, Spectator y el Spectrum. 


\section{EL PSA Y EL NUEVO ANDALUCISMO. UNA RELECTURA DEL PROCESO DEMOCRATIZADOR Y AUTONÓMICO A TRAVÉS DE LAS FUENTES ORALES (1973-1982)*}

Javier Contreras-Becerra

Universidad de Granada

\section{Introducción}

La comunicación que aquí presentamos forma parte de nuestra tesis doctoral, donde se trata la relación entre el movimiento vecinal y autonomista con las tres principales culturas políticas de la izquierda andaluza desde 1977 hasta la primera mitad de los 80: andalucismo, comunismo y socialismo.

Como se puede comprobar por el título, el texto se ha focalizado en torno a la investigación del andalucismo político representado por el PSA (Partido Socialista de Andalucía). Formación que no hay que confundir con el PSOE de Andalucía, con quien se disputó el espacio político socialista'. Constituido oficialmente como partido político en 1976 (si bien como veremos sus antecedentes se remontan a años atrás, con CPSA y ASA), pasó por una serie de transformaciones, hasta llegar al V Congreso de 1984, en el que adopta su denominación actual: Partido Andalucista ${ }^{2}$.

La perspectiva que hemos adoptado en esta investigación pasa por complejizar la historia del proceso democratizador y de descentralización autonómica en Andalucía. Ello implica matizar el relato oficial que se ha construido sobre la consecución de la autonomía andaluza, situando en su justa medida la aportación del andalucismo político. Además, obliga a revisar o, al menos, a contextualizar la imagen que se ha atribuido al PSA como "partido de derechas", por la evolución posterior de sus políticas, sus alianzas electorales y la actuación de sus dirigentes. Visión que se ha aplicado de forma acrítica a la hora de enjuiciar el papel del PSA en la transición andaluza. Sin negar los errores tácticos y el transformismo ideológico que impregnó al PSA (al igual que el PCE y el PSOE), esta visión acrítica obvia el izquierdismo que predominó en una parte importante de su base militante y sus planteamientos innovadores: abogar por un regionalismo socialista y después por un nacionalismo popular, solidario con el resto de territorios; recoger en su órgano de prensa las demandas medioambientales, feministas... ${ }^{3}$ Partiendo de nuestra condición como miembro de una generación, criada en el marco de un régimen de autogobierno andaluz consolidado, nos cuestionamos el relato oficial del proceso autonómico por incompleto y por invisibilizar a varios actores sociales que consideramos claves para una mejor comprensión del mismo. La insatisfacción personal consiguiente que

* El autor ultima en estos momentos su tesis doctoral, centrada en la construcción de ciudadanía y el aprendizaje democrático en Andalucía. Para la misma ha contado con la financiación de una beca-contrato del Programa de Formación del Profesorado Universitario (Ministerio de Educación). E-mail: jacobe@ugr.es

1 José Enrique ROSENDO RíOS: Andalucia, por sí, para España, Sevilla, Fundación Blas Infante, 199o, pp. 74-75.

2 Jesús VERGARA: Guía histórica de la Sevilla andalucista, Sevilla, Atrapasueños, 2010, pp. 281-282.

3 Manuel RUIZ ROMERO: Andalucía Libre: una Revista Andaluza de la Transición. Indice Bibliográfico, Sevilla, Universidad de Sevilla. 2000. anima este trabajo (egohistoria), sin embargo, no está reñida con la pretensión de realizar una investigación rigurosa del proceso de democratización y consecución de la autonomía en Andalucía. Ello a partir de los presupuestos de la nueva historia política y la nueva historia social, además de recurrir a nuevas fuentes. Dado que la comunicación se presenta dentro de una mesa dedicada a la historia oral, primamos el análisis de fuentes de dicha naturaleza.

\section{Descripción y análisis del trabajo de campo}

La recogida de fuentes orales se acometió entre 2010 y 2013. En total se realizaron once entrevistas orales (diez militantes del PSA y una independiente), con un modelo de entrevista semidirigida y abierta. Previamente, cada una de ellas se preparó con un cuestionario y una relación de temas adaptado a la información disponible sobre la persona. Las entrevistas se registraron por medio de una grabadora digital, cuyo contenido se completó con las notas que efectuó el entrevistador paralelamente a la intervención de su interlocutor/a. Todas las entrevistas iban precedidas de la firma de la correspondiente autorización por parte del entrevistado/a para la grabación y posterior cesión a un archivo histórico (si procediera), así como de la cumplimentación de un formulario biográfico.

La localización de las entrevistas se dejó a criterio de nuestro interlocutor/a, si bien se insistió en que fuera un lugar tranquilo que permitiera una grabación sin un exceso de ruido y/o interrupciones. Cinco de ellas se realizaron en el lugar de trabajo, cuatro en domicilios particulares y dos en cafeterías del centro urbano de Sevilla. Normalmente, se efectuaron varias sesiones, de forma que hubiese siempre una segunda entrevista para completar temas abordados en la primera y/o que quedaron sin tratar. Por motivos de agenda, dos de ellas se prolongaron durante más tiempo: la de Alejandro Rojas-Marcos ${ }^{4}$ (cuatro entrevistas entre 2010 y 2012) y Luis Uruñuela 5 (tres entrevistas, entre 2011 y 2012). Sólo en uno de los casos intervino una persona aparte de la entrevistada (Francisco Torres González, marido de Concepción Fernández-Píñar ${ }^{6}$ y también ex militante andalucista, en la primera sesión)

4 Alejandro Rojas-Marcos de la Viesca, 24 de febrero y 12 de abril de 2010, 29 de junio de 2011 y 15 de junio de 2012, entrevistas realizadas por Javier CONTRERAS BECERRA, Sevilla. Nacido en Sevilla en 1940. Licenciado en Derecho, directivo y asesor empresarial. Ex Secretario General del PSA (19761982), Ex presidente del Partido Andalucista, ex diputado por Cádiz (1979-1982) y Sevilla (19891991) y parlamentario andaluz (1994-1996). Concejal (1987-1991), Alcalde (1991-1995) y teniente de alcalde (1995-1999) en el Ayuntamiento de Sevilla.

5 Luis Uruñuela Fernández, 29 de marzo de 2011, 10 de mayo y 13 de junio de 2012, entrevistas realizadas por Javier CONTRERAS BECERRA, Sevilla. Nacido en Sevilla en 1937. Abogado, profesor, director de EUSA (Estudios Universitarios y Superiores de Andalucía), miembro del Consejo de Gobierno y del Consejo Social de la Universidad de Sevilla. Alcalde andalucista de Sevilla (1979-1983), parlamentario andaluz (1982-1986) y ex Secretario General del PSA-PA (1982-1986). 6 Concepción Fernández-Piñar Lorca, 24 de febrero y 7 de mayo de 2012, entrevistas realizadas por Javier CONTRERAS BECERRA, Gójar (Granada). Nacida en Granada en 1940. Diplomada en Trabajo Social. Ex jefa de Sección de Participación Comunitaria de la Consejería de Salud de la Junta de de Educación del Ayuntamiento de lanada (1979-1981) Ex militante del PSOE y deI PSA. 
Respecto a la tipología, cinco se refieren a dirigentes del comité nacional andalucista (Alejandro Rojas-Marcos, Luis Uruñuela, Ladislao Lara, ${ }^{7}$ Antonio Ibáñez, ${ }^{8}$ Pedro Ruiz), ${ }^{9}$ dos fueron a secretarios de formación de Sevilla y Granada (Rafael Sanmartín ${ }^{10}$ y Sebastián de la Obra) y cuatro miembros de la candidatura del PSA de Granada (Eladio Fernández-Nieto, ${ }^{12}$ Fermina Puerta, ${ }^{13}$ Concepción Fernández-Pínar y María Encarnación López). ${ }^{14}$

Un factor a considerar es la existencia de un discurso marcado, llamativo en una parte de los entrevistados, bien probablemente por estar acostumbrados a tratar con periodistas e investigadores universitarios (destaca la desenvoltura de Rojas-Marcos y Uruñuela), ${ }^{15}$ por efecto

7 Ladislao Lara Palma, 27 de mayo de 2011, entrevista realizada por Javier CONTRERAS BECERRA, Sevilla. Nacido en 1940 en Madrid. Psiquiatra. Ex Director General de Ordenación Sanitaria en Andalucía y ex Gerente del Instituto Andaluz de la Salud Mental. Ex viceconsejero de Medio Ambiente de la Junta de Andalucía. Miembro del Comité Ejecutivo del PSA (1977-1980). Miembro del Ateneo de Huelva, de la Junta Democrática y del colectivo de la Librería Saltés de Huelva. Ex militante del PSOE y del PSA.

8 Antonio Ibáñez García, 23 de febrero y 13 de abril de 2011, entrevistas realizadas por Javier CONTRERAS BECERPA Sevilla Nacido en 1943 en Sanlúcar de Barrameda (Cádiz). Electricista. Miembro del Comité Ejecutivo del PSA (1976-1980). Ex presidente de la Asociación de Cabezas de Familia del Comité Ejecutivo del PSA (1976-1980). Ex presidente de la Asociación de Cabezas de Familia Andalucía. Ex militante del PSOE, del PSA y de Reconstrucción Socialista de Andalucía.

9 Pedro Ruiz Morcillo, 24 de febrero de 2011, entrevistas realizadas por Javier CONTRERAS BECERRA, Pedro Ruiz Morcillo, 24 de febrero de 2011, entrevistas realizadas por Javier CONTRERAS BECERRA,
Sevilla. Nacido en 1946 en Sabiote (Jaén). Profesor de Enseñanza Secundaria. Miembro del Comité Ejecutivo del PSA. Miembro de la Junta Directiva del Colegio de Doctores y Licenciados de Granada. Ex milltante de Izquira

.

10 Rafael Sanmartin Ledesma, 12 y 13 de abril de 2013, entrevistas realizadas por Javier CONTRERAS BECERRA, Sevilla. Nacido en 1956 en Carmona (Sevilla). Periodista y escritor. Presidente del Centro de Estudios Historicos de Andalucía (CEHA) y de Almenara. Asociación para el Progreso de Andalucía. Presidente de la asociación Averroes. Estudio Andal usi (años 70). Ex militante de ASA/PSA (1973-1982) 11 Sebastián de la Obra Sierra, 19 y 23 de febrero, entrevistas realizadas por Javier CONTRERAS BECERRA, Córdoba y Sevilla. Nacido en 1958 en Úbeda (Jaén). Director del Archivo y Servicio de Documentación del Parlamento de Andalucía y Director de la Casa de Sefarad-Casa de la Memoria de Córdoba. Adjunto al Defensor del Pueblo Andaluz (1996-2007). Director de la Biblioteca del Parlamento de Andalucía (1984-1993). Diplomado en Magisterio y Licenciado en Historia (Universidad de Granada), Doctor en Documentación (Universidad de Sevilla). Ex militante del PSA y de JGR. Fundador y miembro de la A.VV. del Camino de Ronda. Presidente de la Asociación de Derechos Humanos de Andalucía. Patrono de la Fundación Sevilla Acoge. Candidato independiente al Senado en las listas del PA por Córdoba (2011).

12 Eladio Fernández-Nieto Fernández, 22 de enero y 5 de febrero de 2011, entrevistas realizadas por Javier CONTRERAS BECERRA, Granada. Nacido en 1953 en Granada. Antiguo trabajador del Instituto Municipal de Formacion y Empleo (IMFE) del Ayuntamiento de Granada, hoy suprimido. Ex Secretario provincial del Partido Andalucista de Granada (1994-1996). Corrector de pruebas en el Servicio de Publicaciones de la Universidad de Granada. Licenciado en Historia Contemporanea. Candidato independiente de IU al Parlamento Andaluz (1986). Concejal de Festejos (1979-1981). Socio de la A.VV. del Polígono de Cartuja. Militante de ASA/PSA (1973-1981). Ex miembro de un grupo scout católico.

13 Fermina Puerta Rodríguez, 10 y 14 de febrero de 2011, entrevistas realizadas por Javier CONTRERAS BECERRA, Granada. Nacida en 1948 en Gualchos (Granada). Trabajadora Social en el Servicio Andaluz de Salud. Militante del Movimiento de No violencia de Granada, de Solidaridad Andaluza y de la HOAC. Ex concejal independiente elegida en la lista del PSA al Ayuntamiento de Granada (1979-1981).

14 María Encarnación López Rejón, 3 y 17 de febrero de 2011, entrevistas realizadas por Javier CONTRERAS BECERRA, Granada. Nacida en 1948 en Granada. Enseñante y administrativa. Socia de la AVV. del Polígono de Cartuja. Ex militante del PSA. Ex miembro de un grupo scout católico.

15 Nos consta que al menos Alejandro Rojas-Marcos ha sido entrevistado por los autores de sendas tesis don el contexto de la transición política (1975-1982), Tesis doctoral, Universidad Pablo de Olavide, 2003 Enrique C. PÉREZ NIETO: EI Partido Andalucista: Origen y evolución de un partido regionalista (1976. 2005). Tesis doctoral, Universidad de Granada, 2006. de su formación cristiana militante (Fermina Puerta), por las experiencias profesionales (Rafael Sanmartín) o fruto de una trayectoria pública y cultural (Sebastián de la Obra). La mayoría de los entrevistados/as coinciden en que han abandonado el andalucismo político, sobre todo los "granadinos" (Pedro Ruiz Morcillo, Concepción Fernández-Pínar, María Encarnación López) Esto no quiere decir que en algunos casos no sigan participando en el andalucismo cultural.

La tarea no hubiera sido la misma sin la labor de ciertos porteros, ${ }^{16}$ que nos proporcionaron el contacto con parte de nuestros entrevistados/as. Gracias a la mediación de dos responsables de la sede nacional del PA en Sevilla, conseguimos entrevistar a Alejandro Rojas-Marcos y Luis Uruñuela, tras fijar las citas correspondientes con sus respectivos secretarios/as. A partir de la profesora de la Universidad de Granada, Amparo Ferrer, ex militante del PSA, pudimos acceder a Fermina Puerta Rodríguez y María Encarnación López Rejón. El andalucista e investigador jiennense Manuel Medina Casado hizo lo propio con Rafael Sanmartín. Por otro lado, intervino el factor de la "bola de nieve": 17 Sebastián de la Obra nos remitió a Concepción Fernández-Píñar, mientras que López Rejón nos aconsejó como "voz autorizada" a Pedro Ruiz Morcillo. En cambio, Eladio Fernández-Nieto, Ladislao Lara y Antonio Ibáñez fueron localizados en la guía telefónica y contactados sin intermediación.

A través de las entrevistas, pretendimos obtener información de la trayectoria del PSA y su relación con el movimiento vecinal y autonomista en Andalucía, si bien en la práctica abundaron más las referencias a Cádiz, Granada, Huelva y Sevilla. La selección de los entrevistados se rigió por el criterio de no contentarnos únicamente con la visión de los secretarios generales y la necesidad de confrontar distintas visiones (dirigentes nacionales-dirigentes locales y provinciales-militantes y simpatizantes).

Por otro lado, la labor de documentación que permitió el paso de los relatos de vida ${ }^{18}$ a la elaboración de unas historia de vida ${ }^{19}$ experimentó momentos de avances y retrocesos. Lógicamente, estas circunstancias repercutieron en el momento de las entrevistas (condicionantes ignorados, ${ }^{20}$ preguntas que no se formularon) y en el resultado final de este texto. El intento de acceso a archivos particulares de ex militantes supuso varias gestiones infructuosas (salvo en casos puntuales). No obstante, pudieron solventarse con la consulta de los números de Andalucía Libre (órgano de prensa del PSA), la documentación de la antigua sede del Partido Andalucista en Córdoba y más tardíamente, la del archivo del Partido Andalucista-Fundación Alhambra. Se prevé que los fondos de este último sean transferidos a la Cátedra Rafael Escuredo de la Universidad de Almería.

\section{El uso del presente en la historia oral del andalucismo}

Durante los dos años que ocuparon el trabajo de campo se sucedieron varios acontecimientos que influyeron, de una manera u otra, en la percepción del objeto de estudio y las respuestas y la reelaboración que hicieron los informantes de sus memorias. Como afirma Eduardo González Calleja, los recuerdos son procesos biológicos, si bien la memoria no es sólo el producto almacenado de lo que experimentamos, sentimos e imaginamos. Se trata de una

16 Rosa GARCíA-ORELLÁN: “De la oralidad a la intención biográfica”, en Miren LLONA (coord./ed.) Entreverse. Teoría y metodología práctica de las fuentes orales, Bilbao, Servicio Editorial de la Universidad del País Vasco, 2012, p. 70.

17 Pilar FOLGUERA: Cómo se hace historia oral, Madrid, Eudema, 1994, pp. 32-33.

18 Daniel BERTAUX: Los relatos de vida. Perspectiva etnosociológica, Barcelona, Edicions Bellaterra, 2005, pp. 73-74.

19 Juan José PUJADAS MUÑOZ: El método biográfico: El uso de las historias de vida en ciencias sociales, Madrid, Centro de Investigaciones Sociológicas, 2002, pp. 13-14.

20 En particular, algunas críticas al "personalismo" y la gestión política de Rojas Marcos en el pasado, que explicarían ciertas respuestas en clave autojustificativa. 
facultad versátil, maleable y frágil, muy vulnerable al cambio, al error y a la falsificación. ${ }^{21}$

El año 2011 comenzó con las primeras protestas de la que luego se conocería como Primavera árabe. La caída del régimen libio de Gadaffi, por lo pronto, hizo resurgir el debate acerca de las relaciones y presunta financiación de su gobierno al PSA-PA. ${ }^{22}$ Esto obligó al entrevistador a plantear las preguntas sobre las relaciones internacionales del PSA de una forma más cuidada, procurando no herir susceptibilidades.

Con motivo de la convocatoria electoral de noviembre de 2011 se produjo un hecho que podría enmarcarse dentro de la tradicional controversia entre historiadores/as y la ficción televisiva. ${ }^{23}$ En plena campaña de las generales, un episodio de la popular serie "Cuéntame cómo pasó", ofreció una interpretación sui generis del papel del PSA en la lucha por la autonomía andaluza. ${ }^{24}$ Se atribuía al PSA de Granada la preferencia por dos Andalucías autónomas en vez de una, cuando en realidad había sido una opción de la UCD granadina, encabezada por José Sánchez Faba. ${ }^{25}$ Además, la dirigente del PSA en la Junta de Andalucía, que en el episodio contactaba con los hermanos Alcántara, aparecía caracterizada como una terrateniente sevillana. Hay que tener en cuenta que los andalucistas sólo controlaron (entre 1979 y 1981) una consejería en la Junta preautonómica de Andalucía, la de Medio Ambiente. ${ }^{26}$ Ahora bien, ¿por qué presentar a la dirigente del PSA como una terrateniente? ¿Licencia de los guionistas? ¿Uso de ciertos tópicos? ¿O una metáfora de las críticas que se habían vertido contra Rojas-Marcos desde la Transición por proceder de una familia de buena posición en la sociedad sevillana? Otra licencia cinematográfica era la afirmación de que los andaluces habían comprado banderas verdiblancas en Madrid, cuando en realidad se podían adquirir en comercios en Andalucía desde antes de las manifestaciones proautonomía de diciembre de $1977 .{ }^{27}$ Para contrarrestar la imagen que se transmitía, María Pilar González Modino, Secretaria General del Partido Andalucista y candidata al Congreso por Madrid; y Fernando Álvarez-Ossorio, candidato al Congreso por Sevilla; junto con varios militantes, escenificaron una parodia del capítulo. ${ }^{28}$ Igualmente, el PA transmitió sus quejas a RTVE por la polémica. ${ }^{29}$

La pregunta que cabía plantearse es: ¿ayudaba este capítulo de una serie, que no olvidemos es un producto cultural, a un mejor conocimiento del pasado? ¿O contribuía a redundar en tópicos y en una lectura interesada de la Transición que en parte esta investigación pretendía matizar?

21 Eduardo GONZÁLEZ CALLEJA: Memoria e historia. Vademécum de conceptos y debates fundamentales, Madrid, Los Libros de La Catarata, 2013, pp. 17-18.

22 José AGUILAR: "Los amigos andaluces de Gadaff", Diario de Sevilla, 13 de marzo de 2011. Recuperado de internet http://www.diariodesevilla.es/article/andalucia/926104/las/amistades/ andaluzas/muamar/gadafi.html

23 Sobre la diferencia entre el lenguaje escrito y el cinematográfico para abordar el conocimiento de la Historia cf. Robert A. ROSENSTONE: El pasado en imágenes. El desafio del cine a nuestra idea de la historia, Barcelona, Editorial Ariel, 1997, pp. 17-23. 24 RTVE:Cuéntame cómo pasó-T.13-Capitulo 224,España, 2011. Recuperado de internet (http://www.
rtve.es/alacarta/videos/cuentame-como-paso/cuentame-como-paso-t13-capitulo-224/1246307/) rtve.es/alacarta/videos/cuentame-como-paso/cuentame-como-paso-t13-capitulo-224/1246307/)
Roberto VILLA GARCIAA: “Granada ante el proceso autonómico andaluz: La cuestión de las dos Roberto VILLA GARCíA: "Granada ante el proceso autonómico andaluz: La cuestión de las dos
Andalucías en la transición política española", en Fernando ARCAS CUBERO y Cristóbal GARCíA MONTORO (eds.): Andalucía y España. Identidad y conflicto en la historia contemporánea, Málaga, Fundación Unicaja, 2008, pp. 371-394.

26 Fermín OLVERA PORCEL: La emergencia de la administración autonómica andaluza (1978-1985), Granada, Editorial Universidad de Granada, 2003, pp. 159-161.

27 "Andalucía Viva. Bandera andaluza", Tierras del Sur, n $.43,7$ de marzo de 1977, p. 31.

28 "Cuéntame (de verdad) cómo pasó", Público, 16 de noviembre de 2011. Recuperado de internet http://www.publico.es/politica/407244/cuentame-de-verdad-como-paso

29 "El Partido Andalucista "parodia" la serie "Cuéntame" y "clama" contra RTVE", El Mundo edición Andalúa, 15 de noviemb a de la serie "Cuen do/2011/11/15/television/1321373740.html
El fracaso en las elecciones al Parlamento Andaluz provocó la dimisión de González Modino y su salida del PA al mes siguiente, promoviendo en los siguientes meses la plataforma Primavera Andaluza. La ex Secretaria General, en el momento de su salida, criticó una presunta intervención de Rojas-Marcos para superar la crisis interna. $3^{\circ}$ Este escenario influyó en alguna de las respuestas de la segunda entrevista a Luis Uruñuela, donde el ex Secretario General andalucista se quejaba de la "Ilamativa cobertura informativa" de la prensa a la crisis interna del PA, en comparación con las circunstancias normales y las crisis internas de otros partidos hegemónicos. ${ }^{31}$

\section{El andalucismo político de los años 70: un partido ex novo}

Los antecedentes del Partido Socialista de Andalucía se remontan a las reuniones políticas de los dos grupos que animaban Alejandro Rojas Marcos y Luis Uruñuela en la Sevilla de 1965 denominadas Compromiso Político. ${ }^{32} \mathrm{~A}$ partir de cierto momento, dichas reuniones se justificaron detrás de la fórmula de una sociedad anónima, con las siglas C.P.S.A. ${ }^{33}$

Entre finales de los años sesenta y los primeros años de la década de los setenta, la entidad apoyó las candidaturas de dos de sus miembros por el tercio familiar al Ayuntamiento de Sevilla: la del propio Rojas Marcos (que consiguió la elección) y la del médico Diego de los Santos (frustrada). ${ }^{34}$ Rojas Marcos dimitió tras denunciar las limitaciones del sistema y, posteriormente, fue procesado y desterrado por el Tribunal de Orden Público a causa de su actividad opositora. ${ }^{35}$ C.P.S.A. se extiende por otras poblaciones de Andalucía y en 1973 pasa a denominarse Alianza Socialista de Andalucía (ASA). En ese momento, adopta un ideario regionalista, que se refleja en su manifiesto fundacional, recogido en noviembre de 1973 en Cuadernos de Ruedo Ibérico. ${ }^{36} \mathrm{ASA}$ se extenderá por el territorio andaluz y participa en las plataformas de oposición antifranquista, si bien se auto excluye de Coordinadora Democrática por no incluir el principio de igualdad entre regiones y reproducir las estructuras estatales de dicha entidad en Andalucía. ${ }^{77}$ En 1976, Alianza Socialista de Andalucía, Reconstrucción Socialista de Andalucía y otros grupos convergen en un congreso para constituir el Partido Socialista de Andalucía.

Hemos aludido a que el PSA representó un andalucismo ex novo..$^{38}$ Esto se debe a que Blas Infante, la figura principal del andalucismo histórico, no fundó propiamente un partido nacionalista. Además, en la fecha en la que ASA abrazó las ideas de Blas Infante, todavía existía un

30 "Pilar González renuncia a volver a liderar el PA pero rechaza que Rojas Marcos pretenda tutelarIo", El Mundo, edición Andalucía, 30 de abril de 2012. Recuperado de internet http://www.elmundo.es/elmundo/2012/04/10/andalucia/1334059062.html

31 Luis Uruñuela Fernández, 10 de mayo de 2012, entrevista realizada por Javier CONTRERAS BECERRA, Sevilla.

32 Luis Uruñuela Fernández, 29 de marzo de 2011, entrevista realizada por Javier CONTRERAS BECERRA, Sevilla.

33 Alejandro Rojas-Marcos de la Viesca, 12 de abril de 2010 y 29 de junio de 2011, entrevistas realizadas por Javier CONTRERAS BECERRA, Sevilla.

34 José María de los SANTOS LÓPEZ: Andalucía en la transición (1976-1982), Sevilla, Centro de Estudios Andaluces, 2002, pp. 204-205.

35 Juan TEBA: La Sevilla de Rojas Marcos, Barcelona, Editorial Planeta, 1981, pp. 150-159 y 216-241.

36 "Alianza Socialista de Andalucía. Manifiesto fundacional (diciembre 1973)", Archivo Histórico del PCE (AHPCE, Madrid), Sección Nacionalidades y Regiones, Caja 82, carpeta 1/8. Correspondencia con Sevilla.

37 Manuel RUIZ ROMERO: “El sistema de partidos en la Andalucía de la transición: el fracaso de un discurso diferencial", en Actas del VIII Congreso de la Asociación de Historia Contemporánea. Con-
greso de la Asociación de Historia Contemporánea, Santiago de Compostela, Universidad de Santiago de Compostela, 2004, pp. 1-20.

38 Luis Uruñuela Fernández, 29 de marzo de 2011. 
cierto desconocimiento sobre su figura. EI PSA representó un nuevo andalucismo por cuanto incorporó a las ideas blasinfantianas un discurso acerca del atraso y la dependencia económica, política y cultural (una Andalucía sometida al subdesarrollo por razones de dependencia económica y su función de colonia interior). ${ }^{39}$ Aquí, las teorías de la dependencia confluyeron con el marxismo, muy presente en las principales culturas políticas de la izquierda y en los intelectuales; con el "compromiso cristiano" 40 y la visión crítica que manejaba el cristianismo progresista sobre la problemática andaluza. ${ }^{41}$ De hecho, el salesiano José María de los Santos López y los jesuitas José “Pope" Godoy y José María García Mauriño mantuvieron una relación estrecha con el PSA. Pope Godoy y García Mauriño fundaron con Fermina Puerta la asociación Solidaridad Andaluza, que trataba de concienciar acerca de los problemas que padecía Andalucía y reivindicar soluciones. EI PSA empleó los montajes audiovisuales de Solidaridad Andaluza en campañas electorales y en el referéndum de 1980.

EI PSA, como otra de sus señas de identidad, introdujo en su ideario el socialismo autogestionario a través de la integración de Reconstrucción Socialista de Andalucía, partido impulsado por la Unión Sindical Obrera.42

La organización delimitó en sus primeros momentos cinco frentes de lucha con organización autónoma respecto del Partido: Frente obrero, frente de barrios, frente de la juventud, frente de la liberación de la mujer y frente de la Emigración (Novena provincia).43 De estos, tres al menos conocieron un mayor desarrollo hasta los primeros años ochenta: el obrero, el de barrios (a través del compromiso directo en las asociaciones de vecinos) ${ }^{44}$ y el de la emigración. En cuanto al obrero, a partir de 1978 el PSA intentó impulsar una central sindical nacionalista, el Sindicato Andaluz, con desigual éxito y escaso mantenimiento en el tiempo. ${ }^{45}$

\section{La "confrontación" de memorias andalucistas}

La práctica totalidad de las personas entrevistadas, menos una, militaron en el PSA entre 1977 y 1981. En todos los casos, se trataron de abordar cuestiones comunes. Por ello, los relatos

39 José María de los SANTOS LÓPEZ: Andalucía..., pp. 206-207.

40 Una parte de nuestros entrevistados, al igual que otros dirigentes del PSA, se socializaron en movimientos apostólicos de Acción Católica o en organizaciones cristianas (Luis Uruñuela en la JUMAC, Antonio Ibáñez en la JOC, Concepción Fernández-Píñar en la JEC, Eladio Fernández-Nieto y María Encarnación López, en los scouts católicos...) José HURTADO SANCHEZ: La Iglesia y el movimiento obrero de Sevilla (1940-1977). Antropología política de los cristianos de izquierda, Sevilla, Fundación El Monte, 2006, pp. 444-449.

41 Manuel MEDINA CASADO: Andalucía: Historia y compromiso, Torredonjimeno, Centro de Estudios Históricos de Andalucía, 2002, p. 131. José Godoy López, 29 de enero de 2011, entrevistas realizadas por Javier CONTRERAS BECERRA, Andújar (Jaén). Nacido en 1933 en Canena (Jaén). Licenciado en Filosofía, Teología, Ciencias Orientales y Siriaco. Ex jesuita obrero. Dirigente del Movimiento de No Violencia de Granada y de Solidaridad Andaluza. Simpatizante del PSA. Ex concejal y portavoz de IU en el Ayuntamiento de Andújar (1995-1999). José María García-Mauriño Hergueta, 11-12 de marzo de 2011, entrevistas realizadas por Javier CONTRERAS BECERRA, Madrid. Nacido en 1929 en El Escorial. Licenciado en Filosofía, Teología, Estudios Eclesiásticos, Humanidades Clásicas y ex profesor de la Fundación Universitaria San Pablo CEU. Miembro de Cristianos por el Socialismo y de Redes cristianas. Dirigente de Solidaridad Andaluza.

42 Antonio lbáñez García, 23 de febrero de 2011.

43 "Respuesta a la encuesta de Diario 16", 1977, Archivo del Partido Andalucista-Fundación Alhambra (APA-FA, Sevilla), Caja Dossier prensa PSA 1977.

44 CIDUR: Movimiento de barrios y partidos políticos, Madrid, Editorial Mañana, 1977.

45 Luis Uruñuela Fernández, 10 de mayo de 2012. Antonio Ibáñez García, 13 de abril de 2011. B. J. CAÑIBAÑO: "En centenares de empresas andaluzas no se han celebrado elecciones. El sindicalismo nacionalista andaluz ha perdido una oportunidad histórica para despegar" ABC. edición Sevilla de enero de 18 . Recuperado de internet http://hemeroteca abchesevilla., es/ nav/Navigate. 4 hemeroteca/sevilla/abc.sevilla/1981/01/04/025.html de vida permiten determinar las razones o, al menos, cómo reinterpretan nuestros entrevistados hoy en día el momento de sus inicios en el compromiso militante.

Lógicamente, las diferentes trayectorias de las personas entrevistadas se ha traducido en algunos posicionamientos desde los que se replantean y reinterpretan los valores, prácticas y actuaciones de las bases y los dirigentes del PSA. Fue la impresión que obtuvimos, por ejemplo, de algunos comentarios expresados por Pedro Ruiz Morcillo en su entrevista ${ }^{46}$. El relato hegemónico de la Transición, de la justificación de las renuncias y del moderantismo por encima de posturas radicales, la idealización de la gestión municipal, del espíritu del consenso entre fuerzas políticas, ha calado en algunos de ellos. La nota discordante respecto a la imagen de un gobierno municipal exento de tensiones la puso Luis Uruñuela, al evocar los intentos de PSOE de desgastar su gestión al frente de la alcaldía. Éste, en su entrevista, recordó que fue el único de los tres alcaldes nacionalistas de capitales de provincia que agotó el mandato (en contraste con los de A Coruña y Las Palmas de Gran Canaria). ${ }^{47}$

No obstante, la mayoría de los entrevistados parecen expresar su orgullo por su experiencia militante, haciendo hincapié en la consecución de un poder andaluz, una alternativa anticentralista desde el que combatir las lacras que sufría Andalucía en los años 70 (paro, analfabetismo, emigración, "colonización cultural"). Otro rasgo que destacan la mayoría son las difíciles relaciones con el PSOE, exceptuando el buen trato individual con determinados políticos socialistas, como indicaron Ladislao Lara y Pedro Ruiz Morcillo. ${ }^{48}$

Resultaría complejo hablar de una única "memoria andalucista". Incluso para el caso del PSA de Granada. No obstante, hubo valores e ideas que le dieron cohesión como grupo. De hecho, buena parte de los ex andalucistas granadinos insisten en sus entrevistas que el Partido "nunca levantó cabeza" en Granada después de la crisis interna de 1980-1981. Sin embargo, algunos pequeños éxitos electorales posteriores (aunque esporádicos) cuestionan esta visión extendida. ¿Por qué se reproduce esta afirmación? Probablemente, a la reelaboración del recuerdo que se produce en estos ex militantes, que incluye enfatizar los momentos de militancia entregada y voluntariosa dentro del PSA, ${ }^{49}$ la percepción de la crisis interna de 1980-1981 como un episodio traumático (sobre todo para los que sufrieron medidas disciplinarias) y que la evolución de las políticas del PSA hipotecó para siempre los apoyos electorales de la sociedad granadina.

La recogida de los relatos de vida nos permite intuir el valor de las redes de afinidad y confianza que tejieron los andalucistas, que en el caso de Pedro Ruiz Morcillo le condujo a la militancia a instancias de sus amigos Eladio Fernández-Nieto y María Encarnación López ${ }^{50}$. EI descubrimiento del Manifiesto fundacional de ASA y la mediación de un jesuita, pariente de la primera mujer de Rojas-Marcos; fue determinante para que una parte del Grupo 32 de scouts católicos, entre los que se contaban Eladio Fernández-Nieto y María Encarnación López entrasen en la organización. ${ }^{51}$ Sebastián de la Obra dio el paso por su concepción de lo que era Andalucía. ${ }^{2} \mathrm{Al}$ menos cuatro entrevistados (Eladio Fernández-Nieto, María Encarnación López, Sebastián de la Obra y Rafael Sanmartín) decidieron incorporarse al andalucismo en el momento de la existencia de ASA.

Otra faceta sugerente de las entrevistas la encontramos al rastrear la tipología de los militantes andalucistas. Un fenómeno que pretendíamos explicar era la notable presencia de enseñan-

46 Pedro Ruiz Morcillo, 24 de febrero de 2011.

47 Luis Uruñuela Fernández, 10 de mayo y 13 de junio de 2012.

48 Pedro Ruiz Morcillo, 24 de febrero de 2011. Ladislao Lara Palma, 27 de mayo de 2011.

49 Como rememoró López Rejón, al aludir al esfuerzo de las campañas electorales del PSA. María Encarnación López Rejón, 17 de febrero de 2011

50 Pedro Ruiz Morcillo, 24 de febrero de 2011.

51 Eladio Fernández-Nieto Fernández, 22 de enero de 2011.

52 Sebastián de la Obra Sierra, 19 de febrero de 2011. 
tes (maestros y profesores) en el PSA. Rojas-Marcos lo atribuía a su carácter accesible hacia los postulados andalucistas y cómo la cultura genera liderazgos. ${ }^{53}$ Eladio Fernández-Nieto se refirió a que el origen del Partido en muchos sitios se explicaba en función de los primeros captados. ${ }^{54}$

¿Cómo gestionó el PSA el poder municipal que alcanzó en las elecciones locales de 1979? Intentar responder a esta pregunta implicaba previamente interesarse por el desarrollo de los pactos municipales y un tema que para cierto entrevistados podría resultar problemático: la renuncia de los candidatos andalucistas a detentar las alcaldías de Granada y Huelva a cambio de garantizar la de Sevilla en manos de Luis Uruñuela y la gestión de todas las concejalías de cultura de las ocho capitales andaluzas. Rojas-Marcos insistió en su entrevista en remarcar el papel estratégico de la ciudad hispalense y lo que podía suponer para el PSA. ${ }^{55}$ Rafael Sanmartín destacó el error de querer gobernar en aquel momento por las limitaciones que sufrían los ayuntamientos y que en su día sugirió no hacerlo si no se había alcanzado mayoría absoluta. ${ }^{56}$

Popularmente, la renuncia a la alcaldía de Granada por la de Sevilla se ha entendido po parte de algunos sectores de la sociedad granadina como un desprecio hacia las provincias de la zona oriental de Andalucía. Sin embargo, la propia decisión de los pactos de izquierda determinó que dos capitales de provincia en la parte oriental y occidental de Andalucía (Granada y Huelva) no pasaran a ser gestionadas por el PSA, lo que cuestiona esa idea. La imposibilidad de obtener la alcaldía de Granada, particularmente, tuvo un impacto especial en la militancia de base y en la opinión pública debido tanto a la percepción de "traición" ${ }^{57}$ o de "imposición desde Sevilla", ${ }^{8}$ enfatizada además por una parte de los medios de comunicación. Al margen de la rivalidad entre ciudades (el agravio comparativo con Sevilla), hay que tener en cuenta otros factores, como el esfuerzo que habían invertido las candidaturas del PSA de Granada y Huelva el diferente peso dentro de la organización de los candidatos de las tres ciudades ${ }^{59}$ y la posible condición de Granada como capital sentimental. ${ }^{60}$ No pocos almerienses, jiennenses y malagueños, cuando iniciaban sus estudios superiores, lo hacían en la Universidad de Granada, de la cual dependían los Colegios Universitarios de Almería y Jaén.

Respecto a la gestión municipal desarrollada por el PSA, Luis Uruñuela y Eladio Fernández-Nieto coincidieron en afirmar las dificultades económicas que atravesaban los Ayuntamientos de Sevilla y Granada cuando la nueva corporación democrática inició su mandato. A pesar de ello, Fermina Puertas y Concepción Fernández-Píñar resaltan los avances experimentados en prestación de servicios a los barrios periféricos y en materia de guarderías y escuelas. ${ }^{6}$

Durante un tiempo el PSA llevó la iniciativa del proceso autonómico andaluz. Sin embargo, esta capacidad se frenó a partir de la adopción del presidente de la Junta de Andalucía, Rafael Escuredo (PSOE) del discurso andalucista. En este sentido, Antonio lbáñez indicó que "no íbamos por delante, íbamos siguiéndoles a ellos [al PSOE]" 62 La campaña del referéndum del 28-f de 1980 no estuvo exenta de muchos esfuerzos individuales pues, según Ladislao Lara, se

53 Alejandro Rojas-Marcos de la Viesca, 29 de junio de 2011

54 Eladio Fernández-Nieto Fernández, 5 de febrero de 2011

55 Alejandro Rojas-Marcos, 12 de abril de 2010.

56 Rafael Sanmartín Ledesma, 12 de abril de 2013

57 Sebastián de la Obra Sierra, 23 de febrero de 2011.

58 Concepción Fernández-Piñar Lorca, 7 de mayo de 2012

59 Arsenio GUTIÉRREZ PÉREZ: El Andalucismo en la Transición. PSA-PA en la provincia de Almeria (19761982), Almería, Instituto de Estudios Almerienses, 2011, pp. 163-164.

60 Agradezco a Antonio Lombardo Lijarcio, ex militante del PSA y del Frente de la Emigración, que compartiera conmigo dicha reflexión.

61 Fermina Puerta Rodríguez, 10 y 14 de febrero de 2011. Concepción Fernández-Píñar Lorca, 7 de mayo de 2012

62 Antonio lbáñez García, 13 de abril de 2011 hizo "a costa de lomos personales" en Granada y Huelva. ${ }^{63}$ Con todo, otros andalucistas como Eladio Fernández-Nieto evocaron el notable esfuerzo que los concejales andalucistas realizaron en unión con otras fuerzas políticas y entidades ciudadanas a través de la comisión cívica municipal pro autonomía, que participó activamente en la campaña unitaria en Granada.

A partir de aquí, el interés gira en torno a otro momento controvertido: la crisis del PSA en 1980-1981. Mientras que unos la atribuyen al voto decisivo andalucista en el Parlamento a UCD, el descontento por el reparto de alcaldías, cómo se había gestionado el referéndum de 28-f y las relaciones con Rojas-Marcos, otros se refieren a la disconformidad por los acuerdos con UCD y la campaña de desprestigio contra el PSA. ${ }^{64}$

En diciembre de 1980 el PSA convocó un Congreso extraordinario, que se saldó con la expulsión de varios de sus dirigentes y la apertura de expedientes. Con independencia del destino que tomaron los militantes expulsados o que se dieron de baja, el hecho de que algunos de ellos se integraran en el PSOE, bien por motivos ideológicos (oposición al transformismo ideológico del PSA-PA, coincidencia con el ideario socialista), ${ }^{65}$ bien por interés personal, suscitó la crítica de los que afirman que el PSOE alimentaba la crisis. ${ }^{66}$ Este hecho refuerza los argumentos de algunos de los entrevistados en torno a la estrategia socialista de debilitamiento del andalucismo político y de la adopción estratégica del andalucismo por el PSOE de Andalucía (el "escuredismo").67

También en esta crisis interna las redes de afinidad y confianza influyeron en cierto modo en el posicionamiento de parte de los entrevistados ante la crisis interna. Algunos miembros de las agrupaciones provinciales de Granada y Huelva (las dos pertenecientes al sector crítico), mantenían una relación estrecha. Por ejemplo, sus dos secretarios, los psiquiatras Francisco Torres y Ladislao Lara, amigos desde su época de estudiantes en la Facultad de Medicina de Granada, donde además militaron en grupos cristianos universitarios. ${ }^{68}$

\section{Conclusiones}

La comunicación ha señalado que existen ausencias y cuestiones no resueltas de manera satisfactoria en el relato oficial del proceso autonómico en Andalucía. Hemos pretendido matizar ese relato a través de una revisión historiográfica del papel jugado por el andalucismo político, representado por el PSA. Una revisión, al margen de los tópicos sobre dicha formación política, basada en el recurso a nuevas fuentes, la confrontación de los imaginarios manejados por dirigentes nacionales, dirigentes provinciales y militantes de base y la comparación entre las distintas agrupaciones del PSA. Como señalamos al principio, nos interesaba obtener información sobre la contribución del PSA al movimiento vecinal y autonomista.

Como nuestro trabajo se presenta dentro una mesa de historia oral, hemos incidido en el análisis de los relatos de vida recogidos e historias de vida, elaboradas a partir del cruce entre dichos relatos y otras fuentes. Por tanto, expusimos la metodología seguida, consistente en realizar entrevistas semidirigidas a dirigentes del comité nacional, dos miembros de sendos comités provinciales (de Granada y Sevilla) y miembros de la candidatura al Ayuntamiento granadino. Gracias a las once entrevistas, pudimos rastrear la aparición y desarrollo del PSA en Cádiz, Granada, Huelva y Sevilla. En particular, las entrevistas nos aportaron detalles reveladores para determinar cómo se operaban los comienzos de militancia y cómo se percibió la ac-

63 Ladislao Lara Palma, 27 de mayo de 2011.

64 Luis Uruñuela Fernández, 13 de junio de 2012

65 Ladislao Lara Palma, 27 de mayo de 2011.

66 Alejandro Rojas-Marcos de la Viesca, 29 de junio de 2011.

67 Rafael Sanmartín Ledesma, 13 de abril de 2013.

68 Ladislao Lara Palma, 27 de mayo de 2011. 
tuación del partido ante los pactos municipales de la izquierda en 1979, la gestión municipal, el referéndum autonómico del 28 de febrero de 1980 y la crisis interna.

Naturalmente, construimos un relato histórico desde nuestro presente. Los acontecimientos que se sucedieron entre 2010 y 2013 influyeron en el transcurso del trabajo de campo (recogida de relatos de vida). La ficción televisiva, además, se encargó en un momento clave (elecciones generales de 2011) de fomentar a la polémica sobre los usos del pasado y la relación que mantienen sus responsables con los historiadores. Un guión de la serie "Cuéntame cómo pasó", no acorde con las circunstancias históricas del proceso autonómico andaluz, es un botón de muestra.

Para contextualizar mejor la confrontación de "memorias andalucistas", explicamos el proceso de aparición del nuevo andalucismo político, a partir de las reuniones que empezaron a celebrar los grupos liderados por Alejandro Rojas-Marcos y Luis Uruñuela en 1965. Denominadas Compromiso Político, derivaron a una preocupación especial por los problemas de Andalucía cuando este grupo se convirtió en Alianza Socialista de Andalucía. Posteriormente se constituyó en partido político, a partir de la confluencia de ASA y Reconstrucción Socialista de Andalucía, con el nombre de Partido Socialista de Andalucía.

Los relatos de vida nos permiten identificar o intuir las redes de afinidad y confianza que animaron a parte de los entrevistados a iniciar su militancia en ASA/PSA. Como rasgos comunes, podemos señalar el plantear una alternativa anticentralista a los problemas de Andalucía a través de la consecución de un poder andaluz que combatiera las lacras del paro, la emigración, el analfabetismo y la "colonización cultural", entre otras. También, el orgullo expresado en la mayoría de los casos por la experiencia militante.

Finalmente, exponemos someramente cómo reflejan estas "memorias andalucistas" momentos como las elecciones locales de 1979 y los pactos municipales de la izquierda, la campaña del referéndum del 28 de febrero de 1980 y la crisis interna del PSA entre 1980 y 1981. 


\section{ESTUDIO E INVESTIGACIÓN SOBRE LOS NATIVOS \\ NORTEAMERICANOS, PROBLEMÁTICA, ENFOOUE}

\section{METODOLÓGICO Y TEÓRICO DE LA HISTORIA ORAL}

Inge Fernández Bueno

Universidad del País Vasco de forma generalizada, sus consecuencias son palpables. ${ }^{3}$ Destacaremos dos en particular, las pautas de una nueva metodología y las fuentes orales.

La historia de los nativos norteamericanos ha sido interpretada e investigada mediante procedimientos no nativos. La metodología utilizada, en definitiva, no ha sido la correcta. Hasta hace bien poco ha existido la idea de que los investigadores de diferentes disciplinas, entre ellas la historia, tenían información y fuentes necesarias para el estudio de los nativos norteamericanos. En ningún caso consideraron que la historia oral fuese importante a la hora de analizar a los nativos, por tanto durante años estas fuentes fueron minusvaloradas. Sin duda alguna, esto plantea un problema, ya que una de las piedras angulares en las culturas nativas norteamericanas y fuente principal de información, ha sido transmitida por vía oral. Sin embargo, a raíz de los cambios anteriormente citados, han empezado a aplicarse nuevas metodologías para el análisis de la historia de esta minoría étnica.

\section{Contexto histórico, cambios en los estudios indígenas}

Durante muchos años los nativos americanos han visto como su cultura, religión y tradiciones han sido violadas y destruidas. Sus conocimientos, tradiciones y sabiduría han sido saqueadas sin piedad y utilizadas en la mayoría de casos en beneficio del "hombre blanco", habiendo sido reflejado desde una perspectiva totalmente occidental.'

Los cambios más significativos en los estudios sobre los nativos americanos fueron evolucionando acorde a la situación social que se vivió en las décadas de 1960-70 en la sociedad estadounidense. Es en esta época, cuando la lucha por los derechos civiles comienza a tener relevancia. La lucha por la autodeterminación indígena y por los derechos de los nativos, comenzó su andadura y en pocos años se obtuvieron los primeros beneficios políticos.

En 1968 el gobierno de Estados Unidos promulgó la Ley de los Derechos Civiles de los Indios. Esta ley fue precedida por la Ley de Educación y Ayuda para la autodeterminación indígena de 1975. De esta forma los nativos americanos fueron profundizando en su autogobierno y en la autodeterminación. ${ }^{2}$

El activismo nativo norteamericano también tuvo repercusión en la creación de programas de estudios nativos americanos. Así, a raíz de estos nuevos factores, en las últimas décadas se han instituido departamentos específicos para el estudio de los indígenas norteamericanos. Estos cambios han posibilitado que los nativos tengan mayor presencia en los medios de comunicación, el mundo académico o en el ámbito político. Todo ello en beneficio de beneficio de la autodeterminación indígena.

En las siguientes páginas destacaremos algunos cambios que se han efectuado en el mundo académico. Concretamente nos centraremos en la metodología indígena y especialmente en la historia oral.

\section{Estudio de los nativos americanos}

Hasta la década de 1960 los escritores especializados en el estudio de los Nativos Americanos utilizaban las fuentes escritas como base de sus investigaciones.

El estudio formal de los Nativos Americanos comenzó a principios del siglo XIX. Las investigaciones realizadas en los primeros contactos con los nativos evidencian las creencias eurocéntricas de los científicos. En estos estudios los nativos eran plasmados como salvajes que tenían que ser conquistados y socializados. La actitud paternalista y colonialista hacia los indígenas norteamericanos se arraigaría profundamente, tanto que hoy en día, aunque no

1 Alvin M. JOSEPHY JR., Joane NAGEL y Troy JOHNSON: The American Indian's Fight for Freedom, Red Power, Lincoln and London, University of Nebraska press, 1999, p. 119 .

2 Alvin M. JOSEPHY JR., Joane NAGEL y Troy JOHNSON, The American Indian's Fight for Freedom... p.119.

\section{Metodología indígena}

La metodología indígena es la regla y el postulado que se emplea para el estudio de los nativos. La tarea principal de la metodología indígena es garantizar que la investigación se hace de una manera respetuosa, ética, correcta y útil desde el punto de vista indígena.

Hasta hace dos décadas, la mayor parte de la historiografía ha estado ligada a los intereses particulares de los investigadores exclusivamente no indígenas. ${ }^{4}$ Sus resultados interpretativos han causado la pérdida de poder de los indígenas, que durante mucho tiempo han sido objetos pasivos en las investigaciones realizadas en un contexto totalmente occidentalizado. Aunque la recogida de información pueda parecer una contribución al cuerpo del saber, desde una perspectiva indígena, la recopilación de la información puede parecer un "robo", ya que el saber "robado" es utilizado en beneficio de las personas que lo han expoliado. ${ }^{5}$

Los investigadores, las comunidades nativas y el movimiento por la autodeterminación indigena proclama el poder de los indígenas (empowerment) para decidir las temáticas, los objetivos y las metodologías en relación a las investigaciones. Por tanto, es necesario un cambio en el paradigma de investigación: la utilización de enfoques y metodologías indígenas que puedan ser válidas tanto para los investigadores indígenas como para los no indígenas. ${ }^{6}$

Esta pretensión de cambio no ha estado falta de polémica. Es necesario recalcar que la procedencia del investigador nunca será un privilegio y siempre se tomará en cuenta la responsabilidad, el respeto y la corrección en el proceso de investigación que un investigador pueda tener. Es evidente que el investigador tiene que tener en cuenta que los intereses, experiencias y conocimientos de los indígenas son una parte fundamental de su metodología y parte de la construcción del saber indigena.
3 Devon Abbott MIHESUAH: Indigenous American Women: Decolonization, empowerment and activism, Lincoln and London, University of Nebraska Press, 2003, pp. 41-61.

4 Elizabeth COOK-LYNN:"Who stole the nativa studies?", Wicazo Sa Review, 23-3 (1994), pp. 9-28.

5 Linda TUHIWAI SMITH: Decoloniizing methodologies: Research and indigenous peoples, London, Zed Books, 1999, p. 40 .

6 Elizabeth COOK-LYNN: “Who stole the nativa studies"... pp. 9-28. 
Varios artículos han concretado algunos principios generales que deberían de aplicarse en los estudios: ${ }^{7}$

1. Definir la agenda para los proyectos de investigación.

2. Investigar y teorizar desde una perspectiva indígena.

3. Incluir o consultar a los indígenas, no como objetos sino como integrantes de la investigación.

El respeto y la reciprocidad son necesarios siendo inexcusable un cuestionamiento previo a las investigaciones. Reflexionar para quién se investiga, a quién pertenece el estudio, a qué intereses sirve, quién se beneficiará de ello, quién ha diseñado las preguntas o quién escribirá. ${ }^{8}$ Es necesario el compromiso para la transformación, descolonización, recuperación y el desarrollo de las comunidades indígenas.

\section{Cuestiones a tener en cuenta sobre las fuentes orales}

Aunque las fuentes orales finalmente han conseguido mayor transcendencia con la creación de nuevos departamentos sobre los estudios de los Nativos Americanos (Native American Studies), ${ }^{9}$ su recopilación y manejo no es tarea fácil y plantea nuevos retos.

La historia oral se refiere al estudio del pasado reciente a través de historias vividas o recuerdos personales, en los que los informantes hablan de sus propias experiencias, mientras que la tradición oral es la transmisión de la información que se transfiere de generación en generación. ${ }^{10}$

Recopilar, interpretar y estudiar las fuentes orales en las investigaciones puede ser complicado. Angela Cavender Wilson" sostiene que la dificultad reside en gran parte en el poco entendimiento que ha habido a la hora de comprender la visión del mundo que tienen los nativos americanos y en el empeño de utilizar los parámetros occidentales de análisis y escritura, con las que difícilmente se han conseguido estudios fidedignos.

Una de las mayores confusiones es la utilización errónea de la historia oral y la tradición oral. Los expertos ${ }^{12}$ en el tema subrayan continuamente la necesidad de diferenciar y entender que la historia oral y tradición oral no son la misma cosa. ${ }^{13}$ En el caso de los nativos americanos el término genérico "historia oral" tiene varios significados. Para los indígenas, la sabiduría indígena, narración oral o la tradición oral representan años de conocimiento que se entrelazan dentro de las culturas indígenas pasando de generación en generación. Estas historias se consideran documentos del presente porque se cuentan en el presente pero contienen un mensaje del pasado. ${ }^{14}$

Desde la perspectiva nativa, algunos autores afirman que la historia oral se encuentra dentro de la tradición oral. Angela Cavender Wilson argumenta que, por ejemplo, entre los Dakota Sioux la tradición oral alude a la manera en que la información es transmitida en lugar de

7 Justin MCDONALD: "A model for conducting research with american indian participants", en Jamie D. Davis et al. (eds.): Workgroup on American Indian research and program evaluation methodology. Symposium and research and evaluation methodology: Lifespan issues related to American dology. Symposium and research and evaluation methodology: Lifespan issues related to An
Indian/Alaska with disabilities, Flagstaff, Northern Arizona University, 2002, pp. 176-178.

8 Devon MIHESUAH: SO you want to write about American Indians?, Lincoln and London, University Devon MIHESUAH: SO you want
of Nebraska Press, 2005, p. 74 .

9 Philip DELORIA y Neal SALISBURY: “Historiography” en Philip DELORIA (ed.): A Companion to American Indian History, Oxford, Blackwell Publishers, 2002.

10 David HENIGE: Oral Hitoriography... p.2.

1 Angela CAVENDER WILSON: "Power to the spoken Word", en Donald FIXICO: Rethinking American Indian History, Albuquerque, New Mexico University Press, 1997, p. 102.

12 David HENIGE: Oral Hitoriography, London, Longman, 1982.

13 Donald FIXICO: Rethinking American Indian History, Albuquerque, New Mexico University Press, 1997, p. 102.

14 Jan VANISA: Oral Tradition as History, Madison, University of Wisconsin Press, 1985, p.xii. aludir al periodo de tiempo en que se haya narrado ${ }^{15}$. Por tanto, las experiencias personales, los recuerdos, los acontecimientos, los incidentes, y otros fenómenos pueden convertirse en una parte de la tradición oral en el momento en que ocurren o en el momento en que son dichas, siemprey cuando la persona que transmite esas ex Su empleo hace que sea necesario el entendimiento y utilización de las lenguas nativas. Es fundamental que exista un buen entendimiento entre el entrevistador y el entrevistado. Durante años la diferencia lingüística y la utilización de traductores a desempeñado en muchos casos que la recopilación de información sea más dificultosa. Para facilitar esta labor, dentro de los departamentos de Estudios de los Nativos Americanos, se ha intentado impulsar la formación en las lenguas y culturas nativas. ${ }^{16}$

La manera en que los Nativos Americanos utilizan el proceso y el contenido de la información que recolectan y preservan puede variar considerablemente dependiendo de la tradición cultural y los protocolos establecidos por cada tribu. No hay una única voz India ${ }^{17}$. Las tribus son tan diferentes como lo son la cultura Japonesa de la cultura Polaca ${ }^{18}$. Sin embargo todas las tribus comparten algunas características comunes que expondremos a continuación.

Caracteristicas de la historia oral indigena

Aunque la historia oral es algo que todas las culturas comparten, la historia oral nativa norteamericana tiene sus propias singularidades. Dada la complejidad del tema, es recomendable tener en cuenta algunos factores para la recolección de la información oral' ${ }^{19}$.

El primer factor a considerar es el uso de la memoria. La historia oral, en su definición más estándar, se basa en los recuerdos de experiencias de primera mano. La información tradicional, por el contrario, es parte de la memoria de una persona, pero no necesariamente contiene hechos vividos en primera persona del individuo que los rememora. Como David Henige ha señalado, en la tradición oral, las decisiones sobre qué recordar y quién se encargará de recordar y enseñar a la próxima generación son muy importantes, al igual que las decisiones sobre la nueva información que se adquiere..$^{20}$ Elde Stella Neff afirma que cuando se narra una historia es necesario utilizar las mismas palabras. El cambio de las palabras podría afectar el grupo entero. La memoria, aunque sea narrada por una persona, no pertenece al individuo, corresponde al colectivo, a la familia, al clan o a la tribu. ${ }^{2}$

El segundo factor afecta a los métodos para recoger la información oral indígena. Algunos cuentos tradicionales que se relatan en la actualidad, utilizan a veces el tiempo presente, y pueden representar la realidad contemporánea, pero no describen recuerdos de primera mano. El narrador, sin embargo, también puede ofrecer información de primera mano acerca de las narraciones.

15 Angela CAVENDER WILSON: “Power to the spoken Word”, en Donald FIXICO: Rethinking American Indian History, Albuquerque, New Mexico University Press, 1997, p. 103

16 VVAA: "Culturally competent research with american indians adn Alaska natives: Findings and recomendations of the first symposium of the work group on American Indian research and program evaluation methodology", The Journal of the National Center, 12 (2005), pp.1-21.

17 Devon MIHESUAH: "Voices, interpretations, and the "New Indian History": Comment on the American Indian Quarterly's special issue on writing about American Indians" en American Indian Quarterly, 20, N.1, (1996), p. 93

18 Rick HILL: "More tan feathers and casinos: Rethinking Native American education" en Cultural arts resources for teachers and students, City Lore, New york, 2003, p. 6.

19 Charles E. TRIMBLE, Barbara W. SOMMER y Mary Kay QUINIAN: The American Indian oral history manual: Making many voices Heard, Walnut Creek, California, 2008, p.16.

20 David HENIGE: Oral Hitoriography, London, Longman, 1982, p. 5.

21 Charles E. TRIMBLE, Barbara W. SOMMER y Mary Kay OUINIAN: The American Indian oral... , p. 17. 
Otro factor a tener en cuenta son los roles que los mitos y las leyendas tienen en las información indígena. Estos cuentan una versión alternativa de la historia, cada uno con un propósito diferente. Los mitos son historias cuyos orígenes se pierden en el tiempo y que son "desconocidos a nuestras experiencias o cómo sabemos que el mundo funciona". ${ }^{22}$ Las leyendas hablan a cerca de héroes populares o eventos trazables a un tiempo o época determinada. Las historias sobre la creación de los nativos americanos o la génesis del mundo, muchos de los cuales incluyen historias de inundaciones, son ejemplos de mitos. Aunque tienen un gran valor como memoria cultural no ofrecen con exactitud el tiempo o fechas. ${ }^{23}$

El cuarto factor tiene que ver con la narración de las historias sagradas. La historia oral indígena puede contener información que ya sea en forma de tradiciones o como parte de los recuerdos de una persona, tiene connotaciones divinas para el conjunto de la tribu. Cuestiones como quién puede decir la información, quién puede oírla, cómo y cuándo se puede contar o a quién se le permite el acceso a esa información, son algunas de las cuestiones más importantes para los profesionales de la historia oral indigena. ${ }^{24}$

La importancia de los protocolos es también otro factor a tener en consideración. En la tradición oral, recitar una historia va unida a unos protocolos a seguir. También es significativo el modo en que se narra una historia. La información puede ser recitada delante de un público o en una entrevista más reducida. Como parte del proceso de aprendizaje las historias son repetidas una y otra vez, ${ }^{25}$ el narrador es parte fundamental ya que es el responsable de actuar según los protocolos establecidos.

El sexto factor a tener cuenta es como estructurar una entrevista. En la teoría clásica de la historia oral, se entiende que una entrevista es un entrevistador preparado que pregunta al narrador mientras que la conversación es grabada. ${ }^{26}$ Sin embargo, en un contexto indígena, esto puede no ser válido. En el entorno nativo, las historias tradicionales pueden ser recitadas en una manera ordenada, pero no necesariamente en un formato de preguntas-respuestas. El registro de información en primera persona y utilizando el formato de entrevista puede ser valorado por los nativos como un nuevo método de reconstruir el pasado. ${ }^{27}$

Las entrevistas en primera persona pueden ser menos estructuradas. ${ }^{28}$ Es decir, puede se una mezcla de antiguos y modernos métodos de entrevista, que reflejan los patrones de comunicación culturales indígenas específicas del narrador.

No obstante, un entrevistador cualificado es, sin duda alguna, fundamental para la recopilación de fuentes orales. Sin embargo en un ámbito indigena, su preparación y el rol que juega serán diferentes. 29

El séptimo factor es el uso de las grabaciones. Los historiadores orales utilizan grabadoras para poder recopilar la información de las entrevistas. Su uso, ya sea en formato de audio o video, es fundamental para la historia oral. Mientras que los registradores hacer una copia de las entrevistas, preservando la información relatada, otros investigadores acceden a las transcripciones de las entrevistas que se han grabado anteriormente. Sin embargo, aunque

22 William SCHNEIDER:....So they understand:Cultural issues in oral history, Utah State University Press, Logan, 2002, pp. 57-58.

23 Patty LOEW: Indian Nations of Wisconsin: Histories of Endurance and Removal, Utah University Press, Logan, 2002, pp. $10-11$.

24 Charles E. TRIMBLE, Barbara W. SOMMER y Mary Kay OUINIAN: The American Indian oral..., p. 17.

25 William SCHNEIDER:....So they understand..., p. 64

26 Donald R. RICHIE: Doing Oral History: A Practical Guide, Oxford University Press, New York, 2003, p. 19.

27 Patty LOEW: Indian Nations of Wisconsin: Histories of Endurance and Removal, Utah University Press, Logan, 2002, p.11

28 Patty LOEW: Indian Nations...p.11.

29 Charles E. TRIMBLE, Barbara W. SOMMER y Mary Kay OUINIAN: The American Indian oral... p. 19. las grabaciones posibilitan una mayor accesibilidad a la información, eliminan el contacto en primera persona. ${ }^{3 \circ}$ El proceso de archivar la historia oral ayuda a grabar y preservar la memoria cultural colectiva pero también las narraciones personales e historias individuales. A pesar de que narrar historias personales no es parte de la tradición oral, muchas comunidades y tribus utilizan este proceso para recolectar información en primera persona. ${ }^{31}$

Finalmente es necesario prestar atención al procesamiento de la información. Escribir literalmente lo que se ha grabado hace que el acceso a la voz del narrador desaparezca, fundamental en las comunidades nativas. Por otro lado, también es necesario que las transcripciones estén reproducidas tanto en la lengua propia del indígena como en inglés.

Los protocolos tribales también se deberían de tenerse en cuenta a la hora de transcribir. Por ejemplo, al recopilar y transcribir las entrevistas de los Ojibwe, se respetan sus costumbres. Así, las historias de invierno se recopilan en invierno, también se procura transcribirlas y traducirlas en el mismo periodo. ${ }^{32}$

Para los Nativos Americanos la transmisión oral pueden ser recuerdos en primera persona o mensajes que se aprenden y pasan de generación en generación. Las directrices que hacen respetar la información oral, sea la tradición oral como los relatos en primera persona, pueden beneficiar a todos los miembros de las comunidades indígenas. La información en la memoria de los miembros de la comunidad, refleja como entienden el entorno, las experiencias, el poder o la identidad. La construcción de la memoria indígena no puede estar basada solo en documentos, la recopilación de historias/tradición orales es fundamental para el futuro de las comunidades nativas y su gente.

\section{Conclusión}

En resumen, los cambios políticos acaecidos en las últimas décadas han propiciado cambios políticos y sociales que en gran medida han ayudado en la creación de los departamentos de estudios de los Nativos Americanos. Esto ha impulsado un cambio en los enfoques teóricos y metodológicos y en consecuencia ha favorecido la aparición de investigaciones competentes. Todo ello ha tenido como consecuencia una paulatina recuperación del poder de los nativos sobre sus estudios y ha dado lugar al comienzo de la descolonización de los mismos.

Sin embargo, es necesario continuar con el proceso de descolonización y empoderamiento de los estudios indígenas ya que los nuevos enfoques y métodos de investigación no han reemplazado completamente los estudios de dudoso rigor científico.

Si queremos que los cambios perduren y tengan una base solida, la comprensión, colaboración y entendimiento de los investigadores tanto nativos como no nativos es necesaria, así como la utilización de métodos propiamente indígenas y el empleo de fuentes de diversa índole.

30 Charles E. TRIMBLE, Barbara W. SOMMER y Mary Kay QUINIAN: The American Indian oral... p. 19. 31 Luke ERIC LASSITER: “Kiowa: on song and memory", en Jacob J. CLIMO y Maria G. CATTELL (ed.): Social Memory and History: Anthropological Perspectives, Walnut Creek, AltaMira Press, 2002, p. 140 32 Charles E. TRIMBLE, Barbara W. SOMMER y Mary Kay QUINIAN: The American Indian oral... pp. 20-21. 


\section{EL RECUERDO DEL EXILIO. EL TESTIMONIO DE UN}

\section{EXILIADO: ANTONIO CARMONA PINTO}

Ángela González Bellver

Universitat de València

A mon pare que se'n va anar massa pronte, però que m'acompanya cada dia en els meus pensaments.

A Antonio, el protagonista d'aquesta història que malauradament no podrà veure-la publicada.

\section{Introducción y justificación}

Alguien dijo una vez que la Historia la escriben primero los vencedores, pero que después, la rescriben los vencidos. Y es verdad. No hay más que esperar: al final siempre se acaba rescatando el pasado de aquellos en el que el recuerdo ha permanecido. El Franquismo ahogó la memoria de los derrotados de la guerra civil durante décadas, pero la Transición y la posterior consolidación de la Democracia en España, hicieron que muchos abuelos y padres, se atreviesen a contar lo que habían guardado durante tantos años a las nuevas generaciones que no la habíamos vivido y que estábamos deseosos de estudiar y conocer nuestra historia.

Aunque en los libros de historia se suelen recoger los nombres de los protagonistas que se consideran relevantes, coincido con Thompsom cuando afirma que, los que verdaderamente hacen la Historia son la gente anónima, los combatientes que luchaban en el frente, las personas que trataban de sobrevivir a los bombardeos, los centenares de miles de personas que lo perdieron todo y tuvieron que exiliarse.

El historiador por excelencia en el trabajo y la utilización de la metodología de fuentes orales es, sin lugar a duda, Ronald Fraser. De él, me gustaría destacar unas palabras que pronunció en el Coloquio Internacional sobre la Guerra Civil Española que se celebró en el Palau de Congresos de Barcelona en abril de 1979. En este congreso presentó su trabajo "Recuérdalo tú, y recuérdalo a los otros", donde se recogían 250 testimonios de "gente corriente" de la Guerra Civil española

Quería ir más allá de la historia de los dirigentes, que es la que casi siempre se hace, porque los dirigentes tienen una representación política y sindical que depende y tiende más a la justificación que al reto objetivo. Me interesaba más conocer el punto de vista de la gente del pueblo, la que ha hecho realmente la Historia y la que ha sufrido más duramente sus consecuencias. Es gente que difícilmente dejará nada escrito y por eso, es importante recoger sus testimonios ahora que todavía viven.

La cuestión relativa a la guerra civil española me apasiona desde siempre. Mis abuelos vivieron la guerra, mi abuelo fue a luchar al frente y mi abuela fue represaliada al finalizar la contienda. Mis padres no la vivieron, pero si que padecieron la posguerra y la represión fran-

1 Ronald FRASER: Recuérdalo tú y recuérdalo a los otros, Barcelona, Crítica, 1979.

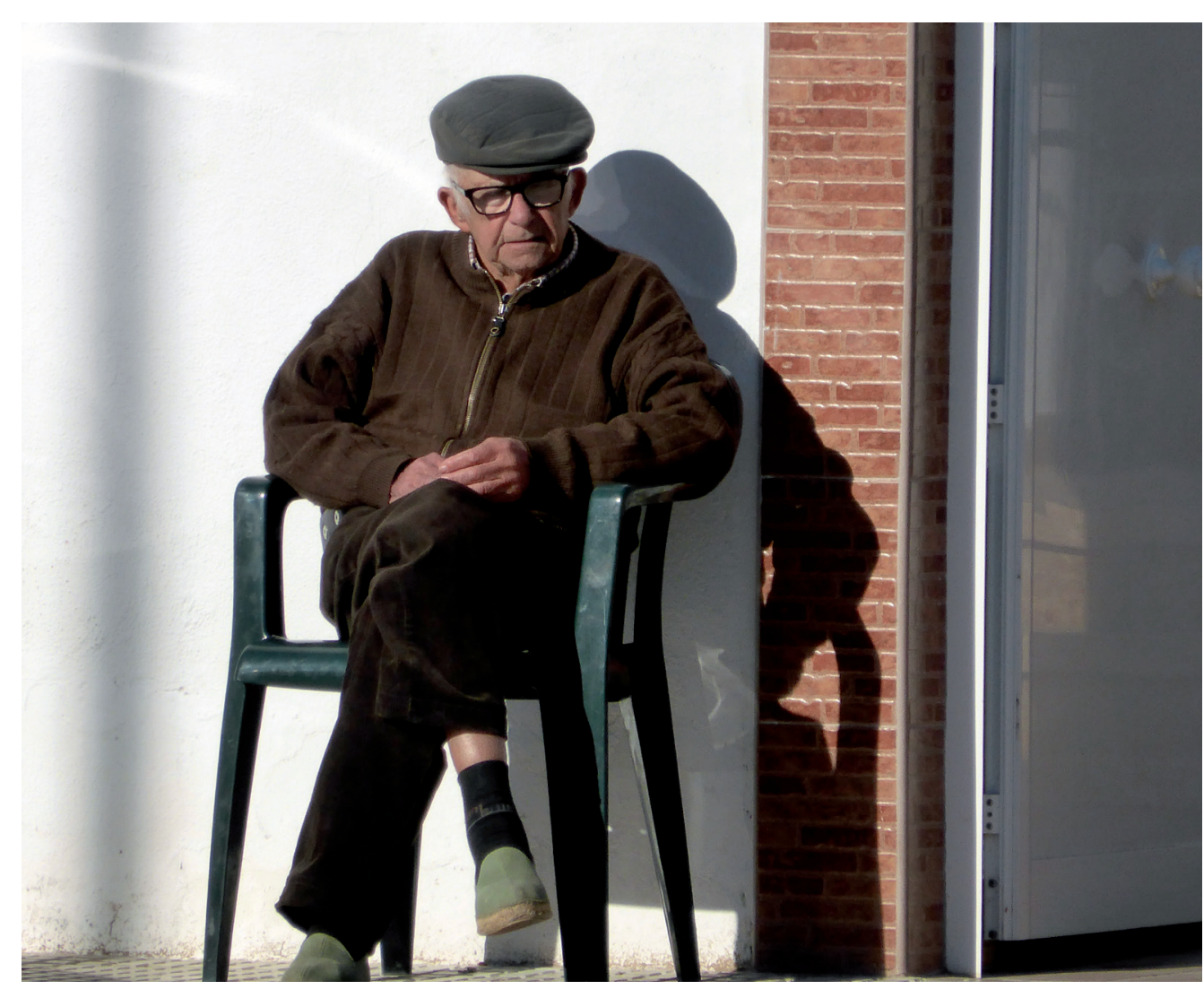

Img. 01 En su apartamento de Miramar. 20 días antes de morir (fuente: Josep Antoni Carmona, 2007).

quista. Supongo que, como muchas familias, padecieron las consecuencias de este drama. A pesar de la estrecha relación que tuve con ellos, nunca me hablaron de la guerra. Mis familiares, al igual que el resto de personas que la padecieron, no la querían recordar. Querían olvidar.

$Y$ ha sido precisamente este silencio y este olvido, el que generó que realizase la investigación sobre las vivencias de la gente corriente durante la guerra civil. Pensando en esta gente anónima, he hecho mi trabajo de investigación. En ella, se pretende hacer visible a la gente anónima de abajo que padecieron las consecuencias de las decisiones que tomaron los que estaban arriba. En ella he trabajado con 15 testimonios. La mayoría de los entrevistados pertenecen a los vencidos de la guerra. Son un grupo de personas heterogéneo que vive en diferentes municipios de la provincia de Valencia. Hombres y mujeres de familias trabajadoras, algunos militantes del Partido Comunista, otros miembros de la CNT... De ellos, he elegido el testimonio de Antonio Carmona Pinto. Él vivió el exilio francés en primera persona. Nos aporta un punto de vista mucho más positivo del que se suele tener sobre la diáspora republicana. Si bien tuvo que abandonar España junto a toda su familia, la situación vivida en Francia fue mejor que la del resto de españoles que tuvieron que padecer los campos de concentración franceses. Por eso expongo aquí su vida, ya que él nos dará una visión diferente del exilio de los vencidos.

\section{El recuerdo del exilio. El testimonio de un exiliado: Antonio Carmona Pinto}

Antonio² (Img. 01) nació el 15 de abril de 1932 en Rodas de Andalucía, provincia de Sevilla. Aunque es andaluz de nacimiento, se considera valenciano de adopción pues ha vivido, la mayor parte de su vida en Valencia y aquí ha formado su familia. Después de la rebelión militar del 17 y 18 de julio de 1936, España quedó rápidamente dividida en dos bandos, el leal a la República y

2 Antonio Carmona Pinto, 13 de febrero de 2012, Xàtiva, entrevista realizada por Ángela GONZÁLEZ BELLVER. 
el sublevado. A Julián Carmona, el padre de Antonio, le tocó ir a luchar en el frente defensor del gobierno republicano. Como por el pueblo se escuchaban comentarios de las barbaridades que los nacionales ${ }^{3}$ estaban haciendo por los pueblos de alrededor, por el simple hecho de ser tildado de rojo, "y aunque no hubieses hecho nada", su padre aterrorizado, le dijo a su madre que por el bien de la familia, él se iría. La madre de Antonio no se lo pensó ni un momento, le dijo que "si te vas tú, nos vamos todos". Ante esta situación, la familia entera -el padre, la madre, Antonio y su hermana que era un año menor que él-, decidió emprender un largo viaje. Como relata Antonio, "Le dejamos las llaves de mi casa a la hermana de mi abuela y nos fuimos".

Tengo que puntualizar que la madre de Antonio estaba embarazada en el momento de hacer el viaje. Así pues, cogieron el tren y partieron hacia Málaga, donde estaban todos los refugiados en ese momento. Alli estuvieron entre 8 y 9 meses. Antonio recuerda muy bien el ruido de las bombas que escucharon en el camino "tenía cuatro años pero lo recuerdo como si fuese ayer". Durante este tiempo, pasaron muchas penurias, calamidades y permanecieron concentrados con muchísima gente. Todas estas condiciones, junto al hecho de que la comida escaseaba, propiciaron que la hermana más pequeña, recién nacida, muriera a los tres meses de vida.

Cuando los rebeldes iban a entrar a Málaga, una gran parte de la población se fue. Aquí se produjo uno de los capítulos más crueles de la Guerra Civil: los destructores Gran Canaria y Baleares, bajo las órdenes del admirante Carrero Blanco, bombardearon a toda la marea humana que se dirigía a Almería, sabiendo que se trataba de población civil.

Como sabían que en cuanto llegasen a Almería "estarían esperándonos" y ante estas circunstancias, decidieron hacer el trayecto de Málaga a Almería a pie, campo a través. Durante el trayecto, como Antonio y su hermana eran unos niños, iban en la espalda de sus padres "como si fuera un macuto". Durante el viaje, a Antonio se le quedaron grabadas dos escenas que no ha podido olvidar nunca en su vida:

Recuerdo perfectamente, que debajo de un algarrobo, había una familia entera, con sus hijos que habían muerto por los bombardeos, me acuerdo como si lo estuviese viendo. Los niños llevaban el babi con rayas azules de ir a la escuela. No lo he podido olvidar nunca. Otra escena que me impactó mucho fue, que un guardia de asalto que también estaba huyendo y nos acompañaba en el viaje, sacó su pistola y ante la angustia y la desesperación de la huida, se pegó un tiro. Mis padres y mi madre vieron más cosas, yo era solo un niño, pero estas dos escenas que presencié, me han acompañada a lo largo de mi vida.

Con este relato se puede observar la situación de terror que se fue extendiendo durante los primeros meses de la guerra. Este miedo fue el que provocó que Antonio y su familia abandonasen su pueblo y lo dejaran todo. Tengo que puntualizar que durante la entrevista, Antonio me comentó que durante toda su vida, estuvo comentándole a su hermana que él siempre pensó que, aunque se hubiesen quedado en el pueblo y, al estar ellos libres de delitos de sangre, no les hubiese pasado nada. Ouizás el discurso del dictador Franco cuando pronunció "todo aquel que no tenga delitos de sangre que no padezca" le influyera en esta idea. Este mismo miedo, hizo vivir situaciones de desesperación entre la población civil. El mismo miedo por ejemplo, creó el caos en los puertos de Gandía y Alacant, donde se reunieron miles y miles

3 Los instigadores de la rebelión, los generales Mola, Franco y Queipo de Llano, aplicaron en España el terror ejemplarizante que habían aprendido a emplear en el norte de África. Cuando el genera camezas clavadas en sus bayonetas. Durante la Guerra Civil, el terror del ejército africano se desplegó por la Península como instrumento de un plan frí mente calculado para a poyar un futuro régimen dictatorial. Paul PRESTON. El holocausto español Odio y exterminio en lo Guerra Civily después, Madrid, Debate, 2011. de personas que querían embarcar camino del exilio ante la inevitable derrota de la República en 1939. Esto generó, que mucha gente, ante la desesperación de la situación se suicidara. Nuestro entrevistado, Antonio Carmona, fue testigo de uno de estos suicidios, aunque en lugar y tiempo diferente. Lo que él presenció fue la antesala de lo que más tarde se repetiría.

Otra experiencia significativa en la vida de Antonio tuvo lugar en Almería. Cuando estaban alli, les estaba esperando un barco para llevarse a los refugiados. Como eran miles de personas, y ante la desesperación de la situación, Antonio se soltó de la mano de su padre y se perdió. Sus padres le buscaron desesperados por dentro y fuera del barco y afortunadamente, le encontraron y todo quedó en un susto, pero los momentos de angustia fueron muy grandes. En este mismo barco fueron a Roses, un pequeño pueblo pesquero de la provincia de Girona. "No te puedo decir exactamente cuanto tiempo, pero unos cuantos meses", apostillaba Antonio. Después, se trasladaron a Figueres. Aquí se quedaron unos cuantos meses más hasta que su padre tuvo que volver al frente. En Figueres Antonio contrajo unas fiebres altísimas, hasta el punto que el médico le dijo a su madre que no pintaba nada bien y que Antonio estaba muy grave. Ante esta situación, su madre le escribió una carta a su padre, en ella explicaba que el niño estaba muy enfermo, en la que según Antonio "me estaba muriendo". Julián pidió permiso a sus superiores para ir a ver a su hijo pero ante la negativa, desertó del ejército para ir a ver al niño. "Mi padre estuvo encerrado por los dos bandos: por deserción por parte de los republicanos - totalmente comprensible pues su hijo estaba gravemente enfermo-,y por parte de los franquistas - como veremos a continuación". Por fortuna, Antonio se restableció y su padre volvió al frente.

En 1939, casi acabando la guerra ya, Julián se reunió con la familia en Figueres. Allí les dijo que se fueran a Francia y les prometió que él se reuniría más tarde con ellos, que los buscaría y los encontraría. Aquí empieza el viaje por los Pirineos (Img. oz). Antonio tenía ya casi siete años. La marcha se realizó en invierno. Se fueron Antonio, su madre, su hermana y un grupo más de pueblo y de los pueblos de alrededor. Muchos fueron los españoles que hicieron este trayecto, con miedo por si les sorprendían los rebeldes, con la oscuridad de la noche, con hambre, con el ruido de las bombas y con el aire frío que soplaba de las montañas nevadas. Este camino

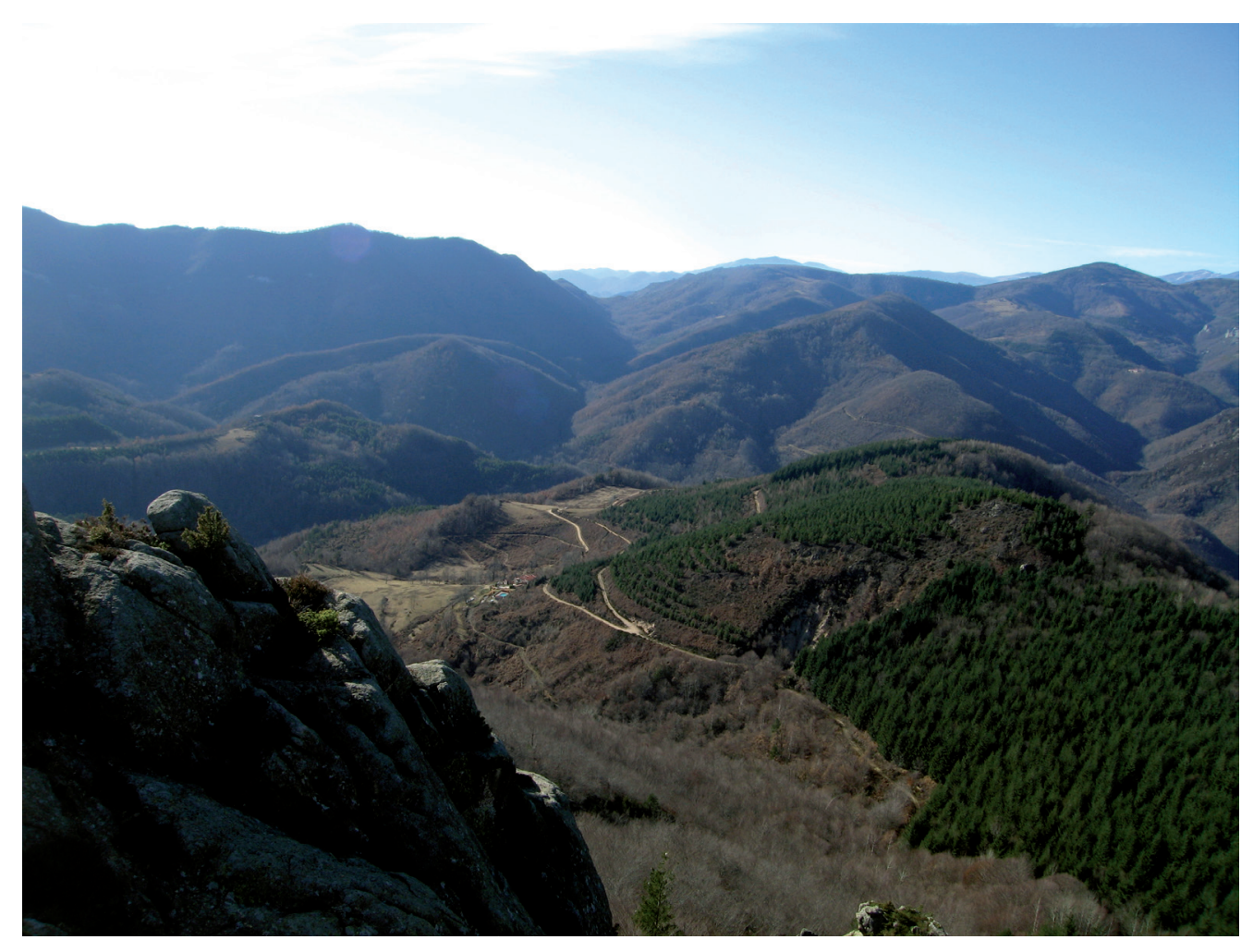

Img. 02 El recorrido por donde pasaria No me lo pudo asegurar pero de no ser asi sería muy similar (fuente: Josep Antoni Carmona, 2007). 


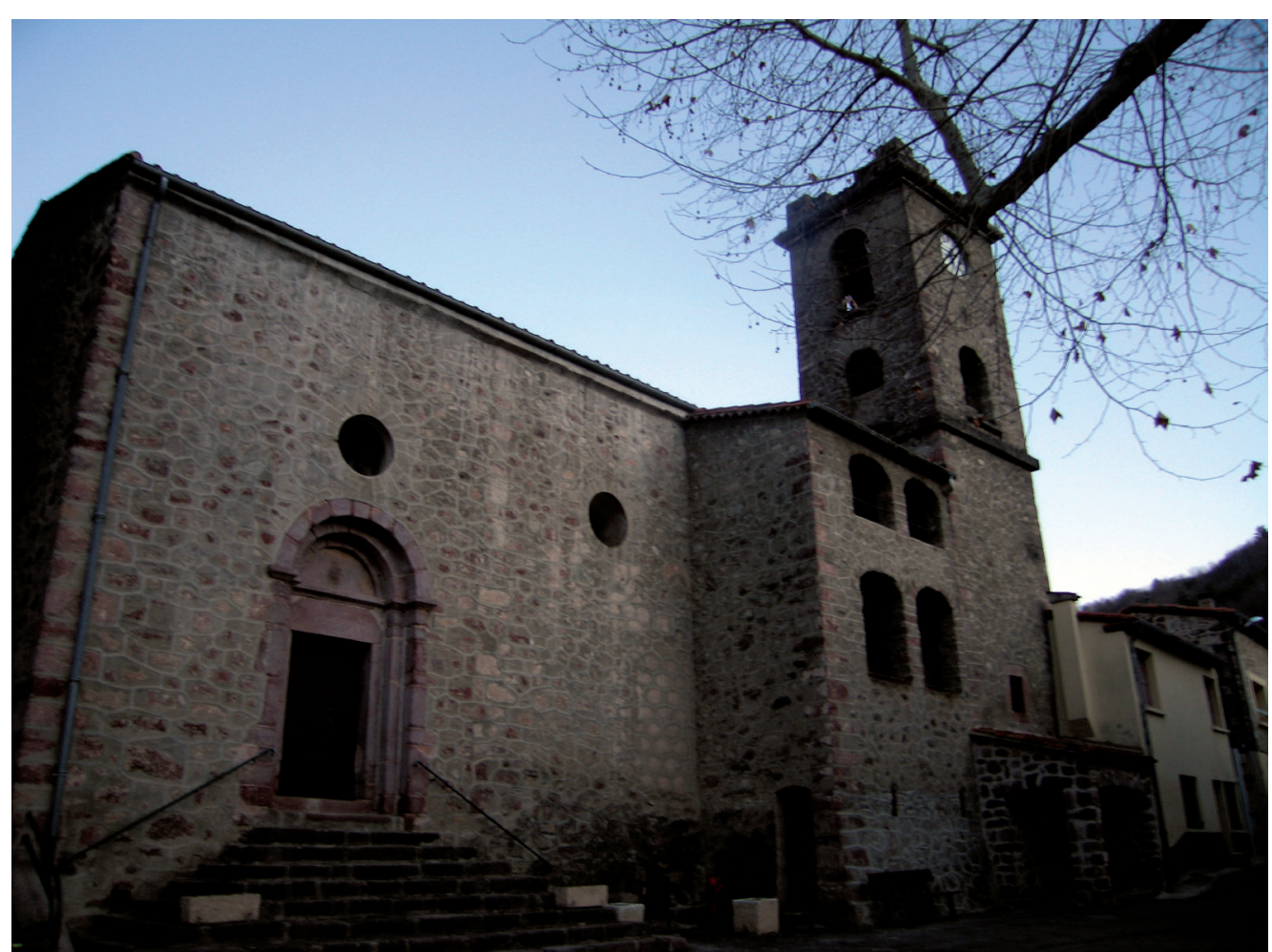

Img.03 La iglesia en la que fue acogido Antonio los primeros días. Población La Menera la localidad más meridional de Francia y la primera que se ve desde Figueres que es de donde partió Antonio (fuente: Josep Antoni Carmona, 2007).

que hicieron a pie durante varios días, les salvó de ir a parar a los campos de concentración franceses. Ellos no cruzaron por La Jonquera, donde los españoles que sí que lo hicieron, eran sistemáticamente transportados a los campos de reclutamiento.

Yo sé que hubo mucha gente que fue a los campos de concentración franceses, lo he podido saber muchos años después leyendo los libros. Mi hijo me lo ha dicho también muchas veces -el hijo de Antonio es profesor de secundaria de lengua y literatura catalana-. Sé que padecieron mucha hambre, frío y enfermedades, pero ese no fue mi caso. Yo tuve la suerte de poder evitar los campos e ir a un pueblo con una familia donde me trataron muy bien.

La diáspora republicana provocó que, durante la guerra y sobre todo, a partir de 1939, medio millón de personas abandonasen España. Aunque fueron muchos los destinos que se eligieron para hacerlo, fue Francia el país que mayor número de exiliados acogió. En él, no todos tuvieron la misma suerte. Si bien es cierto que muchos volvieron al cabo de poco tiempo, otros padecieron los campos de reclutamiento y posteriormente, el estallido de la Segunda Guerra Mundial en la que se vieron obligados a alistarse en el bando francés que luchó contra el nazismo. También hubo algunos "privilegiados" que corrieron mejor suerte. Este fue el caso de Antonio y de su familia.

Llegados a Francia fueron a parar a una aldea muy pequeña "no me acuerdo exactamente del nombre". Aquí fueron bien recibidos y pasaron varios días:

Recuerdo que, al llegar a Francia, fuimos a una iglesia, (Img. o3) ¡qué calor tan bueno! ¡Nos dieron chocolate caliente con churros! ¡Que bueno! Después del frío que pasamos por los Pirineos. Al cabo de unos días, llegaron unos camiones y nos tomaron la filiación, los datos personales, sobre todo a los más pequeños y también la destinación que íbamos a tener cada uno y, nos trasladaron al interior de Francia.
Estos camiones iban repartiendo a los refugiados a lo largo de los pueblos franceses. En los pueblos diferenciaban a las madres que iban a unas casas y a los pequeños, que iban a otras. Antonio y su hermana fueron a Molières, (Img. o4) un pueblo de la provincia de Montalbanc. A los dos hermanos les ubicaron en casas diferentes donde estaban durante el día, pero por la noche se reunían con las madres. Cuando le preguntas a Antonio que cómo le trataron en su casa, se emociona hasta el punto que tuvimos que parar la grabación: "¡Como a un hijo! Era el niño de la casa. Era un matrimonio que tenia los hijos ya mayores y yo era el juguete de la casa. Recuerdo que tenían una tienda y que todas las mañanas me decían "allez», e íbamos repartiendo los encargos con la furgoneta por todos los pueblos de la cercanía". Antonio también iba a la escuela y rápidamente aprendió francés.

El tiempo pasó y su padre cumplió la promesa que les hizo antes de partir: les encontró. No hay palabras para describir la emoción y felicidad que transmitía Antonio cuando me contaba esto. Allí la familia pasó unos cuantos meses más, hasta que Julián, pudo encontrar trabajo. Julián pudo encontrar trabajo en la obra, y aunque su sueldo no les daba para vivir en la abundancia, éste, junto a la ayuda inestimable de la familia francesa, hizo que poco a poco fueran saliendo adelante.

La Guerra Civil española terminó en 1939. El resultado y la historia de la misma son bien conocidos por todos. Al cabo de unos siete u ocho meses, la familia de Julián le convencieron para que volviesen todos a España:

Nos decían que volviésemos, que nosotros no habíamos hecho nada y que no teníamos por qué sufrir. Al final tomamos la decisión de volver. ¿Y no teníais miedo a las represalias? -le pregunté yo-. Al principio si, pero añorábamos España. La tierra siempre es la tierra y, convencidos de que nos pasaría nada, decidimos volver al pueblo y no emigrar a Argentina. ¿Argentina, pregunté yo extrañada? Mi abuelo materno dejó a mi abuela y se fue a Argentina. Alli formó otra familia. A pesar de todo, mi madre siempre mantuvo el

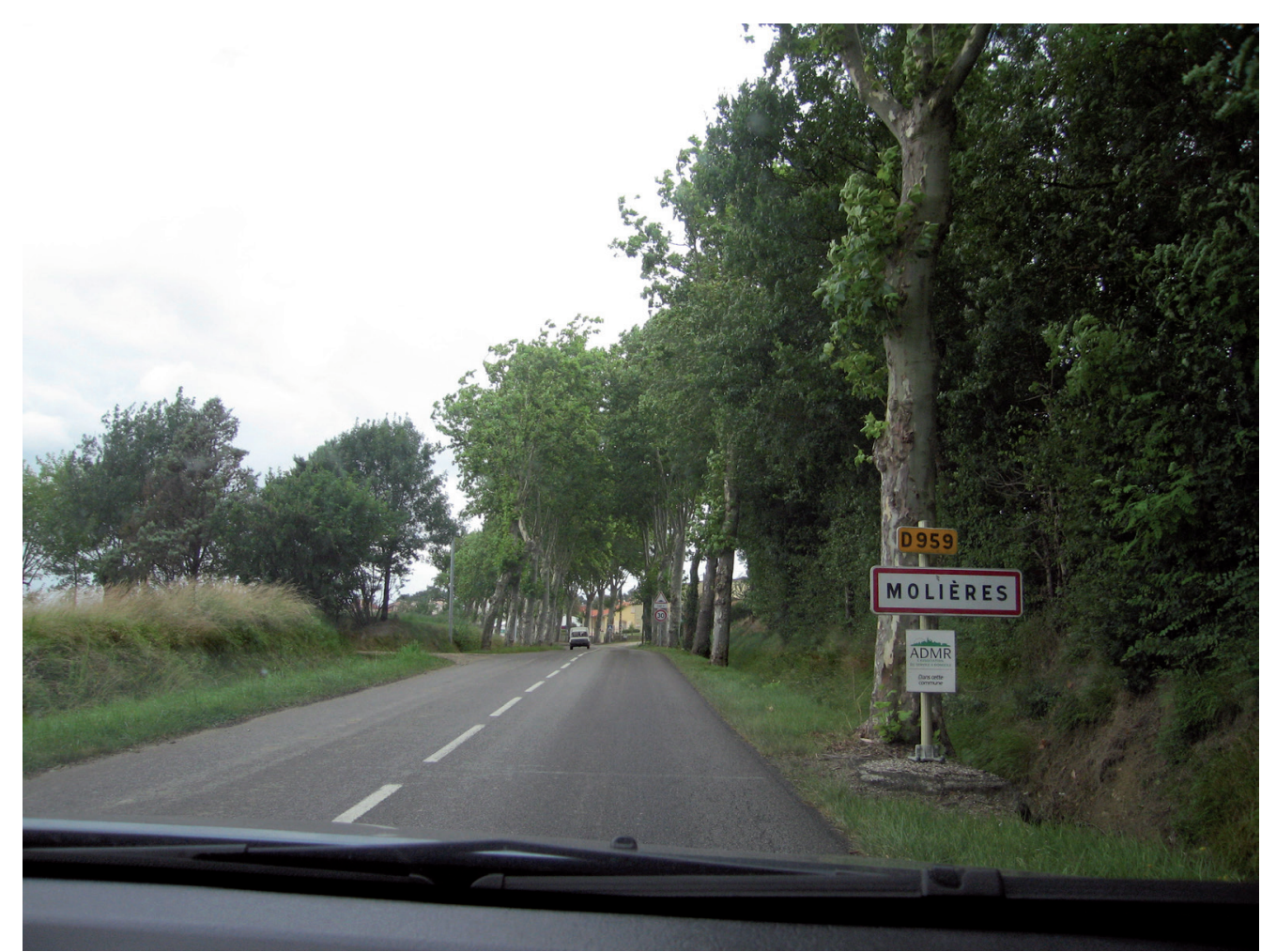

Img o4 Es la entrada del pueblo francés donde fue llevado y donde vivió con la familia francesa (fuente: Josep Antoni Carmona, 2007). 
contacto con él. Ella le escribió una carta contándole nuestra situación y si podríamos ir a Argentina con él. Mi abuelo le dijo que si, que él le mandaría dinero para comprar los pasajes de ella, de mi hermana y mío pero no el de mi padre. Ante esta condición mi madre se negó. Este fue el detonante por el que la familia decidió regresar al pueblo.

Antonio me contó emocionado que cuando su padre le dijo a su familia francesa que volvían a España, el padre francés les dijo que no se fueran. "Allí no será igual, no sabéis lo que os puede pasar. Aquí Antonio se hará un hombre, nosotros os ayudaremos en todo lo que podamos". Estas palabras las escuchó Antonio y se puso a llorar, nunca ha podido olvidarlas. Aún se emociona cuando las recuerda y las cuenta. Por desgracia la relación no continuó y acabó perdiéndose. Hay que tener en cuenta que, a pesar de la familiaridad con la que les trataron los franceses, la situación en España era muy difícil. Una guerra, una posguerra y la Dictadura, con la cruel represión y censura que, complicaba mucho la comunicación con el exterior, y que propiciaron que la relación se acabara.

Así pues, la familia regresó al pueblo. Fueron con un tren de mercancías, con animales y así cruzaron toda España. Cuando llegaron, fueron a pedirle las llaves a su tía. "Recuerdo que mi casa estaba llena de polvo, jhabía estado cerrada cinco años! Y así como pudimos, pasamos la primera noche".

Al día siguiente, a las ocho y media de la mañana llamaron a la puerta. Era la Guardia Civil que detuvo y se llevó a su padre. Era un pueblo muy pequeño, de unos 3000 habitantes y las envidias entre unos y otros eran muy grandes. Además, las delaciones estaban al orden del día. Muchos de los entrevistados coinciden con Antonio cuando afirman que "en el pueblo había mucha gente que se dedicaba a delatar a los propios vecinos". Y esta situación era una constante ya que todos los entrevistados lo indican y son, como se ha indicado anteriormente de diferentes municipios valencianos. Era como muchos autores han calificado, una sociedad espía de sí misma. ${ }^{4}$ A Julián se lo llevaron a Estepa, a 19 kilómetros del pueblo de Antonio. Una semana después se lo llevaron a la prisión de San Roque y allí estuvo encerrado durante más de un año. Durante todo este tiempo, la familia solo pudo verlo una vez antes de que se lo llevaran a la cárcel. Cuando pasaron estos 22 meses aproximadamente, su padre pudo volver a casa pero, "ya estaba marcado, ya era un rojo que había estado encerrado en prisión".

Durante la Dictadura, la represión franquista no consistió "solo" en la eliminación física del contrario. Los vencidos quedaron marcados. Así por ejemplo, otros de los testimonios entrevistados, coinciden con Antonio en afirmar que nadie les quería dar trabajo. En el mejor de los casos, si conseguían encontrarlo, era siempre en peores condiciones y con salarios más bajos que el resto de gente. Así por ejemplo, nos narran que los años posteriores a la salida de los padres de prisión fueron muy duros. Nadie quería darle trabajo a un rojo que había estado encerrado en la cárcel. A parte de las ejecuciones en juicios sumarísimos, estaban también las humillaciones a las que eran sometidos como el rapado del pelo a las mujeres e hijas. Por otro lado, en las escuelas franquistas, la diferenciación entre los hijos de unos y los hijos de otros eran enormes. No solo por parte de los profesores, "todos los que venían de una familia que había tenido un pasado familiar oscuro estábamos discriminados en el día a día", sino también entre los propios compañeros de clase donde eran frecuentes los insultos, y las frases del tipo "eres el hijo de un preso rojo".

Antonio y su familia sufrieron toda esta discriminación. Bajo el estigma de rojos, en el pueblo las cosas les iban mal. "Siempre estaban machacándonos, éramos rojos". Por este motivo, Julián le escribió una carta a su hermana que vivía en la Llosa de Ranes, para ver si podian ir a vivir alli. "En Sevilla solo teníamos olivas, no teníamos futuro". Así que malvendieron la casa que la tenían embargada por 12.000 pesetas de la época -hablamos de finales de 1946 principios de 1947 - y la familia se fue. Tardaron tres días en llegar a Xàtiva en tren. Cuando llegaron se quedaron en una casita de campo los cinco, pues la familia había aumentado con el nacimiento del hermano pequeño en 1944. Las 12.000 pesetas se terminaron enseguida. Como en La Llosa no tenían trabajo fueron a Xàtiva donde, en principio, al ser un pueblo más grande, iban a tener más posibilidades. Aquí se instalaron, en la habitación de una casa por la que pagaban 100 pesetas al mes de alquiler "mucho dinero para la época". Aquel invierno fue cruel en Xàtiva, con mucho frío y una gran nevada. En esta habitación pasaban mucho frío y además, estaba llena de goteras asi que, se fueron a una casa sin nada, donde por no tener no tenían ni para calentarse, se calentaban con paja. "No teníamos ni mantas, nos tapábamos con sacos". Poco a poco fueron saliendo adelante. Su padre encontró trabajo en un pueblo de al lado, de albañil y Antonio empezó a trabajar con él:

Mi padre salía por las mañanas antes que yo, para ver si encontraba alguna naranja y poder comérnosla. Todos los días hacíamos el trayecto a pie, 9 kilómetros para ir y 9 kilómetros para volver. Un día, a mi padre, que había conseguido comprar un kilo de uvas gracias al estraperlo de la época, le paró un cabo de la Guardia Civil, se lo quitó, lo tiró al suelo, lo pisó y le pegó dos bofetadas sin más... En aquella época, mi padre y yo trabajábamos de sol a sol y él ganaba 15 pesetas al día y yo 7,5 pesetas porque trabajaba de ayudante; les llevaba el agua, la arena... Para que te hagas una idea, un kilo de harina valía 25 pesetas, ¡con el jornal de todo un día, entre los dos, no teníamos suficiente!

\section{Conclusiones}

La investigación realizada con diferentes testimonios, nos permite ver, la percepción y memoria de las personas. Nos permite comprobar, cómo han elaborado estas personas en su memoria, en sus recuerdos, los hechos vividos.

Del mismo modo, los testimonios recogidos, nos permiten conocer las experiencias vividas por las personas. Estas experiencias que son propias, coinciden muchas veces con otros testimonios y relatos al salir a la luz y al darse a conocer. Es el caso por ejemplo de la discriminación que sufrían en el día a día por ser estigmatizados por rojos, o el hecho de que por una delación, tuvieron algún familiar detenido o represaliado.

No hay que olvidar tampoco que, en una narración conversacional, las voces de los entrevistados están atravesadas por el momento histórico en que se producen pero también, por los ojos que miran al pasado y en consecuencia, tiempo histórico, personal y familiar interactúan en el relato. Por todo esto podemos afirmar que, las fuentes orales, son particularmente apropiadas para aproximarnos a la experiencia de los sujetos y al significado de los acontecimientos.

Por otro lado, en una disciplina como la Historia en donde se venera el documento escrito, la fuente oral y la memoria de las personas, nos permiten conocer los hechos que no quedan reflejados en el papel del registro, archivos o hemerotecas. Éste ha sido durante demasiados años, el caso de los sujetos olvidados por la Historia: minorías étnicas o de cualquier otro tipo, mujeres, vencidos de las guerras...Por todo esto, las fuentes orales son necesarias para rescatar el valor del testimonio como fuente válida para la reconstrucción histórica. Solo escuchando a todos los sujetos que forman parte de la historia se puede construir la verdadera Historia. Por último, me gustaría terminar estas conclusiones con una cita de Walter Benjamín que leí hace ya algún tiempo: "Honrar la memoria de las gentes anónimas es una tarea más ardua que honrar la de las personas célebres. La idea de construcción histórica se consagra a esta memoria de los que no tienen nombre".

$$
\text { me }
$$




\section{VOCES PERDIDAS... Y RECOBRADAS. LA INVESTIGACIÓN \\ DE LA II REPÚBLICA, LA GUERRA CIVIL Y LA REPRESIÓN \\ A TRAVÉS DE LA HISTORIA ORAL. EL CASO DE UNA \\ COMARCA ANDALUZA: ANTEOUERA}

Miguel Ángel Melero Vargas

Universidad de Málaga

Fundación Alfonso Perales

Introducción. ¿Por qué una historia oral de la República, la Guerra y el Franquismo en Antequera?

Toda historia tiene un principio, y el de la investigación que para el caso de Antequera hemos desarrollado desde hace casi una década y que cristalizó hace pocos meses en nuestra Tesis Doctoral', surge de la necesidad de dotar de contenido un vacío informativo relativo a la etapa que comprende desde los prolegómenos de la proclamación de la Segunda República al proceso de instauración y consolidación del Franquismo.

Una investigación para la que, junto a las fuentes tradicionales escritas, así como aquellas proporcionadas por los avances tecnológicos, ha resultado absolutamente fundamental el empleo de los testimonios personales o relatos de vida como una fuente primaria y directa más, para complementar y completar vacíos incapaces de ser llenados por las otras.

Por ello la presente comunicación pretende ser una reivindicación de la importancia y eficacia ya demostrada del empleo de la fuente oral, a través del estudio de la experiencia de la República, la Guerra y el Franquismo en esta paradigmática comarca andaluza, y a través de protagonistas que de alguna manera, y con independencia de su situación, tanto en la etapa republicana, el estallido de la sublevación, el desarrollo de la guerra, o el inicio de una nueva realidad impregnada por el Franquismo, habían permanecido silenciados, y por tanto, desaprovechados para un mejor conocimiento de esta etapa en la zona antequerana.

En este caso, hemos llevado a cabo una selección de treinta y tres protagonistas -veinticinco hombres y ocho mujeres- con una fecha de nacimiento que oscila entre noviembre de 1911 y enero de 1938, naturales de los nueve municipios y anejos que conformaban el término antequerano, y adscritos socioprofesionalmente en su mayoría a una clase obrera jornalera, trabajadora del campo -hablamos de una comarca netamente agraria y latifundista- y por ello destinatarios también y en sus diferentes grados e intensidades, de un voraz proceso represivo sublevado y franquista, y que paradójicamente solo había sido reflejado, de una forma atenuada e indirecta, e incluso justificada, por las fuentes acuñadas por los de alguna forma agentes de esa represión.

Sin embargo, también recogemos los casos de aquellos que, aún sin alejarse en exceso de esta categorización social, fueron testigos de otras realidades y protagonistas de otras circunstancias, como por ejemplo su contrariedad ante la labor de los comités en la retaguardia republicana, su encuadramiento como voluntarios dentro de fuerzas militares sublevadas, o su vínculo con sectores perseguidos como parte de la violencia desatada en la guerra, como el estamento religioso.

1 Miguel Ángel MELERO VARGAS: (2013): De la Esperanza al Sometimiento. II República, Guerra Civil y Primer Franquismo en una comarca andaluza. El caso de Antequera, Tesis Doctoral, Universidad de Málaga, 2013.
En definitiva, una compilación de testimonios que pretenden contribuir a un conocimiento más completo y objetivo de una etapa que para el caso de Antequera solo se había mostrado a través de una información escasa, y además sesgada ideológicamente.

\section{Un estado de la cuestión que reafirma un propósito}

En la que es considerada como una de las obras míticas dentro del estudio de la Guerra Civi española, por su carácter pionero y precursor en el empleo de las fuentes orales para la investigación histórica del conflicto español, Blood of Spain, cuya traducción al castellano cristalizaría como Recuérdalo tú y recuérdalo a otros. Historia oral de la Guerra Civil Española, Ronald Fraser lanzaba una cuestión que él mismo se encargaría de responder: “De quién es la Historia? ¿De quienes la han vivido o de quienes la han escrito? Ni de unos ni de otros, porque no pertenece a nadie, sino que es un debate continuo, de duración indefinida".2

Entendemos sin embargo que la Historia pertenece a todos, y que desde luego todos contri-

buyen a ese debate que la enriquece, la perfecciona, y la convierte en un valor de uso colectivo.

Pero sí que es cierto que, dentro de esta pertenencia compartida, y fundamentalmente en el caso concreto del empleo e investigación de las fuentes orales, concurren actores que desarrollan un protagonismo especial en ese diálogo que se establece entre pasado y presente una "cata en el presente del pasado"3, entre la experiencia y la construcción de la memoria, personificadas ambas en las figuras del testigo y el historiador.

Y dentro de éstos, con un protagonismo especial para los que el propio Fraser, en la entrevista concedida al periódico El País el 17 de abril de 1979, día de la presentación de la mencionada obra en España, calificaba como "gente corriente... que no deja constancia de su existencia en documentos y escritos... que hace la Historia y que la sufre, pero que no aparece en los libros de Historia tradicionales". 4

Así, juntos, testigo e historiador, protagonistas ambos, debían recorrer ese camino "serpenteante e inesperado"s dentro de la construcción de la memoria, como lo definiera la profesora Mercedes Vilanova ${ }^{6}$, y sobre el que incluso Fraser, en la mencionada entrevista, atribuye un escalón más en la importancia del proceso, el de restitución, lo que podría llevarnos a elevar también el papel del historiador como arqueólogo de la memoria.

Se iniciaba por tanto, y con la primera obra, el debate en torno a la aparición de esta considerada como variante dentro de la investigación histórica, de su terminología y conceptualización, de su fiabilidad para la construcción del proceso cognoscitivo, epistemológico; en definitiva de su dimensión y su validez, pero sin poner en ningún momento en tela de juicio los que eran principales actores del proceso, sobre los que recaería la responsabilidad conjunta de la creación "de nuevos saberes a través de la creación de nuevas fuentes históricas" 7 y donde resultaba fundamental la relación de confianza entre el testigo y un histo-

2 Del Prefacio a la edición de 2005. Ronald FRASER: Recuérdalo tú y recuérdalo a otros. Historia oral de la Guerra Civil Española, Barcelona, Planeta, 1979.

3 Fernando ARCAS CUBERO (Dir.): Yo estaba alli. Una historia oral de la Guerra Civil y el Franquismo en Málaga, Sarriá, Málaga, 2011, p. 12

4 Ronald FRASER: "Mi libro trata de restituir la historia al pueblo español", El País, 18 de abril de 1979. La entrevista puede ser además consultada en www.epais.com/diario/1979/04/18/sociedad/293234412 $850215 \cdot h t m l$

5 Lucía PRIETO BORREGO y Encarnación BARRANOUERO TEXEIRA, Encarnación: Población y guerra civil en Málaga: caída, éxodo y refugio. Málaga. CEDMA, 2007, p. 14.

6 Mercedes VILANOVA: "La historia presente y la historia oral. Relaciones, balance y perspectivas", Cuadernos de Historia Contemporánea, 20 (1998) pp. 79-113.

7 Fernando ARCAS CUBERO (Dir.): Yo estaba alli..., p. 15 . 
riador que debe escuchar más que preguntar ${ }^{8}$, creando una atmósfera proclive al diálogo, y del que posteriormente obtenga la información.

Sin embargo, y junto a la obvia necesidad de base de aquiescencia entre testigo e investigador, debían tenerse en cuenta otros parámetros que han ido siendo desgranados en los diferentes trabajos que componen la prolífica bibliografía generada por esta temática desde hace dos décadas, y que desde luego han permitido ir superando debates y de paso eliminando mitos y complejos acerca de una disciplina fundamental para la investigación en Historia Reciente.

Así por ejemplo el surgido entre objetividad y subjetividad, que no es sino el resultado de la confrontación entre el rechazo a esta Historia Oral, Relatos de Vida o parte de una Historia sin Adjetivos ${ }^{9}$, por parte de la historiografía tradicional, y su abrazo por parte de la denominada como Nueva Historia. ${ }^{10}$

También de los que resaltan el carácter falible de otro actor fundamental en el proceso, la memoria, el recuerdo, centrando su crítica a la Historia Oral en el hecho de que ésta se basara en algo tan fluctuable como la memoria, así como que el recuerdo llevaba aparejado el error."

Pero también podía transmitir acontecimientos veraces, residiendo en este hecho lo que Portelli entendía como función principal del historiador, establecer la relación entre los hechos contrastados y la subjetividad. ${ }^{2}$

De nuevo pues, la subjetividad, que el propio Portelli definiría como "premio y maldición de la Historia Oral"13, y sobre la que el historiador debía establecer su otra gran labor en el proceso, la captación de esa subjetividad y su separación para la depuración del proceso cognoscitivo; una labor realizada a través del análisis detenido de los relatos, de la búsqueda de coincidencias constantes que, a través de la evolución desde las líneas de fuerza pertinente a los puntos de saturación ${ }^{14}$, establezcan coincidencias repetitivas convertidas en certezas, o lo que es lo mismo, convertir en objetividad múltiples subjetividades coincidentes.

Pero al margen de esta reflexión, recogida y compartida entre algunos de los principales especialistas en la materia, entendemos que la subjetividad también puede ser aplacable al documento escrito, que la fuente escrita también es susceptible de ser subjetiva, falible, y conducir a engaño. ¿Y entonces qué? ¿Sigue siendo más fiable que la Historia Oral?

Esta reflexión que venimos realizando no busca otro objetivo que el de reincidir en la necesidad recíproca entre fuente escrita y oral para el proceso de construcción de una Historia sin Adjetivos, de una Historia Completa y de alguna forma, Definitiva; una labor de "sentido común"15, base de una interpretación histórica más certera, donde el hecho de que la Historia Oral nos introduzca en un territorio vedado a las fuentes escritas, suponga elevar el papel de los testimonios orales a la categoría de instrumentos de comprensión crítica del pasado, en un plano de igualdad con el de los documentos escritos. ${ }^{16}$

Pero de la misma forma las fuentes orales no bastan por sí mismas, sino que se requiere una labor imprescindible -anterior, durante y posterior- de investigación de fuentes prima-

8 Ronald FRASER: "La Historia Oral como historia desde abajo", Ayer, 12 (1993) pp. 79-92.

9 Mercedes VILANOVA: "La historia presente y la historia oral...", pp. 79-113.

10 Lucía PRIETO BORREGO y Encarnación BARRANOUERO TEXEIRA, Encarnación: Población y guerra civil en Málaga..., p. 15.

11 Eric HOBSBAWM: History from Below, Oxford, Frederiek Krantz, 1988. Castilla del Pino, mencionado Eric HOBSBAWM: History from Below, Oxford, Frederie
en Fernando ARCAS CUBERO: Yo estaba alli.., p. 14.

12 Alessandro PORTELLI: The death of Luigi Trastulli, and Other Stories: Form and Meaning in Oral History, NewYork, Sunny Press, 1991.

13 Ibid., p. 14

14 Daniel BERTAUX: “Los relatos de vida en el análisis social”, Historia y Fuente Oral, 1 (1989) p. 87-96.

15 Mercedes VILANOVA: "La historia presente y la historia oral...", pp. 61-70.

16 Fernando ARCAS CUBERO (Dir.): Yo estaba alli..., p. 18. rias y secundarias, en una constante relectura que proporcione un proceso comprehensivo más completo. ${ }^{17}$

Al margen de todo ello, defendemos que las fuentes orales, entendidas como herramientas de trabajo de la Historia desde abajo, no pueden permitir que su creación sea relacionada exclusivamente con la necesidad de establecer mecanismos para grupos o clases sociales que, por su marginación o acoso, no habían tenido la oportunidad de crear las suyas propias, como una especie de terapia contra el trauma colectivo de los protagonistas, así como de conocimiento y recuperación de la memoria , tanto para los que desde el presente desconocemos de primera mano los hechos, como para las generaciones posteriores.

Al contrario opinamos que esta variante de la investigación histórica no tiene por qué ser excluyente, sino que puede aplicarse a colectivos que ya tuvieron oportunidad de ser escuchados y leídos, pero que ahora pueden ofrecer otra visión, con la óptica del paso del tiempo, quizás desprovistos de complejos, miedos, recelos y mitos, y que también pueden complementarse con los testimonios de los no-escuchados hasta ahora, que a pesar de todo siguen siendo para nosotros los más valiosos, en el sentido sobre todo de paliar esa descompensación informativa producto de un alargado silencio de cuarenta años de dictadura.

El caso es que la Historia Oral supone una forma efectiva e inmediata de recuperación de la memoria histórica, de equilibrio entre el olvido y el recuerdo, pero no solo de los lastimados ${ }^{18}$, sino también de los que pudieron causar el dolor, como en definitiva de los que fueron testigos de los hechos narrados, con independencia de su situación y protagonismo dentro de los mismos.

\section{La investigación a través de las fuentes orales en el caso malagueño}

La investigación histórica a través de las fuentes orales, y muy especialmente la relacionada con las casi dos décadas que transcurren entre la proclamación de la II República y el fenómeno de la resistencia guerrillera antifranquista, ha gozado de una especial sensibilidad en el caso de la provincia de Málaga, a través de una serie de trabajos deudores de primigenio de Ronald Fraser. ${ }^{19}$

Así por ejemplo pudimos valernos de ella para nuestro primer y embrionario trabajo sobre la etapa republicana en la ciudad de Antequera ${ }^{20}$, de la misma forma que ésta resultó absolutamente fundamental para la recuperación historiográfica de aspectos relacionados con la República, la Guerra Civil y el Primer Franquismo en la provincia, a través del ya mencionado trabajo dirigido por el profesor Fernando Arcas, Yo estaba alli. ${ }^{21}$

La probablemente principal consecuencia de la guerra en la provincia malagueña, y a la postre uno de los grandes éxodos poblacionales motivados por el conflicto, el de la huida de la carretera Málaga-Almería, la conocida "desbandá", sería el tema central de otros trabajos que se nutrían casi exclusivamente de las fuentes orales para su elaboración, como el ya mencionado de las profesoras Barranquero Texeira y Prieto Borrego ${ }^{22}$, al que se unían otros como el de Jesús Majada y Fernando Bueno. ${ }^{23}$

17 Ronald FRASER: “La Historia Oral...”, pp. 79-92.

18 Como se defiende en Voces recobradas. Revista de Historia Oral, 1 (1991) p. 3.

19 Un último acercamiento al trabajo del investigador alemán en Julián CASANOVA: “Así se recuerda lo que sucedió. La historia oral de Ronald Fraser", Ayer, 90 (2013) pp. 219-229.

20 Miguel Ángel MELERO VARGAS: Antequera, la ciudad republicana. Propiedad y poder en Antequera (1931-1936) Antequera, Fundación Municipal de Cultura, 2006

21 Fernando ARCAS CUBERO (Dir.): Yo estaba alli...

22 Lucía PRIETO BORREGO y Encarnación BARRANOUERO TEXEIRA, Encarnación: Población y guerra civil en Málaga...; íD.: Asi sobrevivimos al hambre. Estrategias de supervivencia de las mujeres en la postguerra española, Málaga, CEDMA, 2003

23 Jesús MAJADA NEILA y Fernando BUENO PÉREZ, Fernando: Carretera Málaga-Almería (febrero, 
El miedo ligado a la represión sería el hilo conductor por el que discurriría el diálogo directo entre protagonista e historiador, y que cristalizaría en una nueva obra de $\mathrm{Fraser}^{24}$, sobre la conversión del Alcalde republicano de la población malagueña de Mijas, en topo en el Franquismo, permaneciendo más de tres décadas oculto en su propio domicilio.

Mientras, la oposición al Franquismo, más allá del final de la guerra, a través de la huida y la clandestinidad ligadas al fenómeno maqui en la provincia malagueña, sería recreada a partir de los testimonios recogidos en los trabajos de los investigadores José María Azuaga, que ya a principios de la década de los noventa del siglo pasado realiza un estudio de las mentalidades y la vida cotidiana en la agrupación guerrillera Málaga- Granada²5, o José Aurelio Romero Navas, también con numerosos trabajos sobre este temática en la provincia. ${ }^{26}$

Los trabajos más recientes para el caso malagueño, corresponden a este mismo año de 2013, con la obra de la profesora Prieto Borrego para el caso de la comarca de la Costa del Sol occidental ${ }^{27}$, así como nuestra ya mencionada Tesis Doctoral, para la comarca de Antequera.

\section{Voces de la República, la Guerra y la Represión en Antequera}

Para este último caso concreto hemos pretendido seguir de alguna manera las directrices marcadas por Portelli en cuanto a las formas de uso de las fuentes orales, como la de la elaboración de una historia sin adjetivos, el uso de las fuentes orales como auxiliares, el establecimiento de diálogos entre los entrevistados -protagonistas- la recreación de un diálogo entre fuentes e historiador, así como la edición de las entrevistas precedidas de introducción explicativa.

Con éstas y otras fórmulas, hemos podido conocer efectivamente aspectos, hechos, datos y vivencias que, o bien no podrían haber llegado a ser conocidos, o no lo habrían hecho de forma más veraz y completa, como al mismo tiempo no exenta de un componente más sentimental y humano, de no ser por su recuperación a través de los testimonios, de estos relatos de vida.

Así por ejemplo, hemos podido recabar nuevos datos a través de vivencias personales relacionadas con la dureza de las condiciones de vida existentes en una comarca netamente agrícola y latifundista como la antequerana, con anterioridad a la proclamación de la II República, producto de profundas desigualdades sociales, y que por ejemplo se traducirían en una temprana incorporación laboral. Así por ejemplo lo recuerda José al señalar que "desde chicos no tuvimos más que hacer que trabajar, guardando guarros, arando, segando, cogiendo aceitunas... pero dineros había menos" 28 , o María que afirma que "como mi padre trabajaba, y mi madre también, entonces una con diez años ya tenía que trabajar... y mi hermano igual...por lo menos por la comida". ${ }^{29}$

Un hecho que implicaba unas prácticamente nulas posibilidades de formación, tanto en el caso de los niños, donde señala Francisco Casasola que "a los catorce años ya me dijo el maestro -ya no puede ser, porque ya tienen que entrar otros- Yo ya no podía seguir porque

1937) Málaga, Caligrama Ediciones, 2006.

Ronald FRASER. Escondido. El calvario de Manuel Cortés, Barcelona, Crítica, 2006.

25 José María AZUAGA RICO: "La agrupación guerrillera Granada-Málaga: estudio sobre las mentalidades y la da cotidiana", Espacio, tiempo y forma. Serie V. Historia contemporánea, 4 (1991) pp. 139-170.

26 José Aurelio ROMERO NAVAS: "Un testimonio oral sobre la guerrilla antifranquista en Málaga", Cristóbal GARCÍA MONTORO (Coord.): Voces de la memoria. Retazos de vida en Málaga (S.XVIII-XX) Málaga, Universidad de Málaga, 2002, pp. 161-198.

27 Lucía PRIETO BORREGO: Los dias de la ira. Entre Mijas y el Guadiaro. De la República a la Sierra, Málaga, Universidad de Málaga, 2013.

28 José Ordóñez, 22 de marzo de 2006, Mollina. Todas las entrevistas reflejadas en esta comunicación han sido realizadas por el Grupo de Investigación Historia, Imagen y Memoria de Andalucía de la Universidad de Málaga.

29 María Doblado, 17 de mayo de 2006, Bobadilla. mi padre no podía pagar un bachillerato"30, o Francisco García, que aún se lamenta al recordar que "no, no he tenido escuela. Vine aquí a la escuela, de noche, y me decía el maestro -¿tú por qué no vienes de día?-y uno decía -yo estoy guardando cabras- el otro -yo estoy guardando los guarros- otro -yo porque me lleva mi padre al campo- total, que no tenía aquí escuela más o menos un mes o dos de noche y ya está. ${ }^{31}$

Como de las niñas, donde por ejemplo María asistió "a la escuela hasta los 11 años. Murió mi padre y me coloqué a trabajar en la fonda... y ya está" ${ }^{32}$, o María de las Nieves que lamenta cómo "nos daban la lección, pero malamente. Y demasiado que nos la daban...".33

Con el espíritu reformador de la República, llega de alguna forma la esperanza, que va a suponer por ejemplo una mejora en las condiciones de trabajo: "Hubo manifestaciones y un movimiento grande cuando la República, y los concejales eran todos socialistas, y aquello marchaba muy bien en aquellos tiempos, porque los patronos tenían acobardada a mucha gente, y ellos apretaban al capital". 34

Se ganaba más sueldo y luego el asunto del trabajo también varió. Porque aquí había una costumbre de trabajar de sol a sol, y eso se perdió. Antes se ganaba un duro segando, y luego eran diez pesetillas, con lo que ya había mejorado aquello algo, y el trato para los obreros también, que ya podían hablar algo, que antes no se podía hablar, y luego ya entró otro que tampoco se podía hablar. ${ }^{35}$

Pero con la República llega también el recrudecimiento de un antagonismo de clase, entre una oligarquía terrateniente históricamente privilegiada, y que va a materializarse en un proceso de fuerte conflictividad laboral en el campo antequerano, entre patronos y jornaleros, con procesos como repartos de obreros, trabajos al tope, invasiones de fincas o huelgas. Esta tensión sigue presente en el recuerdo de Francisco que destaca cómo "a los propietarios que no trabajaban sus fincas les repartían mucha gente, y eso a los patronos les caía tan mal como un tiro. Cuando había una huelga, algunas veces se formaban piquetes y se traían a los gañanes, cabreros... para que se quedara todo paralizado y no hubiera trabajo ninguno". ${ }^{6}$

Una conflictividad que incluso despierta el ingenio de los murguistas del Carnaval antequerano de aquellos años, y que Antonio reproduce con admirable memoria pese a su edad:

Siembra trigo el labrador, La tierra le da figura, Lo recoge el segador, $Y$ el trillero lo desnuda, A cambio de su dinero, Lo vende su propietario, $Y$ lo encierra en el granero, El más rico millonario., Y en la jornada gloriosa, Lo refina el molinero, Y en la noche silenciosa, Lo hace pan el panadero, para que el burgués lo coma., Y el que la siembra y trabaja, Hambre tiene en recompensa, Para las bestias la paja..., Y el pan para los sinvergüenzas. ${ }^{37}$

La República supuso también el nacimiento de una política laicista, y que contribuiría a im-

30 Francisco Casasola, 17 de mayo de 2006, Bobadilla.

32 Maria Doblado, 17 de mayo de $2006 \ldots$.

33 Maria de las Nieves Vegas, 1 de junio de 2006, Villanueva de Cauche.

34 Francisco Garcia, 22 de marzo de 2006.

35 Andrés Núnez, 29 de mayo de 2006, Antequera.

36 Francisco García, 22 de marzo de 2006

37 Antonio Alarcón, 13 de marzo de 2006, Humilladero. Coplas carnavalescas como esta de carácter social conllevarian con independencia del contexto festivo en que eran recitados, una crítica punsocial contevarian, con ine la yeficaz para el ańlisis de la memoria de un pueblo. 
pregnar de anticlericalismo la cotidianeidad de estos años, a todos los niveles. Concepción fue testigo de uno de esos episodios y recuerda cómo "mi madre era muy de la religión y cuando se murió en 1936 no consintieron de que fuera el cura. Le pusieron la bandera republicana" ${ }^{8}$

La sublevación de julio de 1936, su fracaso en Antequera, y con él su nueva rol de retaguardia republicana, será una constante en los testimonios recogidos, por ejemplo sobre las primeras operaciones militares de intento de contención de un avance rebelde que permanecía apostado a escasos kilómetros de zona antequerana, del papel de las fuerzas del Orden en relación a la sublevación -en especial la Guardia Civil y su sorprendente actitud de apoyo a la legalidad republicana- de la organización revolucionaria a través del Comité, pero sobre todo en el importante proceso de violencia desarrollado sobre determinados sectores, como el propietario y el religioso; y que diferirá en intensidad entre unos municipios y otros, ofreciendo variados y muy interesantes matices.

Así por ejemplo Mariano recuerda el asesinato de varios labradores en el anejo antequerano de Villanueva de Cauche, cuando "los sacaron de esos cortijos y los pobres iban clamando por las calles jay por mis hijitos, tan chiquitos!- $y$ ahí les echaron gasolina y les pagaron fuego, que vi yo el humo de salir". 39

Mientras, en otro anejo, Bobadilla, coincidían los testimonios al señalar que "aquí no mataron a nadie, porque hasta el cura huyó a Málaga y mi suegra lo escondió". ${ }^{\circ}$

Una situación coincidente para el caso de otro municipio del término, Humilladero, y donde se pone de manifiesto un aspecto repetido constantemente en muchos testimonios, el de la nula correspondencia entre los numerosos comportamientos de respeto a la vida por encima de excepcionalidades, durante la etapa de dominio republicano, y la voraz represión desarrollada con posterioridad, tras la ocupación rebelde. Señala Antonio cómo "aquí los que había se los traían para que no les pasara a ninguno nada, y mira el pago que dieron luego, porque aquí protegieron mucho a los caciques, que eran como familia, algo normal en los pueblos chiquitos, criados juntos desde siempre, pero luego éstos cometieron en cambio unos crímenes horrorosos". ${ }^{4}$

Y lo mismo ocurriría en Mollina, donde observa Francisco que "metieron a unos pocos señoritos detenidos, pero no pasó nada, y aquí vino gente de Málaga que nos dijo - ¿ah, qué no queréis matarlos? Pues ya os matarán luego a ustedes....". ${ }^{42}$

Pero en todo caso la violencia, física y material existió, y muy pronunciada, y Antequera es un buen ejemplo de ello, con más de ochenta muertes en veintiséis días, y donde hemos rescatado visiones sobre algunos de los hechos más señeros, como el del asesinato de los Trece de la Moraleda, o sobre siete frailes de la comunidad capuchina antequerana, de los que José recuerda su muerte recordando que "mataron a trece, doce millonarios y uno que era el chivato de ellos, que iba siempre contando todo a la Guardia Civil" 43 , o Antonio que rememora cómo "los capuchinos serían veinte, $y$ quince de ellos buenas personas, pero basta que hubiera uno que fuera a merendar a casa de los ricos, para que cayeran una pila. Pero en todo caso no era tanto un odio a la religión, sino al cura como aliado de las clases prepotentes que explotaban a los pobres". ${ }^{44}$

Una violencia, como hemos dicho fundamentalmente sobre una oligarquía propietaria y terrateniente, y un estamento religioso, donde estos relatos de vida refuerzan aspectos, quizá más relacionados con tópicos, e incluso con mitificaciones, como el de la participación de denominado como elemento extraño, es decir, de los venidos de fuera como agentes y eje-

38 Concepción Hinojosa, 17 de mayo de 2006, Bobadilla.

39 Mariano Podadera, 1 de junio de 2006, Villanueva de Cauche.

40 María Doblado, 17 de mayo de 2006.

41 Antonio Alarcón, 13 de marzo de 2006

42 Francisco García, 22 de marzo de 2006.

43 José Acedo, 20 de abril de 2006, Antequera.

44 Antonio Martín, 20 de junio de 2006, Antequera. cutores de la violencia en la retaguardia republicana, en el caso de Antequera centrada en el papel de la FAI como ejecutora casi exclusiva de violencia, generando incluso enfrentamientos constantes con el Comité, lo que por otro lado desmitifica totalmente la idea propagada po la literatura nacionalista de atribuir a estos órganos revolucionarios exclusivamente un papel represivo:

Aquí cuando estalló la guerra, todos los presos de las cárceles de Sevilla se apuntaron a la FAl y vinieron a parar aquí, gente mala que no era del pueblo, que no dejaban que nos moviéramos, que mataron cabras, vacas y caballos, y que por menos de nada te pegaba un tiro. Pero ellos no estaban en el frente, solo dando patrullas, y haciendo el gamberro. Eran lo peor, una canalla, una gentuza con la que ni el Comité ni la gente del pueblo quería relacionarse. 45

Y junto a este, el otro aspecto mitificado sería el del intento de demonización de la mujer republicana, situándola como corresponsable moral en la comisión de comportamientos de violencia, a través de la atribución de actitudes exaltadas, vejatorias, y que pretendían mostrarla como poco femenina, brutalizada, e incluso libertina. Antonio recuerda el día en que "el cura de una parroquia cayó muerto, y entonces llegó La Cacheta, se levantó la falda y se meó en la boca del cura... ¡Vaya unas ganas de mear que tendría la mujer!". ${ }^{6}$

De la investigación de esta etapa a través de los testimonios recogidos, no solo hemos aprendido a través de la interpretación de los silencios, sobre los que compartimos su absoluta importancia con la profesora Mercedes Vilanova, sino también de la gestualización en los comportamientos de determinados entrevistados que, por lo general en entrevistas colectivas, ejercen su influencia sobre el resto, mostrando la idoneidad o no de responder a según qué cuestiones. Sin embargo siempre suele existir afortunadamente una figura de contrapunto para la que esta prohibición de hablar no supone más que un incentivo precisamente para hacerlo.

Las fuentes orales para la investigación de esta etapa en Antequera, van a ser también de gran utilidad para contar con nuevas perspectivas en aspectos como los relacionados por ejemplo con las operaciones militares, sobre todo en lo que respecta en el conocimiento del día a día en el frente, y que no reflejaban los partes de guerra.

También sobre otros relacionados con el proceso de instauración del Franquismo, de la supeditación a la presencia militar, la participación ciudadana en el proceso, los nuevos poderes locales, el remozamiento de la religiosidad, pero muy por encima del resto con el proceso represivo, en sus diferentes manifestaciones, grados e intensidades, ligado a este.

Un hecho que se presenta como fundamental, sobre todo por la opacidad mostrada por las fuentes documentales ligadas a esta parcela dentro de la investigación de la guerra y el Franquismo, y que si bien ofrecen parte del proceso punitivo, o el desenlace, nunca podrán mostrar la verdadera dimensión del mismo, ni mucho menos la forma en que lo afrontarán sus víctimas -directas o subsidiarias- o aquellos que fueron testigos del fatal desenlace de los que desgraciadamente nunca gozarían de la oportunidad de ofrecer su visión y hacer oír su voz.

Así, la cantidad de testimonios cuya esencia gira en torno a la represión, sublevada primero, y franquista después -sobre la muerte o el tránsito punitivo, la laboral o la económica, como la ejercida en el día a día de la vida de las víctimas y su entorno- es absolutamente ingente, y resulta muy difícil - e incluso de alguna forma casi injusto- resaltar un relato sobre otro, pues todos son estremecedores en lo humano y vitales en nuestro proceso de investigación.

45 Federico Molina, 20 de mayo de 2006, Villanueva de la Concepción.

46 Antonio Martín, 20 de junio de 2006. 
Pero quisiera reflejar uno, fundamental por el sentido y significación que engloba pues, aparte de enfatizar a través de adverbios de cantidad, el alcance de la represión, vista a los ojos de un protagonista, recoge otro aspecto fundamental al hablar de esta etapa, el de la perdida del miedo, del que es un claro ejemplo Francisco, al afirmar que "yo he visto ya muchas cosas, muchas, muchas, y matar a personas, y hacer muchas perrerías, muchas, pero esto es lo que me queda, poder hablar, porque antes me daba miedo, pero ahora...".47

Sintetizaba magistralmente este testimonio la importancia del relato de vida para nuestra investigación, e incluso nos llevaba a enlazarlo con la declaración de intenciones que vislumbraba la primera Editorial de la revista argentina Voces recobradas, al señalar cómo "la construcción de las memorias debe ser grabada aunque las identidades sean protegidas, porque el truccion de las memorias debe ser grabada aunque las identidades sean proto serio como para no tener registros de lo que se diga".48

Una reflexión que da, no solo sentido, sino absoluta vigencia, a nuestro trabajo. 


\section{COMUNIDADES DE DOLOR. NARRAR LO OCURRIDO,}

\section{O CONSERVARLO EN EL CUERPO}

rene Murillo Aced

Universidad de Zaragoza

Jay Winter advertía en su prólogo a Sites of memory, sites of mourning, de que existían cientos de libros, enteras librerías, sobre los aspectos militares, económicos o diplomáticos de la Primera Guerra Mundial. Sin embargo, no se podía decir lo mismo sobre la atención que se había prestado, más bien nula, al proceso a través del cual los europeos intentaron encontrar maneras de comprender primero y trascender después, las catástrofes de aquella Gran Guerra. Una afirmación que podríamos hacer extensible, con matices, al fenómeno que envuelve los llamados Estudios sobre el Franquismo, un campo de estudio que, en estimaciones numéricas, baraja números de entre 20.000 y 40.000 libros al considerar los escritos, únicamente, acerca de la Guerra Civil española. ${ }^{2}$ A esta ingente cantidad habría que añadir los escritos sobre el Franquismo, cuyo dinamismo se ha valorado en términos de impacto editorial hasta el punto de haber sido calificados de género literario. ${ }^{3}$

Hasta aquí, un breve estado de la cuestión sobre la historiografía en torno a la guerra y la dictadura sería, cuanto menos, optimista. Además, aun cuando estos datos se topan con limitaciones (la cantidad no es siempre sinónimo de calidad), ${ }_{4}^{4}$ es obvio que la labor de la historia profesional ha dejado muy atrás aquella otra narrativa cercenada que tuvo lugar dentro de la península durante los años de la dictadura y que, en nuestro análisis posterior, calificaremos

* Este artículo se inscribe dentro del grupo de investigación del Ministerio “Discursos e identidades de género en las culturas políticas de la derecha española, 1875-1975", código HAR2912-32539.

1 Jay WINTER: Sites of memory, sites of mourning. The Great War in European cultural history: Cambridge, Cambridge University Press, 1995. No sólo los europeos, añadiría yo, tuvieron que comprender y trascender las heridas de la Gran Guerra, pues las potencias beligerantes obligaron a sus poblaciones coloniales a participar en el esfuerzo bélico de luchar por derechos y libertades que luego no gozarían sino las metrópolis, y tampoco todos sus habitantes.

2 Michael Seidman, en la introducción a su libro sobre los apoyos sociales y económicos al régimen de Franco, reproduce una cifra que estimaría en más de 20.000 los libros escritos sobre la Guerra Civil Española. Cifra que Juan Andrés Blanco eleva al doble, 40.000 incluyendo los volúmenes publicados fuera de las fronteras del Estado español desde el momento en que tuvo lugar la contienda hasta el presente. Michael SEIDMAN: La victoria nacional. La eficacia contrarrevolucionaria en la guerra civil, Alianza, Madrid, 2012. Juan Andrés BLANCO: “La historiografía de la guerra civil española", Hispania Nova, 7 (2007), online.

3 Sobre la Guerra como género literario y el peligro de su trivialización sentimental, ver la entrevista a José Carlos MAINER en la edición digital de El País de 12 de noviembre de 2005, en http://elpais. com/diario/2005/11/12/babelia/1131755950_850215.html

4 Así lo ponen de manifiesto los estados de la cuestión al respecto. Tanto el de Juan Andrés BLANCO: "La historiografía ...", como el de Hugo GARCíA: “La historiografía de la Guerra Civil en el nuevo siglo", Ayer, 62 (2006), pp. 285-305 de "memoria usurera" tal como lo haga Jordi lbáñez. ${ }^{5}$ Asimismo, tres décadas de investigación en democracia ha conseguido superar, de un lado, aquella Historia política del Franquismo que "convirtió en protagonistas de su relato al Estado y sus servidores", así como también la Historia social que le siguio y que "en muchas ocasiones, hizo lo propio con las victimas la represion primeroy con la represión primero y con los militantes de las organizaciones antifranquistas después". ${ }^{6}$ En este sentido, la historia de la dictadura goza de buena salud y quienes investigan este periodo hace ya décadas que han incorporado visiones y acercamientos a las fuentes que se separan del tradicional relato político desde arriba.

No obstante, lo cierto es que la afirmación que hacía Julio Aróstegui en 1992 puede todavía sostenerse, aunque con matices, a día de hoy: «se ha hecho mucho más trabajo sobre lo que fue "el régimen" que sobre "la sociedad" que lo disfrutó o padeció».7 Y es que, aunque la escasez de trabajos sobre quienes vivieron bajo la dictadura no sea ya tan alarmante y avancen a pasos rápidos los análisis sobre actitudes populares ante la misma, los Estudios sobre el Franquismo todavía necesitan polemizar y trascender lo que llamaré aquí el problema de la victimización. He querido referirme con este término a una tendencia general que no hace sino insertarse en su coyuntura histórica: una torpe Transición Democrática enclaustrada en su pacto de silencio que, al no permitir una vía constitucional para la verdad, la justicia y la reparación públicas y estatales de las víctimas de la dictadura, acabó cediendo a la comunidad historiográfica la función pedagógica de la memoria. Así, desde mitades de los años 80 las necesidades de la inmediatez propiciaron alianzas entre la producción de conocimiento y la historiografía, que llevó a cabo la tarea de describir y sacar a la luz los excesos represivos de la dictadura dando voz a sus víctimas.

Esta tendencia historiográfica, consecuencia en parte de decisiones políticas, derivó en una ingente tarea de investigación que, a través de sus hilos locales, ofreció un análisis de la sociedad un tanto reduccionista ya que observaba a la población civil como una masa de víctimas inertes que se había limitado a recibir pasivamente la represión de la dictadura. Y es que la categoría analítica "víctimas", si bien en un principio sirvió para cuantificar y cualificar el calado de la violencia perpetrada por la dictadura, desde la física hasta la laboral pasando por la económica, ${ }^{8}$ acabó por crear un contagio semántico. De la categoría jurídica de la víctima, es

5 A pesar de ello, en los últimos años hemos asistido a un auge de la historia neofranquista. Aunque 政 no obstante en la Real Academia de la Historia, y ha estado muy presente en la polémica sobre el Diccionario Biografico Español. Sobre la historia revisionista o "fenomeno Moa" se advierte en Hugo GARCIA: "La historiografia ..." p. 286. Sobre la polemica del Diccionario, leer José Luis LEDESMA: "El Diccionario Biográfico Español, el pasado y los historiadores", Ayer, 88, (2012), pp. 247-265.

6 Óscar RODRIGUEZ BARREIRA: "Vivir y narrar el Franquismo desde los márgenes", en Óscar RODRÍGUEZ BARREIRA (ed.): El Franquismo desde los márgenes. Campesinos, mujeres, delatores, menores... Lleida, Editorial Universidad de Almería/ Edicions de la Universitat de Lleida, 2013, p. 21.

7 Julio ARÓSTEGUI: "La historiografía sobre la España de Franco. Promesas y debilidades", Historia Contemporánea, 7 (1992), p. 89. Una puesta al día de la historia social desde abajo y un pronóstico
más o menos optimista sobre la misma en, respectivamente, Ángela CENARRO "La historia desde abajo del Franquismo" y Óscar RODRÍGUEZ BARREIRA “Vivir y narrar el Franquismo...”, pp. 29-44 y pp. 11-28.

8 Una visibilización de las violencias, en plural, que el análisis de la represión franquista comparte con otros fenómenos. Por vijemplo, con el esfurzollevadoa cabo para visibilizary poner rostro los con otros fenómenos. Por ejemplo, con el esfuerzo llevado a cabo para visibilizary poner rostro a los moneda de cambio, como instrumento para demostraciones de fuerza, como objeto del odio y a misoginia En la normalización de la bapariey el estado permanente de cuera para los cuerpos de las mujeres, estarian los feminicidios acometidos en varios paises de América Latina principalmente México y Guatemala; los castigos físicos y lapidaciones de mujeres adúlteras; las mutilaciones genitales femeninas que afoctan a entre 100 y 140 millones de mujers y niñas de entre 4 y 12 años; las violaciones corras a la 
decir, de la necesidad de crear una figura que condensase el derecho a justicia, verdad, trato justo, resarcimiento, indemnización y asistencia; al olvido de la capacidad esas mismas personas para apropiarse de las condiciones de dominación. ${ }^{9}$

Las implicaciones de este modelo serían, en nuestra opinión, varias. La construcción de un imaginario colectivo pobre y parcial que únicamente atiende al discurso hegemónico creyendo analizar la sociedad. Unos principios analíticos que consideran a la ciudadanía incapaz, por sí misma, de resistir los embates del poder, a no ser que tengan representación política. Y tercero, la despreocupación por la manera en que este sufrimiento social y dominación se integró en la vida cotidiana. Como propuesta para evitar estas tendencias, al fin y al cabo un condicionamiento al modo en que el científico o científica social observa y analiza sus fuentes, sugerimos limitar la categoría víctima a un modelo legal de protección, evitando que, por sí misma, predefina a los individuos o grupos de personas cuyos derechos han sido vulnerados. El haber sido víctima de alguno de los modos en que las estructuras de poder se ejecutan no excluye de por sí la iniciativa y las capacidades de estas personas. En este sentido, las líneas que aquí se presentan son también una apuesta por no olvidar los modos en que los sufrientes "padecen la violencia, negocian y obtienen reductos de dignidad (a veces de manera poco evidente), resisten y reconstruyen sus relaciones cotidianas, y sobrellevan la huella de la violencia de un modo que no siempre aparece perceptible para quien proviene de fuera, sea este científico social, funcionario, político o militante nacionalista". ${ }^{\circ}$

\section{La incorporación de la noción de experiencia al sufrimiento social}

"Dicen que no guardo duelo, llorona, porque no me ven llorar. (...) Hay muertos que no hacen ruido, llorona, y es más grande su pena."."

Elaborado este diagnóstico, las siguientes páginas las abordaremos más como una propuesta de investigación, un work in progress, que como una apuesta cerrada con resultados tangibles. La idea que subyace es ser capaces de, a través de sujetos históricos concretos, es tudiar cómo la dimensión emocional y subjetiva de las experiencias de sufrimiento social es incorporada y trascendida como conocimiento envenenado en la cotidianidad. ${ }^{12}$ Estas líneas serán pues un intento de emprender un acercamiento a la Guerra Civil y el Franquismo que atienda a cómo la población vivió y manejó la violencia social que se insertó tanto en las relaciones como en el recuerdo intentando sustraer a la comunidad las herramientas para que

ámbito de las relaciones personales, donde el Estado español asiste impasible a decenas de asesinatos machistas cada año; o el acoso, la humillación y persecución cotidiana de millones de mujeres en el mundo a la que últimamente se le ha dado el nombre de micromachismos.

9 Sobre los debates de la década de los 90 en el seno del feminismo en torno al proceso de "victimización" de las mujeres, ver Alison CONVERY: "No Victims No Oppression Feminist Theory and the Denial of Victimhood", artículo presentado en 2006, en Australasian Political Studies Association Conference, University of Newcastle, Australia. Consultado online en junio de 2012 en http:// www.newcastle.edu.au/Resources/Schools/Newcastle\%20Business\%20School/APSA/FEMGEN/ Convery-Alison.pdf

1o Francisco Alberto ORTEGA: "Rehabitar la cotidianidad", en Francisco A. ORTEGA (ed.): Veena Das. Sujetos del dolor: agentes de dignidad, Bogotá, Universidad Nacional de Colombia, 2008, p. 21.

11 Fragmento de la canción oaxaqueña "La llorona" cantada por Lila Downs.

12 Por sufrimiento social entiendo el resultado de las injurias perpetradas por las fuerzas sociales sobre la experiencia humana y por lo tanto, sobre particulares. El término conocimiento envenenado lo extraigo de Veena Das, poisonous knowledge, aquel que entra del pasado al presente, no como trauma sino como un modo pe ocupación que pasa por ser consciente de ese sufrimiento. Veena DAS: Life and words. Violence and descent into the ordinary: Oxford, Oxford University Press, 2006 , p. 59 y siguientes. sus miembros habitasen el mundo juntos. ${ }^{13}$ En este sentido, el artículo aboga por comprender este periodo histórico atendiendo a los hilos culturales y emocionales que el trabajo con la historia oral puede poner de manifiesto, encontrando el nexo que conecta las experiencias colectivas con las individuales. Asi tambien nos parece interesante incorporar al analisis plantilla de ejemplos históricos que permitan ampliar la reflexión desde el Franquismo hacia otros contextos y experiencias.

Algunas de las preguntas que subyacen son: ¿Cómo el sufrimiento social es enfrentado po personas particulares?; ¿ ha sido posible, históricamente, transformar el lenguaje del cuerpo en un lenguaje que trascendiera el dolor individual y diera forma ética a un sufrimiento más transversal (global) al que hacerle frente?; cuando los proyectos por crear una identidad colectiva y una memoria única, tras experiencias de intenso conflicto, han venido dilapidando identidades particulares y memorias heterogéneas, ¿es pertinente alejarnos de las recreaciones y relatos oficiales y acercarnos históricamente al problema de la memoria intentando conocer la violencia perpetrada a través de relatos de experiencias individuales?

Como punto de partida tomamos el nivel colectivo de las representaciones y en concreto, el modo en que las instituciones y las redes de poder intentan, a partir de narrativas históricas oficiales, formularse o fabricarse para configurar las identidades y memorias de un grupo social. ${ }^{14} \mathrm{El}$ modo en que estas narrativas oficiales acaban por monopolizar la interpretación de los hechos supone la escritura de una Historia unívoca y peligrosa, que distingue el sufrimiento social por la categoría de la ciudadanía sobre la que ha sido infringido y considera que el cuerpo dañado tras un conflicto es el cuerpo político de la nación, despreciando por omisión los cuerpos individuales y las experiencias individuales o bien convirtiéndolos en "muertos vigilantes" (o "vivos vigilantes") ante los que justificar la futura nación. En este sentido, si queremos comprender la muerte y el sufrimiento social tenemos que hacerlo a través de los que quedaron vivos y de cómo esas personas vivieron los procesos de rememoración y olvido. Si seguimos las teorías del trauma social, éstas nos dicen que

ningún evento, en sí y por sí, es traumático. Lo que determina si un grupo desarrolla síntomas de trauma social no es la estructura de los eventos -la violencia sísmica, las estrategias usadas por el agresor, los daños materiales de la infraestructura-, sino la estructura de la experiencia social de ciertos eventos (...) las tasas de PTSD son muy bajas para las catástrofes naturales, una vez que las víctimas aceptan la dimensión arbitraria propia de estos eventos. No obstante, los mismos estudios señalan que la elaboración del duelo se hace más difícil si las víctimas descubren que las autoridades o instituciones políticas no cumplen con las expectativas colectivas (...) y por lo tanto se considera que el sufrimiento hubiera sido evitable. ${ }^{15}$

Como ponen de manifiesto los estudios feministas que abordan la guerra no como un acontecimiento aislado sino como una violencia constante, una red de decisiones y puntos de fricción que forman parte del tejido social y no residen únicamente en las armas, entendemos que la

13 Francisco Alberto ORTEGA: "Rehabitar la cotidianidad", p. 26.

14 El papel del Estado en la negación de la historia de grupos marginados o subalternos ha sido uno de los temas más estudiados dentro del movimiento pos-colonial, así como las maneras en que tales grupos reaccionaron y construyeron sus propias memorias y subjetividades. Ver, por ejemplo Komatra CHUENGSATIANSUP: "Marginality, suffering and community", en Veena DAS, Arthur plo Komatra CHUENGSATIANSUP: "Marginality, suffering and community", en Veena DAS, Arthur and recovery: Berkeley, University of California Press, 2001

15 Francisco A. ORTEGA: “La ética de la historia: una imposible memoria de lo que olvida”, en Revisto

de psicoanálisis. Desde el jardín de Freud, 4, (2004), p. 105-106. 
violencia no cesa cuando callan los cañones. ${ }^{16}$ Así, el trauma del "evento", en este caso la Guerra Civil, se extiende en la construcción del después. En esta dirección se pregunta Paul Farmer,

¿Son ciertas agresiones "acontecimiento", como la tortura o la violación, más propensas a producir secuelas tardías que el sufrimiento más continuo e insidioso, como el dolor que nace de la indigencia o de racismo? (...) Los antropólogos que parten de estas preguntas en su investigación estudian tanto la experiencia individual como la matriz social en la que está inserta, para poder ver cómo las diversas fuerzas sociales a gran escala llegan a traducirse en problemas personales y enfermedad. ${ }^{77}$

Así, en el caso que nos ocupa, la narrativa hegemónica de "lo que pasó" durante la Guerra Civil española se transformó, mediante políticas muy concretas, en una memoria usurera que desterró el relato de otros testimonios heterogéneos y diversos al oficial, no sólo a nivel discursivo sino también práctico. Una memoria usurera que ejerció violencia sobre el recuerdo, auto-representándose como colectiva y asumiendo "una voz que ni es la suma de todas las voces ni es en realidad ninguna voz humana". ${ }^{8}$ En esta línea nos adscribimos a la descripción de la dictadura de Franco como una construcción excluyente, cuyos muertos nacionales, mártires y caídos, fueron en sus representaciones la puesta en marcha de una interpretación unívoca y asimétrica de lo que la población había vivido y de cómo debían organizarse los vivos y los muertos que quedaban en el campo de batalla de la posguerra.

No han sido muchos los trabajos que han hecho alusión a esta política de las emociones como vía para captar la posguerra, y sin embargo, sí han sido varias las menciones al Franquismo como un sistema que, precisamente por este régimen de memoria, fomentó en la generación de quienes vivieron la guerra siendo niños la incapacidad para olvidar y una sensación de frustración y angustia. 19 Para captar estas historias de la vida cotidiana utilizaremos aquí la noción de experiencia como una categoría intersubjetiva para comprender procesos que Arthur Kleinman y Joan Kleinman Ilaman microculturales e infrapolíticos. Al fin y al cabo, tras una catástrofe social de estas dimensiones, el dolor y el sufrimiento son "de origen cultural pues surge, se reproduce y se mantiene vigente en culturas basadas en relaciones de control, apropiación, desconfianza, sometimiento, competencia y dominación. En todos los casos este dolor está vinculado a historias de vida cotidiana de seres humanos individuales y de grupos sociales o pueblos"..$^{\circ}$

Como pone de manifiesto Ignacio Fernández de la Mata, "recordar -en español- es volver desde el sentimiento, desde el corazón -cor, en latín-. Su sentido se solapa con el de revivir, que sin ser posible en la repetición de la experiencia pasada, retoma las sensaciones que lo evocado produjo. Recordar es volver a sentir" ${ }^{21}$ A partir encontraríamos dos modos de enfrentarse al recuerdo y re-agenciarse de él. Una supone su comunicación y otra su silencio. Si bien en

16 Chris J. CUOMO: "War Is Not Just an Event: Reflections on the Significance of Everyday Violence", Hypatia, 11-4, (1996), pp. 30-45.

17 Paul FARMER: “On suffering and structural violence. A view from below”, en Daedalus, 125 (1996), pp. 251-283.

El têrmino memoria usurera proviene de Jordi IBÁÑEZ FANÉS: Antígona y el duelo. Una reflexión moral sobre la memoria histórica, Barcelona, Ensayo Tusquets, 2009. La cita es de p. 66.

19 En Michael RICHARDS: “El régimen de Franco y la política de la memoria de la guerra civil española", en Julio ARÓSTEGUI y François GODICHEAU (eds.), Guerra civil. Mito y memoria, Madrid, Marcial Pons/Casa de Velázquez, 2006, p. 169.

20 Amandine FULCHIRONE (coord.): Tejidos que lleva el alma. Memoria de las mujeres mayas sobrevivientes de violación sexual durante el conflicto armado, Equipo de Estudios Comunitarios y Acción Psicosocial y Unión Nacional de Mujeres Guatemaltecas, 2009, p. 1 .

21 Ignacio FERNÁNDEZ DE LA MATA: "La memoria y la escucha, la ruptura del mundo y el conflicto de memorias", en Hispania Nova, 6 (2006), online. ambas situaciones el cuerpo se sitúa como un "médium" principal, veremos cómo en el segundo caso es especialmente importante: cuando los excesos del programa de hegemonía y de la memoria usurera ejercen una especial violencia sobre las experiencias individuales y éstas no consiguen expresarse de modo verbal, quedando como tabús, como censuras, en las propias narrativas familiares... esas críticas al sufrimiento que está siendo provocado se silencian y son acogidas literalmente por el cuerpo. Un caso paradigmático que ha creado un corpus enorme de bibliografía al respecto ha sido la cuestión de la incomunicabilidad del dolor vivido en el Holocausto. ${ }^{22}$ Otro caso estudiado por la medicina antropológica llevada a cabo por Arthur y Joan Kleiman ha sido la Revolución Cultural China, donde los autores trabajan los niveles de neurastenia, con depresiones mayores en Beijing o Tapei..23

A menudo, en el estudio mediante fuentes orales de la Guerra Civil y el Franquismo aparecen también estos momentos de incomunicabilidad, de lo que Elaine Scarry llama el "prelenguaje": ante experiencias inenarrables, el informante o la informante se rompe, de modo que en ocasiones la salida es el lloro. ${ }^{24}$ Puede ocurrir que tras esta inenarrabilidad esconda a su vez la inenarrabilidad de la primera generación. Así me encuentro a un hijo de fusilado, GL, que al recordar cómo su madre tuvo que sacarles adelante a su hermana y a él, quiebra en llanto. Más adelante, el informante relata cómo su madre nunca les habló del asesinato de su padre si bien era algo que siempre estuvo presente. En primer lugar, mediante el recordatorio constante de la relación de sus padres mediante el aspecto físico de su madre: ella nunca se cortó el pelo, desde 1936 y hasta su muerte, pues era con el pelo largo como más le gustaba a su marido. En segundo lugar, mediante la experiencia de ataques de angustia y pánico nocturno que durante años despertaron a su madre, y con ella a GL y a su hermana, recordándoles la presencia de un silencio no narrado. ${ }^{25}$

Una segunda vía para re-agenciarse del recuerdo es enfrentarse a los hechos sucedidos, a conocimiento envenenado y a la versión oficial reivindicando la propia experiencia divergente a través del testimonio y del recuerdo. Si partimos, con Freud, de que entre una catástrofe social y una catástrofe natural la diferencia es que mientras las primeras desagregan y dividen e cuerpo social, las segundas lo solidarizan, ¿es posible encontrar conexión entre comunidades de dolor a través de lo que está en juego para quien narra y padece, sus mundos locales? ${ }^{26} \mathrm{~S}$ así fuera, como creemos, la función social del recuerdo, "responder a la disgregación vivenciada y producir un re-agenciamiento en el sufriente", ${ }^{27}$ pudiera transformar esta salida en una apuesta ética y política. Al fin y al cabo, y como se ha defendido en otros lugares, el proceso por el que una persona transita el camino hacia la transformación en sujeto político suele ser

22 Ignacio Fernández de la Mata cita unas palabras muy elocuentes de la novela de Benny Barbash My first sony: "These poor people... want to translate their experiences into a language that hasn't been invented and will probably never be invented". En Ignacio FERNÁNDEZ DE LA MATA "La memoria y la escucha...", online.

23 La neurastenia es una sensación de debilidad, agotamiento corporal y físico tras realizar esfuerzos (mentales o fisicos) mínimos y puede acompañarse con dolores o molestias musculares, incapacidad para relajarse, vértigo o sensación de inestabilidad. Suele cursar con estados de ánimo ansiosos y depresivos. Con frecuencia aparecen alteraciones del sueño como insomnio, somnolencia o hipersomnia. Arthur KLEINMAN y Joan KLEINMAN: "How bodies remember: social memory and bodily experience of criticism, resistance, and delegitimation following China's Cultural Revolution", en New Literary History, 25 (1994), pp. 707-723.

24 Elaine SCARRY: The body in pan: the making and unmaking of the world, New York, Oxford University Press, 1985.

25 Gregorio Lagunas, 10 de Agosto de 2011, Blesa (Teruel). Entrevista realizada por Irene MURILLO. El informante, natural de María de Huerva, es hijo de fusilado en los primeros días tras el golpe de Estado.

26 Arthur KLEINMAN, Joan KLEINMAN: "Suffering and its professional transformation: toward an ethnography of interpersonal experience" en Culture, Medicine and Psychiatry, 15-3, (1991), pp. 275-301.

27 Francisco A. ORTEGA: “La ética de la historia...", p. 108. 
una experiencia de subyugación personal. ${ }^{28}$ "Decir que uno ha sido vejado es decir que hay un poder exterior causando problemas internos, que los filamentos del primero se extienden profundamente en el interior del último". 29

Encontramos ejemplos como Rigoberta Menchú, que con la publicación en 1983 de su autobiografía Me llamo Rigoberta Menchú y asi me nació la conciencia, desafió las representaciones guatemaltecas de las mujeres mayas y consiguió visibilizar a nivel internacional la lucha de las guatemaltecas por defender sus tierras, sus comunidades y su cultura ante la violencia creciente del Estado. De hecho, "Rigoberta llegó a representar la antítesis de los estereotipos de las mujeres mayas como silenciosas, tradicionales, estáticas, sin política y sin agencia". ${ }^{30}$

En esta dirección, si bien con fuentes documentales escritas, me he ocupado de los casos en que las viudas y madres de republicanos aragoneses desafiaron el discurso público y oficial del régimen de Franco. Primero, desvelando los fusilamientos y las fosas comunes frente a los asépticos "fallecimiento" que constaban en las fuentes oficiales. Es decir, activando su voz como reacción hacia el ejercicio de poder simbólico que suponía negar el luto al colectivo republicano y recuperando la memoria silenciada constituyéndose a sí mismas como sujetos éticos, sujetos políticos y sujetos de la resistencia..$^{31} Y$ en segundo lugar, si bien estos testimonios era expresión del sufrimiento social y del trastorno y del dolor de la pérdida, eran también la prueba de que estas mujeres habían seguido adelante. Se habían convertido en agentes de la memoria, en testimonios vivos de la implantación del régimen por las armas y en portadoras de experiencias de lo que consideraba una injusticia, un error irreparable. Así, no obstante la reivindicación de su carácter de víctimas y damnificadas, y de la visibilización de las condiciones de dominación que las múltiples legislaciones represivas habían llevado consigo, estamos ante una reclamación de la naturaleza de superviviente..$^{32}$

Como propuesta avanzaremos dos conclusiones. La primera de ella tiene que ver con ese sufrimiento social del que hemos hablado. Por ampliar el marco de análisis y seguir con la idea de la comunidad de duelo, me gustaría traer a colación algunos casos cercanos en los que el luto público ha estado asociado a procesos de disenso para con las versiones oficiales de "lo que pasó". Así fue en el caso de la búsqueda de los desaparecidos en Argentina, con el fenómeno de las Madres de la Plaza de Mayo. Así fue también más recientemente, en el accidente en la Línea 1 del metro de Valencia, de cuya reivindicación de responsabilidades ha nacido la

28 Desde el plano teórico lo ha trabajado Judith BUTLER: Mecanismos psíquicos del poder: teorias sobre la sujeción, Cátedra, Madrid, 2001. Combinando teoría y ejemplos históricos, Veena DAS: “The act of witnessing. Violence, poisonous knowledge, and subjectivity", en Veena DAS, Arthur KLEINMAN, Mamphela RAMPHELE y Pamela REYNOLDS: Violence and subjectivity, Berkeley/Los Ángeles, University of California Press, 2000, pp. 205-225; Irene MURILLO: "Dignidad, supervivencia y luto. Agencias y resistencias de mujeres aragonesas de guerra y posguerra", en Mercedes YUSTA e Ignacio PEIRÓ (coord.): Heterodoxas, guerrilleras y ciudadanas. Formas de resistencia femenina en la España moderna y contemporánea, Zaragoza, Institución Fernando el Católico, 2014, en prensa.

29 De Arthur KLEINMAN, Joan KLEINMAN, “Lo moral, lo político y lo médico. Una visión socio-somática del sufrimiento", en Emilio GONZÁLEZ FERNÁNDDEZ y Josep M. COMELLES (comp.): Psiquiatría transcultural, Madrid, Asociación Española de Neuropsiquiatría, 2000, p. 20. Citado en Ignacio FERNÁNDEZ DE LA MATA: “La memoria y la escucha...", online.

30 Como estudia Victoria Sanford, tanto las representaciones románticas como las oficiales, negaban a las mujeres mayas la capacidad de respuesta política ante las estructuras. Victoria SANFORD: "From I, Rigoberta to the Commissioning of truth:Maya women and the reshaping of Guatemalan history", en Cultural Critique, 47 (2001), pp. 16-53.

31 La idea de sujeto ético, político y resistente procede de Foucault. En Rodrigo CASTRO ORELLANA: Foucault y el cuidado de la libertad. Ética para un rostro de arena, Santiago de Chile, LOM Ediciones, 2008, pp. 186-190.

32 Irene MURILLO ACED: En defensa de mi hogar y mi pan. Estrategias femeninas de resistencia civil y cotidiana en la posquerra zaragozana, 193-1945, Zaragoza, Prensas Universitarias de Zaragoza, 2013. plataforma "Asociación víctimas del metro del 3 de Julio". En todo caso, me gustaría avanzar aquí la idea de que una comunidad de dolor que se convierta en una comunidad de victimización, sin posibilidad de crear lazos de solidaridad para con otras realidades y traumas sociales, sin empatia y sin capacidad de formularse un futuro utopico de justicia no entendida de modo excluyente, está abocada a convertirse en una comunidad de resentimiento.

La segunda tiene que ver con desechar el binomio por el cual ser una víctima y ser un agente son conceptos excluyentes. En lo referente a los Estudios sobre el Franquismo, me parece necesario desvincularse del mero análisis de las personas que sobrevivieron a la Guerra como víctimas y estar atentas, sin dejar de lado el análisis de la violencia social, a las estrategias en que "los individuos sin nombre han respondido, ingeniosamente e insubordinadamente, a las camisas de fuerza de la cultura y la sociedad". ${ }^{33}$ El énfasis en la capacidad de agencia individual permitiría tomar en serio "el esfuerzo que dedica la gente a "hacer" sus propias vidas, aunque no en las circunstancias que ellos mismos hubieran elegido".34

Ouizá encontrar esa iniciativa histórica pasa por deshacerse de la noción jurídica de víctima a la hora de historiar e incorporar las experiencias plurales y heterodoxas de estas personas evitando correr el riesgo de encorsetarlas, o de encorsetar la mirada de quien observa. Y por hacer una apuesta por un imaginario colectivo, la incapacidad de enfrentar el sufrimiento en la historia con maneras positivas de llevar al nacimiento del sujeto. Se pregunta Veena Das, "¿hay otros caminos por los que pueda darse la creación del yo, a través de la reocupación de mismo espacio de la devastación, acogiendo los signos de la injuria y convirtiéndolos en maneras de devenir sujetos?".35
33 Michael SEIDMAN: "Social History and antisocial History", Common Knowledge, vol.13,1, (2007), p. 49 34 James AMELANG: "En estado frágil", Historia Social, 6o (2008), p. 137.

35 Veena DAS: “La antropología del dolor", en Francisco Alberto ORTEGA (ed.): Veena Das. Sujetos del dolor..., p.159. 


\section{LA MEMORIA HISTÓRICA Y LA MEMORIA LITERARIA DE}

\section{MICAELA VILLEGAS EN LOS SIGLOS XIX Y XX}

Gisela Pagès

Universitat Autònoma de Barcelona

"Micaela Villegas ha sido y sigue siendo hasta hoy uno de los personajes femeninos más recordados de la historia colonial peruana".' Las palabras de la historiadora peruana llana Aragón ponen de manifiesto la trascendencia que tienen figuras históricas concretas en la memoria colectiva, en este caso, una mujer de la época de la colonia. La imbricación de Micaela Villegas en el imaginario popular ha sido y sigue siendo tan fuerte que ha llevado a otros a decir que "es la peruana más popular después de Santa Rosa de Lima",, esto es, se la equipara a la patrona y al principal símbolo de la nación peruana y más concretamente de la ciudad de Lima. Junto a los nombres de los ilustres próceres de la independencia que han engrosado la memoria histórica y literaria del territorio, figura el nombre de Micaela Villegas. Pero ¿qué tiene de particular para que haya sido ensalzada como emblema de Perú y todos los grupos sociales y raciales la hayan abanderado como símbolo en algún momento histórico? Sin duda, la trascendencia de su biografía, con toques legendarios, que acabó convirtiéndose en materia de literatos y adquiriendo trascendencia internacional de la mano de algunas de las más conocidas plumas.

Micaela Villegas, actriz de teatro limeña del siglo XVIII, ha contribuido a la configuración de una identidad nacional peruana y latinoamericana. Su personaje es un claro paradigma de proceso por el cual una figura histórica es convertida en un icono mediático hasta el punto de ser imposible la diferenciación entre la historia y la leyenda. Al mismo tiempo, su personaje ilustra cómo la búsqueda de una identidad peruana ha ido modelando y readaptando la visión que se tiene de ella. Su figura no tan sólo causó impacto en su época histórica, generando un gran escándalo, sino que ha tenido significación posteriormente inaugurando un tema publicístico, literario, artístico y operístico que ha llegado hasta nuestros días representado últimamente en los medios de comunicación de masas por la novela histórica, la televisión y el cine. ${ }^{3}$ Este tipo de aproximaciones poco han aportado al conocimiento de la realidad histórica de

Ilana ARAGÓN NORIEGA: “La casa de la Alameda, ¿un monumento al amor? Precisiones históricas en torno a la vida de Micaela Villegas", Revista del Archivo General de la Nación, 24 (2002), p. 165.

Max RADIGUET: Lima y la sociedad peruana, edición a cargo de Estuardo Núñez, Alicante, Biblioteca Virtual Miguel de Cervantes, 2001 3 Tenemos la novela de Jeamel FLORES: La rosa del virreinato, La Paz, Plural, 2007. En cuanto al cine se han hecho varias peliculas: La Perricholi, una producción peruana de 1928, dirigida por Enzo Longhi (1953) interpretada per Anno con en (1953), interpretada por Anna Magnani, en la que la protagonista es Camila (el nombre asignado a tres versiones cinematográficas basadas en el libro de Thornton Wilder, El puente de San Luis Rey: primera de 1929 dirigida por elinglés Charles $J$ Brabin la segunda, de 1944 dirigida por el estadoupridera, de 29 , digida por el ingles Charles J.Brabin; la segunda, de 1944, dirigida por en estadounidense Rowland V. Lee; y la tercera, de 2004, dirigida por Mary McGuckian. En la pequeña pantalla li, bajo a dirección de Edual Pen. En Alfonso Santiesteban. En 2011 se emitió una nueva serie de 70 capitulos con el mismo título. personaje, pero han contribuido a alimentar su mito y su memoria, generando una multiplicidad de lecturas sobre la misma que llegan hasta la actualidad porque su figura y su historia son constantemente reinterpretadas.

El objetivo de la presente comunicación consiste en analizar la construcción del mito y de la memoria de Micaela Villegas, tanto a nivel histórico como literario, durante los siglos XIX y $X X$, centurias fundamentales en la fijación de su memoria, tanto en el Perú como a nivel internacional. A lo largo de estos dos siglos se construyeron memorias diferentes y contrapuestas en función de quiénes elaboraban o escribian sobre su figura. Me voy a centrar en dos tipos de memorias. La primera es la memoria hispanista, que tuvo dos núcleos de emisión, uno peruano y el otro europeo, y que ensalzó a la actriz como un símbolo representativo del periodo colonial, pero también como un símbolo de rasgos hispánicos. De hecho, su figura encarnó todos los tópicos que según los europeos reunían las mujeres peninsulares. Por otra parte, y en contraposición a la anterior, se creó, mayoritariamente en el siglo XX y desde el Perú, una memoria indigenista y mestiza, según la cual Micaela Villegas era la representante de los grupos indígenas y mestizos, considerados los "auténticos" representantes de la nación.

Previamente al análisis de ambas memorias, voy a describir a grandes rasgos su trayectoria biográfica para comprender posteriormente cómo se ha construido su memoria y cómo se ha manipulado al mismo tiempo. Son muchas las incógnitas que todavía hoy no han quedado resueltas de su biografía. No obstante, ha habido un gran esfuerzo por parte de los historiadores por intentar separar la leyenda de la realidad histórica y ofrecer una biografía basada en aportes documentales y alejada de tintes literarios. ${ }^{4}$

\section{La trayectoria biográfica de Micaela Villegas}

Micaela Villegas nació en Lima, capital del virreinato de Perú, el 28 de septiembre de 1748 , en un contexto marcado por la devastación causada por un terremoto dos años antes y que destrozó completamente la ciudad y el principal puerto, situado en El Callao. Fue hija de crioIlos, el capitán arequipeño José Villegas y la limeña Teresa Hurtado de Mendoza. ${ }^{5}$ Era la mayor de siete hermanos, a los que se sumaban los cuatro hijos del primer matrimonio de su padre con una mujer de nacionalidad inglesa, María Micaela de Godard.

Pertenecía a una familia acomodada y de prestigio social. Sin embargo, los problemas financieros de la misma se fueron agravando con el paso de los años y cuando Micaela tenía diez años el deterioro económico había llegado a una situación extrema, hecho que obligó al abandono de la casa familiar, perdiendo todos los derechos sobre la misma (1758). Fue la gravedad de esta situación la que impulsó a la joven Micaela a empezar a trabajar de cómica, pese a la oposición familiar por la mala reputación de las actrices. En la época de la colonia, las mujeres

4 Guillermo LOHMANN: El arte dramático en Lima durante el virreinato, Madrid, Publicaciones de la Escuela de Estudios Hispano-Americanos de Sevilla, 1945. Raúl PORRAS BARRENECHEA: "La Perricholi: personaje histórico", Estudios de Teatro Peruano, serie IV, nº 9o, 1972. Alberto TAURO: Enciclopedia ilustrada del Perú, Lima, PEISA, 1987. Alberto TAURO: Diccionario Enciclopédico del Perú iluspedia ilustrada del Peru, Lima, PEISA, 1987. Alberto TAURO: Diccionario Enciclopédico del Perú ilus-
trado, Lima, Mejía Baca, t. I-IV, 1966-1975. Gustavo A. LEON Y LEON DURAN: La Perricholi: apuntes trado, Lima, Mejia Baca, t. I-IV, 1966-1975. Gustavo A. LEON Y LEON DURAN: La Perricholi: apuntes
histórico genealógicos de Micaela Villegas, Lima, Claire, 1990. Gustavo BACACORZO: La Perricholi: historico genealogicos de Micaela Villegas, Lima, Claire, 1990. Gustavo BACACORZO: La Perricholi,
$D^{a}$ Micaela Villegas, nulidad y reposición históricas, Lima, G. Herrera Editores, 1994. Ilana ARAGÓN $D^{a}$ Micaela Villegas, nulidad y reposición históricas, Lima, G. Herrera Editores, 1994. Ilana ARAGON
NORIEGA: “El teatro, los negocios y los amores: Micaela Villegas, la Perricholi”, en Carlos PARDO-FINORIEGA: "EI teatro, los negocios y los amores: Micaela Villegas, la Perricholi", en Carlos PARDO-FIsidad Católica del Perú-Instituto Riva-Agüero, 2004, pp. 353-403.

5 Sin embargo Porras Barrenechea advierte que parece ser hija de padres españoles porque su partida de bautismo se encontraba entre los follos de de diciembre de 1748, fue bautizada por el padre Fay Francisco Enrique del orden de San Agustín con el nombre de Maria Micaela. La madha fue la propia madre. Luis Antonio Eguiguren fue el incompleta R. Porras la transcribe integramente en el diario La Prensa el 11 de septiembre de 1944 
dedicadas a la farándula recibieron todo tipo de críticas pues eran consideradas mujeres de baja honra y de vida ligera y libertina, que no merecían ni la sepultura eclesiástica. El mundo de los cómicos y de las cómicas era muy endogámico y estaba caracterizado por una multiplicidad racial. ${ }^{6}$ Este elemento permite entender el fuerte rechazo de la familia de Micaela porque, a pesar de estar arruinados económicamente, eran criollos, es decir, tenían un origen europeo y eran de piel blanca. Y en el Nuevo Mundo, las cuestiones raciales estaban muy presentes.

Con el paso del tiempo, la joven Villegas consiguió imponerse en la escena gracias a los contactos y a las relaciones que mantuvo con el actor José Estacio y con el empresario Bartolomé Massa, pero también es cierto que destacó por una gracia y una versatilidad naturales, cosechando un éxito importante en el Coliseo de Comedias de Lima, el principal teatro de la ciudad.

En 1761 el noble de origen catalán, Manuel Amat, llegó a tierras peruanas procedente de Chile, como nuevo virrey. Con su llegada el teatro cobró un nuevo impulso debido a su nueva política urbanística y al fomento de los entretenimientos y los espacios de sociabilidad de tipo francés como los cafés y los paseos. En la documentación consta que el virrey era un asiduo de los espectáculos teatrales.? Seguramente en una de estas noches conoció a Micaela Villegas, que estaría actuando en el escenario. Sin embargo, se desconoce exactamente cuándo empezaron sus amoríos. Algunos autores creen que comenzaron en 1764 (G. León Duran) y otros en 1766 (A. Tauro) cuando ella todavía ejercía papeles secundarios. El historiador Gustavo León Durán nos dice lo siguiente:

Era mujer que en la flor de su juventud contaba sin lugar a dudas con un atractivo fulgurante sino una belleza encantadora, cualidades harto recomendables para destacar en e teatro, y que las ha de haber aprovechado para seducir al representante del rey y obtener incondicionalmente sus favores. Todo lo demás que se sostenga constituirá, a falta de mayores pruebas, puras especulaciones sin fundamento sólido. ${ }^{8}$

Es decir, poco se sabe acerca de cómo transcurrió la relación amorosa, aunque hay constancia de que existió. La mayor parte de episodios han entrado a formar parte de la leyenda que rodea la figura de la Villegas y a día de hoy todavía no se han podido verificar históricamente. Por ejemplo, uno de los episodios legendarios que siguen reproduciendo prácticamente todos los autores que han escrito sobre la actriz es el hijo que tuvo poco tiempo después de empezar la relación con el virrey. Un hijo al que habrían bautizado como Manuelito y que habría nacido en 1769 o 1770, pero aún no se ha encontrado su partida de nacimiento.

Un hecho que está claro es que el apoyo del virrey Amat catapultó a la fama a la joven Villegas. Gracias a su protección, la actriz adquirió varios bienes que le aseguraron una cierta estabilidad económica.

Entre 1773-1775 Micaela estuvo separada de los teatros y de los favores del virrey. No se saben os motivos exactos, aunque todos los autores-biógrafos comentan que fue a raíz de una discusión que mantuvo con el empresario Massa, al que abofeteó durante la representación de una obra, generando un gran escándalo en la ciudad de Lima. De inmediato fue reemplazada por otra actriz, Inés de Mayorga, conocida como la Inesilla y con quién ya habían surgido fuertes rivalidades. Pasados estos dos años, la actriz regresó a escena el 4 de noviembre de 1775 gracias

6 Gisela PAGĖs: “Actrices y empresarias de teatro. Las mujeres y las artes escénicas en la Lima colonial", comunicación presentada en la XII Reunión Científica de la Fundación Española de Historia Moderna. En prensa.

7 Ha quedado testimonio de su asistencia en algunas noches, como la del martes 8 de septiembre de 1767 , cuando presenció la comedia dramática de Calderón El mayor monstruo los celos. Guillermo LOHMANN: El arte dramático..., p. 439.

8 Gustavo A. LEÓN Y LEÓN DURAN: La Perricholi..., p. 71 . también al papel de mediador de su compañero de teatro, José Estacio. Su vuelta a los escenarios marcó el inicio de su momento de gloria. A partir de entonces se difundió el nombre con el que se la conoce, la Perricholi, ${ }^{9}$ que representa, en palabras de Guillermo Lohmann, a "la mujer criolla con espíritu creador y luchador, mujer que sabe imponerse con su oficio y alcanza el triunfo profesional. La que, desdeñosa y desdeñada, termina arrancándole el aplauso a sus críticos, aplauso espontáneo, imprevisto, que su gracia y arte saben hacer estallar"..$^{\circ}$ La alegría, sin embargo, duró poco ya que en julio de 1776 Manuel Amat fue relevado del gobierno y regresó a España. Desde entonces Micaela abandonó el oficio de cómica. Sabemos que el 22 de junio del mismo año dio a luz a una niña, Manuela, fruto de las relaciones con Martín de Armendáriz, coronel navarro de la provincia de Atacama y teniente general de la de San Juan de Lucanas. Es probable que falleciera porque se pierde su rastro y Micaela tampoco la menciona en su testamento."

En 1777, la Villegas volvió al negocio teatral, pero en esta ocasión como asentista, convirtiéndose en la nueva regente del Coliseo de Comedias y creando una compañía con el antiguo encargado del local, José de Villaverde. Compartía con éste el control económico y todo lo referente a la dirección escénica, incluida la selección de actores. Unos años más tarde, en abri de 1781, Fermín Vicente Echarri, el nuevo compañero sentimental de Micaela, sustituyó a Villaverde y se constituyó en su nuevo socio. Juntos dieron gran impulso al Coliseo de Comedias. Estuvieron ocho años al frente del negocio, después de los cuales se retiraron como asentistas. Unos años más tarde, el 4 de agosto de 1795 contrajeron matrimonio en la parroquia de San Lázaro después de conocer la noticia de la muerte del virrey Amat.12

Ya viuda de Echarri en 1807, Micaela vivió sus últimos años en la casa molino de la Alameda de los Descalzos, esquina con Copacabana, con su hermano José Felix, su hijo, su nuera y sus cinco nietos. La finca la había comprada el 13 de noviembre de 1781 a Pedro Nolasco del Portillo, y se convirtió en una de las casas más notables de la ciudad, especialmente por el valor comercial del molino, pues eran pocos los propietarios de molinos en la ciudad. Éste consiguió mantenerse en constante actividad y llegar a un nivel óptimo de productividad gracias a la exitosa tarea de Micaela. ${ }^{13}$ En paralelo, su casa se convirtió en un centro de personas distinguidas que se reunían para ver los desfiles de las carrozas. Entre sus amigos y parientes figuraban personajes vinculados a ideas favorables a la emancipación: Antonio de Bedoya y Valverde, abogado de la Real Audiencia, decano del colegio de Lima y firmante del acta del cabildo, fue su cuñado; Felipe Santiago Estenós, secretario de Simón Bolívar, fue firmante de su testamento en calidad de testigo; y cultivó la amistad de Mariano Alejo Álvarez, abogado de la Real Audiencia de Lima y precursor reformista de ideas independentistas.

Micaela Villegas murió el 7 de mayo de 1819 con un patrimonio nada desdeñable: la finca del molino, una casa en la calle del Huevo, otra en la calle Tintoreros, un rancho en el pueblo de Chorrillos, terrenos, vestidos, joyas, una calesa, muebles, esclavos y una colección de 125 libros, un patrimonio que en total sumaba 72.724 pesos. Su partida de defunción se encuentra en la iglesia de San Lázaro. Fue enterrada en el convento de los Descalzos y no en el cementerio general como era su voluntad.

9 Existen muchas leyendas sobre el origen de su apelativo, que todavía hoy siguen siendo motivo de fabulación y discusión. Algunos lo atribuyen al virrey Amat haciendo derivar el mote de la expresión perra chola o bien del término pretichol. Otros lo atribuyen al pueblo o a la aristocracia. Unos la llaman Perrachola, otros Perrichola y los peruanos la conocen como Perricholi aunque algunos autores consideran que el término correcto es Pirricholi.

10 Gustavo A. LEÓN Y LEÓN DURAN: La Perricholi..., p. 5.

11 La partida de bautismo fue hallada por Raúl Porras en los Libros Parroquiales de San Marcelo de Lima y fue publicada por él en "La Perricholi...", p.8.

12 Ilana ARAGÓN NORIEGA: “El teatro, los negocios y los amores...”, p. 398.

13 Ilana Lucia ARAGÓN: “El teatro, los negocios y los amores...”, p. 174 
En la cuarta cláusula de su testamento, expedido el 20 de marzo del mismo año manifestaba:"Tengo por mi hijo natural a don Manuel de Amat, habido antes del expresado matrimonio (con Echarri), lo que declaro para que conste".14 En esta cláusula no se especifica nada más, sin embargo, se quiere hacer constar que tuvo un hijo que, curiosamente, comparte el mismo apeIlido con el virrey. Son muchas pistas que nos informan que podría ser hijo de Manuel Amat, pero sin la partida de nacimiento no se puede confirmar.

Estos son los datos históricos y fidedignos que poseemos de la vida de Micaela Villegas, cuya biografía precisamente ha entrado en un terreno legendario por la relación que mantuvo con el virrey Amat. De hecho, dichos episodios legendarios han arraigado tanto en el imaginario popular que hoy en día es más fuerte la leyenda que la historia.

Micaela Villegas, junto con Santa Rosa de Lima, como hemos mencionado anteriormente, ha sido uno de los personajes más universales del Perú convirtiéndose en un símbolo nacional. Es un personaje histórico que para muchos simboliza el apogeo, el ocaso y la muerte del Imperio español ya que el tiempo de los españoles en el Perú sigue siendo para muchos españoles y peruanos el tiempo de la Perricholi, que comprende de mediados del s. XVIII hasta mediados del s. XIX, un tiempo histórico que se inserta entre el apogeo del virreinato y la proclamación de la independencia..$^{15}$

Precisamente, la trayectoria vital de Micaela Villegas basculó entre estos dos periodos históricos: el de la colonia de su infancia y su juventud al lado del virrey Amat, coincidiendo precisamente con los últimos suspiros del esplendor virreinal; y el de la emancipación de su etapa de madurez y vejez rodeándose de personajes favorables a la independencia, si bien no pudo ver un Perú independiente porque murió dos años antes de la proclamación en 1821. En este sentido el personaje de Micaela Villegas resulta fascinante porque encarna dos simbolismos claramente enfrentados, el del esplendor virreinal y colonial, asociado a la ocupación española y al hispanismo, y el de la emancipación, vinculado, a su vez, a las reivindicaciones indigenistas y mestizas de las provincias. Desde esta premisa, la historia de Micaela Villegas ha sufrido múltiples interpretaciones surgidas al calor de los acontecimientos históricos, políticos y sociales del Perú, que se han alineado en una de las dos vertientes simbólicas comentadas.

\section{Micaela Villegas, representante del hispanismo}

Micaela Villegas vivió su infancia de apuros y su juventud de opulencia y triunfos en la Lima colonial. Precisamente, este periodo de esplendor y de éxito junto al virrey Amat la asocia directamente con un momento de vitalidad en la Ciudad de los Reyes en todos los niveles: arquitectónico, intelectual, cultural, etc. Durante el periodo de gobierno de Amat, Lima se convirtió en el centro principal de irradiación de la influencia colonial, una brillantez que desde entonces fue progresivamente de capa caída, hecho que preconizó la pérdida de Imperio colonial español. Consecuentemente, al estar asociada al Perú y a la Lima del s. XVIII, el periodo último de esplendor del virreinato, Micaela Villegas se ha convertido en el emblema de la época virreinal peruana y en el símbolo de una generación hispanista que, con la intención de recuperar o emular un pasado colonial, evocó a la famosa actriz.

14 El testamento fue publicado por Andrés Echevarría Maúrtua el 18 de noviembre de 1928 en el diario El Comercio.

15 Jean DESCOLA: La vida cotidiana en el Perú en tiempo de los españoles: 1710-1820, Buenos Aires, Hachette, 1962, p. 18.
El movimiento hispanista peruano, conocido como la generación de fin de siglo o generación del novecientos, defendió la tendencia hispanófila que se extendió por América Latina en la época de entre siglos a raíz de la controversia entre latinos y anglosajones. Esta tendencia hispanófila encontró en el Perú a un grupo de intelectuales que desde diversas perspectivas trazaron sus propuestas sobre la defensa y la reivindicación de las raíces y los valores hispánicos. ${ }^{16}$

Enfrentados al desastre nacional de la guerra del Pacífico (1879-1883), estos autores empezaron a analizar las deficiencias de la sociedad peruana y el pasado literario se convirtió en un terreno de sumo interés para sus indagaciones. Con la intención de robustecer un sentimiento nacional que se creía dormido, fijaron sus ojos en las etapas históricas precedentes, focalizándose en el pasado virreinal. Adentrándose en el pasado colonial para conocerlo mejor, descubrieron en la colonia una variedad de momentos históricos y culturales, además de las trazas de una herencia española de gran riqueza. Las Tradiciones peruanas (1872-1883) del ensayista y literato Ricardo Palma, cuya mayor parte están ambientadas en el periodo de la colonia, se convirtieron en el libro esencial del patriotismo peruano de raíz hispanista. Palma es considerado el fundador literario de la capital peruana y el cronista clásico de la Lima vieja, un periodo que comprende desde el siglo XVI hasta el siglo XIX. A través de sus múltiples tradiciones recreó, con un tono jocoso, pícaro o moralista, episodios y personajes de la sociedad virreinal.

Palma escribió varias tradiciones ambientadas en el periodo de gobierno del virrey Amat, pero sin duda, la que más se centró en Micaela Villegas es la que lleva por título "Genialidades de la Perricholi". ${ }^{17}$ Este interés por la figura de la actriz formaba parte de un programa más amplio de recuperación de las raíces hispánicas de la nación peruana. Se consideraba que su figura reunía el simbolismo de la colonia. La trascendencia del personaje fue tal que incluso se creó un concepto nuevo derivado del mote de la actriz: "perricholismo". Dicha expresión fue utilizada por esta generación hispanista para hacer referencia a todo aquello que pertenecía al periodo colonial. Desde el punto de vista hispanista, el "perricholismo", también conocido como limeñismo, neocolonialismo o pasadismo, era entendido como la restauración y la glorificación del periodo colonial (especialmente el virreinato) en el pensamiento y en la literatura del Perú durante las tres primeras décadas del s. XX. ${ }^{8}$ Para los autores de la generación del novecientos, en el "perricholismo" era donde se encontraban las raíces de la nacionalidad es decir, en tiempos de la colonia.

Fue José Antonio de Lavalle (1833-1893), diplomático, historiador y literato peruano quien elaboró una primera biografía de Micaela Villegas, publicada en 1863 en La Revista de Lima bajo el título "La Perricholi". En ella definió a la actriz como la personificación de la limeña genuina del s. XVIII, que reuniría las siguientes características: graciosa, seductora y un tanto exótica, inteligente, viva, amante del lujo y del placer y profundamente religiosa. ${ }^{19} \mathrm{En}$ la descripción de Lavalle, Micaela es dotada de una serie de elementos que la convierten en el espectáculo preferido de una corte colonial picaresca. Nos dice: "era completamente seductora, de formas pulidas y graciosas, su tez ligeramente morena, era suave como un tercio-

16 Esta generación tuvo como abanderado y guía al intelectual José de la Riva Agüero que se convirtió en el representante de un positivismo conservador y en uno de los responsables principales del colonialismo literario en el sentido de la restauración del hispanismo. Otros miembros de la generación fueron los escritores e intelectuales Francisco García Calderón, su hermano Ventura y Víctor Andrés Belaúnde.Teodosio FERNÁNDEZ: "La generación del novecientos y los discursos de identidad", América sin nombre, 13-14 (2009), pp. 85-93.

17 Ricardo PALMA: "Genialidades de la Perricholi", en Tradiciones peruanas, Barcelona, Montaner y Simón, 1893-1996, t. II, pp. 389-400.

18 Jorge BASADRE: Siete ensayos de interpretación de la realidad peruana, Caracas, Biblioteca Ayacucho, 1979, p. 240.

19 José Antonio de LAVALLE: “La Perricholi", La Revista de Lima: periódico quincenal, vol. 7 (1863) pp. $221-236$ 
pelo, sus grandes y acerados ojos, ora lanzaban dardos ardientes, ora se velaban lánguidos bajo la doble cortina de sus pestañas rizadas".20 Básicamente se destaca el aspecto físico de la actriz, a la que se rodea de un componente erótico. Sin embargo, lo que quiero destacar es la asociación que establece entre la Villegas y la Lima colonial en un proceso mayor de vinculación del periodo colonial con las mujeres limeñas. Es decir, el virreinato peruano estaría representado por las mujeres de la capital y concretamente por las tapadas, mujeres de origen criollo que vestían un atuendo singular con el que se cubrían enteramente el rostro dejando un solo ojo al descubierto. ${ }^{21}$ Micaela Villegas, como criolla y como limeña, es erigida en el estandarte de las tapadas, convertidas a la par que en símbolo nacional, en un símbolo sexual por la tentación de su traje..$^{22} \mathrm{Y}$ es mediante este atuendo que Micaela Villegas seduce al virrey Amat. Precisamente su relación amorosa con uno de los máximos representantes del Imperio español en Perú es lo que la vincula a las raíces hispánicas. La actriz es asociada a lo español e incluso perpetuaría su linaje con el hijo que tendría con el virrey Amat. Dicha vinculación a lo hispánico se efectúa también apelando a su origen criollo pues es descendiente de peninsulares. La generación hispanista peruana consideraba que los criollos, en tanto que descendientes de los españoles, eran los que debían liderar el proceso de formación de la nación peruana, reivindicando la blancura del Perú, o al menos, de las élites dirigentes.

Mientras que para los hispanistas peruanos Micaela Villegas fue la representante de la colonia y de las mujeres limeñas, los hispanistas europeos la ensalzaron como el prototipo de la mujer hispánica. Los intelectuales y los viajeros europeos del siglo XIX establecieron una identificación entre España y los territorios latinoamericanos. Durante esta centuria, Es paña se convirtió en el país romántico por excelencia, una reserva de exotismo cuya esencia estaba asociada a conceptos como la sensualidad, la crueldad, el honor y el tradicionalismo. Se consideraba que todo lo que estaba situado más al sur de los Pirineos constituía otra realidad diferente de la europea, que se asociaba al mundo oriental. Y si España era exótica, también lo tenían que ser las excolonias por tener raices hispánicas. Dicha asociación, marcada por la uniformización y la homogeneización, tenía su razón de ser. Servía como proceso para subalternizar a España y América Latina. Había un interés por diferenciar el mundo hispánico del europeo y proyectar sobre él una actitud de superioridad y una mirada colonialista. De esta manera se creó la percepción de que el pueblo hispánico tenía una psicología particular. Y en este proceso de fijación de imágenes y de estereotipos la literatura tuvo un papel relevante. De hecho, fueron los primeros hispanistas literarios los que tuvieron un

20 Sara CASTRO-KLARÉN: “El siglo XVIII: sujetos sub-alternos y el teatro de la Perricholi” en Francisco LA RUBIA PRADO y Jesús TORRECILLA, (dirs): Razón, tradición y modernidad: revisión de la llustración Hispánica, Madrid, Tecnos, 1996, p. 90.

21 El vestido de las tapadas estaba formado por dos piezas. La saya era una pieza similar a una falda plegada que se utilizaba para ceñir las caderas, se detenía a la mitad de la pierna para dejar visible la media de seda y el pie de las limeñas. El manto servía para cubrir la mitad superior del cuerpo, incluida la cabeza, dejando tan sólo al descubierto un ojo. Eva Ma VALRRO JUAN:"Otra perspectiva urbana para la historia literaria del Perú: la «tapada» como símbolo de la Lima colonial", América sin nombre, 15 (2010), pp. 69-78.

22 Eva Ma VALERO JUAN: "La construcción literaria de la tapada como icono de la Lima virreinal" I Encuentro internacional Virtual Mujer lite inderinal" rado de internet (http.//www.miradamar independencias iberoamericanas, Madrid, 2008. Recuperado de in en su obra Peregrinaciones de una paria lima, Centro de la Mujer Peruana Flora Tristán 2006 pp. 490-497. Carmen Rodriguez de Tembleque. "Un traje para la insinuación, la provocación y el

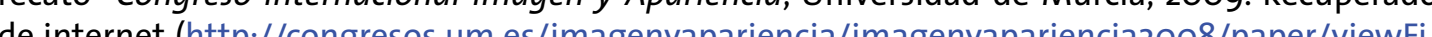
le/2761/2701).
les://congresos.um.es/Imagenyapariencia/imagenyapariencia2008/paper/viewFi- papel fundamental en la creación de una determinada imagen de Hispanoamérica, los mismos que recuperaron y universalizaron la historia de Micaela Villegas como la representante de los rasgos típicamente hispánicos.

Por encima de todos ellos destaca el francés Prosper Mérimée (1803-1870) que con sus obras contribuyó a configurar un arquetipo del mundo hispánico que cristalizó dentro del imaginario europeo manteniéndose hasta los años 30 del siglo XX.23 Precisamente este autor, en una obra de juventud que llevaba por título Le Carrosse du Saint Sacrement (1829) fue el que trazó a nive literario las primeras escenas amorosas entre el virrey Amat y la actriz Micaela Villegas, universalizando su mito. ${ }^{24} \mathrm{El}$ mismo autor que inauguraría en 1845 uno de los grandes tópicos de la imagen de España en el mundo a través de los amores entre la gitana Carmen y el militar Don José. No obstante, su obra ambientada en el Perú contiene de forma embrionaria algunos de los tópicos del ideal romántico de la mujer hispana que posteriormente serán explotados en Carmen. ${ }^{25}$ Así, la imagen tópica de la mujer española encuentra sus orígenes en la mujer peruana.

Mérimée sintetizó los tópicos y los estereotipos hispánicos tanto en Carmen como en Le Carrosse. En las obras del literato francés los elementos hispanos se españolizaban y los españoles quedaban tipificados como andaluces. Es decir, para Mérimée, que había recorrido el territorio peninsular y dejó testimonio de ello, Andalucía acabó representando el verdadero espíritu nacional español. Y dicha asociación se observa en la caracterización de Micaela Villegas que es convertida en una Carmen peruana al encarnar el modelo de mujer andaluza de cabellos y ojos negros, dientes blancos, sensual, exótica, pasional y un poco peligrosa. La caracterización de Mérimée transpiraba una esencia oriental-andaluza, con ciertos aires moriscos, cuestión que se evidenciaba en el atuendo de las mujeres limeñas. El manto de las tapadas procede de las mujeres musulmanas del sur de la Península lbérica. De esta manera se establece una asociación clara entre las moriscas y gitanas de Andalucía -Carmen también viste el manto-y las mujeres limeñas, simbolizando todas ellas el tópico de la mujer hispánica por excelencia.

Micaela Villegas entró a formar parte de una memoria hispanista. En el caso peruano fue asociada al periodo de la colonia, considerado un tiempo de esplendor, mientras que en el caso europeo fue vinculada al mundo español-andaluz.

\section{Micaela Villegas como símbolo indigenista}

La construcción de una memoria indigenista y mestiza de Micaela Villegas tuvo lugar mayoritariamente en el siglo XX, momento en que se produjo una multiplicación de las representaciones literarias sobre la actriz. Dicha memoria convirtió a Micaela en el estandarte de los grupos mestizos e indígenas de la sierra peruana, no obstante su origen criollo y limeño. Hubo, por tanto, una manipulación de la memoria histórica del personaje, a pesar de que desde los años 40, con el hallazgo de su partida de nacimiento, se puso fin a la controversia sobre la localidad de su origen, ubicada en Lima. Sin embargo, existe toda una tradición histórica y literaria indigenista vinculada a su figura que ha calado fuertemente en el imaginario popular y que llega hasta la actualidad, pues todavía hay versiones que le siguen atribuyendo unos orígenes indigenas y serranos. Buena muestra de ello es la casa-museo que existe en Huánuco, población del interior del Perú y que se reivindica como la localidad dónde nació la famosa actriz y donde habría vivido parte de su infancia antes de trasladarse a la capital.

La defensa de un origen provinciano (léase mestizo/indígena) de Micaela Villegas esta vinculada a una corriente literaria que surgió en Perú en la década de los años 20 del s.

23 León-François HOFFMANN: Romantique Espagne. L'image de l'Espagne en France entre 1800 et 1850, Publications du Département de Langues Romanes de l'Université de Princeton, 1961.

24 Prósper Mérimée: Le Carrosse du Saint-Sacrement, Paris, L’arche Éditeur, 1959.

25 Prósper Mérimée: Carmen, Madrid, Cátedra, 1989. Edición a cargo de Luis López Jiménez y Luis-Eduardo López Esteve. 
XX y que tenía la intención de romper con la tendencia hispanófila comentada en el anterior apartado. Los principales representantes de esta ruptura fueron los escritores Manue González Prada, Abraham Valdelomar y José María Eguren. Estos autores reivindicaron una nueva conciencia que dirigiera su mirada hacia extramuros de la ciudad de Lima para contemplar la sierra andina, indígena y mestiza, donde se encontraban las auténticas raíces de la nacionalidad peruana. Esta generación, que se creó alrededor de la revista Colónida, pretendía romper la dependencia de la cultura peruana respecto la española. Y curiosamente, dicha generación también utilizó el término "perricholismo", derivado del mote de Micaela Villegas, pero en un sentido totalmente contrario al empleado por la generación hispanista. Fue el escritor Luis Alberto Sánchez, representante de esta nueva corriente, quien, con un tono irónico y crítico denominó al brote hispanista "perricholismo", entendido, en palabras suyas, como "la adoración incondicional del virreinato, de la anécdota, de lo trivial y gracioso dejando a un lado lo profundo e intenso: es la idolatría de la superficialidad". ${ }^{26}$ Es decir el periodo del virreinato sería banal, postizo y estaría marcado por un deseo de ascensión social, siendo Micaela Villegas la máxima representante de esta actitud frivola al unirse al virrey Amat para obtener mayores prerrogativas. El "perricholismo" simbolizaría, por tanto, la unión al poder para ascender socialmente.

Sin embargo, estos mismos autores que criticaron a Micaela Villegas, o más bien su actitud por encarnar la frivolidad virreinal, escribieron sobre ella readaptando su biografía a sus intereses nacionalistas. Precisamente Luis Albero Sánchez elaboró en 1936 una novela biográfica en la que, a pesar de reconocer que la actriz había nacido en Lima, afirmaba que se habría criado en la sierra peruana. ${ }^{27}$ Era una manera de reconvertir un símbolo criollo y costeño en uno indígena y serrano, una estrategia que formaba parte de una pugna más amplia entre precisamente el limeñismo y el serranismo y que se vinculaba a las discusiones sobre dónde se encontraban las auténticas raíces nacionales.

Micaela Villegas fue utilizada para idear un proyecto de patria en el que se incluyeran a las clases indígenas. La invención de unos orígenes serranos para la actriz respondía a un propósito muy claro: se quería hacer frente al modelo de patria criollo y blanco costeño y reivindicar la participación indígena en la formación de la nación. Y que más útil que transformar uno de los símbolos criollos por excelencia en un prototipo serrano.

Así pues, en la lectura de Micaela Villegas como símbolo indígena hay una interpretación positiva de las mujeres, consideradas las auténticas portadoras de la nacionalidad peruana. Cuestión que se hace evidente en la novela de Enrique López Albújar, El hechizo de Tomaiquichua, en la que se relata el poder de seducción de la sierra, personificada en Miquita -un alter ego de Micaela Villegas-..$^{28}$ La lectura indigenista defiende una vida austera, en armonía con la naturaleza y esta vida se encuentra depositada en las mujeres provincianas. En la sierra uno vive a la manera nacional y patriótica porque en esta región se encuentra la esencia de la auténtica nacionalidad peruana personalizada en la figura de las mujeres indigenas. Precisamente, se reivindica la aportación materna de las mujeres indígenas en el proceso de mestuvieron el papel de dar a los hijos la lengua materna y las raíces en el suelo americano, pero fueron descalificadas por su supuesta sensualidad y vicio. Aun así, no todas las mujeres han tenido un mismo tratamiento memorístico e ideológico en lo que se refiere a esta cuestión. La Malinche o la Pocahontas, mujeres ambiguas, permiten reflexionar sobre la aportación materna indígena del mestizaje. La Malinche es considerada la mujer que da origen al mestizaje

26 Luis Alberto SÁNCHEZ: Panorama de la literatura del Perú. Desde sus origenes hasta nuestros dias, Lima, Milla Bartres, 1974, p. 97

27 Luis Alberto SÁNCHEZ, La Perricholi, 1936.

28 Enrique LÓPEZ ALBÚJAR, El hechizo de Tomaiquichua, Lima, Ediciones Peruanidad, 1943 mexicano, a una nueva raza. La Pocahontas, por otra parte, ha sido interpretada como una intermediaria entre los nativos y los extranjeros.

Como mujer indígena/mestiza, según la interpretación de los autores indigenistas, Micaela construye todo un escenario de desafío. La actriz es considerada una precursora de la causa emancipadora y esto es ejemplificado, en primer lugar, con su actitud altiva frente al virrey, al que obliga a satisfacer todos sus caprichos y deseos, llegando éste a convertirse en una marioneta en sus manos. Todo ello es interpretado como una especie de "victoria" de los grupos subalternos frente a los españoles. En segundo lugar, es mostrado con el hijo mestizo que tiene con el virrey Amat, Manuel Amat y Villegas y que, según la leyenda, fue uno de los firmantes del acta de independencia del Perú. ${ }^{29}$ La Villegas, como la Malinche, sería la portadora de una nueva raza, en este caso, la que encabezaría el proceso emancipatorio del Perú.Y el joven Manuel Villegas sería la sangre de la nueva nación que "sabía que encarnaba el nuevo Perú, el que se forjaría de la pasión ilegítima, de la sangre hirviendo en las calles y en los colchones, el que emergió a partir de la colisión de dos mundos condenados a no entenderse por los siglos de los siglos".30

La memoria indigenista de Micaela Villegas fue elaborada mayoritariamente por autores peruanos, pues en ella había un componente de tipo nacional. Construyendo un símbolo patrio de raíces indigenas se pretendía reivindicar la aportación de los grupos indígenas en la construcción de la nación. Sin embargo, la influencia de esta corriente llegó a autores de otras nacionalidades que contribuyeron a perpetuar el origen serrano de la actriz. ${ }^{31}$

\section{Conclusiones}

Las lecturas simbólicas que se han elaborado alrededor del personaje de Micaela Villegas son múltiples. En esta comunicación nos hemos querido acercar a dos de ellas, que están alineadas, asimismo, a dos procesos de construcción de la memoria histórica del personaje. Por una parte, una memoria hispanista, que al mismo tiempo ha tenido dos claves interpretativas en función del espacio geográfico desde dónde se ha construido dicha memoria. Desde e territorio del Perú, la Villegas ha sido ensalzada como el prototipo de la colonia, considerada una época esplendorosa, así como el arquetipo de la auténtica mujer peruana, representada por las tapadas limeñas. Por otra parte, desde una visión europea, ha sido ensalzada como el tópico de la mujer hispánica que incluso antecede algunos rasgos de la famosísima Carmen de Mérimée.

En paralelo se ha construido una memoria indigenista y mestiza, básicamente procedente del Perú que, reconvirtiendo determinados aspectos de su biografía, la han asociado al mundo de la sierra, considerado el espacio de las auténticas tradiciones y nacionalidad y la han erigido en el símbolo de la independencia por "vencer" al virrey y por dar a luz a su hijo mestizo.

Tenemos, por tanto, dos memorias muy diferentes, incluso opuestas, pero que ambas, contribuyen y siguen perpetuando la figura Micaela Villegas como un símbolo nacional del Perú.

29 Sin embargo, he consultado el acta de independencia del Perú y entre el número de firmas, no consta la de Manuel Amat y Villegas. Se puede considerar, por tanto, un episodio legendario.

30 Jeamel FLORES: La rosa del virreinato, La Paz, Plural, 2007, p. 17.

31 Uno de ellos fue el premio Pulitzer Thornton Wilder que en su obra, El puente de San Luis Rey (1927) la dibujaba como el prototipo de la mestiza peruana. 


\section{Introducción}

Cuando en 1898 Charles Seignobos y Charles Langlois publicaron Introduction aux études historiques, se convirtió en manual de referencia para todo joven estudiante e historiado que quisiera hacer del estudio del pasado su profesión. En él se definía su objetivo y método de acceso a dicho pasado: "describir por medio de documentos" las sociedades a las cuales se pretendía conocer.

Así parecía quedar constituido un método histórico con unos fundamentos basados en una propuesta rankeana y sólo sería posible un avance e introducción de nuevos métodos y enfoques cuando este "blindaje rankeano" ${ }^{2}$ fue desmantelado sobre la hegemonía de la fuente escrita, el documento como huella única y verdadera del pasado histórico.

Allan Nevins en los años cuarenta del siglo pasado fue el primero que, provisto de una grabadora, fue desarrollando una serie de entrevistas sobre las actuaciones y manifestaciones de los diferentes grupos dominantes en esos momentos en la sociedad norteamericana. ${ }^{3}$ Todo ello acabó formando el Columbia Oral History Office, fue el nacimiento de lo que se conoció como historia oral. Dos décadas más tarde serían las luchas pro derechos civiles de Estados Unidos los que reclamarían con voz propia el valor de la historia oral, de su experiencia de vida.

Fueron los testimonios directos de los que hasta ese momento no habian tenido voz propia los que utilizaban las nuevas formas de hacer historia. Fue en esa búsqueda de dar la palabra a los grupos que hasta ahora no habían podido tenerla, donde se les doto de voz propia a los excluidos. Como apunta Morales Ferreira la historia oral "se reafirmaba como un instrumento de construcción de identidad de grupos y de transformación social". ${ }^{4}$

Es en ese contexto de descubrimiento del otro cercano donde nuestra propuesta historiográfica adquiere protagonismo. Para ello comentaremos dos propuestas sobre el conocimiento que se tiene sobre la población gitana, utilizando para ello dos propuestas de historiadores cuyo método ha sido el uso de la fuente oral como principal herramienta de trabajo.

A través de las entrevistas, como método de producción de fuentes orales a la hora de investigar el pasado más presente de dicho grupo, éstas se convierten en la piedra angular de dicho método. En nuestro caso se convierten, de hecho, en la única. La cultura gitana extendida por toda Europa es una sociedad ágrafa donde el acceso a su pasado se nos presenta, como mínimo, escurridizo y de manera a veces oblicua.

Marieta de MORALES FERREIRA: "Historia oral: una brújula para los desafíos de la historia", HAFO, 28 (2002), pp. 141-142.

2 Elena HERNÁNDEZ SANDOICA: Tendencias historiográficas actuales, Madrid, Akal, 2004

3 Marieta de MORALES FERREIRA: “Historia oral...", pp. 147-148.

4 Ibid., pp. 149-150.
Recordar solamente las palabras de Ronald Fraser sobre el valor "mediador"de la fuente oral: "nos proporcionan dos ventajas considerables, en mi opinión. Como por su naturaleza, son simultáneamente representaciones de situaciones y de reacciones a estas situaciones, la realidad socio-histórica tanto como el resultado de estructuras 'objetivas' puras o como el resultado de la acción subjetiva pura. Por eso creo que es mediante la praxis del sujeto como las fuentes orales pueden captar mejor la experiencia". ${ }^{5}$

\section{Dos propuestas}

La primera de ellas corresponde a Jean Luc Poueyto aparecida en la revista Historia, Antropología y Fuentes Orales, 2, 30, 2003 y titulada Los recuerdos de los campos de concentración de los gitanos de la región de Pau. Nos recuerda la importancia que desde el siglo XIX en Francia han tenido instituciones como la Dirección Nacional de Archivos (públicos o privados), la Dirección de los Museos nacionales o la Dirección de Arquitectura y Patrimonio a la hora de recabar datos, preservar y difundir el papel de la memoria francesa.

La influencia de Pierre Nora a través de su Les lieux de mémoire no deja nunca de planear sobre dicho planteamiento. Su propuesta de una historia de "políticas de memoria" y "una historia de memorias colectivas" en Francia son las que sirven de base sobre el planteamiento en la búsqueda de nuevas perspectivas. ${ }^{6}$

Luc Poueyto nos habla de cómo la sociedad francesa está llevando a cabo una profunda revisión sobre su pasado más reciente, una vez superado el corsé historiográfico de la escuela de los Annales donde relegaban al olvido el papel del testimonio directo y de cualquier fuente oral. Nos habla incluso de la revisión que se está llevando a cabo sobre la guerra de Argelia, sobre cómo lo olvidado, lo no nombrado, esta siendo puesto encima de la mesa.

Dentro de este nuevo revisionismo de la sociedad francesa hay un sector que sigue siendo relegado al inefable olvido, los gitanos franceses, los manouches, los cuales fueron deportados e internados durante la II Guerra Mundial en Francia. ¿Por qué este olvido? ¿Cómo se accede a una memoria colectiva? ¿Cómo llegamos a conocer al "otro" cuando esta tan cerca?

Su objetivo principal es acceder a los recuerdos de los supervivientes de los campos de concentración. Para ello parte desde los presupuestos historiográficos descritos anteriormente, la recopilación de testimonios directos como fuente principal para la reconstrucción del pasado de la comunidad de los manouches.

Podemos sintetizar su trabajo en diez puntos clave de los cuales extraeremos algunas de las conclusiones más interesantes sobre el tratamiento de la oralidad en la comunidad gitana en particular.

Primeramente, el poco interés que ha despertado el estudio de dicho pueblo por el Estado francés. Desde el propio gobierno no ha tenido el suficiente apoyo, ni para su estudio ni para su valoración colectiva dentro de la sociedad francesa.

Seguidamente también llama la atención el escaso tratamiento que dicho colectivo ha recibido por parte de la comunidad de historiadores, siendo él mismo uno de los pocos que se ha atrevido a realizar una incursión en el tema.

En segundo lugar, alude al silencio. Silencio por parte de los propios gitanos. Un silencio imbricado de "respeto" hacia los "ausentes y presentes a la vez". La propia visión del pasado que se nos transmite a través del tratamiento que reciben los muertos en esta cultura es ambiguo. La

5 Elena HERNÁNDEZ SANDOICA: Tendencias historiográficas actuales, Madrid, Akal, 2004 6 Marieta de MORALES FERREIRA: "Historia oral: una brújula para los desafíos de la historia", HAFO, 28 (2002), pp. 141-150.

7 Jean LUC POUEYTO: "Los recuerdos de los campos de concentración de los gitanos de la región de Pau”, HAFO, 30 (2003), pp. 109-117. 
presencia inmaterial tiene un peso real en la actitud y las acciones de los vivos. Llegando incluso a moldear hechos, actitudes y posicionamientos sociales rígidos. Aquí la tradición juega un pape primordial para entender los lazos emocionales y simbólicos que fundamentan dicha actitud.

Estrictamente ligado al apartado anterior es el trato que recibe el Tiempo. El tiempo para los manouches, según Poueyto, acontece sin ruptura. Pasado y presente es uno, los vivos y los muertos transitan por él sin problemas. Pero se olvida de algo, como sostiene Liégeois: es "la reminiscencia constante del presente" lo que marca inexorablemente al gitano. Un presente que se perpetúa, es infinito. No es que no haya ruptura entre pasado-presente, lo que no hay es dicotomía sobre la cual dividir el tiempo. Botey, apunta a "una existencia ahistórica" 9 , lo que acaba invalidando cualquier proyección de futuro y restándole cualquier valor a la cronología, tal y como se entiende fuera de dicho grupo. Para nosotros todo este planteamiento sería explicable mediante la idea del "tiempo circular". No hay pasado por qué no hay futuro, sólo un presente que se perpetua.

La identificación de los otros ocuparía el punto siguiente. La identificación del "Otro", otro no gitano, no rom, no manouche, otro que no pertenece a la comunidad de los hombres como ellos "los verdaderos". Por ello, la identificación ante la responsabilidad de un hecho traumático como el internamiento se hace complicado, se problematiza ante nuestros ojos. No para ellos. Para los gitanos cualquier otra persona son los culpables. Por que la mirada de los otros - sociedad francesa - hacia ellos - gitanos - sigue siendo muy parecida a la época de los campos de concentración como pone de relieve nuestro autor al comentar un artículo del alcalde de Pau, Francia. ${ }^{\circ}$

Merece nuestra atención el qué se transmite y cómo se transmite por esta comunidad. Lo que para Poueyto se constató fue que la mayoría de edad simbólica se adquiere a una edad más temprana y esto implica que la memoria de la cual dispone el grupo, el colectivo, es mucho más precaria si cabe. Él apunta: "entre los manouches, las persona mueren y se casan mucho más jóvenes"1. La recepción, custodia y transmisión de un contenido siempre resulta problemática. Y este hecho se agudiza, se agrava más aún, cuando se multiplica el número de recipientes entre los que se trasvasa el contenido. Al aumentar el número de eslabones en la cadena de custodia de la memoria colectiva, el contenido simbólico se ha ido modificando.

Dicha modificación no es percibida por el grupo "todos afirman que - saben -" ${ }^{12}$ constituyéndose en una sola voz. Como se constató en el seno del grupo de supervivientes de los campos de concentración, la transmisión se efectuaba de forma oral de generación en generación, pero no quedaban testimonios vivos de la guerra. Ellos insistieron en que su conocimiento de la guerra, del hecho que había marcado a sus mayores como hecho traumático, también les pertenecía.

En su artículo, el discurso de Poueyto acaba revelándose como insuficiente a la hora de acceder al mundo de los manouches. Acaba confesándonos de una manera muy gráfica su frustración "Más allá de una transmisión - sorda - de dichos acontecimientos, que sigue siendo un misterio para mí". ${ }^{13}$ Así la transmisión de los hechos, de los acontecimientos vividos por los integrantes de la colectividad, se le muestra escurridiza a causa de la tradición.

La incertidumbre que produce el silencio sobre un pasado que no se puede nombrar desarma también de manera desalentadora al historiador que intenta acceder a dicho pasado. El mutismo, o un discurso fragmentado, es lo único que se acaba recibiendo. Pero además añade que el silencio no es sólo hacia fuera, hacia el historiador que intenta acceder a ese mundo como agente extraño dentro del mundo de los manouches, sino también hacia adentro, al no

8 Jean-Pierre LIEGEOIS: Gitanos e Itinerantes, Madrid, Presencia Gitana, 1987.

9 Sergio RODRÍGUEZ: Gitanidad, Barcelona, Kairós, 2011.

10 Jean Luc POUEYTO: “Los recuerdos de...”, pp. 109-110.

11 Ibid., pp. 110-111.

12 Ibid., pp. 113-114.

13 lbid., pp. 116-117. poder hablar por tradición entre ellos mismos de su pasado de una forma clara. Entendida la tradición como carga emocional y simbólica que acaba cuestionando, configurando y modificando las actitudes del individuo dentro del grupo social. Esto se efectúa al menos en dos niveles. Primero en la relación del propio individuo con otro individuo y en segundo lugar la relación que establece dicho individuo con el "grupo", con la sociedad a la cual pertenece.

En este tipo de concepción de la tradición, la reconstrucción del relato del grupo queda desarmado. No existiendo "relato histórico", la narración cronológica de los hechos, pero sí el simbólico que es percibido y entendido por la colectividad sin problemas. El silencio no es un no querer contar un pasado vergonzoso o traumático. Este tipo de silencio es respeto hacia un presente que se vive día a día. Tal como se entiende por parte de los gitanos este mutismo ensordecedor de la tradición, el respeto a uno mismo y al grupo, se acaba legitimando a si mismo. El que habla de un hecho que no se puede hablar esta traicionándose a sí mismo en primer lugar y a su pueblo en segundo.

Ante esta disonancia de información, Poueyto nos revela que la colectividad acaba componiendo su propio relato con fragmentos que toman prestados del exterior: "a través de la televisión, los libros y la crudeza de los discursos",14 como necesidad para el mantenimiento de su memoria colectiva. Ante el silencio interno del grupo el individuo necesita calmar su sed de información. El hecho que se entienda el sistema mediante el cual su propio grupo permanece cohesionado no excluye que siga necesitando una fuente de conocimiento.

Formula así una hipótesis de como se realiza la transmisión de los hechos por parte de dicha comunidad. La transmisión es defectuosa, parcial y fragmentaria, en primer lugar. Y en segundo término que las informaciones históricas proceden del exterior. Así el discurso que se acabaría transmitiendo mediante el relato no sería del todo completo. Lo cual vuelve a incidir en un sentimiento de desesperanza ante la forma de acceder a un pasado de un grupo que no posee escritura.

En conclusión para nuestro historiador, el acceso a la verdad o a un cierto conocimiento de la verdad estaría siempre vetado. La no respuesta, el silencio, un pasado difuso y el peso de una tradición imposibilitarían el acceso a su historia. Nos encontraríamos con una paradoja a la hora de acceder a su pasado histórico. La única vía de acceso a dicho conocimiento serí mediante la constatación de una tradición formulada bajo el no acceso a dicho pasado, ya que es un presente continuo.

La segunda propuesta que vamos a comentar corresponde al historiador Juan Carlos Baranco, cuyo artículo La venta al lote. Estrategias económicas de los gitanos valencianos, apareció en la Revista "Gitanos. Pensamiento y Cultura" N 44, Abril 2008.

Barranco nos propone conocer una de las principales actividades económicas llevadas a cabo por los gitanos españoles, la venta al lote. Su artículo recoge un amplio abanico de entrevistas de gitanos valencianos recogidas entre 1995 y 2003 . Mediante este método recoge los testimonios directos de la comunidad gitana en Valencia desde los años 50 hasta mediados de la primera década del siglo XXI.

Describe de forma sintética la situación económica del campo valenciano desde finales de la década del 50 y las distintas estrategias de compra-venta hasta la época del desarrollismo de los setenta y como de la venta ambulante los gitanos efectúan lentamente la transición hacia los mercadillos ambulantes de los pueblos. Cómo se pasa de una venta itinerante sin control por parte de las autoridades administrativas a otra que se lleva a cabo bajo las nuevas ordenanzas municipales para el control de este tipo de venta.

Barranco da desde el primer párrafo la palabra a los gitanos que ha entrevistado, que ha ido conociendo con grabadora en mano a lo largo de los años. El trabajo de campo ha dado 
su fruto y podemos rastrear toda una serie de testimonios directos de cómo eran este tipo de estrategias económicas por parte de la comunidad gitana valenciana.

Podemos analizar el trabajo de Barranco desde los siguientes aspectos. Primeramente, la fluidez con la cual se nos presenta la propia narración de los testimonios directos. Estos son presentados como fragmentos, extractos concretos de la conversación que viene a ilustrar o reformar el contenido histórico propiamente dicho: “- ¿De qué ha trabajado de joven? - ¿Yo? Vendiendo. A vender: sábanas, colchas, mantelerías, de todo. Si me costaba un duro la mantelería, la vendía por catorce (...)"16

El acceso al relato se nos presenta sin problemas, directo, sin silencios. A preguntas directas hay unas respuestas concretas. No existe el escapismo en la contestación recibida. La realidad de la cual parten ambos interlocutores es la misma. Ambos se sitúan en el mismo plano cognoscitivo ante el hecho de acceder a un entendimiento común.

La comunicación aparece sin problemas incluso cuando en la narración aparecen aspectos conflictivos. Cuando se nos muestra prácticas menos claras, oblicuas, de la población gitana: “- ¡Ganabas muchos billetes! ¿Eh? - Que si ganaba billetes... - ¡Cuenta la jojana que hiciste en el convento con la (tela de) retorta, eh!"”

Barranco nos explica que las jujanas provienen del romanó ${ }^{18}$ xoxanav que significa "mentir". Así mismo cuando se hace referencia a este concepto normalmente se realiza en contextos donde la estafa o el engaño son el marco de referencia donde habría que situarlo.

Es decir, los interlocutores son plenamente conscientes de la información que transmiten. $Y$ en segundo lugar lo realizan sin pudor a la hora de una posible reprimenda ética o prejuicios morales añadidos. La exteriorización, aclaración y narración de comportamientos susceptibles de ser catalogados negativamente se realiza sin ruptura, sin ambigüedad. Lo cual nos permite acceder al relato de vida de los individuos de una manera directa.

La transmisión se realiza mediante un lenguaje directo, donde los giros lingüísticos de los propios entrevistados adquieren un matiz de protagonismo:"- Mi madre se buscó una serie de clientes y que en aquel entonces se usaba mucho por los pueblos sobre todo hacer los ajuares de las mujeres y mi madre pues les proporcionaba pues tela blanca, (...)"..19

Todo ello adquiere relevancia si lo ponemos en relación con la narración o el intento de narración de los testimonios recogidos por Poueyto sobre el internamiento en los campos de concentración: "Además, hay manouches que han vuelto a ver a algunos clisté, algunos policías, que expulsaron a su familia a Alemania. - Yo he visto reportajes sobre todo eso, sí...No sé cómo decirlo, creo que es injusto (...)". ${ }^{20}$

El relato es elíptico y fragmentario, no acaba de tener coherencia y el propio testimonio acaba admitiendo su incapacidad para expresar lo que quiere decir. Todo ello configura un discurso inconexo además de ir creando el precedente negativo en la propia conciencia del transmisor.

En el artículo de Barranco el discurso es coherente y con un alto grado de plasticidad lo cual ayuda a entender mejor el universo de valores simbólicos de los entrevistados. La accesibilidad al pasado histórico se produce sin ruptura. El discurso configura un relato a la hora de acceder a una tradición inserta en una memoria colectiva.

Igualmente en el artículo mencionado la información que se nos proporciona sobre los hechos históricos analizados van acompañados por los testimonios directos a lo largo de un viaje

15 Juan Carlos BARRANCO: “La venta al lote. Estrategias económicas de los gitanos valencianos", Gitanos. Pensamiento y Cultura, 44 (2008), pp. 21-23.

16 lbid., p. 21.

17 lbid., p. 23.

18 Ibid., p. 23.

19 Ibid., p. 22.

20 Jean Luc POUEYTO: “Los recuerdos...”, p. 114 diacrónico. El tiempo histórico es parejo al tiempo emocional o vivido de los entrevistados. La intra-historia subjetiva plasmada en el recuerdo de lo vivido confirma la propia evolución de la sociedad en la cual se desarrollan los relatos de vida.

Tras iniciar contacto con el historiador Juan Carlos Barranco confirmamos nuestras primeras impresiones respecto al artículo analizado. El propio Barranco confirmó que en transcurso de sus múltiples encuentros y entrevistas con la población gitana de Valencia jamás tuvo problema alguno a la hora de acceder a las informaciones que él solicitaba. Tras varios años de trabajo de campo recopilando testimonios directos el acceso para Barranco ha sido siempre fructífero como él mismo nos ha comentado reiteradamente. ${ }^{2}$

Si comparamos ambos intentos de acceso a una cultura ágrafa como es la gitana (uno en Pau, Francia y otro en Valencia, España) observamos rápidamente las diferencias entre ambas propuestas.

Mientras que Jean Luc Poueyto acababa confesando su imposibilidad de acceso al material simbólico del grupo, la memoria colectiva. Por otro lado Juan Carlos Barranco accede sin problemas. El testimonio en ambos casos es la fuente histórica primordial, mientras que en uno el silencio, el lenguaje, la tradición y el mismo concepto de tiempo son puestos en cuestión, actuando como verdaderos agentes negativos. En otro caso el lenguaje, se articula de forma coherente, ordenada y clara permitiendo el acceso a ese universo colectivo de valores.

El tiempo, la tradición aquí no son cuestionados sino incluso confirmados ya que la intra-historia del grupo es contrastada y explicada también desde el tiempo histórico en el cua se desarrolla. El cambio de hábitos de venta (el paso de veta al lote al mercadillo) es propiciado por la propia evolución socio-económica de la sociedad valenciana del último cuarto de siglo $\mathrm{XX}$. Aquí ambas sociedad comparten un mismo tiempo diacrónico y sincrónico mediante el cual se han ido articulando mutuamente.

\section{Conclusiones e hipótesis de trabajo}

Todo el anterior planteamiento gira en torno de la idoneidad de las fuentes orales en el descubrimiento, comprensión y análisis de una cultura ágrafa como es la gitana. Las dos propuestas de análisis de dos espacios culturales analizados (uno sobre un hecho traumático y el segundo sobre las estrategias económicas) nos han planteado un reto interpretativo.

Por un lado observamos como elementos sustanciales a la hora de componer un relato histórico nos son vetados, tales como: un lenguaje incorrecto o la no adecuación para expresar lo que se quiere transmitir; la escasa disponibilidad por parte de los individuos a la hora de hablar sobre un hecho socialmente conocido; los múltiples elementos culturales que estrangulan dicho acceso como puede ser el propio tratamiento de un tiempo no histórico o el peso de las tradiciones; siendo al final un tiempo no narrativo en el cual no cabe la explicación de lo vivido.

En contra partida disponemos de otros aspectos que contradicen lo anterior. Primeramente la propia predisposición de los sujetos a contar su pasado, su experiencia vital. Ligado a esto el tiempo como concepto aprensible, los hechos pueden ser descritos, contados porque pueden ser puestos en orden cronológico.

El lenguaje no es una barrera para el entendimiento, sino que acaba siendo un poderoso aspecto de cohesión del grupo (un lenguaje propio, romanó, caló, etc.) 22 Por ello la articulación de un relato no sólo es posible sino necesaria. El testimonio directo se acaba constituyendo como primer referente y fuente de acceso a dicha cultura.

21 Juan Carlos Barranco, 2 de julio de 2013, Fundación Secretariado Gitano Valencia, entrevista realizada por Ricardo TORRES SILVA. Juan Carlos Barranco es Licenciado en Historia y trabaja desde hace más de una década para la FSG-Valencia.

22 "Romanó" es el nombre genérico que se suele dar a la lengua que hablan los gitanos de Europa.

La variedad dialectal que los gitanos españoles hablan se conoce como "caló". 
Lo que nosotros avanzamos como hipótesis de futuros trabajos con dicha colectividad es que ambas percepciones son ciertas. Nos podemos encontrar con estas dos posturas encontradas en esta sociedad. Estas dos posiciones son dos de las múltiples caras que puede tener e acceso a un pasado por parte de los historiadores. No por ser más o menos obvio hay que dejar de analizar los puntos clave de cómo se produce este proceso. El contexto del cual debemos arrancar nos marcará profundamente así como el ámbito de estudio que estemos tratando.

La conciliación vendrá determinada según el enfoque que adoptemos. En los casos que se nos presente de forma clara, fluida, coherente y cohesionada el acceso debemos aprovecharlo. La disponibilidad de testimonios accesibles y capaces de construir su propio discurso serán en sí mismo objeto de otros análisis con mayor detenimiento.

En aquellos casos donde dichos testimonios se nos presenten de forma oblicua, fragmentada, mediante un collage de distintas fuentes, incluso contradictorias, no invalida la idoneidad de dichas fuentes. Lo que hay que aplicar es otra forma de enfoque o método, a la hora de conseguir nuestro objetivo. El desvelamiento del "misterio" del grupo pasa por adecuar, modular y ampliar nuestro propio campo de visión como historiadores. 
Parte 4.

USOS PÚBLICOS DE LA HISTORIA EN LA

ESPAÑA CONTEMPORÁNEA: NACIONALISMOS, REGIONALISMOS Y MODELOS DE ESTADO 


\section{USOS PÚBLICOS DE LA HISTORIA EN LA \\ ESPANA CONTEMPORANEA.NACIONALISMOS, \\ REGIONALISMOS Y MODELOS DE ESTADO}

Luis Vicente Clemente Quijada*

Universidad de Extremadura

César Rina Simón**

Universidad de Navarra

Los historiadores nos acercamos al pasado desde el horizonte cultural en el que vivimos,

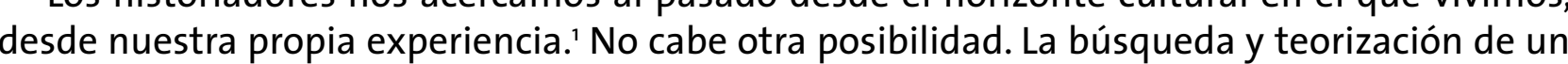
método historiográfico que incluyera la historiografía en el amplio campo de las disciplinas científico-sociales no ha logrado superar el estricto presentismo de nuestro trabajo. Desde Benedetto Croce a E. H. Carr, pasando por los representantes de los denominados cultural turn y linguistic turn, se ha planteado la interrelación entre el historiador y su tiempo y el historiador y su objeto de estudio. Se trata de una cuestión ontológica fundamental a la hora de acercarnos a los usos públicos de la historia.

En las siguientes páginas tratamos de reseñar la vigencia que tienen los debates en torno a los usos políticos, sociales y educativos de la disciplina en la actualidad, así como tratar de sintetizar las múltiples formas de gestión del conocimiento histórico de cara a la transmisión de saberes sintetizados y divulgados en los medios de comunicación o en los sistemas educativos. ${ }^{2}$ Hablar de los usos políticos y de las narraciones del pasado nos acerca a otros conceptos circundantes y complementarios, como son los de memoria, identidad, olvido, constructivismo, consolidación de las narrativas nacionales o legitimación historicista de los modelos de estado. Es por esto que, lejos de ser un asunto estrictamente historiográfico, la utilización de discursos históricos con una significación política, ideológica o normativa afecta a la cultura política de las sociedades y la dimensión "imaginaria" de los colectivos. ${ }^{3}$

Becario F.P.U. Departamento de Historia de la Universidad de Extremadura.

** Becario F.P.U. Departamento de Historia, Historia del Arte y Geografía de la Universidad de Navarra.

1 Vid. Paul RICOEUR: La memoria, la historia, el olvido, Madrid, Trotta, 2003

2 Con estos fines se celebró en Zaragoza, entre el 19 y 21 de septiembre de 2002, el primer congreso dedicado a los "usos públicos de la historia" en España. Carlos FORCADELL, et al. (coords.): Usos públicos de la Historia. VI Congreso de la Asociación de Historia Contemporánea, Zaragoza. Instituto Fernando EI Católico, 2002; Juan José CARRERAS y Carlos FORCADELL (eds.): Usos públicos de la Historia, Madrid, Marcial Pons, 2003. 3 Enzo TRAVERSO: El pasado. Instrucciones de uso. Historia, memoria, política, Madrid, Marcial Pons, la memoria y fantasmas del pasado. Usos y abusos de la memoria colectiva, Oviedo, Eikarras de Gonzalo PASAMAR: "Los historiadores y el uso público de la historia: viejo problema y desafio reciente", Ayer, 49 (2003) pp. 221-248; Ignacio PEIRÓ: "La era de Ia memoria: reflexiones sobre la historia la opinión pública y los historiadores", Memoria y Civilización: anuario de historia de la Universidad de Navarra, 7 (2004), pp. 243-294.

\section{Apuntes terminológicos}

El término "usos públicos de la historia" fue acuñado por Jürgen Habermas en 1986 en el seno de los debates intelectuales, políticos e historiográficos en torno a los orígenes y la dimensión del nazismo. ${ }^{4}$ Dicha utilización del pasado generaba una memoria encaminada a la comprensión de determinadas circunstancias políticas que conducían a la opinión pública o a la comunidad científica a desplegar sobre el presente un entramado de ideas e interpretaciones legitimadas en base al trabajo historiográfico. De esta forma, Habermas alertaba de la tendencia de los historiadores conservadores alemanes a integrar su trabajo en una disputa política -anticomunista, en este caso- que llevaría a la historiografía a márgenes indeseables, como sería la conversión del discurso histórico en memoria o identidad. En cierto modo, Habermas valoraba el proceso de conocimiento histórico desde una perspectiva racional-ilustrada, si bien no le faltaban argumentos para señalar la intencionalidad política e ideológica de determinados ensayos. ${ }^{5}$

La historiografía, en último término, es un conocimiento público por naturaleza y su profesionalización, precisamente, no ha despolitizado sus narraciones. No hay acontecimiento pretérito que no pueda ser arrastrado por el historiador hacia el presente para conducir el voto, generar corrientes de opinión o asentar instituciones políticas que reivindican esferas de poder en nombre de un pasado que sería el que les habría otorgado la legitimidad en el presente.

Sería conveniente establecer criterios de estratificación en el concepto de "usos públicos de la historia" para evitar su simplificación en un "todo" sin distinción, atendiendo a las circunstancias políticas que rodean al historiador, la legislación vigente, su compromiso ideológico, los modelos académicos de reproducción y prestigio así como los resortes de reconocimiento institucionales y la autocensura académica.

En primer lugar, cabría señalar la existencia de un uso público normativo, sometido a la legislación de los estados. Éste tipo es el más frecuente en modelos dictatoriales y totalitarios, que imponen una verdad histórica legitimista del régimen y aplican medidas coercitivas a los historiadores que no se acogen a dicha narración. ${ }^{6}$ También es el modelo de contro político del pasado de los sistemas parlamentarios que incluyen en su corpus legislativo referencias a un pasado que funciona a modo de imaginario identitario incuestionable. En las sociedades democráticas también tienen cabida determinadas medidas coercitivas, si bien las autoridades concentran sus esfuerzos en imponer una determinada explicación histórica en los sistemas educativos, en los programas conmemorativos o dotando de un áurea historicista a los símbolos oficiales.

Publicado en el semanario Die Zeit el 7 de noviembre de 1986 bajo el título "Del uso público de la historia. La visión oficial que la República Federal tiene de sí misma está estallando", Habermas se preguntaba por los puntos de unión entre el apasionamiento político y la frialdad del oficio del historiador. La disputa historiográfica, también conocida como Historikerstreit, enfrentó a Ernst Nolte, partidario de una comprensión revisionista del nazismo como respuesta al comunismo, y a Jügen Habermas. Nolte, desde una perspectiva historicista, consideraba el nazismo como un fenómeno ajeno a la historia alemana, como un movimiento provocado por circunstancias externas a la dinámica de la nación. Contradecía así los trabajos canónicos de Hannah Arendt: Los Origenes del Totalitarismo (1951) y Eichman en Jerusalén. Un estudio sobre la banalidad del mal (1961). De fondo, se estaba debatiendo el posicionamiento internacional de la República Federal Alemana respecto a la URSS y valorando el comunismo como sistema ideológico equiparable o no al nazismo.

5 Por su parte, Nicola GALLERANO: L'Uso pubblico della storia, Milano, Franco Angeli, 1995, pp. 17 y ss, consideraba restrictivas las conclusiones de Habermas, en tanto que el historiador no puede sustraerse de su época. Como han apuntado François HARTOG y Jacques REVEL: Les usages politiques du passé, Paris, EHESS, 2001, pp. 13 y ss., el uso de la historia con fines políticos es tan antiguo como la propia escritura del pasado.

6 Vid. Tzvetan TODOROV Los abusos de la memoria, Barcelona, Paidós, 2000. 
Encontramos un claro ejemplo de este uso público de la historia en la redacción de los Estatutos de Autonomía tras la aprobación de la Constitución en 1978. De esta forma, en el preám bulo del Estatuto de Andalucía, se definía dicha identidad en términos de singularidad como "pueblo, asentado desde épocas milenarias en un ámbito geográfico diferenciado. (...) La interculturalidad de prácticas, hábitos y modos de vida se ha expresado a lo largo del tiempo sobre una unidad de fondo que acrisola una pluralidad histórica, y se manifiesta en un patrimonio cultural (...) único entre las culturas del mundo."? La Autonomía sería la culminación de un proceso histórico teleológico. El esquema se repite en todas las comunidades autónomas, independientemente de su trayectoria histórica, de su lengua o de su movilización regional o nacional. ${ }^{8}$ Resaltar los principios historicistas que legitiman y constituyen los valores identitarios que constituyen las nuevas entidades políticas supone cuestionar sus principios constitutivos.

Encontramos otra fórmula de lo que hemos denominado usos públicos normativos en la Ley de la Memoria Histórica aprobada en el Congreso de los Diputados el 31 de octubre de 2007. En el texto, se reconocían a las víctimas de la guerra civil y de la dictadura, se fosilizaba determinada interpretación del pasado que a pocos convencía y se entraba en el campo de debate historiográfico. ${ }^{9} \mathrm{O}$ en la polémica desatada en Francia a raíz de una ley aprobada el 23 de febrero de 2005 por la que se decretaba que en los manuales escolares figurasen referencias explícitas a la influencia benigna que había ejercido la cultura francesa en sus colonias. En oposición a esta ingerencia legislativa y en defensa de la libertad de expresión en el trabajo historiográfico surgió la asociación Liberté pour l'Histoire, cuyo manifiesto fundacional firmaron, entre otros, Marc Ferro, Pierre Nora, Paul Veyne, Pierre Vidal, René Rémond, etc. ${ }^{10}$ Unos

7 Andalucía. Ley Orgánica 2/2007, de 19 de marzo, de reforma del Estatuto de Autonomía para Andalucia, Boletin Oficial de la Junta de Andalucia, 56, 20 de marzo de 2007, p. 2

8 Aragón. Ley Orgánica 5/2007, de 20 de abril, de reforma del Estatuto de Autonomía de Aragón, Boletín Oficial de Aragón, 47, 23 de abril de 2007, p. 6258: "El Reino de Aragón es la referencia de una larga historia del pueblo aragonés que durante siglos dio nombre y contribuyó a la expansión de la Corona de Aragón. Seña de identidad de su Historia es el Derecho Foral, que se fundamento en derechos originarios de los valores aragoneses de pacto, lealtad y libertad." En EXTREMADURA: Ley Orgánica 1/2011, de 28 de enero, de reforma del Estatuto de la Comunidad Autónoma de Extremadura, Mérida, Asamblea de Extremadura, 2011, p. 15: "desde las cuevas prehistóricas a los centros tecnológicos, se ha ido escribiendo silenciosamente la crónica de una voluntad de sentir, pensar, ser y estar en el mundo." O en CATALUNYA: Estatuto de Autonomía de Cataluña 2006, Barcelona, Generalitat de Catalunya, 2006, p. 7: "El pueblo de Cataluña ha mantenido a lo largo de los siglos una vocación constante de autogobierno." Vid. Juan Sisinio PÉREZ GARZÓN: “Los historiadores en la política española", en Carlos FORCADELL, et al. (coords.): Usos públicos de la historia..., 107-144; Í I. et. al.: La gestión de la memoria. La historia de España al servicio del poder, Barcelona, Crítica, 2000.

9 El documento final no contentó a la mayoría de partidos ni a las asociaciones que habían surgido para la "recuperación de la memoria histórica." Una crónica reflexiva del proceso en Santos JULIÁ: moria", Revista de Occidente, 302-303 (2006), pp. 7-8: "la historia en cuanto conocimiento crítico molia, Revista de Occidente, 302-303 (2006), pp. 7-8: "la historia en cuanto conocimiento critico como herramienta para transformar si no el pasado - porque el pasado es inamovible y del futuro no sabemos nada- al menos su representación. ÍD.: "El retorno del pasado al debate parlamentario. (1996-2003)", Alcores. Revista de Historia Contemporánea, 7 (2009), pp. 231-256; íD.: "Políticas públicas de la memoria", Informe sobre la democracia española 2011, Madrid, Fundación Alternativas, 2011, pp. 147-169. Favorable a este proceso memorialístico, entre otros, Francisco ESPINOSA MAESTRE: Contra el olvido. Historia y memoria de la guerra civil, Barcelona, Crítica, 2006.

10 Manifiesto firmado el 14 de diciembre de 2005: "La Historia no es una religión. El historiador no Manta ninún acepta ningún dogma. (...) El papel del historiador no es exaltar o condenar si no explicar. La Histemporáneos y no introduce en los acontecimientos de otras épocas la sensibilidad de hoy. (.) Historia no es un objeto juridico. En un Estado libre no corresponde ni al parlomento ni a la autoridad judicial definir la verdad histórica." Vid. Pierre NORA y Françise CHANDERNAGOR: Liberté meses antes, los historiadores Gérard Noiriel, Nicolas Offendstadt, Michael Giraud y Michèle Riot.Sarcey crearon el Comité de vigilante face aux usages publics de l'histoire para supervisa las injerencias públicas y políticas en el oficio de la Historia. En el manifiesto constitucional aprobado el 17 de junio de 2005, afirmaban:

nosotros, como profesores e investigadores, no podemos aceptar que el pasado se instrumentalice. Debemos esforzarnos para poner en disposición de todos los conocimientos y cuestionamientos que puedan contribuir a que se alcance una mejor comprensión de la historia. Se trata de alimentar el pensamiento crítico de los ciudadanos y, al mismo tiempo, proporcionarles elementos que les permitan enriquecer su propia opinión política, en lugar de hablar por ellos."

Esta injerencia estatal en la mentalidad de los ciudadanos se produce también de manera velada mediante el sistema educativo, entre otros recursos. El Estado educa a sus ciudadanos en la ilusión de la libertad, sin precisarles que se trata de una libertad vigilada. El control de los curriculum por parte de las instituciones (ministerios, consejerías...) genera un pasado "oficial" que debe ser aprendido e interiorizado y sobre el cual no siempre se enseña a reflexionar desde perspectivas alternativas. Así hay etapas, como el Medievo o el Antiguo Régimen, que acaban asociadas a una serie de adjetivos negativos, como los de injusticia, guerra, oscuriantismo, despotismo o fanatismo. El pasado se convierte de esta forma en una suerte de antisociedad por parte del Estado. La finalidad no es otra que generar una recreación donde el educando encuentre reflejados una serie de elementos que debe despreciar de acuerdo con los valores que se le desea inculcar. Véanse como ejemplo las líneas con las que se describía la Edad Media a los alumnos de un programa de Educación para Adultos puesto en marcha por la Junta de Extremadura: "Habrás oído el caso de gente rica que procede de padres muy humildes. Eso ocurre ahora con frecuencia, pero en la Edad Media, el que nacía noble o campesino no podía cambiar su situación, salvo ingresando en el estamento eclesiástico. En cuanto a los privilegios, actualmente no existen. Todos somos iguales, ricos y pobres contamos ante la ley con los mismos derechos y obligaciones." ${ }^{12}$ El grado de cinismo alcanzado en este párrafo se observa en la poca sutileza con la que el redactor/a oponía dos sociedades que él mismo había representado. Había un momento histórico donde ningún progreso personal era posible y donde el ser humano estaba sometido a los privilegiados. El alumno, tras la lectura de este párrafo, puede interpretar que, pese a su mala situación, el modelo actual es el menos malo. Supone así que en la Edad Media la gente vivía peor y que por tanto no será conveniente modifica las bases del sistema político contemporáneo, por si acaso se produjese el retorno de algo parecido al Medievo. Por tanto, mediante una supuesta intencionalidad formativa, el Estado adoctrina en el conformismo a sus alumnos mediante las deformaciones intencionadas de pasado. No dejaría de ser interesante que los Estados incluyesen en los curriculum de Historia una reflexión sobre los modelos económicos, unas líneas donde se presentasen alternativas a pensamiento único imperante en materia de derechos. Pero, en su lugar, prefieren atemorizar a sus alumnos con vagas generalidades sobre el injusto gobierno de las sociedades anteriores a los sistemas democráticos.

pour l'historie, Paris, CNRS Editions, 2008.

11 Consultado en la web del Comité el o9/01/2014: http://cvuh.blogspot.pt/2007/02/manifiesto-del-comite-de-vigilance-face.html

12 Unidad de aprendizaje 2 para Ámbito Social correspondiente al Nivel I, Módulo II: La Edad Media Una sociedad multicultural, recuperado de internet (http://avanza.educarex.es/cursos/course/ view.php?id=549). 
El Estado, en las sociedades contemporáneas, juega un papel relevante en la fijación de una memoria oficial. Es decir, delimita lo que se debe recordar y olvidar, lo conmemorable y lo despreciable del pasado, desde un eje cronológico que se proyecta desde el ayer hasta el presente, rememorando acontecimientos que tengan una utilidad pública para los motores de memoria y proyectando una imagen de futuro que permite la perpetuación del modelo de estado o de la identidad. La historia, como ha señalado Luis Castells, "ha sido y es una disciplina acosada desde los poderes públicos, que pretenden reiteradamente seducirla y atraerla para emplearla conforme a sus intereses."13 Dentro de esta dinámica, los relatos historiográficos se actualizan con las nuevas coyunturas político-culturales, socioeconómicas y con los cambios en el oficio de la historia.

El segundo estrato de usos públicos es el que podríamos denominar ideológico o de combate, y se caracterizaría por la búsqueda en el pasado de elementos que acrediten o doten de fuerza explicativa la escala de valores o el compromiso político del historiador. ${ }^{14}$ Encontramos ejemplos desde la fractura del espacio de experiencia y el horizonte de expectativas, lo que para Koselleck constituye la conciencia histórica que nace con la "Modernidad" y se caracteriza por una noción del tiempo lineal, en la que el pasado es una entidad ajena al presente. ${ }^{15}$ Fruto de esta fractura surgiría el pasado como entidad determinada, diferenciada del presente y baúl de un tiempo histórico encaminado hacia el futuro. La noción de "Modernidad" trae consigo el divorcio entre las experiencias (presente-pasado) y las expectativas (presente-futuro) provocado por la noción de progreso, que rompe la continuidad del tiempo. El interés por el pasado radica en su capacidad evocadora y en la potencialidad que tienen las narraciones para dar sentido al presente. De esta forma, a lo largo de toda la contemporaneidad, el recurso a la Historia ha permitido consolidar modelos políticos, ideologías, sistemas económicos, etc. ${ }^{16}$

Un debate característico de la utilización de la historia en el combate político se manifestó en el año 2010 en torno a los límites y significados de la "transición" política española. Josep Fontana, historiador que nunca ha ocultado su decepción ante el "moderantismo" o "traición" del PSOE y del PCE en las últimas décadas, publicaba un artículo de opinión en las páginas de Público que cuestionaba la idealización política e historiográfica de la "transición" y la Ley de Amnistía de 1977.7 Denunciaba la imposición de una memoria "incuestionable", construida sobre mitos como el pacifismo o el consenso colectivo. La tesis doctoral de Juan Andrade Blanco vendría a ratificar y completar las formulaciones del catedrático catalán: la transición política se hizo de espaldas a la militancia antifranquista, PCE y PSOE renunciaron paulatinamente a sus progra-

13 Luis CASTELLS ARTECHE: "La historia como actividad humana, como práctica”, Carlos FORCADELL (ed.): Razones de historiador. Magisterio y presencia de Juan José Carreras, Zaragoza, Institución Fernando el Católico, 2009, p. 215

14 Vid. Enzo TRAVERSO: La historia como campo de batalla. Interpretar las violencias el siglo XX, México, Fondo de Cultura Económica, 2012. Historiadores como Josep Fontana, a lo largo de toda su trayectoria profesional, ha desarrollado una concepción de la historia como un campo de batalla y del historiador como un ideólogo que a través del estudio del pasado puede transformar la sociedad. Josep FONTANA: Historia: Análisis del pasado y proyecto social, Barcelona, Crítica, 1999, p. 9: "Toda visión global de la historia constituye una genealogía del presente. Selecciona y ordena los hechos del pasado de forma que conduzcan en su secuencia hasta dar cuenta de la configuración del presente, casi siempre con el fin, consciente o no, de justificarla." La historia, por lo tanto, tendría una función y un compromiso social, y la labor del historiador de partido o de compromiso sería deslegitimar el historicismo del sistema capitalista.

15 Reinhart KOSELLECK: Futuro Pasado. Para una semántica de los tiempos históricos, Barcelona, Paidós, 1993; ÍD.: L'expérience de l'histoire, Paris, Points, 2011. Es lo que Hartog ha conceptualizado como régimen de historicidad. François HARTOG: Régimes d'historicité. Presentisme et expériences du temps, Paris, Seuil, 2003

16 David LOWENTHAL: El pasado es un país extraño, Madrid, Akal, 1998.

17 Josep FONTANA: “Tra(ns)ición”, Público, 5 de mayo de 2010. mas ideológicos con el fin de entrar en el juego parlamentario y el sistema pseudo-democrático se consolidó fruto del continuismo y la mutación de las élites políticas de la dictadura. ${ }^{18} \mathrm{El}$ artículo de Fontana respondía a una reflexión publicada en El País por Santos Juliá, donde llamaba la atención sobre el exceso memorialístico-surfeit of memory- latente en las sociedades contemporáneas y denunciaba la "marea de memorias" que afectaban a la interpretación histórica de España como fórmula presentista y académica de cuestionar el pasado y "mejorar la calidad de presente. ${ }^{19}$ Para Juliá, la Ley de Amnistía, el olvido voluntario, no fue una imposición de las élites franquistas, si no la aceptación por parte de todas las fuerzas políticas que la "venganza" no iba a facilitar la construcción de un nuevo modelo de estado democrático. ${ }^{20}$

Los debates en torno a la "transición" implican inevitablemente un posicionamiento político entre aquellos que consideran que el PSOE tuvo un comportamiento modélico en aras de la consecución del régimen de libertades y aquellos que tratan de dirigir el voto de la izquierda hacia otras formaciones por la renuncia histórica del partido a sus bases. Bien sea para justificarla o rechazarla, los historiadores parten de posiciones fijas en las que el alegato a la objetividad del oficio funciona como un argumento de autoridad dentro de entramado discursivo histórico e ideológico.

Otro caso paradigmático de usos públicos de la historia lo encontramos en la celebración bajo el amparo de la Generalitat de Catalunya, de un simposio académico intitulado "España contra Cataluña: una mirada histórica (1714-2014)", en el que diferentes historiadores profesionales fijaban su atención en las desavenencias históricas entre ambos territorios en aras de dirigir el recuerdo del pasado hacia determinadas posturas soberanistas. Julián Casanova, refiriéndose a dicho simposio, lamentaba "las declaraciones interesadas sobre la historia, ampliamente difundidas y manipuladas por medios de comunicación de diferente signo" que "contribuyen a articular una memoria popular sobre determinados hechos del pasado "Concluía haciendo una llamada a los historiadores para "promover una buena educación sobre la historia" mientras "las celebraciones oficiales siguen alimentando relatos míticos, simplificados, para consumo popular, a mayor gloria del poder."21

En suma, se busca a través de esta lectura del pasado un elemento aglutinante de las ideas del presente. La aparición de nuevas parcelas cronológicas en el eje de la Historia, como es el caso de la Tardoantigüedad, constituye un ejemplo ilustrativo de lo que aquí venimos planteando. Desde la publicación de la obra de Pirenne se abrió el debate sobre la formación de la civilización occidental, entendida como la evolución propia de elementos germano-latinos a partir del final de las relaciones mediterráneas, periodo que arrancaba con la llegada de los musulmanes..$^{22}$ Pero, sin duda, ha sido durante la segunda mitad del siglo XX cuando el se ha popularizado el estudio de lo tardoantiguo. Ouizá no sea una casualidad que se haya prestado una mayor atención al mismo a medida que se ha ido forjando la Unión Europea. El

8 Juan ANDRADE BLANCO: El PCE y el PSOE en (la) transición. La evolución ideológica de la izquierda durante el proceso de cambio político, Madrid, Siglo XXI, 2012. Ideas apuntadas previamente en Paloma AGUILAR FERNÁNDEZ: "Justicia, política y memoria, los legados del franquismo en la transición", A. BARAHONA DE BRITO, P. AGUILAR FERNÁNDEZ, y E. GONZÁLEZ ENRÍOUUEZ (eds.): Las políticas hacia el pasado. Juicios, depuraciones, perdón y olvido en las nuevas democracias, Madrid, Istmo, 2002, pp. 135-193; Vincent NAVARRO: “Consecuencias de la transición inmodélica”, El Pais, 8 de enero de 2003, pp. 14-24.

19 Santos JULIÁ: "Mirando hacia atrás", El País, 25 de abril de 2010.

20 Santos JULIÁ: "Echar al olvido. Memoria y amnistía en la transición", Claves de Razón Práctica, 129 (2003), p. 17: "una verdadera amnistía, en cuanto implica la decisión de echar al olvido el pasado, es todo lo contrario a una amnesia, que en castellano se diría caer en el olvido."

21 Julián CASANOVA: "Usos y abusos de la historia", El Pais, 11 de diciembre de 2013.

22 Nos referimos a los planteamientos defendidos en Henri PIRENNE: Mahoma y Carlomagno, Buenos Aires, Claridad, 2013 
concepto introducía una nueva coherencia para los países europeos al integrar en una etapa histórica con rasgos comunes a una Europa en construcción. La romanización había sido hasta entonces el primer nexo de unión de Europa, pero este formato estaba dejando de funcionar porque tenía implícito un cierto carácter exclusivista. Así, había países del occidente europeo a los que nunca llegó la romanización y que ahora tenían un papel capital en la formación de la identidad comunitaria. Había, por así decirlo, dos Europas: la romanizada y la bárbara. La Tardoantigüedad ha supuesto un marco de análisis en el cual se sitúa la formación de Europa o de la civilización del Occidente europeo. Es entonces cuando se sientan las bases de lo que después será el mundo occidental. Occidente se definirá como una civilización basada en elementos germánicos y latinos, sincretismo que se produjo en las centurias posteriores a la caída del imperio romano en el siglo V. Las pautas comunes observadas en diferentes espacios continentales durante la Tardoantigüedad han servido de marco analítico y han respondido adecuadamente a la necesidad de un pasado genético común.

El último de los tipos de usos públicos de la historia que destacamos sería el consustancial al oficio del historiador. La interrogación al pasado siempre estará tamizada por la experiencia del investigador, su compromiso político, el horizonte académico, el campo de reflexión historiográfico o los paradigmas científicos, filosóficos, culturales o morales de cada época. Una muestra de esto último lo constituyen algunos planteamientos de la historiografía medieval española de finales del siglo XIX. En esos momentos, cuando se intentaba definir las esencias de la civilización española o de la nación, el pasado era analizado en busca de esa unidad. La Historia de Modesto Lafuente consideró que el carácter español se había formado en las continuas luchas de los habitantes del suelo peninsular contra los sucesivos invasores. En este sentido, la Edad Media constituyó una etapa crucial en tanto que el enfrentamiento con el musulmán contribuyó también a la forja del valor que se estimaba característico de los españoles. Se gestó así una concepción belicosa de la Reconquista, que no fue la única ni tampoco la más extendida, pero que alcanzó una popularidad superior al resto, especialmente durante la dictadura franquista. Para sus seguidores, el mundo cristiano medieval era contemplado como esencia de la españolidad y, por tanto, portador del Estado atemporal que había quedado relegado a un reducto de las montañas astures. El discurso historiográfico fijó un esquema que nos resulta conocido: creación del Estado español con la unificación peninsular de Leovigildo, su posterior vinculación al catolicismo con Recaredo, invasión musulmana y reconquista astur-aragonesa que finalmente culminó en la Unión de Coronas con los Reyes Católicos. Desde luego, no faltaron concepciones más benévolas con el musulmán. La Historia de Rafae Altamira presenta con total naturalidad las relaciones entre ambas civilizaciones e incluso describe los intercambios económicos, culturales y políticos que se daban en tiempos de paz. Sin embargo, en la historiografía liberal dominante, el medievo era visto como el momento de la formación de España, en tanto que en él se produjo la unificación visigoda y la definitiva unión con los Reyes Católicos. En medio de ambos quedaba un periodo de luchas encaminadas a la recuperación del suelo perdido por parte de diferentes entidades políticas. Esta preocupación por la unidad, acrecentada tras la irrupción de los nacionalismos periféricos a finales de siglo XIX, llegó incluso a influir sobre la sistematización del arte visigodo propuesta por Camps Cazorla. Para él, en línea con las concepciones imperantes en la época, podían distinguirse dos momentos en cuanto a la organización política del Reino de Toledo, separados por el reinado unificador de Leovigildo y la conversión de Recaredo al catolicismo. ${ }^{23}$ De esta forma, a la pri-

23 "El primero de ellos se extiende entre los años 415 y 587 y se caracteriza por la coexistencia de varios términos irreductibles ( ). El segundo periodo se extiende entre los años 587 y 711 y en todo rios terminos irreductibles (...). El segundo periodo se extiende entre los años 587 y 711 , y en todo suevosy Emilio CAMPS CAZORLA: "El arte hispanovisigodo", en Ramón MENÉNDEZ PIDAL (dir): Historia de mera etapa del reino toledano, marcado por el enfrentamiento y la dualidad entre invasores y peninsulares, correspondería también un arte diferente, "sin rumbo fijo", como apuntó Gómez Moreno. Apenas quedaban vestigios del mismo, pero los pocos que se mantuvieron evidenciaban, desde su punto de vista, cómo las diferencias sociales y el continuo enfrentamiento supusieron un escollo al desarrollo cultural. Sin una identidad común, no podía existir tampoco un arte definitorio del periodo. No obstante, tras la creación por Leovigildo y Recaredo de un reino unificado legislativa, territorial y socialmente, floreció un nuevo estilo artístico homogéneo y común a todo el reino, representado por las iglesias de planta cruciforme, que él asoció a ese periodo y para las que hoy se ofrece una cronología posterior que las sitúa en el siglo X. Asistimos con Camps Cazorla a la periodización del arte visigodo, asociando una cierta unidad del estilo artístico con la etapa de paz y homogeneidad étnica que se abre, según él, tras las luchas de Leovigildo y la conversión de Recaredo. Si hasta entonces ésta etapa se había estudiado fundamentalmente en términos políticos, con Camps Cazorla se añade el elemento cultural común, de modo que el Reino Visigodo posterior a Leovigildo, con su legislación común y su identidad artística, se nos parece más a un Estado-Nación ideal según los preceptos de la Restauración que a una formación política de la Tardoantigüedad.

\section{Conclusiones}

"El olvido e incluso diría que el error histórico son un factor esencial en la creación

de una nación y de aquí que el progreso de los estudios históricos

sea frecuentemente un peligro para la nacionalidad."

Ernest Renan, ¿Qué es una nación?, 1882.

La Historia es una disciplina con una proyección evidente sobre el presente, lo cual la dota de trascendencia en el campo de la confrontación política. Ya no tiene cabida en el horizonte historiográfico la idea webberiana de la neutralidad axiológica de las ciencias sociales, visión heredera de la cosmovisión ilustrada y positivista. Con la paulatina profesionalización de la Historia, su conceptualización metodológica y la crisis de los metarrelatos en un horizonte académico globalizado, burocrático y atomizado, lejos de desaparecer la historia de compromiso y los usos públicos de la historia, el trabajo historiográfico se mantiene como un campo de combate imprescindible donde pugnan diferentes concepciones sociales, económicas o culturales por el control de los imaginarios contemporáneos. Sin embargo, ya no son los partidos o las macro-ideologías las que protagonizan el combate, si no que son los historiadores -individualizados- de las minorías, de las identidades "dolientes", del feminismo o de las "clases subalternas" los que pugnan en el horizonte historiográfico por explicar el presente y proyectar la sociedad hacia un futuro determinado.

En 1874, Friedrich Nietzsche, en su ensayo Sobre la utilidad y el Perjuicio de la Historia para la vida, alertaba del exceso de pasado de las sociedades contemporáneas y de los modelos nacionales, y comparaba, en clave dicotómica, el estadio de felicidad presentista del animal y el insoportable peso que ejerce sobre la sociedad el pasado y el futuro. ${ }^{24}$ En este sentido, cabe preguntarse cuál debe ser la posición del historiador ante los usos públicos de la historia, habida cuenta de la común aceptación de que tanto grupos, modelos de estado o identidades requieren de una narración histórica y de un imaginario compartido sobre el pasado que los legitimen, o su capacidad para construir cosmovisiones históricas ante la creciente afonía del

España, Madrid, Espasa Calpe, 1946, vol. III, p 496.

24 Friedrich NIETZSCHE: Sobre la Utilidad y el Perjuicio de la Historia para la vida, Madrid, Biblioteca Nueva, 1990; Règine ROBIN: La mémoire saturée, Paris, Éditions Stock, 2003 
oficio respecto a los mass media y a la red. ${ }^{25}$ La toma de conciencia de los diferentes niveles de usos públicos de la historia nos permite asumir una posición crítica respecto a los discursos normativos del pasado y tomar conciencia de las connivencias y entendimientos entre conceptos teóricos-oxímoron- de difícil anclaje.

25 Vid. Manuel CRUZ (comp.): Hacia dónde va el pasado. El porvenir de la Memoria en el mundo Contemporáneo, Barcelona, Paidós, 2002; Olivier DUMOULIN: Le rôle social de l'histoiren. De la chaire au prétoire, Paris, Albin Michel, 2003; Francisco Javier CASPISTEGUI: "Más allá de su oficio, el historiador en sociedad", Alcores: revista de historia contemporánea, 1 (2006), pp. 63-93; Enzo TRA- 


\section{EL ESTADO INTEGRAL Y SUS FUENTES: \\ UNA LECTURA COMPARADA*}

Giacomo Demarch

Università di Milano

Han pasado más de 25 años desde que Francisco Tomás y Valiente evidenció que era necesaio enfocar más y mejor una fórmula tanto repetida, cuanto en realidad poco conocida, como la de "Estado Integral", modelo teórico y práctico de arreglo territorial que la Segunda República Española puso como fundamento de su declinación de la autonomía político-administrativa.' Un j'accuse historiográfico más que necesario, siendo que la gran mayoría de las investigaciones dejaban en suspenso muchas preguntas acerca del uso, nacimiento y orígenes de un termino que fue tan duramente atacado cuanto fuertemente defendido. ${ }^{2}$ El panorama no ha cam biado demasiado en los años siguientes: las muchas publicaciones que luego han abordado el constitucionalismo de la Segunda República, en la mayoría de los casos, no han conseguido alejarse de los modelos interpretativos consolidados. ${ }^{3}$ Vamos entonces a retomar este discurso a partir de tres puntos de partida fundamentales que Tomás y Valiente empezó a desarrollar: la génesis parlamentaria del término, la relevancia de la lección alemana y la centralidad del debate jurídico europeo de entre-guerras, procurando integrar el debate doctrinal con los fundamentos concretos del discurso territorial elaborado por los constituyentes republicanos. ${ }^{4}$

* Se presentan aquí unos resultados de mi Tesis, defendida en Marzo de 2012, bajo cotutela entre la Universidad de Messina y la Universidad Autónoma de Madrid, titulada Costituzione, provincia e territorio nella seconda repubblica spagnola: una prospettiva comparata, en curso de traducción para su publicación por la Universidad Carlos III de Madrid.

1 Francisco Tomás y Valiente: "El Estado Integral: nacimiento y virtualidad de una fórmula poco estudiada", en José Luis GARCíA DELGADO, Manuel TUÑÓN DE LARA: La II República. El primer bienio, Madrid, Siglo XXI, 1987, pp. 379-396.

2 Véase entre las muchas: Nicolas PÉREZ SERRANO: La constitución española (9 diciembre 1931) - TeXtos, Bases, Antecedentes, Madrid, Editorial Revista Derecho Privado, 1932; Adolfo POSADA: La nouvelle constitution espagnol: le régime constitutionnel en Espagne, evolution, textes, comentaires, Paris, Librairie du Recueil Sirey, 1932 (disponible en traducción castellana: La nueva Constitución española: el régimen constitucional español, evolución-textos-comentarios, Madrid, INAP, 2006 , con un estudio introductorio de Joaquín Varela Suanzes-Carpegna); Francisco ASTARLOA VILLENA: Región y religión en las constituyentes de 1931, Valencia, Universidad de Valencia, 1976; Adolfo HERNANDEZ LAFUENTE: Autonomía e integración en la Segunda República, Madrid, Encuentro, 1980.

3 Juan Enrique ALBACETE EZCURRA: El Estado integral de la Segunda República española, Murcia Nausícaä, 2006; Carlos Alberto CHERNICHERO DIAZ: El estado integral en la constitución de la II República, Cadiz, Servicio Publicaciones UCA, 2007.

4 Cabe sin embargo destacar dos publicaciones que adelantaron algunas de las consideraciones de Tomás y Valiente: la primera la de Gaspare AMBROSINI: Autonomia Regionale e federalismo - Austria - Spagna - Germania - Urss, Roma, Edizioni Italiane 1944 en la cual aunque a nivel modelistico, se trazan unverdadero panorama comparado del modelo regional a segunda la introducción de Miguel Herrero de Miñón a la edición española del ensayo de Jellinek über Staatsfragmente (Fragmentos de Estado, Madrid, Civitas, 1978), en el cual el autor avanza una su-
Resulta imposible aquí resumir el debate constituyente de la II República: una tarea más complicada aún si se piensa que los cimientos de las distintas posturas remontaban como mínimo a la gran crisis que supuso el Desastre del ' 98.5 Por ello resulta más conveniente centrarnos directamente en la primera aparición oficial de la definición de "Estado Integral", es decir en el conocido discurso de presentación del proyecto de la Comisión de Constitución, realizado por Luís Jiménez de Asúa como Presidente de la misma. ${ }^{6}$ El destacado penalista intentó poner de relieve como en la evolución del constitucionalismo resultaban superadas las categorías del Estado federal y del centralizado, aplicando en su lectura el exitoso modelo del constitucionalismo racionalizado de entre-guerras desarrollado por Mirkine:?

El ensayo de Hugo Preuss, ese gran talento que vió cerradas todas las vías oficiales por la incomprensión de Gierke y Jellinek, representantes del oficialismo de Alemania, ha fijado con su gran mente poderosa y elegante, las doctrinas del Estado integral y ha intentado llevarlas a la Constitución, obra suya, de 1919, aún cuando no lo ha logrado por entero, tratando, de una parte, que los residuos de la soberanía de los Estados queden reducidos a una autonomía que no es más que político-administrativa, y por otra, dando a las provincias de Prusia una gran descentralización. Esto es to que hoy viene haciéndose y esto es to que ha querido hacer la Comisión- un Estado integral. ${ }^{8}$

Lo que tuvo un considerable grado de originalidad fue la centralidad que Jiménez de Asúa dió a la figura de Hugo Preuss, cabeza y coordinador del discurso constituyente weimariano del 1919: el conocido jurista alemán se convirtió en el principal referente a la hora de buscar una definición que permitiese alcanzar un modelo territorial funcional al proyecto constitucional republicano. 9

Cabe destacar tres puntos en el planteamiento de Asua. En primer lugar, un conocimiento y una admiración de Preuss que parecen ir más allá de la simple estima hacia el gran arquitecto de texto weimariano: un hecho con toda probabilidad vinculado con la formación juvenil de

gerente hipótesis de relación entre el termino Gesamtsstaat utilizado por Jellinek y lo de Estado Integral: sin embargo las críticas movidas a Jellinek por el mismo Jiménez de Asúa en defensa de la labor de Preuss a la hora de comentar el modelo del Estado Integral levantan no pocas dudas alrededor de esta interpretación. Entre trabajos más recientes hay que acordar Antonio MARTINO Spanien zwischen Regionalismus und Föderalismus: Entstehung und Entwicklung des Staates der Autonomien als historischer Prozess, Frankfurt am Main, Lang. 2004, que estructura una interesante comparación entre los proyecto originarios de Hugo Preuss y el modelo de Estado Integral: creo que sin embargo el modelo uniforme de Länder prospectado por Preuss más bien recuerde el modelo ortegiano de la "gran Comarca" que el modelo abierto del Estado Integral. Sobre Ortega y Gasset y la cuestión territorial: Fernando H. LLANO ALONSO: "Reforma territorial y política nacional desde la perspectiva teórica de José Ortega y Gasset", en Revista de estudios politicos, $N^{\circ} 13$ (2006), pp. 113-140.

5 Manuel TUÑON DE LARA: Medio siglo de cultura española - (1885-1936), Madrid, Tecnos, 1984.

6 Diario de Sesiones de las Cortes Constituyentes (DSCC), n. 28 del 27 agosto 1931, pp. $641-648$. Una pormenorizada voz bio-bliográfica sobre el gran penalista es posible encontrarla en linea en el Diccionario de catedráticos españoles de Derecho, http://portal.uczm.es/portal/page/ portal/instituto_figuerola/programas/phu/diccionariodecatedraticos/lcatedraticos/jasua, 05/02/2014, h. 15:25

7 Boris MIRKINE-GUETZEVITCH: Modernas tendencias del derecho constitucional, Madrid, Reus, 1934 Francisco Javier CORCUERA ATIENZA: “La Constitución española de 1931 en la historia constitucional comparada", en Fundamentos: Cuadernos monográficos de teoría delestado, derecho público e historia constitucional, № 2 (2000), pp. 629-695.

8 DSCC, n. 28 del 27 agosto 1931, p. 645.

9 Sandro MEZZADRA: La costituzione del sociale - il pensiero politico e giuridico di Hugo Preuss, Bologna, il Mulino, 1999. 
Jiménez de Asua en el mundo del Linksliberalismus alemán, en el marco de aquella increíble experiencia de circulación cultural que fue la Junta de Ampliación de Estudios..$^{10}$ En segundo lugar, la clara atribución de la paternidad preussiana de este modelo territorial, que como núcleo tenía la descentralización hacia las provincias prusianas.

Sin embargo, creo que más determinantes fue un tercer aspecto, que es probablemente lo que más se ha subestimado: el carácter inacabado del proyecto de Preuss. Esta idea, ya presente en su discurso en las Cortes, resalta más aún en su conocido comentario a la Constitución republicana:

La superación de la antítesis por una síntesis integralista del Estado, fué el intento sagaz de Preuss, que no pudo realizarse plenamente, pero que está en marcha de realización en Alemania desde que fué aprobada su Constitución."

Dos elementos aparecen aquí con toda claridad: la admiración hacia el proyecto preussiano y la conciencia de como todavía estuviese en marcha en área alemana un proceso de solución de las anomalías del federalismo alemán, que permitiese acabar la obra que Preuss solo consiguió esbozar en la Constitución del 1919. Resulta entonces claro como el modelo del Estado Integral tuviese sus referentes más próximos no tanto en el texto weimariano, como tampoco en el original proyecto de Preuss, sino más bien en el debate que a lo largo de los años Veinte del siglo pasado se produjo alrededor de la necesidad de reformar el modelo territorial sancionado en la
Constitución del 1919, considerado por los mismos contemporáneos un compromiso provisional: aunque la Constitución de Weimar contemplase unos mecanismos de reforma territorial, la necesidad de superar las contradicciones que generaba la presencia de una Prusia de 40 millones de habitantes en un Reich de 60 empujaron el mundo académico alemán hacia la búsqueda de soluciones que permitiesen alcanzar un mayor grado de coherencia al nuevo Reich republicano.."

A pesar de todo, hasta final de los años Veinte, todas las propuestas se quedaron en un nivel más bien teórico, algo comprensible si se piensa en los problemas más urgentes de supervivencia a los cuales Weimar tuvo que enfrentarse. Sin embargo, la mejora progresiva que la República alemana experimentó, tanto en su vida interior cuanto en su situación internacional a partir de 1925, hizo posible que ya en 1927 se pudiese reanudar la cuestión de la superación de los límites tanto modelo territorial cuanto de la constante inestabilidad política del gobierno del Reich. ${ }^{3}$ Un hecho que chocaba aún más si comparado con la salud de la cual gozaban los gobiernos de Prusia y Bavaria: solo la superación de las aporías territoriales que el compromiso del 1919 había dejado en suspenso, habría permitido encontrar un más estable equilibrio. Con la finalidad de elaborar una solución práctica al problema nació en 1927 la Liga para la renovación del Reich: asociación privada compuesta por las más varias élites económicas, culturales y políticas, que bajo la presidencia de Hans Luther promovió soluciones concretas al desequilibrio territorial y de poder que suponía la presencia del la Prusia en el Reich. ${ }^{14}$

10 Sandra REBOCK (coord.): Traspasar Fronteras - Un siglo de intercambio cientifico entre España y Alemania, Madrid, CSIC - DAAD, 2010

11 Luís JIMÉNEZ DE ASÚA: Proceso histórico de la Constitución de la República Española, Madrid, Reus, 1932, p. 56 .

12 Cristoph GUSY: Die Weimarer Reichsverfassung, Tübingen, Mohr Siebeck, 1997; Fulco LANCHESTER: Alle origini di Weimar: il dibattito costituzionalistico tedesco tra il 1900 e il 1918, Milano, Giuffrè, 1985.

3 Kurt Düwell "Fra federalismo, unitarismo e centralismo. La riforma del Reich e la ristrutturazione die Länder nella Repubblica di Weimar", en Oliver. Janz, Pierangelo SCHIERA, Hannes. Siegrist (a cura di), Centralismo e federalismo in Italia e Germania. Due modelli a confronto, Bologna, II Mulino, 1997 pp. 293-308. Para un panorama en castellano: Francisco SOSA WAGNER: Maestros alemánes del pp. 293-308. Para un panorama en castella
derecho público, Madrid, Marcial Pons, 2005

14 Karl-Ulrich GELBERG: "Bund zur Erneuerung des Reiches (Luther-Bund), 1928-1933/34”, in: Historis-
Un proceso de movilización que consiguió despertar el interés alrededor de la reforma constitucional, culminando en el 1928 con la convocación de una comisión permanente compues ta por miembros del gobierno del Reich y de los Länder (la Länderkonferenz) que, después de dos años de trabajos, consiguió en 1930 proponer al Reichstag un borrador muy avanzado, en el cúal se prospectaba una "solución unitaria pero diferenciada" (differenzierte Gesamtslösung) al problema territorial alemán: si por un lado se despojaba la Prusia de sus atribuciones políticas, trasladando sus poderes al gobierno del Reich, por otro se proponía una reforma territorial multi-nivel..$^{15}$ La antigua ambición de Hugo Preuss, la división de la Prusia en tantos Länder cuantas eran sus provincias, se concretaba articulando la estructura territorial del Reich a través de dos distintas categorías de Länder: unos, de nuevo cuño, caracterizados por una fuerte descentralización administrativa, otros, de antiguo cuño, que mantenían su autonomía política. ${ }^{16}$

Estas reformas se quedaron sin aplicación, víctimas de la crisis política que el terremoto económico del 29 desencadenó, aunque en 1931 el gobierno técnico presidencial de Brüning intentase llevar a cabo una parcial aplicación. ${ }^{17} \mathrm{~A}$ lo largo de los años Veinte nos encontramos entonces, tanto en Alemania como en España, con dos paralelos trayectos de reconstrucción territorial y constitucional que, a pesar de vivir historias distintas, siguieron en constante contacto. El problema de la superación del federalismo bismarckiano y de la centralidad de la Prusia como real lugar del poder, en favor de una visión más unitaria del Reich alemán, en el cual tuviese cabida una idea de autonomía política y administrativa fundamentada en un liberalismo orgánico y representativo, puso a Alemania en un contexto no muy distinto de lo que se desarrolló en España al terminar en Europa la Gran Guerra.

La idea de una superación del modelo constitucional de 1876, que resolviese los crónicos problemas del liberalismo hispano a través de un real desarrollo del concepto de autonomía desenlazó un taller constitucional que de hecho no terminó hasta el advenimiento de la República: ${ }^{18}$ los proyectos de Mancomunidad elaborados en la etapa maurista, las soluciones autonómicas del 1919, la nueva articulación de administración y territorio que habrían tenido que introducir los Estatutos municipales y provinciales por parte del Directorio, fueron tentativas muy diferentes (y con muy distintas finalidades) de superación del modelo canovista, sin de todas formas presuponer un nuevo proceso constituyente. ${ }^{19}$

ches Lexikon Bayerns, URL- <http.//www historisches-lexikon-bayerns.de/artikel/artikel 44406> (01.02.2014).

15 Arnold BRECHT: Föderalismus, Regionalismus und die Teilung Preussens, Bonn, Dümmler, 1949; Ludwig BIEWER: Reichsreformsbestrebungen in der Weimarer Republik, Frankfurt am Main, Peter Lang 1980; Helmut KLAUS: Der Dualismus Preußen versus Reich in der Weimarer Republik in Politik und Verwaltung, Godesberg, Forum, 2006

16 REICHSMINISTERIUM DES INNERN: Verfassungsausschuß der Länderkonferenz. Niederschrift über die Verhandlungen des Verfassungsausschusses vom 21. Juni 1930 und Beschlüsse des Verfassungsausschusses über 1. Die Abgrenzung d. Zuständigkeit zwischen Reich u. Ländern 2. Organisation d. Länder u. d. Einfluß d. Länder auf $d$. Reich, Berlin, Reichs- und Staatsverlag, 1930.

17 Gerhard Schulz: Zwischen Demokratie und Diktatur - vol.3. Von Brüning zu Hitler: der Wandel des politischen Systems in Deutschland 1930 - 1933, Berlin, de Gruyter, 1992.

18 Santos JULIÁ DÍAZ (a cura de): La Constitución de 1931, Madrid, lustel, 2009, pp. 13-28.

19 Sobre la Mancomunidad vease: Albert Balcells: El projecte d'autonomia de la mancomunitat de Catalunya del 1919 i el seu context històric, Barcelona, Parlament de Catalunya, 2010; Xavier Arbós Marin: "Los inicios del derecho público contemporaneo en Cataluña", Revista Catalana de Dret Púdel testigo dejado por José CALVO SOTELO: Mis servicios al estado. Seis años de gestión - Apuntes para la historia Madrid IEAL 177 (2 ed, veáse: Sebastián. MARTÍN RETORTILO Enrique - Apuntes MURGADAS Descentralización administrativa y organización política Aproximación histórica (18121931). Madrid, Alfaguara, 1973 pp. 315-369; José Antonio GARCÍA-TREVVIIANO FOS (coord), Cincuentenario del Estatuto Municipal : estudios conmemorativos, Madrid, INAP, 1975; Enrique ORDUÑ 
En este sentido la convocación de la Asamblea Nacional primoriverista supuso una ruptura: se prospectaba la elaboración de un nuevo texto, con el cual se amparaba la existencia de la Monarquía en el marco de un conservadurismo de sabor corporativo; todo ello complementado por una estructura territorial y administrativa fundamentada en una autonomía solo administrativa, funcional a una Nación concebida como indisoluble y "politicamente unitaria". ${ }^{20}$

Que esta idea de Nación unitaria fuese al mismo tiempo la clave de bóveda y el punto más complicado de todo el entramado constitucional lo aclaró el mismo Primo de Rivera en su primer discurso frente a la comisión constitucional de la Asamblea nacional en octubre de 1927:

Repito, pues descentralización cuanto sea posible; pero nada de concentración de regiones, porque no se puede olvidar que España está compuesta, no de regiones diversas, sino de naciones. En la memoria de los habitantes de esas regiones está todavía viva su historia como nación independiente, que llegó hasta el siglo XV; $[. . .]^{21}$

Lo que el Directorio quiso dejar claro fue la necesidad de encontrar la manera de fortalecer la idea unitaria de la estructura nacional española a través de una noción de autonomía que quitase capacidad de acción política a los regionalismos más activos. ${ }^{22}$

Esto significaba, sin embargo, volver a poner en marcha un debate que afectaba el crucial triángulo Soberanía-Territorio-Autonomía, con todos aquellos problemas que, congelados en un primer momento con el Directorio Militar no habían recibido todavía respuestas verdaderamente satisfactorias. Todo esto supuso una movilización de los recursos intelectuales y académicos que si por un lado la Dictadura intentó encauzar hacia la búsqueda de modelos viables y apoyos doctrinarios a su proyecto constitucional, por otra parte se convirtió en pocos meses en una poderosa arma en las manos de una oposición siempre más amplia a Primo de Rivera: el debate alrededor de la reforma constitucional era un foro perfecto en el cual demonstrar la debilidad del Régimen, buscando soluciones que llegasen por fin a asentar en el constitucionalismo español tanto un verdadero parlamentarismo cuanto una real aplicación de la autonomía político-administrativa. ${ }^{23}$

Por supuesto, esto despertó de nuevo el interés por el gran taller constitucional que se desarrolló en Europa a terminar la Gran Guerra: lo que podría extrañar es que, a pesar de las diferentes finalidades, tanto las élites intelectuales que apoyaron la Asamblea primoriverista cuanto sus opositores buscaron respuestas a los antiguos problemas de Nación, autonomía y territorio mirando a Alemania. ${ }^{24} \mathrm{En}$ realidad, más allá de la admiración que cualquier jurista

REBOLLO, "La reforma de la Administración local: de la frustración maurista al estatuto de Calvo Sotelo" en Reformistas y reformas en la administración española - 3. Seminario de Historia de la Administración, Madrid, INAP, 2005,pp. 143-176.

20 Mariano GARCÍA CANALES: El problema constitucional de la Dictadura de Primo de Rivera , Madrid, CEC, 1980; Gonzalo ALVAREZ CHILLIDA: "El fracaso de un proyecto autoritario: el debate constitucional en la asamblea nacional de Primo de Rivera", en Revista de estudios politicos, n. 93, 1996, pp. 359-375

21 Acta de Sesiones de la Sección Primera de la Asamblea Nacional: sesión del 26 de octubre 1927, p. 5, Archivo Congreso Diputados (ACD), Serie General, leg. 667, exp. $1(1)$.

22 Para un panorama de la ideología nacionalista primoriverista: Alejandro OUIROGA FERNÁNDEZ DE SOTO, Haciendo españoles. La nacionalización de las masas en la Dictadura de Primo de Rivera (1923-1930), Madrid, CEPC, 2008.

23 Eduardo GONZALEZ CALLEJA: La España de Primo de Rivera, Madrid, Alianza, 2005 pp. 129-153 y pp. 373-379.

24 Ernst-Wolfgang PÖPPINGHAUS: Moralische Eroberungen? Kultur und Politik in den deutsch-spanischen Beziehungen der Jahre 1919 bis 1933, Frankfurt am Main, Vervuert, 1999; Dietrich BRIE作 pañola desde 1898 hasta 1936, Berlin, Iberoamericana Vervuert Verlagsgesellschaft, 2000; Jesús tenía hacia la que se consideraba una de las grandes patrias del Derecho, antiguos vínculos ligaban la cultura jurídica y constitucional española al mundo alemán: ambas habían siempre vivido de manera dialéctica la pertenencia a la llamada "cultura occidental"; ambas tuvieron que enfrentarse a la idea de Nación con un invasivo pasado imperial. ${ }^{25}$ Pero sobre todo en ambas las ideas de Nación y Constitución, tanto en sus declinaciones conservadoras cuanto en aquellas progresistas, se construyeron a lo largo del siglo XIX y XX alejándose tanto del liberalismo individualista, cuanto de la lógica de ruptura con el pasado que supuso la Revolución francesa. ${ }^{26}$ Prueba es que, tanto en España como en Alemania, el organicismo funcionó como idea aglutinadora de la más distintas opciones ideológicas: el enfrentamiento entre neo-tomismo y krausismo en el contexto español sea tal vez el caso más llamativo de ideologías divergentes fundamentadas en una visión social y armónica de la sociedad. ${ }^{27}$

Obvio era entonces que se mirase al contexto alemán, desde la más distintas perspectivas, a la hora de poner en marcha un proceso de reforma constitucional que tenía como vexata quaestio el problema de la construcción de un ideal nacional, que pasase a través de una nueva definición tanto de la estructura territorial, como de la idea de autonomía: más aún cuando en el Reich weimariano, como se ha visto, se empezaba otra vez a discutir activamente la necesidad de superar la anomalía prusiana a favor de un fortalecimiento de las instituciones del Reich.

En este proceso de rastreo y asimilación fueron por supuesto fundamentales los avances que, en la circulación y comparación de modelos y textos constitucionales, se lograron en el contexto hispano, sobre todo a partir de los primeros años del siglo XX: la ya referida enriquecedora obra de la JAE, como los primeros pasos de una verdadera ciencia de la comparación constitucional, fueron los pilares sobre los cuales se edificaron experiencias tan significativas para la formación de las restringidas élites de la cultura jurídica republicana ${ }^{28}$.

Buen ejemplo de esta temperie, es la elaboración en 1927 por parte de Nicolás Pérez Serrano y Carlos González Posada, ambos cercanos a la lección krauso-positivista de Adolfo Posada y miembros de la Secretaría del Congreso de los Diputados, de una traducción sistemática de diversos textos constitucionales extranjeros, con un enfoque comparado que iba más allá de la simple compilación. ${ }^{29}$ No es casualidad que a partir de este círculo tan reducido, construido entre mundo universitario, jurídico y parlamentario, se plasmase, en

DE LA HERA MARTÍNEZ: La politica cultural de Alemania en España en el periodo de entreguerras, Madrid, CSIC, 2002

25 En este sentido muy llamativo es el testigo dejado por Francisco AYALA en Recuerdos y olvidos (1906-2006), Madrid, Alianza Editorial, 2011 (2. ed.), pp. 153: “[...]Si; culturalmente España había vuelto a ponerse en el mapa de Europa, y para conseguir este resultado el contacto con Alemania había sido decisivo. En un proceso que se inicia con Sanz del Río a la conquista del vellocino de oro krausista, y que terminará con los últimos becarios a quienes le sorprendió la guerra civil española cuando estudiaban en Alemania".

26 José ALVAREZ JUNCO: Mater dolorosa: la idea de España en el siglo XIX, Madrid, Taurus, 2001 Marzia PONSO: Una storia particolare - "Sonderweg" tedesco e identità europea , Bologna, II Mulino, 2011.

27 Juan José GIL CREMADES: El reformismo español - krausismo, escuela histórica, neotomismo, Barcelona, Ariel, 1969; Gonzalo CAPELLAN DE MIGUEL: La España armónica - El proyecto del krausismo español para una sociedad en conflicto, Madrid, Biblioteca Nueva, 2006; İD.: "De la filosofía del derecho a la Ciencia Política. Una aportación fundamental - yolvidada - del krauso-institucionismo español", en Manuel Suárez Cortina (coord.), Libertad, armonia y toleranciala. Cultura institucionista en la España contemporánea, Madrid, Tecnos, 2011.

28 Sebastian MARTÍN MARTÍN, “Funciones del jurista y transformaciones del pensamiento juridico-político español (1870-1945) (I)", Historia constitucional: revista electrónica de historia constitucional, 11 (2010), pp. 89-125 (aqui sobre todo pp. 112-125).

29 Nicolás PÉREZ SERRANO, Carlos GONZÁLEZ POSADA, Constituciones de Europa y América, Madrid,

Libreria General de Victoriano Suarez, 1927. 
los movedizos años de la dictablanda de Berenguer, la revista Política, como iniciativa de los miembros más dinámicos de los oficiales de la Secretaría y caldo de cultivo de la sucesiva Revista de Derecho público. ${ }^{30}$

Iniciativas como esta encontraban tal vez sus raíces más profundas en la creación en 1910 del Boletín analítico de los principales documentos parlamentarios extranjeros, publicación oficial de la Secretaría del Congreso de los Diputados, nacida con al finalidad de proporcionar tanto los textos más importantes de las diferentes asambleas parlamentarias extranjeras traducidos, como informaciones bibliográficas alrededor de las diferentes ramas del derecho. No extraña entonces encontrar detalladas informaciones de los referidos proyectos de la Länderkonferenz alemana en el primer número de 1928 del Boletín de la Asamblea Nacional, prosecución en los últimos años del primoriverismo del Boletín analítico: en la sección de la revista titulada "Noticias políticas y parlamentarias" (un apartado que representaba una significativa novedad del Boletín de la Asamblea frente al anterior) se daba noticia de como

En la histórica sala de la cancillería del Reichstag, donde se reunió en 1878 el Congreso de Berlín, inauguróse el 16 de enero actual, bajo la presidencia del canciller Marx, la anunciada conferencia entre el Gobierno y los Estados federales con el fin de estudiar una fórmula que permita simplificar las relaciones administrativas y políticas entre el Reich y dichos Estados. [...]

Dicha conferencia terminó el día 18, pronunciando el discurso de clausura el ministro de Justicia, señor Hergt. Los resultados de la conferencia son los que se consignan en el siguiente comunicado oficial:

"El gobierno del Reich y los gobiernos de los estados entienden que el procedimiento establecido en la constitución de Weimar, para regular las relaciones entre el Reich y los estados, debe sufrir una reforma completa.

La conferencia no ha podido ponerse de acuerdo acerca de como podrían consolidarse las fuerzas unitarias o federativas, ni acerca del modo en que estas dos fuerzas podrian quedar reunidas en una forma nueva. La necesidad de un fuerte poder central ha sido admitida por unanimidad.[...]". ${ }^{31}$

No se trató de la única referencia a los trabajos de dicha conferencia en el Boletín, siendo que en 1929 se relataba alrededor de unos cuantos resultados provisionales:

La subcomisión del Comité constitucional de la Conferencia de los estados particulares Alemanes, que se ha reunido en Berlín bajo la presidencia del ministro del Interior de Reich, el prohombre socialista Severing, ha aprobado el proyecto de unión de los pequeños países y de Prusia con el Reich, pero dejando subsistir en el Sur cuatro "países": Sajonia, Baviera, Wüttemberg y Baden.

De prosperar este proyecto, desaparecerán los pequeños países y también Prusia, así que Alemania constará del Reich y de cuatro países del Sur. En Berlín ya no habrá dos gobiernos y dos Parlamentos, como en la actualidad (los de Prusia y los del Reich), sino que solo funcionarán un Parlamento y un Gobierno, lo mismo para la Prusia de hoy que para todo el Reich. En cierto aspecto aumentará la importancia de Prusia, pero en otro perderá su

30 Gabriel GUILLÉN KALLE, La "Revista de derecho público"(1932-1936): el "ideal" de la Segunda República española, Murcia, Isabor, 2004: ID, Joaquin ALMOGUERA CARRERES Hacia una nueva profesión de fe - estudio crítico para la reproducción realizada por el Congreso de los Diputados en 2006 de Política : revista mensual de doctrina y crítica,Madrid, 1930.

31 "Noticias políticas y Parlamentarias - Alemania”, Boletín de la Asamblea Nacional, n. 1 del 1928,, pp. 202-203. personalidad. El gobierno del Reich mandará en el territorio que hoy forma a Prusia, pero en Baviera solo podrá intervenir bajo ciertas condiciones. ${ }^{32}$

Las aportaciones culturales de las élites funcionariales del Congreso fueron entonces fundamentales en la construcción del armazón teórico a lo largo del debate constituyente republicano:33 un hecho puesto de relieve por Jiménez de Asúa, el cual en su ya recordado ensayo Proceso histórico de la Constitución de la República Española destacó el fundamental papel que tuvieron el ya citado Pérez Serrano y el menos conocido Miguel Cuevas. ${ }^{34}$

Como el destacado penalista acordaba: "Su desinteresada y competente ayuda, no sólo me fue valiosísima en la busca de libros y datos, sino que me permitió superar el difícil trance que para mí representaba el discurso de presentación del Proyecto constitucional que pronuncié en las Cortes el 27 de Agosto." 35

Un personaje Cuevas determinante en nuestro discurso, siendo que Peréz Serrano mismo le atribuye, no sin criticar su elección y fundamentación, la paternidad de la formula del Estado Integral:

Obedece, probablemente, a un criterio personal y sugestivo, pero harto discutible, defendido entre nosotros por el culto profesor D. Miguel Cuevas, que sostiene la superación de los viejos conceptos del Estado unitario y del Estado federal por un tipo nuevo modelado sobre el caso de la Alemania contemporánea ${ }^{36}$

Que al hablar de "el caso de la Alemania contemporánea" se hiciese referencia a la actualidad constitucional de aquel entonces, se puede encontrar una ulterior prueba en las noticias que el canal diplomático proporcionó sobre el tema: también en este caso, es necesario volver a los años del Directorio Civil para penetrar estas complejas dinámicas en toda su profundidad.

La circulación de las reformas constitucionales alemanas y su conocimiento por parte de la clase dirigente española tuvieron un importante canal en Fernando Espinosa de los Monteros, protagonista y miembro desde las primeras horas del Directorio Militar y embajador en Berlín justo desde el 1927: ya atento observador de la evolución de los modelos administrativos y territoriales extranjeros en su posición de encargado de la cartera de Estado en el primer Directorio militar, demostró la misma atención hacia los temas del Derecho público como cabeza de la diplomacia española primoriverista en la capital alemana. ${ }^{37} \mathrm{~A}$ partir de final de 1927 es posible encontrar en la relaciones semanales remitidas por el embajador a Madrid varias

32 "Noticias políticas y Parlamentarias - Alemania", Boletín de la Asamblea Nacional, n. 18 del 1929, p. 517 33 En perspectiva comparada me permito remitir a: Giacomo DEMARCHI, "Le burocrazie costituent Tecnici del diritto e circolazione giuridica fra le due guerre mondiali: prospetti comparati e mediazione accademica lombarda", in Danilo ZARDIN (a cura di), Lombardia e Europa. Incroci di storia e cultura, Milano, Vita e Pensiero, 2014 (en curso de publicación).

34 Nicolás PÉREZ-SERRANO JÁUREGUI, "Nicolás Pérez Serrano (1890-1961): semblanza y datos biográficos", Teoría y realidad constitucional, n. 18, 2006, pp. 503-528. Para un perfil comparado de Pérez Serrano y otros destacado miembro de la cultura jurídica de los años treinta cuales Ayala y Lloréns: Sebastián MARTíN MARTíN, (est. prel. y notas), El derecho político de la Segunda República - Francisco Ayala, Eduardo L. Llorens, Nicolás Pérez Serrano, Dickinson - Uni. Carlos III, Madrid, 2011. Cerca de Miguel Cuevas remito a Giacomo DEMARCHI, “Técnicos parlamentarios y Cortes Constituyentes: Miguel Cuevas y Cuevas en la forja del constitucionalismo de la Segunda República EspañoIa", en Diana REPETO GARCIA (coord.): Las Cortes de Cádiz y la Historia Parlamentaria, Servicio de publicaciones de la Universidad, Cádiz, 2012.

35 LUis JIMÉNEZ DE ASUA, Proceso histórico de la ... p.X.

36 Nicolás PÉREZ SERRANO: La constitución española...pp. 62-63.

37 Su expediente personal se encuentra en Archivo Ministerio Asuntos Exteriores y Cooperación

(AMAEC), Personal, leg. PGoo86, exp. 21853, car. I y II. 
referencias de la avanzada del movimiento político favorable a un mayor grado de unidad en la estructura territorial del Reich.

Sin embargo, es desde el 1928, con el comienzo de la Länderkonferenz, que se multiplican las referencias: muchas de las notas informativas sobre la vida interna del Reich incluyen noticias y comentarios sobre la Conferencia de los Länder, subrayando y exaltando más allá de lo real su tendencia hacia la centralización. ${ }^{38}$

El papel de la embajada española en Berlín siguió siendo fundamental también con la proclamación de la República, que nombró a un destacado intelectual como Américo Castro nuevo embajador en el Reich alemán 39 .

A pesar de la brevedad de su encargo, su permanencia en Berlín coincidió justo con la temporada constituyente española, a lo largo de la cual Castro siguió dando referencias en los Informes sobre la política interna del denso debate de reforma territorial weimariano: entre final de agosto y empezar de septiembre, es a decir cuando las Cortes debatían sobre la generalidad del texto y empezaban a discutir el título preliminar y el tema de la organización nacional, Castro relacionaba sobre los renovados proyectos de fusión entre Reich y Prusia promovidos por el Gobierno Brüning. ${ }^{40}$

Las noticias que Américo Castro enviaba de Berlín eran entonces la de un sistema efectivamente en crisis, que sin embargo no había todavía caído en aquella espiral que lo llevó luego al Nacionalsocialismo: por eso el contexto weimariano podía ser una referencia todavía viva y vital para la joven República española. Es más: si la carta weimariana y la doctrina constitucional alemana eran dos fuentes fundamentales para los constituyentes, más aún se podian aprovechar los análisis de los problemas y las soluciones elaboradas para resolver esta honda crisis institucional, en búsqueda de un nuevo equilibrio en la articulación centro-periferia.

Oue Weimar como realidad constitucional todavía dinámica y en desarrollo pudiese ser un referente de primera fila en el intrincado trayecto constituyente republicano español lo demuestra, entre otras cosas, la publicación en mayo de 1931, por parte de una editorial como la Labor, de la Constitución de la República alemana en la versión comentada por Ottmar Bühler: una edición que, además de un extenso comentario integrado por una completa bibliografía y una nota histórica sobre la evolución del constitucionalismo alemán, incluía un capítulo de cierre sobre los principios fundamentales de la carta y su desarrollo en la práctica constitucional, actualizado hasta final del 28.4

Lo que permitía esta traducción era proporcionar, a un público potencialmente amplio un cuadro actualizado hasta una fecha muy cercana de la vida constitucional alemana en lengua española. En este comentario especial atención dedicaba Bühler al problema federal: recordando como la solución encontrada en el 1919 "fue pronto considerada de carácter meramente provisional por casi todos los interesados", exponía la evolución de las distintas posturas, es a decir la unitarista, la original preussiana y la del Erneuerbund, terminando con

38 Se trata de los Informes de política interior que el embajador remitía al Ministerio de Estado: aquí nos referimos a: AMAEC, Fondo Histórico, leg. H2294, Informes n. 256 del 24 septiembre 1927, n. 292 del 29 octubre 1927, n. 310 del 12 noviembre 1927, n. 347 del 17 diciembre 1927 y leg. H2295, Informes n. 7 del 7 enero 1928, n. 88 del 17 marzo 1928, n. 255 del 11 agosto 1928, n. 299 del 6 de octubre 1928, n. 321 del 27 octubre 1928 .

39 Miguel Ángel RODRIGUEZ MIGUEL: "Luis Araquistain ante la crisis de la República de Weimar (1932-1933)", en Cuadernos de Historia Contemporánea,, Madrid, n. 18 1996, pp. $67-83$ (aquí 71-73). 40 Américo CASTRO: Informes de política interior, AMAEC - Fondo Renovado, leg. R-320/2, n. 85 del 27 abril, n.133 del 27 julio, 336 del 10 agosto.

41 Ottmar BÜHLER: La Constitución alemána de 11 de agosto 1919 - texto completo, comentarios, introducción histórica y juicio general por el Dr. Ottmar Bühler, trad.: José ROVIRA ARMENGOL, Barcelona, Editorial Labor, 1931.

\begin{abstract}
Labor, 1931.
\end{abstract}
una sintética pero rigurosa descripción de la Länderkonferenz como término medio entre el original proyecto preussiano y el modelo Reichsland.

El interés que las reformas territoriales de la tarda República weimariana despertaron en el contexto español, no se circunscribió al mundo de los especialistas: si por un lado fue posible conocer directamente las fuentes y los textos en lengua original que permitieron la elaboración de la Differenzierte Gesamtlösung, como demuestra la adquisición no más tarde de septiembre de 1931, por parte de la Museo Pedagógico Nacional, del ensayo de Medicus sobre la Länderkonferenz, también la misma prensa periódica demostró vivo interés hacia el tema y, al igual que las publicaciones especializadas, ya a partir de los últimos años del Directorio. ${ }^{42}$ Muy significativos son unos cuantos artículos publicados por un periódico conservador como el $A B C$ : el 20 de enero de 1928 publicó una selección de comentarios salidos en la prensa alemana con tema la primera reunión de la Länderkonferenz; un tema que desarrolló pocos días después, el 27 de enero, en un artículo titulado de manera muy llamativa: "La decadencia del federalismo". ${ }^{43}$ De por sí los dos artículos podrían parecer simples relatos de acontecimientos políticos alemanes: en realidad a leer el texto del segundo se nota de manera muy clara que el verdadero referente es el contexto español y el problema de la cabida constitucional de la idea de autonomía política, como demuestran de manera clara las conclusiones con las cuales el periodista termina: "Es que fracasa en todas partes el regionalismo político. La historia enseña que los estados federativos tienden a centralizarse."

El $A B C$ volvió sobre el tema al mes siguiente con un editorial de Alfredo Manes, enviado cultural en Alemania, en el cual, a la hora de profundizar las posiciones encabezadas por el Erneurbund, puso el acento en la trascendencia política de esta reforma, afirmando como: "Si en Alemania se habla hoy tanto de unificación, es porque la fuerza de las cosas hace sentir, con más claridad cada día, la urgente conciencia, la necesitad inevitable de unificar." 44

Resulta entonces claro como un periódico de área conservadora y monárquica, cercano a unos planteamientos del Directorio, procurase demostrar como las reformas de la Dictadura no se alejasen de un movimiento constitucional de respiro europeo, en el cual hasta un país de fuerte tradición federal como Alemania marchaba hacia el unitarismo.

Si el proyecto elaborado por la Länderkonferenz se convertía, en el diseño constitucional de Directorio, en una prueba más de un irresistible movimiento hacia la unificación en el discurso constitucional europeo, con otras y más fidedignas lentes fueron leídas las reformas territoriales que Weimar procuró poner en marcha antes de su colapso por parte de la cultura constitucional republicana, en el marco del proceso constituyente empezado en abril de 1931.

Los proyectos de reforma territoriales weimarianos, que fueron antes utilizados como justificación doctrinal por la construcción de la "Nación politicamente unitaria" del primoriverismo, en realidad leídos de manera no distorsionada, por parte de la prensa republicana podían convertirse en un modelo de referencia fundamental para una jóven democracia intencionada a resolver el secular enigma nacional hispano, a través de la afirmación de la idea de autonomía: el primero de septiembre de 1931 el diario Crisol publicó un artículo titulado "Las autonomías regionales": finalidad declarada era poner de relieve como fuese

42 Franz Albrecht MEDICUS: Reichsreform und Länderkonferenz - Die Beratungen und Beschlüsse der Länderkonferenz und ihrer Ausschüsse, Berlin, Karl Hermann Verlag, 1930. Se ha encontrado el recibo de adquisición de este libro en los registros de la Biblioteca del Museo Pedagogico Nacional, en la actualidad depositados en la Residencia de Estudiantes, (registro. n. 19 del 20 de septiembre 1931), donde todavía se conserva este ensayo. Fundamental para ubicarse en el contexto de la prensa republicana: Antonio Checa Godoy, Prensa y partidos políticos durante la II República, Salamanca, Editorial Universidad de Salamanca, 2011 (2. ed. actualizada).

43 "Boletín del día", $A B C$, 27/01/1928, p. 29.

44 Alfredo MANES: "La Unificación", ABC, 23 febrero 1928, pp. 5-6. 
A la actitud presurosa de los autonomistas catalanes ha respondido, por explicable reac ción psicológica, una especie de contracción, de actitud defensiva, que en modo alguno se hubiera producido en un planteamiento normal del asunto. 45

No había entonces que atascarse en un enfrentamiento entre ideas irreductibles, sino más bien:

...encontrar la formula - si es original tanto mejor - que por acertar el interés de sus regiones promueva el interés de España entera. Es necesario restituir a cada una de aquellas su natural centro de gravedad, ponerlas en condiciones de que desarrollen su personalidad de forma normal, de que, en los límites de sus posibilidades reales, si basten a sí mismas, sin tener que acudir para todo al poder central, omnipresente.

Un problema para nada baladí, si tenemos en cuenta los presionados tiempos de la Constituyente. Un problema al que sin embargo era posible aplicar soluciones que ya otras realidades, que se habían tenido que enfrentar a la formación de entidades estatales a partir de sistemas plurales:

Ahora mismo, en Alemania (en cuyos gobiernos locales se han encastillado, con mayor empeño aún que los antiguos príncipes, los gobernantes de los Länder) se está tratando de estudiar una reforma del Reich que haga meno costosa la administración pública.

De cuales reformas estuviese hablando Crisol lo aclararon dos artículos del diario Sol: el primero, fechado 9 de septiembre y titulado "La crisis del federalismo alemán", movía de una entrevista que Arnold Brecht, protagonista de la Länderkonferenz, realizó por el folio Europe nouvelle ${ }^{46}$. Sin embargo, el tono del artículo de Sol era muy distinto respecto a lo de Crisol: en el contexto del renovado debate que a mediado de septiembre animó las Cortes alrededor de la introducción del término federal, el periódico quiso destacar como hasta en Alemania, con su larga tradición federal, se buscase una nueva solución territorial que permitiese superar el modelo territorial de la Constitución del 1919, en búsqueda de una mayor estabilidad democrática. No a caso el artículo terminaba recordando: "Que la prensa que ahora controvierte el apellido de la República no se apoye en noticias atrasadas". 47

Sin embargo, es en otro artículo del 20 de septiembre que se encuentra un elemento todavía más significativo en el rastreo de las raíces europeas del modelo del Estado Integral: después de exponer de nuevo las resoluciones propuestas por la Länderkonferenz, resumió los planes de reforma weimarianos de la siguiente manera: "Estas proposiciones, que se llaman sintéticamente "solución total y diferencial", han encontrado un ambiente muy favorable, aunque todavía no han sido recogidas por ningún partido político en sus programas" 48

A este punto creo resulte claro cuales fuesen las raíces del "criterio personal y sugestivo" que Miguel Cuevas sostuvo: el término Gesamtslösung traducido por Sol con "solución total", bien puede ser traducido con "solución integral". 49

45 "Las autonomias regionales", Crisol, 1 de septiembre 1931, p. 1.

46 Arnold BRECHT, “La réforme administrative du Reich”, L'Europe nouvelle, 22 agosto 1931, pp. 11541155 .

47 "La crisis del federalismo alemán", Sol (Madrid), 9 de septiembre 1931, p.1.

48 A.M.: "Problemas germánicos - La reforma administrativa alemana", Sol (Madrid), 20 de septiembre 1931, p.3.

49 Nicolas PÉREZ SERRANO: La constitución..., pp. 62-63.
Con esto no se quiere menospreciar la influencia teórica que hayan podido ejercer unos cuantos grandes protagonistas de la cultura jurídica alemana, como Smend, Heller (y hasta el mismo Preuss), ni tampoco ocultar el grado de originalidad que la solución territorial de la Segunda República alcanzó, sino más bien todo lo contrario: el modelo del Estado Integral nacía como una atenta reflexión sobre intentos y proyectos concretos debatidos en los último años de Weimar, finalizados a encontrar un novedoso punto mediano entre Soberanía y Autonomía en la relación Estado-Territorio. De ninguna manera los constituyentes republicanos españoles se pusieron a experimentar extraños términos y modelos extemporáneos: el Estado Integral era la aplicación perfeccionada, y meditada a la luz de las necesidades españolas, no tanto del ya envejecido modelo territorial de Weimar de 1919, sino más bien de los más avanzados proyectos de reformas territorial y constitucional que el más grande taller constitucional de entre-guerras intentó, aunque sin éxito, llevar a cabo. 


\section{JESÚS GALÍNDEZ SUÁREZ.}

\section{POLÍTICO, PROFESOR, SÍMBOLO*}

David Mota Zurdo

Universidad del País Vasco/ Euskal Herriko Unibersitatea

Virginia López de Maturana

Universidad del País Vasco/Euskal Herriko Unibertsitatea

"Lo más importante es la justicia de una causa; no los hombres que la defienden". (Jesús Galíndez)

\section{Introducción}

Si en la Historia del nacionalismo vasco existe una figura controvertida esa es la de Jesús Galíndez Suárez. Comunista, espía, homosexual y agente de la CIA han sido las etiquetas más utilizadas para definir a este político, escritor y profesor, por historiadores y periodistas que se han dejado de llevar más por el mito que por la realidad.' La existencia de un gran número de libros y artículos que únicamente se detienen en su figura para destacar, muchas veces de forma errónea, su trabajo como informador en las diferentes agencias de espionaje dependientes del Gobierno de los Estados Unidos ha eclipsado la obra política, literaria y docente que desempeñó durante su exilio en América. $Y$ es que este madrileño de nacimiento, pero vasco de adopción y sentimiento, fue uno de los exiliados republicanos de la Guerra Civil española que más contribuyó al conocimiento del régimen dictatorial dominicano gracias a su tesis doctoral (La Era Trujillo) que, póstumamente, fue publicada por la Columbia University.

\section{Biografia}

Su figura resulta controvertida desde el momento en que el investigador ha de situar geográficamente su lugar de nacimiento. ¿Madrid o Amurrio? Existe un reducido grupo de escritores, periodistas e historiadores, afines al nacionalismo vasco, que han situado a la localidad de Amurrio (Álava) como su lugar natal. Sin embargo, la gran mayoría de los historiadores profesionales han señalado que nació un 12 de octubre de 1915 en Madrid. Probablemente esta confusión se deba a que el Partido Nacionalista Vasco dotó a su figura de un halo romántico que interpretó la muerte de Galíndez como la de un mártir que dio su vida por la libertad de su patria. Por esta razón, no resulta baladí la ubicación errónea de su lugar de nacimiento sino que se trata de una equivocación con una gran carga ideológica que denota la conversión de su figura en símbolo, omitiendo los aspectos de su vida más espurios. ¿Cómo iba a haber nacido en la capital de España alguien que había muerto por defender la democracia milenaria vasca? Asimismo, hay otra serie aspectos que a continuación abordaremos, que resultan esenciales para comprender la idiosincrasia y personalidad de Jesús Galíndez. Por un lado, su familia. Debido a la muerte de su madre durante el parto sufrió importantes problemas psicológicos

* Este artículo forma parte de un proyecto de investigación subvencionado por la Secretaría de Estado de Investigación, Desarrollo e Innovación (HAR2011-24387), en el marco de un Grupo de Investigación de la Universidad del País Vasco/Euskal Herriko Unibertsitatea (GIU 11/21).

1 Montserrat MAGARIÑOS FIDALGO: “El poder y el individuo en Galindez", recuperado de Internet (http://hispanismo.cervantes.es/documentos/magarinos.pdf). que, presentados durante la adolescencia, desarrollaron en su personalidad un profundo sentimiento de culpabilidad. Su padre se hizo cargo de él, pero este pronto rehízo su vida, se afincó en Madrid, se casó de nuevo y tuvo otro hijo, Fermín. No obstante, a pesar de que esta fuera que le contó su padre y su abuelo sobre el prestigio social de su familia, Galíndez empezó a sentir arraigo por una tierra que había hecho grande a su linaje. ${ }^{2}$ Este sentimiento fue uno de los factores clave que le llevó a entablar sus primeros contactos con el nacionalismo vasco y, con tan solo 18 años, a plasmar estas impresiones en su obra La muy noble y muy leal tierra de Ayala, su señorío y su fuero, una loa a la "cuadrilla" 3 en la que habían vivido sus antepasados.

En 1936 Jesús Galíndez se graduó en Derecho por la Universidad Complutense de Madrid, obteniendo el premio nacional de Licenciatura por su tesis El Caserío Vasco y al poco tiempo se convirtió en profesor ayudante del catedrático de Derecho Civil, Felipe Sánchez Román ${ }^{4} \mathrm{~A}$ pesar de sus largas estancias en Madrid, mantuvo una estrecha relación con Amurrio y el nacionalismo vasco. En 1932 se afilió al Partido Nacionalista Vasco (PNV) e ingresó en las filas de la agrupación de estudiantes vascos, Eusko lkasle Abertzale Batza. Durante la guerra civil española, participó como asesor jurídico del partido en Madrid; por orden de José Antonio Aguirre se puso al frente de un Comité-Delegación del PNV con la misión de expedir salvoconductos que identificaban a los portadores como simpatizantes de la República y facilitaban su evacuación hacia otras zonas más seguras en Valencia y Barcelona; ${ }^{5}$ y desempeñó labores humanitarias dentro de la Sección de Presos y Desaparecidos del Gobierno Republicano, asociada al ministerio de Justicia que presidía el jeltzale ${ }^{6}$ Manuel Irujo. Como muchos vascos en el Madrid sitiado, Jesús Galíndez tuvo la oportunidad de trasladarse a zona republicana, pero decidió luchar en el frente de batalla a favor del Gobierno vasco -constituido en octubre de 1936- en primer lugar, como jefe de la Guardia del Partido Nacionalista Vasco, defendiendo con gran firmeza la capital de España, y en segundo, tras la caída de Bilbao en 1937, como oficial del cuerpo jurídico de la 142 Brigada Mixta Vasco-Pirenaica en la que combatió hasta la caída del frente catalán.?

\section{Exilio: República Dominicana y Estados Unidos}

Tras la toma de Cataluña por las fuerzas militares franquistas, Galíndez pasó a Francia junto con otros soldados republicanos en febrero de 1939. Aquí no solo sufrió la dureza del destierro sino que fue recluido en el campo de concentración de Vernet-les-Bains, donde permaneció siete meses hasta que pudo escapar a Burdeos. Allí, gracias a las gestiones realizadas por Julio Jáure-

2 Amurrio se encuentra dentro del valle de Ayala una zona que está situada al noroeste de Álava, limitando con Vizcaya y Burgos. A ojos de Galíndez representaría a la Euskadi más bucólica y más limitando con
tradicional.

3 Cuadrilla es el término utilizado para subdividir comarcalmente el territorio alavés y cuya procedencia es del siglo XVI. Su función era la de atender a las zonas rurales donde no llegaban todos los servicios dotándoles de un organismo que se ocupara ellos.

4 Hijo del ministro del Partido Liberal, Felipe Sánchez Román, que fue ministro del Estado durante la presidencia de Montero Ríos en 1905. Felipe Sánchez Román hijo abandonó su cátedra como forma de oponerse al régimen dictatorial instaurado por Miguel Primo de Rivera. Asimismo participó en el movimiento republicano estando presente en el pacto de San Sebastián. En 1934 fundó el Partido Nacional Republicano y en 1936 fue ministro sin cartera del efímero gobierno de Diego Martínez Barrio instaurado el 19 de julio de 1936.

5 Iñaki BERNARDO e Iñaki GOIOGANA: Galíndez: la tumba abierta. Guerra, exilio y frustración, Bilbao, Fundación Sabino Arana, 2006, pp. 28-29.

6 Este término se utiliza para referirse a los políticos del PNV al hacer referencia a su lema fundacional, JEL (Jaungoikoa eta Legi Zaharra, Dios y Ley Vieja).

7 Constancio CASSÁ BERNALDO DE QUURÓS (comp.): Jesús de Galindez. Escritos desde Santo Domingo y articulos contra el régimen de Trujillo en el exterior, Santo Domingo, Comisión Permanente de Efemérides Patrias, Archivo General de la Nación, 2010, vol. CXI, p. 19. 
gui y Miguel José Garmendia, con quienes mantenía comunicación directa a través de la valija interna del PNV y del Gobierno vasco, consiguió un pasaje de barco para la República Dominicana que pagó su padre en el otoño de 1939 con la intención de evitar un fatídico desenlace debido al estallido de la II Guerra Mundial y las precarias condiciones del exilio vasco en Francia.

La elección del país caribeño fue producto de sus contactos con el ministro de asuntos exteriores dominicano, César Tolentino Rojas, quién le sugirió esta posibilidad a finales de noviembre de 1939. Las razones de por qué eligió la isla de Santo Domingo las dio en su obra La Era Trujillo:

busqué desde el principio un país pequeño a donde no se dirigiera la riada de refugiados y pudiera actuar por mí mismo, para bien o para mal. Pensé en la República Dominicana y Paraguay, por haber conocido a sus representantes diplomáticos en Madrid durante el sitio; no pude localizar al encargado de Negocios paraguayo, pero en una de mis aventuras por Francia en el año 1939 encontré toda clases de facilidades en el cónsul dominicano de Burdeos, Narciso Félix (q.e.p.d.), a cuya memoria siempre estaré agradecido. ${ }^{8}$

Yendo a la República Dominicana Galíndez quiso evitar ser partícipe de los problemas que, a su modo de ver, provocaba la emigración masiva dirigida por el S.E.R.E. (Servicio de Evacuación de Refugiados Españoles), auspiciado por el socialista Negrín, y la J.A.R.E. (Junta de Auxilio de a los Republicanos Españoles), patrocinada por Prieto, a países como México, Chile o Venezuela. Por eso optó por el país caribeño aprovechando que Trujillo se mostró favorable a la recepción de los exiliados republicanos españoles a los que consideraba mano de obra cualificada para modernizar el país. ${ }^{9}$ La sorpresa fue soberbia cuando el caudillo se encontró con una emigración de intelectuales y políticos que sobremanera dieron un empujón al desarrollo cultural e intelectual de la República Dominicana pero que muy poco hicieron por favorecer a la coyuntura económica.

Galíndez llegó solo, soltero y con 24 años a la isla de Santo Domingo pero tenía amigos que conservaba de su etapa de estudiante como el caso de Alfredo Matilla, antiguo profesor de la Universidad Central de Madrid, que le ofreció su hospitalidad y con quién vivió durante buena parte de su estancia en la isla caribeña. Pronto empezó a trabajar como taquígrafo, copiando los cursos y conferencias de los docentes para venderlos a los estudiantes, y prestando servicios de redacción para tesis universitarias. Merecidamente consiguió la cátedra de la Escuela Diplomática y Consular del Departamento de relaciones exteriores, dependiente de la secretaría del mismo nombre que presidía A. Despradel. Esta posición le sirvió como trampolín para desempeñar funciones de asesor del Departamento del Tesoro y del Departamento de Trabajo y Economía.

Paralelamente a estas labores, Galíndez investigó y escribió ensayos y libros de variada temática, en su mayoría publicados por la Editorial nacionalista EKIN en Argentina y México, como La aportación vasca al Derecho Internacional, Los vascos en el Madrid sitiado o Principales conflictos de leyes en la América actual. También se encargó de asuntos relacionados con el Gobierno Vasco como ayudar en las labores de la delegación del Gobierno Vasco en la República Dominicana, primero, dirigida por Eusebio de Irujo, y, luego, encabezada por él mismo hasta su marcha a Nueva York. Así, podríamos decir que su estancia en Ciudad Trujillo, se definió por su cargo de delegado de Gobierno Vasco; por sus trabajos de información para el agregado militar de la embajada estadounidense, a la que informó sobre la marina mercante nazi que se dirigía al Caribe y Latinoamérica; por sus relaciones con el FBI, para el que investigó la infiltración de agentes nazis, falangistas y comunistas dentro de la colonia española; pero, sobre

8 Jesús GALíndEZ: La Era Trujillo, Santo Domingo, Santo Domingo, 1999, p. 264.

9 Iñaki BERNARDO e Iñaki GOIOGANA: Galíndez..., p. 50. todo, por su labor como docente universitario y como asesor político, que le permitió conocer -quizá demasiado- los entresijos del régimen trujillista.

Tras el fin de la II Guerra Mundial, el lehendakari Aguirre requirió de sus servicios en Nueva York. Su intención era que junto a Antón Irala acudiera a las sesiones de la O.N.U.y, siguiendo la estrategia política diseñada por el lehendakari de sumar esfuerzos con las personalidades políticas republicanas en el exilio, hacer labores de lobbying para conseguir el aislamiento político y económico del régimen de Franco. Asimismo, ya en la Gran Manzana, se encargó de la delegación del Gobierno vasco llevando a cabo gestiones en el medio político norteamericano, asistiendo así a reuniones en Washington DC, recaudando y enviando dinero del PNV y de las instituciones republicanas y vascas a Francia y otros países, asistiendo a mítines, etc., y pudo compaginar esta labor con el desempeño de importantes cargos docentes en la Universidad de Columbia donde impartió clases de Historia de la Civilización Íbero-americana y Relaciones Internacionales.

La influencia que obtuvo en la República Dominicana pronto tuvo su contrapunto en Nue-

va York. Se convirtió en uno de los máximos expertos en Latinoamericanismo y por ello fue invitado a numerosos congresos y mesas redondas sobre los derechos de la humanidad a pensamiento libre. Igualmente escribió numerosos artículos en reputadas revistas como Vision, Hemispherica, Cuadernos Americanos, Revista de América e Ibérica, dirigida esta última por Victoria Kent. Muchos de sus artículos se centraron en un internacionalismo entendido como la destrucción de las grandes potencias y de los nacionalismos imperialistas para así salvaguardar a las pequeñas naciones, junto a otros artículos caracterizados por resaltar la foralidad y la milenaria democracia vasca. Esta notoriedad incluso le permitió ser representante del Gobierno vasco en la Inter-American Association for Democracy and Freedom, que presidía Frances R. Grant, una organización que impulsó la implantación de sistemas democráticos en Latinoamérica. ${ }^{10}$ El prestigio intelectual de Galíndez siempre tuvo como meta el trabajo para y por Euskadi. De hecho, su puesto como profesor en la Columbia University no solo lo valoró como el culmen a una notoria carrera intelectual sino que también lo utilizó como "carta de presentación" que le avalara ante algunos foros diplomáticos americanos. De hecho, participó en varios mítines del Partido Demócrata en Nueva York e incluso se planteó la participación en la política municipal en los distritos de importante presencia portorriqueña. Todo estas actividades se malograron cuando misteriosamente desapareció el 12 de marzo de 1956. Al parecer, según las investigaciones realizadas por las autoridades policiales, fue secuestrado y trasladado a la República Dominicana donde fue torturado y asesinado por orden de Trujillo.

\section{El símbolo}

Desde el momento de su desaparición, Galíndez se convirtió en un símbolo del PNV. La prensa del exilio - de la que era asiduo colaborador- publicó artículos in memoriam y breves biografías suyas. Significativamente, todas ellas ubicaban el nacimiento de Galíndez en Amurrio, con el fin de incrementar su pedigrí vasco. Estos artículos periodísticos, que realizaban siempre un pequeño recorrido por las características humanas de Galíndez, destacaban por encima de cualquier otro rasgo su defensa de la libertad. De este modo, un mes después de su secuestro, el periódico Euzko Deya de Buenos Aires dedicaba al delegado vasco un artículo titulado "La desaparición de Jesús Galíndez, el vasco luchador de la libertad universal"."

La prensa nacionalista convirtió a Galíndez en defensor de la libertad universal porque ha-

bía luchado contra dos dictaduras: durante la Guerra Civil contra el franquismo y en el exilio

10 María Pilar RODRÍGUEZ: "La universidad de Columbia en la ciudad de Nueva York: conexiones con el exilio vasco", en José Ángel ASCUNCE, Mónica JATO y María Luisa SAN MIGUEL: VIII Congreso Internacional. Exilio y Universidad: presencias y realidades 1936-1955, Donostia-San Sebastián, Saturraran, 2008, pp. 703-711.

11 Euzko Deya (Buenos Aires), 30 de abril de 1956. 
contra el trujillismo. Es decir, había luchado con las armas contra el opresor de su propia causa, y, posteriormente, se había implicado en la lucha por la libertad del pueblo dominicano y, por extensión, de los pueblos latinoamericanos. ${ }^{12}$ Estas publicaciones llegaron a comparar a Galíndez con Guernica, la villa símbolo del nacionalismo vasco bombardeada en abril de 1937. Así, para Euzko Deya, "una y otro, además de otros sangrantes episodios de la guerra de defensa que en aquella fecha hubimos de sostener contra el monstruo totalitario, constituyen otros tantos hitos de nuestra pugna por la libertad"..13

Esa mitificación de Galíndez como símbolo de la libertad vasca y universal llevó al nacionalismo a relacionarlo con diversos personajes históricos. En el mencionado acto de homenaje de 1956, el escritor mexicano Gonzalo Báez-Camargo veía en Galíndez la continuación de la obra de Simón Bolivar y Javier Mina a favor de la libertad y la independencia de los pueblos oprimidos de América. ${ }^{14}$ En la década de 1960 -en la que se produjo el proceso de independencia de la mayoría de las colonias africanas y asiáticas-cambió el discurso sobre la figura de Galíndez, que pasó a ser no solo defensor de la libertad universal, sino también de la autodeterminación de los pueblos. Tal y como escribía un artículo del diario La Plata, recogido en la prensa vasca del exilio, en Galíndez no podían "deslindarse los problemas de un pueblo de los que enfrentan a otras colectividades" y esta idea "le hizo enfrentarse en Europa primero y posteriormente en América a todos los sistemas de opresión absolutista".

En esta misma línea, una de las primeras revistas de ETA publicaba en 1961 un artículo en el que prometía que "la nación más antigua de la vieja Europa, cuna de libertad antes de que la Historia naciera [Euskadi]" sería testigo en breve de un proceso de descolonización que la liberaría de su metrópoli [España]. Este artículo, escrito poco después de que el dictador Trujillo

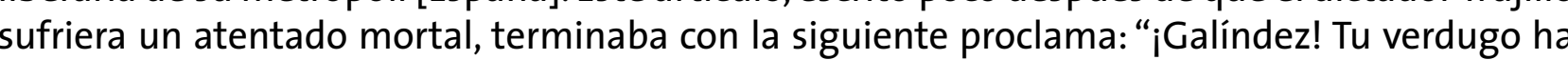
caído. Los de Euzkadi caerán también. Te lo prometemos". Se establecía así una comparación entre la lucha que estaba llevando a cabo ETA en Euskadi y la que había arrastrado a Galíndez a la muerte porque, según esta organización, "el Hombre, los pueblos oprimidos, prosiguen en su lucha por la libertad. Nadie quiere morir. Cada David se enfrenta a su Goliat". Galíndez -sacrificado-se había enfrentado en solitario a Trujillo, que finalmente había caído. ETA ahora se encaraba sola contra "dos gigantes [España y Francia] mil veces más fuertes que el mismo Goliat" ${ }^{5}$

Si en este artículo ETA aprovechaba para asegurar que Euskadi no dependería de ninguno de los dos bloques en los que se había dividido el mundo como consecuencia de la Guerra Fría apostando por una tercera vía de no alineación en la que se integrarían buena parte de los países descolonizados, la visión del PNV era bien distinta. El delegado vasco en Buenos Aires, Pedro Basaldúa, argumentaba que el telón de acero había dividido el mundo en dos sectores: el oriental, "que desconoce la libertad de los pueblos y los hombres", y el occidental, "que está adscripto a esas libertades y lucha por ellas". Basaldúa subrayaba que Galíndez había luchado en este último bando, "y por eso se oponía a todas las dictaduras, las de izquierda y las de derecha". ${ }^{16} \mathrm{Sin}$ embargo, en esta alocución Basaldúa no tuvo en cuenta que los dos dictadores contra los que había luchado Galíndez -como agente del FBI y, posiblemente, de la $\mathrm{CIA}^{-17}$ eran claros aliados de Estados Unidos, la potencia occidental dominante. Trujillo gobernó gracias al apoyo norteamericano y formó parte de la Organización de las Naciones Unidas (ONU) desde su fundación en 1945. Por su parte, España entró a formar parte de dicha organización en 1955, tras la firma del pacto con

Euzko Deya (México), mayo de 1956. Tierra Vasca, 1 de julio de 1956.

13 Euzko Deya (Buenos Aires), 28 de febrero de 1957.

14 Euzko Deya (México), noviembre de 1956

15 Zutik: en tierras americanas, $11(1961)$.

16 Euzko Deya (Buenos Aires), 30 de marzo de 1959

17 Santiago DE PABLO: En tierra de nadie. Los nacionalistas vascos en Álava, Vitoria-Gasteiz, Ikusager,

2008, pp. 305-306. los Estados Unidos en 1953, lo que, junto a la firma del Concordato con la Santa Sede ese mismo año, le valió al régimen franquista el reconocimiento internacional. Una vez que ETA se introdujo en su línea de nacionalismo radical revolucionario y violento, Galíndez no solo dejó de aparece cediéndolo casi por completo al PNV. Es significativo que una editorial vinculada a la izquierda abertzale reeditara un libro sobre Galíndez, publicado en 1988 en Nueva York, aprovechando su figura para criticar indirectamente a un PNV que habría vendido su alma a los Estados Unidos a cambio de un plato de lentejas. En el prólogo de este libro -que denuncia a los "imperialistas", autores de "crímenes repartidos con generosidad en nombre del anticomunismo, la democracia y la desvergüenza"- se llega a decir que Galíndez era la "cara liberal del fascismo. O la cara fascista del liberalismo", en el que no había ninguna "ambivalencia".18

Desde su desaparición hasta la actualidad, Galíndez ha sido objeto de numerosos homenajes -buena parte de ellos al pie del retoño del árbol de Guernica que existe en Buenos Airesse han escrito varios libros y producido películas sobre él, se han creado premios y fundaciones en su nombre, se han erigido monumentos (como el que existe en Amurrio, que sigue reivindicándolo como hijo suyo) y se le han dedicado calles en diversas localidades vascas y latinoamericanas, incluyendo Bilbao, Santo Domingo o Mar del Plata, ciudad argentina donde la principal avenida lleva su nombre. En 1962 la revista Gudari de Caracas le dedicó un número especial en el que se recopilaban buena parte de los artículos publicados tras su desaparición. Diversos Aberri Eguna en el exilio homenajearon su figura y, simbólicamente, la prensa del exilio utilizó el recurso - ya aplicado por Jagi-Jagien la década de 1930 y cuyo uso extendería posteriormente la izquierda abertzale- de dejar una página en blanco en su memoria para expresar la falta de libertad de expresión impuesta por las dictaduras. ${ }^{19}$

En realidad, Galíndez fue un personaje con menor alcance político del que posteriormente se ha querido transmitir. Su secuestro y ulterior asesinato en extrañas circunstancias y a manos de un dictador llevaron al PNV a sobredimensionar al personaje, hasta convertirlo en un símbolo de la libertad vasca y de la lucha contra las dictaduras. El que la desaparición de Galíndez tuviera lugar precisamente cuando el PNV sufría una importante crisis -como consecuencia del reconocimiento internacional del franquismo, hecho al que pronto se unió el nacimiento de ETA-ayudó a que este partido necesitara aferrarse a nuevos símbolos y mitos, como Galíndez, que mantuvieran vivo el ánimo de sus seguidores para seguir creyendo en la causa vasca.

Una vez muerto Franco e instaurada la democracia, el PNV alcanzó un gran poder institucional en el País Vasco. Frente a la constante actividad movilizadora de la izquierda abertzale el PNV no necesitaba ya mantener el mismo nivel de movilización de la etapa anterior a 1975. Posiblemente esto explica que en las últimas décadas la figura de Galíndez, con su ambigüedad y sus puntos oscuros, no haya sido tan reivindicada como lo fue en el exilio. Sin embargo, Galíndez no es un personaje desconocido, ni tampoco olvidado, tal y como demostraron las publicaciones, homenajes y exposiciones que tuvieron lugar en 2006, con motivo del quincuagésimo aniversario de su desaparición.

18 Manuel DE DIOS UNANUE: EI caso Galíndez: los vascos en los Servicios de Inteligencia de EE.UU, Tafalla, Txalaparta, 1999, p. 10. (1 ${ }^{\mathrm{a}}$ ed.: Nueva York, Cupre, 1988).

19 Euzko Deya (México), mayo de 1956 


\section{EL IDEARIO CARLISTA DURANTE LA PRIMERA GUERRA:}

\section{EL CASO DE LA GACETA OFICIAL DE OÑATE (1835-1837)'}

Juan Pedro Recio Cuesta

Universidad de Extremadura / GEHCEx

\section{Liberalismo y carlismo, las memorias del siglo XIX}

El carlismo, en no pocas veces calificado como un mero acontecimiento que tuvo lugar en el siglo XIX y que no va más allá de una simple reivindicación dinástica, no se trata simplemente de un movimiento de carácter legitimista, aunque esta sí sea su principal causa, sino que defiende un modelo de sociedad concreto, expresando "el mantenimiento de la tradición y el combate con el liberalismo y todo aquello que este significaba y comportaba", y se inserta en un contexto más amplio como es la contrarrevolución legitimista del siglo $\mathrm{XIX} .{ }^{3}$ En el lado opuesto, el Ochocientos va a ser, por excelencia el siglo del liberalismo, tanto político como económico, dentro del territorio europeo.

En España, en el tiempo de la invasión francesa encabezada por Napoleón, se dieron los primeros pasos en la instauración de un régimen liberal, teniendo a Cádiz y su Constitución, en e año 1812, como principal hito. A partir de aquí comenzaba un proceso discontinuo y no exento de escollos en la implantación del liberalismo en España.

El clima de conflictividad que se fue instalando en la esfera política y social española una vez que regresó Fernando VII de su cautiverio y, más aún, a lo largo de la década de 1820 con la polarización e inestabilidad a la que se llegó en el Trienio Liberal y continuó tras el nuevo retorno del citado monarca, presagiaba un desenlace que, inevitablemente, iba a ser solventado por las armas. Y, efectivamente: el resultado es bien conocido. A partir de finales de septiembre de 1833 con la muerte de Fernando VII, desaparecido ya el Rey Felón, -el cual fue no mucho antes el Deseado-es cuando verdaderamente estalló un conflicto bélico que tuvo sumida a España en un estado casi permanente de guerra hasta 1840: la Primera Guerra Carlista (1833-1840). Dejando a un lado en este recorrido las causas que originaron el conflicto por la gran cantidad de referencias ya existentes y accesibles al lector, ${ }^{4}$ el que fuera Infante de España, don Carlos María Isidro de Borbón, contando con notables apoyos esparcidos por

1 Se ha mantenido la grafía original, tal y como aparece en la fuente estudiada, en los fragmentos que se han insertado en el presente texto

Jordi CANAL: Banderas blancas, boinas rojas. Una historia politica del carlismo, 1876-1939, Madrid, Marcial Pons, 2006, p. 22

3 Un caso excepcional dentro del marco europeo lo es el carlismo puesto que, como movimiento contrarrevolucionario legitimista, como señala Jordi CANAL: Banderas blancas..., p. 19, "sobrevivió con cierta fuerza tras la etapa de crisis que estos vivieron en los años sesenta, setenta y ochenta del siglo XIX".

4 Sobre este episodio histórico hay una vasta información publicada. Para un mejor conocimiento de las causas que hicior deto hay unavasta in PIRALA: Historia de la guerra civil y de los partidos liberal y carlista, Madrid, Impr. de los Sres. F de P. Mellado, 186 y Román OYARZUN: Historia del carlismo Valladolid Maxtor 2008 . la detallada monografía de Alfonso BULLÓN DE MENDOZA: La Primera Guerra Carlista, Madrid, Actas, 1992. la geografía española, no tardaría en proclamar sus derechos al trono ante la usurpación que, a su juicio y al de sus partidarios, se estaba cometiendo. Y no solo se combatirá por sus derechos al trono, si no, como líneas atrás señalamos, por el modelo de sociedad en sí que encarnaba su causa, frente a un modelo emergente que pretendía dar carpetazo al pasado e introducir en España los preceptos del liberalismo político y económico.

Una vez dado por don Carlos su manifiesto desde suelo portugués (Abrantes) el 1 de octubre de 1833, en Talavera de la Reina fue Manuel María González y un grupo de Voluntarios Realistas el día siguiente, quienes, al grito de “¡Viva Carlos V!" protagonizaron una las primeras muestras en favor de la causa de la legitimidad. En los meses inmediatamente posteriores, el bastión del carlismo se concentraría en las provincias del norte, y el general guipuzcoano don Tomás de Zumalacárregui se erigiría como su principal figura militar. Éste, en nombre de la Diputación de Vizcaya, también llamaba a sumarse a la causa de don Carlos:

Navarros: La diputación de Vizcaya, viendo próxima á perderse la villa de Bilbao, principa joya de su señorío, os llama á toda prisa en su socorro. [...] Si después de invocar de este joya de su señorío, os llama á toda prisa en su socorro. [...] Si después de invocar de este que os vio nacer; de este suelo llamado por antonomasia el país clásico de la lealtad [...].5

Durante estos primeros compases del conflicto, aparte de consolidar un núcleo territorial, el carlismo también se encargó de erigir un discurso que legitimara su causa; es decir, de edificar un ideario dotado de una mayor solidez y que fuese más allá de la mera cuestión dinástica. ${ }^{6} Y$ es que, además de luchar en los campos y ciudades de España, los carlistas sabían que uno de sus fuertes residía en atacar, mediante argumentos, al contrincante isabelino. A fin de cuentas, el carlismo tenía ante sí el reto de edificar una propuesta política propia, es decir, más allá de la mera cuestión dinástica: ¿en qué se basaba su lucha? o ¿qué implicaba su causa frente a las incipientes, por aquel entonces, ideas liberales?

Llegados a este punto, la Gaceta Oficial,7 publicación objeto de estudio en este texto y que será una de sus principales voceras ${ }^{8}$ durante buena parte de esta Primera Guerra, nacía, según sus propias palabras, con el fin de:

rebatir tal perniciosas ideas, disipar la ilusión con que se pretende fascinar al pueblo incauto por unos hombres, que llamándose los regeneradores de la España, consuman por todos los medios imaginables la ruina de este país desventurado, y pulverizar los torpes paralogismos con que se pretende estraviar la opinión pública. ${ }^{9}$

Su andadura comenzó en la segunda quincena de octubre de 1835, habiendo pasado ya dos años del inicio de la contienda e incluso habiendo muerto ya el general Zumalacárregui. Por

5 Proclama recogida en Manuel MONTERO, e Imanol VILLA: Las batallas de Zumalacárregui. Acierto y limitaciones de un líder militar legendario, San Sebastián, Txertoa, 2012, p. 100

6 Ideario y objetivos caracterizados por una in-concreción ideológica que, según Jordi CANAL: El carlismo: dos siglos de contrarrevolución en España, Madrid, Alianza Ed., 200o, p. 118, junto con su heterogéneo apoyo social, constituye "un elemento que se nos aparece como clave a la hora de evaluar tanto la importancia como el arraigo de la movilización carlista".

7 A pesar de que generalmente la publicación objeto de estudio es conocida por el nombre de Gaceta Oficial, en José Carlos CLEMENTE: Diccionario histórico del carlismo, Pamplona, Pamiela, 2006, pp. 237-238, se mencionan diferentes nombres, como Gaceta del Real de Oñate o Boletín Carlista.

8 Aunque no la única, puesto que como afirma Alfonso BULLÓN DE MENDOZA:La Primera Guerra..., p. 551, "conscientes de la importancia de la prensa, los carlistas publicaron periódicos en todos los territorios donde llegaron a establecer una base territorial firme".

9 Gaceta Oficial, $n^{\circ}$ Prospecto, $10 / 1835$ 
estas fechas, el carlismo era un movimiento generalizado en Navarra y en el País Vasco, además de contar con una adhesión considerable en otros territorios, y suponía un reto de gran magnitud para el emergente y frágil Estado liberal.

En cuanto a su contenido, siendo su principal objetivo apoyar la causa de la legitimidad y tratar de defenderse de las plumas isabelinas, ${ }^{10}$ inserta, entre otros contenidos, partes de guerra, comentarios de noticias aparecidas en los principales periódicos europeos y escritos, tanto de don Carlos como de destacadas figuras militares o civiles que se adhirieron a sus filas. Siendo publicada dos veces a la semana, normalmente martes y viernes además de tener números extraordinarios, arranca en octubre de 1835 y su último número aparece en el mismo mes de 1837, dos años después. A partir de este momento, con una estructura y contenidos muy similares, la Gaceta Oficial, "en atención a las circunstancias", pasa a denominarse Boletín de Navarra y Provincias Vascongadas."

De este modo, realizado un somero acercamiento al contexto histórico y demás vicisitudes, en las líneas que siguen se van a tratar multitud de aspectos y conceptos aparecidos en la publicación carlista, teniendo en cuenta el agitado contexto europeo en el tiempo de las revoluciones liberales y, por supuesto, las turbulencias en las que España estaba sumida en esta década de 1830

\section{Tradición frente a revolución en España.}

Como ya se ha señalado, en España no solamente se estaba librando una guerra por la sucesión del trono, sino que estaba teniendo lugar un fuerte enfrentamiento entre dos concepciones de entender el mundo. Por ello, las referencias a la cosmovisión que defendian los carlistas son abundantes en esta fuente histórica, proclamándose defensores de ciertos aspectos del antiguo orden existente en España, aunque sin llegar a concretar o definir, recordemos, un determinado modelo. En este sentido, velando por ese sistema antiguo, basado en la tradición, criticado y menospreciado por el emergente Estado liberal, señalaban entre sus virtudes "que en el transcurso de muchos siglos ha sido la gloria de la España, su ventura y aun su libertad bien entendida", además de que "la España con sus leyes, ni se ha sometido á los romanos, ni á los musulmanes, ni á la Inglaterra, ni á las armas de Napoleón", y para rebatir la nueva concepción liberal centralista del poder apuntan que

con la centralización, con una capital que reuniese en sí todas las fuerzas sociales, hubiera desaparecido la nacionalidad española, su riqueza, su inteligencia, su vigor, y sus derechos; de donde se infiere, que la antigua desorganización [...] era muy preferible á la decantada organización de la época presente. ${ }^{12}$

Por ello, frente al liberalismo emergente, la causa encarnada en don Carlos recogía la verdadera esencia de esa España ya que "representa [...] la antigua libertad, y aquella monarquía fundada sobre las costumbres y sobre las leyes, en que los derechos del pueblo, los de la Religión y los del REY forman una poderosa é indestructible unidad."

10 El bando isabelino también hará uso de sus plumas con el fin de desacreditar a don Carlos y a sus partidarios, destacando publicaciones como la Gaceta de Madrid o EI Vapor, las cuales calificaban a los carlistas como facciosos o retrógrados, entre otros muchos epítetos.

11 Gaceta Oficial, o3 de octubre de 1837. Para obtener una visión mucho más detallada sobre los aspectos formales de esta publicación (organización, suscriptores, difusión, etc.), tanto de la propia Gaceta Oficial como de su sucesor el Boletín de Navarra y Provincias Vascongadas remitimos al escrito de José Ramón UROUIJO GOITIA: “Prensa carlista durante la primera guerra (1833-1840)" en Alberto GIL NOVALES (ed): La prensa en la Revolución liberal, Madrid, Universidad Complutense, 1983, pp. 319-336.

12 Gaceta Oficial, 19 de agosto de 1836 .

13 Gaceta Oficial, 29 de marzo de 1836
Pero aparte de defender ese sistema antiguo en peligro y en proceso de desaparecer, también se hace referencia a la naturaleza de sus defensores. Haciendo un uso interesado de la historia sobre varios episodios o personajes históricos, es ilustrativo el siguiente texto:

Pero si la revolución ha obtenido fáciles sucesos sobre poblaciones desarmadas y sorprendidas, en el norte de España se encuentran hombres invencibles, á quienes ningún obstáculo detiene, y ningún peligro intimida. Descendientes de los valerosos Cántabros y de aquellos cristianos antiguos, dignos compañeros de Pelayo, se han reunido hoy bajo el estandarte del honor; y para que nada faltase á esta lección admirable que hoy da al mundo todo este puñado de héroes, su Rey sin esperar el día del triunfo para presentarse entre sus filas, ha volado a la velocidad de un rayo á la cabeza de sus fieles defensores; y la espada de un Borbón amenaza y castiga la deslealtad, la felonía y la usurpación. ${ }^{4}$

Así pues, aquellos héroes que recibían a su Rey en la llegada de éste al frente del norte, eran la continuidad de sus antiguos frente a lo extraño de lo foráneo, encarnando su causa, en medio de un contexto revolucionario, "el único recurso que resta a los españoles para recobra sus antiguas libertades, su antigua prosperidad y poderío". ${ }^{5}$

Del mismo modo, en aquella guerra que era la defensa de la "santa" causa de don Carlos, y haciendo un símil con otro episodio de la historia del siglo XIX español, en esta contienda, "en lugar de cien mil extranjeros como en el año 1823, hay ahora cien mil españoles, que combaten por el restablecimiento de la Monarquía lejítima, de la soberanía Real y de los privilegios nacionales, violados por la usurpación y la revolución". ${ }^{6}$

Aparte de citar notables hechos o episodios de la historia peninsular y orientarlos hacia su causa, también la Gaceta se retrotrae al siglo XVIII para hacer referencia a los derechos de sucesión que, bajo su punto de vista, pertenecen a don Carlos. De este modo, aborda la figura de Felipe V, primer Borbón que reinó en España, y sus sucesores, para llegar al asunto de la controvertida Pragmática Sanción dada por Fernando VII en marzo de 1830, la cual es "nula a todas luces", y sentenciando que no existe más verdad que:

ninguna ley puede tener efecto retroactivo. Este es un principio innegable, y admitido por todos los jurisconsultos del universo. Ahora bien: nuestro Soberano actual el Señor Don Carlos $\mathrm{V}$ desde el momento que nació, adquirió un derecho incontestable a la á la corona, y en este supuesto aunque Carlos IV y Fernando hubieran pretendido derogar la ley de sucesión agnática, el acto era ilegal y nulo, respecto del Señor Don Carlos V, pues tenía ya un derecho adquirido lejitimamente, y de que nadie sobre la tierra pudo despojarle. ${ }^{17}$

Por otra parte, siendo el liberalismo una doctrina foránea, ajena a la tradición secular de España, del exterior -exceptuando algunos casos concretos que veremos- se ofrece una visión muy poco o nada positiva, tanto de los diferentes países que lo han abrazado o apoyan al naciente Estado liberal de España como de los propios preceptos liberales. ${ }^{18}$

14 Gaceta Oficial, 24 de octubre de 1835

15 Gaceta Oficial, 21 de febrero de 1837.

16 Gaceta Oficial, 22 de setiembre de 1837

17 Gaceta Oficial, 179, 11 de julio de 1837 .

18 Construyéndose una visión nada positiva sobre determinados países, en el otro extremo, sí que habrá simpatias hacia la causa legitimista de Portugal, el miguelismo, o hacia las potencias del habrá simpatías hacia la causa legitimista de Por norte de Europa. 
Para el primero de los casos, Francia e Inglaterra van a ser dos países asiduamente mencionados en la publicación carlista. Teniendo en consideración lo sucedido en Francia, germen de la revolución liberal en Europa, se dice que en España se estaba intentando "reproducir los ensayos sangrientos, que hicieron tan abominable el terrorismo"19 en ese país. De Inglaterra, pues no olvidemos el envío de la Legión Auxiliar Británica para apoyar la causa isabelina, ${ }^{20}$ y más concretamente de dicha fuerza, se dice que era "imposible reunir a tantos oficiales borrachos, insolentes e insubordinados como los de esta expedición." ${ }^{21}$

Por ello, haciendo referencia a la nefasta intervención extranjera que para nada ayudaba a la resolución del conflicto, bien fuera a través de ayuda militar o introduciendo los preceptos de liberalismo, la Gaceta carlista inserta una nota del periódico británico Morning Post del 13 de mayo, en donde se señalaba que "la cuestión que se ventila entre $D^{a}$ Isabel y Don Carlos es puramente nacional, y si se hubiese dejado decidirla á los españoles, la guerra civil se hubiera concluido ya, y el legitimo reclamador del trono estaría en la posesión indisputable de su Corona."2z

Por otra parte, se ponen de manifiesto las calamidades que está sufriendo España desde la introducción del liberalismo en la Monarquía como institución y en las Cortes. Como ejemplo ilustrativo, la soberanía nacional es calificada como "teoría mágica [y] espantoso conjuro," ${ }^{23}$ además de ser la desencadenante de las insurrecciones populares. ${ }^{24}$ Por su parte, las Cortes, acompañadas por el calificativo de revolucionarias en no pocos casos, se aseme jan a una "taberna de tahúres" 25 y se critica al gobierno de tipo representativo, el cual es causa de "los alborotos, los partidos, el espíritu de vértigo, la bullanga, la sedición, y la insaciabilidad política." ${ }^{26} \mathrm{~A}$ parte de ofrecer esta visión negativa sobre la nueva situación política, también se reprueban las decisiones del gobierno liberal en lo referente a la construcción de sus héroes. Como ejemplo concreto, la publicación carlista carga contra la decisión de erigi una estatua a Rafael del Riego en Sevilla y lo califica como "insubordinada soldadesca." ${ }^{27} \mathrm{En}$ contraposición a este sinsentido para los carlistas, se pone el ejemplo de las proezas de Hernán Cortés o Pelayo, aquellos que verdaderamente son dignos de reconocimiento. ${ }^{28}$

De esta manera, la doctrina carlista, aunque sin un gran grado de concreción, iba estableciéndose frente a la paulatina, aunque frágil, instauración del Estado liberal. Por ello, a estas alturas ya no podían existir ambigüedades, siendo, en este sentido, muy relevante el texto que sigue:

19 Gaceta Oficial, Prospecto, octubre de 1835

20 Alfonso BULLÓN DE MENDOZA: La Primera Guerra... p. 419. Un aspecto que tendrá importancia en esta Primera Guerra es la firma del tratado de la Cuádruple Alianza el 22 de abril de 1834. España, por ello, recibiría ayuda francesa e inglesa a cambio de una serie de condiciones.

21 Gaceta Oficial, o2 de febrero de 1836 .

22 Gaceta Oficial, 31 de mayo de 1836

23 Gaceta Oficial, o2 de setiembre de 1836

24 Gaceta Oficial, 30 de mayo de 1837. "Nunca se acabarán las insurrecciones populares, mientras no se corte radicalmente el principio que las justifica, las canoniza y las convierte en rasgos de virtud y de heroísmo. Jamás dejará de haber insurrecciones, tumultos y asonadas, si prevalece en el pueblo la idea de que él es el soberano, y que puede á su arbitrio cambiar su gobierno y sus leyes".

25 Gaceta Oficial, og de junio de 1837. En este caso es bien explícito el carácter peyorativo con el que emplean el término, clasificando a los procuradores que allí se daban cita como meros jugadores. 26 Gaceta Oficial, 18 de diciembre de 1835

27 Gaceta Oficial, 11 de diciembre de 1835. “illamar héroes, y erigir estatuas á los que promovieron, y ejecutaron un crímen, que en todos los siglos, y en todas las naciones fue siempre mirado como el más horrendo, y castigado con la pena capital! i Rendir homenages honoríficos á unos soldados cobardes, que por no embarcarse para América y exponerse á los peligros de aquella guerra, prefirieron el partido de la sedición, haciendo perder á su patria sus inmensas colonias, despojando al REY de su autoridad, y sembrando por todas partes la desolación y el desórden! Y ¿estos son los héroes de la culta España".

28 Gaceta Oficial, 28 de octubre de 1836 . elegid entre un Rey legítimo que os da Dios, la ley y la costumbre; y una niña que colocó al frente de vuestros destinos la sangrienta revolución, sin más derechos que la fuerza, la intriga y los amaños; elegid entre un gobierno benéfico, pero que sepa hacerse respetar, que comprima la licencia, que haga cesar de una vez los desórdenes y los tumultos, y que libre á la España de las sangrientas garras de la anarquía, encadenando este monstruo con prisiones de diamante; y un gobierno tímido, insubsistente, débil é irresoluto, que transige con el desenfreno, y que carece de la entereza necesaria para salvar las leyes y la patria. Elegid entre un gobierno, que mantenga en su mayor esplendor la Religión de vuestros padres, que proteja la moral pública, y reprima los excesos del atolondramiento y el furor; y un gobierno, que mira á la Religión con una indiferencia sacrílega, que destruye los templos subvierte los altares, confina los ministros, autoriza el incendio de los monasterios, descuida la moral de los pueblos, y se humilla ante la exigente y furibunda multitud. Elegid por último entre la paz, y la guerra civil interminable; entre el imperio de

un Monarca accesible y piadoso, y el reinado de la plebe, y el furor de los partidos. ${ }^{29}$

Así pues, sirviendo este texto para resumir lo hasta ahora expuesto, y tras ofrecer unas notas sobre algunos contenidos especialmente significativos para contextualizar el pensamiento político-institucional característico de este carlismo de la Primera Guerra a través de una fuente procedente de las propias plumas carlistas, pasamos a abordar ahora el que, por antonomasia, ha sido su trinomio -Dios, Patria y Rey- en base a los escritos aparecidos en la publicación objeto de estudio.

\section{El ideario carlista a través del trinomio Dios, Patria y Rey}

\section{Dios: la Religión por encima de todo}

Comenzando este breve recorrido por el primero de los conceptos que componen el ya clásico trinomio carlista, señalar que la publicación se posicionará en defensa de la religión católica y aprovechará cualquier acción del gobierno liberal que pudiera considerarla sacrílega, pues, para los partidarios de don Carlos, el liberalismo era considerado "el desorden y la herejía." ${ }^{30} Y$ es que, teniendo en cuenta que "la defensa de Dios y la Religión es una constante dentro de la documentación carlista", ${ }^{11}$ se llegaba a afirmar sin reservas que "si el decálogo no dimana de Dios, no puede haber sociedad entre los hombres, ni seguridad en los pueblos", 32 resumiendo de esta manera que la única religión era -y tenía que ser- la católica y dentro de la lucha de los carlistas también estaba su preservación en España.

Así pues, la lucha por la conservación de la fe católica en España constituye uno de los principales pilares de su ideario en lo que a este primer componente del trinomio se refiere. $Y$ aparte de hacer reiteradas referencias en su defensa, también se insertan textos con un alto componente religioso, como el que bajo el título Flumen verborum, sed mentis guta subraya que bajo la corta estancia de María Cristina como regente de su hija, se había permitido "que se canonicen los vicios y se haga la apología del más asqueroso cinismo, [...] que se ridiculice en farsas indecentes el sagrado ministerio de la Religión." 33 Por otra parte, la publicación se utilizócomo plataforma para la difusión de alocuciones del Papa, quien también subrayaba que

29 Gaceta Oficial, 29 de diciembre de 1835. En este sentido, son destacables las palabras de Manue MONTERO e Imanol VILLA: Las batallas de Zumalacárregui... p. 61. ya que, desde los primeros compases de la guerra, "en el imaginario carlista se construyeron rápidamente dos mundos enfrentados". 30 Manuel MONTERO e Imanol VILLA: Las batallas de Zumalacárregui... p. 62.

31 Alfonso BULLÓN DE MENDOZA: La Primera Guerra... p. 565

32 Gaceta Oficial, 29 de diciembre de 1835.

33 Gaceta Oficial, o2 de febrero de 1836 . 
la religión estaba en peligro en España. El Pontífice, por aquel entonces Gregorio XVI, apuntaba lo siguiente:"¿quién ignora la inmensa calamidad que hoy aflige á la Iglesia de Jesucristo con motivo de la revolución, que infecta á la desgraciada España, tan distinguida en otro tiempo por la pureza de su fe y por la inviolable adhesión á la Sede Apostólica?"34

Y dentro de la religión y la defensa de la fe católica como dogma, también hará lo propio con su principal institución: la Iglesia. Los carlistas cargarían contra el proceso de desamortizaciones puesto en marcha por Mendizábal mediante sucesivos decretos de febrero y marzo de 1836 ya que el gobierno se apropiaba de "los bienes de las iglesias, conventos y otros establecimientos públicos, [...] contra todo principio de justicia." 35 También tomó partido en favor de las autoridades eclesiásticas que habían sido víctimas de ese proceso. Por citar uno de los tantos casos ocurridos y expuestos por la Gaceta, se hacía referencia a la expropiación cometida al Arzobispo de Zaragoza, ${ }^{36}$ adicto a la causa de don Carlos y sustituido por alguien más proclive a Isabel II.

A fin de cuentas, con las manifestaciones que hemos señalado, la Gaceta fue una plataforma de la defensa de la fe católica en España y de los intereses de la Iglesia, mostrando una actitud beligerante ante las medidas llevadas a cabo por el Gobierno liberal y dando lugar a una abundante cantidad de artículos, reflexiones... relacionados con este tema.

Patria: los territorios del carlismo

Pululan por todas partes lo que se llama facciones, y no es sino el pronunciamiento de la España: en todas las provincias del Reino ondea el estandarte sagrado de la legitimidad; y el grito de Religión y de Rey resuena en todos los ángulos de la antigua Iberia. ${ }^{37}$

Atendiendo a la anterior cita, no cabe duda que el carlismo también edificó una imagen de los territorios en donde su causa alcanzó un mayor grado de adhesión, considerándolos como el paladín de la legitimidad. En este sentido, entre otros, ${ }^{38}$ encontramos repetidas referencias a tres lugares concretos de la geografía española: Navarra, provincias vascas y Cataluña.

De Navarra, una de sus principales bases territoriales desde los inicios de la guerra a finales de 1833 , se construirá una imagen similar a un territorio prácticamente inexpugnable y seña de la tradición. Así lo muestran cuando se insinúa que, una vez muerto el general navarro Espoz y Mina, ${ }^{39}$ una de sus bestias negras en el frente del norte, se le haría un monumento y sus restos serían llevados a la capital navarra. A este respecto, la publicación carlista se pronunció de la siguiente manera:

la fiel Navarra que tiene armados tantos batallones en defensa de la legitimidad, que ha sacrificado sus riquezas, y derramado á torrentes la sangre de sus hijos, no quiere ni aun las cenizas de un monstruo, que la cubrió de luto, y sembró por todas partes la desolación

34 Gaceta Oficial, $n^{\circ}$ extraordinario, 27 de febrero de 1836 . El Papa Gregorio XVI, quien ocupó el pontificado hasta 1846, lanzaría en marzo de 1841 una encíclica -Afflictas in Hispania- en la que critica35 Gaceta Oficial, 11 de diciembre de 1835 .

36 Gaceta Oficial, 19 de enero de 1836 .

37 Gaceta Oficial, 13 de mayo de 1836 .

38 Si bien abundan las referencias a Navarra o el País Vasco, también las hay para otras zonas. Por ejemplo, con la expedición del general Gómez en 1836, se pondrá de relieve la garra de otros territorios en los que, en un primer momento de la guerra, el carlismo no tenía tanto peso. Este es el caso de Andalucía, calificado como el "Santo Reino".

39 Murió en Barcelona en 1836. Finalmente, sus restos serían transportados a la catedral de Pamplona, en donde se conservan hoy día. y la muerte. [...] Otras glorias más sólidas y durables se ha adquirido el leal, el invencible reino de Navarra: hechos heróicos, que recordará entre incrédula y atónita la historia de los siglos. ${ }^{40}$

El mismo don Carlos, haciendo gala de la adhesión a su causa en el norte de España, se sumó a las arengas a Navarra y a las provincias vascas:

Pueblos Vascongados y Navarros: vuestra memoria vivirá conmigo eternamente; jamás podré olvidar vuestros servicios, vuestros padecimientos, vuestra fidelidad llevada al último grado de heroísmo. [...] Por Mi parte, me complazco en repetirlo, no creo que pueda haber vasallos más dignos. ${ }^{41}$

Aparte de ensalzar el territorio en cuestión, el bando carlista se dedicó también a difundir sus gestas, siendo quizá uno de los casos más destacables en esta Primera Guerra la batalla de Oriamendi, lugar que se convertiría en simbólico para su causa y que, cuando se tuvo noticia que han logrado alli frente a las tropas liberales, fue calificado como un "memorable acontecimiento", el cual la historia iba a ser la encargada de transmitirlo "de siglo en siglo." 42

Por su parte, la adhesión en Cataluña también será de importancia-sobre todo cuando la guerra tomó aquí un peso mayor-, por lo que desde la Gaceta se dedican notables loas a dicho territorio. Muestra de ello, y ante las tropelías que, a su juicio, las fuerzas liberales estaban cometiendo, señalaba que:

los catalanes son defensores de la más justa de las causas, sirven á Carlos V; son dignos imitadores de los que en estas fidelísimas Provincias [Navarra y provincias vascas] han sabido dar glorioso realce á sus continuadas victorias con la generosidad y la clemencia, tan propias de un Soberano que sabe hermanar la piedad y la justicia. ${ }^{43}$

En relación a este territorio tampoco faltaron alabanzas por parte de personalidades $\mathrm{mi}$ litares del carlismo. Por ejemplo, D. Blas María Royo de León se dirigía a sus habitantes de la siguiente manera: "ha llegado el día de sacudir un yugo tan ominoso, y de ocupar el lugar distinguido que os corresponde en esta gloriosa lucha. En la mano tenéis vuestra libertad, y la pronta salvación de vuestra Patria." 44

Incluso también se llega a señalar de zonas como el Bajo Aragón, pues el Maestrazgo constituyó un núcleo fundamental en buena parte de esta Primera Guerra en los progresos la causa de su Religión, su Rey y de la verdadera libertad, sustrayéndose a la feroz dominación de los terroristas." 45

Además detener una notable presencia en los territorios peninsulares citados, también mostraba simpatías hacia otros puntos del Viejo Continente. En la publicación se alude a Rusia y a su colosal Imperio, a determinados sectores de la sociedad de Portugal y su fe en don Miguel o se alaba la rectitud de Austria al haber "purgado [a] todos los extranjeros sospecho-

40 Gaceta Oficial, 10 de marzo de 1837

41 Gaceta Oficial, 15 de abril de 1836, p. 1.En una de sus intervenciones dirigidas a sus partidarios de estos territorios, se comprometía a una "exacta observancia de los Fueros que solemnemente me he ofrecido conservar, y que conservaré fielmente durante mi Reinado"

42 Gaceta Oficial, 17 de marzo de 1837 .

43 Gaceta Oficial, 13 de mayo de 1836 .

44 Gaceta Oficial, 25 de abril de 1837

45 Gaceta Oficial, o1 de abril de 1836 . 
sos" 46 y así evitar cualquier conato de revolución. Para los carlistas, las Potencias del Norte constituían todo un ejemplo ya que

disfrutan de una paz interior muy sólida y duradera; y no á beneficio de una dominación despótica, sino por el esmero con que evitan la introducción de los principios revolucionarios. En las Potencias del Norte se mantiene ileso el gran dogma de la lejitimidad, el derecho hereditario, el esplendor de los tronos, los antiguos fueros y traiciones del país y sus creencias, y la observancia de sus veneradas leyes, introduciendo gradual y progresivamente las mejoras que reclaman el tiempo y las circunstancias. Véase por qué no se experimentan alli convulsiones emanadas de un principio político. ${ }^{47}$

Finalmente, dejando a un lado las florituras empleadas en los territorios mencionados, en el extremo opuesto se situaba el caso de Madrid, la cual representaba ese centralismo tan vilipendiado por los carlistas y siendo el núcleo del Gobierno liberal, de la se llegaba a decir que "alli se ha constituido el centro de una conjuración permanente contra todos los tronos de Europa, contra todos los altares, contra todos los gobiernos existentes, contra todos los interéses de la sociedad y del órden." 48

\section{Rey: Don Carlos como pieza central}

Don Carlos María Isidro, como eje de la causa carlista, también hizo sus apariciones en la publicación en forma de proclamas o arengas a las tropas. Mensajes que si bien en muchas ocasiones son repetitivos, constituyen un buen ejemplo del ideario que se había fraguado en torno a su causa.

Éste, que al estallar la guerra se encontraba en Portugal, no tardaría demasiado en trasladarse al frente del norte-tras una efímera estancia en Inglaterra-, lugar desde donde, a partir de julio de 1834, lanzaría una serie de exhortos a sus súbditos y correligionarios. Su corte, durante el tiempo de publicación del periódico, no será fija y pasará por núcleos como Oñate, Cáseda, Elorrio o Durango.

La gran parte de los números de la Gaceta, en su página inicial, daban cuenta de la situación de los miembros de la Familia Real -carlista, claro está- que se encontraban en el exilio. En la misma, también hará aparición don Carlos para seguir reclamando sus derechos y arenga a los adeptos a su causa, haciendo acto de presencia otro importante miembro de la familia real, el Infante Don Sebastián Gabriel, su sobrino y al que, por un tiempo, se le hace jefe de sus ejércitos. Tratándose de una Real Persona, las loas al hermano del difunto Fernando VII son abundantes; $y$ es que, haciéndose eco de un escrito aparecido en un periódico francés, si se dejara gobernar a don Carlos "por las reglas dulces y bien conocidas de la religión, [...] entonces cesará la horrible guerra de exterminio que destruye este pueblo generoso." 49 Y encarnando su figura la de un monarca benévolo, protector de su pueblo, entre otros calificativos, añade que:

un solo remedio hay, y es el triunfo de CARLOS V, nuestro único y verdadero REY, protector de la Iglesia, sostén y amparo de la Religión, cuya causa se ha identificado con la del mismo Dios, y cuya gloria va á hacer brillar la gloria de Dios mismo. Este es el deseo unánime de todos los buenos. ${ }^{50}$

46 Ibid.

47 Gaceta Oficial, 03 de octubre de 1837

48 Gaceta Oficial, 11 de octubre de 1836 .

49 Gaceta Oficial, 29 de abril de 1836.

50 Gaceta Oficial, 26 de julio de 1836
Además de la configuración de este ideario cuya pieza central era la religión y el Rey, la corte carlista también dirigía sus esfuerzos a la creación de sus propias instituciones en el territorio en el que su presencia era mayoritaria ${ }^{51}$ e incluso a escribir su historia..$^{52}$

\section{Conclusiones}

Como se ha podido observar en ciertas cuestiones mencionadas, la Historiase puede convertir en una valiosa fuente de legitimación, y en no pocas veces se recurre al pasado para tal menester. En el caso que nos ha ocupado en estas líneas, se ha tenido la oportunidad de observar tal afirmación, ya que desde el carlismo, durante esta Primera Guerra, se hicieron gran cantidad de referencias a una cosmovisión ya existente que se vio quebrada por la por la irrupción del liberalismo. No solamente se luchaba por llevar a don Carlos a Madrid, sino que el carlismo dirigió sus esfuerzos, en concreto en la publicación estudiada, para construir un ideario basado, como se ha visto, en tres pilares fundamentales: Dios -la defensa de la religión y la Iglesia ante lo que suponía su pérdida de influencia-; Patria-ensalzando los territorios en donde la causa adquirió gran protagonismo y rechazando el centralismo de Madrid-,y Rey,-encarnado en don Carlos, elemento aglutinador de la causa-; todos ellos conceptos cargados de contenido que por sí mismos constituían toda una cosmovisión ya existente, arraigada en el colectivo popular, y en peligro ante las novedades que introducian las ideas liberales.

El abrazo de Vergara en agosto de 1839, hito destacable en la Historia contemporánea española, supuso el principio del final de más de un lustro de enfrentamientos que finalizarían "con el paso de la frontera de las tropas de Ramón Cabrera, en el mes de julio del año 1840."53 Una vez finalizada la Primera Guerra es cuando afloraron diferentes textos con un grado mayor de elaboración, ya que no hay que olvidar que "entre 1833 y 1840 el partido carlista se encuentra comprometido en una lucha a muerte [...] y la mayoría de las obras que aparecen en esta época son obras de combate, destinadas a mostrar los derechos de don Carlos." $54 \mathrm{~A}$ partir de aquí, y durante el siglo XIX, el carlismo siguió su evolución como movimiento político-social, teniendo a la cuestión dinástica como principal motivo de sus reclamaciones, y estableció una nada desdeñable red de prensa desde el final mismo de la guerra y, más adelante, un cuerpo político con gran importancia durante este espacio temporal y en gran parte del siglo XX.

51 Gaceta Oficial, 11 de diciembre de 1835. Tras su llegada al frente del norte, se puso en marcha la creación "de un Estado incipiente que reclamaba su legitimidad frente a otro Estado", Vid. Jord CANAL: El carlismo: dos siglos... p. 73.

52 Gaceta Oficial, 10 de marzo de 1837. La Gaceta anunciaba la traducción al español de la obra Un capitulo de la historia de Carlos V, escrita originalmente en francés por Louis Xavier Auguet de Saint-Sylvain, más conocido por el Barón de los Valles, en 1835. Dicha obra estaba disponible para su compra en "la librería Viuda de la Lama en Tolosa, en las administraciones de Correos de Azpeitia, Mondragón, Durango, Estella, Irún, Hernani, y en Oñate".

53 Jordi CANAL: El carlismo: dos siglos... p. 118. Un amplio sector del carlismo no reconocería este tratado, calificándolo como la "traición" de Vergara, por lo que proseguiría las hostilidades hasta cas un año después.

54 Alfonso BULLÓN DE MENDOZA: La Primera Guerra... p. 549 
Durante esta amplia trayectoria que abarca gran parte de la contemporaneidad española, ha habido momentos en los que su propia historia ha constituido una fuente de legitimación produciéndose esfuerzos historiográficos dentro de su propio seno como la magna obra de Ferrer Dalmau, 55 y coyunturas en las que se han dado profundas revisiones, e incluso mutaciones, dentro del ideario carlista también buscando una fuente de legitimación en el pasado. Solo por citar algunos casos, las desavenencias que tuvieron lugar en el seno de la familia carlista una vez producida la escisión integrista o la formulación hecha por el Partido Carlista a principios de la década de los 70 del pasado siglo y seguida por una parte de sus bases sociales, hecho que ya sucedió en una época muy diferente del periodo aquí estudiado, por lo que con estas líneas ponemos fin a este breve análisis. 
Parte 5.

SOBRE LAS RUINAS DE "ESE

NOBLE SUEÑO". ESTUDIOS "POST",

MOVIMIENTOS SOCIALES E

INVESTIGACIÓN ACTIVISTA EN LA

HISTORIA 


\section{PRESENTACIÓN DE LA MESA ECLÉCTICA DEL IV ENCUENTRO DE JÓVENES INVESTIGADORES EN HISTORIA CONTEMPORÁNEA}

Colectivo Revista Ecléctica

El taller-seminario titulado Sobre las ruinas de "ese noble sueño". Estudios "post", movimientos sociales e investigación activista en la Historia pretendía generar por encima de todo un lugar de encuentro para investigadoras/es que se sienten extraños en los lugares asignados. Es por ello que se intentó fomentar la transdisciplinariedad, incluso quizá la "indisciplinariedad", para dar más potencia a las posibilidades del taller y para cuestionar las prácticas del pensamiento cómodo que obstaculizan el aprendizaje co-creativo y transformador. Se buscaba abrir reflexiones que consideramos que deberían ser constantes en el trabajo historiográfico y de las ciencias sociales, y que en numerosas ocasiones parece que son eludidas o que se encuentran estancadas. Análogamente, también se tenía como objetivo establecer un diálogo multidireccional y horizontal con las esferas sociales donde permea la historia desde abajo o de la cultura popular. Lugares (comunes) donde se cultivan las prácticas, las concepciones y las relaciones de las culturas políticas que precisamente se debaten en profundidad en la historiografía académica. Era una apuesta por la apertura, por la interacción, por los préstamos y por las encrucijadas entre conocimiento histórico, ámbitos de construcción socio-política, sujetos y cambio social.

Coordinada por varios miembros del colectivo editor de Ecléctica. Revista de Estudios Culturales, el formato tradicional de mesa se desbordó para ofrecer un espacio de voces plurales, intentando construir un conocimiento colectivo y compartido. Para guiar el debate y no dejarlo absolutamente abierto se preparó un dossier con fragmentos de textos que enfocaban temas diversos como la crítica a la historiografía desde el narrativismo, la incorporación de los propios procesos de subjetivación de las/os investigadoras/es o reflejos de la investigación como acción e intervención social. El dossier estaba dividido en dos partes, con textos que se complementaban y, en ocasiones, se cuestionaban entre sí. Cada bloque iba acompañado de una pregunta abierta que servía como guión flexible para cada sesión. Por otro lado, estaba pensado para ofrecer una introducción no autoritaria a aquellos que estuviesen interesados en los temas en torno a los cuales giraba la sesión la sesión pero que no hubiesen podido asistir. Consideramos que la mejor forma de expresar tanto los propósitos como la esencia de la mesa es reproduciendo algunos de estos textos-guía:

\section{Sobre la igualdad de inteligencias}

La virtud primera de nuestra inteligencia es la virtud poética. La imposibilidad de decir la verdad a pesar de sentirla nos hace hablar como poetas, narrar las aventuras de nuestro espíritu y comprobar que son entendidas por otros aventureros [...]. En el acto de la palabra, el hombre no transmite su conocimiento, sino que poetiza, traduce e invita a los otros a hacer lo mismo. Comunica como artesano: manipulando las palabras como herramientas [...]. La inteligencia es la potencia de hacerse comprender que pasa por la verificación del otro. Y solamente el igual comprende al igual. Igualdad e inteligencia son términos sinónimos [para comunicar con otros hay que creer en el principio de la igualdad de todas las inteligencias].

El doble filo del margen: sobre las epistemologías situadas

Siempre existe el grave riesgo de caer en una especie de enfoque "romántico" de los "márgenes" como exterioridades. Escribe Rosi Braidotti que "los márgenes están siempre dentro, en el interior de un espacio social que no es liso, sino multilinear, discontinuo y poroso" Tras ello, añade "pienso en efecto que uno de los peores avatares del marxismo es el desprecio -a menudo más retórico que real- del centro y de la centralidad y el amor romántico de los márgenes y los marginales" (Braidotti, 2003). Vinculado al primero, percibo que el riesgo siempre presente de caer en un enfoque no menos romántico, naturalizante/esencialista de las minorías e idealizador de los saberes de que estas serían portadoras, una especie de idealización de un saber que sería "puro", "ingenuo", "desnudo", "independiente", como si esos saberes no estuvieran ya atravesados por representaciones y visiones, como si ese "ver" no necesitara un "aprender a ver" y un aprender a ver con el otro sin pretender ver en su lugar (Haraway,1988). [....] Y no es en tanto que mujeres que las investigadoras han producido otras formas de producción de saber, otros saberes, ya que no es su propia identidad la que produce la ciencia, sino más bien su posicionamiento crítico (Haraway, 1988). ${ }^{2}$

\section{Por una descolonización del saber: hacia un pluralismo epistemológico}

Como dijimos, el pluralismo epistemológico es otra cosa, se refiere a la existencia de heterogéneas episteme, a la necesaria concurrencia de estas, a su reconocimiento y, por lo tanto, a la búsqueda de diálogo hermenéutico. La importancia del pluralismo hermenéutico no sólo radica en esta heterogeneidad y en la búsqueda de diálogo hermenéutico, sino en plantear como episteme ancestral, como episteme resistente, como episteme alterativa, a los saberes y cosmovisiones nativas, además de reconocer otros saberes, los saberes de la gente, los saberes culturales, los saberes concretos, descalificados por las ciencias. Este pluralismo epistemológico nos lleva al horizonte abierto de la interculturalidad emancipadora, más allá de la multiculturalidad liberal, que concibe una jerarquía cultural, desde el núcleo de la cultura moderna, haciendo concesiones "democráticas" a las otras culturas nativas. En cambio la interculturalidad emancipadora se plantea un descentramiento respecto de la cultura dominante, la moderna, y concibe la equivalencia cultural, comprendiendo la posibilidad civilizatoria de todas las culturas. Una versión avanzada de la interculturalidad emancipatoria se encuentra en la ecología de los saberes propuesta por Boaventura de Sousa Santos, conjuntamente con la sociología de las ausencias y la sociología de las emergencias. La ecología de los saberes concibe la coexistencia y la co-habitabilidad de los saberes como en un sustrato de procesos interconectados e interdependientes, en constante diálogo e interpretación. La sociología de las ausencias estudia lo que ha sido desconocido y descartado por las sociologías académicas, los sujetos sociales mantenidos en la sombra, las relaciones sociales establecidas por estos sujetos descalificados, sus resistencias y sus formas de sociabilidad. La sociología de las emergencias estudia lo que emerge como nuevo, a parti de las resistencias, de las luchas de emancipación y de liberación, por lo tanto los nuevos sujetos y subjetividades, las nuevas relaciones. ${ }^{3}$

1 Fragmento de Jacques RANCIÈRE: El maestro ignorante

Antonella CORSANI: "Politicas de saberes situados. Emanciparse de la epistemología de la economía política y de su crítica"

3 Raúl PRADA ALCOREZA: “Epistemología, pluralismo y descolonización” 


\section{La apuesta benjaminiana: hacia un tiempo abierto}

Sin lugar a dudas, la idea central que da sentido a la concepción benjaminiana de la historia es la apertura del tiempo, la historia como algo no cerrado. [...] Pero no solo en un sentido metafórico [...] sino en un sentido literal y radical, en un sentido tangible, material, como un objeto que se sitúa en medio de nuestro camino.

Esta noción del tiempo abierto y presente hace que la tarea de la historia sea urgente y necesaria, y sobre todo conduce a que la práctica de la historia sea algo que tiene que ver no tanto con el conocimiento como con la acción. En este sentido, más que con historia, aquí nos encontramos con política. La teoría benjaminiana de la historia no es sólo una epistemología, un conocimiento, sino una práctica, algo que requiere la acción política. Sus tesis no son un manual para historiadores, sino un manifiesto para activistas, para aquellos que quieren cambiar las cosas.

[...] La historia, por tanto, está llena de sombras. Por eso hay que pasarle el cepillo a contrapelo. Y este pasarle el cepillo a contrapelo no se trata sólo de un acto de curiosidad histórica. No es una cuestión meramente epistemológica. Sino una cuestión política y ética. ${ }^{4}$

Sobre la "historia desde abajo"

Justamente, la history from below anglosajona (y por extensión la "historia de lo cotidiano" a la germana) se ha presentando como un ambicioso intento de superar esta contraposición, esta brecha entre la historiografía profesional y otros usos de la historia, en particular los usos "populares". En realidad, para ser más exactos debería decirse que se trata solo de un sector de esa history from below; el más ligado a los grupos de la "nueva izquierda".

El origen de esta situación se debe a la sensibilidad de ciertos historiadores profesionales hacia los movimientos contraculturales y populares de los años sesenta y setenta. En Europa, en particular en Gran Bretaña y en la RFA en los años setenta y ochenta, las manifestaciones más notorias de la public history han poseído un claro tono contracultural, a través del cual se expresa la identidad de ciertos colectivos marginados. Dicho rasgo se ha reflejado, como se sabe, en vocablos como "festivales" " "talleres" (workshops history, Geschichtswerkstaten). Todos ellos han sido la manifestación de una curiosidad por la historia (o por la "memoria", según se interprete) entre un variopinto elenco de "historiadores descalzos" (barefoot historians) integrado por maestros, empleados de bibliotecas y museos; miembros de colectivos gay, feministas y pacifistas; o por sindicalistas, estudiantes obreros, cineastas, etc. En todos los casos se observan rasgos que han planteado interrogantes a los historiadores profesionales (y, en muchos casos, desconfianza y recelo). Entre las ambigüedades se destacan particularmente las siguientes: la ausencia de unos límites claros en la prioridad de lo local, en la reivindicación militante de la "historia oral" y en la crítica contra el academicismo; o también la escasa vocación hacia las teorías sociales. ${ }^{5}$

Fragmentos del debate entre Hayden White y Dirk Moses sobre uso público de la historia y la ética Moses dice que yo desafío "el papel de la historiografía profesional en el control de la manera en la que el pasado es invocado en el presente para proyectos políticos". Ciertamente lo hago. No solo rechazo la autoridad de los "historiadores profesionales" para "controlar" [police] cualquier cosa, también rechazo que los historiadores, en su actual

4 Miguel Á. HERNÁNDEZ-NAVARRO: “Materializar el pasado. El artista como historiador (benjaminiano)", se puede consultar una ponencia-resumen aqui.

5 Gonzalo PASAMAR: “Los historiadores y el 'uso público de la historia': viejo problema y desafio reciente", en B. BERENZON (ed.): Historiografia critica del siglo XX, México, Universidad Nacional Autónoma de México, 2004, pp. 107-108. capacidad "profesional", posean los recursos necesarios para generar juicios "éticamente responsables" sobre sea lo que sea que entendamos por "historia". En otras palabras, como consecuencia de los esfuerzos de la historia por convertirse en una "ciencia", por modesta que sea, y pese a las diferencias respecto a los paradigmas de las ciencias fisicas, en su deseo por "contar la verdad (y nada más que la verdad)" sobre el pasado, en su deseo de aislarse a sí misma de las tentaciones de la escritura literaria, el exceso de la filosofía de la historia y el atractivo de la ideología, la historiografía profesional no puede participar honrosamente en las discusiones sobre los principales temas políticos, éticos o ideológicos que asaltan a una sociedad que, al verse privada de religión y metafísica, tiene poco más que historia como fundamento para emitir juicios cognitivamente justificados sobre problemas actuales. ${ }^{6}$

\section{El resto del dossier todavía puede encontrarse en la página del IV Encuentro.7}

Finalmente, contamos con siete comunicaciones, que aquí se reproducen, las cuales respondian a intereses bien diversos y a puntos de partida distantes. A pesar de contar con una serie de ponentes, se procuró generar debate fomentando la participación del muy numeroso quórum de asistentes, ante lo que todavía pesaron las rigideces del sistema de comunicaciones. La mesa, planteada con un taller en el que se ofrecían herramientas para pensar la reconstrucción (si fuese necesaria) de la investigación enfocada hacia los problemas del tránsito temporal, se convirtió en un parlamento abierto en el que se expusieron ideas y casos concretos desde los afectos, los silencios en la historia del anarquismo, aproximaciones a neomarxismo, memoria a través del audiovisual, usos e inscripciones del espacio en el estudio de las ciencias sociales e incluso una provocación abierta desde el activismo académico a repensarnos como historiadoras/es.

En el transcurso del tiempo reservado para nuestra sesión se inició con una breve rueda de intereses y presentación de parte de todos los asistentes; rápidamente se vio que no solo los asistentes no estaban acostumbrados a este tipo de dinámica, sino que el disponer de una única sesión iba a dificultar el desarrollo del debate y el enriquecimiento recíproco en este tipo de formato novedoso. Ouedaron patentes las dificultades a la hora de facilitar el tránsito de la exposición de los textos preparados, hacia el debate en común. Sin embargo, a pesar de las dificultades, la experiencia fue ampliamente positiva. Se observó el gran interés de los asistentes, se practicaron nuevas formas de exposición de comunicaciones y además se congregó a algunas participantes de movimientos sociales de la ciudad, cada uno partiendo de un conocimiento situado muy diverso. Se intentaron abrir líneas para explorar y deconstruir los márgenes y el centro, para desterritorializar algunos de nuestros mapas mentales y de nuestras fronteras simbólicas o para plantear si existen límites del conocimiento crítico. Se trataba, en definitiva y siguiendo ciertas ideas de los textos sugeridos, de una invitación a caminar por las epistemologías del sur, a compartir la ecología de los saberes, a reterritorializar y a contribuir a empoderar a los sujetos que protagonizan la sociología de las ausencias y de las emergencias.

La gran afluencia de la mesa, la más concurrida del IV Encuentro, sobrepasó en cierto modo las formas y los tiempos. Pero ahí queda la necesidad y el interés de abrir espacios de encuentro como este a ideas/prácticas que puedan abrir, repensar y transformar colectivos, espacios, tiempos y personas.

6 Hayden WHITE: "The Public Relevance of Historical Studies: A Reply to Dirk Moses", History and Theory, vol. XLIV, 3, (2005), pp. 333-338.

$7 \mathrm{http}: / /$ valencia2013.net/comunicaciones/, consultado el 14/02/2014. 


\section{LAS NEGRAS TORMENTAS DE LA HISTORIA}

Francisco José Fernández Andújar

Universidad de Granada

La historia no es objetiva, porque el ser humano no lo es. El mundo no está para nosotros: existe, existió y existirá al margen de la raza humana, aunque nos cueste concebirlo así. Por tanto, el ser humano piensa irremediablemente de una manera antropocéntrica: no es objetivo; sino partidista, y por ello, la historia también lo es. La historia es sumamente política y social: se ha pretendido controlar y usar por todos los bandos y sectores humanos, tanto sociales, nacionales como económicos. Se dice que por ello la Historia la escriben los vencedores. O quien la paga. Eso es debido a que hay una lucha política interna en la historia, y no solo un uso manipulador externo y extra-académico.

El anarquismo es uno de los ejemplos de ello. No solo la política, el gobierno, la prensa, o la policía han denigrado y atacado al anarquismo desde posiciones -comprensiblementepartidistas, sino también la Historia, la historia "oficial". El himno libertario A Las Barricadas cantaba en sus primeras líneas unas letras referentes a una lucha revolucionaria y social, que también se da en la Historia: tanto el anarquismo como sus enemigos entablan un enfrentamiento a nivel historiográfico donde la neutralidad no está presente ni en unos ni en otros.

\section{Los anatemas de la Historia contra los anarquistas}

\section{Los milenaristas}

Una de las teorías de los historiadores sobre el anarquismo es su supuesto carácter religioso y milenarista. Interpretando la retórica de emancipación que usaban algunos de sus medios, a menudo llenos de referencias a la redención y a un futuro paraíso, se entiende que el carácter idealista y místico que adquiere el discurso anarquista está unido a unas formas religiosas relacionadas al milenarismo cristiano, del que se desprende ese "fanatismo" místico, irracional, intransigente, dogmático, etc.' Dichos estudios no se detienen a considerar el por qué se hacía este tipo de expresiones, presente solo en algunos medios dentro de la prensa anarquista. Consideramos que la construcción de esos términos en el ideario libertario es solo retórica para acercarse a las clases bajas, que se presumía que era de cultura cristiana, hasta entonces familiarizadas con unas manifestaciones discursivas determinadas culturalmente. Adaptarse a esas expresiones, e invertir sus propios significados, se mostraron como buenas armas de convicción, y no solo fue usado por el anarquismo, sino por la mayoría de los movimientos políticos europeos. No solo hubo credos y cristos anarquistas: también los hubo liberales y comunistas.

Por otra parte, consideramos que este supuesto milenarismo irracional y espontáneo se ve negado por la existencia de publicaciones científicas, culturales, modernistas y sociales, de gran rigor, que ya en la práctica y más allá de la propaganda, exponía un modo de ver la vida para los hombres nuevos, que hacían realidad. Los anarquistas promovieron desde el siglo XIX

1 Gerald BRENNAN: El Laberinto Español. Versión electrónica, Editions Ruedo Ibérico, s/f, p. 110. en España las ideas del aborto, igualdad de la mujer, ecologismo, nudismo, higiene, métodos anticonceptivos, planificación familiar, escuelas libres, y un largo etcétera. ${ }^{2}$ En cuanto a la organización social, Temma Kaplan ${ }^{3}$ toma una posición clara y considera que no hay nada de asociaciones, completamente racional.

Es interesante señalar la existencia de importantes revistas científicas y modernas dentro del anarquismo español, tales como Estudios, Generación Consciente, Brazo y Cerebro, o Iniciales, con la participación de importantes intelectuales como el médico Isaac Puente o Félix Martí Ibáñez, éste último fundador de Medical Doctor News, revista pionera en monografías y novedades de carácter médico-cultural, gran referente internacional durante buena parte del siglo XX. ${ }^{4}$ Como dice Fernández Gómez: "el pensamiento científico y positivista de izquierdas más complejo y avanzado de su época en España".

¿Cómo se llega a considerar al anarquismo como movimiento milenarista? Se entiende el milenarismo como la tendencia social que espera la llegada del nuevo milenio, de diferentes tiempos, recordando mucho a los movimientos medievales que se produjeron en torno al año 1.000, o mejor dicho, en torno a partir del siglo XIV, donde realmente se desenvolvieron estas agitaciones apocalípticas, y fue posteriormente cuando se inventó la leyenda de los movimientos milenaristas en torno al Año Mil histórico, que realmente no existieron más allá de ciertos círculos intelectuales. ${ }^{6}$ Por otra parte, se ha malinterpretado el movimiento milenarista, cuya realidad histórica es prácticamente desconocida y tergiversada, pues ha sido caricaturizada por los historiadores, pero su derrota fue por el aplastamiento militar y no por la supuesta pobreza de sus ideas.? Efectivamente, estas agitaciones colectivas de entonces llevaron consigo unos grandes procesos de renovación, más relacionados con reivindicaciones sociales que religiosas, que no contenían, como se cree bajo los prejuicios actuales, arcaísmos ni elementos primitivos, generando unas críticas al mundo, que poco después se renovará bajo la luz de primitivos, generando unas críticas al mundo, que poco después se renovará bajo la luz del alejado del concepto de la histeria colectiva, es un movimiento distinto al anarquismo: uno es hijo de la llustración y la modernidad; el otro de la renovación espiritual y cognitiva medieval.

Este milenarismo se relaciona con el anarquismo que arraigó en los sectores populares más desfavorecidos. El historiador Constancio Bernaldo de Ouirós ${ }^{8}$ lo califica como desorganizado, caótico y violento, resultado del carácter individual del andaluz, que es consecuencia de su ser biológico, que lo lleva a la delincuencia subversiva anarquista, determinado por el clima de sur hispánico. ${ }^{9}$ Díaz del Moral y otros historiadores destacarán el aparente resurgimiento de

Ideas que en algunos casos se materializaron por primera vez bajo el Ministerio de la anarquista Federica Montseny en la Guerra Civil.

3 Temma KAPLAN: Los origenes sociales del anarquismo en Andalucía, 1868-1903, Barcelona, Crítica, 1977, pp. 25 y $230-237$

4 Fernando A. NAVARRO: Félix Martí Ibáñez (1911-1972), en Laboratorio del Lenguaje, 2011, disponible en Internet: medicablogs.diariomedico.com/laboratorio/2011/12/31/felix-marti-ibanez/

5 Francisco de Paula FERNÁNDEZ GÓMEZ: Oleadas terroristas, Aldarull, 2012, p. 42.

6 Georges DUBY: EI Año Mil, Barcelona, Gedisa, 1989

7 Yves DELHOYSE y George LAPIERRE: El incendio milenarista, Logroño, Pepitas de Calabaza, 2008, p. 9. 8 Constancio BERNALDO DE QUIRÓS: El espartaquismo agrario andaluz, Madrid, Turner, 1974, p. 44.

- Jorge RAMOS TOLOSA: “La cuestión del milenarismo en el anarquismo andaluz”, La Protesta, (Agosto-Septiembre de 2008), p. 10. Seguramente se referirá a la obra ya citada de Ouirós, donde nos encontramos con términos como "Criminalidad colectiva” y factores térmicos en $p$.44, “Estigma de raza (por ser gitano), del nacimiento" p.60 "In vino veritas" (relaciona é éxto de las ideas anarquistas con el consumo delvino, p. 62. Razay folclore en p.73, con implicaciones de género. 
las insurrecciones anarquistas decimonónicas cada diez años, que lo interpreta como síntoma claro de misticismo apocalíptico. ${ }^{10}$

El anarquismo español era un movimiento completamente racional incluso entre sus sectores rurales." Es cierto que impulsaban cualquier levantamiento, a menudo sin estrategia alguna y de una forma espontánea, pero como se ha señalado a menudo, el hambre y la desesperación motivaban más la impaciencia en la revuelta, que una mística de la espontaneidad. Se pensaba racionalmente que ante tanta miseria un levantamiento provocaría una adhesión general. ${ }^{12}$ Asimismo, es tendencioso creer que esta "espontaneidad" sea inferior a una organización permanente, como pretende Hobsbawn. A menudo incluso los movimientos espontáneos tuvieron mucho más éxito que los movimientos disciplinados, como muestran prácticamente las grandes revoluciones de la historia, solo apareciendo la organización posteriormente.

Los primitivos

Para explicar el triunfo del anarquismo en ciertos lugares frente a las ideologías que defienden una modernidad basada en el progreso, han realizado una teoría, ya clásica en la historiografía, sobre el carácter primitivo de muchos sectores sociales para explicar cómo una teoría como el anarquismo les rompe los esquemas y ha llegado a triunfar entre la población, teniendo un protagonismo histórico indiscutible.

Rebeldes Primitivos de Eric Hobsbawn, es quizás el mejor ejemplo de todo esto. En el apartado que dedica específicamente a los anarquistas, basado fundamentalmente en El Laberinto Español de Gerald Brennan, Hobsbawn se aventura en un campo que a todas luces desconoce: llega a situar anacrónicamente acontecimientos como la sublevación de Casas Viejas como parte de un movimiento anarquista aislado del siglo XIX, cuando era un movimiento previamente coordinado de la CNT, ya en los años treinta, a la que se reconoce ya una planificación, estallando la rebelión no solo en el pueblo gaditano, sino en otras zonas de Cataluña, Valencia y Aragón, a pesar que fue cancelado previamente por haberse detenido sus organizadores con antelación al inicio del movimiento. ${ }^{3}$ Hobsbawn llega a calificar a los campesinos sublevados en Loja en 186 como de "indígenas", ${ }^{14}$ como de brutos y salvajes, en contraste al estudio de Bernaldo de Ouirós,

10 Temma KAPLAN: Los origenes sociales..., p. 233. Juan DÍAZ DEL MORAL: Historia de las Agitaciones Campesinas Andaluzas, Madrid, Alianza, 1969, p 44. Si bien, es conocida la simpatía de Díaz del Moral al anarquismo, pero mantiene una visión e interpretación basada en tópicos; pero en tópicos que le gustan, y que de hecho, en su nota al capítulo 8 de su obra citada, defiende ese milenarismo frente a los reproches disciplinantes del marxismo y socialismo.

11 Temma KAPLAN: Los origenes sociales..., pp. 235-236.

12 Francisco OLAYA: Historia del movimiento obrero español, siglo XIX, Nossa y J. Editores, 1994, pp. 176-178 y 567-574. Posteriormente, lo que se denominaría por Joan García Oliver como "gimnasia revolucionaria". Si bien los propios anarquistas reconocían que el hambre más bien acobardaba que agitaba, rompiendo otro tópico, no es menos cierto que arrastraba a la población no concienciada a los movimientos insurreccionales o revolucionarios. El caso de Casas Viejas es paradigmático, pues aunque es cierto que fue planificado e instigado por los anarquistas, no es menos cierto la siguiente carta dirigida al Comité Nacional de la CNT, que escribió un obrero del mencionado pueblo, en Octubre de 1932, unos meses anteriores al levantamiento: El paro obrero es cada vez mayor, elevándose el número de trabajadores parados en ambos pueblos, próximo al millar; el Monterilla no atiende, el Gobernador tampoco, los Panzudos no siembran y los trabajadores también se mueren de hambre; creemos que para alimentar los estómagos preparan balas;... así no es posible vivir; los hombres perecen de inanición. ¿Qué hacemos?

13 Julián CASANOVA: De la calle al frente. El anarcosindicalismo en España (1931.1936), Barcelona, Crítica, 1997, pp. 108-109.

4 Eric J. HOBSBAWN: Rebeldes Primitivos. Estudio sobre las formas arcaicas de los movimientos sociales en los siglos XIX XXX, Barcelona, Ariel, 1983, p. 122 que los describe como disciplinados y nobles..$^{15} \mathrm{El}$ texto tiene más interpretaciones políticas que otra cosa, de manera que Hobsbawn, tras confundir los hechos, llega a unas conclusiones bastante discutibles y señala que si hubiera estado presente una organización política disciplinada -que para Hobsbawn no puede ser otra cosa, por supuesto, que un partido comunista- hubieran llegado estos "rebeldes primitivos" a su ansiada emancipación. El autor, a pesar de ser marxista -o quizás por ello- no llega a comprender las peculiaridades de una organización distinta, y que los campesinos, anarquistas o no, tienen formas de lucha distintas a las urbanas.

De la opinión de Hobsbawn tenemos una amplia gama de historiadores convencidos de que el anarquismo y otros movimientos reivindicativos y rebeldes no marxistas de la Edad Contemporánea son manifestaciones pre-industriales que ha sobrevivido a la destrucción de Antiguo Régimen. Creen que la vida rural en la sociedad estamental es semejante a la vida agrícola de la edad contemporánea, por ser en ambos casos de carácter rural. Sin embargo, el mundo campesino es mucho más complejo que ese panorama, y desde luego el mundo rura contemporáneo es muy distinto al que existía un siglo antes: las tierras comunales fueron desamortizadas y vendidas, y con ellas desaparecieron las formas de vida de por entonces $y$ la gestión local de los comunales. El Estado contemporáneo se hizo omnipresente, eficaz y poderoso. Hay mejora de medios de transportes y de herramientas. Nuevos inventos y comodidades. Surgimiento de las ciudades industriales que afectan al campo. Y un sin fín más de factores que distinguían a la vieja y nueva ruralidad.

Sin embargo, el anarquismo español se desarrolló especialmente en la Cataluña industrial y las capitales de casi todas las provincias españolas, las zonas más "avanzadas" e industrializadas; que fuese más pequeño en comparación con otros países no quita que se pueda comparar con las áreas más agrícolas de España, y ciertamente, los hechos parecen desmentir absolutamente ese primitivismo, por mucho que se quiera matizar. En Andalucía, donde se centra Hobsbawn, tuvo ciertamente influencias en las áreas rurales, pero en general las capitales de provincia andaluzas tenían más militancia y afiliados que en las zonas rurales. En Granada, la CNT controlaba principalmente Granada capital y la socialista UGT era indudablemente superior en las áreas rurales. ${ }^{16}$ Los territorios valencianos tiene muchas zonas rurales donde la CNT domina, pero también la capital, Valencia, así como ciudades industriales como Alicante o Alcoy, que son claramente feudos tradicionales del anarquismo desde los tiempos de la Internacional. En los Congresos de la central anarquista son los sindicatos urbanos los que tienen el mayor peso de decisión, debido a su número de afiliación, casi siempre superior."

Con todo lo dicho, no pretendemos cometer la simpleza de invertir la afirmación y declarar que el anarquismo es un movimiento netamente urbano. El anarquismo, como cualquier otro movimiento social y político, surge en cada lugar por la combinación de una diversidad de factores que no siempre están relacionados con las características económicas que marca la visión burguesa del progreso.

Los incontrolados

Considerado como uno de los mejores especialistas en la violencia política durante la Guerra Civil Española, José Luis Ledesma no está libre de ciertas confusiones sobre los "incontrolados" que le lleva a cometer varios fallos ${ }^{18}$ que hereda de una literatura harta repetida. Si bien Ledesma reconoce las implicaciones políticas y la arbitrariedad del término, sorprende que al mismo

15 Bernaldo CONSTANCIO DE OUIRÓS: El espartaquismo agrario andaluz, pp. 46-47.

16 José Antonio ALARCON CABALLERO: El movimiento obrero en Granada durante la Il República (19311936), Granada, Diputación de Granada, 1990.

17 M. GONZÁLEZ URIÉN y Fidel REVILLA GONZÁLEZ: La C.N.T. a través de sus Congresos, México, Edito-

res Mexicanos Unidos, 1981, pp. 282-307.

18 Cuando habla, por ejemplo, del caso de Luis Bonilla. 
tiempo lo emplee una y otra vez en los contextos que se denuncia. Algunas de sus afirmaciones se refiere a la violencia pre-bélica, que sin duda acierta cuando señala que no justifica el golpe de Estado ni se vivía realmente en una situación de caos. Pero sí llega a decir que "lo que parece incuestionable es que esas violencias y sus anejas retóricas bélicas minaron gravemente la estabilidad del régimen republicano", 19 pareciendo que Ledesma olvida que esa violencia fue ejercida también por el gobierno de la República. No solo nos referiremos a la represión brutal contra los campesinos de Casas Viejas, justificado desde el gobierno republicano ("en Casas Viejas no ha ocurrido (...) sino lo que tenía que ocurrir" dijo Azaña ${ }^{20}$ ) sino también a la represión que se ejerció contra los proclamadores del comunismo libertario en Mas de las Matas o los mineros de Figols. Todos estos casos de represión no desestabilizaron el régimen republicano, sino más bien lo contrario: solo perjudicaron a elementos de algunos partidos políticos por las campañas de la oposición. Desgraciadamente, es frecuente entre los historiadores confundir la República con unos partidos políticos (Acción Republicana, Izquierda Republicana, PSOE, etc.) y no con otros (CEDA, Acción Popular, Renovación Española, Partido Agrario...).

Muchos historiadores ${ }^{21}$ también llegan a creer que la reducción de la violencia a lo largo de los meses de la Guerra se debía a un mayor control efectivo del gobierno republicano, que frenaría la violencia incontrolada. Sin embargo tal decrecimiento obedecía sencillamente a que la mayor parte de los represaliados ya habían sido ejecutados, quedando en las cárceles solo aquellos que se consideraban no muy peligrosos. Y ya no eran muy numerosos: el desarrollo de la guerra no era muy favorable a la República y la cantidad de presos que llegaban era ínfima comparada a la que se hizo a inicios del propio conflicto.

La palabra "incontrolado" tiene indudablemente un trasfondo político. Ello es debido a que se politizó el término en un contexto de lucha ideológica entre partidarios de un modelo revolucionario y los partidarios de mantener el gobierno republicano tal como estaba antes de la guerra, marcando a los incontrolados como una consecuencia -voluntaria o involuntarua- de la política de los primeros. Se suele ignorar por ello los numerosos casos de bondad "incontrolada", que por ejemplo cita Izard en uno de sus recientes trabajos, ${ }^{22}$ debido a que es un término propagandístico y despectivo. Cuando el Golpe de Estado se dio en el verano de 1936 por parte de los militares, el gobierno republicano se desplomó, y fue por la intervención de la población civil como se salva la situación. ${ }^{23}$ Esto produjo un vacío de poder en el bando republicano, que afectó a todas sus instituciones: en el gobierno, en el ejército, en la policía y en la economía. Es entonces cuando los anarquistas aprovechan la oportunidad y comienzan a realizar sus pro-

19 José Luis LEDESMA: Qué violencia para qué retaguardia o la República en guerra de 1936, Ayer, 76 (2009), p. 89

20 En Julián CASANOVA: De la calle al frente..., p. 113.

21 José Luis LEDESMA: Qué violencia para qué retaguardia..., pp. 94-95.

22 Miquel IZARD: Que lo sepan ellos y no lo olvidemos nosotros, Barcelona, Virus, 2012, pp. 271-353.

("C) pen una revista de Historia ("Grandes Enigmas del siglo XX $\mathrm{n}^{\circ} 9$, , Clio: Revista de Historia, 58 (2006), pp 42 50 ), ano pero que fue adjudicado por los revolucionarios en Madrid y Barcelona debido a que gobierno, pero que fue adjudicado cor los revolucionarios en Milnid to to es que no (as batalla estaba ya muy avanzada y el enemigo cansado y sin municiones, ocurriendo tan solo que momento nos bastará recordar las pa vabras de un falangista que luchó en Barcelona contra los rovo Españ CNT-FAl", por tanto, el pueblo revolucionario interviniendo los militares y policias republicanos solo al final cuando ya estaba todo decidido. Minuto 59 del documental. yectos políticos y económicos, creando colectividades, gestionando pueblos enteros, haciendo redes de intercambio, y otras muchas iniciativas más. Sin embargo, los anarquistas también se integraron en la estructura estatal, pues el gobierno republicano se convirtió en el nexo de unión de la lucha contra los golpistas. Se exigía entonces disciplina y control para ganar la guerra. Quien no siguiera esa disciplina y ese control, era un "incontrolado", un agente, consciente o inconsciente, "del fascismo". Incluso para los anarquistas. Pero pronto observarán que el término se politiza contra ellos, y no faltan, entonces, referencias sarcásticas al término, como hace el periódico Hombres Libres (Granada) cuando cita a un colectivista que devuelve una billetera llena de grandes cantidades de dinero a su propietario. ${ }^{24}$

Mientras tanto, el interés por atraer el apoyo internacional y de captar partidarios, generó una guerra de propaganda, donde cada bando, además de alabar su respectiva causa, acusaba al contrario de atrocidades, mostrando lo inadecuado que era apoyarles. Cuando los eficientes servicios de propaganda franquistas denunciaron con cierto éxito en Europa, especialmente en Inglaterra, sobre los crímenes del bando republicano, ${ }^{25}$ solo fue cuestión de tiempo usar el concepto de los "incontrolados" para convertirlos en chivos expiatorios donde el bando republicano no tenía nada que ver.

Sin duda en los primeros momentos del conflicto civil, el derrumbe de las instituciones que hasta entonces habían regido la sociedad, promueve una situación que, mezclada con la violencia iniciada por el golpe, muchos decidiesen arreglar viejas cuentas personales. La violencia de "incontrolados" que a menudo se mencionan a principios de la guerra, es más bien una violencia de carácter personal y acaso económico; rara vez de carácter ideológico o político, y no muy extendida en comparación con la violencia que predominó: la intrínseca y consecuente con un conflicto bélico.

La violencia, incluso la descontrolada, tiene sin embargo un trasfondo social, marcado por el contexto del caciquismo, el aspecto político más importante de la España del siglo XX, que se desarrolló especialmente en las áreas rurales menos politizadas. Los descontrolados obviamente actuaban bajo su cuenta y riesgo, pero no eran ni irracionales ni perversos. Eran por lo general personas que reaccionaban ante una serie de agravios sociales. No mataban a nadie ni por su ideología ni por su religión. Lo hacían por su propio beneficio personal, o por saldar viejos agravios de carácter económico. La violencia política que se ejerció al margen de las instituciones republicanas, se efectuó con mucho control y lógica, y de facto, con la colaboración y apoyo de los agentes de lo que quedaba de las infraestructuras republicanas, y por supuesto, de las organizaciones sindicales y políticas.

Se da por hecho que de haber tomado el control desde el primer momento, la República hubiera sido menos sangrienta. Pero la República en los años previos a la guerra no se mostró menos arbitraria, descontrolada ni sangrienta que los famosos incontrolados, como vemos en la revolución de Asturias.

\section{Los Matacuras}

La violencia anti-clerical es uno de los temas estrellas. La enorme proporción de religiosos víctimas de las represalias en la retaguardia republicana, sumado a la antigua tradición cristiana de victimización, ${ }^{26}$ ha provocado una serie de estudios sobre el tema que ha llegado in-

24 Hombres Libres n 36, de 13 de Agosto de 1937: Cómo proceden los "incontrolados".

25 Hugo GARCÍA FERNÁNDEZ: "Seis y media docena: propaganda de atrocidades y opinión británica durante la Guerra Civil Española", en HISPANIA. Revista Española de Historia, volumen LXVII, nº 226 (2007), mayo-agosto, pp. 671-692.

26 Vicente CÁRCEL ORTí: La persecución religiosa en España durante la II República (1931-1939), Madrid Rialp, 1990. Antonio MORENO MORENO: Historia de la persecución religiosa en España 1936-1939, s.l., s.n., s.a. 
cluso a considerarse dentro de la disciplina antropológica como un fenómeno de "ritual", una serie de costumbres y experiencias colectivas de largo recorrido en los sectores sociales. ${ }^{27}$ Tales estudios afirman que algunos actos sádicos se ejercieron solo contra los religiosos. Sin embargo existieron actos de esta índole contra fascistas laicos y no religiosos. La quema de casinos, de locales derechistas y de algunos bancos o casas nobiliarias, no ha trascendido tanto, por no resultar tan espectacular. ${ }^{28}$ Sin embargo, esos casos existieron, y habría que preguntarse si también responden a rituales religiosos de las clases populares. O eran acciones de simple afirmación política contra los representantes del Golpe de Estado, o aún más frecuente, una re-afirmación de lucha de clases, un término que parece ser más ignorado entre los historiadores de hoy que el de "rituales religiosos" anti-religiosos. No vamos a negar el simbolismo en la violencia no solo contra el clero, sino contra derechistas en general, pero tal violencia no tiene ningún trasfondo ritual ni se ejerció por motivos religiosos. Tal simbolismo era meramente propagandístico y de humillación al rival político.

La propaganda de la Iglesia pretende que tal persecución era de carácter religioso y no político. Sorprende en una institución que niega el reconocimiento de martirio de los párrocos vascos, los cuales para ellos sí fueron ejecutados por tales motivos. Del mismo modo, las ejecuciones de Martín Usero, José Pascual Duaso o Jeroni Alomar por los franquistas. Por otra parte, entre los mártires hay personas implicadas en casos de violencia anteriores a la guerra como Gabino Olaso Zabala, torturador de un sacerdote filipino, Mariano Dacanay. Y en general, una serie de hechos que demuestran el conflicto en sus verdaderas dimensiones: el político, y no el religioso. Por eso, no existen víctimas de los cristianos protestantes o evangelistas en la retaguardia republicana; en contraste con el bando nacional, donde fueron represaliados. ${ }^{29}$

Dentro del bando republicano, donde los anarquistas ejercieron un papel muy activo en las calles, los motivos del odio anti-clerical era, sencillamente, la actividad política de la Iglesia española. No era una institución política neutra, como hoy en día se pretende o cree. Estaban aliados con los caciques locales de cada pueblo y ciudad. Los párrocos solían ser activos militantes que organizaban partidos de derechas..$^{\circ 0}$ Asimismo llegaron a tomar parte en la violencia derechista antes y durante la guerra. Asignados como los ideólogos de los movimientos reaccionarios, era previsible que los ataques políticos se dirigieran en primer lugar contra ellos. Sin embargo, muchos republicanos y anarquistas protegieron a religiosos y párrocos, pero tal dato no resulta tan morboso en la historiografía derechista o eclesiástica. Tenemos numerosos ejemplos, como el de Jesús Arnal, que escribió unas memorias (Yo fui secretario de Durruti, $1972^{31}$ ), donde relata su paso de párroco a secretario de la Columna Durruti. O la protección de Joan Peiró al marista Salvador Oller o a las pasionistas de Tafalla. Y hay muchísimos más, como vemos en la obra ya mencionada de Izard. ${ }^{32}$

27 Víctor LUCEA AYALA: Un pueblo en movimiento, Zaragoza, Prensas Universitarias de Zaragoza, 2009, p. 209. Ejemplos de estudios de este tipo en Bruce LINCOLN."Exhumaciones revolucionarias 2009, p. 209. Ejemplos de estudios de este tipo en Bruce LINCO
en España, Julio 1936" en Historia Social, 35 (1999), pp. 101-118.

28 En Granada, el casino fue el principal blanco de los ataques incendiarios, y son notorios las quemas a principios del régimen republicano de los locales del Noticiero Granadino o del Ideal, el primero por su posición monárquica. En ALARCÓN CABALLERO: El movimiento obrero en Granada..., p. 362.

29 Juan Bautista VILAR RAMíREZ: “La persecución religiosa en la zona nacionalista. El caso de los protestantes españoles", en VV.AA: Los nuevos historiadores ante la Guerra Civil española, volumen 2, Granada, Diputación de Granada, 1990, pp. 169-188.

3o Caso de Santiago Megido Suárez (Mallorca), Mariano Silvestre (Lliria) o el famoso caso de Fermín Yzurdiaga, e innumerables casos en investigaciones sin citar nombres, en lugares como Grado (Asturias).

31 Jesús ARNAL: Yo fui secretario de Durruti, Zaragoza, Mira Editores, 1995

32 Ver nota 22, Miquel IZARD, Que lo sepan ellos...
Si observamos las zonas de mayor virulencia anticlerical, comprobaremos que se dan especialmente en las áreas rurales con una fuerte presencia caciquil y donde el clero forma parte de una manera directa en las relaciones de poder locales. Cuando estalla el conflicto bélico y con ella la percepción de encontrarse en medio de una lucha a muerte, en los pequeños pueblos se persigue inmediatamente al pequeño grupo que ha ejercido el poder local, constituido principalmente por los grandes propietarios, sus amigos políticos, y el clero. Este último era el símbolo definitivo de ese Poder a ojos de la población, por lo cual, quienes se sintiesen oprimidos e injuriados, desatan su furia contra ellos. De esta manera, los momentos más dramáticos de la violencia anti-clerical en la provincia de Granada se da precisamente en la Alpujarra, con una sindicación y afiliación política prácticamente inexistente, pero con una pobreza muy aguda y un caciquismo feroz, que se traducirá durante guerra civil granadina en la zona de la provincia con más incendios de parroquias y exterminio del clero que conocemos a día de hoy. ${ }^{33}$

\section{Los terroristas}

Se entiende por terrorismo como la sucesión de actos de una manera sistemática con el fin de infundir el terror. Sin embargo tiene hoy connotaciones sociales y emocionales muy claras que van más allá de esta definición, y existe una visión del terrorista como un elemento oscuro que aterroriza a la población de una manera indiscriminada como modo de influir y presionar a los gobiernos o a las sociedades. No sorprende que la prensa burguesa decimonónica hiciera descripciones terroríficas en este sentido de famélicos y siniestros anarquistas con bombas en la mano. El término de la "propaganda por el hecho" (y el de la "acción directa") ha sido usado cons tantemente por los historiadores como sinónimo de violencia y como justificante eufemístico del terrorismo, ignorando que incluso en el Congreso de Londres de 1881, donde aparece el concepto, nunca hablan de ello como sinónimo de violencia, sino como una multiplicad de estrategias y acciones definidas por la práctica y no por teorizaciones. ${ }^{34}$ La violencia es, obviamente, una posibilidad, pero solo una entre otras muchas. También se entendía como "propaganda por el hecho" a crear cooperativas económicas, realizar huelgas, ocupaciones de tierras, y en general cualquier acto que animase a la población a seguir el ejemplo de lo que se pretende propagar. Aparte, el movimiento anarquista reaccionó de muy distintas maneras a los atentados, desde la aceptación bajo la óptica de la violencia como motor de la historia; como del más enérgico rechazo por obstaculizar el desarrollo de la organización pública de anarquismo, al promoverse la represión estatal.35

33 Rafael GIL BRACERO: Revolucionarios sin revolución, Granada, Universidad de Granada, 1998, pp. 143-144. 34 No se conservan las actas en sí de este polémico pero importante Congreso internacional, tan solo algunas publicaciones de periódicos anarquistas, entre las que destaca la Révolté que protagonizaba Kropotkin desde Ginebra, no mostrando tampoco un gran entusiasmo por el congreso; gonizaba Kropotkin desde Ginebra, no mostrando tampoco un gran entusiasmo por el congreso tambien encontramos La Revolution Sociale de un confidente de la policia, Serreaux, que se mos-
tró, como otros tantos, como un entusiasta de la violencia. No fue el único confidente policial del tró, como otros tantos, como un entusiasta de la violencia. No fue el único confidente policial del Congreso, y hubo hasta un caso de espia en su comité organizador, que nuevamente, empujaba
a la violencia. Asimismo, existe un informe de la policía francesa sobre el Congreso. Ninguno de a la violencia. Asimismo, existe un informe de la policia francesa sobre el Congreso. Ninguno de estos documentos, asi como los diversos testimonios, son satisfactorios sobre un congreso que no gusto a nadie, pues por su caracter, se pretendió abarcar a todos, tanto como los partidarios no agarrón nada, y nadie salió contento, llevando a sus respectivas organizaciones y regiones, lo no agarró nada, y nadie salió contento, llevando a sus respectivas organizaciones y regiones, lo que interpretaron de las resoluciones, tan amplias, que ninguno mintio. Con todo, es de destacar que en tal comicio nunca jamás se llego a confundir o convertir en sinonimo la propaganda por no dejaron de recomendar, dentro de las resoluciones, el uso de tales violencias como una de las no dejaron de recomendar, dentro de las resoluciones, el uso de tales violencias como una de las formas de propaganda. Para las resoluciones de la violencia: La Révolté, 23-07-1881. Para no

35 José ÁLVAREZ JUNCO: La ideología politica del anarquismo español (1868-1910). Ed. Siglo XXI, 1991, 
Quienes señalan estas actuaciones como "terrorismo", no hace lo propio cuando las ejerce el Estado. Efectivamente, algunos atentados fueron montajes policiales, repletos de informadores de la policía e infiltrados. El ejemplo más claro, pero no el único, es el caso Rull. Un antiguo anarquista se convierte en confidente de la policía, y necesitando dinero que podría conseguir con "soplos", se dedicó él mismo a preparar bombas, para luego denunciarlas e informar a la policía..$^{36}$ En un libro imprescindible para conocer este tema ${ }^{37}$ se señalan numerosos casos de montajes y un análisis de los acontecimientos que nos lleva a pensar la más que probable responsabilidad de los agentes policiales en muchos de los atentados que se realizaron.

Otra forma de la violencia anarquista se dio en España en los años veinte con el fenómeno del pistolerismo. Los propios dirigentes anarquistas, no involucrados en todo esto, pensaban que la violencia con pistolas fue iniciada por sus propios compañeros más violentos, creyendo que era la reacción natural ante el encarcelamiento de los huelguistas y el consecuente fracaso derivado por ello, produciendo una enorme frustración en la clase trabajadora. ${ }^{38}$ Hoy en día sabemos que las hostilidades fueron iniciadas por los patronos que recurrieron a todo tipo de sicarios, policías, mercenarios y hasta de sindicalistas de los llamados Sindicatos Libres, para ejecutar a los dirigentes anarquistas más pacíicos a cambio de una remuneración económica. Los libertarios respondieron organizando a sus grupos de pistoleros, que no atacaron a los autores materiales, sino a los principales financiadores de lo que llamaban "el terrorismo blanco". ${ }^{39}$

\section{Reivindicación de una investigación histórica activista}

La historia es el estudio de los hechos del pasado. El simple recuerdo histórico por el conocimiento puro no motivó la aparición de la historia. Como los cuentos, las leyendas, las moralejas y otros recursos de los pueblos humanos, se buscaba un modo de aprendizaje para los miembros de la comunidad por medio de la experiencia y ejemplos que se relataba en todas esas formas culturales que hemos mencionado. Estos relatos, donde la historia ocupa un lugar proeminente, cumplen una función social determinada. Efectivamente la historia sirve para conocer la realidad del pasado humano. Pero no solo eso, sirve para mucho más. Sirve para analizar el pasado, para sacar lo positivo que ha tenido, y aprender de lo negativo. Es en el fondo lo que sabemos del ser humano con alguna certeza. Y de hecho, el ser humano funciona diariamente con el pasado, especialmente con el reciente, el relativo a lo que se dijo ayer, lo que ya se ha comprado, la factura que llegó hace una semana... En nuestro caso, lo que tratamos es un tiempo más lejano y por tanto más difícil de recordar y verificar.

Los métodos de verificación, la contrastación, los discursos o la investigación no son suficientes ante un mundo lleno de problemas, intereses y posiciones. La historia es una formidable arma política, ideológica, colonial, cultural y hasta científica. De tal modo, se enseña en las escuelas públicas que vivimos en el mejor de los mundos posibles, que el modo de economía

P. 508-510. Se puede añadir mucho más, ya que la bibliografía del conflicto entre la FTRE y el grupo violento de Los Desheredados es abundante y bien conocido.

36 Antoni DALMAU: El cas Rull. Viure del terror a la ciutat de les bombes (1901-1908). Ed. Columna 2008 .

37 Marc VIAPLANA y Raj KUTER: La Barcelona de la dinamita, el plomo y el petróleo 1884-1909. Ed. Grupo de Afinidad de Quico Rivas, 2009

8 Ángel PESTAÑA: Trayectoria Sindicalista. Ed. Tebas, 1971, p. 401. Es un ejemplo claro de militante que creyendo conocer todos los antecedentes, no conocía los inicios del pistolerismo como tal, iniciado por la burguesía en 1917, tal como denunció uno de sus primeros integrantes, Epifanio Casas, el cual más tarde se incorporará a la banda de Bravo Murillo. Esto no quita la existencia de la violencia política anteriormente, traducido en represión y muertes contra los trabajadores, y atentados anarquistas, pero son fenómenos difernetes al del pistolerismo.

39 Pere FOIX, Los Archivos del Terrorismo Blanco. El fichero Lasarte 1910-1930. Ed. La Piqueta, 1978. monetaria y capitalista siempre ha existido de una manera u otra, que el progreso es lineal y beneficioso para el ser humano, que los pueblos rurales o las tribus primitivas son inferiores, que vivimos en sociedades modernas desarrolladas con un nivel de felicidad no conocida hasta entonces, que el uso de la violencia siempre es rechazable excepto en los casos militares-policiales-penitenciarios $y$, en fin, una serie interminable de enseñanzas claramente propias de sistema de dominación ideológica, lo que Althusser definió como los Aparatos Ideológicos del Estado, ${ }^{40}$ que desde hace años ha sido denunciado y expuesto de muy distintas maneras por las nuevas teorías post-coloniales y post-modernas.

Lo primero que se aprende en la Historia es que casi todo es subjetivo y que debemos ser críticos con todos los estudios, artículos y trabajos que nos encontremos, incluso con los documentos. La objetividad es como la Utopía: no es el objetivo en sí, sino el camino a recorrer Es una inspiración, no el método. Esto es así porque la objetividad no existe, como ya hemos dicho, y por tanto no existen historiadores objetivos. Del mismo modo, una Utopía no pretende establecerse en la realidad, pero es lo más necesario que hay, pues su papel es el de inspirar para que sigan su camino, se llegue o no se llegue. Cuando se reconoce lo inevitable que es la subjetividad, estamos dando un paso importante en el oficio de la historia, pues siendo conscientes de ello, pero intentando ser objetivo, podemos hacer una labor historiográfica honrada, sincera, rigurosa y crítica, a la vez que ajustarse dentro de lo que se pueda a la realidad del pasado estudiado.

La subjetividad es definida por su interpretación y no por manipular o tergiversar los hechos. El miedo a la subjetividad se debe a que se la relaciona con la manipulación consciente, bajo la idea que con una interpretación pre-establecida, hará todo en cuanto pueda para adaptar la realidad a su lectura. Tal condición se multiplica ante la historia militante que además de subjetiva, es activista y con caracteres extra-académicos. Pero en realidad, no hay miedo a la interpretación en sí, pues tal cosa está presente en cualquier análisis y estudio histórico sino que hay miedo al engaño. Pero la falsedad -hay que señalarlo- puede deberse tanto a posiciones militantes como no partidistas; puede deberse a intereses económicos, profesionales $y / o$ personales. $Y$ los engaños pueden ser conscientes como inconscientes, debido a errores y equívocos. Lo que no se puede hacer, ciertamente, es falsear y tergiversar intencionadamente la realidad a lo que diga una ideología o creencia personal, sino al contrario, intentar corresponder la ideología a los hechos reales.

El reconocimiento de la subjetividad no debe ignorar que el conocimiento es algo colectivo, y por tanto no podemos desoír a los demás, por lo cual el esfuerzo de llegar a un conocimiento más allá de nuestra subjetividad debe estar siempre presente, lo alcancemos o no. Algunos entienden por relativismo aquello que afirma que no se puede alcanzar el conocimiento real u objetivo, que todo es subjetivo, y que por tanto todas las opiniones, todas las posturas, todas las visiones, son verdaderas. La subjetividad que nosotros defendemos aquí no pretende tal cosa. No todas las posiciones subjetivas son verdaderas o aceptables. Defendemos el derecho y la validez de mantener una postura, de mantener distintas perspectivas sobre la verdad, de tener diferentes interpretaciones sobre ella, pero no se tiene por qué estar de acuerdo con todo y menos todavía aceptarlo como una verdad absoluta. $Y$ al mismo tiempo, defendemos el derecho a reconocer la posición de cada historiador, y por supuesto, de criticarlo, de manera que se elabore un análisis de su postura, discurso y trabajo, no para tacharlo o degradarlo de su nive científico, sino precisamente para hacer un estudio más completo y preciso, ya que la posición de un historiador a menudo puede dar tanta información como su propia investigación en sí.

Los intentos de verificación y metodología, incluso hoy en día, señala el interés de las personas por lo que se ha definido como los objetivos básicos de la modernidad. Dentro de las con-

40 Louis ALTHUSSER: Ideologías y aparatos ideológicos de Estado, Buenos Aires, Nueva Visión, 1974, pp. 20-27. 
retos de la modernidad que siguen pendientes hoy en día: la libertad, la justicia y la igualdad

social. Unas reivindicaciones que se ajustan a las necesidades del ser humano hoy en día y

donde la historia puede jugar un importante papel, a pesar de su supuesta crisis que anuncia

el Apocalipsis postmoderno. 


\section{ANSIEDAD Y REPETICIÓN}

María Gracia Bafalluy

Vladimir López Alcañiz

Universitat Autònoma de Barcelona

\section{PATOLOGÍAS DE LA TEMPORALIDAD PRESENTISTA}

Universidad de Zaragoza

\section{El ocaso de la revolución}

En la modernidad, la historia se repliega sobre sí misma y cobra sentido absoluto, y absorbe también todos los cambios que se producen en el mundo, pues su función es ordenarlos. $\mathrm{Y}$, sin embargo, se hace imposible pensar la historia sin una instancia exterior a ella, sin una exigencia de superación que asedie su propia teleología. Durante los últimos dos siglos, esa instancia ha sido la revolución. Historia, revolución y modernidad constituyen la constelación de significado que da forma a la idea de tiempo histórico. La intimidad entre las tres nociones la ha concebido la modernidad, esto es, como trasfondo del tiempo y el mundo humanos. Así pues, la revolución significa la afirmación de la historia como liberación del simulacro en e que hasta ella se había vivido: un tiempo estancado y cautivo. La experiencia revolucionaria, por ende, presupone no sólo una cierta comprensión histórica del mundo sino, más radicalmente, la historia misma en tanto que horizonte capaz de acoger la totalidad de las acciones humanas. Se observa así cómo las nociones modernas de historia y de revolución pertenecen a un mismo movimiento genealógico: no hay acción revolucionaria sin sujeto histórico. En estos términos, la revolución deviene un mecanismo regulador de la historia capaz de engendrar cuando la situación lo requiera, una transformación radical. En este sentido, puede presentarse bien como la consumación del tiempo histórico, como el cumplimiento de su verdadera vocación, o bien como la corrección - y el correctivo - frente a una historia corrompida y con riesgo de (en)cerrarse en sí misma y anular la temporalidad que le es propia.

Historia y revolución se encuentran en la misma línea del tiempo. Lo que equivale a decir que la revolución, incluso cuando pretende superar una cierta historia, lo que hace es desarrollar una posibilidad inscrita en tal historia. Desde este punto de vista, toda revolución es tardía en cuanto que llega después de una historia que ya está ahí y que es necesaria para pensar la ruptura revolucionaria. Es por eso que el desleimiento de la idea de historia ha ido acompañado de la pérdida de legibilidad del concepto de revolución como paradigma del cambio histórico. Hoy ya no se cree en un acontecimiento decisivo como solución de la historia producida por sí misma. Hoy se impone la creencia —o quizá es la resignación — en un presente autónomo y omnímodo.

La idea moderna de revolución parece, pues, obsoleta. ¿Cómo interpretar este ocaso? Tal vez como una desestructuración del tiempo de la modernidad y de las formas de subjetividad que le eran propias. Hoy día parece que el movimiento histórico de la modernidad haya dado paso a una suerte de puntillismo topológico, a un presente cuyo futuro es la repetición compulsiva de su propia lógica. El tiempo de la historia hacía que todos los instantes estuvieran orientados hacia el futuro como progreso. Pero el presente eterno ya no se reconoce como tiempo histórico, toda vez que se sustrae al devenir. ¿Qué revolución podría entonces pretender ser la histórico, toda vez que se sus
finalidad de este proceso? la población la incierta marcha de la economía, el riesgo de pandemias globales, la producirse, no parece que vayan a deberse a la voluntad de nuestras sociedades, sino a fuerzas que escapan a su control y que tienen un sesgo impersonal y aun fatídicamente naturalista. Hoy en día, incluso el comportamiento de los mercados, sin duda provocado por la acción de algunas personas, parece no obstante seguir esa pauta. $Y$, en cuanto a la historiografía, el estatuto de su saber se ha visto severamente impugnado. El relato histórico se ha asimilado a menudo al relato de ficción. Sus pretensiones científicas han sido tachadas de mitológicas, cientificistas y empobrecedoras. El vaticinio de Le Roy Ladurie en los años sesenta, "el historiador será programador o no será", podría formar parte hoy de una antología de ilusiones perdidas. Y la nación, otrora llamada a ser la expresión particular de los principios universales, hoy ve cuestionado su cometido, y vaciado su contenido, por las tensiones propias de la aldea global: una globalización económica sin rostro humano, y una humana, demasiado humana aldeanización localista meramente defensiva. Este, trazado con brocha gorda, es el panorama en el que nos hallamos, $o$ al menos así es como nosotros lo percibimos. Lo que sigue son unas catas para conocer un poco mejor cómo debiéramos analizarlo.

\section{Tiempo de memoria}

Entre los efectos de las transformaciones de los años sesenta, cuyo perdurable emblema es mayo del 68, está el surgimiento de nuevos discursos sobre la memoria. La convergencia de los procesos de descolonización y liberación nacional con los nuevos movimientos sociales produce entonces un acusado sentido del fin: del sujeto, de la obra de arte, de los metarrelatos, y al poco, como hemos visto, de la historia y de la revolución. Todo lo cual viene acompañado por el planteamiento de historiografías alternativas y revisionistas, por la búsqueda de otras tradiciones y de las tradiciones de los otros, y por la recuperación de la historia de los vencidos. Andreas Huyssen ha señalado que todo ello apunta a la necesidad de recodificar el pasado en curso. Ahi empieza un lento proceso que se acelera en los años ochenta, cuando los discursos sobre la memoria se intensifican de nuevo, reactivados por el debate sobre el holocausto y los llamados 'aniversarios alemanes'. 
Simbólicamente, se ha hecho del proceso a Eichmann en Jerusalén de 1961 el inicio de la 'era del testigo'. Se percibe ahí un claro desplazamiento de la historia a la memoria como principio de intelección del tiempo, un movimiento que anuncia un cambio de época. En efecto, después de Auschwitz determinados fenómenos empiezan a interpretarse en función de una nueva temporalidad, la del crimen contra la humanidad, es decir, la de un tiempo que nunca se convierte en pasado porque su contenido es imprescriptible.

La imprescriptibilidad significa que el criminal permanece contemporáneo del crimen que se le imputa hasta la muerte, pero también que así lo hacen la sociedad que le juzga y la víctima que lo ha padecido. Nuestras sociedades, por esta vía, parecen haber naturalizado ese tiempo de lo imprescriptible, una ficción jurídica seguramente necesaria que, campando a sus anchas, ha dado con un tiempo destemporalizado, vacío. Para la víctima, por su parte, la tragedia que ha sufrido permanece siempre presente, de modo que su padecimiento se inscribe en la temporalidad presentista y, más aún, la refuerza. Su tiempo se ha detenido: el pasado no es para ella una fuente de sentido, sino una instancia sombría en la que se localiza el trauma. Un trauma que, de no superarse, de no elaborarse, como quería Dominick LaCapra, condena a la víctima a la repetición incesante de la escena primordial de su dolor. $Y$, en cuanto al porvenir, Jean Améry ya concluyó tajantemente que el resentimiento bloquea el acceso a la dimensión humana por excelencia: el futuro.

\section{La identidad elusiva}

Se ha dicho, en numerosas ocasiones, que la narrativa es traducible sin menoscabo esencial porque es un metacódigo sobre cuya base pueden transmitirse mensajes entre culturas distintas. Esto ha sido uno de los pilares en los que la historia ha asentado su pretensión de sentido. Pero este, además, ha venido apoyado por otro, aquel que afirma que la historia, en tanto narración, tiene la misma forma que la vida, y por eso es tan apropiada para transmitir mensajes significativos. A este respecto, Paul Ricœur sostiene que conocerse es interpretarse a uno mismo. Para satisfacer esta necesidad, cada cual da forma a un relato de sí mismo, como si estuviera inventando un personaje pero con sus recuerdos e influencias como materiales de trabajo. El resultado de todo ello es lo que se ha llamado la 'identidad narrativa', que se opone a una supuesta identidad permanente, inmutable y esencial.

En obras maestras de la literatura como el Quijote o Madame Bovary podemos ver ese proceso llevado al extremo. Alonso Quijano y Emma Bovary enloquecen porque confunden su propia historia con la de las novelas que leen. Sin embargo, son testimonios de esa acuciante necesidad humana que es responder a la pregunta: ¿quién soy yo? También dan cuenta de que la respuesta a esa pregunta solo puede ser, aparentemente, una historia. Porque la vida no es más que un tejido de historias contadas. Si queremos ir más allá en busca de una respuesta más profunda, más pristina, veremos solo la desnudez y la nulidad de la identidad sustancial.

Así las cosas, cabe preguntarse de qué se compone la identidad narrativa. Un principio de respuesta nos lleva a Aristóteles, gracias al cual sabemos que en toda tragedia la identidad de personaje está imbricada en la trama hasta el punto de que la consistencia de esta determina la legibilidad de aquella. Para saber completamente quién es, el personaje debería conocer de antemano el fin de su acción, en el doble sentido de finalidad y de conclusión, y para ello tendría que conocer toda la trama en la cual su peripecia se inscribe. Lógicamente, ese saber nunca es completo, sino que se va descubriendo a medida que avanza la acción y la trama va desgranando su sentido. Eso es, propiamente, la identidad narrativa.

Asumir la narratividad de toda identidad tiene el poder de relativizar elementos que de otro modo podrían considerarse inamovibles. Como decía Gadamer, toda verdad es una verdad del tiempo. Sin embargo, la redeterminación relativista de la identidad sigue cargada, a un cierto nivel, de eternidad. En efecto, en demasiadas ocasiones la identidad narrativa, vale decir histórica, se ha construido en términos de subordinación del carácter al destino, de los episodios a sentido, y del principio al final. Pero, por encima de todo, se ha constituido atribuyendo al dolor un sentido y un valor de futuro. Dicho llanamente, la historia se ha asentado en la premisa de que el dolor de hoy será un valor mañana, porque nuestros sacrificios serán recompensados o porque nuestros esfuerzos darán con una sociedad mejor: la nación consumada, el paraíso del proletariado, etcétera. La promesa de un futuro de plenitud ha sido, demasiadas veces, una coartada para cercenar las vidas en el presente.

Así pues, es lógico que en algún momento hubiera una cierta revuelta contra la historia, una tentativa de liberarse no solo del peso del pasado, como quiso Hayden White en los años sesenta, sino también de la carga del futuro, de la obligación de sacrificar la voluntad propia a una causa - a una trama- superior y previamente escrita. De ahí, como es evidente, la crisis de los metarrelatos que Lyotard certificó en la década de los setenta. El problema es que, entre aquellos, estaba también el de la emancipación, que en buena medida nos ha dejado huérfanos frente al relato neoliberal que se impuso desde la era de Thatcher y Reagan.

Porque, ciertamente, si la identidad narrativa puede experimentarse como un fardo, su pérdida puede dejarnos en la intemperie. La actual oclusión de la idea de futuro, la facilidad con que el relato de uno mismo pierde sentido al quedar la vida truncada por la indefensión social, convierte la pregunta ‘quién soy yo?' en un factor de ansiedad, puesto que la respuesta ya no puede ser una historia que armonice los tres éxtasis del tiempo, sino un collage de momentos sin conexión, lleno de cambios de rumbo, de trabajo, de país, de elasticidad —o flexibilidad, como prefiere el lenguaje empresarial— infinita, de triunfos provisionales y caídas, quiebras personales y, por encima de todo, incertidumbre y desasosiego en la identidad.

\section{Ansiedad y repetición}

Actualmente, la realidad que nos circunda se ha vuelto por momentos agresiva, hostil. Asimismo, el futuro, cuando nuestro pensamiento se abre a él, se nos aparece con un rostro amenazador. La crisis económica y el progresivo desmantelamiento del Estado del bienestar y de las redes de protección social han generado un sentimiento de inseguridad, de indefensión y de temor generalizados. La precarización de la vida y la desconfianza en el porvenir son factores que producen una sensación de ansiedad y que recortan, claramente, la libertad de acción pues nuestro margen de decisión se ve limitado por el intento de eludir los riesgos de la sociedad global y por la obligación de pensar a corto plazo.

La ansiedad, o angustia, es una sensación que, según Freud, reaparece cada vez que el sujeto se enfrenta a una situación de peligro, lo cual genera paradójicamente una obsesión de repetición que lleva a revivir las situaciones desagradables con el fin de buscar una salida a la experiencia traumatizante. Pero, claro está, la repetición - frente a la alternativa de la elaboración de la memoria y del trabajo del duelo— no hará más que perpetuar una desagradable sensación de angustia.

Paolo Virno ha señalado que quizá sea la infancia la matriz de toda búsqueda de protección frente a los peligros del mundo. En efecto, el niño se protege de lo desconocido a través de la repetición, por eso reclama una vez más el mismo cuento o el mismo juego. La repetición es, entonces, una estrategia para resguardarse del impacto que pueda causar la novedad y lo imprevisible. El filósofo italiano se pregunta, sin embargo, si no se estará hoy transfiriendo esa experiencia infantil a la vida cotidiana de los adultos, a los comportamientos que pueden detectarse en el interior de los grandes núcleos urbanos. Pues, ante la falta de comunidades sustanciales que puedan dar sentido y consistencia a los quehaceres y a las costumbres, la gente parece protegerse de la pérdida o el desvanecimiento de las referencias aferrándose a aquello que puede prever con casi total seguridad: horarios y rutinas, división entre el tiempo de trabajo y el tiempo de ocio, etcétera. En una palabra, en todo aquello que se repite.

Para proseguir con su análisis, Virno rescata una útil distinción de Heidegger entre el miedo y la angustia. Según el maestro alemán, el miedo aparece provocado en el interior de las 
comunidades, en sus formas de vida y comunicación, y la angustia aqueja a los individuos que se alejan de la comunidad de pertenencia y quedan así desarraigados. Eso, claro está, siempre que la comunidad conforme una situación familiar y conocida, y lo que queda fuera de ella represente lo desconocido, lo que nos es hostil. Sin embargo, en las condiciones actuales, la distinción entre el adentro y el afuera está rota y los límites entre lo conocido y lo hostil se difuminan. Las redes sociales, los movimientos globales, las empresas multinacionales, desdibujan la frontera entre lo propio y lo ajeno.

Por todo ello, la repetición afianza su significación en nuestro día a día, como ya hiciese notar Walter Benjamin. Ya no cabe hablar de comunidades sustanciales y las vidas no están sometidas al peso de la tradición y de las repeticiones previsibles. Ahora el futuro es incierto y nos enfrentamos a cambios frenéticos e imprevisibles, de manera que convivimos con la sensación de angustia y el temor constantes. Nunca se habían diagnosticado tantos trastornos por ansiedad como en las últimas décadas.

De esta manera, puede decirse que se extiende la evitación a toda costa de la confrontación con lo desconocido, de tal manera que buscamos reafirmarnos cada día en lo ya conocido, lo ya vivido, en detrimento de aquello novedoso. No nos es sencillo descubrirnos de nuevo cada día, no deseamos sorprendernos, y nos es más tolerable contar con que el yo que somos en este momento es la culminación de un proceso que ya ha terminado o que no va a sufrir alteraciones significativas. Es lo que se ha dado en llamar 'ilusión del fin de la historia', tal como ha sido diagnosticado por un equipo científico de la Universidad de Harvard. En resumidas cuentas, tal ilusión implica que, si proyectamos la imagen que tenemos de nosotros mismos en un futuro no muy lejano, nos imaginamos iguales o muy similares a como somos en la actualidad. Eso sin embargo, se revela ilusorio, puesto que si hacemos la operación inversa, es decir, si nos recordamos a nosotros mismos hace la misma cantidad de tiempo, no podemos dejar de percibir los profundos cambios que hemos sufrido.

\section{¿Una nueva esperanza?}

Decía el historiador romántico Edgar Quinet que solo los pueblos libres tienen historia. Los otros no tienen más que crónicas. Ouizá por eso Alain Badiou detecta en la primavera árabe y en la revuelta española los indicios de un despertar de la historia. Como gran teórico del acontecimiento, Badiou concibe el tiempo histórico como una duración densamente politizada, pautada por la emergencia de las ideas que persiguen la emancipación del género humano. Según él, la revolución francesa alumbró la idea republicana, tras cuyo eclipse sobrevino la idea comunista, que a su vez resultó severamente impugnada tras los 'años rojos' del siglo veinte. Inermes desde entonces, hoy se estaría insinuando una nueva idea, todavía indecisa, en las resistencias al gobierno del mundo que nos ha tocado en suerte.

Desde un punto de vista historiológico, la lectura de nuestro tiempo de Badiou merece atención. Él contraría a quienes hacen hincapié en las diferencias del capitalismo tardío o posmoderno, y sostiene en su lugar que el capitalismo contemporáneo presenta todos los rasgos del capitalismo clásico. Concretamente, cree que la regresión sin precedentes que padecemos pretende adecuar el desarrollo económico y la acción política actuales a las normas de nacimiento del liberalismo de mediados del siglo diecinueve, es decir, al poder omnímodo de una oligarquía financiera e imperial, y a una democracia solo aparente.

De ser así, asistimos hoy al cumplimiento retrógrado de la esencia del capitalismo, al retorno del espíritu que se impuso en Europa tras el congreso de Viena. Los signos de que el capitalismo actual es un retorno a la forma pura del capitalismo se cifran en dos reveladores parecidos. En primer lugar, el que existe entre la restauración monárquica que sucedió en 1815 a la marea revolucionaria de 1789 y la revolución conservadora que se apoderó del mundo después de la oleada de contestación de 1968. Y en segunda instancia, el que hay entre las revueltas de 2011 en el mundo árabe y las revoluciones de 1848 en Europa.
En consecuencia, Badiou saluda el momento actual como el comienzo de un levantamiento popular de alcance mundial contra tal retroceso. Se trata de un movimiento incipiente, vacilante, sin un concepto sólido ni una estructura estable, que puede recordar a las primeras agitaciones obreras del siglo diecinueve. Al mismo tiempo, sin embargo, es un indicio del despertar de la historia contra la repetición de un tiempo cautivo. Lo que haya de llegar es aún incierto, no está escrito. Pero ahí, en la misma liberación de lo posible contra lo necesario, está la espita para dar cauce al futuro.

\section{Una historia más}

Ahora que todo parece nuevo, es necesaria una historia más. La que teníamos, esa que entendíamos como un tiempo que sincronizaba todos los relojes para que marcaran la hora del progreso, ha perdido buena parte de su credibilidad. No es que haya llegado a su fin, es que nosotros, como ha señalado Manuel Cruz, la hemos abandonado. Esto genera la necesidad de articular de nuevo la inteligibilidad de los procesos y las transformaciones que vivimos. Y, si en estas circunstancias se suscita todavía la cuestión de la revolución, deberá hacerse en términos que seguramente están aún por inventar. Sea como fuere, hoy como ayer continuamos no sólo escribiendo historias, sino tratando de comprender la historia y reflexionando sobre nuestro tiempo para que este pueda establecer alguna relación con el pasado y el futuro. De hecho, hoy hemos asumido que una y otra cosa, la comprensión histórica y la reflexión sobre el presente, no pueden deslindarse porque en realidad son dos momentos de un mismo impulso. La cuestión es, pues, cómo hacerlo. Qué forma discursiva corresponde a nuestra historicidad, que por un lado parece abandonar una cierta figura historicista de la historia, y por el otro se enfrenta a la estabilización de una temporalidad radicalmente presentista, que no parece tener ya más historia que la reproducción out of joint de su propio modo de ser.

En esta tesitura, es preciso profundizar en el malestar en el régimen de historicidad que nos rodea. En primer lugar, hay que consignar la crisis del 'tiempo histórico', ese tiempo que reúne las temporalidades diversas de las historias o res gestae tradicionales. Ese es hoy un tiempo en ruinas, y por eso alguien ha podido detectar el desmigajamiento de la historia en una miríada de historias. En segundo lugar, hay que insistir en que la historia ha sido hasta ahora una estructura interpretativa sobre la que se han superpuesto numerosas variaciones. En rigor, ha sido el lazo y el límite de esas variaciones. Pues bien, ese límite es lo que ahora está bajo presión. Haremos bien en escuchar la llamada de Foucault a despojar la historia de todo narcisismo trascendental, de todo lo eterno que haya en ella. $Y$ eso no significa otra cosa que despojar a la historia de la idolatría de sí misma.

¿Qué espacio nos despeja el desbrozo de este claro de bosque? En primer lugar, se hace necesario repensar la gramática del acontecimiento, es decir, la forma de codificar la serie de ocurrencias dispares que se suceden en el tiempo. En segundo lugar, se abre la vía para elaborar un discurso crítico sobre el tiempo propio de la historia europea y de la historiografía 'científica' que quiso dar razón de ella.

¿Cómo empezar? Constatemos esto. La forma de la historia magistra se recortó sobre el fondo de una temporalidad pasadista. Inversamente, la historia moderna se ha inscrito en una temporalidad futurista. La última pregunta, cuya respuesta no podemos más que esbozar, emerge por sí sola. ¿Qué historia escribir en una temporalidad presentista? La 'ontología de presente' foucaultiana, al permitirnos pensar una historia no teleológica, es un buen punto de partida, toda vez que el interrogante axial de dicha ontología ya no es ni de dónde venimos ni hacia dónde vamos, sino qué nos está pasando. El énfasis foucaultiano en la actualidad se erige en el doble crítico del 'presente perpetuo'.

Desde esta perspectiva, es posible empezar a pensar nuevos conceptos sobre la actualidad que ocupen el lugar en el que antes estuvieron las lecciones para siempre de Tucídides o e progreso inexorable de los modernos. Es posible también sustraernos a la dicotomía que plan- 
teara Karl Löwith entre las dos grandes concepciones de la Antigüedad y del cristianismo, que parecerían agotar las posibilidades de la comprensión histórica. Y ello porque la mencionada ontología se asienta en una intelección del presente que corrige una mirada excesivamente enfocada hacia los orígenes, y por eso mismo también hacia los acabamientos, las culminaciones, los logros y los fines.

En resumen, el relato que hoy tenemos que aprender a escribir es una ontología del presente que, si puede, sea al mismo tiempo una genealogía de la historia y una arqueología del futuro.

\section{Bibliografía}

Como se habrá detectado, este texto carece de notas a pie de página. Ello se debe a su naturaleza ensayística, a su vocación polémica y a la voluntad de facilitar una lectura rápida. Para compensar tal licencia académica, he aquí una bibliografía explicativa que sigue de cerca los pasos dados más arriba.

Introducción. La obra a la que se alude al comienzo es la de François Hartog: Régimes d'historicité. Présentisme et expériences du temps, París, Seuil, 2003. Suyas son las nociones de 'presentismo'y de 'régimen de historicidad' que están en la base de nuestra diagnosis. La significación de la 'era de la historia' debe interpretarse a partir de Michel Foucault: Las palabras y las cosas. Una arqueología de las ciencias humanas, Madrid, Siglo xxi, 2006. La formación del discurso de la historia se describe con particular perspicacia en Marcel Gauchet (ed.): Philosophie des sciences historiques. Le moment romantique, París, Seuil, 2002; y en Jacques Rancière: Els noms de la història. Una poètica del saber, València, Publicacions de la Universitat de València, 2005 De la superación de la historia como principio de inteligibilidad habla Manuel Cruz: Adiós, historia, adiós. El abandono del pasado en el mundo actual, Oviedo, Nobel, 2012. El vaticinio in formático puede leerse en la antología de Emmanuel Le Roy Ladurie: Le Territoire de l'historien, París, Seuil, 1977.

El ocaso de la revolución. Sobre la transformación del concepto de historia en la modernidad, el locus clásico es Reinhart Koselleck: historia/Historia, Madrid, Trotta, 2004. En la relación entre la historia, la revolución y la modernidad profundizan las contribuciones recogidas en Jocelyn Benoist y Fabio Merlini (eds.): Une histoire de l'avenir. Messianité et Révolution, París, Vrin, 2004. Al 'presente eterno' se refiere Jérôme Baschet: "'’histoire face au présent perpétuel. Quelques remarques sur la relation passé/futur", en François Hartog y Jacques Revel (eds.): Les usages politiques du passé, Paris, Éditions de l'ehess, 2001, pp. 55-74

Tiempo de memoria. Acerca del surgimiento de nuevos discursos sobre la memoria, seguimos a Andreas Huyssen: En busca del futuro perdido. Cultura y memoria en tiempos de globalización, México df, fce, 2002. La 'era del testigo' es una denominación que ha hecho famosa Annette Wieviorka: L'ère du témoin, París, Plon, 1998. A la temporalidad de lo imprescriptible se refiere François Hartog: Croire en l'histoire, París, Flammarion, 2013. La elaboración del trauma es un motivo de Dominick LaCapra: Historia en tránsito. Experiencia, identidad, teoría crítica Buenos Aires, fce, 2006. La referencia que cierra el capítulo remite a la obra de Jean Améry: Más allá de la culpa y la expiación. Tentativas de superación de una víctima de la violencia, Valencia, Pre-textos, 2004

La identidad elusiva. Sobre la narrativa como metacódigo habla Hayden White: El contenido de la forma. Narrativa, discurso y representación histórica, Barcelona, Paidós, 1992. La formulación de la 'identidad narrativa' se encuentra en Paul Ricœur: Historia y narratividad, Barcelona, Paidós, i.c.e.|u.a.b, 1999. La similitud entre la estructura de la vida y la de la narrativa, en Hans Blumenberg: Conceptos en historias, Madrid, Síntesis, 2003. La 'crisis de los metarrelatos' es el famoso tema de Jean-François Lyotard: La condició postmoderna: informe sobre el saber, Barcelona, Angle, 2004. En la problematización de la 'identidad narrativa' nos amparamos en la obra de José Luís Pardo: Esto no es música. Introducción al malestar en la cultura de masas, Barcelona, Galaxia Gutenberg, 2007. A la 'carga del pasado' alude también, en un artículo fun- damental, Hayden White: “The Burden of History", History and Theory, 2, 5 (1966) pp. 111-34.

Ansiedad y repetición. Las ideas del psicoanálisis que manejamos pueden hallarse, fundamentalmente, en Sigmund Freud: Inhibición, sintoma y angustia, México, Grijalbo, 1970; e id.: Psicología de las masas; Más allá del principio de placer; el porvenir de una ilusión, Madrid Alianza, 1974. El papel del riesgo en nuestra sociedad lo ha puesto de relieve Ulrich Beck: La sociedad del riesgo, Barcelona, Paidós, 1998. Incide en la idea de 'repetición' Paolo Virno: Gramática de la multitud. Para un análisis de las formas de vida contemporáneas, Madrid, Traficantes de sueños, 2003. La distinción entre 'miedo' y 'angustia' pertenece a Martin Heidegger: Ser tiempo, Santia o de Chile, Editorial Universitaria, 2005. El estudio sobre la 'ilusión del fin de la historia' es de Jordi Quoidbach, Daniel T. Gilbert y Timothy D. Wilson: "The End of History Illusion", Science, 339, 6115 (2013), pp. 96-98.

Una nueva esperanza. Esta sección corta se inspira enteramente en la obra de Alain Badiou: El despertar de la historia, Madrid, Clave intelectual, 2012

Una historia más. Del abandono de la historia se hace eco, como hemos señalado, Manue Cruz: Adiós, historia, adiós. El abandono del pasado en el mundo actual, Oviedo, Nobel, 2012. Las condiciones de posibilidad de la historia hoy son el tema de la penetrante obra de Jocelyn Benoist y Fabio Merlini (eds.): Après la fin de l'histoire. Temps, monde, historicité, París, Vrin, 1998 La idea del malestar es, nuevamente, de Sigmund Freud: El malestar en la cultura y otros ensayos, Madrid, Alianza, 1992. Un desarrollo de tal idea en el ámbito de la historiografía puede hallarse en Vladimir López Alcañiz: "Malestar en la historia. Tres respuestas al desafío historiográfico de los setenta", Historia 396, 3:1 (2013), pp. 135-161. Del desmigajamiento de la historia habla François Dosse: L'histoire en miettes. Des « Annales " à la " nouvelle histoire ", París, La Découverte, 1987. El llamamiento a despojar la historia de todo narcicismo trascendental, en Michel Foucault: La arqueología del saber, México df, Siglo xxi, 2007. Asimismo, la 'ontología del presente' también ha sido desarrollada por Michel Foucault: Sobre la llustración, Madrid Tecnos, 2007. Finalmente, la 'arqueología del futuro' es una bella expresión de Fredric Jameson: Arqueologías del futuro. El deseo llamado utopia y otras aproximaciones de ciencia ficción Madrid, Akal, 2009. 
Gustavo Hernández Sánchez

Universidad de Salamanca

La razón de ser de estas notas es la necesidad de construir un debate. Un debate que no tiene como fin el consenso, sino el disenso (disentimiento) o "recreación teórica" en el sentido en que lo entendía Michel Foucault.'

En forma de ensayo, pretendemos verter algunas reflexiones (o planteamientos teóricos y críticos) personales con una dimensión ideológica que después pueda revertir en nuestra práctica historiográfica, construyendo argumentos contra el estado actual de la mayor parte de la academia. Por tanto, este trabajo, que tenemos la intención de ampliar con el debate que pretendemos suscitar, nace de la necesidad de dialogar de forma sosegada pero urgente con nuestros colegas de profesión.

Hechas estas aclaraciones iniciales, partiremos del nuevo marco abierto tras el fin de la guerra fría en la política, el aparente triunfo del (neo)liberalismo en lo socioeconómico y el inicio de la denominada "etapa", "era" o "condición" posmoderna como nuevo contexto cultural y cuya difusión se sitúa normalmente en la obra de Jean Françoise Lyotard, La condición posmoderna. Informe sobre el saber, publicada en 1979; si bien el debate y la influencia de posmodernismo, como pueden sugerir las obras de algunos autores como Fredric Jameson, habían comenzado antes, a comienzos de la década de los setenta. ${ }^{2}$

\section{Globalización y crisis del capitalismo: ¿el fin de las utopias?}

Son numerosos los autores que consideran que el final de la Guerra Fría y la caída de la Unión de Repúblicas Soviéticas Socialistas (URSS) entre 1990 y 1991 suponen la apertura de una nueva etapa de la historia contemporánea, que nosotros caracterizaremos, según la propuesta de Julio Aróstegui, como "historia del tiempo presente". ${ }^{3}$ Esta etapa vendría definida por la denominada globalización (neo)liberal, un contexto que introduce unas coordenadas sociopolíticas, socioeconómicas y socioculturales específicas.

1 Esther DíAZ: La filosofía de Michel Foucault, Buenos Aires, Biblios, 2005, p. 181.

2 "El concepto de posmodernidad empezó a difundirse en 1979, con la publicación del libro de Jean Françoise Lyotard, La condición posmoderna, donde su autor anunciaba el fin de los metarrelatos o las grandes interpretaciones generales como el marxismo, el cristianismo o la idea de progreso". Jaume AURELL y Peter BURKE: "Las tendencias recientes: del giro lingüístico a las historias alternativas" en Jaume AURELL et al.: Comprender el pasado. Una historia de la escritura y el pensamiento tivas" en Jaume AURELL et al.: Comprender el pasado. Una historia de la escritura y el pensamiento derna, Madrid, Cátedra, 1984. Si bien el debate ya lo habian iniciado otros autores con anterioridad, especialmente en lo referente a la teoría del arte. Vid. Fredric JAMESON: El posmodernismo o la lógica cultural del capitalismo avanzado, Barcelona, Paidós, 1991.

3 "La historia del presente es para nosotros la transcripción en un discurso historiográfico de la categoria historia vivida [ ] Es decir el tiempo de la Historia es tenido hoy cada vez menos como categoria historia vivida [...] Es decir, el tiempo de la Historia es tenido hoy cada vez menos como el pasado ARÓSTEGUI: La historia vivida. Sobre la historia del presente, Madrid, Alianza, 2004, p. 9 y p. 201.
La caída de los estados soviéticos, "al que sus oponentes suelen denominar comunismo", de acuerdo con la aclaración de Samir Amin, supuso en un primer momento un espejismo que algunos autores se precipitaron a considerar como "el fin de la historia", y que algunos (neo)liberales; aparentemente, había llegado el "fin de las ideologías". Pero nada más lejos de la realidad, a pesar de que Estados Unidos se hace con el garante de la "hegemonía" en un sistema-mundo globalizado, así lo demuestran fenómenos como la "dolarización" o "macdolarización", no son pocos los autores que en la actualidad describen un orden muy distinto de las cosas, en el que diferentes polos de poder (que bien pueden ser caracterizados como polos imperialistas de poder siguiendo la propuesta de Lenin de 1916, El Imperialismo. Fase superio del capitalismo $)^{5}$ se disputan el control geoestratégico del planeta, es decir, el control de los recursos tecnológicos, naturales y, sobre todo, humanos.

Se trata, por tanto, más que del "fin de las ideologías" o del triunfo del "pensamiento único", de una re-estructuración del capitalismo a escala global, sin el contrapeso que la URSS suponía como freno al capitalismo más salvaje. Y así, consideramos, lo está poniendo de manifiesto la "gestión de la crisis" por parte de las potencias occidentales, quienes no prevén ningún cambio del estado de las cosas más allá del de continuar obteniendo beneficios a partir de la relación capital-trabajo, dentro de una economía capitalista globalizada. Estamos de acuerdo con Josep Fontana en su última obra cuando afirma que asistimos a un "periodo de regresión".

También con la afirmación de Francisco Veiga de que el "nuevo orden mundial" abierto después de 1990 no puede ser caracterizado como una etapa de "equilibrio", como demuestran las guerras de Yugoslavia, el genocidio de Ruanda (1994), las guerras de Chechenia (1994-1996 y 1999-2009), Kosovo (1999), Afganistán (2001), Irak (2003), así como las más recientes guerras del Líbano (2006), Libia (2011), Siria (2012-actualidad) o Mali (2013), las cuales se suman a la "crisis humanitaria" de territorios como el Chad o Somalia en África, Haití en la región del Caribe o fenómenos como la denominada "guerra contra el narcotráfico" en América y un sangriento etcétera que pone de manifiesto el fracaso del sistema orquestado por la Organización de las Naciones Unidas (ONU) y la Organización del Tratado Atlántico Norte (OTAN) y controlado por los Estados Unidos. ${ }^{7}$ Afirma Samir Amin que no podemos hablar del fin de las ideologías cuando "el sistema dominante está intentando imponer una ideología pura jexpresada en su forma más extremadamente primitiva!", ${ }^{8}$ el cual nosotros solo podemos calificar como auténtica barbarie.

Yendo al terreno de lo económico y a pesar de las explicaciones de Marx, en la actualidad el fenómeno de las crisis cíclicas del capitalismo, definido en su obra clave El capital, publicada entre 1867 y 1894,9 se ha complejizado debido a la intermediación del capital financiero (fusión del capital industrial y bancario a través de los monopolios internacionales o transnacionales) y su intervención en las economías nacionales de organismos internacionales como el Banco Mundial (BM), Fondo Monetario Internacional (FMI) o la Organización Mundial de Comercio (OMC). Desde este punto de vista, si trazamos un breve recorrido histórico desde la crisis económica de 1973, denominada "crisis del petróleo", la cual supuso los primeros ajustes

Samir AMIN: El capitalismo en la era de la globalización, Barcelona, Paidós, 1998, p. 118.

5 Vladimir Illich LENIN: Imperialismo: la fase superior del capitalismo, Madrid, Taurus, 2012.

6 Josep FONTANA: El futuro es un país extraño. Una reflexión sobre la crisis social de comienzos del siglo XXI, $1^{\mathrm{a}}$ ed. Barcelona, Pasado\&Presente, 2013, p. 19

Vid. Francisco VEIGA: El desequilibrio como orden. Una historia de la posguerra fría. 1990-2008, Madrid, Alianza, 2006

8 Samir AMIN: El capitalismo en..., p. 92.

9 Nosotros utilizamos la siguiente edición: Karl MARX: El Capital. Crítica de la economía política, Libros I, II y III, Madrid, Akal, 2007. 
del "capital financiero" en una economía "globalizada", hasta la crisis económica iniciada en 2008, en el transcurso de estos años se han producido: el "efecto tequila" en México en 1994 el estallido de la burbuja financiera e inmobiliaria en Japón en la década de los ochenta o "crisis asiática" de 1997 y 1998, el estallido de la burbuja de las empresas puntocom entre 1998 y 2002, las cuales habían sido bautizadas con el nombre de "nueva economía" y, finalmente, el crash de 2008, iniciado en realidad en 2007 con la "crisis de las subprime". Lo que debe ponernos sobre la pista de la recomendación de Eric Hobsbawm en su última obra: "Una vez más, ha llegado la hora de tomarse en serio a Marx".10

A pesar de todo, el impacto de la globalización y la tecnología en las sociedades occidentales es recibido con entusiasmo por la gran mayoría de la población. Incluso se ha acuñado el término de "nueva economía". Autores como Julio Aróstegui ponen en relación esta "nueva economía" con una sociedad "posindustrial, y si se quiere, hasta poscontemporánea"." Nosotros negaremos los planteamientos más optimistas al respecto, pues consideramos que la relación entre desarrollo tecnológico y progreso es otra falacia más empleada por los ideólogos del capitalismo, como puso de manifiesto la obra conjunta de Max Horckheimer y Theodor Adorno, Dialéctica de la ilustración. Fragmentos filosóficos, en una fecha tan temprana como 1944 y motivada, en gran medida, por los horrores del nazismo. ${ }^{2}$ En este punto, creemos más necesaria que nunca la reflexión de Eric Hobsbawm de que: "sin embargo, algo ha cambiado para mejor. Hemos redescubierto que el capitalismo no es la (o no es la única) respuesta, sino la pregunta".

En el terreno de la historiografía, la denominada "crisis de la historia", que supuso la caída de los grandes paradigmas de interpretación, entre los que debemos incluir al marxismo, no propició, sin embargo, El fin de la historia, como proclamase Francis Fukuyama en 1989.14 Sí que puso de actualidad, no obstante, la crítica a las ciencias sociales, especialmente a la historia que había abierto el debate o crítica posmoderna. Consideramos que el debate que abre la posmodernidad trastoca el orden de la historiografía desde el punto de vista de la "complejidad", según la propuesta de Edgar Morín, ${ }^{15}$ que suma, a la tradicional pugna mantenida entre la historia social (en sus vertientes marxista, de Annales, etc.) frente a la historia más conservadora (cultural, política, etc.), otra entre aquellos y aquellas que niegan lo posmoderno (y sus propuestas teóricas y metodológicas) frente a aquellos y aquellas que no lo hacen. ${ }^{16}$

10 Eric HOBSBAWM: Cómo cambiar el mundo. Marx y el marxismo. 1840-2011, Barcelona, Crítica, 2011, p. 424. A este fenómeno debemos incluir la influencia creciente de la mafia en la economía interp. 424. A este fenomeno debemos incluir la influencia creciente de la mafia en la economia inter-
nacional, fenómeno denominado como globalización del crimen organizado. Vid. Misha GLENY: Mc Mafia. Crime Without Frontiers, London, Bodley Head, 2008.

11 Reproducimos la cita completa: "La revolución tecnológica y sus derivaciones inmediatas que vive nuestro tiempo permiten, en cualquier caso, hablar de una "tercera revolución» tecnológica que, precisamente, es la que parece ser el principio de una verdadera civiliza quiere, poscontemporanea". Julio AROSTEGUI: La historia vivida... p. 305.

12 Max HORCKHEIMER y Theodor ADORNO: Dialéctica de la llustración. Fragmentos filosóficos. Obra completa, 3, Madrid, Akal, 2007

13 Eric HOBSBAWM: Cómo cambiar el..., p. 423.

14 Francis FUKUYAMA: El fin de la historia y el último hombre, Barcelona, Planeta, 1992. Si bien, las rectificaciones posteriores del propio autor y al gunas aclaraciones actuales pueden darnos otra visión de las intenciones de Fukuyama con la publicación de su polémica obra. Según opinión de Pablo Sánchez León y Jesús Izquierdo Martín, "Francis Fukuyama, no estaba necesariamente anticipando un mundo sin conflictos; estaba más bien constatando que el liberalismo volvía a ser, como en el siglo XIX, el referente principal de las luchas sociales [... no estaba regodeandose en el fracaso de las escatologías modernas surgidas de la crítica al liberalismo". Pablo SÁNCHEZ LEÓN y Jesús IZOUIERDO MARTíN: “Introducción. El siglo XXI y los fines del historiador" en Pablo SANCHEZ LEON y Jesús IZOUIERDO MARTíN: El fin de los historiadores. Pensar históricamente, $1^{\text {a }}$ ed. Madrid, Siglo XXI, 2008, pp. IX-XXVI. p. IX.

15 Edgar MORIN: Introducción al pensamiento complejo, Barcelona, Gedisa, 1998

16 Esta pugna entre lo que hemos definido como historia social e historia tradicional la tratamos
Entre los primeros estarían las últimas publicaciones de autores como Terry Eagleton, quien se posiciona del lado del cientificismo o racionalismo de un marxismo clásico (no ortodoxo) frente al relativismo, erróneamente tachado a veces de anticientificismo, de parte de la escuela posmoderna. ${ }^{17}$ Junto con él, aquellos y aquellas que a menudo se desvinculan de la carga moral que implica citar abiertamente la filiación ideológica: (neo)positivistas y (neo)historicistas; a quienes podríamos citar como historia académica, la cual se autodefine con términos tales como verdadera y objetiva. Entre los segundos están autores mucho más controvertidos por ser el centro de los debates actuales. El caso paradigmático es el de Hayden White, quien introduce el concepto de "metahistoria" que hace saltar por los aires el "realismo" o aparente objetividad de la historiografía decimonónica y que luego después muchos extendieron de forma interesada al conjunto de la historia. ${ }^{18}$ Pero también otros como Keith Jenkins que se definen dentro de la izquierda política y que es uno de los grandes autores posmodernos de nuestro tiempo. En una de sus obras sobre el tema que tratamos, habla de "escepticismo" como "presupuestos intelectuales dominantes y subyacentes de nuestro tiempo"19 y remite el debate, en última instancia, a la intrínseca relación entre conocimiento y poder, como pusiera de relieve, de forma más extensa, la obra de Michel Foucault. ${ }^{20}$

Cuestiones que rompen de forma irremediable conceptos como el de "pensamiento único" ligado erróneamente a la escuela posmoderna. Desde nuestro punto de vista, se trataría de una crisis de sentido más que de una crisis de la historia, en la que ésta re-estructura su forma de conocer o interpretar el mundo para dotarle de sentido.

\section{Marxismo y crítica del marxismo: ¿Marx ha muerto?}

Todo hace indicar que la actual crisis económica hará que Marx vuelva de entre los muertos. Su metodología, por tanto, se enfrenta desde nuestro punto de vista no solo a la crítica tradicional que se vertió sobre ella, sino además, a la crítica que el posmodernismo plantea a la historiografía en la actualidad y que representan, según propuesta de Jürgen Habermas, el pensamiento postmetafísico. ${ }^{21} \mathrm{~A}$ continuación, comentaremos brevemente algunos de los temas y conceptos que se deberán abordar, tanto desde el campo de la epistemología como del de la filosofía de la historia:

más ampliamente en nuestro artículo Gustavo HERNÁNZEZ SÁNCHEZ: "Historia social frente a historia tradicional. ¿Una cuestión de moda?", Ab initio. Revista digital para estudiantes de Historia, 5 (2012), pp. 81-94.

17 Terry EAGLETON: Después de la teoría, Barcelona, Debate, 2005.

18 "Yo sostengo [Hayden White] que además tienen [la historia y las filosofías de la historia] un contenido estructural profundo que es en general de naturaleza poética, y lingüistica de manera especifica, y que sirve como paradigma precriticamente aceptado de lo que debe ser una interpretación de especie "histórica". Este paradigma funciona como elemento "metahistórico" en todas las obras históricas de alcance mayor que la monografía o el informe de archivo", fragmento extraído de Jaume AURELL y Peter BURKE: "Las tendencias recientes...", p. 299

19 Keit JENKINS: Repensar la historia, Madrid, Siglo XXI, 2009, p. 81.

20 En este sentido tenemos que llamar la atención sobre cómo la academia tiende a simplificar para explicar dinámicas o planteamientos complejos. En el caso de Foucault asistimos a una terrible simplificación (casi caricaturización) de su propuesta, que pasa por convertirse en una nueva ortodoxia. Es él quien ha puesto de manifiesto, entre otras muchas cuestiones, 1. la relación entre conocimiento y poder y 2. cómo la cultura no es simplemente una superestructura sino que se conocimiento y poder y 2. como la cultura no es simplemente una superestructura sino que se inserta en lo cotidiano a través de mecanismos mucho más sutiles de control, y que define a
través del 3. concepto "microfísica del poder" Vid. 1. Michel FOUCAULT: Power/Knowledge. Selected traves del 3. Concepto "microfisica del poder" Vid. 1. Michel FOUCAULT: Power/Knowledge. Selected
interviews and other writings. 1972-1977 by Michel Foucault, Worcester, Billing \& Sons Ldt, 1988. 2. Michel FOUCAULT: La verdad y las formas juridicas, México D.F., Gedisa, 1986. 3. Michel FOUCAULT: Microfisica del poder, Madrid, La Piqueta, 1980.

21 Jürgen HABERMAS: Pensamiento postmetafisico, Madrid, Taurus, 1990. 
El primero de ellos es el progreso. Son muchos quienes rechazan la metodología marxista por su relación con una idea de progreso típicamente decimonónica. Las ciencias sociales, después de la crítica de Theodor Adorno y Max Horckheimer, habrían superado ya esta etapa de confianza en el progreso que encierran los planteamientos de autores como Marx, EngeIs y el propio Lenin, pero de la que tampoco escapan los autores de la teoría liberal clásica, hoy reconvertida en economía (neo)liberal y pensamiento (neo)conservador. No obstante, se trata de una cuestión sobre la que los autores marxistas han reflexionado, tal vez más de lo que lo han hecho (neo)liberales y (neo)conservadores.

Uno de los primeros fue Antonio Gramsci. El italiano lo asocia a una cuestión moderna de fenómenos como la maquinización y la producción fordista propia, en la época, de la economía norteamericana. Afirma que "los industriales norteamericanos han entendido perfectamente esta dialéctica implícita en los nuevos métodos de la industria", la cual se manifestaría "en toda una serie de cautelas y de iniciativas "educativas".".2 Un ejemplo más cercano lo tenemos en Josep Fontana, quien trata de justificar a los clásicos antes citados apelando a que no habrían podido ver los efectos nocivos del capitalismo tales como la destrucción de los recursos naturales. ${ }^{23}$ Terry Eagleton, en cambio, relativiza el valor del progreso en su crítica al posmodernismo. ${ }^{24}$

Pues bien, desde nuestro punto de vista: el fracaso de la humanidad (y del humanismo), que en la actualidad se ha convertido en una verdadera crisis de conciencia o crisis de sentido, está muy en relación con ésta pérdida de confianza en el progreso. No obstante, consideramos que solamente nos indica que la relación liberal tradicional entre progreso entendido como progreso tecnológico y progreso entendido como progreso humano, es una falacia, no que no podamos aspirar a un estadio en el que las dos acepciones de este término puedan converger. Constata al mismo tiempo que: dentro del capitalismo, progreso humano y progreso tecnológico nunca han ido, ni van, al menos hasta la actualidad, de la mano.

En segundo lugar, hablaremos de economicismo, otro punto común de la crítica. Josep Fontana afirma que esto se debe al "error de suponer que el materialismo histórico es fundamentalmente economía". ${ }^{25}$ El propio Marx definía su teoría como "humanismo socialista", 26 mientras que la principal caracteristica del marxismo sería de naturaleza política. ${ }^{27}$

Pero el meollo de esta crítica es la que se hilvana con la acusación de determinismo, esto es, de determinismo económico. Al respecto, debemos destacar la renovación que para el mar-

22 Antonio GRAMSCI: “Taylorismo y mecanización del trabajador" en Antonio GRAMSCI: Antología. Selección, traducción y notas de Manuel Sacristán, México D.F., Siglo XXI, 1970, pp. 480-481.

23 Josep FONTANA: Historia. Análisis del pasado y proyecto social, Barcelona, Crítica, 1982, p. 152.

24 "Los posmodernistas rechazan la idea de progreso porque están trastornados por las grandes narraciones. Ellos suponen que creer en el progreso debe acarrear que la historia en su conjunto ha estado siempre en progreso constante desde el principio, una perspectiva que, por supuesto, ellos desestiman por considerarla una ilusión". Propone: "adoptar una actitud más pragmática ante el progreso y llegar a la correcta aunque aburrida conclusión de que la historia de la humanidad ha mejorado en algunos aspectos mientras que en otros se ha deteriorado". Terry EAGLETON: Después de la..., p. 186.

25 Josep FONTANA: Historia. Análisis del..., p. 140

26 "Lo que ocupa la posición central de la teoría de Marx es el individuo, él la llama "humanismo socialista". Considera la "esencia del hombre" como "el conjunto de las relaciones sociales [...] una combinación de todas las fuerzas sociales que actúan sobre él". George MOSSE: La cultura europea del siglo XIX, Barcelona, Ariel, 1997, p. 209.

27 Destaca el "error de suponer que el materialismo histórico es fundamentalmente economía". Añac. "No es válido operar una separación radical entre historia economí y politicas marxistas (entre análisis del pasado, crítica del presente y propuesta para el futuro) porque cuando se intenta aislar estas piezas se las empobrece notablemente" Y acla "La inten poínue cuando se pensamiento es de naturaleza política". Josep FONTANA: Historia. Análisis del..., p. 140 y p. 141. xismo supuso la escuela británica, liderada por E.P. Thompson, y que devolvió del terreno ciertamente economicista cuestiones que tenían que ver con la capacidad de acción del sujeto sobre la masa (o estructura), o la influencia de la cultura a través de fenómenos como el de la conciencia, que llegó a determinar que una clase solo existiría en tanto que tomase conciencia de sí misma (jalgo que hoy parecen haber olvidado muchos!). ${ }^{28}$

En tercer lugar hablaremos de dogmatismo. Los trabajos citados hasta el momento impiden hablar de un marxismo dogmático, lo que no quiere decir que todos los marxistas no lo fuesen. En efecto, una vez apuntalado el "determinismo economicista" de buena parte de marxismo, muchos se lanzaron a construir una ortodoxia, lo que en muchas ocasiones bastó para acusar a todos los marxistas de dogmáticos sin atender al debate que se abría dentro de su propio seno entre marxistas economicistas, culturalistas y otras consideraciones en torno a la obra de Marx que nos permitirían hablar, con mayor propiedad, de marxismos.

Sobre la cuestión de la cultura, hoy en boga, afirma Terry Eagleton que el marxismo ya incorporó gran parte de estas cuestiones en la obra de Antonio Gramsci, Gyorgy Lukàkcs, Walter Benjamin, Wilheim Reich, Max Horkheimer, Hebert Marcuse, Theodor Adorno, Ernst Bloch, Lucien Goldman, Jean-Paul Sartre o Fredric Jameson; y afirma:

Parece justo decir que gran parte de la nueva teoría cultural nació de un diálogo extraordinariamente creativo con el marxismo. Empezó como una tentativa de buscar un camino que sorteara el marxismo sin dejarlo atrás. Pero acabó haciendo exactamente eso. ${ }^{29}$

Y así lo hicieron las obras de Roland Barthes, Julia Kristeva, Jean-François Lyotard, Jacques Derrida o Michel Foucault.

Desde el campo que se declara estrictamente marxista, más allá del debate entre las corrientes revisionista o dogmática, que afecta al marxismo de forma recurrente desde la misma muerte de Engels, dependiendo de que las interpretaciones se centren en una vía pacífica o de dictadura del proletariado hacia el socialismo (consideramos que ambas tienen que ser necesariamente revolucionarias, sino el proyecto dejaría de ser socialista para convertirse en otra cosa, como sucede en el caso de la socialdemocracia), históricamente podríamos constatar, al menos, dos evoluciones distintas dentro del marxismo, casi divergentes, dependiendo de la posición de éste respecto del poder. El primer caso sería el del marxismo dentro de los regímenes capitalistas. Allí muestra todo su potencial crítico y su carácter transformador; toda su validez científica pero, sobre todo, su carácter humano al denunciar la explotación manifiesta no sólo en la sociedad del presente sino, a través de la historia, en las sociedades del pasado. También propone (y promueve) la utopía de un mundo mejor, moralmente acorde con nuestra condición de ser humano, necesario para alcanzar un hipotético estadio civilizado, de progreso, esta vez sí, tecnológico y humano. El segundo sería el del marxismo en el poder. En este caso, salvo algunas excepciones, se corre el riesgo de caer en las garras de la ortodoxia; una ortodoxia ciertamente mutilante..$^{\circ} \mathrm{El}$ caso paradigmático

28 "La clase obrera cobra existencia cuando algunos hombres, de resulta de sus experiencias comunes (heredadas o compartidas), sienten y articulan la identidad de sus intereses a la vez comunes a ellos mismos y frente a otros hombres cuyos intereses son distintos (y habitualmente opuestos) a los suyos. La experiencia de clase está ampliamente determinada por las relaciones de producción en las que los hombres nacen, o en las que entran de manera involuntaria. La conciencia de clase es la forma en que se expresan estas experiencias en términos culturales". E. P. THOMPSON: La formación histórica de la clase obrera en Inglaterra, Barcelona, Crítica, 1989, pp. XIII-XIV. ÍD Miseria de la teoría, Barcelona, Crítica, 1981. Donde arremete contra el marxismo estructuralista de Louis Althusser. Sobre las características de lo renovador de su propuesta existen numerosos estudios, es interesante el que nos ofrece Ellen MEIKSINS WOOD: "El concepto de clase en E.P. Thompson", Cuadernos políticos, 36 (1983), pp. 87-105.

29 Terry EAGLETON: Después de la... 42.

30 Al respecto, Edgar Morín advierte: "un pensamiento mutilante conduce, necesariamente, a accio- 
es probablemente el de la URSS en el periodo de Stalin, que influyó muy negativamente en el desarrollo de la teoría marxista posterior.

La rápida difusión de esa ortodoxia marxista fue bien acogida por los más críticos para atacarla de forma más sencilla. Se atacaban los tópicos en que la propia ortodoxia caía y que, generalmente, le hacían ponerse en evidencia a sí misma. Como indica Josep Fontana, se trataba de un marxismo simplificado y conservador al servicio del nuevo orden establecido. ${ }^{11}$ No obstante, reducir el marxismo del periodo soviético a la ortodoxia estaliniana sería también una grave simplificación.

En último lugar hablaremos de los conceptos de razón, verdad y objetividad. Afirma Keith Jenkins que "durante esta centuria hemos contemplado la incapacidad de la razón para acabar con el poder del irracionalismo". ${ }^{22}$ Es más, en la actualidad parece constatada la separación entre palabra y mundo, palabra y objeto. ${ }^{33}$ La breve obra de Keith Jenkins citada tiene, desde nuestro punto de vista, la clave interpretativa: la verdad, como hemos tratado de mostrar en el desarrollo de nuestra exposición, estaría relacionada, en última instancia, con el poder. ${ }^{34}$ Lo que no niega la posibilidad de conocer el pasado. Tan sólo niega la posibilidad de emitir un único juicio acerca de él. La objetividad, por tanto, o aspiración a ella, es otra falacia. Reclamamos en este sentido, la necesidad de la filosofía, fundamentalmente de buena parte de los epígonos de la Teoría Crítica de la Sociedad, de poner los pies en el barro del debate y recuperar el análisis, en el sentido propuesto, también desde el campo de la economía y la praxis política. Llegaríamos tal vez a la conclusión de que el marxismo es otra metodología que necesita adaptarse al nuevo contexto, pues de lo contrario, sucumbirá a la crítica que el posmodernismo plantea a la historiografía, junto con sus autores, objetivo que persiguen aquellos y aquellas, tanto los de ayer como los de hoy, que tanto han trabajado por conseguirlo. En este sentido, el marxismo tiene todavía mucho que ofrecer, si bien corre el riesgo de convertirse de nuevo en metafísica u ortodoxia, en un periodo marcado también, precisamente, por la renovación de la misma en muchos aspectos.

La figura del historiador del siglo XXI ha cambiado. ${ }^{35}$ Sólo si aceptamos este hecho conseguiremos salir de la encrucijada que plantea la "crisis de la historia", de la mano de una historiografía que trae nuevos planteamientos, preocupaciones, inquietudes, peligros, logros, aspiraciones y anhelos, y lo que es más importante, todo un largo camino por recorrer.

No debemos olvidar, a la inversa, una crítica desde el marxismo, como metodología ciertamente tradicional, al posmodernismo, que abordaremos muy brevemente desde los dos puntos de vista en los que se centran estas notas: el socioeconómico y el cultural. Desde el primero, autores como Samir Amin acusan al posmodernismo de no ser suficientemente crítico, esto es, de

nes mutilantes" en Edgar MORIN: Introducción al pensamiento..., p. 34

31 Habla del marxismo en el siglo XX y hace referencia a un proceso doble de desnaturalización $\mathrm{Y}$ dogmatismo. "Lo que en Marx ha sido concebido como un método abierto, indisolublemente ligado a un proyecto político a largo plazo, se nos presenta aquí cerrado y simplificado, transformado en doctrina". "Estos dos rasgos -simplificación catequística y función conservadora al servicio del orden establecido- se reflejarán especialmente en la historia, donde van a cobrar especial relieve después de la crisis de 1927 a 1929, de la que surge el fenómeno que acostumbramos a llamar estalinismo". Josep FONTANTA: Historia. Análisis del..., p. 218 y p. 220.

32 Keith JENKINS: Repensar la historia..., p. 38

33 En el pensamiento "reside lo propio del lenguaje, lo que lo distingue a la vez de la representación (de la que no es a su vez sino representación) y de los signos (a los que pertenece sin otro privilegio particular)". Michel FOUCAULT: Las palabras y las cosas. Una arqueología de las ciencias humanas, México D.F., Siglo XXI, 1989, p. 88.

34 "¿Es que no es obvio que un fenómeno legitimador tan importante como la historia está enraizado en las necesidades reales y en el poder?". Keith JENKINS: Repensar la historia..., p. 24. Las referencias a esta relación permanente historia (como discurso legitimador)-poder, son constantes en su ensayo.

Idea que defienden todas las a portaciones de la obra colectiva coordinada por Pablo SÁNCHEZ

LEÓN y Jesús IZOUIERDO MARTÍN: El fin de... no centrarse en el auténtico problema: el sistema de producción capitalista. Los críticos posmodernos, continua, confunden pensamiento moderno con pensamiento burgués. La crítica posmoderna al cientificismo o el empirismo imperante debería enfocarse, desde su punto de vista (licha critica" afirm "debe presentar un sistema de racionalidad alternativo". ${ }^{36}$ Terry Eagleton, en cambio, hace una crítica al posmodernismo desde el punto de vista de la ética y de la moral, situándose en el plano cultural (desde una perspectiva marxista). Define un sujeto posmoderno hedonista, que se inventa a sí mismo e infinitamente adaptativo, y nos advierte acerca de la posibilidad de, en caso de seguir por este camino, "dejar de ser criaturas culturales e históricas". ${ }^{37}$ Según esta propuesta, se estaría produciendo una transformación radical de valores propios de la era posmetafísica, situándonos en un plano éticamente negativo. Pero ¿acaso el siglo XX, definido por Eric Hobsbawm como "la era de las catástrofes", ${ }^{38}$ e incluso la historia anterior, puede definirse dese una perspectiva éticamente positiva?

Estamos de acuerdo con Marisa González de Oleaga en que los postulados posmodernos no introducen tantas novedades desde el punto de vista ontológico, epistemológico o metodológico. ${ }^{9}$ Lo que estaría en juego sería más bien una crisis de sentido en el que la historiografía tradicional ve caer las viejas seguridades frente a una joven historiografía posmoderna que se atreve a cuestionar no solo el papel de la historia, sino el de los propios historiadores.

\section{El marxismo en la encrucijada del siglo XXI}

Llegamos así a la situación actual, en la que la "condición posmoderna" atraviesa de una u otra forma todos los planteamientos de los diferentes autores y autoras. El fenómeno posmoderno, como crítica a la historiografía tradicional, llega incluso a cuestionar la función social del historiador e historiadora en el siglo XXI, y por tanto, de la propia historia. En efecto ¡Ya no hay vuelta atrás! Ahora bien, se plantean dos opciones: hacer caso omiso de ello; o enfrentarnos con las herramientas de que disponemos, tanto las tradicionales como las que introduce la "era poscontemporánea" o "postmetafísica"..$^{\circ}$ Tenemos así una crítica que, desde nuestro punto de vista, se centra en lo que verdaderamente se trata de un ataque demoledor al método, en este caso el marxista, mientras que para el resto de "formas de hacer historia" ${ }_{41}$ la falta de método o el eclecticismo, así como el recurso a otras disciplinas, no sería sino una constatación de la aceptación de esta crítica, en la que la historia, y los historiadores e historiadoras, tienen que volver a dotar de sentido a su trabajo.

Este hecho a menudo se maquilla en los departamentos universitarios de las facultades de historia con la confusión de métodos y técnicas, es decir, procedimientos, con la propia teoría, siguiendo la corriente cientificista actual que identifica y valora todo el proceso de creación cultural en torno a cuestiones técnico-práctico-materiales, las cuales por regla general descartan cualquier atisbo o intento de una cultura crítico-reflexiva-creativa.

36 Samir AMIN: El capitalismo en..., p. 163.

37 Terry EAGLETON: Después de la..., p. 200.

38 Define los años que van de 1914 a 1945 como "era de las catástrofes", epígrafe que da título a la primera parte de su Historia del siglo XX, cuyo título original (Age of Extrems) es mucho más ilustrativo. Eric HOBSBAWM: Historia del siglo XX, Barcelona, Crítica, 2009, pp. 29 y ss.

39 Marisa GONZALEZ de OLEAGA: "EEl fin de los historiadores o el fin de una hegemonía?" en Pablo SÁNCHEZ LEÓN y Jesús IZOUIERDO MARTíN (eds.): El fin de..., pp. 153-178.

40 Jürgen Habermas considera que el pensamiento postmetafísico supone una ruptura con la tradición y entre los motivos que representan el pensamiento postmetafísico incluye el giro lingüístico o la inversión del primado de la teoría sobre la praxis (superación del logocentrismo). Añade: "el

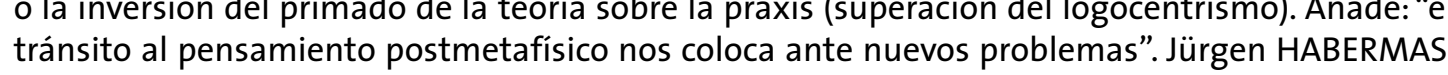
Pensamiento postmetafísico., p. 45

41 Véase: Peter BURKE (coord.): Formas de hacer historia, Madrid, Alianza, 2003. 
En todo caso, la ausencia de alternativa no sería una cuestión exclusivamente posmoderna, lo que tampoco quiere decir que debamos mantenerlo al margen del debate. El ser humano se sitúa así ante la necesidad de pensar no solamente acerca de su presente, lo cual a menudo hace en función del conocimiento o desconocimiento de su pasado (es el "pensar históricamente" que propone Josep Fontana), ${ }^{42}$ sino, sobre todo, de su futuro, y es aquí donde el marxismo presenta toda su capacidad creadora.

La superación a los problemas planteados por la crítica posmoderna, desde nuestro punto de vista, tiene que pasar por un prisma postmetafísico, en el sentido en el que propone Jürgen Habermas. La teoría, filosofía y epistemología de la historia tienen que superarse en el sentido en que el arte abstracto o la arquitectura posmoderna superaron las creaciones anteriores. Y ello pasa tanto por la (auto)reflexión como por el pensamiento complejo, en el sentido de huida de lo simple. 43

Llegamos en este punto a plantear la pregunta maldita del ¿Qué hacer? o, mejor dicho: ¿Cómo hacerlo? Es Eric Hobsbawm quien, en su última obra, nos ofrece algunas de las claves de lo que sería un marxismo para el siglo XXI. Propuesta muy en sintonía con los planteamientos de Antonio Gramsci, figura intelectual y política que hoy reclaman multitud de académicos.

De acuerdo con la propuesta de Gramsci, la neutralidad del historiador o historiadora, una vez desechada cualquier pretensión de objetividad, se torna "neutralidad activa y operante", mientras que la cultura, terreno en el que se desenvuelve su trabajo, deja de concebirse como simple saber enciclopédico. ${ }^{44}$ Afirma el italiano, en referencia a Marx, que no hay que levantar "sobre las obras del maestro una exterior doctrina de afirmaciones dogmáticas e indiscutibles". 45 En efecto, el análisis de Marx sobre el desarrollo y forma de actuar del capitalismo no ha perdido actualidad. Por eso, siguiendo la propuesta de Eric Hobsbawm, "es improbable que vuelva a desaparecer de la escena académica" 46 en tanto que forma parte, para bien o para mal, tanto de nuestro bagaje cultural como de la propia cultura occidental.

Ahora, en el actual periodo histórico, no se trata de distinguir al marxista del que no lo es, para situarse atacando (en contra) o defendiendo (a favor) unos planteamientos dentro de una guerra ideológica que sería capaz de destruir los fundamentos de la historia como ciencia. De lo que se trata, de acuerdo con Hobsbawm, es de restablecer una tradición marxista. Estaríamos desechando, por tanto, el concepto de escuela. ${ }^{47}$ Para ello, como venimos apuntando, consideramos fundamentales algunas de las recomendaciones de Jürgen Habermas para la filosofía. En otra de sus obras nos recomienda que nos guardemos de un falso objetivismo, así como el sometimiento de la disciplina a una constante (auto)reflexión, a una continua crítica, un continuo conocernos a nosotros y nosotras mismos que nos desvelará una realidad tremendamente compleja, no acabada y en continua transformación, como recordaba el propio Gramsci, la cual alejaría los fantasmas de una hipotética "crisis de la historia". ${ }^{48}$

42 Josep FONTANA: Introducció a l'estudi de la historia, Barcelona, Crítica, 2007

43 "Trataremos de ir, no de lo simple a lo complejo, sino de la complejidad hacia aún más complejidad". Edgar MORÍN: Introducción al pensamiento..., p. 61

44 Antonio GRAMSCI: "Socialismo y cultura" en Antonio GRAMSCI: Antología..., pp. 14-17.

45 Antonio GRAMSCI: “La revolución contra «El Capital»” en Antonio GRAMSCI: Antología.., pp. 34-37.

46 Eric HOBSBAWM: Como cambiar el..., p. 217.

47 Ibid., p. 381.

48 "Esta precaución no impide la actividad crítico-revolucionaria, pero si la certeza totalitaria de que la idea por la que esa actividad se deja guiar con muy buenas razones, sea realizable en todas filofía de la práctica tiene inevitablemente que presentarse al principio con actitud polémica y critica como superación in anterior modo de prenary de con pro to mundo cultura existente) [.] no se trata de introducir ex novo una ciencia de la vida individua de utodosn, sino de innovary hase trás criticar una actividad ya existente". Antonio GRAMSCI:
Si bien, no entendemos, desde este punto de vista, el distanciamiento de la acción que la propuesta de la Teoría Crítica de la Sociedad en su Teoría del Conocimiento ha marcado entre numerosos académicos y académicas hasta la actualidad, como si dicha crítica al marxismo, desde el punto de vista de la epistemología, fuese suficiente para abandonar su programa, el cual presenta, por otro lado, plena vigencia en el terreno de lo político y de lo económico.

Nuestra comunicación planteaba además para el debate las siguientes cuestiones, con las que, a través de reflexiones y diálogos como los que surgieron en el encuentro, trataremos de seguir ampliando este trabajo:

- ¿Cuál ha de ser en este contexto el papel de los académicos y académicas o intelectuales?

- ¿Es posible una conciliación entre marxismo, como tradición cultural, y posmodernidad como nuevo contexto cultural?

- ¿Cómo han de ser las (nuevas) prácticas de los historiadores e historiadoras en el siglo XXI? 


\section{EL GRITO. TESTIMONIOS CINEMATOGRÁFICOS}

\section{DEL 68 MEXICANO}

Iris Pascual Gutiérrez

Universidad de Valladolid

Sin duda el año 1968 constituyó un hito fundamental en la conformación del ideario revolucionario y de la izquierda en la segunda mitad del siglo pasado. Supondrá una expresión de descontento global, aun cuando los motivos de protesta no sean unitarios.' Circunscrita además en su totalidad al marco de la cultura occidental: el hecho de que durante 1968 se estén produciendo acontecimientos políticamente relevantes en el mundo afroasiático (como la Guerra de Biafra, o Vietnam) no altera de forma sustancial esta percepción.

Tradicionalmente, se ha marcado una estricta separación entre las protestas en países políticamente desarrollados (como Francia y Estados Unidos) frente a las luchas antiautoritarias en Polonia o Checoslovaquia. Las primeras han sido tachadas incluso de nihilistas, mientras que las segundas se han interpretado (quizá por darse principalmente en países de la Europa sovietizada) como expresión legítima y original de lucha por la democracia. Ahora bien, en algunos círculos de reflexión cercanos a la izquierda esta distinción no es compartida en su totalidad. Daniel Bensaid denuncia, en el caso francés, que "la reducción retrospectiva del movimiento de Mayo a la voluntad de liberación antiautoritaria y de modernización de las costumbres ofrece una lectura despolitizada y despolitizante". ${ }^{2}$ El olvido, por ejemplo, de la conflictividad obrera durante los meses de mayo y junio no habría sido un proceso involuntario. Por el contrario, sería plenamente consciente, y construido a lo largo de las sucesivas conmemoraciones, cada vez más oficiales, del Mayo del 68. Los arquitectos de esta visión "despolitizada y despolitizante" serían los mismos intelectuales de izquierda que tomaron parte en el 68, posteriormente acomodados a la política oficial durante los gobiernos de François Mitterrand, y deseosos por reivindicar su papel protagonista, circunscrito al marco de la Universidad.

Cuestiones como el papel de los estudiantes universitarios frente al de otros colectivos sociales, o el grado de desarrollo de la lucha antiautoritaria durante el año 1968, también han sido objeto de debates candentes en México. Protagonizadas fundamentalmente por estudiantes, las protestas mexicanas aunaron características propias tanto de un clamor de descontento generacional ante una sociedad notablemente conservadora, como de lucha antiautoritaria y democrática. A pesar de ser menos abordado que otros movimientos sociales del mismo año, el mexicano también ha sido notablemente repensado, incluso cuando aún estaba en marcha. La abundancia de estudios no ha impedido (quizás en gran parte ha causado) que, como en el caso francés, no exista una visión unitaria respecto de qué ocurrió en México a partir del 22 de julio de 1968. Las discrepancias interpretativas se pondrán de manifiesto especialmente en lo que

1 Mark KURLANSKY: 1968. El año que conmocionó al mundo. Barcelona, Destino, 2004, p. 17.

2 Daniel BENSAID: "1968, finales y consecuencias", en Manuel GARÍ, Jaime PASTOR y Miguel ROMERO (eds.): 1968. El mundo pudo cambiar de base. Madrid, Viento Sur, 2008, p. 24

Daniel BENSAID: "Mayo Si (caso no archivado)", en Manuel GARÍ, Jaime PASTOR y Miguel ROMERO

(eds.): 1968. El mundo..., p. 44 respecta a su lectura como "movimiento estudiantil" o "movimiento estudiantil-popular". O en otros términos, el grado de conflictividad obrera y de politización revolucionaria del mismo.

Esta comunicación pretende actualizar y crear un estado de la cuestión en torno a los principales debates "post-68" mexicanos, tomando como punto el documental El Grito, rodado por los alumnos del Centro Universitario de Estudios Cinematográficos (CUEC) de la UNAM durante el propio año 1968. Así, se dividirá en dos partes bien marcadas. Por un lado, las discusiones "post-68" propiamente dichas. Y por otro, el análisis crítico de El Grito como aproximación alternativa al pasado. No tanto por el hecho de emplear una película para ello (lo que en sí mismo no es novedoso), sino porque este documental se realizó con la intención explícita de constituir una interpretación libre y no oficial del 1968 mexicano. Con el valor añadido, de constituir un testimonio de primera mano del desarrollo de las manifestaciones, así como de la represión desencadenada contra ellas.

\section{Principales debates post- 68 .}

No va a ser nuestra intención elaborar un relato cronológico sobre el 68 mexicano, cuestión ésta que ya ha sido suficientemente desarrollada. ${ }^{4}$ En su lugar, se ha optado por un análisis breve de los (a nuestro juicio) principales debates "post-68", tratando de marcar claramente las diferentes posturas ante cada tema; y con ellas establecer un "estado de la cuestión" lo más certero posible respecto a cada uno de estos debates. Así, se pretende una aproximación general a lo que el ciclo de protestas de 1968 representó para la sociedad mexicana y cómo han repercutido en la evolución posterior de su sistema político y sus estructuras socio-culturales.

Las discusiones emanadas del 68 mexicano serían, en líneas generales cuatro: su terminología y definición, su grado de concienciación política, su carácter precursor o no de la democracia formal mexicana, y el impacto de la represión en movimientos sociales posteriores. Como ya se ha mencionado, no se pretende una cronología de los hechos. Sin embargo, se señalarán de forma oportuna los hitos que se han considerado necesarios para la correcta contextualización de estas cuatro cuestiones.

El primer debate acerca del 68 mexicano afecta a su terminología: jestamos ante un movimiento "estudiantil" o "estudiantil-popular"? La denominación más aceptada identifica las protestas de 1968 en México como una expresión de descontento esencialmente de la juventud de clase media, circunscrito principalmente a la universidad. ${ }^{5}$ Por su parte, la definición "estudiantil-popular", actualmente desprestigiada, fue esgrimida por aquellos grupos más politizados dentro del movimiento, vinculados al PCM. Estos, como José Revueltas, consideran que los estudiantes, definidos como "pequeña burguesía intelectual revolucionaria" cuyo movimiento "se ha venido desarrollando dentro de un curso proletario" debe liderar el cambio político y social ante el control que el aparato priista ejerce sobre "el proletariado". ${ }^{6}$ Dos formas de concebir el movimiento que habrían reavivado la división tradicional de los grupos estudiantiles. No bajo dos maneras distintas de entender la educación, sino la acción política de oposición: la "democrática", moderada, y la "revolucionaria", que en ocasiones se decantó

4 La mayor parte de las obras, ya sean de análisis literario, político o cinematográfico sobre el 68 mexicano incluyen un apartado con los principales hitos del movimiento. Para su consulta puede verse Carlos MONSIVÁlS: El 68. La tradición de la resistencia. México, Editores Independientes, 2008. Una visión no estrictamente cronológica, pero que constituye el principal relato, combinando la crónica periodistica y la ficción literaria en Elena PONIATOWSKA: La noche de Tlatelolco. México, Ediciones Era, 2000.

5 "Los obreros no abucheaban a las brigadas estudiantiles, e incluso podían mostrarles una pasiva simpatía, pero nunca dieron pasos concretos para sumarse al movimiento". Enrique KRAUZE: La presidencia imperial. Ascenso y caída del sistema politico mexicano 1940-1996. Barcelona, Tusquets, 1997, p. 392.

6 Phillippe CHERON y Andrea REVUELTAS (comps.): José Revueltas y el 68. México, Era, 1998, pp. 85-86. 
por la vía armada, tendiendo a considerarse una "vanguardia" del colectivo estudiantil.7 No obstante, la interpretación más aceptada actualmente entiende las protestas del verano de 1968 en México ante todo como un fenómeno universitario y de clase media, bastante alejado de un "proletariado" mediatizado por un sindicalismo oficial completamente dependiente del PRI y del aparato estatal, dos realidades difícilmente disociables en estos momentos. ${ }^{8} \mathrm{El}$ gobierno de Gustavo Díaz Ordaz y los medios de comunicación cultivarán una imagen del estudiante como individuo privilegiado y desagradecido, retrato que será interiorizado por amplias capas de la sociedad mexicana, especialmente las más desfavorecidas, y por tanto las más dependientes del modelo corporativista vigente. A ello se le unirá el hecho de ser un acontecimiento urbano, casi exclusivamente circunscrito al Distrito Federal. Y por tanto, con poco significado para el amplísimo México rural. De esta manera, la capacidad de la movilización estudiantil para conectar con el obrero industrial y con el campesino será reducida, cas nula. A pesar que las grandes manifestaciones, como la ocupación del Zócalo el 27 de agosto, no estaban formadas exclusivamente por estudiantes. Este desencuentro entre estudiantes y trabajadores no será un hecho exclusivamente mexicano, sino que se producirá también en Francia o Estados Unidos. Por tanto, podemos concluir que el 68 mexicano fue un "movimiento estudiantil", y como tal lo denominaremos de ahora en adelante.

Esta cuestión va unida a otras, como por ejemplo el grado de conciencia política que presentaban los participantes en las concentraciones. A este respecto las posiciones no son unitarias tan siquiera entre los mismos integrantes del movimiento. En septiembre de 1993 la revista Nexos publica un artículo firmado por Luis González de Alba, uno de los principales líderes del Consejo Nacional de Huelga (CNH) en el que se propone desmontar algunos "mitos y lugares comunes". Denunciará la "represión interna" del movimiento, la intransigencia del CNH o la creencia en una conspiración gubernamental fruto de "las tardes de ocio que da la cárcel". Sin embargo, su principal aseveración se orienta contra la supuesta inspiración de las protestas en el movimiento ferrocarrilero de 1958-1959 y la reivindicación de libertad para sus cabecillas, Campa y Vallejo. Ironiza sobre la politización del alumnado, al atribuir al "Espíritu Santo de la conciencia social descendió súbitamente sobre los estudiantes en renovado Pentecostés" que estudiantes de centros como la Universidad Iberoamericana, que rechazaban a los grupos más ideologizados, e incluso tenderían a solicitar dureza policial contra la izquierda, se uniera a las marchas. Ello se debería, para él, a la institucionalización de la protesta cuando interviene el rector, Barros Sierra, y a que peticiones como la libertad de los detenidos y la disolución de los cuerpos represivos, incluidas en el pliego petitorio del $\mathrm{CNH}$ eran populares. No así la libertad para los presos políticos o la derogación del artículo 145 (disolución social), reivindicaciones únicamente esgrimidas por las minorías más politizadas del IPN y la UNAM. 9 El rechazo a la guerra de Vietnam será otro motivo de movilización, pero también minoritario. Así, el 68 mexicano no tendría únicamente motivaciones ideológicas, sino que ante todo respondería a un clima de rebeldía generacional e insatisfacción moral y personal:

¿Por qué los mismos que nos corrían a pedradas de sus escuelas y facultades un mes antes marcharon luego tomados del brazo con nosotros? No salieron a liberar a Vallejo

7 Antonio GÓMEZ NASHIKI: “El movimiento estudiantil mexicano. Notas históricas de las organizaciones políticas, 1917-1970", Revista mexicana de investigación educativa, Vol. 8, 17 (2003), pp. 187-220.

8 Una muestra de esta actitud puede verse cuando, el 6 de septiembre de 1968 el sindicato CTM (Confederación de Trabajadores de México) publica un "Manifiesto a la Nación" en los principales periódicos del país, respaldando sin fisuras las posiciones gubernamentales, en concreto el violento desalojo de manifestantes acampados en el Zócalo de Ciudad de México la noche del 27 al 28 de agosto. El Nacional, 6 de septiembre de 1968, p. 8, sección 1

9 Luis GONZÁLEZ DE ALBA: "1968: la fiesta y la tragedia", Nexos, 168 (1993), pp. 23-31. ni por Campa. Salieron para romper su propia cárcel: acabamos con el país de sacristía y cacique priista. ${ }^{10}$

Sin embargo, esta no es, obviamente, una visión única. Marcelino Perelló, otra de las cabezas visibles del $\mathrm{CNH}$ considera que con los años los relatos del 68 se han centrado en la represión, obviando las propuestas y su conciencia política activa." En la misma línea José Revueltas sienta un nexo entre el 68 y el movimiento ferrocarrilero, afirmando que la libertad de sus líderes era una de los principales motivos de protesta del movimiento estudiantil. ${ }^{12}$

En tercer lugar, pero no menos importante, quizá uno de los debates más enconados que el post 68 ha despertado en la sociedad mexicana es el del movimiento estudiantil como precursor de la democracia formal en el país. Actualmente, la consideración generalizada es la del movimiento estudiantil como una expresión política inédita en la historia mexicana, de funcionamiento lento pero democrático. ${ }^{13}$ Naturalmente, supondrá un parteaguas en la historia de México. Implicará el rechazo del sistema autoritario por parte de los sectores sociales en ascenso, beneficiados por la política económica desarrollista implementada por los diferentes gobiernos desde la década de 1940. En este sentido Enrique Krauze afirma que "el movimiento estudiantil de 1968 abría una grieta en el sistema político mexicano por donde éste menos lo esperaba: en la zona de sus mayores beneficiarios, los hijos de la clase media".14 Las autoridades, considerando al PRI expresión legítima de la totalidad del país, y acostumbradas a una sociedad dócil y que se expresaba únicamente por conducto de las vías corporativas sindicales y partidistas ad hoc, se sentirán acosadas, lo que contribuye a explicar la dura respuesta oficial. ${ }^{15}$ Las protestas de 1968 y su posterior represión constituyen la ruptura definitiva del "consenso postrevolucionario": por primera vez un grupo social numeroso se desliga voluntariamente de la rígida estructuración social priísta. Eduardo de la Vega Alfaro cita a algunos de los oradores en un mitin conmemorativo en 1998, en cuya opinión "los avances democráticos logrados en México durante las últimas décadas tienen su origen más evidente en las intensas jornadas que integraron la lucha política llevada a cabo en el año axial de $1968{ }^{\prime \prime}{ }^{16}$ En sucesivas obras de la primera mitad de los años 1970, como Posdata, Octavio Paz respaldará este enfoque. ${ }^{17}$ Esta rehabilitación de la democracia tendría como peculiaridad la reivindicación de una democracia formal, la vuelta al texto de las leyes, ante la enorme disparidad entre los procedimientos legalmente establecidos para la transmisión y el ejercicio del poder y las prácticas reales de los mismos..$^{18}$ Ahora bien, al igual que respecto a la politización de los manifestantes, tampoco hay acuerdo a este respecto. Participantes en las protestas, como Marcelino Perelló, sostienen que la democracia no fue uno de sus objetivos:

10 Luis GONZÁLEZ DE ALBA y Marcelino PERELLÓ: “El 68, cartas cruzadas”, Letras Libres, Año 5, 57 (2003), pp. 41-46.

11 Ibid.

12 Phillippe CHERON y Andrea REVUELTAS, (comps): José Revueltas..., pp. 97-98.

13 Sergio RODRÍGUEZ LASCANO: “México", en Manuel GARí, Jaime PASTOR y Miguel ROMERO (eds.): Sergio RODRIGUEZ LASCAN

14 Enrique KRAUZE: La presidencia imperial..., p. 391.

15 Octavio PAZ: El ogro filantrópico. México, Joaquín Mortiz, 1979, p 145.

16 Eduardo DE LA VEGA ALFARO: “Notas sobre el movimiento estudiantil-popular de 1968 en el cine mexicano", Secuencias: revista de historia del cine, 10 (1999), p. 66.

17 Octavio PAZ: Posdata. México, Siglo XXI, 1979, p. 35.

18 Antonio CAMOU: “Gobernabilidad y transición democrática en México", Perfiles latinoamericanos, 9 (1996), pp. 133-152. 
La represión propiamente dicha, en este país, ha reculado muy significativamente. De momento, esa es toda nuestra herencia. No la intransigencia. Ni tampoco la democracia, como más de un heredero advenedizo se ha apresurado a reclamar. La democracia entendida ésta como la realización de comicios, no fraudulentos, no estuvo nunca entre nuestras miras. ${ }^{19}$

Desde un primer momento, no faltó quienes percibieron que el movimiento estudiantil era un fenómeno democrático, pero no en sus reivindicaciones, sino en sus prácticas. En éstas se incluirían el uso de la asamblea la resistencia civica o la exigencia de un diálogo público con las autoridades al margen de las componendas privadas con que el régimen solía solventar los estallidos de descontento. Otras consecuencias positivas de orden político habrían sido el despertar de la sociedad civil o la modernización ideológica de la izquierda, desde el estalinismo a la democracia. ${ }^{20}$ Sin embargo, y con todo, para autores como Monsiváis, no dejaría de se una expresión de descontento generacional y rechazo de una jerarquía de valores obsoleta y un sistema castrante, tanto político como social, educativo o moral.

Finalmente, y para dar por terminadas las reflexiones "post-68", es necesario dedicar un espacio a la huella dejada en la sociedad mexicana por la durísima represión desencadenada contra el movimiento estudiantil. La ocupación militar de la UNAM el 18 de septiembre, y so bre todo la matanza de la Plaza de las Tres Culturas, el 2 de octubre, se habrían convertido en los elementos más visibles y recordados de todo el movimiento. Violencia que, por otro lado, fue fundamental en la generalización de las protestas. En el caso mexicano, al igual que en las manifestaciones celebradas en París o Columbia, la dureza policial actuó como un eficaz "efecto llamada". La desmedida respuesta de las autoridades, en todos estos casos, no hizo sino masificar protestas que, en sus orígenes no pasaban de expresiones de descontento bastante acotadas. ${ }^{21}$ La identificación entre 68 y violencia daría lugar a una situación que a entender de algunos es necesario mantener vigente y presente, y para otros, no olvidar, pero sí superar. Carlos Monsiváis cree necesario hacer hincapié en lo "no mítico del 68", la dureza de la intervención policial y militar, y su impunidad. ${ }^{22}$ Por el contrario, según los sectores más politizados que tomaron parte en las manifestaciones, la represión, innegable y condenable, habría contribuido a mantener en el olvido las propias reivindicaciones del movimiento, reivindicaciones que, como hemos visto, para Marcelino Perelló, entre otros, iban mucho más allá de la propia democracia formal. Sea como fuere, el duro castigo a las manifestaciones, reeditada por el siguiente gobierno en junio de 1971, contribuyó de forma decisiva al desprestigio del sistema autoritario. A partir de la segunda mitad de la década de 1980, como consecuencia de la grave crisis económica que atraviesa el país, será cuando el presidente Miguel de la Madrid comience a desmontar muchos de los mecanismos de control político del PRI. Es ahora cuando se inicia un cambio de actitud hacia la violencia. La "gravitación de Tlatelolco" ${ }^{23}$ se manifestaría en el conjunto de la sociedad, pero con especial fuerza entre unos grupos gobernantes que desde este momento se mostraran extremadamente renuentes a emplear la fuerza (incluida la que denominan "fuerza legítima") contra la trasgresión de la ley en nombre de un objetivo o ideal social. Lo que no impedirá, por otro lado, que la mexicana sea una sociedad que exige el rigor extremo en la lucha contra los delitos individuales. Esta posición se pondrá de manifiesto especialmente en la década de 1990, época de plena revisión del 68 a la luz de la consolidación

9 Luis GONZÁLEZ DE ALBA y Marcelino PERELLÓ: “El 68, cartas...”, pp. 41-46.

20 Carlos MONSIVÁIS: El 68. La tradición..., p. 24

21 Mark KURLANSKY: 1968. El año..., p. 432.

22 Carlos MONSIVÁlS: El 68. La tradición..., pp. 30-31.

23 Luis DE LA BARREDA SOLÓRZANO y Luis GONZÁLEZ DE ALBA: “La gravitación de Tlatelolco", Letras

Libres, Año 8, 94 (2006), pp. 28-35. de la apertura política durante el sexenio de Ernesto Zedillo. La negociación con el EZLN desde 1994 o la paralización de la UNAM entre marzo de 1999 y febrero de 2000, ejemplificarían esta nueva actitud oficial hacia el uso de la violencia contra la protesta política.

\section{El Grito. El movimiento estudiantil mexicano visto por sí mismo ${ }^{24}$}

Cuando en julio de 1968 se producen las primeras manifestaciones protagonizadas por estudiantes, los alumnos del Centro Universitario de Estudios Cinematográficos (CUEC) entienden que la manera más cabal de tomar partido es filmarlas, y elaborar los "Comunicados de Consejo Nacional de Huelga". Producto de este material será el documental El Grito.

El objetivo de estos comunicados, filmados por Paul Leduc y Rafael Castanedo, sería, según Federico Weigarsthofer, contrarrestar la información oficialista que predominaba en la prensa mexicana:"la idea era poner el material al servicio del interés popular más que del nivel personal o creativo". ${ }^{25}$ Tras el 2 de octubre y el encarcelamiento de muchos de los miembros del CNH y otro participantes en el movimiento, Leobardo López Arretche, (principal reportero del movimiento), apoyado por Alfredo Joskowicz (dirección), Ramón Aupart (edición) y Rodolfo Sánchez Alvarado (sonido) acometen la elaboración de un documental que congregase los principales materiales filmados entre julio y octubre de 1968. El resultado será El Grito, probablemente la cinta independiente más destacada del cine mexicano, ni mucho menos por su calidad, pero sí por la relevancia que en su momento alcanzó la denuncia de la represión oficial.

Acerca de la trascendencia de El Grito, al igual que de las consecuencias del propio movimiento, no hay unanimidad. Para Jorge Ayala Blanco esta cinta representa "el único testimonio de un movimiento opositor en México en los últimos 30 años". ${ }^{26}$ Pero por el contrario, en opinión de Emilio García Riera, el otro gran crítico de cine mexicano, se trata de una cinta mucho menos meritoria. Sostiene que "en efecto la película sirvió de bandera de unos estudiantes ávidos de ver en ella el reflejo de las fuerzas y la justicia de su causa [...] pero aún su valor como testimonio histórico resulta muy escaso, para no hablar de sus casi nulos méritos cinematográficos". ${ }^{27}$ En una línea semejante se expresa Eduardo de la Vega Alfaro, para quien en El grito, a pesar de tratar de ser sintética "nunca aparece en la obra el menor intento por ir al fondo de los hechos, lo que sin duda hubiera hecho aparecer los no pocos errores y las contradicciones en que incurrieron los militantes".

Con esta cinta, al igual que con los "Comunicados", Arretche, Joskowicz, etc aspiran a da la "verdadera" imagen del movimiento, frente a la manipulación mediática de prensa, radio y televisión. Debemos tener en cuenta que la "contrainformación" es uno de los objetivos fundamentales del Tercer Cine. El Nuevo Cine Latinoamericano trataría de expresar la "realidad" iberoamericana, frente a la imagen deformada de la misma trasmitida por el cine norteamericano y las industrias cinematográficas locales. Éstas serían culpables de vehicular un discurso imperialista y favorable al mantenimiento de relaciones económicas, pero también culturales, de dependencia, "subdesarrolladas" entre las "metrópolis" norteamericanas y europeas y las "nuevas colonias" afroasiáticas y suramericanas. ${ }^{29}$

24 Leobardo LÓPEZ ARRETCHE: El Grito, México, 1968, 102 minutos.

25 Entrevista a F. Weigarsthofer, parte de la serie de entrevistas "La violencia en la Universidad", in cluidas como material adicional a lbid. Acerca de los instrumentos de control oficial sobre la prensa en México en el ámbito del 68, puede consultarse Peter WATT: "The Invisible Tyranny of the mexican media: Tlatelolco and beyond". Sincronía, 3, (2009), on line

26 Jorge AYALA BLANCO: La búsqueda del cine mexicano 1968-1972. México, UNAM, 1974, p. 399.

27 Emilio GARCíA RIERA: Historia documental del cine mexicano. 14, 1968-1969. Guadalajara, Universidad de Guadalajara, 1993, pp. 182-183.

28 Eduardo DE LA VEGA ALFARO: “Notas sobre el movimiento...", p. 71

29 Ramón GIL OLIVO: “Ideología y cine: el nuevo cine latinoamericano, 1954-1973”, Secuencias: revista 
Puesto que un elemento fundamental del Tercer Cine será la expresión de la realidad, el cine documental ocupa un lugar clave en su desarrollo. Autores como Fernando Birri inician esta tendencia en Argentina con Tire dié (1958-1960) Otro director destacado será el boliviano Jorge Sanjinés. Sin embargo, en su denuncia del subdesarrollo el documental del Nuevo Cine Latinoamericano adolecerá de la pretensión de objetividad: "la función del documental [...] Ponerse a la realidad con una cámara y documentarla, documentar más el subdesarrollo".30

El Grito nunca alcanzará la complejidad argumental de los ejemplos anteriores. Se limitará a una relación de los principales hitos del movimiento estudiantil, presentados de una forma exclusivamente cronológica. Para ello, se divide en varios "capítulos" con fundidos en negro que separan los acontecimientos de los distintos meses. La denuncia del tratamiento sesgado en prensa es un elemento recurrente a lo largo del film. Puesto que, según Ayala Blanco, esta obra aspiraría a reseñar los hechos, sin calificarlos, es notoria la ausencia de uno de los recursos más clásicos del documental: la voz en off narrativa. Tan sólo aparece en ocasiones una voz femenina que lee textos de la periodista italiana Oriana Fallacci, quien presenció la intervención policial y militar del 2 de octubre. Sería el único recurso de "autoridad" en toda la película. A través de estos textos se denuncia la desproporcionada represión contra los manifestantes. Para Fallacci Tlatelolco sería una escena cuasi bélica, con la diferencia notable respecto a las guerras "de verdad" como Vietnam, que en México se enfrentan grupos armados, el ejército, y desarmados, los estudiantes.

Aparte de esta vocación de contrainformación, no se aprecia un hilo narrativo en El Grito, más allá de la pura presentación cronológica de los hechos. Sin embargo, puesto que se trata de una recopilación de materiales rodados de forma independiente, sí es posible observar la presencia de varias manos en la filmación, lo que se manifestará en diferentes enfoques ideológicos de cara a la presentación de los acontecimientos. En la sección dedicada al mes de agosto el discurso del rector Javier Barros Sierra toma una gran importancia. Su voz, sobreimpresionada en imágenes de la gran manifestación del 1 de agosto, subraya que las protestas son tanto a favor de la libertad en la Universidad como en el conjunto del país. Más adelante se dedicará un espacio considerable a las actividades culturales en el campus de la UNAM, con conciertos, teatro o pintura, que contribuirían a dar una imagen pacífica de las concentraciones, con presencia de familias, y con personas de toda extracción social, si bien no participando directamente, mostrando su apoyo desde las ventanas. Estas imágenes contrastarán con otras en las que subyace una posición política más radicalizada. Así, en la gran manifestación que concluirá en el Zócalo, el 27 de agosto, se oyen proclamas pidiendo la libertad para Demetrio Vallejo, uno de los líderes ferrocarrileros encarcelados desde 1959. Mostrando claramente, además, cómo la manifestación discurre por las principales avenidas del centro de Ciudad de México mientas grupos de clase acomodada se mantienen notoriamente al margen, en las aceras.

Se podría observar, de esta manera, cómo los cámaras que filmaban las manifestaciones para los "Comunicados del Consejo Nacional de Huelga" tratan de conjugar, por un lado, una visión moderada del movimiento, y por otro, su propia ideología. No será hasta la ocupación de la Universidad por el ejército cuando se aprecie en El grito una radicalización. Pancartas y pintadas permiten apreciar una mayor politización, y la consideración del CNH como "vanguardia" de los grupos estudiantiles. La moderación política de la que hacían gala varios profesores del Instituto Politécnico Nacional en la primera quincena de septiembre, cuando sostienen que la lucha por la democracia equivale al cumplimiento estricto de la Constitución, parece haber quedado atrás.

de historia del cine, 10 (1999), pp. 38-51.

O Ana MARTÍN MORÁN y María Luisa ORTEGA: "Imaginarios del desarrollo: un cruce de miradas entre las teorías del cambio social y el cine documental en América Latina", Secuencias: revista de historia del cine, 18 (2003). p. 33 .
Pero por encima de todo, El Grito es una denuncia de la represión sufrida por los manifestantes. No únicamente el 2 de octubre, sino la desencadenada desde el comienzo del movimiento, e incluso con anterioridad. La foto fija será el recurso habitual para representar la como una de las caracteristicas intrinsecas del sistema politico mexicano. Sería la respuesta lógica ante una expresión de descontento independiente, "que no se deja transar", y que por eso mismo muestra las crisis e inconsistencias de la sociedad mexicana bajo el "desarrollo estabilizador".31 En El grito cartas de protesta leídas durante las marchas aparecen sobreimpresionadas a imágenes de personas de extracción humilde interponiendo reclamando ante funcionarios, al parecer por agresiones o buscando familiares, presumiblemente desatendidas. Contribuiría a mostrar así el olvido en que el modelo económico seguido desde 1954 sumía a una parte importante de la población, invisible para las autoridades salvo en procesos electorales. Diferentes escenas con manifestantes arrestados muestran el gran flujo de detenidos y encarcelados a lo largo de estos meses, proceso que culminará, posteriormente al 2 de octubre, con 113 condenas a prisión, para Krauze "uno de los capítulos más vergonzosos de la triste y servil historia del aparato judicial mexicano".32

El grito será la primera obra que aborde cinematográicamente el 68 mexicano, pero no será ni mucho menos la última. Durante la década de 1970 el tema de la corrupción de la sociedad y el desencanto de los grupos sociales con el sistema, con referencias más o menos explícitas al 68, se refugiará en el cine independiente universitario. El formato "Súper 8" será el medio escogido por alumnos del CUEC como Alfredo Joskowicz (El cambio, 1971) o Carlos Gómez Morantes (Tómalo como quieras, 1971) para buscar nuevas formas expresivas, y mostrar su compromiso ideológico. Entroncarían con ejemplos del Nuevo Cine Latinoamericano como Me gustan los estudiantes (Mario Handler, 1968) o Carvalho (Alberto Mejía, 1969). ${ }^{33}$

Pasarán varios años hasta la primera incursión del 68 en el cine comercial mexicano. Para Eduardo de la Vega será en 1975, de forma incidental, con Canoa, de Felipe Cazals. Habrá que esperar a finales de la década de 1980 cuando el movimiento estudiantil de 1968, y la matanza de Tlatelolco en particular, sea abordado por el cine comercial, con Rojo Amanecer, (Jorge Fons, $1989)^{34}$

\section{Conclusiones.}

No cabe duda que el movimiento estudiantil de 1968 constituye un episodio crucial en la historia contemporánea de México, probablemente el más relevante de la segunda mitad de siglo XX. Parece probado que, aunque la democracia formal no estaba entre las aspiraciones de los manifestantes, estas protestas fueron decisivas para la evolución posterior del sistema político mexicano. Aun cuando muchos de los participantes en el 68 fueron cooptados por el sistema en los años siguientes, el modelo de trasmisión pacífica del poder, en el seno de la "familia revolucionaria", comienza a resquebrajarse. Un sector social novedoso, alumbrado por el progreso económico de las zonas urbanas, mostrará signos de rechazo evidente tanto de un modelo político autoritario como de una sociedad francamente anclada en el pasado y de una economía con cada vez menos perspectivas profesionales. Se trata, asimismo, de una juventud profundamente influenciada por la cultura norteamericana, tanto en lo que a gustos musicales, usos sociales, formas artísticas, etc se refiere, como en lo tocante a los movimientos políticos de la "nueva izquierda". Al contrario que en Francia, donde la revisión "despolitizada"

31 Sergio RODRÍGUEZ LASCANO: “México", pp. 192-193.

32 Enrique KRAUZE: La presidencia imperial..., p. 389

33 Jorge AYALA BLANCO: La búsqueda del cine..., pp. 352-353.

34 Eduardo DE LA VEGA ALFARO: “Notas sobre el movimiento...”, pp. 79-81. 
de Mayo del 68 achacaría a este acontecimiento los retrasos históricos del país, ${ }^{35}$ en México la consideración de este fenómeno como "movimiento estudiantil" lleva aparejada su valoración como inicio de la fase terminal de monopolio del poder por el PRI. Etapa final que todavía se prolongaría 32 años más.

Respecto a El Grito, supondrá un hito clave en la cinematografía mexicana. Ni su calidad técnica ni su complejidad argumental están a la altura del cine documental argentino o boliviano de estos años. Sin embargo, junto con otros títulos como La manzana de la discordia (del mismo año 1968, dirigida por Felipe Cazals) abrirá la puerta a la elaboración de películas al margen de las temáticas y los circuitos característicos del cine mexicano de la época. Desde la segunda mitad de la década de 1940 el cine mexicano se encontraba embarcado en un proceso de descenso de calidad y presupuestos, y pérdida de mercados, cuyo exponente más proceso de descenso de calidad y presupuestos, y perdida de mercados, cuyo exponente más temática habitualmente melodramática. Este proceso culminará en el sexenio 1970-1976 con la práctica nacionalización de la industria cinematográfica. Los concursos de "Súper 8 " y los circuitos universitarios e independientes permitirán la creación cinematográfica a los autores, mayormente licenciados del CUEC, descontentos tanto con el cine tradicional como con la nueva industria estatalizada echeverrista. El gobierno de Luis Echeverría será, por tanto, el último momento en que el aparato estatal disponga de un control absoluto, tanto de la vida política como de la industria cinematográfica, monopolio que el movimiento estudiantil de 1968 y su reflejo en El Grito contribuyeron a socavar. 
Parte 6.

LOS PROCESOS DE TRANSICIÓN DEMOCRÁTICA A DEBATE 


\section{LOS PROCESOS DE TRANSICIÓN}

\section{DEMOCRÁTICA A DEBATE}

Nicolás Sesma Landrin

Universidad de Zaragoza

Jorge de Hoyos Puente

UNED

El estudio de los procesos de transición entre regímenes políticos ha sido, hasta fechas muy recientes, un territorio prácticamente exclusivo de la sociología y la ciencia política. Nacida a comienzos de los años setenta, al calor del impacto producido en Latinoamérica por el derrocamiento del presidente Salvador Allende y el incierto futuro de los países del sur de Europa tras el previsible colapso de sus dictaduras, la transitología fue desarrollando sus señas de identidad, en la estela de los grandes modelos de la sociología política y los análisis históricos comparativos, a partir del pionero trabajo de Dankwart A. Rustow,' para quedar definitivamente consolidada gracias a las ya clásicas obras de Juan José Linz y Alfred Stepan sobre la quiebra de los sistemas democráticos, ${ }^{2}$ Philippe C. Schmitter, Laurence Whitehead y Guillermo O'Donnell sobre las transiciones desde gobiernos autoritarios ${ }^{3}$ y Samuel P. Huntington sobre la tipología de transformaciones conformadoras de una "tercera ola democratizadora" que caracterizaría el final del siglo pasado, y que incluiría no solo a los dos ámbitos geográficos mencionados anteriormente, sino también a la nueva Europa del Este surgida tras la caída de los regímenes comunistas. 4

En atención a la propia naturaleza de su disciplina, marcada por la disponibilidad en el acceso a las fuentes y la necesidad de una mínima perspectiva, fue tan solo una vez establecidos estos marcos de referencia teórica que los historiadores comenzaron a dar entrada en sus investigaciones al estudio de los procesos de transición de manera especializada, y no únicamente como una etapa más dentro del análisis de las respectivas historias nacionales o de ámbito internacional. No obstante, pese a su condición de latecomers, los historiadores pronto demostraron su capacidad para dotar de contenido concreto a los, en ocasiones, excesivamente rígidos esquemas interpretativos de la politología, a los que aportaron no solo densidad argumental y una mayor profundidad en la aproximación, sino también una visión menos determinista de los acontecimientos y de las decisiones tomadas por sus protagonistas,

Trabajo enmarcado dentro del proyecto HAR2012-36528, "Continuidad y cambio en el comportamiento político de los españoles en el segundo franquismo y la transición desde una perspectiva comparada (1966-1982)", financiado por el Ministerio de Economía y dirigido por Miguel Ángel Ruiz Carnicer.

1 Dankwart A. RUSTOW: “Transitions to Democracy: Towards a Dynamic Model", Comparative Politics, vol. 2, 3 (1970), pp. 337-367.

Juan José LINZ y Alfred STEPAN (eds.): The Breakdown of Democratic Regimes, Baltimore, Johns Hopkins University Press, 1978

3 Guillermo O'DONNELL, Philippe C. SCHMITTER y Laurence WHITEHEAD: Transitions from Authoritarian Rule. 4 vols: Southern Europe; Latin America; Comparative Perspectives; Tentative Conclusions About Uncertain Democracies, Baltimore-London, Johns Hopkins University Press, 1986.

4 Samuel P. HUNTINGTON: The Third Wave: Democratization in the Late Twentieth Century, Oklahoma, University of Oklahoma Press, 1991. individuales y colectivos. ${ }^{5}$ Así, sin perjuicio de que efectivamente pudieran establecerse líneas comunes de actuación y tipos evolutivos ideales a lo largo del tiempo, los beneficios para e conocimiento de estos procesos derivados de una atención más detallada a los casos particulares y sus dinámicas específicas vinieron a recordar la necesidad de dialogo, interacción metodológica y acción combinada entre ambas disciplinas. ${ }^{6}$

Diseñada desde tales premisas, nuestra mesa pretendía ser una muestra de la madurez alcanzada por las contribuciones al estudio de los procesos de transición desde el punto de vista de la investigación histórica. En este sentido, su planteamiento respondía a una concepción abierta, capaz de integrar tanto los acercamientos más habituales -relativos al análisis de las personalidades y grupos representativos de los distintos proyectos políticos o el grado de ruptura y continuidad producido en los aparatos del Estado como consecuencia del cambio políticocomo aquellos de carácter innovador -tales como la evolución de las diversas culturas políticas coexistentes y su interacción, la recepción, memoria y protagonismo de los colectivos exiliados y las trayectorias y reacciones de los grupos extraparlamentarios-, todo ello sin perder de vista en ningún momento la perspectiva internacional, inherente a la propia naturaleza de los objetos de estudio. A este respecto, se trataba además, como se ha apuntado con anterioridad, no sólo de profundizar en la comparativa entre los estudios de caso y resaltar las posibles particularidades y dinámicas propias de algunas de las experiencias aglutinadas hasta el momento en una misma oleada por razones de funcionalidad interpretativa -lo que dejaba desatendidas muchas de sus diferencias, desde la variable extensión del apoyo social a los partidos comunistas en cada uno de los países del bloque socialista hasta la presencia o ausencia del factor colonial en las transiciones ibéricas7-, sino también de atender a la concreta actuación de los agentes externos en el devenir de los acontecimientos, de tal forma que, más allá de la mera contextualización pudiera calibrarse hasta qué punto otros actores estatales e instituciones multilaterales se encontraron implicados en los procesos, como impulsores del cambio o como freno del mismo. Un aspecto este último especialmente desmitificador, puesto que, de confirmarse dicha injerencia, podría desafiarse buena parte del relato canónico de varias de estas transiciones, presentadas por lo general a la opinión pública en clave fundamentalmente interna. ${ }^{8}$

Desde una perspectiva de conjunto, y dicha circunstancia supuso para los coordinadores una confirmación de la pertinencia de plantear un estado de la cuestión sobre esta temática las comunicaciones finalmente recibidas y presentadas a debate vinieron a cubrir tanto el principio fundamental como la práctica totalidad de los elementos decisivos en todo proceso de transición a la democracia. Una serie de cuestiones que, como está poniéndose una

5 Así, al comentar sus primeros escritos sobre la quiebra de las democracias, muy inspirados en la caída de la Segunda República Española, el propio Linz reconocia que "la enorme aportación y calidad de la historiografia posterior le permitiria documentar y matizar su trabajo. Sobre todo, le obligaría a matizar los juicios sobre algunas personalidades" en Thomas J. MILEY y José Ramón MONTERO: "Introducción. Los estudios de Juan J. Linz sobre las democracias", en Juan José LINZ: Obras Escogidas, vol. 4, Democracias: quiebras, transiciones y retos, Madrid, Centro de Estudios Políticos y Constitucionales, 2009, p. XXXV.

6 Para una reflexión sobre dicha colaboración, Santos JULIÁ: Historia social / sociología histórica Madrid, Siglo XXI, 1989. Un reciente ejemplo de combinación de las herramientas metodológicas de ambas disciplinas en Ignacio SÁNCHEZ-CUENCA: Atado y mal atado. El suicidio institucional del franquismo y el surgimiento de la democracia, Madrid, Alianza Editorial, 2014.

7 Rudolf L. TÖKÉS: “"Transitology». Global Dreams and Post-Communist Realities", Central Europe Review, vol. 2, 10 (2000).

8 Una visión de conjunto de esta circunstancia para la experiencia española en Oscar José MARTíN GARCÍA y Manuel ORTIZ HERAS (coords): Claves internacionales en la transición española, Madrid LARCIA y Manuel ORTIZ HERAS (coords.): Claves internacionales en la transición española, Madrid participantes de la mesa, en Antonio MUÑOZ SÁNCHEZ: El amigo alemán. EI SPD yel PSOE de Io dictadura a la democracia, Barcelona, RBA Libros, 2012. 
vez más de manifiesto en el curso de la denominada "Primavera Árabe" -con seguridad, el siguiente conjunto de movimientos destinado a ser incorporado al paradigma de las grandes oleadas democratizadoras ${ }^{9}$, , parecen permanecer invariables en líneas generales, aunque la investigación vaya desvelando sus entresijos, variantes y la creciente complejidad en la toma de decisiones, y de cuya adecuada resolución depende, en buena medida, no tanto el comienzo del cambio político como su definitiva consolidación. ${ }^{10}$

De esta forma, nuestra mesa partía del principio, hoy día aceptado de manera casi unánime, de que la incertidumbre preside la evolución de los procesos de transición, cuyo desenlace en forma de consecución de un sistema político plenamente democrático no se encuentra en absoluto garantizado, no es el único resultado posible ni proyectado y, lo que es más importante, es incluso reversible, pues depende en última instancia de las relaciones de fuerza entre los distintos actores y de sus respectivas estrategias e intereses. A esta ausencia de determinismos y final abierto se aludía expresamente en la comunicación presentada por Joaquín Baeza Belda a propósito de la salida, en 1983, del régimen militar en la República Argentina, marcada por la situación jurídica en la que quedaban los uniformados y las equívocas actitudes de algunos segmentos del peronismo, el principal movimiento político del país, con respecto a la democracia, circunstancias ambas que contribuían a fomentar un clima de aplazamiento de las decisiones y ausencia de certezas entre la población.

A partir de esta máxima general, iban surgiendo en las comunicaciones toda esa serie de jalones imprescindibles -institucionales, legislativos y estructurales- para la visualización del cambio político y la efectiva construcción de un verdadero sistema participativo.

En primer lugar, la adopción de una determinada forma de gobierno, así como la manera de establecerla, aspecto clave a la hora de clarificar la naturaleza rupturista o pactada de una transición y el grado de participación popular en la toma de decisiones, con una casuística que abarca desde la celebración de referéndums para dirimir la cuestión, como en los casos de Italia en 1946 y Grecia en 1974, pasando por la mera aceptación del sistema de Estado imperante como requisito para la entrada en el escenario político, como sucedió en España entre 1975 y 1977 en relación con la instaurada monarquía, hasta mecanismos híbridos como la consulta popular ocurrida en Bélgica en 1950, relativa no a la propia forma de gobierno sino a la persona destinada a ocupar la jefatura del Estado, y cuyo desenlace vino a demostrar la posibilidad de un reconocimiento muy condicionado de la voluntad expresada en las urnas."

En estrecha relación con este punto, se plantea en segundo lugar la creación de un sistema de partidos, ya sea como recuperación del previamente existente o como una construcción de nueva planta. Tal y como teorizó en su momento Giovanni Sartori, de su equilibrio entre representatividad y operatividad, así como de la lealtad, o al menos la asunción accidental de los partidos a la forma de gobierno finalmente adoptada, va a depender en gran medida la estabilidad política y el normal desarrollo institucional del país. ${ }^{12}$ En este sentido, al margen del evidente componente del cálculo simbólico y de legitimación para la monarquía, en el ánimo de las autoridades españolas que, con vistas a las primeras elecciones democráticas tras

9 Philippe C. SCHMITTER: "Reflections on «transitology». Before and After", en Reconsidering the Transition Paradigm, http://www.jasmine-foundation.org/? $p=1389$ (ultimo acceso el 11 de abril de 2014), p. 2.

10 A propósito de la importancia de dicha etapa, la "fase de habituación" en expresión de Rustow, difíilmente ya reversible dado el grado de legitimidad alcanzado por el nuevo sistema, véase Salvador MARTí: “¿ $Y$ después de las transiciones qué?", Revista de Estudios Políticos (Nueva Época), 113 (2001), pp. 101-124.

11 Tony JUDT: Postwar. A History of Europe since 1945, New York, The Penguin Press, 2005, p. 79 y ss.

12 Giovanni SARTORI: Parties and Party Systems. A Framework for Analysis, Cambridge-London-New York Cambridge University Press, 1976 . Véase igualmente Maurice DUVERCER. Los partidos politicos, México, Fondo de Cultura Económica, 1957 (1951) la dictadura franquista, dilataron la legalización de las formaciones republicanas, pesaba sin duda el hecho de que la Segunda República fuera habitualmente señalada por los politólogos -por lo general, junto a la República de Weimar-como ejemplo de los riesgos inherentes a la cristalización de un sistema de partidos permisivo con la presencia de fuerzas anti-sistema y tendente a la polarización. Una visión que, cumpliendo con las funciones de profundización y revisión que mencionábamos anteriormente, ha sido convincentemente rebatida con posterioridad por la historiografia, que ha remarcado a su vez la importancia de las estrategias políticas por encima de la asunción de determinados modelos institucionales. ${ }^{13}$

A una y a otra cuestión fundamental, en especial a la segunda de ellas, quedaban referidas las comunicaciones de Cristian Ferrer González sobre los carlismos frente a la transición es pañola y de Natalia Urigüen sobre los partidos demócrata-cristianos hispanos y la ayuda que recibieron por parte de la Unión Demócrata Cristiana alemana (CDU). En ambos estudios, en línea con la complejidad derivada de la atención a la singularidad de cada proceso, y lejos ya de las historias de éxito tan habituales en el relato canónico de nuestra democratización, nos encontramos ante un rotundo fracaso a la hora de integrarse en el nuevo sistema de partidos, y por parte de dos fuerzas políticas llamadas en principio a correr una suerte dispar. De esta forma, si bien el fiasco constituía, hasta cierto punto, un resultado previsible en el caso del tradicionalismo, el movimiento cristiano-demócrata contaba a priori con muchas posibilidades de consolidación, dada su masiva presencia en el conjunto del continente, lo que abre la puerta a una explicación multicausal, en la que aspectos como las rencillas personales, el oportunismo y las redes de contactos entran a formar parte de la ecuación transicional. A este respecto, resulta igualmente constatable en ambos textos, como sucede también en el trabajo de Antonio Muñoz Sánchez sobre el PSOE y el apoyo de la social-democracia alemana en la creación de su Instituto de Investigaciones Económicas y Sociales Aplicadas, tanto el doble proceso, enunciado por Gramsci, de captación de la antigua intelligentsia y construcción de una nueva, ${ }^{14}$ producido en el seno de las fuerzas políticas, como la confirmación de que, al hablar de partidos, no se trata ya únicamente de plataformas electorales, sino de maquinarias compuestas, articuladas mediante toda una pléyade de organismos complementarios.

Como lógica consecuencia de los elementos anteriores, la implantación del procedimiento electoral -nuevamente, ya sea de estreno o basado en la prórroga de la normativa anterior-y la apertura de un proceso constituyente aparecen en tercer y cuarto lugar.

De la opción por uno u otro modelo de legislación electoral, de su grado de representatividad, de su apoyatura en un sistema proporcional o mayoritario y del tamaño de las circunscripciones se derivan importantísimas consecuencias que condicionan la dinámica política de un país, hasta el punto de que se ha señalado la directa correlación que la adopción de un modelo conlleva sobre la consolidación del juego de partidos -caso de la denominada «ley de Duverger", que relaciona el sistema mayoritario uninominal con la aparición del bipartidismo's-, teorías, no obstante, fuertemente contestadas por otros especialistas, como el politólogo germano Dieter Nohlen, que, a propósito del comportamiento partidista, prioriza la influencia de sus respectivas culturas políticas sobre la existencia de un determinado sistema electoral. ${ }^{16}$

13 A este respecto, el pionero trabajo de Santos JULIÁ: "Sistema de partidos y problemas de consolidación de la democracia", Ayer, 20 (1995), pp. 111-139. Véase también Rafael QUUIROSA (ed.): Los partidos en la Transición. Las organizaciones políticas en la construcción de la democracia española, Madrid, Biblioteca Nueva, 2013

14 Antonio GRAMSCI: "Apuntes y notas dispersas para un grupo de ensayos sobre la historia de los intelectuales", en Cuadernos de la cárcel, vol. IV, México, Era, 1985, p. 356.

15 Maurice DUVERGER: Party Politics and Pressure Groups. A comparative Introduction, New York Crowell, 1972, pp. 23-32. Una revisión de sus enunciados en Maurice DUVERGER y Giovanni SARTORI: Los sistemas electorales, San José, CAPEL, 1988.

16 Dieter NOHLEN: Sistemas electorales y partidos políticos, México, Fondo de Cultura Económica, 2004. 
En este contexto, especialmente relevante, al tiempo que, una vez más, perfectamente coherente con la labor de la historiografía, es la realización de estudios sobre cada una de las consultas electorales efectuadas desde la recuperación de la democracia, al objeto de conocer entre otros muchos factores, el aprendizaje de los mecanismos del sufragio por parte de la población, la lectura en clave nacional de elecciones locales, autonómicas y, más adelante, europeas, o las ideas-fuerza de las campañas y su reflejo de las corrientes de pensamiento imperantes en un momento determinado. En todas estas direcciones incide la comunicación de Marcos Marina a propósito de los comicios municipales celebrados en España en 1979, primeros de ámbito local y últimos del ciclo de renovación institucional, concretamente en la ciudad de Madrid, caso del que el autor se sirve para reflexionar sobre la democratización de las administraciones, las técnicas de control de la iniciativa política reformista y la articulación y resultados prácticos del sistema de partidos, aspecto muy interesante al tratarse de la capital, donde quedaba prácticamente sin efecto el conocido fenómeno de la inversión de la distribución de la población en relación con los cargos políticos locales, lo que permite trazar una panorámica mucho más representativa. ${ }^{17}$

Por su parte, aunque los procesos constituyentes como tales no recibieron la atención de ninguna de las comunicaciones - pese a dibujarse como telón de fondo en varias de ellas-, sí lo hizo para el caso español, la etapa siguiente a la elaboración y aprobación del texto constitucional: su desarrollo legislativo. El análisis de dicha etapa, de hecho, mercería situarse como verdadera piedra de toque para calibrar la realidad del tan publicitado "consenso" teóricamente producido durante la transición, ya que la puesta negro sobre blanco de la Constitución mediante leyes orgánicas, destinadas a articular el modelo institucional, social y cultural del país, resultaba y resulta mucho más complicada que ponerse de acuerdo sobre lo que no dejaba de ser, con su trascendental importancia, una declaración de principios -en especial dado que la ley fundamental de 1978 postergaba la mayor parte de las decisiones polémicas, lo que añadía otra particularidad más a la adjudicación de tareas constituyentes a unas cortes no convocadas oficialmente para dicho cometido ${ }^{18}$-. Particularmente paradigmática, en este sentido, es la aportación de Vicent Marin sobre las leyes de Educación, uno de los caballos de batalla legales más recurrentes desde el retorno de la democracia, lo que ha traído como consecuencia la imposibilidad de asentar un sistema educativo capaz de trascender el color de los sucesivos gobiernos.

En quinto lugar, aunque no por ello de menor importancia, aparece la actitud de las fuerzas armadas ante el cambio político. Sin duda, un factor diferencial entre las dictaduras latinoamericanas e ibéricas, por un lado, y las dictaduras comunistas de la Europa del Este, por otro, puesto que si en aquellas los ejércitos nacionales constituían el eje o uno de los principales pilares de sus respectivos regímenes, en estas era una fuerza exógena, el ejército rojo, la encargada de sustentar las bóvedas estatales -con la eficaz colaboración de cada uno de los servicios secretos, estos sí autóctonos-, una circunstancia que, confirmado el colapso de las armas soviéticas, facilitó el desmantelamiento de dichos regímenes y sus transiciones a la democracia, mientras que en la Europa y la América del sur estos procesos tuvieron que acometerse bajo un permanente «ruido de sables». ${ }^{19}$ Ahora bien, dentro de este cuadro general, también

17 Véanse, a este respecto, los trabajos de Jordi CAPÓ GIOL: "La formación de una elite política local", Revista de Estudios Políticos (Nueva Época), 59 (1988), p. 203 y "La elite política local en España", Revista de Estudios Políticos (Nueva Época), 76 (1992), pp. 131-132.

18 Pablo Lucas VERDÚ: "La singularidad del proceso constituyente español", Revista de Estudios Políticos (Nueva Época), 1 (1978), pp. 9-28.

19 Manuel ALCÁNTARA SÁEZ: "Las transiciones a la democracia en España, América Latina y Europa Manuel ALCANTARA SAEZ: "Las transiciones a la democracia en España, América Latina y Europa Oriental. Elementos de aproximación a un estudio comparativo", Revista del Centro de Estudios Constitucionales, 11 (1992), pp. 9-42. Un ejemplo de estudio de caso en Carlos H. ACUNA y Catalina en VVAA. Jucios, castigosy memorias. Derechos humanos yusticia en la politica argentina, Buenos existieron diferencias significativas, entre las que se destaca la participación en escenarios bélicos de alto impacto político y simbólico, tales como las invasiones de Chipre por parte de la dictadura de los coroneles y las Islas Malvinas por la Junta Militar argentina o las guerras coloniales lusas. A este último caso, la diferenciación que supuso con respecto a lo sucedido con los militares españoles, y a cómo afectó a la postura de los partidos políticos de oposición, se consagra la comunicación de Octavio González Robles, centrada en las diferentes reacciones del PSOE y el PCE ante la Revolución de los Claveles.

A continuación se situaría la revisión del poder judicial, otro de los elementos estructurales del Estado y otra de las reformas más controvertidas y dificultosas en cualquier proceso de transición a la democracia, hasta el punto de que, probablemente, se trata del ámbito que presenta un mayor porcentaje de continuidad en relación con los antiguos regímenes dictatoriales -lo que incluye la Alemania posterior a la Segunda Guerra Mundial-, con toda la problemática que ello conlleva respecto al tema de la impunidad de la anterior clase dirigente, la depuración de responsabilidades criminales y económicas, la restitución de la memoria, etc. ${ }^{20}$ Con todo, a pesar de su relevancia histórica tanto en América Latina como en Europa y su creciente inclusión en el debate público en España, no se recibieron textos alusivos a dicha cuestión, con lo que tan solo resta a los coordinadores de la mesa su promoción de cara a futuros encuentros.

Finalmente, aparecen dos elementos de carácter transversal. El primero de ellos, la presión desde abajo ejercida por la reconstruida sociedad civil en forma de sindicatos, agrupaciones culturales, asociaciones de vecinos y demás colectivos representativos de los nuevos movimientos sociales -feministas, ecologistas, pacifistas, de derechos de los homosexuales-, que, como ha sido puesto de manifiesto por la historiografía, en contraste con las visiones clásicas de estos procesos como fruto exclusivo de la voluntad de elites político-económicas, jugó un rol decisivo para la adopción de determinadas medidas y en cuanto a la definitiva configuración institucional de los nuevos regímenes -en el caso español, sin ir más lejos, desde la legalización del PCE a la propia organización territorial del Estado-. A estos parámetros responde la comunicación de Esther Mora Bleda, que reconstruye la aportación del movimiento feminista en un contexto regional y de la mano de otro de los mecanismos de presión más utilizados en aquellos años, la prensa, percibida y organizada como un verdadero "parlamento de papel". ${ }^{21}$

El segundo elemento, recurrente a lo largo de la totalidad de la sesión, es el factor internacional en los procesos de transición, cuya relevancia global ha sido ya señalada con anterioridad y sobre cuya importancia para la salida democratizadora española giraban nada menos que cuatro comunicaciones, orientadas en una doble dirección. Así, por una parte, la contribución de Gregorio Sabater Navarro y la ya citada de Octavio González Robles se ocupan de la influencia ejercida por la revolución portuguesa y su proceso rupturista con el Estado Novo sobre las formaciones más representativas de la izquierda española -con lo que contienen igualmente reflexiones sobre el sistema de partidos-, con especial énfasis en la asimilación de las experiencias lusas por parte del PCE. Sus conclusiones parecen venir, a este respecto, a confirmar la idea, formulada por algunos de los más destacados estudiosos de las relaciones peninsulares, del paralelismo entre las trayectorias históricas de los pueblos ibéricos. ${ }^{22}$ Por otra

Aires, Nueva Visión, 1995

20 Una introducción a dicha cuestión en Ernesto GARZÓN VALDÉS: "El papel del poder judicial en la transición a la democracia", Isonomía, 18 (2003), pp. 27-46. Las consecuencias de esta continuidad sobre la calidad democrática de los nuevos regimenes en Bruce ACKERMAN: The future of Liberal Revolution, New Heaven y London, Yale University Press, 1992, p. 72.

21 Rafael QUIROSA (ed.): Prensa y democracia. Los medios de comunicación en la Transición, Madrid, Biblioteca Nueva, 2009

22 Hipólito de la TORRE: “Portugal y España: ¿Historias paralelas?”, en Hipólito de la TORRE y Antonio 
parte, la República Federal Alemana y la actuación de sus dos principales fuerzas políticas, demócrata-cristianos y social-demócratas, destinada a favorecer a sus homólogas españolas es el eclipsado ángulo sobre el que tratan de poner el foco las mencionadas aportaciones de Natalia Urigüen y Antonio Muñoz Sánchez, para lo que se sirven de un magnífico repertorio temático que incluye desde aspectos políticos como las lealtades ideológicas, la geoestrategia de la Guerra Fría y el mero cálculo de intereses hasta procedimentales, como la formación de cuadros, la asesoría jurídica, el desarrollo de las encuentras de opinión y los procesos de socialización democrática de la población.

Las comunicaciones presentadas dieron origen a un rico debate entre los autores y demás público presente, articulado en torno a varios ejes, siendo el caso español el que prácticamente monopolizó el tiempo disponible. En primer lugar se confrontaron ideas en torno a la importancia de la definición de la forma de Gobierno en clave de análisis del proceso de transición. En ese sentido, la discusión giró alrededor del papel desarrollado por el equilibrio de fuerzas existentes a la hora de definir un marco constitucional democrático y el diseño de las garantías ciudadanas imprescindibles para la homologación con otros regímenes similares.

En segundo lugar, se debatió el cambio de modelos explicativos sobre la transición española y el papel desempeñado por las elites. En torno a ello se confrontaron opiniones acerca de los mencionados excesos explicativos cometidos desde un modelo determinista que había explicado la transición desde el pacto entre los dirigentes, minusvalorando la presencia en las calles y la lucha social articulada en los sindicatos, las asociaciones vecinales y las profesionales. Vinculado a esta cuestión se plantearon los peligros de transitar hacia una nueva explicación mecanicista, que hiciera del factor exterior y de las influencias desarrolladas desde otros ámbitos políticos europeos y norteamericanos, el núcleo de un nuevo determinismo. En ese sentido, los investigadores plantearon el convencimiento de la necesidad de atender a explicaciones complejas y multifactoriales a la hora de afrontar una historiografía crítica de la transición, alejada de los estereotipos hagiográficos que han venido produciéndose como instrumento de legitimación del sistema.

Por último, en contraste con la citada ausencia de textos explícitos sobre dicha temática, se abordaron también las profundas limitaciones en torno a la restauración memorialística de la tradición democrática española, encarnada por la Segunda República, los problemas derivados de la Ley de Amnistía y las prohibiciones a la participación política de los sectores abiertamente partidarios de la República como forma de gobierno durante los estadios iniciales de la transición.

as conclusiones, en todo caso provisionales y siempre de carácter abierto, se orientaron hacia dos direcciones principales. De un lado, en torno a la confirmación de que la adopción de un modelo pactista de transición a la democracia que lleve consigo leyes de amnistía y renuncias al establecimiento de compensaciones simbólicas y económicas, por las razones que fuere -reconciliación nacional, amenaza golpista, o, por regla general, una combinación de múltiples factores-, resulta efectiva a corto plazo pero, si no cuenta con una segunda oleada de profundización democrática, genera con facilidad desafección y desencanto en el seno de la sociedad civil, lo que comporta serios implicaciones en todos los órdenes sociales.

De otro lado, la mesa vino a poner una vez más en evidencia la necesidad de la interdisciplinariedad a la hora de abordar el análisis de las transiciones. Partiendo de los modelos teorizados desde la ciencia política y la sociología, la aportación de la historiografía debe complejizar Pedro VICENTE (coords.): España-Portugal. Estudios de Historia Contemporánea, Madrid, Editorial Complutense, 1998, pp. 135-141; Josep SANCHEZ CERVELLO: La revolucion portuguesa y su influencia DO: España y Portugal en transición. Los caminos a la democracia en la Peninsula lbérica, Madrid, Silex, 2009. y cuestionar los elementos estructurales y las categorías excesivamente rígidas que han sido elaboradas desde esas disciplinas, así como desarrollar un espíritu crítico hacia los relatos es tablecidos desde los medios de comunicación, que han prácticamente canonizado la difusión de una imagen excesivamente heroica y protagónica de los integrantes de la elite dirigente. 


\section{LOS CARLISMOS DE LA TRANSICIÓN: LAS \\ IDIOSINCRASIAS CARLISTAS FRENTE AL CAMBIO \\ POLÍTICO (1963-1979)*}

Cristian Ferrer Gonzàlez

Universitat Autònoma de Barcelona (UAB)

Han sido múltiples las interpretaciones dadas sobre el carlismo en el periodo del tardofranquismo y la transición a la democracia. A menudo se han explicado de manera sesgada e insertos en debates exclusivamente políticos y excesivamente ideologizados. La presente comunicación pretende diseccionar las diferentes actitudes de los carlismos frente a la urgencia del cambio político, así como su posibilidad real de incidir sobre éste a favor de sus propios posicionamientos. Para ello, resulta fundamental evidenciar, previamente, la heterogeneidad de este movimiento centenario y explicar las causas de su diversos posicionamientos políticos mediante el análisis de cada uno de los partidos y movimientos políticos declarados de herencia tradicionalista en dicho periodo.

\section{Renovación y división del carlismo en el tardofranquismo}

Decía Pedro Rújula que el carlismo es un asunto del que se ha hablado mucho sin ningún conocimiento.' Lo cierto es que en los estudios sobre el carlismo en el franquismo y en el cambio político han primado visiones sesgadas -o que en cualquier caso han sobredimensionado, a nuestro parecer, su papel histórico- por no mencionar la marginalidad que en éstas obras han ocupado otras múltiples formaciones declaradas también herederas del tradicionalismo. En este sentido, el presente escrito aspira a ordenar y modestamente ubicar en el lugar que les corresponde a las diversas corrientes declaradas de tradición carlista que en la década de los años sesenta y setenta interaccionaron con los distintos actores políticos y sociales en búsqueda de sus propios objetivos políticos e ideológicos; ya fuese por la ruptura, como por el continuismo.

Grosso modo, podemos dividir el carlismo posterior a la Guerra Civil entre quienes apos-

taron por el contubernio con el franquismo y aquellos grupos, ciertamente minoritarios, que se ubicaron en contra de la dictadura de Franco por considerarla una traición a los ideales de Alzamiento del 18 de Julio. Este hecho conllevó una serie de escisiones diversas, mayoritariamente de signo integrista, que debilitaron el movimiento carlista. Entrados los años sesenta, y bebiendo de los aires de renovación del Concilio Vaticano Il y del cambio social derivado de la etapa de desarrollismo capitalista en el Estado español, el carlismo oficialista encabezado por Francisco Javier de Borbón-Parma y, sobretodo, por su hijo Carlos Hugo, inició un viraje ideológico auspiciado por las corrientes renovadoras de la Asociación de Estudiantes Tradicionalistas (AET)

* He de agradecer a Miguel Ángel del Río sus diversas aportaciones al presente escrito, sin que ello le haga responsable de mis errores. Asimismo, debo hacer extensible mi agradecimiento a Jorge de Hoyos y Nicolás Sesma, por su buena labor coordinadora en la mesa-taller que acogió este estudio en València.

1 Afirmación hecha en el congreso de homenaje al difunto profesor Pere Anguera editado recientemente. Pedro RÚULA: “Liberalismo y antiliberalismo, el Carlismo", en Ramon ARNABAT yntoni GAVALDÁ (eds): Projectes nacional identitats i relacions Catalunya-Espanya. Homenatge al doctor Pere Anguera (II), Barcelona, Catarroja, 2012.
Dicha corriente interna conseguiría imponer, poco a poco, su hegemonía ideológica en la Comunión a mediados de los años sesenta consiguiendo que el príncipe Carlos Hugo hiciese suyo el socialismo (no marxista) autogestionario, el federalismo y la monarquía popular, todo ello revestido de un componente preeminentemente católico. Para los detractores de esta nueva tendencia izquierdista, bajo el mandato del llamado Príncipe Rojo, el carlismo había evolucionado ideológicamente hacia un "neo-marxismo al promover: la desaparición de la propiedad privada, la autogestión como sistema de democracia económica y la Monarquía Social como forma de Gobierno". Por lo que consideraban que era necesario oponerse a la entrada del "caballo de Troya (...) en el bastión del Carlismo", ya que "a semejanza de la célebre historia de los griegos para ocupar la fortaleza, Hugo ${ }^{2}$ y sus nuevos seguidores habian penetrado silenciosamente y sigilosamente en las estructuras de la Comunión Tradicionalista y, poco a poco, empezó a influir con sus teorías socialistas en los elementos jóvenes". ${ }^{3}$ Efectivamente, a partir de 1963, con la asunción fehaciente de los postulados de la AET por parte de Carlos Hugo, empezó la transmutación de la histórica Comunión Tradicionalista, políticamente reforzada tras la reincorporación de antiguas escisiones y, ante el escándalo de los carlistas más veteranos, la Comunión adoptaría la denominación de Partido Carlista en 1966.

La rama más numerosa que retornó al carlismo oficialista fue la encabezada por Carles Feliu de Travy en 1964, quien entrados los setenta sería el representante del Partit Carlí catalán en el Consell de Forces Polítiques de Catalunya dejando atrás a una débil y marginal Regencia Nacional y Carlista de Estella (RENACE), encabezada por el antiguo jefe regional catalán de la Comunión Tradicionalista y ferviente ultraderechista, integrista y antifranquista, Mauricio de Sivatte. Estos grupos carlistas serían vistos como contaminaciones ideológicas por otros sectores no-dinásticos del carlismo. El más prolífero de ellos fue el liderado por el ulldeconense Ramón Forcadell i Prats, quien decidió mantener una línea operativa autónoma a la de Carlos Hugo y de De Sivatte, a la vez que apostaba por un mayor acercamiento al régimen franquista. Creían, así, que podrían presionar internamente para instaurar la monarquía católica y tradicional que anhelaban. Para ello, Forcadell transformó su unión de excombatientes tradicionalistas, la Hermandad del Maestrazgo, en un ente de ámbito estatal en $1971,{ }^{4}$ constituyendo, a la práctica, una Comunión Tradicional alternativa a la homogeneizada por el izquierdismo católico de Carlos Hugo. ${ }^{5}$

Amenazado por el riesgo a la irrelevancia política, en 1966 el grupo de De Sivatte había intentado un quimérico golpe de fuerza exigiendo a Franco y al Ejército que depositaran el poder en el carlismo para que éste se hiciera "cargo del Estado y del Gobierno sin más tardan-

2 Los carlismos ultras jamás Ilamarían al hijo de Francisco Javier como Carlos Hugo, sino sólo Hugo para desvincularlo de cualquier referencia carlista. José $\mathrm{M}^{\mathrm{a}}$ Domingo-Arnau explica que el nombre de Carlos se lo puso a posteriori. En cualquier caso, se enfatizaba el nombre de Hugo por ser el también fundador de la dinastía capeta de Francia, nacionalidad de la que gozaba la familia Borbón-Parma.

3 José María DOMINGO-ARNAU y ROVIRA: Operación Maestrazgo, Ulldecona, Hermandad Nacional Monárquica del Maestrazgo, 1998, pp. 83-84.

4 Ramón Forcadell había sido nombrado alcalde de Ulldecona en 1964, coincidiendo con su táctica de acercamiento al régimen, pero en 1971 fue destituido "per un incident que s'havia produit", sin lograr esclarecer hasta la fecha la naturaleza del mismo (Jeroni Castell Guarch, 31 de julio de 2012, Ulldecona, entrevista realizada por Cristian FERRER GONZÁLEZ a quien fuera último alcalde franUlldecona, entrevista realizada por Cristian FERRER GONZALEZ a quien fuera último alcalde fran-
quista de la población y miembro de la UNE, la AP y el PP, respectivamente). Forcadell sería sustiquista de la población y miembro de la UNE, la AP y el PP, respectivamente). Forcadell sería susti-
tuido por Castell en la alcaldía, su delfin político, quien acabaría por separarse del forcadellismo a partir de 1974 cuando ingresó en la Unión Nacional Española, al tiempo que Forcadell trataba a partir de 1974 cuando ingreso en la Unión Nacional Española, al tiempo que Forcadell trataba GONZÄLEZ: "Ulldecona i el canvi polític: dictadura, contra-hegemonia i democràcia (1964-1983)", Raïls, 30 (2014), pp. 7-53.

5 “¿Otra nueva Comunión Tradicionalista?”, Informaciones, 8 de mayo de 1971. 
za". ${ }^{6}$ La dimisión de José Ma Valiente en 1967, presidente carlista y fiel al tradicionalismo de la Comunión y a Franco, y la estupefacción del régimen ante la creciente atomización y radicalización de los carlismos, llevó a decretar el 20 de diciembre de 1968 la expulsión de la familia Borbón-Parma "dada su participación en actividades de carácter político, en las que según sus promesas, había de abstenerse". ? Se han interpretado dichas expulsiones como "el resultado de la nueva actitud carlista, fruto de su dinámica interna que le hace pasar de la crítica del totalitarismo a la crítica del capitalismo que es su causa esencial y le hace optar por un proyecto socialista", ${ }^{8}$ pero lo cierto es que no fue hasta la designación de Juan Carlos de Borbón como Príncipe de España en 1969 y la consiguiente radicalización carlista ante la perspectiva de la irrelevancia política -especialmente a partir de 1972 en adelante- que el carlismo oficialista inició su actividad de movilización antifranquista. Si bien es cierto que sectores carlistas participaron en "infiltraciones" en ayuntamientos y sindicatos verticales des de inicios de los setenta a través de las elecciones a tercios, conviene destacar que únicamente en el bienio 1975-1976 el Partido Carlista cobró cierta notoriedad popular, más por la represión gubernamental que por su decidida acción de masas.

\section{Los carlismos durante la crisis de régimen y ante el cambio político}

El mes de mayo de 1975, el pretendiente Francisco Javier abdicó públicamente en favor de su hijo Carlos Hugo delante de la multitud que había asistido a la romería anual de Montejurra. Los franquistas empezaron entonces a gestar una operación para eliminar el carlismo -de una presencia relativa nada despreciable en Cataluña y las vascongadas- como potencial actor político que podría poner en entredicho la Monarquía del 18 de Julio después de la esperada próxima muerte del dictador, quien al parecer había lamentado "dejar a España una guerra de sucesión". 9 Desde el régimen se intentó producir más división entre los carlistas presentando figuras del tradicionalismo vinculadas al franquismo que denunciaban las "desviaciones" de la línea oficialista. Sin embargo, dicha operación no granjeó éxito alguno al presentar personajes más bien de segunda fila, incapaces de atraer un número significativo de seguidores. No fue hasta el 28 de octubre de 1975 cuando se presentó una nueva y eficaz estrategia gubernamental: utilizar al hermano menor de Carlos Hugo, el conocido neofascista Sixto Enrique de Borbón-Parma, para atraer a los sectores integristas del carlismo. Éste había declarado en el diario Pueblo ser "abanderado del tradicionalismo, defendiendo los principios carlistas que son, por su propia naturaleza, inalterables", añadiendo que "se encuentra ideológicamente en la línea de los ideales de la Cruzada del 18 de Julio, que defiende"..10 Tras dichas declaraciones Sixto Enrique fue expulsado del Partido Carlista.

El corto pero intenso bienio de Sixto Enrique -apoyado económica y logísticamente por el gobierno Arias-Fraga-" guarda relación con lo que se ha denominado ampliamente Operación Reconquista y su vinculación internacional con grupos neonazis y neofascistas de mundo occidental con conexiones políticas y logísticas con la OTAN, todos ellos in crescendo en los primeros años setenta para luchar contra las opciones democráticas en el Estado es-

6 César ALCALÁ: Documentos sobre la legitimidad, 1945-1981. Apéndice documental de la obra "Don Mauricio de Sivatte", Barcelona, Cuadernos Carlistas 2, 2001, p. 137.

Boletín Oficial del Congreso, $\mathrm{n}^{\circ} 1044,27$ de febrero de 1969.

8 Josep Carles CLEMENTE: El Carlismo contra Franco. De la guerra civil a Montejurra 76, Barcelona, Flor del viento, 2003, p. 250

9 Citado en José María DOMINGO-ARNAU y ROVIRA: Operación Maestrazgo... p. 112

10 Citado en Josep Carles CLEMENTE: Historia general del Carlismo, Madrid, F. Mesa, 1992, pp. 414-415.

eliminar al carlismo oficialista. Ibíd. p. 417 pañol. ${ }^{12}$ Movimientos violentos que, por otra parte, ya existían en España con sus vertientes ideológicas diversas, también de signo tradicionalista, como el grupo de matones Guerrilleros de Cristo Rey que se dedicaban a apalizar con cadenas a la oposición universitaria ante la complacencia de la Policía Armada.

Días antes de los conocidos sucesos de Montejurra de 1976, había ido en aumento el intercambio de amenazas entre las alas derecha e izquierda del carlismo, acrecentado, más aún si cabe, con el anuncio de Carlos Hugo confirmando su presencia en el vía crucis pese a estarle prohibida su entrada en el Estado español. Según información del Partido Carlista, el embajador de los Países Bajos en Madrid habría recibido durante esos días un mensaje verbal del ministro español de Asuntos Exteriores, José $M^{a}$ de Areilza, informándole de que su gobierno no podía hacerse responsable de la seguridad de la princesa Irene-esposa de Carlos Hugo- y su familia si asistían a la romería de Montejurra. ${ }^{13}$ Sixto Enrique, "Sixto-Rey" para sus seguidores, anunció con una retórica mesiánica, por su parte, que aquel era "un momento grave para España y para el mundo" y que él era el único capaz de ofrecer "una doctrina y organización ajenas a cualquier materialismo, sea marxista o capitalista, basado, sobre todo, en su raíz histórica". ${ }^{4}$ Lo cierto es que después del sangriento Montejurra de 1976 se desinfló el apoyo a Sixto-Rey y el integrismo de la rama sixtina no tuvo continuidad más allá de los aislados episodios de violencia de los tradicionalistas; si exceptuamos, claro está, el caso de la políticamente exitosa Unión Nacional Española (UNE).

Nacida en 1974 al amparo de la Ley Arias de asociaciones políticas, la UNE fue fundada por personalidades del tradicionalismo franquista como el declarado admirador de Pinochet y Carrero Blanco, Gonzalo Fernández de la Mora y otros como Antonio de Oriol, José Luís Zamanillo o José $M^{a}$ Valiente, ex-presidente de la Comunión y expulsado del Partido Carlista en 1971 por negarse a aceptar tanto la nueva denominación como, especialmente, su viraje ideológico. La UNE renegaba de la legitimidad de Francisco Javier, de su hijo Carlos Hugo y de la deriva izquierdista del carlismo oficialista en general, por lo que cabe inscribirlos en el integrismo ideológico y considerarlos el último intento del tradicionalismo institucional debido a la íntima relación de sus miembros con el régimen y con la monarquía de Juan Carlos I, garante de los Principios Fundamentales del Movimiento. ${ }^{15}$

Poco después de haber declinado su ingreso en la Hermandad del Maestrazgo ${ }^{16}$ y tras poco de los sucesos de Montejurra, el grupo de Fernández de la Mora estableció un pacto electoral con formaciones ultras del régimen -no estrictamente tradicionalistas- como la inicialmente suarista Unión del Pueblo Español (UDPE), la Asociación Nacional para el Estudio de los Problemas Actuales (ANEPA) y el falangista Frente Nacional Español (FNE) -promocionado por el histórico Raimundo Fernández-Cuesta, que reivindicaba el legado de José Antonio- con el objetivo, decían, de "lograr, sin rupturas ni riesgos, la construcción de un

12 José Antonio Sáenz de Santa María hablaba de la participación de grupos de extrema derecha como el Batallón Vasco Español, los Guerrilleros de Cristo Rey y otros grupúsculos neofascistas internacionales; Cf. Diego CARCEDO: Sáenz de Santa María. El general que cambió de bando, Madrid, Temas de Hoy, 2004. Por otro lado, la participación ultra internacional recuerda a sucesos de la revolución portuguesa donde grupos terroristas subvencionados por el Estado español actuaron en territorio luso en apoyo a la contrarrevolución; $C$ f. Josep SÁNCHEZ CERVELLÓ: La revolución portuguesa y su influencia en la transición española (1961-1976), Madrid, Nerea, 1995

13 "Dosier Informativo del Partido Carlista sobre el Montejurra 76", disponible íntegramente en Josep Carles CLEMENTE: La otra dinastía. Los reyes carlistas en la España contemporánea, Madrid, Papeles del tiempo, 2006, pp. 153-158.

14 Ismael LÓPEZ MUÑOZ: "Carlos Hugo y Sixto Enrique se disputan el carlismo", El Pais, 9 de mayo de 1976. 15 Jordi CANAL: El carlismo. Dos siglos de contrarrevolución en España, Madrid, Alianza, 2000, p. 383.

16 M. M. M.: "Declaración del Presidente Nacional a la revista Gentelman, $n^{\circ} 22$ ", Maestrazgo: Dios, Patria, Fueros, Rey, febrero de 1975 
futuro esperanzador para la sociedad española (...) sobre la base de la Institución Monárquica (...) del Rey Don Juan Carlos" sin renegar por ello de la "incuestionable obra instauradora acometida y realizada bajo la jefatura de Francisco Franco", ${ }^{17}$ definiendo claramente, así, la idiosincrasia ultra de dicho grupo político. Pocos meses más tarde se integró a la alianza electoral el brazo político de la Hermandad del Maestrazgo, el Frente Institucional, liderado por los también tradicionalistas-integristas, juancarlistas y filofranquistas Ramón Forcadell y Enrique Castellá Bertrán..$^{18}$ Tanto el grupo de Fernández de la Mora como el de Forcadell se declaraban defensores de la "legitimidad que arranca el 18 de julio". 19 Poco después dicha alianza fracasó y la mayoría de miembros del Frente Institucional ingresaron en la UNE, y a primeros de octubre de 1976 la formación de Ramón Forcadell se inscribió en el registro de asociaciones políticas bajo el nombre de Partido Social Regionalista (PSR), ${ }^{20}$ en el que acabarían militando figuras tan relevantes del tradicionalismo como José $M^{\text {a }}$ Valiente.

El 9 de octubre de 1976, los llamados "siete magníficos", liderados por Manuel Fraga Iribarne, fundaban la formación política Alianza Popular. Entre los fundadores del grupo de extrema derecha neofranquista "operativa" ${ }^{21}$ se encontraba el sector tradicionalista-integrista de Fernández de la Mora. Como hemos visto, ésta era la formación carlofranquista más integrista y derechista, no únicamente entre el atomizado mundo carlista -si exceptuamos los sivattistas de la Regencia de Estella-, sino también entre las formaciones de la propia Alianza Popular; la derecha de la derecha del régimen. Detrás de la fachada exterior y más allá del terror que causaban sus jóvenes seguidores por sus prácticas pandilleras, la UNE de Fernández de la Mora carecía de una base social y de un ideario que pudiera ir más allá de reivindicar el legado de la dictadura de Franco. En el mundo carlista, la UNE se posicionó públicamente en apoyo a Sixto-Rey durante la Operación Reconquista en complicidad con Fraga Iribarne por la matanza de Montejurra. Complicidad que, por otro lado, se afianzó con la fundación de Alianza Popular en octubre de ese mismo año. En un plano institucional, después de finalizar la "reconquista" de Montejurra, la UNE siguió apoyando la Monarquía del 18 de Julio encarnada por el rey Juan Carlos I, como de hecho hicieron la mayoría de franquistas.

En esta lucha abierta por la legitimidad del carlismo entre facciones atomizadas, radicalizadas y enemistadas entre si, se hizo evidente el aislacionismo del integrismo sivattista de la Regencia de Estella. Situación acrecentada con el "hecho biológico" de la muerte del dictador que relegó a la marginalidad política a los sivattistas reunidos en el lujoso Hotel Majestic de Barcelona, atónitos y definitivamente superados por la efervescente y cambiante realidad social, política e institucional. Los escasos seguidores de Mauricio De Sivatte culpabilizaban a Franco del procesos de cambio político dada su tibieza e indecisión en ceder el poder al carlo-integrismo, tal y como la Regencia había reclamado años atrás. A medida que los sivattistas quedaban marginados en el proceso de cambio, se acentuaba su integrismo e intransigencia, llegando a situarse a la derecha de Blas Piñar. ${ }^{22}$ El proceso de atrincheramiento progresivo de la Regencia hizo aumentar las proclamas cuasi paranoicas sobre supuestas confabulaciones

17 “U.D.P.E., ANEPA, F.N. y U.N.E. 'Adecuar la herencia recibida a las nuevas circunstancias"', $A b c, 25$ de mayo de 1976.

18 "UNE, FI, ANEPA y UDPE reiteran que su alianza se debe únicamente a fines electorales", $A b c, 12$ de junio de 1976

19 Gonzalo FERNÁNDEZ de la MORA: Río arriba. Memorias, Barcelona, Planeta, pp. 176-213.

20 "Veintidós solicitudes presentadas en el Registro de Asociaciones Políticas", Abc, 2 de octubre de 1976.

21 Miguel Ángel del RÍO MORILLAS: De la extrema derecha neofranquista a la derecha conservadora. Los origenes de Alianza Popular (1973-1979), Tesis doctoral, Universitat Autònoma de Barcelona, 2013, especialmente las pp. 245-260 y el tercer capítulo, pp. 298-400. 22 Xavier CASALS i MESSEGUER: Ultracatalunya. L'extrema dreta a Catalunya: de l'emergència del Carles CLEMENTE: El Carlismo contra Franco... p. 222. globales en contra de las esencias del carlismo que ellos decían representar. En el aplec sivattista celebrado en Montserrat el 23 de mayo de 1976 corrieron rumores que gente armada de Partido Carlista se había instalado en el hogar de la Moreneta con la intención de vengar la sangre derramada en la sacra montaña de Montejurra. A pesar que dicho rumor resultó falso y que los carlistas de De Sivatte pudieron celebrar su aplec sin impedimento alguno, el hecho resulta indicativo del clima de tensión y paranoia existente en el integrismo carlista.

Ramón Forcadell continuó su camino mediante la construcción de su propia formación carlo-integrista, un partido que -según sus palabras- debía quedar "por encima de derechas, izquierdas y centros, en un esfuerzo integrador de una sociedad con más puntos comunes que diferentes", 23 aunque, en la práctica, devino el referente de la extrema derecha allí dónde consiguió enraizar. ${ }^{24}$ Después de fracasar el acercamiento con la formación de Fraga Iribarne, el tradicionalismo juancarlista de Forcadell buscó colaborar con el presidente de la Diputación de Barcelona, Juan Antonio Samaranch, quien promovió una "coalición entre su Partido Conservador, el Catalònia y un fantasmal Partido Social Regionalista de estirpe carlista, bajo el rótulo de Concòrdia Catalana, que durante la primavera de 1977 llenaría las calles de una propaganda más recordada por sus estridentes colores amarillo y negro que por sus ánodos eslóganes". ${ }^{25} \mathrm{En}$ tre las proposiciones de Samaranch, en las que participó inicialmente el PSR, aparecían algunas propuestas, ciertamente absurdas, como reivindicar la Mancomunitat frente a la Generalitat.

El 15 de junio de 1977 se celebraron las primeras elecciones democráticas en el Estado español des de 1936. Contrariamente a lo que había previsto el gobierno Suárez, esos comicios a cortes abrirían un proceso constituyente debido a la fuerza electoral de la oposición. ${ }^{26}$ Los carlismos diseccionados a lo largo de esta comunicación se presentaron dentro de formaciones diversas, u otros ni siquiera llegaron a presentarse. El Partido Carlista no pudo comparecer el 15-J dada su ilegalidad y debido a que cuestionaba la impuesta forma monárquica del Estado. Además, no había sido concedida la nacionalidad española a Carlos Hugo intencionadamente. Pese a que miembros oficialistas del carlismo se presentaron en listas electorales de otras formaciones -especialmente en el País Vasco y Navarra dentro del Euskadiko Partidu Komunista (EPK)- ninguno de ellos consiguió representación en el Congreso. Por otro lado, los filofranquistas del PSR no llegaron a presentarse a las generales al considerar, acertadamente, que no contaban con el apoyo suficiente para ello. Los únicos elementos remotamente carlistas que lograron representación parlamentaria en 1977 fueron los integristas de la UNE agrupados en la neofranquista Alianza Popular.

Dicho sector ultra fue, precisamente, el que más problemas ocasionó en el momento de aprobar el texto constitucional. Las tensiones internas entre las formaciones personalistas que formaban la Alianza Popular, a raíz de los debates constitucionales en la legislatura 19771979 y la presentación pública del dirigente comunista Santiago Carrillo por parte de Fraga Iribarne en el Club Siglo XXI, hicieron que los diputados miembros de la UNE abandonaran la alianza de extrema derecha neofranquista ${ }^{27}$ y que en 1978 propiciaran su unión a la formación ultra y neofranquista ortodoxa o residual promocionada por Blas Piñar, Derecha Democrática

23 Ramón FORCADELL i PRATS: P.S.R. Unión Institucional, Bilbao, Aliba, 1977, p. 10.

24 En su pueblo natal, Ulldecona, el PSR obtuvo el 23,4\% de los votos y tres regidores en los comicios municipales de 1979.

25 Traducido del catalán. Joan Baptista CULLA i CLARÀ: “'évolució de l'espai centrista a Catalunya”, Working Paper, 4 (1989), p. 2.

26 Entre los innumerables trabajos de quienes consideramos el final del franquismo como obra de la oposición antifranquista y producto de la crisis del régimen, están principalmente Carme Moline ro y Pere Ysàs. Una versión sintética, y por ello accesible, de dicha tesis se halla en Pere YSȦs: “La Transición española. Luces y sombras", Ayer, 79 (2010), pp. 31-57, especialmente las pp. 52-57.

27 “Unión Nacional Española se separa de Alianza Popular", El País, 28 de octubre de 1977. 
Española (DDE) ${ }^{28}$ La UNE quedaría entonces diluida entre el integrismo ultraderechista neofranquista que fue incapaz de integrarse y adaptarse a la nueva situación constitucional, a la práctica desapareciendo como formación política en 1979, pese al posterior fracaso de la DDE. EI PSR, por su parte, intentó sobrevivir a la instauración democrática -oponiéndose a capa y espada-convirtiéndose en un partido "democrático", de un modo similar al que lo hizo Fraga Iribarne y el sector superviviente de Alianza Popular. ${ }^{29}$

En suma, podrían vincularse algunos de los diputados populares -no todos- que dieron su voto negativo a la Constitución con una cierta tradición "carlista": el presidente de la UNE, Gonzalo Fernández de la Mora; el requeté durante la guerra, Pedro Mendizábal y Uriarte; e incluso podríamos dar cabida al fundador de Acción Democrática Española, Federico Silva Muñoz, quien después se separaría de Alianza Popular para integrarse, también, en la neofranquista ortodoxa y residual DDE. Cabe mencionar que Silva Muñoz nunca fue estrictamente tradicionalista, pero le unía a éstos el ultracatolicismo de origen franquista. Desde las atalayas perdidas de la Regencia de Estella, por otra parte, se consideraba la nueva Constitución como el "resultado de un pastiche de intereses", por lo que sentenciaron la ilegitimidad de la misma y se opusieron encarnizadamente al proceso autonómico. Decían, "si frente a la pluralidad de herencias históricas, étnicas y lingüisticas de las regiones, que se aglutinan en la unidad nacional de la patria, se concibe a España como una pluralidad de naciones, sólo la fuerza podrá justificar la unidad de nuestra nación". ${ }^{30}$

\section{Epílogo de una lucha centenaria}

Durante el proceso de promulgación constitucional se produjo un acercamiento, digamos, espiritual de la Regencia hacia los ortodoxos neofranquistas de Fuerza Nueva. De hecho, el proceso vital de la Regencia en la década de los setenta fue bastante paralelo al del resto de "búnker" franquista: una oposición frontal al gobierno de Arias Navarro en tiempo de Franco y después -en defensa del Régimen del 18 de Julio-, un férreo menosprecio al proceso constitucional forzado por el antifranquismo, odio a la construcción de la democracia y consecuentemente a todos los gobiernos surgidos de dicho proceso. De este modo, una parte de la extrema derecha del Régimen de Franco se convirtió, también, en la nueva extrema derecha del Régimen de $1978 .{ }^{31} \mathrm{El}$ mismo año de promulgación de la Carta Magna la Regencia fundó el órgano Unión Carlista, que el 1980 se convertiría en la nueva rama política del sivattismo. A pesar de ello, la nueva Comunión pronto quedaría huérfana y descabezada tras el fallecimiento del anciano Mauricio de Sivatte en junio del mismo año. En desaparecer el incansable luchador por las esencias clásicas del tradicionalismo, la Unión Carlista se vio abocada a una grave crisis de liderazgo. En los ochenta, el carlo-integrismo intransigente promocionó la formación de la Comunión Tradicionalista Carlista, que acabarían reconociendo la "ilegítima" rama Borbón-Parma y, en concreto, la legitimidad proscrita de Sixto-Rey, pero nunca conseguirían la menor presencia social ni política en democracia.

Después de la frustración, dada la marginalidad del carlismo en el proceso constituyente, Carlos Hugo abandonaría brevemente la vida política en noviembre de $1978,{ }^{32}$ para regresar y

28 “Constituida la Derecha Democrática Española", El País, 22 de diciembre de 1978.

29 Cristian FERRER GONZÀLEZ: Lluitadors quotidians. L'antifranquisme, el canvi polític i la construcció de la democràcia al Montsià (1972-1979), Lleida, UdL, 2014, pp. 144-153.

30 Citado en Xavier CASALS: Ultracatalunya. L'extrema dreta a Catalunya... p. 219.

31 Tesis de Ferran GALLEGO: Una patria imaginaria. La extrema derecha española (1973-2005). Madrid, Síntesis, 2006. Una explicación de dicho proceso, atribuido a Fuerza Nueva pero extrapolable a la RENACE, trazado por Miguel Ángel del RÍO MORILLAS: “La extrema derecha neofranquista a inicios del posterior franquismo", Revista HMiC, 9 (2011), pp. 98 -99.

32 "Obligado por la actitud jacobina de sus seguidores, por un lado, y el radicalismo cerril, por otro", liderar las listas por Navarra del Partido Carlista en los comicios generales de marzo de $19799^{33}$ tras habérsele concedido la nacionalidad española. ${ }^{34}$ Obtuvo 50.552 votos y el o,28\% de los su fragios, quedando nuevamente sin representación parlamentaria. Los malos resultados de 1979 fueron un gran golpe para el Partido Carlista, a pesar de haber conseguido numerosas alcaldías navarras en abril del mismo año y haber incluso conseguido avanzar electoralmente al EPK en el partido judicial de Azpeitia, y quedar únicamente a doscientos votos de aquel en Tolosa.

Tras el último intento del carlismo oficialista para incidir en la vida política y llevar a cabo su ideario, el Partido Carlista decidió "retirarse a los cuarteles de invierno, a esperar tiempos más propicios". ${ }^{35}$ Los carlistas se dedicaron, a partir de entonces, a la difusión y promoción de la tradición y cultura carlistas, especialmente. Carlos Hugo, por su parte, siguió como titular y representante de la dinastía carlista hasta su muerte en 2010, siendo sustituido por su hijo Carlos Javier de Borbón-Parma. A finales de 1980, Carlos Hugo había recibido la invitación de los profesores John K. Galbraith y Benjamin Brown para incorporarse como docente de economía en la Universidad de Harvard. A partir de entonces la vida política del partido quedó aislada y centrada en las alcaldías conquistadas en Navarra y el País Vasco. Cuando en 1986 se presentó la coalición Izquierda Unida, surgida de la descomposición del Partido Comunista de España, los carlistas oficialistas participaron en su fundación y llegaron a presentarse en dichas candidaturas para las elecciones generales de junio de aquel año. No obstante, debido a los malos resultados obtenidos, el Partido Carlista abandonaría la coalición y, como el Guadiana, iría apareciendo esporádicamente a lo largo de la década para dar apoyo a causas de su interés.

\section{Balance}

A lo largo de estas líneas se ha tratado de dibujar las trayectorias políticas de las diversas familias declaradas herederas de la tradición carlista. Ésta no ha sido una tarea de análisis estático, como si de una fotografía o de una pintura paisajística se tratara, sino que se ha intentado plasmar los ritmos diversos y cambiantes que confeccionaron el posicionamiento táctico de cada uno de los carlismos en el momento del cambio político. No sorprenderemos a nadie si afirmamos que ninguno de los carlismos no oficiales se habían estado preparando para el cambio político y el desmantelamiento del franquismo. Ni los franquistas ni los antifranquistas tardíos habían previsto realmente las consecuencias del fin próximo del régimen para su movimiento. Si entramos en la anatomía de cada uno de los carlismos y sopesamos las posibilidades reales de éxito de sus posicionamientos -es decir, de imponer una hegemonía política acuerdo a sus intereses-, basándonos en su programa, actitud y resultados ante la emergencia del cambio político, encontramos:

En primer lugar, el carlismo aquí definido como "oficialista" del heredero dinástico Carlos Hugo de Borbón-Parma, agrupado en torno al Partido Carlista y del socialismo (no marxista) autogestionario, federal y católico. Esta opción política, en realidad, tal y como era presentada por el Partido Carlista, tenía escasa o nula posibilidad de éxito dado que difícilmente el carlismo podía llegar a imponerse sobre los monárquicos juancarlistas, representados políticamente por toda la fuerza de la derecha parlamentaria. Ni aunque se hubiera conseguido una hipotética mayoría izquierdista en el parlamento, formada por los carlistas y sus partidos compañeros en las plataformas antifranquistas, no parece plausible que se hubiera producido la entronización de Carlos Hugo como rey de España con el apoyo de unos partidos mayoritariamente de carácter republicano. Carlos Hugo, en este sentido, era consciente de dicha limita-

escribe Josep Carles CLEMENTE: El Carlismo contra Franco... p. 263.

33 "Carlos Hugo de Borbón, candidato por Navarra", El País, 20 de enero de 1979.

34 "Concedida la nacionalidad española a Carlos Hugo de Borbón", El País, 9 de enero de 1979.

35 Josep Carles CLEMENTE: El Carlismo contra Franco... p. 264. 
ción del Partido Carlista como movimiento político e ideológico junto con la herencia dinástica que él encarnaba. Únicamente, en contadas ocasiones, se definió como Rey mientras que sí se definía como político y eran habituales en la prensa los esclarecimientos sobre el carácter político y no dinástico del carlismo oficialista.

Xavier Casals define perfectamente la causa de la Regencia de Estella de Mauricio de Sivatte como lost cause, ya que su radical intransigencia ideológica, moral y política producía una auto-marginación y cerraba cualquier vía de acceso al poder político o presencia social operativa para este movimiento. No es de extrañar la marginalidad popular de la Regencia y su consecuente atrincheramiento en posiciones ultras e intransigentes. Resulta curioso el acercamiento que harían a finales de la década con la neofranquista "ortodoxa" o "residual" Fuerza Nueva de Blas Piñar, representante de las herencias del 18 de Julio, que tanto había aburrido y combatido De Sivatte durante la dictadura. En el plano del carlismo ultraderechista, hay que valorar el bienio de Sixto Enrique aunque sólo sea por la importancia de los hechos de Montejurra de 1976. Hay que decir que la estrategia del régimen y de otros movimientos que dieron apoyo a "Sixto-Rey" durante el bienio 1975-1976, no fue nunca la de instaurar la monarquía en la figura de Sixto Enrique. El terrorismo carlista ultraderechista debe inscribirse en la "estrategia de la tensión" gubernamental para de desarticular, en este caso, la rama izquierdista del carlismo encarnada en Carlos Hugo, así como la oposición antifranquista en general debido a la deslegitimación pública que producía para el régimen. Tanto el gobierno Arias-Fraga como la UNE abandonarían rápidamente su apoyo al hijo menor de Francisco Javier. Así pues, el sixtismo surgió de manera coyuntural durante el bienio para marchar y nunca más volver, a pesar que la Comunión Tradicionalista Carlista, heredera de la Regencia de Estella, sigue defendiendo teóricamente la entronización de Sixto-Rey.

La UNE, por su parte, representaría una de las ramas del carlismo integrista operativo más exitoso. Su procedencia del partido único FET y de las JONS - por tanto, de fuera de la Comunión Tradicionalista sensu stricto- hizo que pudiera jugar el papel de tradicionalista, franquista e institucional encuadrada en el carlismo no dinástico de ideología ultra y católica. Su mayor éxito fue entrar en la formación de extrema derecha neofranquista operativa Alianza Popula de Fraga Iribarne y obtener representación en el parlamento en las elecciones a cortes (constituyentes) de 1977. Dado que no pretendió nunca imponer un candidato dinástico diferente al rey Juan Carlos I, la UNE se topó con menos obstáculos que sortear que el Partido Carlista, por ejemplo. Su objetivo fundamental era mantener el régimen franquista lo más intacto posible, objetivo que no lograría ni tan sólo entre los socios de su propia coalición. El apoyo de parte de Alianza Popular a la Constitución de 1978, provocó su salida de la coalición, por considerar que España era ya “un Estado perfectamente constituido". Después de 1978, la UNE buscó su espacio ideológico a la derecha de Fraga Iribarne y estableció relaciones con la neofranquista ortodoxa y residual DDE, en la que se integraría un año más tarde, y desaparecería como actor autónomo del tradicionalismo, al tiempo que se desvanecía la propia DDE.

Una similitud estratégica con la UNE la encontramos con el PSR de Ramón Forcadell. No obstante el forcadellismo tenía ciertas características que habría que diferenciar para no confundir todos estos movimientos en una amalgama de integrismo y monarquismo reaccionario difícilmente distinguibles entre $s i$, y a los que uno pueda ubicar en el espacio político de los fascismos. EI PSR representaba una estrategia genuina y dual, en no cerrar ninguna puerta y a mismo tiempo no dejar de jugar en ningún momento su propia carta. Esta estrategia, al igual que la UNE -y esto es lo que las hace más similares-fue de las más exitosas referente a la posibilidad real de imponer su hegemonía política a través de pactos más amplios. Si focalizamos en el tardofranquismo, observamos que la entonces Hermandad del Maestrazgo empleó la estrategia posibilista de utilizar el régimen para llevar a cabo sus propios intereses, lo que en cierto modo se consiguió con la designación de Juan Carlos como Príncipe de España en 1969 aunque no fuera por su actuación. Por otra parte, el PSR jugó la baza de partido monárquico juancarlista con una ideología integrista. Atribuimos un error estratégico de la formación no terminar integrándose en el Alianza Popular de su amigo Fraga Iribarne, ya que esto le hubiera permitido una mayor visualización pública. Sin embargo, el partido de Ramón Forcadel consiguió atraer a personajes importantes del tradicionalismo español como José $M^{a}$ Valiente y mantener una presencia e influencia notables en los lugares donde consiguió arraigar. No obstante esta estrategia de éxito del PSR difícilmente podía perdurar a gran escala en democracia, ya que la formación se movía en los parámetros del amiguismo, del partido de cuadros y del populismo derechista que hubiera fracasado en su praxis a largo plazo.

Habría que realizar un balance sobre el peso real del los Carlismos en la Transición. En este sentido, y a pesar de todo lo que aquí se ha discutido, los carlismos de los años setenta no fueron capaces de imponer su hegemonía cultural y política, si no era-parcialmente- a través de movimientos más amplios y diversos como el de Alianza Popular o las plataformas antifranquistas. Ninguno de ellos, sin embargo, tenía la base y fuerza suficientes para lleva a cabo dicha empresa. A diferencia de buena parte del siglo XIX, el carlismo del último tercio del XX ya no contaba con el alimento y difusión ideológica de la Iglesia católica, ni el Estado franquista era un régimen tradicionalista. A pesar de la pervivencia de una verdadera cultura carlista transmitida por vía familiar, ésta nunca tuvo ninguna posibilidad de conquistar una hegemonía, más allá de la consanguinidad, mediante los nuevos canales disponibles con la revolución tecnológica o a través de la transmisión popular. Además, el propio carácter endogámico del tradicionalismo hacía que difícilmente pudiera captar nuevos adeptos y abrirse a un verdadero movimiento de masas. Tal vez el surgimiento del fascismo hizo que en realidad el tradicionalismo sensu stricto hubiese desaparecido. Quizás su contubernio con el régimen durante largo tiempo y su atomización hacían que las masas desconfiaran. Al fin y al cabo, el antifranquismo luchaba por la democracia y el carlismo había sido uno de los fundadores del Estado del 18 de Julio que se pretendía derribar. 
España y Portugal son dos países vecinos, dos países que comparten el suelo de la península ibérica, pero que comparten muchas más cosas. No sólo comparten un lugar geográfico en una de las esquinas de Europa, también comparten una profunda indiferencia el uno por el otro; sin embargo, detrás de esa inferencia hay un transcurrir histórico bastante semejante. Resulta curioso comprobar cómo durante los dos últimos siglos, la historia de estos dos países ibéricos se entrecruza y cómo los fenómenos políticos y sociales que afectaron a uno, al final, tarde o temprano, acabaron sucediéndole al otro. Así sucedió con la lucha entre el liberalismo y los defensores del Antiguo Régimen, la proclamación de la república, la instauración de regímenes dictatoriales, la caída de estos últimos y la instauración de democracias liberales. Quizá, mucho de este transcurrir entrecruzado tenga que ver con su posición de semi-periferia, con su atraso en la incorporación a la modernidad europea y con una incorporación imperfecta que hace de los dos países dos compañeros de viaje con escaso diálogo entre ellos, más obsesionados en perseguir esa modernidad que en reflexionar sobre sobre sus identidades y posibilidades dentro de un mundo globalizado.

Como no podía ser de otra forma, la revolución de los claveles impactó de manera decisiva más, mucho más de lo que normalmente nos imaginamos en la historia reciente de España, más concretamente en su transición hacia la democracia. En esta comunicación nos fijaremos en la influencia que el discurrir de la revolución tuvo en los dos grande partidos de la izquierda española, el PSOE y el PCE, que en aquellos momentos estaban intentando jugar un papel destacado en la transición y luchando por convertirse en el partido hegemónico de la izquierda española.

Los dos partidos acogieron los acontecimientos del 25 de abril, que suponían el fin de la dictadura en Portugal, con sumo entusiasmo. En las primeras valoraciones Santiago Carrillo consideraba que el programa de la Junta de Salvación Nacional era el mismo programa democrático que un Gobierno Provisional pondría en marcha en España. Además atribuía la caída de la dictadura portuguesa a la acción de un movimiento político y social que se asemejaba al "pacto por la libertad" que el PCE preconizaba: la convergencia entre el movimiento obrero y popular y los grupos neocapitalistas.' Así expresaba Carrillo las conclusiones que sacaba de los sucesos portugueses:

¿Qué enseña lo sucedido en el país vecino? Enseña que ningún régimen fascista, es eterno. Oue a corto plazo, y pese que aparentemente la "sucesión" se habría realizado con normalidad, la dictadura de Oliveira Salazar no ha sobrevivido a éste. Una lección para quienes sueñan que la dictadura franquista pueda sobrevivir a Franco, entronizando en la

"Alocución de Santiago Carrillo en Radio España Independiente el 26 de abril. La experiencia de Portugal. ¡Gobierno de reconciliación nacional para España! jLibertad!", Mundo Obrero, 9,8 de mayo de 1974, pp. 1-2

de 1974, pp. 1-2

jefatura del Estado a Juan Carlos. Si éste, si Juan Carlos tuviera un mínimo de sentido político, se reuniría sin tardar con su padre en Estoril y desde allí anunciaría su propósito de inclinarse ante lo que la voluntad nacional decida en elecciones libres convocadas por un Gobierno provisional de reconciliación nacional, previo al restablecimiento de las libertades, los Partido políticos, los Sindicatos, la prensa libre, la amnistía a los presos y exiliados políticos. Y Juan Carlos aprovecharía su condición de sucesor designado solamente para una cosa: encargar al ejército de asegurar con su apoyo, la formación de dicho Gobierno provisional, la transición de la dictadura a la democracia. ${ }^{2}$

Y concluye: "Pero no ignoró, que esto es mucho pedir, que no tengo ninguna razón para imaginar en Juan Carlos tan alto sentido de responsabilidad política".

Santiago Carrillo pretendía, tras los "inesperados" sucesos de Portugal meter presión a una parte del régimen para que iniciara la transición, una transición que, todavía consideraba, podía ser por ruptura. Afirmaba que la muerte del dictador español iba a suponer el final del régimen y que los sectores más moderados del mismo podrían acercarse a la oposición y así lograr la ruptura. Poco tiempo después seguía sacando conclusiones de lo sucedido en Portugal y la relevancia que esos hechos habían tenido en España. Estos hechos, según Carrillo, habían posibilitado que toda la temática política hubiera asomado a la prensa y, por lo tanto se estaba viviendo en España un momento de agitación que hacia prioritario abandonar cualquier atisbo de sectarismo para conseguir el mayor número de aliados posibles. Rechazaba por completo que en España los militares fueran a levantarse, el ejército no estaba empeñado en una guerra colonial perdida que pudiera determinar la toma de conciencia de sus cuadros. Por eso, suponía que sólo la clase obrera y el pueblo, mediante una huelga general política y la huelga nacional podían acelerar el cambio y ser protagonistas de éste. 4

EI PSOE, por su parte, a través de su órgano de expresión, expresaba su alegría y deseaba que la intervención del ejército no fuera más lejos, siendo el pueblo soberano quien decidiera su destino. Consideraba que "el restablecimiento de los derechos humanos y de la democracia en Portugal era un gran aliento para el pueblo español que todavía estaba sometido a un régimen oprobioso semejante al padecido por los portugueses" y, además, consideraba que los sucesos de Portugal aceleraban el final del franquismo. ${ }^{5}$ Sin embargo el PSOE parecía no apreciar en sus justos términos lo que había sucedido en Portugal, por lo menos eso podemos deducir de las siguientes palabras: "En Portugal, un ejército de derechas, de la derecha, y para la derecha, ha descubierto que su renovación pasa por la devolución al pueblo de su soberanía y por la democracia incipiente que en su programa esboza". 6

Estas afirmaciones parecían ignorar la profunda transformación que los oficiales del ejército portugués, debido a la guerra colonial, habían sufrido. Pero esta desconfianza hacia el ejército portugués no desapareció de los análisis del PSOE hasta la caída del V gobierno provisional. Sólo en una ocasión utiliza como ejemplo al ejército portugués, y es para afirmar que el ejército español, tras los sucesos de Portugal, debía tomar partido o por el franquismo y su camarilla o por el pueblo español.7 EI PSOE, lejos de saludar al MFA mostró siempre recelo hacia esta organización, bien por la desconfianza que le generaban los militares solo por el mero hecho

2 Ibid. pp 1-2

3 Ibid. pp.1-2

4 Santiago CARRILLO: “La primavera de Portugal y sus repercusiones en España”, Mundo Obrero, 10, 1974, p. 1.

5 Comisión Ejecutiva del PSOE y de la UGT:"Portugal: Ahora corresponde al pueblo soberano determinar libremente su futuro", El Socialista, segunda quincena de mayo de 1974, p. 1

6 "Portugal y España", El Socialista, segunda quincena de mayo de 1974, p.

7 “EEjército español o ejército franquista?", El Socialista, segunda quincena de mayo de 1974, p. 2 
de serlo o bien porque consideraba que el MFA estaba controlado por el PCP y los copconistas, representantes de la izquierda más radical. EI PSOE, siempre defendió las tesis planteadas po el Partido Socialista Portugués, y si bien es cierto que éste tuvo influencia dentro del MFA, no lo es menos que no lo pudo controlar del todo hasta la formación del VI gobierno provisional.

Otro acontecimiento de la revolución portuguesa que marco a la izquierda española, acontecimiento que supuso el final de una fase y el comienzo de otra nueva en la dinámica revolucionaría, fue el intento de golpe de Estado del 28 de septiembre. La respuesta del PCE fue solidarizarse con los partidos de la izquierda portuguesa, así como con el MFA. Después de este momento parece evidenciarse un mayor acercamiento del PCE a los postulados del PCP y sobre todo del MFA. Así quedaba reflejado en el hecho de que el Mundo Obrero publicara un extracto del programa del MFA, que había aparecido en el boletín de ese movimiento. ${ }^{8}$ Carrillo en un artículo en el Mundo Obrero, sacaba como conclusiones de los acontecimientos de septiembre que en Portugal no había una derecha civilizada: "Pero el drama de la derecha portuguesa es precisamente ése: que allí no existía una "derecha civilizada" que antes del cambio hubiera dado a conocer su posición antidictatorial y democrática y hubiera actuado en ese sentido"'. 9

En un momento en el que el franquismo se hallaba en crisis, está reflexión por parte del secretario del PCE, parecía insinuar que la derecha española, o una parte de ella, debían empezar a desmarcarse del régimen demostrando sus credenciales democráticas. El mismo Carrillo se responde a la pregunta de si en España existe una derecha civilizada con la que la oposición pueda negociar una ruptura del régimen: ¿Existe en España esa derecha? Yo creo que sí. La he visto en la Junta Democrática, personificada en hombres como Rafael Calvo Serer y otros, que no están ahí en calidad de "dóciles compañeros de viaje", sino dispuestos a defender en un régimen de libertades políticas los intereses sociales que representan. ${ }^{\circ}$

Y proseguía afirmando que el ejército español debía sacar como lección de los sucesos del septiembre portugués, que el poder civil democrático debía estar formado en un principio por un Gobierno provisional que iría, con los plazos previstos, creando las instituciones democráticas:

Enseña a los generales españoles: cuando un país está maduro para la democracia $-y$ España está archimadura- los generales deben respetar el poder civil democrático y sostenerlo para que cree, en el plazo previsto, las instituciones democráticas que tienen que responder a la voluntad popular y no pueden ser ninguna concesión paternalista."

Pero Carrillo también sacaba lecciones para la izquierda portuguesa y española. Para la portuguesa, se mostraba partidario de la unidad entre la Fuerzas Armadas y el pueblo como base para la consolidación democrática, pero advertía de que el fracaso del golpe pudiera "conducir al MFA y a los partidos de izquierda a apartarse de la vía democrática y a imponer, por medios de fuerzas transformaciones radicales aceleradas" y con ello quebrar al movimiento de alianzas democráticas que está creciendo en Europa y particularmente en el Mediterráneo. Está preocupación, como veremos más adelante, fue uno de los factores que hicieron que el PCE fuera evolucionando desde el apoyo inicial al PCP hasta una más que velada crítica y retirada de apoyo. La lección que según Carrillo podían sacar los comunistas españoles era "mantener las fuerzas unidas de la actual oposición, de izquierda y derecha".12

Esa evolución del PCE, de la que hablamos más arriba, quedaba constatada en la presencia del secretario de este partido en el Congreso del PS, celebrado en diciembre de ese mismo año.

8 "Programa del MFA", Mundo Obrero, 17, 1974, p.7

9 Santiago CARRILLO: “La lección del septiembre portugués", Mundo Obrero, 19, 1974, pp. 1 y 3.

10 Ibid. pp. 1 y 3

11 lbid.pp. 1 у 3

12 lbid.pp. 1 y 3
Carrillo fue entrevistado por el Mundo Obrero poco después, en lo que parecía un intento por explicar a sus militantes su presencia en ese Congreso. En la entrevista intentaba dejar claro que su presencia le había dado la oportunidad de reunirse con los miembros de la Comisión Política del PCP. Añadía que había supuesto una oportunidad para intercambiar opiniones con fuerzas socialistas y socialdemócratas sobre los problemas de cooperación de comunistas y socialistas en Europa, a fin de actuar para una salida progresista a la crisis. Concluía que su presencia en el Congreso del PS, no fue la única de un partido comunista, allí había estado e Partido Comunista Italiano y el Partido Comunista de Rumania y, afirmaba, que los partidos comunistas también solían invitar a partidos socialistas, como así había ocurrido en el Congreso del PC de Rumania al que habían acudido el PSOE y el Partido Socialista Popular. Estas justificaciones no ocultan el distanciamiento que el PCE quería tomar sobre el PCP y el MFA, influido por su estrategia de mostrarse ante el mundo como un partido de probadas credenciales democráticas y poder, así, conseguir una ruptura pactada en la futura transición española. ${ }^{3}$

A ese mismo Congreso también, como es obvio, acudió el PSOE. Sus valoraciones del Congreso las reflejaba en un artículo de El Socialista, donde acusaba a Álvaro Cunhal de perpetuar esquemas autocráticos en el ejercicio del poder; mostraba inquietud por las actitudes personales de algunos dirigentes del partido que se encontraban más preocupados por la oportunidad política que por la "adopción de posiciones socialistas que encaren perspectivas a medio y largo plazo". ${ }^{14}$ Esta inquietud obedecía a que en ese Congreso se habían prohibido las tendencias organizadas dentro del partido, aunque si se permitían las corrientes de opinión. Debido a esta medida, el grupo Movimiento Socialista Popular, liderado por Manuel Serra, se escindió del PS y formó el Frente Socialista Popular, poco después de la celebración de este Congreso. Finalmente el artículo afirmaba, preocupado por el problema de futuras escisiones, que el socialismo sólo se podría conseguir "Si llegan a controlar los personalismos, construyendo una línea política sobre un método de análisis marxista que tenga en cuenta que la lucha del partido es algo más que la consecución de un resultado beneficioso para una mera coyuntura transitoria"15

Pero el PSOE no solo criticaba y se mostraba crítico con los comunistas y con las escisiones que se producían en el seno del PS, también era crítico con el MFA. Criticaba la institucionalización de éste y la tutela que quería ejercer para conseguir que se cumpliera la futura Constitución. ${ }^{16}$ Como vemos el PSOE se alineaba con el PS y se alejaba de las organizaciones o movimientos que pretendían acelerar el paso de la revolución. El PSOE, al contrario que el PCE, no necesitaba mostrar sus credenciales democráticas en occidente, entre otras cosas porque recibía el apoyo de la Internacional Socialista y de los principales partidos socialdemócratas europeos, muchos con responsabilidad de gobierno. Pero siguiendo las tesis del PS con respecto al PCP y al MFA conseguía encuadrar al PCE fuera del marco democrático, o por lo menos presentarlo como un partido guia encuadrar al PCE fuera del marco democrático, o por lo menos presentarlo
con inclinaciones autocráticas como estaba sucediendo en Portugal con el PCP.

El otro acontecimiento que marcó la revolución portuguesa y que supuso el inicio de la tercera fase de la misma, fue el intento de golpe de Estado del 11 de marzo de 1975. Tras este acontecimiento los dos grandes partidos de la izquierda española se vieron obligados a alejarse de discurso crítico que habían mantenido respecto al MFA y al PCP. Ouien hace más esfuerzos por desmarcarse de ese discurso mantenido hasta entonces es el PSOE, un esfuerzo mayor porque el PCE a pesar de su alejamiento del PCP siempre había intentado mantener cierta ambigüedad con el fin de no confundir a sus militantes. Así, en un editorial de El Socialista consideraba

13 "La presencia de nuestro partido en el congreso de los socialistas portugueses -al habla con Santiago Carrillo-", Mundo Obrero, 23, 1974.

14 "Portugal: Congreso Socialista", El Socialista, 32, segunda quincena de enero de 1975, p. 11.

15 Ibid. p. 11

16 "El papel del Movimiento de las Fuerzas Armadas", El Socialista, 34, segunda quincena de febrero

de 1975, p. 2 . 
injusta la valoración que se hacía desde Europa del proceso portugués afirmando que "todos se lanzan a señalar los riegos de una dictadura de izquierda"; sin embargo, señalaba que "durante cuarenta y ocho años de una dictadura fascista contó con el silencio aprobatorio de Europa" 17 En ese mismo número aparecía un artículo donde se descartaba que el golpe hubiera sido una trampa del gobierno para eliminar a los elementos màs conservadores de las Fuerzas Armadas; criticaba las argumentaciones que defendian el golpe como un intento de devolver la revolución a sus orígenes y consideraba que no había sido más que un golpe contrarrevolucionario como había sucedido en Chile. Finalmente defendía que ahora, más que nunca, era necesaria la celebración de unas elecciones libres porque sólo la voluntad popular podía impedir estas situaciones. ${ }^{18}$ Habían desaparecido, pues, las críticas al PCP y, por supuesto, al MFA, héroe de nuevo al frenar, algunos de sus miembros más representativos, el intento de golpe de Estado.

Pero este alejamiento del discurso crítico con los sectores más radicales duró muy poco. Las elecciones a la Asamblea Constituyente supusieron, nuevamente, volver a ese discurso crítico con los sectores más radicales de la revolución portuguesa. Los socialistas españoles retomaron las críticas al MFA y volvieron a pedir el abandono del poder por parte de los militares y que se entregara éste a los civiles. Además, consideraban que el gobierno debía ser reestructurado con arreglo a los votos obtenidos en las pasadas elecciones. Las elecciones en el país vecino, añadía, eran una lección para España porque mostraban como un país al que se le consideraba analfabeto en cuestiones políticas había conseguido constituirse en un ejemplo y las pantallas alrededor del PCP habían fracasado. En una lectura interna, esta última lección supone un claro ataque a la Junta Democrática que había sido formada el pasado año alrededor del PCE y su intento de hegemonizar la oposición al franquismo.

Por su parte el PCE, después de estas elecciones, recuperaba y ahondaba el discurso que bus caba establecer distancias con el PCP y con el MFA. En una entrevista a Carrillo realizada por Rinascita, revista del $\mathrm{PCl}$, y recogida por Mundo Obrero, afirmaba que "más de la mitad del pueblo portugués se ha pronunciado por los partido favorables a una orientación socialista". ${ }^{19}$ Pero si esta frase no suponía ningún desmarque respecto al PCP y al MFA sí que lo eran las siguientes: "El pueblo portugués tras haber soportado cuarenta años de dictadura fascista, no quiere saber más de dictaduras de cualquier tipo, quiere vivir en un régimen de libertad democrática".20

Continúa: "Cada pueblo progresa políticamente eligiendo sus propias vías: las repeticiones mecánicas, que responden a otras experiencias, los excesos voluntaristas, pueden provocar consecuencias contraproducentes". ${ }^{21}$

Carrillo parecía insinuar que el PCP y el MFA llevaban a cabo planes políticos que podían poner en riesgo la democracia en el país vecino. Lo que no aclaraba suficientemente era si el excesivo voluntarismo traería un golpe contrarrevolucionario que acabaría con la democracia, o sería el PCP y el MFA con sus estrategias políticas y sus planes quienes acabarian con ella. De nuevo Carrillo volvía a pensar en clave interna, prefería mantenerse alejado del PCP para no poner en riesgo la Junta Democrática que aún no tenía un año de vida. Necesitaba una oposición unida para forzar la ruptura pactada y esto era imposible si el PCE mostraba veleidades revolucionarias.

La presentación del programa Alianza Pueblo-MFA no hizo más que acentuar ese alejamiento de los dos grandes partidos de la oposición de los sectores más radicales de la revolución portuguesa. Quienes más duros se mostraban con el desarrollo de los acontecimientos en el país vecino eran Santiago Carrillo, secretario general del PCE, y Enrico Berlinguer, secretario general

17 “Portugal, España, Europa”, El Socialista, 36, segunda quincena de marzo de 1975, p. 1.

18 "El frustrado golpe de Portugal", El Socialista, 36 , segunda quincena de marzo de 1975, p. 1 y 4

19 "Entrevista a Santiago Carrillo por Risnacita", Mundo Obrero, 16, quinta semana de mayo de 1975,

p. 8.

20 lbid. p. 8

21 lbid p. 8 del PCl. Ambos en un mitin celebrado en Livorno se mostraron muy críticos con algunas decisiones que se habían tomado en el gobierno portugués. Carrillo afirmaba en aquel mitin

Ante los últimos acontecimientos de la evolución política portuguesa tenemos que mostrar preocupación e inquietud. Si se produjera la ruptura de la alianza que se creó el 25 de abril en torno al MFA, si se rompe el juego democrático definitivamente, eso comprometería gravemente la suerte de la revolución, con daño en primer lugar para el pueblo portugués y para la causa de la democracia..

Más duro se mostraba Berlinguer:

Es a partir de estos principios que nosotros, tras haber saludado el otro acontecimiento de este periodo que fue el hundimiento de la dictadura fascista en Portugal, y de las guerras coloniales que aquel país desarrollaba en África, hemos expresado serena pero claramente nuestro desacuerdo hacia posiciones políticas y actos de los comunistas portugueses así como de los dirigentes de las Fuerzas Armadas de aquel país. Un desacuerdo que se acentúa ante las últimas decisiones del MFA, decisiones que nos preocupan en tanto que limitan las libertades y en cuanto puedan reducir el área de consenso y de participación de todas las expresiones de la voluntad popular, consenso y participación que constituyen la única garantía de una renovación de la sociedad portuguesa y su protección ante cualquier retorno reaccionario. ${ }^{23}$

Sorprende que dos partidos comunistas se mostraran tan críticos con lo que estaba sucediendo en Portugal, más si tenemos en cuenta que en el programa Alianza Pueblo-MFA venia la constitución de una Asamblea Nacional Popular, cuyos representantes iban a ser elegidos a través de asambleas de vecinos, de trabajo y otras. Si algo podía parecerse a los soviets, era el funcionamiento de aquella asamblea; sin embargo como veremos más adelante las estrategias del PCE y del PCI distaban mucho de la seguida por el PCP, quien sí que apoyaba esa nueva asamblea. Los comunistas italianos y los españoles intentaban alejarse lo máximo posible de cualquier intento que supusiera romper con la democracia liberal. Ambos, tenían intereses muy importantes para mantener esta postura: el $\mathrm{PCl}$, quería llegar al poder a través del "compromiso histórico" con los democristianos y el PCE, intentaba una ruptura pactada, que necesitaba del apoyo de los elementos más moderados del régimen franquista

Por su parte los socialistas españoles, contrarios al programa Alianza Pueblo-MFA, tomaron partido claramente por uno de los sectores en los que se dividió el MFA a causa de ese mismo programa, el sector moderado liderado por Melo Antunes y cercano al PS. Así en un artículo de El Socialista se criticaba duramente al gobierno de Vasco Gonçalves por el intento de controlar la prensa; por la creación de unas Asambleas Populares que consideraba que "no tienen operatividad política ni sindical al no tener representatividad por medio de los partidos del gobierno, y al ser la intersindical un organismo controlado reaccionariamente por los comunistas de Cunhal". ${ }^{24}$ Pero iba más lejos y afirmaba que la violenta campaña contra el PCP "no obedecía a un anticomunismo visceral y reaccionario, sino a una clara oposición a un modo concreto de protagonismo que ha llevado el PCP a desarrollar no un plan propio de alternativa comunista, sino ante un claro oportunismo". Continuaba la crítica al PCP asemejando éste a los partidos fascistas y afirmando que gracias al "fuerte respaldo popular del PS ha permitido que la si-

22 "Socialismo y democracia. Los clichés sectarios aíslan a la vanguardia. Discursos de Carrillo y Ber-

linguer en Livorno", Mundo Obrero, 20, cuarta semana de junio, 1975, p. 4.

23 Ibid.p. 4

24 "Portugal una hora crucial", El Socialista, 46, segunda quincena de agosto, 1975, p. 2. 
tuación no degenere, por ahora, en una forma más de dictadura". 25 Podemos preguntarnos, ¿por qué estos mismos actores políticos que atacaron al PCP en el "verano caliente" apenas se movilizaron con tanta intensidad durante cuarenta y ocho años de dictadura fascista? Acaso había menos libertades en el Portugal de 1975 que en el de 1973

Después de la dimisión de Vasco Gonçalves y de la formación del gobierno de Pinheiro Azevedo las críticas empezaron a amainar tanto en el PCE como en el PSOE. El primero mostró un claro apoyo al nuevo gobierno portugués y afirmaba de nuevo que no se podían quemar etapas hacia el socialismo. Eso sí, se mostraba a favor de la reforma agraria, de las nacionalizaciones y de otras medidas antimonopolistas. Por su parte, el PSOE, después de que el MFA viró hacia las posturas defendidas por Melo Antunes, consideraba a este movimiento como fundamental. El MFA, ahora, tenía que jugar el papel de conciliador entre los distintos partidos políticos y garantizar el orden y la estabilidad necesarios para que el proceso continuara sin sobresaltos. Es curioso comprobar como el PSOE que llevaba desde el principio de la revolución clamando por el alejamiento de los militares de la escena política, ahora los consideraba un factor fundamental en esa misma escena.

Los acontecimientos de noviembre de 1975 no son recogidos por ninguno de los órganos de los dos grandes partidos de la izquierda, ni por ninguna de sus revistas teóricas. Silencio absoluto. Todo parece indicar que este silencio era consecuencia del acontecimiento trans cendental que estaba sucediendo en España: la muerte de Franco. A partir de este momento el PCE y el PSOE centraron su atención en la oportunidad política que se habría en España y más teniendo en cuenta que el peligro revolucionario del país vecino, por fin, para alivio de ambos, había concluido.

Los dos grandes partidos de la izquierda española mantuvieron una posición distinta en relación a los sucesos portugueses; sin embargo, los dos intentaron mantenerse alejados de las posiciones más radicales que se producían dentro del proceso.

EI PSOE, al igual que el PS, era un partido con fuertes vínculos con la socialdemocracia europea y con la Internacional Socialista. Esa vinculación les permitió obtener un certificado de autenticidad socialista; les confirió un prestigio tremendo al identificarse con los gobiernos socialdemócratas más importantes; les dotó de un considerable apoyo económico para la reactivación de sus aparatos y la formación de sus cuadros; y una presión diplomática por parte de los gobiernos socialdemócratas para que los partidos socialistas de la península tuvieran un trato más benévolo cuando se encontraba en la oposición..$^{26}$ Todo este apoyo se tradujo en una fidelidad a los postulados de los centros de poder europeo, que no querían ningún tipo de experimento revolucionario en el sur de Europa. Los dos partidos socialistas, a pesar de su fraseología de un socialismo autogestionario, nunca pensaron en instaurar en sus países nada parecido a lo que proclamaban. EI PS portugués fue el factor fundamental que moderó el fervor revolucionario de los portugueses para encuadrarlos en las coordenadas geopolíticas del bloque occidental. Para el PSOE, la experiencia portuguesa fue un curso de formación política intensivo.

EI PCE, al igual que el PCP, compartían el mismo problema, los dos, como cualquier partido comunista, habían sido creados para hacer la revolución. Sin embargo, la época que les tocó vivir puso de manifiesto la imposibilidad de alcanzar tal objetivo. En ese contexto, el PCE apostó por el eurocomunismo, un fenómeno ideológico que aportaba novedades importantes. En primer lugar, la conveniencia de utilizar las instituciones liberales en la transición al socialis mo y respetar una parte fundamental de éstas en la propia sociedad socialista. En segundo lugar, la ruptura con la tutela soviética y una crítica más o menos abierta al denominado So-

25 Ibid.p. 2

26 Joan GARCÉS: Soberanos e intervenidos. Estrategias globales, americanos y españoles, Madrid, Siglo

XXI, 1996, cap. 4.
. cialismo Real. ${ }^{27}$ Pero si bien el PCE se adscribió al eurocomunismo para presentarse como un partido democrático, el PCP no creyó en ningún momento que fuera necesario hacerlo para considerarse más democrático. Cuando el PCP se encontró con el golpe de abril y con ello la caída de la dictadura, vio la posibilidad de aplicar la estrategia que Cunhal había presentado al Comité Central en abril de 1964. La estrategia contemplaba que una vez derribada la dictadura se acometería un amplio plan de nacionalizaciones y una progresiva transferencia del poder a los trabajadores gracias a la construcción de un nuevo aparato institucional que, sin acabar con el pluripartidismo, pivotaría sobre el partido comunista en tanto que partido de vanguardia. ${ }^{28}$ La estrategia la llevó al límite, hasta el umbral de una guerra civil en Portugal queriendo conservar la dirección del proceso cuando las primeras elecciones constituyentes le situaron como tercera fuerza política. Al final el PCP dio marcha atrás y ante la amenaza militar del Grupo de los Nueve, afines al PS, renunció a dar un golpe de fuerza. Como resultado de esto los comunistas portugueses hicieron un pacto tácito en virtud del cual se consiguió parar un más que posible enfrentamiento armado a cambio de mantener las conquistas revolucionarias consagrándolas en la futura Constitución.

EI PCE, siempre vio como una amenaza para su estrategia los acontecimientos que estaban sucediendo en Portugal. Apoyar al PCP significaba que en Europa no lo verían como un partido verdaderamente democrático y que la oposición moderada al franquismo, ahora integrada en la Junta Democrática, podría abandonarlo y perder con ella la posibilidad de hegemonizar esa oposición. Los partidos comunistas del sur de Europa estaban muy lejos de poder o querer protagonizar una revolución, sólo el PCP, una vez caída la dictadura, tuvo que hacer frente a un proceso revolucionario que en ningún momento pretendió llevar más allá del marco de una democracia parlamentaria. Resulta sorprendente que partidos que nacieron para hacer la revolución decidieran no apoyarla donde se ofrecía una posibilidad, ya sea dentro de sus países como en el mayo del 68 o fuera de ellos como en Portugal. Entre las razones de este posicionamiento están la división del mundo en bloques, la profunda asimilación del ejercicio de la política como un juego político de élites y la incapacidad de ver que ellos mismos habían entrado en la lógica del capital. Cuando tuvieron responsabilidades de gobierno, como en el caso portugués, o la capacidad de influir en las políticas estatales, apostaron por medidas económicas que trataban de corregir la caída de los rendimientos del capital a costa de disciplinar al movimiento obrero. Ningún partido comunista fue capaz de leer con claridad la crisis de los años setenta, una crisis que no sólo afectaba a la economía, sino que iba mucho más allá y planteaba enormes desafíos en la esfera política y cultural.

27 Juan Antonio ANDRADE BLANCO: "La revolución de los claveles y la transición: la izquierda ante el cambio político en España y Portugal", http://www.ahistcon.org/docs/murcia/contenido/pdf/16/ juan_antonio_andrade_blanco_talleri6.pdf.

28 Alvaro CUNHAL: Rumo á Vitoria. As tarefas do Partido na Revoluçao Democrática e Nacional, Lisboa, Avante, 2001. 


\section{LA DIFÍCIL PUESTA EN MARCHA DE LA CONSTITUCIÓN: \\ EL CASO PARADIGMÁTICO DE LA LEY ORGÁNICA}

REGULADORA DEL DERECHO A LA EDUCACIÓN (LODE)

Vincent Marin

Universidad de Albi

Durante la II Legislatura de España, el Partido Socialista Obrero Español llevó a cabo un ambicioso proyecto reformista cuya piedra angular era el cambio prometido durante la campaña electoral para las elecciones generales del 28 de octubre de 1982. Paradójicamente, en muchos ámbitos, este cambio no suponía una ruptura con el pasado sino la consolidación de los avances democráticos recién conseguidos. En materia educativa, fue José María Maravall, catedrático de Sociología política de la Universidad Complutense y entonces descrito por el diario conservador $A B C$ como "un ideólogo moderado", el que fue encargado de llevar a cabo la política educativa. La principal tarea del nuevo Ministro consistía en completar o volver a redactar una legislación acorde con el texto constitucional elaborado por la Comisión de Asuntos Constitucionales y Libertadas Públicas que había sido creada a finales de julio de 1977 y que había reunido a siete diputados de distintos signos políticos. ${ }^{2}$ Pero si el contenido del artículo 27 de la Constitución había permitido hablar en el momento de su redacción de "pacto escolar" o de "consenso", el desarrollo de una legislación fiel a los principios constitucionales no fue un camino de rosas: cinco apartados de la Ley Orgánica por la que se regulaba el Estatuto de Centros Escolares (LOECE) aprobada por el anterior gobierno de UCD el 19 de junio de 1980 habían sido declarados parcialmente nulos por el Tribunal Constitucional ${ }^{3}$ y varios artículos de la Carta Magna 4 no habían sido lo suficientemente considerados o incluso no habían sido contemplados en dicho texto. Finalmente, habría que esperar dos años de tramitación puntuados por multitudinarias manifestaciones para que se publicara en el Boletín Oficial del Estado la Ley Orgánica 8/1985, del 3 de julio, reguladora del Derecho a la Educación (LODE).

El problema que se plantea desde el punto de vista historiográfico consiste en saber po qué un texto de ley que pretendía constituir "una nueva norma que desarroll[ara] cabal y

1 "El Gabinete de Felipe González", $A B C, 3$ de diciembre de 1982, p. 26

2 Los denominados "Padres de la Constitución" pertenecían a los cinco partidos políticos más importantes de aquel entonces. Eran tres diputados de UCD -Gabriel Cisneros Laborda, Miguel Herrero y Rodriguez de Miñón y José Pedro Pèrez-Llorca Rodrigo-, uno de AP -Manuel Fraga Iribarneuno del PSOE - Gregorio Peces-Barba Martínez, - uno del PCE -Jordi Solé Tura,- y otro de CiU -Miquel Roca i Junyent.

3 Sentencia de 13 de febrero de 1981, Boletín Oficial del Estado, 24 de febrero de 1981, Supl. al núm. 47 , pp. 16-30. Los puntos declarados inconstitucionales eran esencialmente apartados de los artículos vinculados con la participación de la comunidad escolar en la gestión de los centros.

4 Se trata en particular de los apartados 5, 7 y 9 del artículo 27.

5 Después de la presentación del anteproyecto de ley el 9 de junio de 1983 , el trámite parlamentario duró desde el 11 octubre de 1983 hasta el 15 de marzo de 1984 L L LODE fue aprobada por 196 votos du favor correspondientes al Grupo Socialista y a la Minoria Catalana, 96 en contra, del Crupo Popular y la Minoria Vasca, y seis abstenciones del Grupo Mixto. Finalmente, habria que esperar la publicación de la sentencis del Tribunat Constitucionat publicada el 28 de junio de 1985 para que entrara en vigor unos días después. armónicamente los principios que, en materia de educación, conten[ía] la Constitución española, respetando tanto su tenor literal como el espíritu que presidió su redacción"6 se convirtió en la fuente de divisiones más importante de toda la II Legislatura tanto en la esfera parlamentaria como en la sociedad civil.

\section{Un "pacto escolar" de trampantojo}

En primer lugar, el estallido de una "guerra escolar" en torno a la LODE brotó de los problemas derivados del supuesto "pacto escolar" que se había concluido en torno al artículo 27 de la Constitución. A pesar de un aparente acercamiento de posiciones, el pacto alcanzado no conllevó una renuncia efectiva de las distintas fuerzas políticas a su respectivo modelo educativo, lo cual se manifestó claramente a la hora de impulsar una legislación en materia educativa.

Une primera lectura del artículo 27 parece indicar que el éxito del pacto escolar alcanzado por las distintas fuerzas políticas fue permitida en gran medida por las renuncias mutuas a ciertos principios e ideales educativos heredados de corrientes de pensamientos antagónicos, lo que deja suponer, como lo señala el catedrático de Política de la educación Manuel de Puelles Benítez, que "los partidos principales tuvieron que hacer importantes concesiones".? El paso más significativo por parte de los partidos progresistas fue sin duda el renunciar a un sistema escolar exclusivamente público ${ }^{8}$ y el aceptar la dualidad del sistema educativo. En cuanto a los partidos conservadores, parecieron conceder al Estado cierta capacidad de regulación respecto a los centros privados, en su gran mayoría regidos por órdenes confesionales.

A pesar del empeño manifestado por los partidos políticos en demostrar que sus respectivos planteamientos no eran excluyentes, la feroz batalla librada a posteriori entre partidos conservadores y progresistas en torno a la LOECE y más todavía a la LODE permite poner en tela de juicio la efectividad del pacto escolar. En efecto, una vez redactada la Constitución, la puesta en marcha de una legislación acorde con los principios constitucionales menoscabó considerablemente el supuesto "consenso" alcanzado entre las distintas fuerzas políticas durante un proceso democratizador marcado por la necesidad de no polarizar posiciones. Mariano Pérez Galán, a la par militante socialista, Director del departamento de Educación y Cultura del Gabinete de la Presidencia durante la II Legislatura y autor de La LODE : infrahistoria de una ley ${ }^{9}$ afirma al respecto que "todas [las fuerzas políticas] apoy[aban] la Constitución y cada un[a] le[ía] el articulo 27 desde [su] propia concepción educativa". Así pues, mientras los partidos políticos conservadores pretendían en su oferta electoral proteger ante todo "el derecho de los padres a elegir el centro y el tipo de enseñanza más de acuerdo con sus ideas y aspiraciones personales" 10 los partidos de izquierdas ponían especial énfasis en la educación como servicio público y en la necesaria democratización de los centros docentes.

Terminado el proceso constituyente, los gobiernos de turno tuvieron que jerarquizar prioridades en la definición de su política educativa, mientras que el principal partido de la opo-

6 Ley Orgánica 8/1985 de 3 de julio, reguladora del Derecho a la Educación, Boletín Oficial del Estado, jueves 4 de julio de 1985, núm. 159, p. 21015.

7 Manuel DE PUELLES BENITEZ: Modernidad, republicanismo y democracia: una historia de la educación en España, 1898-2008, Valencia, Tirant lo Blanch, 2009, p. 403.

8 Distaba en gran medida de las resoluciones del XXVII Congreso del PSOE de diciembre de 1976 , que proponían nada menos que la suspensión de todo tipo de ayuda estatal a los centros privados, la desaparición de las materias confesionales de los planes de estudio y la autogestión de los centros docentes.

9 A pesar de ser redactado por -el propio autor reconoce que "está escrito por un socialista"- este libro constituye una herramienta imprescindible a la hora de aprehender la elaboración de la Ley y la estrategia del Ministro Maravall en su puesta en marcha.

10 Alianza Popular, "Es hora de soluciones". Programa de Alianza Popular, s.l., s.n., 1982, p. 103.

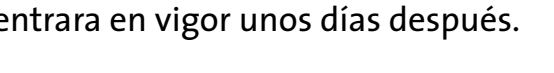


sición se erigía en defensor de los principios constitucionales correspondientes a su modelo educativo. Así pues, en un documento destinado a condenar el contenido del proyecto de LOECE, el PSOE desde la oposición afirmaba lo siguiente:

Los enseñantes esperaban que con el proceso democrático se diera paso a una nueva orientación de la enseñanza, que habría de basarse en los principios que recoge nuestra Constitución: gestión democrática, igualdad de oportunidades, pluralismo ideológico, libertad de cátedra, control de los fondos públicos, etcétera. Sin embargo, el proyecto de Ley por el que se regula el Estatuto de centros docentes no universitarios viene a frustrar las esperanzas democráticas de los enseñantes y mantiene la situación precedente: es una nueva ley para perpetuar las viejas."

Los temas aquí mencionados corresponden precisamente a los puntos defendidos por los socialistas durante la redacción de la Carta Magna. Una vez en la oposición, los partidos de derechas adoptaron semejante estrategia, lamentando que no se respetaba el derecho de los padres a elegir el tipo de educación acorde con sus convicciones, la libertad de creación y dirección de centros. Varios años después del llamado "pacto escolar", el debate en torno a la educación seguía fuertemente polarizado en torno a dos modelos educativos opuestos. En vez de retocar los puntos declarados inconstitucionales, el PSOE quiso derogar, como lo había anunciado en su programa electoral, la totalidad del arsenal legislativo desarrollado por el anterior Gobierno.12 Para sacar adelante esta promesa electoral, a pesar de que el PSOE detentara una abrumadora mayoría absoluta en las Cortes, el Ministro Maravall quiso preparar e terreno antes de darse público el primer borrador del texto de Ley. Decidió optar por la vía de la concertación y del diálogo reuniéndose en varias ocasiones con las distintas instituciones religiosas y educativas susceptibles de provocar un duro enfrentamiento con el Gobierno. ${ }^{13}$ Pero diálogo no fue sinónimo de negociación y en ningún momento abandonó los grandes propósitos que se había planteado, y que consistían fundamentalmente en recuperar el protagonismo del Estado en materia educativa tanto pública como privada y en modificar las instancias de decisión en los centros docentes.

\section{Las discrepancias en torno al papel del Estado en la educación}

Cuatro de los nueve apartados del artículo 27 de la Carta Magna sobre educación no universitaria asignan explícitamente al Estado varios papeles en esta materia. Así pues, los poderes públicos aparecen como una fuerza de apoyo garantizando ciertos derechos (artículos 3 y 5 ) y ayudando financieramente a los centros docentes (artículo 9) pero también desempeñan una

11 PSOE: Una educación democrática para la democracia. Suplemento del dossier "Los socialistas y el estatuto de centros docentes", Madrid, Secretaría Federal de Prensa y Propaganda, Secretaría Federal de Política Sectorial, 1980, p. 3 .

12 En el punto dedicado a la educación, en la segunda parte del programa titulado "Una sociedad más justa e igualitaria" se formula explícitamente este deseo: "Los centros docentes serán transformados progresivamente en auténticas comunidades escolares, en las que la educación será asumida como una tarea común. Las comunidades escolares intervendrán en el control y la gestión de los centros a través de los Consejos escolares, cuya creación no se limitará sólo a los centros, sino que se extenderá a otros ámbitos más amplios. A tales efectos se derogará la actual Ley de Estatutos de Centros, sustituyéndola por otra adecuada al texto constitucional".

13 Mariano Pérez Galán revela que las reuniones con la Conferencia Episcopal empezaron el 11 de Mariem el 11 de los sindicatos de la enseñanza privada sostuvieron tres reuniones formales para tratar del anteproyecto de LODE" entre el 20 de abril y el 15 de mayo de 1983 . Véase Mariano PÉREZ CAĹN: La LODE: infrahistoria de una ley, Toledo, Junta de Comunidades de Castilla-La Mancha, 2001, pp. 51-69. función reguladora "inspeccion[ando] y homolog[ando] el sistema educativo para garantizar el cumplimiento de las leyes" (artículo 8). Sin negar la garantía de derechos y las ayudas financieras a centros privados, el Ministro Maravall, que en varias ocasiones había denunciado "la inhibición del Estado" y el principio de "subsidiariedad del Estado respecto de la iniciativa privada", 14 quiso afianzar el papel regulador del Estado en materia educativa mediante la racionalización de dichas ayudas y la puesta en tela de juicio del sacrosanto "ideario" consagrado en la LOECE.

El tema de la financiación de la enseñanza obligatoria era un asunto pendiente, puesto que el proyecto de ley que había elaborado el Gobierno de UCD ni siquiera había sido tramitado al Congreso. Existía pues un vacío jurídico en la materia. A pesar de que el Ministro Maravall expresara su deseo de querer garantizar y amparar la educación privada, la cuestión de la financiación de los centros concertados fue manejada para exigir una mayor intervención del Estado en las decisiones inherentes a dichos centros. En el primer proyecto de ley que se hizo público a principios de junio de 1983 no se hacía referencia a la fijación por el Estado del coste del puesto escolar y no se detallaban las futuras modalidades de financiación de los centros privados subvencionados destinados a convertirse en "centros concertados". Conforme se fue precisando el proyecto de ley, el Gobierno aludió a dos tipos de costes: los de personal y los de funcionamiento. Los centros privados subvencionados consideraron estos términos como demasiado restrictivos y acusaron al Gobierno de querer destruir la enseñanza confesional en su intento de racionalización de las subvenciones. ${ }^{15}$ La tensión se fue exacerbando cuando en el tema de los costes salariales, el 7 de junio de 1983, el Ministro de Economía y Hacienda, Miguel Boyer, deseoso de no incrementar el gasto público introdujo modificaciones económicas en el proyecto de ley de educación para evitar la equiparación salarial de los sueldos percibidos por los profesores de los centros privados con los de la escuela pública. El 3 de agosto de 1984, la Conferencia Episcopal hizo público un comunicado en el cual se estipulaba que la LODE "no permite prever ni la creación de nuevos centros docentes de iniciativa privada, ni la simple pervivencia de la mayor parte de los centros privados existentes". ${ }^{16} \mathrm{El} 26$ de septiembre de 1983, o sea incluso antes de la presentación del proyecto de ley en el Congreso, el Grupo parlamentario Popular se hizo eco de los temores ex presados por la Conferencia Episcopal pidiendo que el Estado fijara el coste del puesto escolar común a los centro públicos y privados subvencionados y que fuera el Director del centro el que repartiera a su antojo y voluntad el dinero recibido del Estado. Si esta petición no fue tenida en cuenta por el Gobierno socialista, lo que sí ampliaron fueron los tipos de subvenciones otorgadas a la enseñanza privada al substituir "los costes de funcionamiento" por "los costes no salariales". Por otra parte, en los años correspondientes a la tramitación de la LODE, se pudo observar un notable incremento de las subvenciones otorgadas a dichos centros, tanto para la educación general básica como para la educación especial y la formación profesional. Resulta particularmente perceptible en el caso de la Educación General Básica (EGB), que fue la que más subvenciones obtuvo, con un ritmo de incremento tan sostenido e incluso superior a los años de gobiernos ucedistas. ${ }^{77}$ Este incremento debe sin duda interpretarse como la voluntad por parte del Gobierno socialista de tranquilizar a los representantes de los centros privados temerosos ante una posible estatalización de la educación y al mismo tiempo de utilizar las subvenciones como variable de ajuste durante la tramitación del proyecto de ley.

14 Diario de sesiones del Congreso de los Diputados, Pleno y Diputación Permanente, núm. 67, 11 de octubre de 1983, pp. 2973-2974.

Vease Esteban S. BARCIA: Reportaje: La financiación de los centros concertados, problema de fondo de la Ley de Educación", El Pais, 4 de julio de 1983.

16 Joaquina PRADES: "Los obispos españoles advierten que mantienen reservas críticas hacia la nueva ley de Educación", El Pais, 4 de agosto de 1983

17 El incremento fue de un $15,4 \%$ en 1983 y de un $16,3 \%$ y 1984 según la cifras del Ministerio de Educación y Ciencia. 
Otro objetivo del Gobierno socialista fue garantizar una programación general de la enseñanza sin perjudicar el "derecho que asiste a los padres para que sus hijos reciban la formación religiosa y moral que esté de acuerdo con sus propias convicciones" contenido en el artículo 3 de la Carta Magna. Aunque el anteproyecto de ley distaba mucho de tener la fuerte componente laica que había caracterizado la política educativa desarrollada por los Gobiernos de izquierdas durante la II República, el Ministro Maravall quería evitar que en los centros privados fuera la iniciativa privada la que definiera unilateralmente sus contenidos pedagógicos. El concepto de "ideario" -eje de la LOECE pero no recogido como tal en la Constitución ${ }^{18}$ y que había sido calificado por los socialistas como "la creación de auténticos ghettos ideológicos o confesionales"19- fue puesto en tela de juicio. Para conseguir su propósito, el Gobierno no quiso cuestionar formalmente la existencia de un ideario - ya que éste había sido avalado por el Tribunal Constitucional en su sentencia del 13 de febrero de $1981^{20}$ - y optó por eliminarlo indirectamente mediante el reforzamiento en la nueva ley de dos principios constitucionales: la libertad de cátedra ${ }^{21}$ y la participación efectiva de amplios sectores en la programación de la enseñanza. Como en otros puntos de la Ley, los sectores conservadores vieron en estas iniciativas un ataque a la independencia de los centros privados. El 14 de junio de 1983, unos días después de la publicación del anteproyecto de Ley, la Federación Española de Religiosos de la Enseñanza (FERE), a través de su secretario general el padre Martín Jiménez, afirmó que la LODE era "una ley mucho más grave que la despenalización del aborto para un católico ya que está pensada maquiavélicamente para cargarse la libertad de enseñanza y, a largo plazo, el ideario católico de los centros".22 Este debate en torno al ideario fue agravado por la denominada "guerra de los catequismos" que estalló cuando el Gobierno prohibió la utilización de libros de textos escolar editados por la Conferencia Episcopal en septiembre de 1983. Otero Novas que, durante su gestión como Ministro de Educación entre abril de 1979 y septiembre de 1980 había introducido el concepto de ideario en la LOECE, hizo de esta cuestión su caballo de batalla. Formulando su temor a que "se implante la autogestión en las escuelas" y a que "España se convierta en otra Yugoslavia", no dudó en afirmar que el principal objetivo de la LOECE había sido "garantizar el ideario del centro, porque nadie puede impedir que los cristianos queramos educar cristianamente a nuestros hijos en centros subvencionados por el Estado". ${ }^{23}$ Una vez más, los partidos conservadores concordaron con las asociaciones y autoridades religiosas y se encargaron de relegar los temores expresados por la Conferencia Episcopal en la esfera parlamentaria. En la sociedad civil, la patronal de la enseñanza privada y las asociaciones de padres

18 Sólo aparece en el artículo 3 que "los poderes públicos garantizan el derecho que asiste a los padres para que sus hijos reciban la formación religiosa y moral que esté de acuerdo con sus propias convicciones".

9 PSOE: Una educación democrática..., p. 5

20 En el punto 8 de los fundamentos jurídicos de la sentencia del Tribunal se declara que "este precepto seria, efectivamente, inconstitucional, como el recurrente pretende, si no señalase limitaciones al alcance del ideario, pero mediante esa referencia a los principios y declaraciones de la Constitución los establece de manera genérica y suficiente, y no puede ser tachado de inconstitucionalidad".

21 La libertad de cátedra fue reforzada pero con límites, dado que la sentencia del Tribunal constitucional del 13 de febrero de 1981 había definido que "son los planes de estudios establecidos por la autoridad competente, y no el propio profesor, los que determinan cuál haya de ser el contenido mínimo de la enseñanza, y son también estas autoridades las que establecen cuál es el elenco de medios pedagógicos entre los que puede optar el profesor". Véase la sentencia de 13 de febrero de 1985, Boletín Oficial del Estado, 24 de febrero de 1981, Supl. al núm. 47, p. 20.

22 "La LODE,'más grave que la del aborto para un católico', según el padre Martín Jiménez", El País, 14 de junio de 1983.

23 Joaquina PRADES: “El Parlamento, el Tribunal Constitucional y la movilización en la calle, tres frentes del Grupo Popular contra la LODE", El Pais, 26 de septiembre de 1983. católicos reunieron en torno a la defensa del ideario a cientos de miles de personas en varias ciudades españolas el 17 de diciembre de 1983, el 25 de febrero de 1984 y el 18 de noviembre de 1984 pero no consiguieron que el Gobierno hiciera marcha atrás.

\section{La cuestión de la democratización}

Introducidos a demanda de los partidos progresistas en la Carta Magna, el artículo 5 que establece que "los poderes públicos garantizan el derecho de todos a la educación, mediante una programación general de la enseñanza, con participación efectiva de todos los sectores afectados y la creación de centros docentes" y el 7 según el cual "los profesores, los padres y, en su caso, los alumnos intervendrán en el control y gestión de todos los centros sostenidos por la Administración con fondos públicos, en los términos que la ley establezca" casi no habían sido plasmados en la legislación durante los gobiernos ucedistas. Característica fundamental del programa educativo socialista, la cuestión de una mayor democratización de las instituciones mediante la creación de Consejos escolares y el nombramiento del Director de los centros docentes concertados constituye uno de los elementos más polémicos recogidos en los borradores e in fine en el texto definitivo de la LODE.

La participación efectiva de padres, profesores y alumnos tanto en una vertiente pedagógica - la programación general de la enseñanza- como financiera -la gestión de los centros docentes- constituía una prioridad para el PSOE incluso antes de la aprobación de la Constitución..$^{24}$ Además de las instancias directivas unipersonales ya existentes -Director, secretario, jefe de estudios...- e independientemente del claustro de profesores la LODE quiso introduci - y de hecho introdujo- en los centros la creación de un órgano de gobierno colegiado: el Consejo Escolar del Centro. Compuesto de las instancias directivas pero también de personales de la administración, de representantes del Ayuntamiento y de padres y alumnos, este Consejo se convirtió en el máximo órgano de gestión de un centro docente. La creación de este Consejo al nivel del centro vino acompañada de la creación de un Consejo escolar estatal y de un Consejo escolar de ámbito territorial para garantizar un mayor grado de democratización a diferentes escalas y el principio de programación de la enseñanza. Con la publicación de un millón de folletos explicativos publicados en el marco de una campaña explicativa en octubre de 1983, el PSOE quiso explicar a los ciudadanos el contenido de la ley recordando que "era necesaria por imperativo constitucional (...), por las consecuencias derivadas de la sentencia de Tribunal Constitucional que fuerza la modificación de la legislación anterior" pero asumiendo un enfoque progresista en la puesta en marcha del desarrollo del principio constitucional de participación:

La creación de este Consejo es testimonio práctico de que el PSOE no quiere una educación dirigista, sino la mayor participación posible, y pasará a la historia de la educación española que, teniendo los socialistas mayoría absoluta en el Parlamento, y siendo el Gobierno monocolor PSOE, se estableció un órgano de participación al máximo nivel, de una amplitud en su composición y competencias sin precedentes en nuestro país. 25

A lo largo de la tramitación de la LODE, las instituciones y partidos conservadores expresaron en varias ocasiones su disconformidad hacia la creación y sobre todo las competencias atribuidas a dicho órgano, al denunciar, como lo muestra una nota del Consejo de la Escuela

24 El 9 de febrero de 1978 había presentado un proyecto de ley sobre constitución de Consejos escolares que había sido rechazada.

25 PSOE, Grupo federal de educación y UGT, Federación española de trabajadores de la enseñanza:

Ley orgánica del derecho a la educación, LODE: aprender en libertad, Madrid, PSOE-UGT, 1983, pp. 1- 2 . 
Cristiana de Cataluña del 20 de marzo de 1985, "el acento abusivo en la participación, estableciendo un Consejo Escolar con unas atribuciones que van más allá de lo que es razonable en un órgano colegiado de un centro educativo". ${ }^{26}$ Cabe recalcar que las discrepancias en torno a la creación de dicho órgano tenía tanto una vertiente ideológica heredada de concepciones educativas antagónicas entre conservadores y liberales como política, puesto que su introducción afectaba las estructuras de poder ya existentes.

En nombre de una mejor democratización de las instancias educativas, los cambios introducidos por la LODE en las modalidades de nombramiento del Director y del equipo directivo constituyeron otro punto de gran conflictividad desde el anteproyecto de ley hasta su aprobación. Este cambio suponía una limitación a la posibilidad de actuación de los titulares de los centros privados financiados con dinero público, que hasta entonces eran los únicos capacitados para ello. Con la LODE, se le concedió al Consejo Escolar del Centro ya evocado anteriormente la capacidad de elegir - y, en caso de falta grave de cesar o de suspender- al Director en los centros estatales y los centros concertados. Desde el principio de los debates parlamentarios el democristiano del Partido Demócrata Popular (PDP) Óscar Alzaga en nombre del Grupo Popular en el Congreso, argumentó que las nuevas modalidades del nombramiento del Director constituía un claro motivo de inconstitucionalidad:

Si el titular del centro no puede establecer ni directamente ni a través del Director las líneas pedagógicas del mismo, no puede seleccionar el profesorado, no puede despedir al profesorado, no puede normar el régimen interior del centro, etcétera, ¿en qué queda el derecho constitucional a la dirección del centro; es decir, en qué queda la titularidad de dirigir el propio centro incorporada a la Constitución? ${ }^{27}$

Esta queja quedó plasmada en el motivo $5^{\circ}$ del recurso previo de inconstitucionalidad presentado el 16 de abril de 1984 por el Grupo Popular según el cual "no se respet[aba] el contenido esencial de las facultades directivas del titular" pero no fue avalado por el Tribuna constitucional. ${ }^{28}$

\section{Conclusión}

El estudio de la tramitación de la LODE resulta paradigmático de las dificultades heredadas del exitoso proceso constituyente llevado a cabo unos años antes. Durante el proceso de Transición como tal, las fuerzas políticas, conscientes de lo que estaba en juego, aceptaron plasmar en el texto constitucional planteamientos que habían sido hasta entonces excluyentes, convirtiendo la Carta Magna en una especie de cajón de sastre. Una vez terminado este proceso, presentado a los ciudadanos como fruto de consenso, empezó la segunda etapa identificada como "consolidación de la Transición". En esta segunda etapa no fueron los miembros de varias fuerzas políticas los que decidieron acerca de las reformas que había que impulsar para poner en marcha una legislación acorde con los principios constitucionales, sino un gobierno marcado por un determinado signo político. Por mucho que se defendiera de ello, ${ }^{29}$ y más allá

26 Secretariado de la Escuela Cristiana: Aciertos y errores de la LODE, Barcelona, Secretariado de la Escuela Cristiana, 1985 p. 4.

Diario de sesiones del Congreso de los Diputados, Pleno y Diputación Permanente, 11 de octubre de 1983 , núm. 64, p. 2991.

28 Sentencia número $77 / 1985$, de 27 de junio de 1985, Boletín Oficial del Estado, 17 de julio de 1985 , núm. 170. Suplemento, pp. 21-41.

29 En el caso de la LODE, el Ministo Maravall empezó su discurso de presentación del proyecto de ley afirmando que dicho proyecto "no pretend[ía] reflejar una concepción partidista, que hubiera de los motivos jurídicos avanzados para legitimar -o, en el caso de rechazarlos, deslegitimar los proyectos legislativos-, el legislador fue guiado por criterios interpretativos de índoles ideoló gicas y políticas. ${ }^{30} \mathrm{Si}$ contrariamente al proyecto de ley de Alain Savary que pretendía crear un gran servicio público de educación, la LODE salió adelante, ${ }^{31}$ fue sin duda porque el Ministro Maravall soltó lastre en el tema de la financiación otorgando contrapartidas económicas que se tradujeron por un incremento notable de las ayudas públicas a los centros concertados especialmente en los dos años de tramitación de la Ley. A falta de constituir una verdadera síntesis consensuada de varias tradiciones antagónicas, el texto constitucional permitió establece un "sistema de pesos y contrapesos" 32 que obligó a los gobiernos de turno a integrar en la legislación, aunque sea a regañadientes, principios heredados de modelos educativos plurales. podido dar lugar a un proyecto centrado en torno a la oferta estatal de educación y a la escuela pública como modelo" véase Diario de sesiones del Congreso de los Diputados, Pleno y Diputación Permanente, 11 de octubre de 1983, núm. 64, p. 2976.

30 Dichos criterios se pueden observar de la misma manera en el recurso previo de inconstitucionalidad presentado por el Grupo parlamentario Popular el 16 de abril de 1984.

31 De los 16 artículos impugnados por Alianza Popular en su recurso previo de inconstitucionalidad, sólo fue declarado inconstitucional el segundo párrafo del artículo 22.2.

32 Expresión utilizada por el Ministro Maravall en los debates parlamentarios: véase Diario de sesiones del Congreso de los Diputados, Pleno y Diputación Permanente, 11 de octubre de 1983, núm. 64 政 enseñanza, Barcelona, Laia, 1984, p. 23. 


\section{LA HORA DE DEMOCRATIZAR LOS AYUNTAMIENTOS: LAS ELECCIONES MUNICIPALES DE ABRIL \\ DE 1979 EN MADRID}

Marcos Marina Carranza

Universidad Autónoma de Madrid

La evolución de la investigación historiográfica ha hecho que determinadas cuestiones que forman parte del proceso de transición a la democracia sean, a día de hoy, menos conocidas que otras debido a la escasa atención que han prestado hacia ellas los estudios realizados sobre el mencionado fenómeno. El resultado de este panorama se asemeja a un poliedro en el que algunas de sus caras aparecen perfectamente definidas y delimitadas, mientras que otras están ligeramente esbozadas o ni siquiera son visibles. Una de estos campos prácticamente oscuros es la dimensión municipal del cambio político, aquella dedicada al análisis de la democratización de la administración local.' Una línea de investigación esencial para conocer no solo las características de la llegada de la democracia a los ayuntamientos españoles sino también la importancia que tuvo en el proceso de cambio político a nivel estatal.

El objetivo de la presente comunicación es, precisamente, resaltar la trascendencia de la perspectiva local en los estudios sobre la democratización española. Para ello, se ha escogido un caso muy específico, el desarrollo en la ciudad de Madrid de las elecciones municipales de 1979. Concebido como el momento en que formalmente la democracia llegó a las corporaciones locales, se pretende remarcar la importancia tanto de la cita con las urnas como de lo sucedido en Madrid, en calidad de capital del Estado. El tratamiento de los diferentes ingredientes que conformaron esa convocatoria dará pie para que, al final del texto, se reflexione sobre esta cuestión a partir de las conclusiones obtenidas.

\section{Las candidaturas electorales}

A comienzos del año 1979 el gobierno presidido por Adolfo Suárez convocó elecciones municipales, que debían celebrarse el martes 3 de abril. Se trató del momento en que alcaldes y concejales pasaron a ser democráticamente elegidos por la ciudadanía, consumando una renovación de poder local que la oposición estuvo reclamando con creciente insistencia durante los años anteriores y que el ejecutivo ucedista fue sucesivamente aplazando. Como consecuencia, los ayuntamientos fueron la última instancia administrativa en democratizarse, provocando una "ruptura real entre el mundo local y los órganos políticos del Estado", tal como afirmó Irene Delgado."

1 La poca presencia de este tipo de estudios puede comprobarse en los estados de la cuestión sobre el recorrido historiográfico del proceso de democratización acontecido en España. Tres ejemplos en Manuel Ortiz Heras: "Historiografía de la transición", en La transición a la democracia en España Actas de las VI Jornadas de Castilla-La Mancha sobre investigación en archivos, Guadalajara, ANABAD Castilla-La Mancha, 2004, pp. 223-242; Rafael Ouirosa-Cheyrouze: "La Transición a la democracia: una perspectiva historiográfica", en Rafael Quirosa-Cheyrouze (coord.): Historia de la transición en España: los inicios del proceso democratizador, Madrid, Biblioteca Nueva, 2007, pp. 13-27: y Álvaro Soto Carmona: "Ni modélica ni fracasada. La transición a la democracia en España", Indice histórico español, 125 (2012).

Cita tomada de Irene Delgado: El comportamiento electoral municipal español, 1979-1995, Madrid,

Centro de Investigaciones Sociológicas, 1997, p. 140
Fueron doce las candidaturas que se presentaron a los comicios locales en Madrid. ${ }^{3}$ Todas ellas pertenecían a partidos de implantación nacional, por lo que ninguna era independiente ni representaba a alguna agrupación de electores, algo infrecuente al tratarse de unas elecciones municipales. Las tres principales formaciones del momento situaron, como cabezas de lista, a grandes figuras del escenario político. De este modo, José Luis Álvarez lideraba la candidatura de Unión de Centro Democrático (UCD), Enrique Tierno Galván hacía lo propio con la del Partido Socialista Obrero Español (PSOE) y Ramón Tamames era el número uno de la lista del Partido Comunista de España (PCE). Coordinación Democrática (CD), el partido encabezado por Manuel Fraga, decidió no concurrir a las elecciones municipales en multitud de localidades, entre ellas Madrid, debido a los pobres resultados cosechados en los recientes comicios legislativos celebrados el 1 de marzo y las pocas esperanzas que albergaban para los locales. 4 Unión Nacional tampoco se presentó. Sí lo hizo la Organización Revolucionaria de Trabajadores (ORT), concentrando cierto eco mediático dado el carácter emblemático de su candidata Francisca Sauquillo, y aspirando a poder entrar en la nueva corporación.

Atendiendo a los programas electorales presentados, la candidatura centrista se amparó en la gestión llevada a cabo por su cabeza de lista durante el periodo en que fue alcalde de Madrid. En ese sentido, reivindicó la puesta en marcha de dos actuaciones, el Plan Especial, destinado a la protección de los edificios con un alto valor histórico-artístico, y el Anillo Verde que buscaba la ampliación de los parques y jardines urbanos. Se trató de una base de actuación a desarrollar y profundizar una vez que UCD alcanzase el gobierno local. La experiencia a frente de la corporación fue otra de sus grandes bazas, pues entre los integrantes de su lista se encontraban varias personas que habían desempeñado cargos municipales, aunque también se recurrió a rostros populares como los deportistas Ángel Nieto o Sagrario Aguado.

Socialistas y comunistas, mientras tanto, apostaron por ofrecer una ciudad regida por la eficacia y la honradez, acabando con la especulación urbanística y buscando la igualdad entre los ciudadanos. Este nuevo modelo de gestión debería sustentarse en la autosuficiencia financiera y en la descentralización del poder. Ambos partidos hicieron un diagnóstico muy similar de los problemas más graves que padecía la capital y presentaron unas soluciones parecidas, si bien las propuestas del PCE eran, en cierto modo, más ambiciosas. ${ }^{5}$ En ese sentido, los comunistas prepararon un proyecto de Carta Municipal para, a través del cumplimiento del artículo 140 de la Constitución, garantizar la autonomía política y financiera de la ciudad, manifestando además su voluntad por lograr una mayor participación ciudadana mediante una activa implicación del movimiento vecinal.

\section{La campaña electoral}

La campaña electoral comenzó el día 12 de marzo, menos de dos semanas después de la celebración de las generales. Este arranque se produjo a un ritmo muy lento, sirviendo como muestra el acto inaugural de UCD, al que acudieron sesenta personas. ${ }^{6}$ Para encontrar la razón de este escaso interés por parte del electorado hay que tener en cuenta la saturación electoral

3 Información extraida de la página web del Ministerio del Interior dedicada a consultas electorales: (http://www.infoelectoral.mir.es/min/busquedaAvanzadaAction.html;jsessionid=A664003FA204A0C71525913ADBF842A6.app2)[consultado el 26 de mayo de 2013].

4 "Coalición Democrática de retira de las elecciones en Madrid capital", $A B C, 16$ de marzo de 1979, p.13.

5 "Programa Municipal Federal del Partido Socialista Obrero Español", Archivo de la Fundación Pablo Iglesias, Fondo Biblioteca, Fa 207; "Programa para Madrid. Municipales 79", Archivo de la Fundación Pablo Iglesias, Fondo Biblioteca, Fa 691; “Programa electoral estatal del Partido Comunista de España" Archivo Histórico del Partido Comunista de España, carpeta 289; "Programa del Partido Comunista de España en Madrid", Archivo Histórico del Partido Comunista de España, carpeta 289.

6 "Sesenta personas en el primer mitin de UCD", El País, 13 de marzo de 1979, p. 19. 
que se padecía por aquellas fechas, puesto que en dos años y medio los españoles habían acudido cinco veces a las urnas: en diciembre de 1976 con motivo del referéndum de la Ley para la Reforma Política, en junio de 1977 para las elecciones legislativas, en diciembre de 1978 para ratificar la Constitución, en marzo de 1979 ante unos nuevos comicios generales y en abril de ese mismo año para los locales. Esta concentración de convocatorias en tan corto espacio de tiempo provocó desinterés entre la ciudadanía.

Con el paso de los días, el tono de la campaña fue aumentando gracias a la posibilidad de que PSOE y PCE alcanzasen un acuerdo para hacerse con la alcaldía. Una rumorología que extendió la prensa, afirmando que "cada vez se perfila con más claridad una unión final de los partidos de izquierdas", 7 y que los candidatos no desmintieron. Ramón Tamames, en el cierre de campaña del PCE, dijo que "es necesaria la colaboración municipal entre socialistas y comunistas". ${ }^{8}$ Por su parte, Tierno Galván, el mismo día de la votación, declaró que "el acuerdo de izquierdas propiciará un alcalde socialista". ${ }^{9}$ No obstante, toda opción de apoyo mutuo entre ambos partidos, tanto en la capital como en el conjunto del Estado, debería negociarse tras la jornada electoral, una vez se hiciesen públicos los resultados.

La cercanía de la cita con las urnas y la incertidumbre sobre quién ocuparía la alcaldía madrileña hicieron crecer la tensión entre los contendientes, provocando que la recta final de la campaña se viera salpicada de ataques personales y descalificaciones. Mientras Tierno Galván sentenció que "hay trabajadores que votan UCD. El trabajador que vota derecha no solo no va en contra de los intereses de su clase, de sus hijos; además, es un necio, porque es necedad que el esclavo vote a favor de su dueño", ${ }^{\circ}$ desde las filas de la UCD replicaron que el candidato socialista era un "ultraizquierdista disfrazado" que se presentaba "como un hombre bueno, por encima del bien y del mal" y que incurría en "chabacanas coacciones verbales" con las que pretendía ocultar "su falta de condiciones personales y de preparación técnica", cualidades que hacía extensivas a "la mayor parte de los componentes de su candidatura"." Esta escalada no se detuvo ahí, puesto que dirigentes socialistas afirmaron que José Luis Álvarez era "la ultraderecha de UCD", ${ }^{12}$ le calificaron como "el alcalde de las inmobiliarias" ${ }^{13}$ y denunciaron que "mantuvo abierta su notaría mientras fue alcalde, con una falta de ética profesional". ${ }^{14}$ Como resultado de este intercambio de descalificaciones, representantes de la candidatura ucedista interpusieron el día 28 una "demanda de conciliación previa y preceptiva a la querella por injurias y calumnias" ante el juez decano de Madrid, contra diversos eslóganes electorales del PSOE. ${ }^{5}$ Llama la atención que se pasara por encima de los lemas utilizados por el PCE, con un tono muy similar a aquellos, ${ }^{16} \mathrm{evi}$ -

7 "La villa, centro de reunión de candidatos municipales", $A B C, 14$ de marzo de 1979, p. 15

8 “Es necesaria la colaboración municipal entre socialistas y comunistas", El Pais, 3 de abril de 1979, p. 22.

9 "El acuerdo de izquierdas propiciará un alcalde socialista", El País, 4 de abril de 1979, p. 15.

10 "Tierno Galván llama necios a los obreros que votan a UCD", $A B C, 27$ de marzo de 1979, p. 17.

11 "Tierno Galván ha descendido a niveles de vulgaridad y mal gusto", $A B C, 28$ de marzo de 1979, p.13.

12 "UCD y PSOE se acusan de nerviosismo", El País, 28 de marzo de 1979, p. 21.

13 "José Luis Álvarez: «Las acusaciones socialistas son de juzgado de guardia»", El País, 3 de abril de 1979, p. 21.

14 "Estalla el conflicto entre Álvarez y Tierno", El Pais, 29 de marzo de 1979, p. 23.

15 Algunos de los eslóganes sobre los que se basaba la denuncia eran "Para barrer de una vez la corrupción y la incompetencia del Ayuntamiento, vota Tierno Galván", "Para que Madrid tenga un alcalde honrado, que ya va siendo hora, vota Tierno Galván” o "Para ellos, Madrid no es una ciudad, es un negocio. Vota honradez, vota Tierno Galván". Íbid.

16 Los eslóganes utilizados por el PCE fueron "Ouita un cacique, elige un alcalde", "Lo primero es lo primero: exige una escuela" "Cana el convenio de tu bacio" "Si quieres campos deportivos, lo primero: exige una escuela", "Gana el convenio de tu barrio", "Si quieres campos deportivos, "Si quieres hositales, corta por bano", "Desconecta los unchufes"” "Un barrio solidario es un barrio seguro" o "Pon verde tu barrio". denciando quizá que se trataba de una maniobra destinada a atacar la imagen de la candidatura socialista y reducir sus posibilidades de alcanzar la alcaldía.

\section{La jornada electoral y los resultados}

El martes 3 de abril se celebraron las elecciones, una jornada que transcurrió sin grandes sobresaltos. Como sucedió en el conjunto del país, UCD se alzó con la victoria tras recibir 634.925 votos. Por detrás se situaron el PSOE, que logró 622.971 votos, y el PCE, que quedó como tercera fuerza política gracias a sus 231.268 votos. ${ }^{17}$ Traducidos a concejales, ucedistas y socialistas quedaron empatados con 25 ediles cada uno, mientras que los comunistas obtuvieron 9 . Ningún otro partido consiguió los a poyos suficientes para poder formar parte de la nueva corporación municipal, que según la legislación vigente se cifraban en el $5 \%$ del total de los votos emitidos.

Si se comparan los resultados de las elecciones municipales con los de las anteriores generales, que tuvieron lugar apenas un mes antes, se aprecian algunas diferencias dignas de mención. Los tres grandes partidos incrementaron los votos recibidos, destacando especialmente el PSOE, que logró 82.251 votos más. UCD creció en 30.142 votos y el PCE lo hizo en 13.498 votos. También hubo un importante aumento de la abstención, que pasó del $24,69 \%$ al $32,27 \% .^{18}$

Otro interesante vector de análisis puede ser la distribución de votos en los distritos urbanos, permitiendo una observación más detallada de los apoyos electorales con que contó cada partido. En relación con los comicios legislativos del mes de marzo, el PSOE creció en los dieciocho distritos madrileños y el PCE en prácticamente todos ellos, mientras que UCD solo lo hizo en aquellos en los que resultó ser la opción vencedora (Centro, Arganzuela, Retiro, Salamanca, Chamartín, Tetuán, Chamberí y Moncloa). Como consecuencia, en los distritos del centro de la ciudad predominó el voto al partido centrista, mientras que los de la periferia apoyaron mayoritariamente a las candidaturas de izquierda. Además, los socialistas lograron arrebatarle a partido centrista tres distritos, Fuencarral, Latina y Ciudad Lineal, claves para explicar la reducción de la distancia que les separaba de UCD.

Pasando a un análisis explicativo de los resultados electorales, puede sostenerse que el descenso de la participación y la retirada de $C D$ perjudicaron los intereses de la candidatura de UCD Buena parte del electorado del partido de Manuel Fraga no se movilizó, engrosando las cifras de la abstención. Esta actitud dificultó las aspiraciones de José Luis Álvarez y su equipo, pues solamente podrían hacerse con la alcaldía y contaban con la mayoría absoluta de los concejales. Parece ser que los mensajes que transmitían las candidaturas también influyeron en las orientaciones del voto. Así, el halo de renovación y democratización que se desprendía de las propuestas hechas por socialistas y comunistas tuvieron un mayor calado entre la ciudadanía, frente al aire continuista que emanaba de la lista de UCD, en cierto modo identificada con la gestión llevada a cabo por corporaciones anteriores. Gracias a ello puede comprenderse el notable incremento de los apoyos del PSOE y del PCE y las diferencias de voto respecto a las elecciones generales.

\section{La constitución del Ayuntamiento}

Una vez que se conocieron los resultados, desde las filas de UCD aparecieron voces críticas con un posible acuerdo entre socialistas y comunistas. Por ejemplo, Fernando Abril Martorell, entonces vicepresidente segundo del gobierno y ministro de Economía, declaró que "el PSOE ha quedado prisionero del PCE" y "ha renunciado a ser alternativa autónoma del Poder", 19 lle-

17 Los resultados electorales proceden de Boletín Estadistico Municipal, 3 (1987), anexo I.

8 Datos procedentes de lbid., anexo I.

19 “El PSOE queda prisionero del PCE”, ABC, 6 de abril de 1979, P. 16.

seguro" o"Pon verde tu barrio".


gando a calificar dicho pacto como "una alianza de marxistas contra no marxistas". ${ }^{20}$ Declaraciones como estas intentaban torpedear el entendimiento entre los dos partidos mayoritarios de la izquierda puesto que, si se apoyaban, muchas ciudades españolas pasarían a estar gobernadas por alcaldes de ambas formaciones. Madrid era uno de los ejemplos más significativos de esta situación. Al día siguiente de que la población acudiera a las urnas ya hubo una reunión entre representantes de ambos partidos, ${ }^{21}$ y posteriormente se formaron comisiones mixtas para dirimir los casos correspondientes a cada provincia. ${ }^{22}$

Los rumores habidos durante la campaña y estos contactos iniciales presagiaban que el acuerdo se alcanzaría con relativa facilidad, pero fue dilatándose en el tiempo. Aparte de las declaraciones de miembros de UCD y de alguna maniobra destinada a hacer fracasar el pacto, ${ }^{23}$ hubo posturas divergentes durante las negociaciones. EI PCE pretendía que Ramón Tamames ocupase la presidencia de la Diputación Provincial. EI PSOE, por otro lado, argumentaba que ese cargo debía corresponder a un miembro de su partido, tal como sucedía en el ayuntamiento, ofreciendo al candidato comunista la Gerencia Municipal de Urbanismo. ${ }^{24}$

No fue hasta el 18 de abril, un día antes de la constitución de las nuevas corporaciones, cuando se firmó el pacto entre los dos partidos. En él se comprometían a "apoyar en las votaciones para la alcaldía al cabeza de lista más votada entre los dos partidos", con el objetivo de "trabajar conjuntamente por la democratización plena de los municipios y por una gestión eficaz y honrada, por una mejoría en las condiciones de vida de los pueblos y ciudades". Se especificó además que en cada municipio se diseñaría un plan de actuación propio, a partir de las propuestas hechas por cada fuerza política, y que el reparto de responsabilidades se haría de forma proporcional a los resultados obtenidos. ${ }^{25}$

El jueves 19 de abril se constituyeron los ayuntamientos salidos de las urnas. En el consistorio madrileño se cumplieron los pronósticos y Tierno Galván resultó elegido alcalde con el apoyo de los concejales del PSOE y del PCE, tras una sesión en la que representantes de los tres grupos políticos con presencia en la corporación tuvieron la oportunidad el sentido de su voto. ${ }^{26}$

La formación del equipo de gobierno, cuestión que había generado problemas en la negociación del acuerdo entre socialistas y comunistas, respondió a criterios proporcionales en el reparto de cargos, como se recogía en el propio pacto. Finalmente, el PCE obtuvo la primera tenencia de alcaldía, tres áreas de gobierno y la Gerencia Municipal de Urbanismo, mientras que concejales del PSOE ocuparon las dos restantes tenencias de alcaldía y ocho áreas de gobier-

20 "El pacto de socialistas y comunistas preocupa al partido del Gobierno", El Pais, 6 de abril de 1979, p. 15. 21 Participaron, por parte socialista, Felipe González, Alfonso Guerra, Enrique Múgica, Luis Gómez Llorente, Guillermo Galeote y Luis Fajardo, y, en representación comunista, Santiago Carrillo, Simón Sanchez Montero, Ignacio Gallego, Carlos Alonso Zaldivar, Eugenio Triana y Enrique Curiel. "Pacto PSOE-PCE para lograr ayuntamientos con mayoria de la izquierda", El Pais, 5 de abril de 1979, p. 11.

22 En Madrid, la comisión estuvo formada por los socialistas Alonso Puerta, Adolfo Luxán, Baltasar Aymerich y Carlos Revilla, y por los comunistas Emilio Rodríguez, Eduardo Mangada, Alfredo Tejero y Juan Francisco Plá. "El lunes culminan las negociaciones entre el PSOE y el PCE”, ABC, 12 de abril de 1979, p. 19.

23 La prensa dio cuenta de sendas reuniones de Jaime Cortezo y Miguel Herrero y Rodriguez de Miñón (UCD) con Simón Sánchez Montero (PCE), y de Rafael Arias-Salgado (UCD) con altos cargos del PSOE. “UCD intentó romper el acuerdo municipal de la izquierda”, El Pais, 11 de abril de 1979, p. 9.

24 "Socialistas y comunistas llegan a un «acuerdo definitivo» en el pacto municipal", El Pais, 18 de abril de 1979, p. 15.

25 El texto completo del pacto entre PSOE y PCE está disponible en las páginas 226 y 227 del CD que acompaña, como anexo documental, a Guillermo Márquez Cruz: Política y gobierno local. La formación de gobierno en las Entidades locales en España, Madrid, Centro de Estudios Políticos y Constitucionales, 2007

26 Libro Borrador de Actas del Ayuntamiento de Madrid, abril de 1979, Archivo Histórico de la Villa de Madrid. no. ${ }^{27} \mathrm{~A}$ su vez, trece presidencias de Juntas Municipales de Distrito correspondieron a socialistas y cinco a comunistas. Esta distribución de puestos de responsabilidad acentuó el carácter rupturista de la nueva corporación municipal, al no contar con ningún miembro de UCD.

\section{Una recapitulación y una propuesta de investigación}

En abril de 1979, con la celebración de las elecciones municipales, los ayuntamientos es pañoles se democratizaron. A pesar de que UCD fue el partido que obtuvo un mayor número de votos, la victoria política correspondió a la oposición de izquierdas, que obtuvo el gobierno de numerosas localidades, entre ellas las principales ciudades del país. En Madrid, en virtud del pacto suscrito entre PSOE y PCE, Tierno Galván se convirtió en alcalde. Tal como se afirmaba al comienzo de esta comunicación, el breve recorrido que se ha hecho en las páginas precedentes a lo largo del desarrollo de estos comicios en la capital del Estado ha perseguido dos objetivos.

El primero de ellos cabe relacionarlo con el significado de estos comicios. La cita con las urnas debe interpretarse como el momento en que, formalmente, la democracia llegó al poder local, estableciendo un punto de ruptura con la vida municipal heredada de la dictadura franquista. Una separación que no solamente debe contemplarse desde un punto de vista legal, sino que debe incluir procedimientos, modelos de gestión y, en muchas ocasiones, al propio personal político

El momento en que se celebraron las elecciones no debe pasarse por alto a la hora de caracterizarlas. La decisión del gobierno de postergar la renovación de las corporaciones locales estaba encaminada a mantener el control sobre el poder municipal y evitar que una hipotética derrota en las urnas le arrebatara la iniciativa en el proceso de cambio político, pasando esta a los partidos de la oposición. El resultado provocó que los ayuntamientos fueran los últimos niveles de la administración en democratizarse, e incidió más directamente en el bajo perfil de la campaña, que concentró una escasa atención por parte del electorado que redundó en un descenso de la participación.

A todo ello hay que unir el especial valor que cobraron las elecciones locales en el caso madrileño. La condición de capitalidad ostentada por la ciudad le confirió un eco mediático muy alto, que no puede compararse a lo ocurrido con otras localidades. De este modo, la información sobre el transcurso de la campaña, sobre la jornada electoral o sobre la constitución de la nueva corporación ocupó siempre un lugar destacado en la prensa escrita de la época. Además, el enorme peso político de las candidaturas certificó el interés de las formaciones en disputar la batalla por Madrid, pudiendo interpretarse como una segunda vuelta de los comicios generales.

La segunda finalidad está vinculada con un horizonte más lejano, pretendiendo que el estudio sobre el desarrollo de las elecciones municipales en la ciudad de Madrid pretende servir de punto de partida para un análisis histórico más amplio, que contemple el proceso de cambio político a nivel local. Remarcando la importancia de la convocatoria electoral, que ha de verse como el parteaguas que separó el poder local franquista del democrático, se conseguirá revalorizar también la dimensión municipal del proceso de cambio político como objeto de

27 La composición del gobierno municipal fue la siguiente: Enrique Tierno Galván (PSOE), alcalde, Ramón Tamames (PCE) prim Ramón Tamán (PCE), PRO (PSOE) tercer teniente de alcalde y concejal de Seguridad y Policia Municipal; Javier Angelina (PSOE), concejal de Obras; Ángel Hernández (PSOE), concejal de Acción Vecinal; Joaquín Leguina (PSOE), concejal de Hacienda; Adolfo Luxán (PSOE), concejal de Relaciones Sociales; Luis Martin Pacin (PCE), concejal de Circulación y Transportes; Manuel Mella (PSOE), Sociales; Luis Martín Palacin (PCE), concejal de Circulación y Transportes; Manuel Mella (PSOE),
concejal de Saneamiento; Enrique del Moral (PSOE), concejal de Cultura; Juan Francisco Plá (PCE), concejal de Saneamiento; Enrique del Moral (PSOE), concejal de Cultura; Juan Francisco Plá (PCE), Educación y Eduardo Mangada (PCE), Gerente Municipal de Urbanismo. 
estudio de los historiadores. Son escasas las publicaciones ya realizadas, pero poco a poco más investigadores se van orientando hacia este objeto de estudio y van apareciendo nuevas obras fruto de su trabajo. ${ }^{28}$

Ahora bien, ¿qué tipo de conocimiento han de proporcionar los análisis que profundicen en este tema? Su principal meta será introducir a las ciudades en las interpretaciones sobre el cambio político, desentrañando el proceso mediante el cual la democracia llegó a las instituciones más próximas a los ciudadanos, un aspecto vital pero que pasa normalmente desapercibido. A su vez, permitirá identificar no solo los ritmos propios dentro de los cuales se movió la democratización del poder local, sino también las relaciones establecidas con el proceso análogo a nivel estatal y la interacción habida entre ambas realidades. Posiblemente, las decisiones en torno a la convocatoria de las primeras elecciones municipales y la articulación de la administración local en el texto constitucional sean las cuestiones de mayor calado en este aspecto. Los estudios de caso darán pie, incluso, a señalar semejanzas y diferencias en torno a acontecimientos o prácticas que se hayan producido en las ciudades abordadas. Por último, otro vector de análisis debe incidir en la participación del movimiento vecinal en el proceso de democratización del poder municipal, introduciéndose así en el papel jugado por la sociedad civil en dicho fenómeno y en la relación entre gobernantes y gobernados.

A lo largo de estas páginas se ha intentado poner en valor la importancia que tuvieron las elecciones municipales de 1979 dentro del proceso de cambio político, remarcar el carácter singular que tuvieron los comicios celebrados en la ciudad de Madrid y manifestar la necesidad de que los historiadores incluyan la perspectiva local en sus investigaciones sobre la democratización española para tener una idea más completa de la misma. Queda mucho camino por recorrer, pero para comenzarlo es necesario tener claro el punto de partida, los medios con los que se cuenta para afrontarlo y el destino al que se quiere llegar.

28 Hasta el momento solamente hay una obra que aborda la democratización del poder municipal de manera global, Rafael Quirosa-Cheyrouze y Mónica Fernández Amador: Poder local y transición a la democracia en España, Granada, Centro de Estudios Municipales y de Cooperación Internacional, 2010. A su vez, hay otros trabajos dedicados a algunas ciudades o regiones, como por ejemplo David Encinas Rodríguez: El ayuntamiento de Valladolid en la transición (193-1987). Política y gestión, Tesis doctoral, Universidad de Valladolid, 2008; Mónica Fernández Amador: “La Transición y los municipios andaluces: el Ayuntamiento de Almería", en XII Congreso sobre el Andalucismo Histórico, Sevilla, Fundación Blas Infante, 2008, pp. 353-368; María del Mar LARRAZA: "El ayuntamien-
to pamplonés en el tardofranquismo" en Actes del Congrés La transició de la dictadura franquista to pamplones en el tardofranquismo", en Actes del Congrés La transició de la dictadura franquista a la democracia, Bellaterra, Universitat Autonoma de Barceloa y Centre d'Studis sobre les Epoques
Franquista i Democrática, 2005, pp. 68-79: Marti Marin: Els ajuntaments franquistes a Catalunya: Franquista i Democrática, 2005, pp. 68-79; Martí Marín: Els ajuntaments franquistes a Catalunya:
política i administració municipal, 1938-1979, Lleida, Pagès editors, 2000, pp. 481-485; Óscar Martín politica i administració municipal, 1938-1979, Lleida, Pages editors, 2000, pp. 481-485; Oscar Martín García: Albacete en transición: el Ayuntamiento y el cambio politico, 1970-1979, Albacete, Instituto de Estudios Albaceteños Don Juan Manuel, 2006; Pedro Juan Parra Verdú: Tardofranquismo y transición democrática en la ciudad de Alcoy (1973-1979), Alcoy, Miseria \& Cía, 2008. Por ultimo, hay dos Colomer, y otra acerca de Sevilla, realizada por Carlos Sánchez Fernández. 


\section{EL SUJETO FEMENINO EN TRANSICIÓN.}

\section{MUJERESYESTRATEGIAS EN LA PRENSA REGIONAL}

\section{MURCIANA, AÑO 1975}

Esther Mora Bleda

Universidad de Murcia

En esta mesa titulada "Proceso de Transición a Debate", han predominado los trabajos sobre perspectiva política enriquecidos con la comparativa de otros países y procesos (Portugal, Alemania, Argentina, etc.). Atendiendo a los objetivos de la mesa-taller, se propone en esta investigación una perspectiva social cohesionada con "lo político": se atiende a las estrategias adoptadas por la población femenina española en el crucial año 1975, a las causas y consecuencias de sus actuaciones, asi como a los cambios que introducen no sólo para las mujeres sino para la sociedad en conjunto. Las cuestiones que planteo son: ¿cómo el sujeto femenino visualiza el año 1975 y desde qué posicionamientos? ¿Qué reivindican como mujeres y sujetos? ¿Cómo se hacen visibles y se organizan? ¿Oué aportan al debate de la transición las mujeres organizadas?

\section{Marco Historiográfico. Estado de la cuestión}

Esta investigación presenta a las mujeres murcianas, y por ende españolas, como agentes sociales y políticos, sujeto colectivo que contribuyó a la lucha y defensa de los valores democráticos de la Transición Española, y se plantea desde dos perspectivas: primera, desde la académica e historiográfica, por la progresiva inclusión de las mujeres en los estudios de la Transición que supone en sí una cuestión a debatir; y, segunda, desde la categoría "mujer", su proceso de reconceptualización y redefinición de las relaciones de género de los españoles y las españolas, aspectos que se encuentran inmersos en su propio proceso de transición. El objetivo perseguido es dar respuesta a las cuestiones planteadas y vislumbrar las estrategias de las mujeres en sus organizaciones y actuaciones para el año 1975, "Año Internacional de la Mujer", mediante el análisis de la fuente hemerográfica (discurso, representaciones, información, etc.), del diario La Verdad de Murcia.

El sujeto femenino ha sido durante décadas un ejemplo del olvido existente en la praxis historiográfica, concretamente en el análisis del proceso de la Transición Española. Pero reuniones científicas como este IV Encuentro de Jóvenes Investigadores en Historia Contemporánea, ayudan a cubrir los vacíos existentes mediante las mesas-taller "Los agentes de cambio. De la crisis del Franquismo a la consolidación de la democracia: participación social, cultura colectiva y prácticas políticas" " "Procesos de Transición a Debate", permitiendo visibilizar a las mujeres como protagonistas sociales y políticas de este período histórico, así como evidenciar que las relaciones de género son versátiles y, por consiguiente modificables.

Este trabajo se sustenta en las investigaciones realizadas hasta el momento y la que llevo

1 Naciones Unidas. Resolución de la Asamblea General núm. 2010. Año Internacional de la Mujer. XXVIII. Período de Sesiones, 18 de diciembre de 1972, p. 73. Elena DÍAZ SILVA: "El Año Internacional

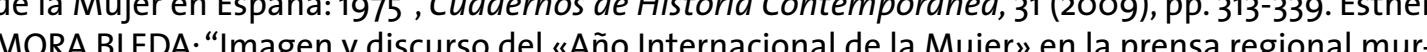
ciana, El Futuro del Pasado, 3 (2012), pp. 185-207. en curso con motivo de mi proyecto de Tesis doctoral titulada: “"Españolas» en papel. Un análisis desde la perspectiva histórica y de género de la transición española (1975-1982)". Desde esta experiencia investigadora valoro el impacto otorgado a las figuras políticas por parte de la historiografía de la transición, sujetos políticos del cambio que buscaban la redefinición de un nuevo sistema para este período; mientras, la sociedad y, concretamente para el caso aquí analizado, las figuras femeninas pertenecientes a colectivos, asociaciones, grupos o al movimiento feminista, eran conscientes no solo de los problemas correlativos a la mujer sino también de las deficiencias del sistema y de los pilares necesarios de reforma, conformando una subcultura política democrática ${ }^{2}$ y presentado unas propuestas en consonancia con la realidad social. Asi pues, los estudios concernientes al proceso de transición se caracterizaban por el predominante enfoque androcéntrico ${ }^{3}$ masculino que se ha enriquecido al plantearnos otras preguntas o cuestiones sobre los procesos históricos transicionales y sus sujetos, incluyéndose los campos que estaban en los márgenes, como es la Historia de género e Historia de las mujeres. ${ }^{4}$ Ambas disciplinas han contribuido a la visibilización del sujeto femenino dentro del marco político de la transición, y en esta nueva perspectiva historiográfica se ha puesto de relieve la participación femenina en: primero, el proceso constituyente de la Transición y de la Constitución; ${ }^{5}$ segundo, el movimiento obrero con reivindicaciones propiamente femeninas $y$, otras formas de lucha, con esposos, hijos o compañeros; ${ }^{6}$ tercero, estudios sobre el movimientos feminista (Movimiento democrático de mujeres, Jornadas de Liberación de la Mujer, etc.); ${ }^{7}$ y, cuarto, descubriendo la importante participación y actividad asociacionista realizada por las mujeres españolas, que ocuparon puestos de base o la dirección en las asociaciones de vecinos y de barrio (vocalías de mujeres), asociaciones familiares (Asociaciones de Padres y Alumnos, Cabezas de Familia) Colectivos de Educación para Adultos (ejemplo: Colectivo "Carmen Conde" de educación para adultos de Cartagena), etc. Las investigaciones de Pamela Radcliff y Beatriz Bustos ${ }^{8}$ resaltan la

2 Ana AGUADO y Teresa María ORTEGA (eds.): Feminismos y antifeminismo. Culturas políticas e identidades de género en la España del siglo XX. Valencia, Universitat de València, 2011; Ana Jacqueline tidades de género en la España del siglo XX, Valencia, Universitat de València, 2011; A

3 Lola G. LUNA: "El androcentrismo y los estudios de la mujer", Revista Brujas: Las mujeres escriben Medellín, Abril (1985), pp. 12-14

4 Cristina BORDERÍAS (ed.): La Historia de las mujeres. Perspectivas actuales, Barcelona, Jería, 2009 Joan W. SCOTT: "El género: una categoría útil para el análisis histórico", en El género: la construcción cultural de la diferencia sexual, México, PUEG, 1996, pp. 265-308; ÍD: Género e Historia, México, Universidad Autónoma de la Ciudad de México, 2008; Sonya O. ROSE: ¿Qué es la Historia de Género?, Madrid, Alianza Editorial S.A., 2012.

5 Olivia ACOSTA: Las Constituyentes, s. I., Olivavá Producciones, 2011; Gloria NIELFA y otros: "El acceso de las mujeres a los poderes locales en España", en Ángeles BARRIO ALONSO, Jorge de HOYOS PUENTE, Rebeca SAAVEDRA ARIAS (eds.): Nuevos horizontes del pasado, culturas políticas, identidades y formas de representación, Cantabria, Actas del X Congreso de la Asociación de Historia Contemporánea, Publican (Ediciones de la Universidad de Cantabria), 2011, Cd.

6 Pilar Díaz Sánchez: "Del taller de costura a la fábrica. El trabajo de las mujeres en la confección-textil madrileña", Cuadernos de Historia Contemporánea, 21 (1999), pp. 279-293; ÍD.: "Las luchas de las mujeres en el tardofranquismo: los barrios y las fábricas" en Jerónimo de Uztariz, 21 (2005), pp. 39-54; ÍD:: "En libertad, las mujeres se organizan (1975-200o), en ¿Invisibles? Mujeres, trabajo y sindicalismo en España 1939-2000, s.l., Comisiones Obreras, Abril, 2004

$7 M^{a}$ Ángeles LARRUMBE: Una inmensa minoría. Influencia y feminismo en la Transición, Zaragoza Prensas Universitarias de Zaragoza, 2002; ÍD.: Las que dijeron no. Palabra y acción del feminismo en la Transición, Zaragoza, Prensas Universitarias de Zaragoza, 2004; Julio PÉREZ SERRANO: "Demola Transición, Zaragoza, Prensas Universitarias de Zaragoza, 2004; Julio PÉREZ SERRANO: "Demo-"
cracia y Feminismos: La Lucha por la liberación de la Mujer en la Transición Española, 1975-1983", Regards, 17 (2011), pp. 11-23.

8 Beatriz BUSTOS MENDOZA: Mujeres y movilización vecinal del Barrio Virgen del Remedio de Alicante (1975-1982), Trabajo de Investigación de Doctorado, Centro de Estudios sobre la Mujer, Universitat de Alicante, 2005; ÍD.:"El protagonismo femenino en las asociaciones vecinales de Alicante 
importancia de la participación y pertenencia de las mujeres en las asociaciones de vecinos -en los casos de Madrid y Alicante- para poder participar en la vida política y construir una "conciencia femenina".9 Pero esta inclusión de las mujeres en la Historia ha sido un proceso lento y pausado y, por ello, me centro en esta contribución en el ámbito regional murciano, pues tras la valoración y análisis de la historiografía concerniente al Tardofranquismo y Proceso de Transición se llega al resultado de la necesaria inclusión de la perspectiva de género. Mientras que los importantes trabajos de Encarna Nicolás Marín, ${ }^{10}$ Carmen González $z^{11}$ y Fuensanta Escudero $^{12}$ son un referente para conocer el ámbito elegido desde una perspectiva política y de los movimientos sociales, como por ejemplo el obrero y el estudiantil, se considera que existe un importante campo abierto y pendiente de investigación: el de las mujeres organizadas, agentes que perfilaron el proceso de transición española desde la sociedad.

El análisis de la fuente hemerográfica central en esta investigación muestra una pluralidad de discursos e imágenes, todos ellos muy importantes para la reconstrucción del relato histórico, en especial para el período de la Transición Española que es conocido como el "Parlamento de Papel" (1977-1982), 13 pues durante esas fechas la prensa fue el medio de mayor influencia. La elección del diario La Verdad de Murcia, como fuente principal para esta investigación, se justifica por varios motivos: primero, es un diario con una larga vida que ha superado los diferentes baches surgidos del devenir histórico, segundo, tiene una gran tirada regional, en especial, en la zona de levante (Albacete, Alicante, Cartagena, Murcia, etc.) y, tercero, coincidiendo con el "Año Internacional de la Mujer", esta fuente fue nombrada Mejor Diario Español y Mejor Diario de Cobertura Regional. ${ }^{14}$ Por consiguiente, con el análisis del material presentado se procurará responder a las cuestiones planteadas en este estudio. durante los años sesenta", Pasado y Memoria. Revista de Historia Contemporánea, 5 (2006), pp.
289-294; Constantino GONZALO: "Mujeres y vecinas en la transición: el caso de Valladolid, 1970289-294; Constantino GONZALO: "Mujeres y vecinas en la transición: el caso de Valladolid, 19701986, Cuadernos Köre. Revista de historia y pensamiento de género, 6 (2012), pp. 148-175; Pamela Beth RADC "último franquismo", Actes del Congrés la Transició da Asociaciones de Vecinos en Madrid en el útimo franquismo", Actes del Congrés la Transició de la dictadura franquista a la democracia, Barcelona, 2005, pp. 96-101, ID.: "Cludadanas: las mujeres de las Asociaciones de Veci(eds.): Memoria ciudadana y movimiento vecinal, Madrid, Ed. Catarata, 2008, pp. 54-78.

Temma KLAPAN: "Lucha por la democracia: formas de organización de las mujeres entre los años

9 Temma KLAPAN: "Lucha por la democracia: formas de organización de las mujeres entre los años 50 y 70 ", en Ana AGUADO (ed.): Mujeres, regulaci
cia, Universitat de València, 1999, pp. 89-109.

10 Encarna NICOLÁS MARÍN: “"La transición se hizo en los pueblos». La vida política en Murcia (19681977)", en Rafael QUIROSA-CHEYROUZE Y MUÑOZ (coord.): Historia de la Transición en España. Los inicios del proceso democratizador, Madrid, Biblioteca Nueva, 2007, pp. 251-267; İD: “" jFranco ha muerto! ¿ Y ahora qué?». La construcción de la democracia desde la memoria”, Ayer, 79 (2010), pp. 171-197.

11 Carmen GONZÁLEZ: "El tránsito dictadura a la democracia en Murcia. Acción colectiva, respuestas institucionales y posicionamientos políticos", Ayer, 79 (2010/3), pp. 87-120; Carmen GONZÁLEZ y Fuensanta ESCUDERO ANDÚJAR: "La Transición en Murcia. Movimientos Sociales y poder político. Nuevas perspectivas de investigación", en Rafael QUIROSA-CHEYROUZE y MUÑOZ (ed.): La sociedad española en la Transición. Los movimientos sociales en el proceso democratizador, Madrid, Biblioteca Nueva, 2011, pp. 383-399.

12 Fuensanta ESCUDERO y Carmen GONZÁLEZ MARTíNEZ: “Jóvenes y Rebeldes: El idealismo efímero de la extrema izquierda", $V$ Congreso Internacional "Historia de la Transición en España. Las organizaciones políticas", Almería, 2011, edición CD; İD: "La Tempestad después de la calma: la Universidad de Murcia entre la displicencia de posguerra y las movilizaciones de la Transición", Historia Actual Online, 26 (2011), pp. 41-56.

13 Rafael QUIROSA-CHEYROUZE y Muñoz (eds.): Prensa y Democracia. Los medios de comunicación en la Transición, Madrid, Biblioteca Nueva, 2009.

14 Archivo Municipal de Murcia (en adelante, AMM): La Verdad de Murcia, 26 de noviembre de 1975, p. 24.

\section{Las mujeres españolas en transición}

El tardofranquismo y los inicios de la transición española se caracterizan por la coyuntura de cambios económicos, políticos, culturales y sociales; ámbitos en los que hombres y mujeres actuaron y participaron pero partiendo desde distintos posicionamientos, pues las relaciones de género estaban predefinidas, marcadas e institucionalizadas, teóricamente, por el régimen franquista, les ubicaba en espacios diferentes. Por consiguiente, las posturas, demandas y problemas en ocasiones serán compartidos por ambos sujetos, femenino y masculino (amnistía, desempleo, problemas del barrio), pero las cuestiones femeninas serán exclusivamente de ellas (aborto, ciudadanía, igualdad y paridad, divorcio, etc.)

La historiadora Pilar Pérez Fuentes ${ }^{15}$ explica que las mujeres no solo fueron sujetos visibles y activos de este período histórico, sino que ellas mismas se encontraban en un proceso de transición, pues como se ha podido evidenciar en el diario La Verdad de Murcia, las mujeres al igual que los hombres no pueden analizarse ni encasillarse en compartimentos estancos, pues se caracterizan por su pluralidad (ideológica, profesional, asociacionista, etc.) y, por invisibilizar las líneas de clase, edad, raza en la lucha de sus objetivos. El análisis de la fuente hemerográfica permitió descubrir que la identidad femenina para el año 1975 tenía un claro componente público y político, abandonándose la tradicional separación de los espacios entre hombre y mujeres. La identidad femenina se encontraba en un doble proceso: por un lado, el referente a su identidad como sujetos, agentes psicosociales, y de ciudadanas con demandas específicas a su condición de "mujer" $y$; de otro, imbuidas dentro del conjunto social.

El análisis de la fuente hemerográfica de la década de los '60 hasta el año 1975, permite apreciar el cuestionamiento del rol materno y de los valores del nacional-catolicismo por parte de mujeres españolas en la medida que se producía su integración en la esfera pública, se replanteaba el poder y la autoridad establecida por el sistema, evidenciándose que el "poder se ejerce, no se posee"; ${ }^{16} \mathrm{y}$, por consiguiente las mujeres cuestionaban que la maternidad fuese su única obligación o fin al que pudiese llegar. Las mujeres no negaban su papel de madres, sino que reclamaban otros roles como señas de identidad. Estos nuevos enfoques en la mentalidad femenina se venían gestando por la aglutinación de varios motivos: en primer lugar, el desarrollismo económico de las década de 1950 y 1960 que reincorporó a la mujer casada al mundo laboral mediante la eliminación de la licencia marital. En segundo lugar, promoción del consumo dirigido especialmente a las mujeres como se evidencia en la publicidad (lavadora, frigorífico, etc.) y que tenía como fin facilitar las tareas domésticas de las mujeres dejándoles más tiempo para el trabajo fuera del hogar. En tercer lugar, el boom del turismo extranjero que importo "otros" estereotipos femeninos como la construcción del imaginario de la "Sueca"..$^{7}$ Por último, la repercusión de la segunda oleada del feminismo.$^{18}$ La conjunción de estos motivos promovieron una nueva conceptualización del "ser mujer" desde la igualdad le-

15 Pilar Pérez Fuentes dice asi: las mujeres [...] “no solo participamos de la transición, sino que también nosotras estábamos en transición, éramos un proceso [...] un producto en transición hacía una reconstrucción de genero, hacia una identidad femenina", en Ma Antonia GARCÍA DE LEÓN Rebeldes Ilustradas (La otra Transición), Barcelona, Anthropos, 2008, p. 148.

16 Teresita de BARBIERI: "Sobre la categoría género. Una introducción teórico-metodológica", Debates en Sociología, 18 (1993), pp. 2-19.

17 Mary NASH: "Costa brava, contactos interculturales y de género: prácticas turisticas y cambio cultural en los años 6o", Conferencia en el XI Congreso de la Asociación de Historia Contemporánea Granada, 2012. En esta conferencia se incidió en los choques culturales que se crean en los procesos de sociabilización dando lugar a la construcción de estereotipos identificativos, como pueden ser las figuras del D. Juan y la "Sueca". En este caso "la sueca" constituye el eativos, como pueden ser las figuras del D. Juan y la "Sueca". En este caso "la sueca" constituye el estereotipo que rompe el
modelo español femenino, pues representaba el erotismo y la modernidad, era la "alteridad" social.

18 Carmen MARTINEZ TEN, Purificación GUTIÉRREZ LÓPEZ y Pilar GÓNZALEZ RUIZ (coords.): EI movimiento feminista en España los ãos 70 , Valencia, Fundación Pablo Iglesias, Edición Cátedra, 2009 . 
gislativa, educacional y laboral, en especial, se denota una mayor capacidad organizativa y resolutiva de las mujeres universitarias que se agruparon en: La Asociación Española de Mujeres Universitarias, El Seminario de Estudios Sociológicos de la Mujer, El Movimiento Democrático de Mujeres, La Asociación Española de Mujeres Juristas, Asociación para la Promoción y Evolución Cultural, Asociación de Mujeres Separadas y Seminario Colectivo Feminista, entre otras.

Las mujeres como conjunto plural y no homogéneo, murcianas y españolas, adoptaron distintos posicionamientos y actitudes no solo en cuanto al "Año Internacional de la Mujer" sino respecto a los cambios que se realizaron en el conjunto de la sociedad y del estado. A continuación, se refleja qué actitudes o cómo afrontaron las mujeres desde posturas afines al régimen hasta las disidentes el transcurso del año 1975. En primer lugar, centrarme brevemente en la institución dependiente directamente del régimen, Sección Femenina. Esta organización reflejaba y perpetuaba el modelo femenino que todas las mujeres debían seguir y asumir. Su discurso se basaba en el fomento de la vida social de la mujer entorno al "hogar" y la "familia", así pues, comprometida con las causas de la mujer mantiene en su discurso la inferioridad del sexo femenino respecto al masculino. Este posicionamiento hace entendible que Sección Femenina a pesar de encargase oficialmente de organizar la celebración del Año Internacional de la Mujer surgiesen alternativamente otras organizaciones que clandestinamente programaron dicha celebración con eventos, actividades y charlas más acordes con los intereses de promoción, formación y aprendizaje de las mujeres. Es interesante la evolución de esta organización en sus últimos años de vida pues hasta que no fue patente su desaparición no se replanteo un cambio de discurso acorde con las mujeres españolas, siempre se mantuvo fiel a los pilares del franquismo incluso una vez desaparecido Franco. Por consiguiente, para el debate de la transición esta institución no creó problemas pues terminaría disolviéndose por el Decreto Ley del 1 de Abril de 1977, mediante el cual el nuevo régimen político desmanteló las viejas instituciones y organizaciones del franquismo, con el fin de crear otras más acordes en el nuevo sistema democrático que se estaba inaugurando. En esas fechas, Pilar Primo de Rivera defendía el ideario político creado en sus comienzos para la mujer y su educación, mostrando una absoluta convicción en la ideología falangista de corte tradicional, paternalista y sobre-protectora en lo referido a la mujer.

En un segundo grupo he catalogado las organizaciones de corte católico (Acción Católica, Hermandad Obrera de Acción Católica...) que, sustentadas en los valores tradicionales, introducen un discurso más innovador, atendiendo a problemas de las mujeres como madres (viudas o separadas) y dentro de la familia (maltrato), y también para el mejoramiento de la condición de "ser mujer". Asi pues, puede destacarse la perspectiva y opinión de Pilar Bellosillo" sobre el Año Internacional de la Mujer y qué efectos positivos ha tenido sobre la sociedad, en especial, sobre lo denominado "revolución de la mujer":

Por de pronto una revolución qué duda cabe, que hoy muchas cosas se han transformado, había un cierto orden establecido, ha visto que yo he mencionado un mundo de la mujer y un mundo del hombre. Mientras la mujer ha estado encerrada en ese mundo todo ha ido bien; en el momento que sale e intercede en el mundo del hombre hay un cierto desequilibrio, y al fin y al cabo los dos son parte de él, y cuando el papel de uno cambia, repercute también en el otro, sobre todo en la vida de la familia, en la sociedad. Se trata de encontrar caminos nuevos y originales.

19 AMM: La Verdad de Murcia, Miércoles 17 de diciembre de 1975, p. 7. Pilar Bellosillo fue Presidenta Nacional de las Mujeres de Acción Católica entre 1951 y y 1963, ocupó responsabilidades en el apostolado internacional, como presidenta de la UMOFC (1961-1974) y de la Conferencia de las resándose por eliminariol trata Catolicas (1965-1971). Fue auditora en e Concillo Vaticanoll, intemiembro de la Comisión Pontificia para el estudio del papel de la mujer en la lglesia.
Las voces femeninas católicas analizadas para el año 1975 en el diario La Verdad de Murcia realizan aportaciones muy interesantes y coherentes entre las relaciones de hombres y mujeres; y qué supone el Año Internacional de la Mujer para Acción Católica, así como los fines que se pretenden conseguir. Resulta también destacable cómo las mujeres de Acción Católica crearon su propio discurso sobre las relaciones de género y su modelo de mujer desde la década de los sesenta. ${ }^{20}$ Sus actuaciones centradas en el campo de la ayuda, formación, reuniones, eventos, etc., no constituían un peligro público para el sistema franquista, no suponía una alteración del orden establecido.

La importancia de la fuente hemerográfica seleccionada radica en el panorama rico, multicultural y diverso que ofrece sobre las mujeres. Pues frente a los modelos descritos muestra también un amplio abanico de organizaciones, colectivos, asociaciones o hermandades que para el año 1975 buscan redefinir la división de los sexos socialmente impuesta y, las relaciones entre hombres y mujeres no solo teórica o discursivamente, sino desde la praxis; y, así pues se ha podido identificar las intervenciones públicas protagonizadas por mujeres alterando las normas y el orden público del régimen.

De las organizaciones femeninas del momento encontramos que no todas aparecen continuamente reflejadas, sino que permanecen y actúan desde la clandestinidad, pero in fluenciando sobre otras asociaciones o movimientos de mujeres; y, desde esa clandestinidad conforman la mayor oposición al modelo de la Sección Femenina. En algunos casos estas organizaciones y movimientos de mujeres se vinculan al Partido Comunista Español a través de Movimiento Democrático de Mujeres que se introducía en las Asociaciones de Amas de Casa facilitándole desde esa posición su lucha por los derechos de las mujeres. Durante el año 1975 el Partido Comunista ejerció una considerable actividad; destacarse el llamamiento general a huelga de Madrid, que no fue secundado, masivamente, ni por trabajadores ni empresarios, pero en el que sí hay constancia de participación femenina. La consecuencia para numerosas asociaciones femeninas que participaron en este evento fue su clausura temporal, ${ }^{21}$ entre las afectadas se encontraban: Asociaciones de Mujeres Separadas legalmente, Asociación Castellana de amas de casas, Asociación de Amas de Casa de Getafe, Asociación de amas de hogar del distrito de Ventas... hecho que evidencia la vinculación entre asociaciones femeninas con el partido comunista, y el importante papel público desempeñado por éstas en acciones contestatarias al régimen de Franco. Entre las repercusiones de estos hechos se recoge la información concerniente al juicio contra Lydia Falcón ${ }^{22}$ y Eliseo Rayo. ${ }^{23}$ También son destacables los sucesos acaecidos durante la festividad del Día de la Madre donde varios de estos grupos de mujeres se unieron para protestar en contra del concepto de "maternidad" utilizado en el discurso político y público por la dictadura y contra la pena de muerte. Y, por otra parte, el día de la madre fue suplido por el carácter del Año Internacional de la Mujer, para darle una mayor

20 Mónica MORENO SECO: "De la Caridad al Compromiso: Las mujeres de Acción Católica (19581968)", Historia Contemporánea, 26 (2003), pp. 239-265. En este artículo la autora expone sobre el proyecto de Acción Católica de Mujeres: "En su discurso hacia las mujeres españolas, abandonó el prototipo femenino de la posguerra, encerrada en casa y de una rígida moralidad, para ofrecer una adaptación a una realidad social en proceso de cambio", p. 247.

21 AMM: La Verdad de Murcia, 21 de febrero de 1975, p. 11. “Informa la dirección general de Seguridad: Fracasó en Madrid un Ilamamiento a la huelga general". La Verdad de Murcia, 26 de febrero de 1975, p. 11.

22 Lydia Falcón, nacida en Barcelona el 13 de diciembre de 1935, es una de las principales figuras feministas de la Transición Española asi como de las más perseguidas durante la Dictadura. Es fundadora de la revista Vindicación Feminista y Poder y Libertad. Ha sido presidenta y fundadora de algunas de las más importantes organizaciones feministas de la actualidad y posee una ra de algunas de las mas importantes organizaciones feministas de la actualidad y posee una
amplia bibliografía a consultar. Visitar: http://www.lidiafalcon.com/index.php? $s=1$, consultado el $15 / 06 / 2014$.

23 AMM: La Verdad de Murcia, 26 de febrero de 1975, p. 12 . 
representatividad y difusión. Así pues, ante el acontecer de este evento se deja constancia en la fuente de la celebración en Madrid de un acto Sindical para hacer efectiva la integración social de la mujer trabajadora. ${ }^{24}$

Otras asociaciones con una importante presencia femenina y con una considerable actividad durante este año, a nivel regional y nacional, fueron las Asociaciones de Amas de Casa, Asociaciones de Vecinos o Asociación de Padres de Alumno como evidencia el diario en sus continuas referencias, aludiendo a actividades, reclamaciones, descontentos, soluciones o proyectos con carácter propio... Estas asociaciones enraizadas en la sociedad se preocupaban encarecidamente por las cuestiones propias de la actualidad, como por ejemplo, el encarecimiento de los precios (aceite, electricidad, gas....), o de aquellas necesidades consideradas más primarias, como puede ser el saneamiento y limpieza, acceso a viviendas... Problemas de carácter social que propiciaron demandas, movilizaciones y protestas, como por ejemplo, el boicot organizado en Madrid por varias asociaciones, inclusive, amas de casa, ante el encarecimiento de la vida. Las actuaciones de estas organizaciones muestras que los problemas de la sociedad se debían a fallos del sistema y por ello los ciudadanos y las ciudadanas pedían cambios.

En el caso murciano, se encuentran reivindicaciones de los colectivos profesionales femeninos, cuyos fines pretendidos eran la igualdad y más oportunidades para su desarrollo. Este espacio se convirtió en uno de los lugares claves de reunión y sociabilización femenina, donde la discriminación se parpaba de manera más evidente en salarios, horarios, contratos, etc., pero que permitía a las mujeres desarrollar un pensamiento y una conciencia de sí, de su trabajo, de sus cualidades y capacidades que divergían de los presupuestos teóricos del régimen político franquista. La incorporación laboral de las mujeres en los mismos oficios y espacios que el hombre (empresarias, catedráticas, toreras, pilotos, luchadora libre, etc.) generó un choque entre lo que se entendía como propiamente "femenino" y "masculino", pero benefició especialmente a ésta dotándole una nueva perspectiva sobre su auténtica situación y el posible papel a jugar. Así pues, no debe de extrañarnos que en el año 1975 estas mujeres tuviesen la capacidad, las herramientas y los medios para hacerse escuchar. La acción realizada por estas trabajadoras puede resultar similar a otros caso donde el descontento o malestar le hace presentarse en la institución o entidad competente para entregar sus reclamas. Entre las noticias de ese año destacan los conflictos relacionados con las prestaciones de servicios ante los cuales sobresale la capacidad resolutiva de las trabajadoras para movilizarse y presentarse ante los órganos oficiales. El diario de La Verdad habla para estas fechas de la iniciativa de un grupo de enfermeras murcianas que ante las deficiencias en el transporte público contrataron un servicio privado que pusiera fin a los problemas de desplazamiento hasta su lugar de trabajo. Esta actitud positiva y resolutiva es destacable pues muestra como los colectivos, ante las posibles deficiencias resuelven sus necesidades como trabajadoras buscando sus propias alternativas y de manera autosuficiente ante la inoperatividad de las autoridades. La incorporación de las mujeres al ámbito laboral evidencia el desarrollo de un "individuo" cada vez más psicosocial.

Por otra parte, se debe destacar los movimientos de mujeres caracterizados por ser grupos reducidos de madres y esposas, ${ }^{25}$ organizadas en torno a un tema común, siguiendo unas pautas de organización y empoderamiento del espacio público, concretamente, es interesante observar las múltiples y continuas intervenciones que se producen en el año 1975 por grupos de mujeres murcianas ante el Ayuntamiento o casa consistorial (espacio de representación de pueblo y centro de poder). La ocupación de dicho organismo se produce ante la búsqueda de

24 AMM: La Verdad de Murcia, 29 de abril de 1975, p. 26

25 AMM: La Verdad de Murcia, 10 de agosto 1975, p. 1 y 5; 12 de agosto, p. 1 y 5; y 14 de agosto de 1975, p. 6; ID: "Recibió el Alcalde a un grupo de mujeres de Sangonera: Les prometió resolver lo antes El alcalde recibió a un grupo de mujeres de "Los rosales", 28 de septiembre de 1975, p. 5. soluciones y respuestas a sus demandas de viviendas dignas pues ellas son las representantes de la familia y de la sociedad. Las actuaciones de estas mujeres, madres y esposas, son muy variadas (asentada, firmas, huelgas, protestas, etc.) y, nos llevan hasta un tipo de cultura política democráticos sino también en valores del bienestar (guarderías, centros de salud, señalización vial...): las demandas fundamentales giran en torno a la educación, vivienda, abastecimiento de agua, limpieza y recogida de basura, mejoras de carreteras, etc. Se genera así una identidad femenina aunada contra las precariedades de su medio, consciente de sus papel como encargadas y portavoces del hogar para la solución de los mismos, adquiriendo un papel o protagonismo mayor que el masculino, ya que en diversos casos son las propias mujeres las que interfieren por estos en problemas laborales de ellos, disipando una capacidad resolutiva y eficaz que hasta la fecha ha pasado desapercibida.

Ejemplos como éste, de movimientos de mujeres que desde sus roles tradicionales adquieren conciencia de los problemas que las unen, y luchan por solucionarlos conjuntamente desde su unidad de grupo, serán cada vez más frecuentes en las páginas de papel de la prensa regional murciana. ${ }^{26}$ En esta época se puede apreciar cómo se desarrollan unos lazos de amistad, de hermandad entre las esposas y madres, de apoyo y de ayuda mutua, que les da coraje y fuerza para afrontar los problemas y apoyar públicamente a sus maridos y familiares. Tal es el caso de las esposas de los trabajadores de la empresa Cauchos de Levante, que deciden marchar para apoyar a sus maridos. ${ }^{27}$

El rol desempeñado por estas mujeres parece inicialmente vinculado a la imagen tradicional de la mujer, pero como consecuencia del contexto y del impacto que la situación económica y laboral ejerce sobre ellas, no dudan en ser las portavoces del descontento. En este tipo de movimientos las mujeres no son conscientes del poder que ejercen como ciudadanas, como sujetos políticos, porque sus reivindicaciones van vinculadas a las actividades consideradas "naturales" de madre, esposas y amas de casa. Pero como se observa, son sujetos versátiles que se mueven entre la tradicional separación patriarcal de los espacios doméstico y público haciendo de esa división un mismo espacio en el cual todo converge.

Por último, cabe resaltar las actuaciones de las presas en las cárceles y la acción de las "mujeres" de presos. ${ }^{28}$ Las mujeres encarceladas estaban prisioneras de si mismas, los barrotes limitaban su contacto con el exterior, pero son ellas las que marcan sus relaciones y los lazos con las otras presas, con sus compañeras. Dentro de las cárceles estas figuras desarrollaron unos vínculos especiales que les permitían enseñarse y aprender entre ellas de sus propias relaciones personales. Este grupo no era homogéneo, pues convivían mujeres de distinta clase, educación, ideología, tendencia política, etc. Este amplio abanico posiblemente marcase diferencias en el exterior, pero en prisión desarrollaron unas características propias pues no contaban con herramientas que las ayudasen a ser escuchadas por el exterior. Para las mujeres y madres de presos

26 AMM: La Verdad de Murcia, 5 de diciembre de 1975, p. 15

27 AMM: La Verdad de Murcia, 10 de diciembre de 1975, p. 5. Desde la historiografía regional murciana esta problemática ha sido abordada en Carmen González Martínez y Fuensanta Escudero Andujar: "Significación histórica de la lucha sindical de la construcción y el metal durante la transición en Murcia", en IV Congreso Internacional, Historia de la transición en España, Sociedad y movimientos sociales, Almería, 2009.

28 Irene ABAD, Eva ABAD y Pablo GRACIA (eds.): Fuimos mujeres de preso, Gobierno de Aragón, 2011; Vicenta VERDUGO MARTI: "Franquismo y represion penitenciaria femenina: las presas de Franco en Valencia", Arenal: Revista de historia de mujeres, 15-1 (2008), pp. 151-176; Ana María AGUADO HIZOON y Vicenta VERDUGO: "Las cárceles franquistas de mujeres en Valencia: castigar, purificar y reeducar", Estudia Histórica, 29 (2011), pp. 55-85; ID: "Represión Franquista sobre las mujeres. Prihispanianova.rediris.es/, consultado el 15/06/2014. 
y presas existía un abanico más amplio de posibles formas de actuación reivindicativa que iban desde manifestaciones en las puertas de las cárceles, a otro tipo de actos más violentos y, en algunos casos dirigidos por grupos armados. La necesidad que compartían todas estas mujeres, presas y madres, era la de sentirse pertenecientes a un grupo, a un colectivo o a una hermandad en la que pudiesen encontrar el apoyo y auxilio en los momentos de mayor dureza y, un hombro donde apoyarse para continuar el camino. Si hubiese que delimitar las demandas de este grupo en una palabra para el año 1975, esa sería "Amnistía". El diario La Verdad de Murcia se hace eco de las protestas, atentados y huelgas perpetrados durante el mes de agosto de 1975 contra la cárcel de mujeres en Valencia, acontecimientos que reflejan la relevancia de la cuestión para la sociedad española y, la eminente necesidad de una resolución que fue dada por Juan Carlos de Borbón concediendo el indulto general, pero esta medida no silenció ni a hombres ni a mujeres, pues la amnistía constituía una lucha personal y una seña de identidad de lo que eran.

El discurso femenino, dentro de su diversidad, tenía unas demandas y objetivos claros. A nivel legislativo se lucha por el reconocimiento de la mujer en el trabajo bajo las mismas condiciones, igual remuneración, acceso a los puestos sindicales, reconocimiento de su esfuerzo y no depender del consentimiento masculino para acceder al mundo profesional ya que el hombre no tenía ninguna traba. Se pedían reformas legales que estuviesen acorde a la práctica diaria de la sociedad, pues las existentes distorsionaban con su teoría la realidad social y, especialmente, la femenina, que reclamaba cambios significativos, incluso en las leyes que definían las relaciones dentro del matrimonio. Así pues, para esta fecha se consiguió la promulgación de la ley 14/1975 que reformaba determinados artículos del Código Civil y del Código de Comercio sobre la situación jurídica de la mujer casada y los derechos y deberes de los cónyuges. ${ }^{29}$ En relación a esta nueva situación legal, el diario La Verdad informaba sobre el avance de estas modificaciones pero también muestra la verdadera situación legal de la mujer española en esas fechas, dependiente del hombre en cuestiones económicas y disposición de sus bienes. Entre las nuevas disposiciones mencionar aquella que hace del matrimonio una relación de respeto y protección mutua despareciendo la fórmula discriminatoria de: la protección como atributo del marido y la obediencia como deber de la mujer. Esta nueva situación, ubica en un plano de mayor igualdad a ambos cónyuges, en una relación que debe de caracterizarse como tal, lo que incide en un paulatino cambio de los roles propiamente femeninos y masculinos. ${ }^{30}$ Otra medida conseguida fue el Proyecto de ley de Relaciones Laborales, que reconocía la igualdad entre las mujeres y los hombres en lo referente a los derechos laborales. Incidir en dos aspectos que atiende esta ley, por un lado, la mujer no necesitaba a partir de este momento el consentimiento del marido para trabajar, y también se atiende a la cuestión de la maternidad femenina. En los dos párrafos que la noticia dedica a esta cuestión destaca el lenguaje utilizado al marcar como "pionera" la nueva situación laboral, cuando a nivel internacional esa situación estaba ya solucionada con anterioridad. Resultaba un retraso de sus derechos que en la década de 1970 la muje casada todavía tuviera que depender del marido para tomar decisiones. Esta ley llegaba tardiamente, las necesidades y cuestiones familiares y sociales de las décadas de 1950 y 1960, habían obligado a la mujer a trabajar (en la fábrica, servicio doméstico, etc.).

El aborto fue una temática candente en este año 1975 que distaba de ser un derecho conseguido. Esta demanda femenina y feminista chocaba con el fuerte peso de la religión y mentalidad tradicionalista, una demanda que todavía hoy es objeto de controversia y debate en la actualidad. Así pues, se evidencia mediante el análisis de la fuente propuesta, las diferentes

29 Ley 14/1975 sobre la Reforma que determina dos artículos del Código Civil y del Código de Comercio sobre la situación jurídica de la mujer casada y los derechos y deberes de los cónyuges. Boletín Oficial del Estado (en adelante, BOE), 5 de mayo de 1975, número 107, pp. 9413-9419.

30 AMM: La Verdad de Murcia, 30 de abril de 1975, p. 21. opiniones entre hombre y mujeres sobre el aborto. Mientras que algunas mujeres se posicionan a favor de su aprobación, el hombre justifica su desaprobación señalando que el embrión o feto es otro cuerpo y, por consiguiente no puede decir sobre él además de subyacer la problemática de reformar el Código Penal para legalizar el aborto. ${ }^{31}$ Pero cabe plantearse hasta qué punto el cuerpo de la mujer es propiamente suyo y el embrión independiente del cuerpo de la madre. La cuestión subyace en que la mujer como madre, como persona destinada a tener hijos, no tiene otorgado el poder de decisión sobre cuándo no desea ser madre, cuándo no quiere cumplir los artículos impuestos legalmente desde el hombre. En resumen, es una cuestión de creencias posicionarse en una opinión u en otra, y de valoraciones personales, pero que deben de ser igualmente de respetables y aceptadas. En las noticias reacias al aborto se defiende una figura de la mujer que está destinada a sus funciones reproductoras, y esta medida supone una ruptura de esa visión tradicional. Por consiguiente, entonces como ahora esta lucha resulta espinosa simplemente con plantearla y marca las desigualdades entre hombres y mujeres.

El año 1975 se caracterizó por una gran actividad femenina, diversidad en los posicionamientos ideológicos, en la manera de organizarse, de dibujarse públicamente, de reivindicar todos los problemas sociales y en especial, por transgredir la separación de los espacios. Así pues, como reflejo de todos esos hechos y eventos en el mes de diciembre se celebró el I Congreso de Liberación de la Mujer, donde se establecieron reclamas como: "Educación diferencial y de la doble moral, que marca pautas de comportamiento distintas para el hombre y la mujer desde su nacimiento, así como la desaparición de la mujer como objeto sexual y su manipulación en los medios de comunicación". ${ }^{2}$ Este evento constituía el primer pilar que materializaba la actividad del asociacionismo femenino y del feminismo realizado desde anteriores años y, también fue el primer pilar para continuar con la edificación que luchaba por los derechos de las mujeres españolas, por su reconocimiento en igualdad al hombre, y por una reconceptualización de las relaciones de género, por una sociedad de los y las iguales.

\section{Conclusiones: ¿Qué aportan las mujeres al debate de la transición?}

Las nuevas preguntas planteadas en femenino sobre el proceso de la Transición Española muestran una perspectiva más completa y compleja, que revaloriza el papel desempeñado y jugado por éstas a nivel público y político. Sus formas de organización y de actuación se transmiten en el tiempo, el uso de los medios en su favor las representa y hace perdurable en el tiempo; $y$, además establecieron las bases para continuar con su labor en nuestro presente actual. Su papel en el año 1975 destaca por mostrar públicamente los principales problemáticas de la sociedad española y, entre ellas, de las mujeres; por luchar continuadamente y, poner sobre la palestra temas tan conflictivos, como el divorcio, aborto y violencia doméstica, que perduran en nuestro presente. Por otra parte, los movimientos de mujeres evidencian el importante papel que éstas tuvieron y tienen en el "hogar" y fuera de éste, mediante su constante presión y reivindicación pues su actitud evidencia que la única forma de obtener logros es a base de insistir, de hacerse escuchar.

La perspectiva de este estudio pone en interacción las distintas culturas políticas existentes para el año 1975, los distintos posicionamientos ideológicos y culturales de la sociedad, pero a través de la historia y la visibilidad de las mujeres, y se ha intentado profundizar en cada uno de los modelos $u$ organizaciones femeninas para mostrar su pensamiento, formas de organizarse, reivindicaciones y actuaciones. Las consecuencias de todas estas acciones fueron múltiples en los distintos campos de la sociedad, pues políticamente abrieron una brecha muy

31 AMM: La Verdad de Murcia, 5 de febrero de 1975, p. 2

32 "Resoluciones y conclusiones de las I Jornadas por la liberación de la mujer", Madrid, 1975, pp. 147 150, disponible en: $h$ ttp://www. amparomorenosarda.es/en/node/88, consultado el 15/06/2014. 
Los cambios introducidos afectaron a la mujer en el mundo profesional, y a su mejor preparación y capacitación se une su incorporación a carreras y campos fuertemente masculinizados; abrieron camino, aunque los discursos en ocasiones no apoyaran ni fomentasen estas nuevas incorporaciones, sino que mantenían los principios tradicionales, lo que no fue barrera para que las mujeres continuaran con su avance. Por otra parte, se planteaban reclamos como la ciudadanía, el derecho al voto, el aborto, etc., demandas propiamente femeninas con una larga tradición de lucha y reivindicación; temas de gran complejidad que reflejan la realidad de las peticiones de las mujeres, dependientes de la intermediación y decisiones de los partidos políticos. Por consiguiente, se ha puesto de relieve las percepciones y estrategias, los cambios y permanencias de los posicionamientos y luchas femeninas, así como la aportación que los distintos grupos de mujeres realizaron al período de la Transición. 


\section{LOS PARTIDOS DEMÓCRATA CRISTIANOS \\ ALEMANES EN EL PROCESO DE TRANSICIÓN}

DEMOCRÁTICA ESPAÑOLA*

Natalia Urigüen López de Sandaliano

Universidad Nacional de Educación a Distancia una transición pacífica hacia la democracia. Hasta la fecha únicamente el historiador Antonio Muñoz ha realizado un exhaustivo y profundo trabajo de investigación sobre el papel jugado por uno de los dos grandes partidos políticos alemanes y la fundación política de ideología alemán, SPD y la Fundación Friedrich Ebert (FES

El objeto de la presente investigación es precisamente comenzar a arrojar algo de luz sobre el papel jugado por la democracia cristiana alemana en la transición española, es decir por la Unión Demócrata Cristiana (CDU) y en menor medida su partido hermano en Baviera, el Partido Social Cristiano (CSU). Su ayuda se materializó a través de unas figuras características del sistema político alemán, las fundaciones políticas cercanas a ambos partidos, Fundación Konrad Adenauer (KAS) y Fundación Hanns Seidel (HSS) respectivamente.

La CDU fue el partido en la oposición en los años setenta, pero había estado al frente del gobierno alemán durante veinte años, desde la creación de la RFA en 1949 hasta 1969. Mientras que la contribución de la democracia cristiana alemana a la democratización portuguesa ya ha sido estudiada, apenas existen referencias sobre el papel que jugó en el proceso español. ${ }^{3}$ Dos vectores, la fragmentación del ámbito demócrata cristiano español a mediados de los años setenta y el simple hecho de los desastrosos resultados obtenidos por el grupo demócrata cristiano de ámbito nacional en las elecciones generales de 1977, pueden no animar a iniciar un trabajo de investigación al respecto, presuponiendo el fracaso de la ayuda alemana. Sin embargo, el intento fallido, si es que realmente lo fue, bien puede merecer un estudio profundo. Este trabajo se va a limitar a analizar el papel de la democracia cristiana alemana ante las primeras elecciones democráticas.

El papel de la CDU y la Fundación Konrad Adenauer durante los primeros momentos de andadura democrática

Tras casi cuarenta años de dictadura en España la limitación e inmadurez de los partidos políticos a mediados de los años setenta era un gran problema para la consecución y mantenimiento de la democracia. Uno de los escasos intentos de aperturismo por parte del régimen franquista había sido la Ley de Asociaciones Políticas de $1974,{ }^{4}$ cuyo objetivo era crear un sistema multipartidista, frente al sistema unipartidista de la dictadura. Dadas sus grandes sistema multipartidista, frente al sistema unipartidista de la dictadura. Dadas sus grandes
limitaciones y escaso aperturismo, el intento fracasó y la mayoría de los grupúsculos políticos se mantuvieron en la ilegalidad hasta poco antes de las elecciones generales de 1977 . Sin embargo, el ambiente de apertura que comenzó a extenderse en la política española desde poco antes de 1975 y el miedo a un posible contagio del avance del comunismo portugués, favoreció que la CDU comenzara a interesarse por sus partners españoles.

La CDU no tuvo que enfrentarse al dilema de tener que buscar un interlocutor de ideología afín en territorio español. Ya lo tenía. Se trataba del Equipo Demócrata Cristiano del Estado Español (conocido como EDCEE o Equipo), que representaba a la democracia cristiana española en la Unión Europea Demócrata Cristiana (UEDC). Algunos miembros destacados de la CDU, a nivel extraoficial, mantenían contacto o amistad personal con otros políticos españoles, en su mayoría de ideología democristiana que no pertenecían al Equipo. Esto les permitía obtener otros puntos de vista sobre el desarrollo de la situación en España. Sin embargo, oficialmente,

Antonio MUÑOZ: El amigo alemán. EI SPD y el PSOE de la dictadura a la democracia, Barcelona, RBA Libros, 2012.

3 Matthias STENGER: Transnationale Parteienzusammenarbeit. Die Beziehungen der deutschen und portugiesischen Christlichen Demokraten vor der Nelkenrevolution bis zum Vertrag von Maastricht (1974-1992), Bonn, Droste, 2011

4 Decreto Ley 7/1974 de 21 de diciembre por el que se aprueba el Estatuto Jurídico del Derecho de Asociación Política, en: BOE $n^{\circ}$. 306, 23 de diciembre de 1974.
Este análisis forma parte del trabajo de investigación de la autora pa"
ayuda de la democracia cristiana alemana en la transición española".

1 Sirvan como ejemplo los trabajos de Encarnación LEMUS: Estados Unidos y la Transición española. Entre la Revolución de los Claveles y la Marcha Verde, Madrid, Silex Ediciones, 2011; Charles POWELL: El amigo americano. España y Estados Unidos: de la dictadura a la democracia, Barcelona, Galaxia Gutemberg, 2011. 
entre 1975 y las elecciones de junio de 1977, los demócrata cristianos alemanes apoyaron al Equipo y por lo tanto a los partidos que lo integraban.

Había sido la Unión Europea Demócrata Cristiana, creada en 1965 y heredera de los NouveIles Equipes Internationales, ${ }^{6}$ la que, siguiendo el artículo $3^{\circ}$ de sus estatutos, ${ }^{7}$ había exigido a los pequeños grupúsculos democristianos españoles unirse en un solo grupo para poder ser reconocido oficialmente como su interlocutor en España y a su vez estar éste representado en la organización europea. ${ }^{8}$ El Equipo, formado en diciembre de 1965 , se componía de cuatro grupos democristianos españoles, dos de ellos de ámbito nacional (Izquierda Democrática y Democracia Social Cristiana) y otros dos regionalistas (Partido Nacionalista Vasco y Unió Democrática de Catalunya, a los cuales se unió en 1973 la Unió Democrática del País Valencià). ${ }^{9}$ El empeño que pusieron los partidos integrantes de la UEDC para conseguir que el Equipo se convirtiera en un potencial partido político fuerte y consolidado, resultó un fracaso. Esa unión, más ilusoria que realista, fue un acuerdo de mínimos y pronto dejó ver las fracturas entre sus miembros, ocasionadas por el rechazo dentro del Equipo a las propuestas federalistas de catalanes y vascos, además de por el personalismo de los líderes de los partidos de ámbito nacional, José María Gil Robles y Joaquín Ruiz Giménez, dirigentes de Democracia Social Cristiana e Izquierda Democrática, respectivamente. ${ }^{\circ}$ La actividad del Equipo quedó reducida a la representación conjunta de la democracia cristiana española en los organismos y reuniones internacionales, ya que dentro de España fue muy limitada."

La relación entre la CDU y el Equipo se mantuvo fundamentalmente a través de la Fundación Konrad Adenauer (KAS) hasta las elecciones de 1977. Conviene hacer un inciso para explicar brevemente la naturaleza e importancia de estos agentes transnacionales, característicos del sistema político alemán. Las fundaciones políticas se crearon tras la Segunda Guerra Mundial como organizaciones para la educación política interna, un cometido imprescindible tras doce años de nacionalsocialismo. Están financiadas con fondos públicos, aunque utilizan el status de ONGs. Actúan en el ámbito de la RFA, pero son también muy activas en proyectos políticos internacionales. Por cada partido político existe una fundación de ideología cercana, aunque legalmente son independientes de ellos. ${ }^{12}$

a Fundación Konrad Adenauer, que no abrió su delegación en Madrid hasta el octubre de 1976, había comenzado a interesarse por la situación española desde mediados de 1975. E presidente de la fundación, Bruno Heck (ex Ministro y Diputado de la CDU) dejó en manos de

5 Natalia URIGÜEN: "Von der "traditionellen Freundschaft " zur "notwendigen Nähe" -Entwicklung der Aussenpolitik der Bundesrepublik Deutschland gegenüber Spanien (1949-1979)" Histo-

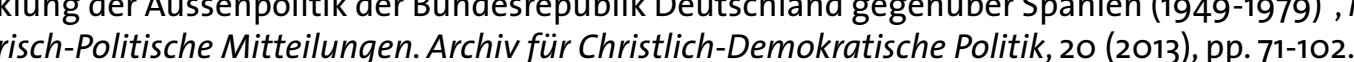

6 Sobre los Nouvelles Equipes Internationales ver Winfried BECKER: "Die Nouvelles Equipes Internationales und der Föderalismus", Historisch- Politische Mitteilungen. Archiv für Christlich-Demokratische Politik, 15 (2008), 2008, pp. 81-102.

7 Según el artículo $3^{\circ}$ de los Estatutos, la Unión Europea Demócrata Cristiana (UEDC) está conformada por los partidos demócrata cristianos europeos. Si en un país existiera más de un partido demo-

Donato BARBA: La oposición durante el franquismo. La democracia cristiana, Madrid, Encuentro, 2001, p. 129.

9 Acuerdo de constitución del Equipo de la U.E.D.C. del Estado Español, del 16 de diciembre de 1965. Archivo personal José María Gil Robles.

10 UEDC/EUCD, Procès-verbal de la reunión du bureau, Rome, 17.12.1966, Archivo Político de la Democracia Cristiana (Archiv für christlich-demokratische Politik, ACDP) 09-004-030, Sankt Augustin, (Bonn).

11 Donato BARBA: La oposición durante el franquismo..., p. 215

12 Natalia URIGÜEN: “Treinta años de política exterior alemana hacia España (1949-1979)". Trabajo

de fin de máster defendido en la UNED, el 27 de septiembre de 2012
Josef Thesing, responsable en la KAS del Institut für Internationale Solidarität, ${ }^{13}$ toda la carga del proyecto español. A Heck le costaba asumir la idea de que para la democratización de España era absolutamente necesario contar sólo con democristianos de la oposición, que no tuvieran nada que ver con el régimen franquista. Thesing estaba convencido de ello, por lo que el presidente de la KAS le dio un voto de confianza al respecto, dejando en sus manos la responsabilidad del proyecto español. Además Thesing contaba con la ventaja de haber hecho un acercamiento al mundo hispano, al haber sido con anterioridad representante de la fundación en Guatemala y Colombia. Los intereses fueron principalmente dos: favorecer la democratización del país con fuerzas democráticas españolas, evitando así la continuidad del franquismo sin Franco y fomentar la entrada de España en la Comunidad Económica Europea. ${ }^{14}$

Con motivo de un viaje de cuatro días realizado a España a principios de junio de 1975, Bruno Heck se reunió con algunos representantes de partidos miembros del Equipo para estudiar la posibilidad de constituir en Madrid un centro o instituto de formación política, que contaría con la asistencia técnica y material de la KAS. ${ }^{15}$ Un mes después del viaje de Heck, entre los días 10 y 16 de Julio, Íñigo Cavero, miembro de Izquierda Democrática, se desplazó a Bonn invitado por la fundación. Se trataba de que Cavero adquiriera un profundo conocimiento de los diferentes organismos que conforman dicha institución y de las posibilidades de ayuda al Equipo. ${ }^{16}$ Durante su estancia se reunió con Josef Thesing elaborando un primer borrador de un programa de trabajo conjunto, con un plan de formación política y financiación para el año 1976 , como continuación a las conversaciones iniciadas en junio con Bruno Heck. ${ }^{7}$

Pasado el verano, el Equipo realizó algunos tanteos en su búsqueda de un centro que pudiera ser utilizado como instituto de formación política, lo cual no era nada fácil en septiembre de 1975, en un momento en el que la represión a los grupos políticos era notoria y las posibilidades de cierre o clausura del local, sobre cuya existencia no tardaría en conocer la Dirección General de Seguridad, eran muy de temer. En concreto se dirigieron a la Fundación Universitaria San Pablo (obra de la Asociación Católica de Propagandistas), que disponía de varios Colegio Universitarios y Mayores, lo cual beneficiaba la discreción de las actuaciones, en medio de un Centro de miles de alumnos. A su vez, permitía a la KAS la posibilidad de concertar un convenio con una entidad española, con personalidad jurídica y cuyos fines estatutarios parecían congruentes con los objetivos del convenio, exigencia de la propia legislación alemana,

13 En paralelo a la creación en la RFA, a principios de los años sesenta, del Bundesministerium für wirtschaftliche Zusammenarbeit und Entwicklung (BMZ), ministerio para la cooperación económica con los paises en vías de desarrollo, la KAS creó en julio de 1962 su propio instituto de solidaridad internacional, el Institut für Internationale Solidarität. A través de esta entidad la fundación canalizó las ayudas recibidas del ministerio y desarrolló los contactos con partidos demócrata cristianos, sindicatos y otras instituciones en los países en vías de desarrollo. La idea general era ayudar a quienes lo necesitaban, bajo las premisas de un entendimiento cristiano de los derechos humanos, democracia y justicia social. Sobre el trabajo que se desarrolla a través del Institut für Internationale Solidarität ver Josef THESING: "Die Konrad-Adenauer-Stiftung in der Welt. Der Beginn der Arbeit des Instituts für Internationale Solidarität", Historisch- Politische Mitteilungen. Archiv für Christlich-Demokratische Politik 19 (2012), pp. 305-318.; íD. (coord.): In der Welt und für die Welt. 40 Jahre internationale Zusammenarbeit, Sankt Augustin, Konrad-Adenauer-Stiftung, 2002. 14 Josef Thesing, Octubre 2012, Sankt Augustin (Bonn), entrevista realizada por Natalia Urigüen.

15 Memorándum redactado por Îñigo Cavero el 17 de marzo de 1976. Archivo personal de Josef Thesing.

16 Nota informativa sobre la Fundación Konrad Adenauer, escrita por Îñigo Cavero a su regreso del viaje a la sede de la fundación, 26 de julio de 1975 . Archivo personal Josef Thesing.

17 Informe de Josef Thesing sobre su viaje a Madrid del 7 al 10 de Septiembre de 1975, Institut für Internationale Solidarität der Konrad-Adenauer-Stiftung e.V., en ACDP 12-001-1261, Sankt Augustin (Bonn). 
controladora de los fondos de las fundaciones políticas. La acogida por el Consejo Nacional de la Asociación Católica de Propagandistas fue favorable..$^{18}$

Entre tanto, en septiembre de 1975, Josef Thesing realizó su primer viaje a España como representante de la Fundación Konrad Adenauer. Los objetivos de su viaje eran dos: concretar definitivamente con los grupos demócrata cristianos españoles la posibilidad de que la fundación colaborara con ellos y la preparación de un proyecto de trabajo conjunto. A lo largo de tres días se entrevistó con varios miembros de Izquierda Democrática y de Federación Popular Democrática (anteriormente Democracia Social Cristiana). Los grupos regionalistas estuvieron representados por los anteriores. Las conversaciones que Thesing mantuvo con los integrantes del Equipo dieron su fruto, puesto que a partir de entonces comenzó a materializarse la ayuda de la Fundación Konrad Adenauer para la creación de un sólido partido demócrata cristiano de carácter federativo. ${ }^{9}$

La colaboración comenzó con la organización de actividades de formación política a través del Instituto de Investigación Socio-Política (INDESP), creado en el seno de la Fundación Universitaria San Pablo. En octubre de 1975 la fundación organizó su primer seminario en Berlín, al que asistieron 25 personas procedentes de los cinco partidos que conformaban el Equipo. ${ }^{20}$ A este primer seminario le siguieron a lo largo de 1976 otros cursos y conferencias organizados en la academia de Eichholz, el Instituto de Ciencias Sociales y el Instituto de Estudios Comunales, todos ellos centros de formación de la Fundación Konrad Adenauer en la RFA. ${ }^{21}$

El 10 de octubre de 1976 la KAS abrió su delegación en Madrid (la primera que abría en Europa) y envió como representante a Manfred Huber, ${ }^{22}$ quien a partir de entonces se encargó de la relación "diaria" con los miembros del Equipo y de la realización de un exhaustivo seguimiento de la evolución de la situación en España, como puede comprobarse a través de todos los informes enviados a Josef Thesing y que éste distribuyó a las más altas esferas de la CDU. ${ }^{23}$

En paralelo al contacto directo con los miembros del Equipo, la Fundación Konrad Adenaue invitó a destacados intelectuales, políticos y periodistas españoles a viajar a la RFA. Su intención era eliminar de las mentes españolas la sensación de aislacionismo y mostrar el pensamiento abierto alemán. Por ello, el abanico de invitados no sólo se limitó a gente de ideología demócrata cristiana. 24

A finales de 1976, la fundación encargó a la empresa DATA, presidida por Juan Linz, la realización de un sondeo de opinión pública muy extenso sobre la realidad política del momento y la intención de voto en España. ${ }^{25}$ Uno de los mayores problemas que observaban Huber y Thesing era la falta de conocimiento del Equipo sobre el comportamiento político de los españoles. Por ello era necesario mentalizar a los cinco partidos demócrata cristianos de las necesidades y voluntad de la sociedad española, antes de las elecciones de junio. Los resultados de dicho sondeo basado en 8.837 entrevistas, se presentaron en enero de 1977: la mayoría de los españoles que-

18 Memorandum redactado por înigo Cavero el 17 de marzo de 1976. Archivo personal de Josef Thesing. 19 Informe de Josef Thesing sobre su viaje a Madrid del 7 al 10 de Septiembre de 1975. Institut für In19 Informe de Josef Thesing sobre su viaje a Madrid del 7 al 10 de Septiembre de 1975, Institut fur In(Bonn).

20 Memorandum redactado por înigo Cavero el 17 de marzo de 1976. Archivo personal de Josef Thesing. 21 Informe personal de Josef Thesing a Bruno Heck, del 21 de Junio de 1976, en ACDP 12-001-1261, Sankt Augustin (Bonn)

22 Josef Thesing, Mayo 2012, Sankt Augustin (Bonn), entrevista realizada por Natalia Urigüen. Manfred Huber, Junio 2013, Sankt Augustin (Bonn), entrevista realizada por Natalia Urigüen

23 Ver los archivos del partido CDU en el ACDP y los archivos personales de Josef Thesing.

24 Sirva como ejemplo la invitación a Bonn de 12 periodistas de diversos rotativos españoles en enero de 1976. Archivo personal de Josef Thesing.

25 Informe confidencial de Josef Thesing para Helmut Kohl, presidente de la CDU (1973-1998), sobre

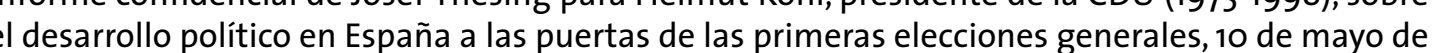
1977. Archivo personal de Josef Thesing. rían la democracia pero rechazaban cualquier política radical y cualquier tipo de experimento en sentido revolucionario. La época de Franco había pasado pero en general, la gente valoraba los beneficios de la reconstrucción económica que se había producido desde los años sesenta. Especialmente la fuerte clase media, que era la mayor beneficiada del desarrollo económico a todos los niveles, no quería correr ningún riesgo político. Nuevas caras como la de Adolfo Suárez, imprimían un nuevo estilo político, con el que se identificaban muchos españoles. Con estas premisas, a la conclusión que se había llegado era que únicamente un partido de centro sería capaz de ganar las primeras elecciones democráticas. Aun presentando estos datos tan relevantes y realizando un gran esfuerzo a todos los niveles, la Fundación Konrad Adenauer no fue capaz de convencer a Gil Robles y Ruiz Giménez de la necesidad de incorporar al Equipo a un gran partido de centro. Fundamentalmente fue el primero quien no quiso unirse con políticos que hubieran tenido algo que ver con el régimen franquista. El resto de los componentes regionalistas del Equipo no tuvieron la fuerza suficiente para cambiar la decisión de los dos anteriores. ${ }^{26}$

En la primavera de 1977 Izquierda Democrática y la Federación Popular Democrática, se unieron en la Federación de la Democracia Cristiana y juntas se presentaron a las elecciones generales de junio. Los resultados fueron desastrosos, obteniendo solamente un 1,18\% de los votos y ninguna representación parlamentaria. ${ }^{27}$

De los interlocutores habituales de la Fundación Konrad Adenauer hubo un grupo liderado por Fernando Álvarez de Miranda, que se había escindido de Izquierda Democrática en primavera de 1976 y había creado el Partido Popular Demócrata Cristiano. Este grupo sí aceptó los consejos de la fundación. ${ }^{28}$ El partido de Álvarez de Miranda se integró en Unión de Centro Democrático, conglomerado 15 de partidos muy heterogéneo -en su seno había grupos políticos que iban desde la socialdemocracia hasta los demócrata cristianos pasando por los liberales- que se había creado pocos meses antes de las elecciones generales. Unión de Centro Democrático, un partido de centro con apenas 3 meses de vida, ${ }^{29}$ ganó las primeras elecciones democráticas consiguiendo 165 escaños: de ellos el grupo demócrata cristiano de Álvarez de Miranda consiguió 34 escaños en el Congreso de los Diputados. ${ }^{30}$

Tras las históricas elecciones generales de junio de 1977, que supusieron la derrota de Gil Robles y Ruiz Giménez, la Fundación Konrad Adenauer decidió centrar su apoyo en la UCD, intentando fomentar a su sector demócrata cristiano y ayudar a su fortalecimiento. ${ }^{31} \mathrm{Hasta}$ su disolución en febrero de 1983, la UCD contó con el apoyo fiel de la CDU. Se trataba de ampliar el sector demócrata cristiano en su seno e integrar al partido en el Partido Popular Europeo, heredero de la UEDC. Sin embargo esto no fue posible al fracasar el proyecto de Unión de Centro Democrático. ${ }^{32}$ Finalmente, avanzados los años ochenta, será Alianza Popular (después Partido Popular) el partido dirigido por Fraga Iribarne, quien acabe siendo en España el partner de la CDU.

26 Ibid.

27 Informe de Josef Thesing "Die Wahlen in Spanien", IIS-Info Auslandsinformationen, 4 de Julio de 1977

28 Fernando Álvarez de Miranda, 14 de febrero de 2013, Madrid, entrevista realizada por Natalia Urigüen. El político reconoce agradecido la gran ayuda de la Fundación Konrad Adenauer y la CDU durante la transición española a la democracia cristiana española.

29 Hay que tener en cuenta que el Partido Socialista Obrero Español, segunda fuerza política por resultados en las elecciones, prácticamente tenía 100 años de vida.

30 Informe de Josef Thesing "Die Wahlen in Spanien", IIS-Info Auslandsinformationen, 4 de Julio de 1977 .

31 Carta de Henning Wegener, responsable de Relaciones Internacionales de la CDU (1977-1981) a Karl Carstens, Presidente del Bundestag, 11 de noviembre de 1977, ACPD 07-001-16009, Sankt Augustin (Bonn).

32 Carlos HUNEEUS: La Unión de Centro Democrático y la transición a la democracia en España, Madrid, Centro de Investigaciones Sociológicas, 1985. 


\section{La CSU y la Fundación Hanns Seide}

Existía a finales de 1975 otra fuerza política que se consideraba a si misma demócrata cristiana y que se había formado en el marco de la Ley de Asociaciones Políticas de diciembre de 1974, la Unión Democrática Española (UDE). Su líder, Federico Silva Muñoz, había sido Ministro de Obras Públicas durante el franquismo. Su partido político estaba dispuesto a trabajar en conjunto con los demócrata cristianos de la oposición y en concreto con los dos partidos de ámbito nacional, Izquierda Democrática y Federación Popular Democrática, ya que como uno de sus objetivos era la realización de una política centralista, no contemplaba la colaboración con los partidos vascos y catalanes. De cualquier manera ninguno de los líderes del Equipo, al igual que otros partidos europeos integrantes de la UEDC, estaba dispuesto a trabajar con un partido cuyo líder había colaborado con el régimen franquista. ${ }^{33}$

La relación de UDE con los demócrata cristianos bávaros de la CSU era estrecha, en buena parte debido a la larga amistad de Silva Muñoz con Franz Josef Strauss. ${ }^{34}$ En diciembre de 1975 la Fundación Hanns Seidel (HSS) ya contemplaba la realización de programas políticos para la asociación española, en paralelo o como contraste a los que la Fundación Konrad Adenauer estaba preparando con los miembros del Equipo.

La HSS abrió su oficina de representación en España en 1977 y colaboró en la creación de nuevo espectro político La fundación apoyó en las primeras elecciones democráticas a Alianza Popular, ${ }^{36}$ partido político que había creado en octubre de 1976 el Exministro de Gobernación Manuel Fraga Iribarne. Alianza Popular integraba a siete grupos políticos (incluido el partido de Silva Muñoz), cuyos dirigentes habían sido en su mayoría afamados ministros franquistas. ${ }^{37}$ Fraga, que hasta entonces se había declarado centrista, daba un giro hacia la derecha y aunaba así bajo un único partido a las fuerzas más reacias al cambio, para poderlas controla y convertir en una "derecha civilizada". La Fundación Hanns Seidel ayudó a la creación del Instituto de Estudios Sociales (IESO, que posteriormente cambió su nombre por Fundación Vives de Estudios Sociales), centro de formación política de Alianza Popular. A través de este centro materializaba su ayuda financiando encuentros con periodistas, seminarios para mujeres y diversos cursos de índole política para simpatizantes del partido. ${ }^{38}$

33 Informe de Klaus Weigelt, representante de la KAS en Venezuela (desde verano de 1975 hasta 1981), tras una estancia en España de tres meses para aprender español, ACDP 12-001-1261, Sankt Augustin (Bonn).

34 Esta amistad se había cultivado desde los años cincuenta en el seno del Centro Europeo de Documentación e Información (CEDI), de ideología cercana a la Abenländische Aktion de los círculos católicos fuertemente conservadores de Baviera. Sobre el CEDI ver Antonio MORENO JUSTE: “EI Centro Europeo de Documentación e Información. Un intento fallido de aproximación a Europa, 1952-1962" en Javier TUSELL et al.: El régimen de Franco (1936-1975), Madrid, UNED, 1993, pp. 459-474; Petra María WEBER: "EI CEDI: promotor del Occidente cristiano y de las relaciones hispano-alemanas de los años cincuenta", Hispania, LIV/3, 188 (1994), pp. 1077-1103.

35 Informe de Heinrich Böx, responsable de Relaciones Internacionales de la CDU (hasta 1976) respecto un sondeo realizado en España sobre la situación política, entre el 8 y 10 de diciembre de 1975, ACDP 12-001-1261, Sankt Augustin (Bonn).

36 "Eine neue Partei stellt sich in Madrid vor", Die Welt, 10 de noviembre 1976.

37 Los partidos políticos que se integraron en Alianza Popular fueron los siguientes: Reforma Democrática (liderada por Manuel Fraga), Unión del Pueblo Español (Cruz Martínez Esteruelas), Democracia Social (Licinio de la Fuente), Acción Regional (Laureano López Rodó), Unión Social Popular (Enrique Thomas de Carranza), Unión Nacional Española (Gonzalo Fernández de la Mora) y Acción Democrática Española (anteriormente Unión Democrática Española liderada por Federico Silva Muñoz).

38 Friedrich MAGER y Paul MAUTNER: Stiftungen im Dienst der Politik. Am Beispiel Spanien, Bayerischer Rundfunk, República Federal de Alemania, 12 de Julio 1977.
A pesar de los malos resultados de Alianza Popular en las elecciones de 1977 y 1979, ${ }^{39}$ la undación alemana mantuvo su ayuda durante los siguientes años. Muchos de los seminarios que se organizaron tuvieron como objetivo dividir a la Unión de Centro Democrático con el fin de captar para Alianza Popular tanto votos como miembros para el partido.40 Desde 1982 la ayuda alemana se canalizó a través de la Fundación Cánovas del Castillo, ${ }^{41}$ que Fraga y otros políticos de su partido habían creado en $1980 .{ }^{42}$

\section{Conclusión}

A diferencia del caso portugués, donde la democracia cristiana alemana tuvo serios problemas para encontrar a un interlocutor de ideología afín, dado que no existía ningún grupo político luso representado en la Unión Europea Demócrata Cristiana cuando se produjo la Re volución de los Claveles, en España tuvieron a los democristianos perfectamente identificados desde el inicio de la transición. Esto favoreció el temprano establecimiento de la ayuda de la CDU a sus partners españoles. El fracaso de estos últimos en las primeras elecciones democráticas podría interpretarse como un fracaso de la ayuda de la Fundación Konrad Adenauer al Equipo. Sin embargo esta afirmación sólo sería parcialmente correcta. Los malos resultados electorales se debieron fundamentalmente a la ineficacia de los líderes de la Federación de la Democracia Cristiana, que no tuvieron la amplitud de miras suficiente para comprender lo que realmente quería y necesitaba el pueblo español tras cuarenta años de régimen dictatorial; $\mathrm{e}$ hicieron prevalecer sus propios intereses. La KAS, desde principios de 1977 y con los resultados del sondeo en la mano, había realizado un pronóstico electoral acertado respecto a la voluntad de los españoles y había recomendado insistentemente a los democristianos su integración en una formación centrista. El grupo escindido de Izquierda Democrática e integrado en UCD, siguiendo los consejos de la fundación política alemana, consiguió un elevado número de escaños en el Congreso de los Diputados. Realmente la ayuda de la CDU para la consecución de la democracia en España no había hecho nada más que empezar.

En cuanto a la democracia cristiana bávara, aún es pronto para poder llegar a conclusiones sobre el éxito o fracaso de su actuación en España ante las elecciones de 1977. Los escasos informes trabajados hasta la fecha sirven para obtener una impresión de la importancia de las relaciones entre los partners políticos. Sin embargo queda por analizar toda la documentación generada por la propia Fundación Hanns Seidel para poder establecer objetivos y logros.

39 En las elecciones de 1977 Alianza Popular no logró más que un $8 \%$ de los votos y 16 escaños, mientras que en las elecciones generales de 1979 el porcentaje de votos se redujo al $6 \%$ y su representación en el Congreso a 9 diputados.

40 Gerlinde Freia NIEHUS: Aussenpolitik im Wandel. Die Aussenpolitik Spaniens von der Diktatur Francos zur parlamentarischen Demokratie, Frankfurt, Vervuert Verlag, 1989, p. 521.

41 Carlos ROBLES, Manuel FRAGA, Francisco SANABRIA: Fundación Cánovas del Castillo. Historia de un trabajo bien hecho, Madrid, FAES, fundación para el análisis y los estudios sociales, 2010.

42 Carlos ROBLES: Memoria de cuatro Españas. República, guerra, franquismo y democracia, Barcelona, Editorial Planeta, 2011, p. 557 . 


\section{EL PROCESO REVOLUCIONARIO PORTUGUÉS Y LA}

\section{OPOSICIÓN ESPAÑOLA: EL PCE EN LA ENCRUCIJADA}

Gregorio Sabater Navarro

Universidad Autónoma de Madrid

\section{Introducción}

La presente comunicación se inscribe en el marco de un proyecto de tesis en el que pretendemos identificar los elementos comunes desarrollados en las transiciones ibéricas, analizando el grado en el que ambos procesos políticos se retroalimentaron el uno del otro. Partimos por tanto de la base de que la transición española y la transición portuguesa, aunque esencialmente diferentes -una se produjo por ruptura y otra por reforma-, pertenecieron a una misma corriente, que Huntington denominó como "tercera ola de democratización"."

El cambio político que se vivió en el sur europeo durante la década de los 70 pone de manifiesto, a pesar de sus múltiples peculiaridades, que, lejos de lo que la historiografía mayoritaria ha venido reflejando con una perspectiva exclusivamente nacional, parece evidente la existencia de una dinámica europea de distensión dentro de la dialéctica de bloques propia de la Guerra Fría, evidenciando una relajación del conflicto expresada en la Conferencia de Helsinki de 1975 (a pesar del desarrollo de hostilidades posteriores). Este contexto político -junto al económico de crisis capitalista iniciada en 1973-, favoreció el desmoronamiento o reforma de los regímenes autoritarios europeos meridionales basados en la contención anticomunista propia del bloque occidental, algo que coloca en un plano de interacción los acontecimientos acaecidos tanto en la península ibérica como en la helénica, por lo que nuestra investigación lejos de ser otro estudio nacional sobre transiciones constituye una historia europea netamente transnacional enmarcada en la historia del tiempo presente.

Hasta hace poco, la historiografía española no había prestado una atención excesiva a las influencias mutuas entre los estados ibéricos, sobre todo en un periodo tan importante como el que nos ocupa. Así algunos autores como Sánchez Cervelló comenzaron a señalar la importancia que tuvo el 25 de abril $^{2}$ en España, ante la semejanza entre los regímenes autoritarios ibéricos, por compartir un mismo espacio geográfico o por las interconexiones que ambos países han desarrollado tradicionalmente a lo largo de su historia. ${ }^{3}$ Algo en lo que coincidió Hipólito de la Torre al hablar de la posible existencia de "historias paralelas" en el devenir de ambos Estados. Para este autor, la presencia de una realidad global propia de la Península lbérica se percibe con bastante claridad desde una perspectiva exterior político-internacional.4

1 Samuel P.HUNTINGTON: The third wave. Democratization in the late twentieth century, Oklahoma, University of Oklahoma Press, Norman, 1991

2 25/04/1974, fecha de la llamada Revolución de los Claveles que acabó con la dictadura portuguesa dando comienzo al proceso de democratización del país y a un difícil proceso de descolonización en sus posesiones africanas.

3 Josep SÁNCHEZ CERVELLÓ: La revolución portuguesa y su influencia en la transición española (19611976), Barcelona, Editorial Nerea, 1995, p. 264

Hipólito DE LA TORRE: “Portugal y España: Historias paralelas?”, en Hipólito DE LA TORRE y Antonio PEDROVICENTE (coord): España-Portugal. Estudioso
De esta manera, diversos expertos han analizado desde este lado de la frontera las influencias concretas de la Revolución de los Claveles en determinados ámbitos de la política y de la realidad hispana del momento. El mencionado Sánchez Cervelló, Encarnación Lemus o Juan Carlos Jiménez Redondo, han diseccionado en muchas de sus obras cómo y en qué grado quedaron afectados distintos compartimentos de la sociedad española, llegando prácticamente a una conclusión cuasi-unánime. Y es que; si para Encarnación Lemus no es posible entender la transición española sin contemplarla precedida por los acontecimientos vividos en Portugal y en Grecia; además de la efectos de la distensión internacional; 5 para Josep Sánchez Cervelló el golpe de Estado portugués fue fundamental para lograr la transición hispana, mientras que para Jiménez Redondo, lo ocurrido al otro lado de la frontera tendría una fuerte repercusión en la política
interna española en el sentido de constituir un acelerador de las demandas democratizadoras. ${ }^{6}$

Encarnación Lemus ha llegado a definir este proceso político común como "transición ibérica", reconociendo en él dos fases más o menos definidas, una primera de influencia portuguesa en España y una posterior de influencia española en Portugal. ${ }^{7}$

Dentro de la primera fase, Sánchez Cervelló la subdivide a su vez en dos, una situada entre el 25 de abril y finales de septiembre del 74, que se puede considerar como de "influencia positiva" -ya que el nuevo régimen dirigido por Spínola aparecía como una ventana abierta que rejuvenecía y agitaba el enmohecido árbol franquista-, y una segunda etapa; desde septiembre del 74 hasta finales del 75, de "influencia negativa" -ya que la política portuguesa se comenzó a percibir como un caballo desbocado que se precipitaba al abismo. Siguiendo esta línea argumental, en la presente comunicación vamos a intentar desentrañar uno de los principales focos de influencia lusa en el contexto español durante el primer periodo mencionado por Lemus, y es el efecto que el proceso político desarrollado en Lisboa tuvo en el principal partido de la oposición antifranquista: el PCE.

Los estudios genéricos sobre el impacto de la revolución y el proceso político luso en España son, cada vez más, un lugar común, lo que sigue siendo un campo de estudio menor son las aportaciones concretas sobre esta relación. Por lo tanto, al aproximarnos al caso específico de PCE, pretendemos ampliar el conocimiento sobre uno de esos casos concretos sobre los que todavía se hace necesario colocar el foco de la actividad investigadora, y siendo dicho partido la principal organización política de la oposición antifranquista, nos parece indudable el interés de este primer acercamiento al objeto de estudio.

En este artículo partiremos de la hipótesis de que la caída de la dictadura de Caetano influyó ampliamente en la estrategia política del PCE al consolidar su apuesta por la "ruptura democrática" y la creación junto a otras siglas de una plataforma opositora, la llamada "Junta Democrática", como una versión española de la portuguesa Junta de Salvación Nacional.

Sin embargo, con el transcurso de los acontecimientos en el vecino país -con un PCP muy distante del eurocomunismo del PCE y un proceso revolucionario en curso con claros tintes izquierdistas- el ejemplo luso dejó de ser útil paradójicamente de cara a lograr los objetivos políticos marcados por la dirección: conseguir la unidad antifranquista y situar al partido en prescindible para la ruptura- como para contrarrestar la fuerte propaganda anticomunista de

rial Complutense, 1998, p. 135

Encarnación LEMUS: En Hamelin... la Transición Española más allá de la Frontera, s.l., Septem Ediciones, 2001, p. 78 .

6 Juan Carlos JIMÉNEZ REDONDO: España y Portugal en transición. Los caminos a la democracia en la Península Ibérica, Madrid, Sílex, 2009, p. 94 7 Encarnación LEMUS: “Las reacciones de la administración Ford ante el 25 de abril”, en Encarnación Centro de Estudios Andaluces, Ediçoes Pluma, 2010. pp. 43-62. 
los medios del régimen. Medios que pretendían identificar al PCE como un "lobo con piel de cordero", un partido totalitario disfrazado con ropajes democráticos.

El espacio temporal en el que se enmarca este trabajo iría por tanto desde la primavera de 1974 hasta noviembre de 1976 aproximadamente, fecha en la que los expertos sitúan la toma de conciencia del PCE sobre la imposibilidad de la ruptura democrática que proponían. El comunismo español pasó en aquel periodo de rechazar la opción "continuista" de Juan Carlos de Borbón, a pretender participar en la reforma que el segundo Gobierno de la monarquía comenzaba a desarrollar. De esta manera, la encrucijada entre ruptura y reforma -debate en el que la cuestión portuguesa constituyó uno de sus ejes- resulta de vital importancia para entender un periodo trascendental en la historia del PCE.

\section{La estrategia de oposición antifranquista del PCE}

De cara a identificar la influencia que los acontecimientos desarrollados tras la Revolución de los Claveles tuvieron en la estrategia política del PCE, se hace necesario explicar cuáles fueron los fundamentos programáticos que se venían desarrollando por este partido antes de la primavera de 1974 .

En este propósito, el cambio que tuvo lugar en el partido en el año 1956 resulta clave para comprender la evolución ideológica vivida en el seno del comunismo español, iniciando una línea política que perduró hasta principios de los 80 y que marcó por lo tanto la postura desarrollada durante la transición a la democracia en España. Aquel cambio, sin llegar a suponer un corte profundo y absolutamente novedoso respecto a la trayectoria anterior, generó en el partido una dinámica sustancialmente diferente. ${ }^{8}$

Después de unas cambiantes políticas antifranquistas durante los años cuarenta hasta mediados de los cincuenta, el PCE había interiorizado que el proceso hacia el socialismo en España debería pasar necesariamente por un período de democracia formal. De esta manera, en el verano de 1956 fue proclamada la base estratégica de lo que se vino a denominar como "Política de Reconciliación Nacional". En ella, el partido intentó romper con su imagen de fuerza totalitaria realizando una declaración plenamente democrática, posicionándose a favor de una transición política sobre la base del entendimiento entre las fuerzas de izquierdas y de derechas. ${ }^{9}$ Esta praxis se enmarcaba en la línea que una parte de los partidos comunistas occidentales fueron adquiriendo, en donde la democracia fue revalorizada como forma política, entre otros motivos, ante el horror generado por la experiencia fascista, por el lento derrumbe del mito soviético, por la actitud de gran potencia de la URSS y por la constatación de que la vía insurreccional al socialismo se había alejado definitivamente como perspectiva en el mundo desarrollado y democrático. ${ }^{10}$

En el caso concreto del PCE, a parte de la influyente crisis del movimiento comunista internacional, la necesidad de articular las alianzas necesarias para acabar con la dictadura; lo que le obligaba, como señala Jesús Sánchez, a ofrecer garantías de un comportamiento democrático al resto de fuerzas antifranquistas con las que mantuvo unas difíciles relaciones hasta el momento, hizo que el partido español acabara abrazando lo que vino a denominarse posteriormente como corriente "eurocomunista".

8 Jesús SÁNCHEZ RODRíGUEZ: “Teoría y práctica democrática en el PCE” (1956-1982), en Manuel BUENO, José HINOJOSA, Carmen GARCIA (Coord): Historia del PCE. I Congreso 1920-1977, Volumen II, s.l., Fundación de Investigaciones Marxistas, 2007, p. 35.

9 Sergio GÁLVEZ y Gustavo SALMERÓN: "Historia de una colaboración y competencia política durante el franquismo: las relaciones PCE-PSOE (1944-1974), en Manuel BUENO, José HINOJOSA, Carmen GARCíA (Coord.): Historia del PCE. I Congreso 1920-1977, Volumen II, s.l., Fundación de Investigaciones Marxistas, 2007, p. 47

10 Jesús SÁNCHEZ RODRÍGUEZ: “Teoría y práctica..., p. 34
La vía democrática defendida por el PCE no era una teorización elaborada ni el reflejo de un modelo exitoso en otro país, se trataba más bien de un agregado de nuevas concepcione y cambios. Las partes que conformaban la vía democrática no eran por lo tanto un todo coherente, iban cambiando con el tiempo y no estaban respaldadas por ningún análisis empírico de la realidad. Lo más definido de esta vía se hacía precisamente más por lo que se rechaza que por lo que se proponía. La vía democrática se definía sobre todo por oposición tanto al modelo seguido en la Unión Soviética y las democracias populares, como al modelo socialdemócrata."

La adopción de esta política permitió al partido aumentar significativamente su infraestructura durante los años sesenta, ayudado por una acción de masas que se canalizó fundamentalmente a través del entrismo sindical de las $\mathrm{CCOO}$, la promoción de sindicatos democráticos en la universidad, la dinamización del movimiento vecinal, la adhesión de profesionales e intelectuales a su proyecto y la apertura hacia los sectores progresistas del catolicismo. La democratización de los espacios sociales, como la universidad o los centros de trabajo, se mostró como una fórmula efectiva para endosar pequeñas derrotas al régimen franquista. Esta eficacia hizo que el partido comenzara a ser considerado como la organización de ámbito nacional preeminente en las luchas políticas del país de cara al periodo trascendental que nos ocupa. ${ }^{12}$ Como señala Juan Antonio Andrade Blanco, si el PCE se convirtió en la fuerza por excelencia del antifranquismo fue porque supo adaptar mejor que nadie su estrategia a las importantes transformaciones económicas, sociales y culturales que se produjeron en España a lo largo de la década de los sesenta. ${ }^{13}$ Estas transformaciones económicas, que vinieron incentivadas en buena medida por el denominado "desarrollismo", generaron las condiciones de posibilidad para abrir una dinámica de conflictividad social y política que desgastó de manera considerable a la dictadura y que, hegemonizada por el PCE, le sirvió de caldo de cultivo para cobrar fuerza y prestigio. ${ }^{14}$

La nueva situación descrita junto al previo distanciamiento del PCE respecto a la URSS, facilitó el inicio de relaciones con la mayoría de fuerzas políticas antifranquistas. De esta manera, el primer organismo unitario de la oposición política no tardaría en aparecer, éste tuvo lugar en Cataluña en 1969 y se trató de la "Taula Rodona de Forces Politiques", donde se integraron diversas siglas que iban desde la democracia cristiana a los comunistas. Este pacto sirvió como nuevo modelo para la oposición unitaria del interior de España, al promover el diálogo como nuevo modelo para la oposición unitaria del interior de España, al promover el diálogo y la convergencia sin exclusiones, la presión de la lucha de masas y un programa de alternativa antifranquista aceptable para todas las fuerzas democráticas. Sin embargo, la experiencia unitaria catalana no llegó a materializarse entonces en una gran plataforma nacional debido a las suspicacias anticomunistas de ciertos sectores de la oposición.

En el verano de 1970 se presentó el llamado "Pacto por la Libertad", algo que no era solamente una propuesta de unión de fuerzas políticas, sino que se trataba, en palabras del propio Carrillo, de "una alternativa global de libertad política en oposición al régimen franquista".15 La derrota del régimen debería gestionarse así en diferentes contextos simultáneos. En primer lugar, era necesario formar un amplio frente entre las fuerzas democráticas y los sectores centristas. Mientras se configuraba este organismo, se debía desactivar los poderes fundamenta-

11 Ibid., p. 41

12 Sergio GÁLVEZ y Gustavo SALMERÓN: “Historia de una colaboración..., p. 48

13 José ANDRADE BLANCO: EI PCE y el PSOE en (la) transición. La evolución ideológica de la izquierda durante el proceso de cambio politico, Madrid, Siglo XXI, 2012, p. 55.

14 Pere YSÁS: "La crisis de la dictadura franquista", en C. MOLINERO (ed.): La Transición treinta años después, Barcelona, Península 2006, p. 31 .

15 Santiago CARRILLO: Informe en nombre del Comité Ejecutivo ante el pleno ampliado del Comité Central, septiembre de 1970 Archivo del Comité Central del Partido Comunista de España (ACCPCE) Documentación del PCE, Archivo delco 
les del sistema vigente, como la Iglesia, la Administración o el Ejército. Sólo con su apoyo, o por lo menos con su neutralidad, sería posible que las fuerzas democráticas y los movimientos de masas consiguieran crear las condiciones objetivas para organizar la "Huelga General Nacional", que llevaría al desplazamiento pacífico del poder franquista por un gobierno de amplia coalición, que estableciera las libertades políticas y convocara las elecciones constituyentes. ${ }^{16}$

Bajo este programa, el primer intento unitario en la oposición a nivel nacional tuvo lugar en 1971. Ésta se dio cuando la Comisión Ejecutiva del interior del PSOE decidió terminar con el veto que de forma tradicional venían imponiendo al PCE para asistir a las reuniones de la llamada UFD (Unión de Fuerzas Democráticas). Sin embargo, los recelos de los grupos minoritarios y el rechazo del PSOE del exterior a los contactos con los comunistas acabaron por frustrar lo que se vino a denominar "Mesa Democrática", demostrando que a la unidad antifranquista todavía le quedaba un largo camino por delante.

\section{La revolución lusa y su afección en el PCE}

\section{La búsqueda de la ruptura. Portugal como modelo}

Poco después de la medianoche del 25 de abril de 1974 se emitía a través de Radio Renascenca la canción prohibida "Grândola, Vila Morena" era la señal para que el Movimiento de las Fuerzas Armadas (MFA) ocupase los lugares estratégicos de Portugal con el objetivo de poner fin a la larga dictadura implantada en 1926. Lo que inicialmente se pensó que iba a ser un golpe de Estado se convirtió, al poco tiempo, en un pronunciamiento militar dada la escasa resistencia de los partidarios del régimen autoritario. Daba así comienzo lo que la historiografía portuguesa ha denominado como "proceso revolucionario en curso", un periodo político no exento de tensiones debido a la disputa de diversas corrientes ideológicas dentro del ejército apoyadas cada una por los distintos partidos del espectro político, para imponer un modelo determinado de país, que iba desde la propuesta de una democracia al estilo occidental de General Spínola, a la república socializante del Coronel Vasco Gonçalves o al modelo revolucionario -más minoritario- del Coronel Saraiva de Carvalho.

Esta disyuntiva, en un Estado miembro fundador de la OTAN y perteneciente al bloque occidental, motivó una clara presión internacional para que el país optara por uno u otro camino, y al mismo tiempo influyó directa o indirectamente en otros procesos políticos -como luego veremos para el caso de España-. Lo que estaba fuera de toda interpretación, más allá de las dudas que generaba el destino final del país, era que la ruptura con la dictadura se había producido con éxito, y que el Estado Novo, la dictadura más longeva de Europa, había dejado de existir casi de la noche a la mañana. Las analogías con el caso español eran por lo tanto inevitables, a pesar de la radical diferencia que suponía contar con un ejército como el portugués, tremendamente ideologizado tras décadas de desastrosa Guerra Colonial y que había constituido el motor de dicho cambio político. Algo que difícilmente podía ocurrir en España, con un ejército fiel en su inmensa mayoría a la figura de Francisco Franco.

Desde el otro lado de la frontera se siguió con enorme atención la sucesión de acontecimientos que tenían lugar en el país vecino durante aquella primavera revolucionaria. La legalización de los distintos partidos políticos, la proclamación de libertades, la formación de un Gobierno Provisional con presencia de distintas fuerzas (incluidos los comunistas) o la promesa de futuras elecciones para un Parlamento constituyente, tuvieron amplio eco en nuestro país. Gran parte de lo recogido en el programa político de los comunistas, madurado tras veinte años de Reconciliación Nacional y Pacto por la Libertad, se estaba tornando en algo tangible, en algo real, a escasos kilómetros de distancia.

16 Sergio GÁLVEZ y Gustavo SALMERÓN: “Historia de una colaboración..., p. 50.
Las primeras reacciones en la directiva del partido no se hicieron esperar, el propio Secretario General, Santiago Carrillo, a través de una alocución radiofónica en Radio España Independiente tan sólo tres días después del pronunciamiento del 25 de abril, señalaba que "como comunistas y demócratas españoles, tenemos que saludar con simpatía el movimiento militar que acaba de triunfar en Portugal. Una dictadura fascista hermana gemela de la del General Franco, que ha oprimido durante medio siglo al pueblo portugués, se ha hundido literalmente de la noche a la mañana".17

La sorpresa ante el desarrollo de los acontecimientos y del rápido colapso de un sistema dictatorial de cinco décadas en apenas doce horas no podía sino colocar al país vecino como el necesario espejo en donde mirarse. Las similitudes de ambas dictaduras (a pesar de que también contaban con distintos orígenes y formas políticas) era claro, por lo que si en Portugal había sido posible, ¿por qué no en España? AI PCE le había surgido un inmejorable ejemplo en el que volcar sus anhelos de cambio madurados tras largos años de oposición y en el que justificar su estrategia que, aunque exitosa en lo que se refiere a la movilización social contra la dictadura, no contaba con una forma clara de concreción, de materialización práctica de la ruptura. Con la percepción ampliamente positiva que tuvo la Revolución lusa entre la sociedad española, ésta se convirtió en un referente de cara a favorecer el apoyo hacia el cambio planteado por el partido.

El primer análisis del Comité Central del PCE no pudo ser más claro en su referencia a lo acontecido en el país vecino. La intención del partido desde el primer momento fue la de identificar su plan de democratización de España expresado en el anterior Pacto por la Libertad con el proceso que había propiciado el fin del Estado Novo. Y es que para el PCE, el 25 de abril había sido posible gracias a la convergencia de tres elementos: del movimiento obrero y popular -del que era principal exponente el PCP-, de gran parte del ejército ante las consecuencias de una guerra colonial anacrónica y sin perspectiva, y en tercer lugar, de la actitud del sector más dinámico y liberal del capitalismo portugués. ${ }^{18}$

Colocar en un primer lugar en este análisis al movimiento obrero y en un segundo plano al que verdaderamente había sido autor del cambio -además de añadir el papel de la parte "dinámica" del capitalismo-, no era sino una forma de analizar los sucesos de abril a través de una perspectiva netamente española. Algo que venía a fortalecer el convencimiento en la idoneidad de las políticas mantenidas por el partido durante largos años. De esta manera, la Revolución de los Claveles sirvió como un elemento reafirmante de las principales propuestas de cambio que el PCE venía realizando desde largo tiempo atrás y que ya hemos detallado en el capítulo anterior. El golpe de abril favorecía la apuesta por la "ruptura democrática" y demostraba al mismo tiempo la inutilidad de los intentos reformistas de ciertos sectores del franquismo.

El dictador depuesto por los capitanes de abril, Marcelo Caetano, había sido el sustituto de Oliveira Salazar en la jefatura del gobierno de la república portuguesa en 1968. Éste había basado su gobierno en una teórica liberalización del Estado Novo de cara a favorecer su propia permanencia en el tiempo, reformismo de corto alcance que provocó justo lo contrario de lo que se proponía, la desestabilización del mismo, agravado todavía más por la costosísima Guerra Colonial y la crisis económica iniciada en 1973. El fracaso del reformismo que suponía la experiencia caetanista fue utilizada por el PCE de cara a desprestigiar, no sólo a las opciones inmovilistas, sino también a los intentos reformistas del franquismo y señalar lo equivocado de la sucesión en el entonces príncipe Don Juan Carlos:

17 Declaración de Santiago Carrillo, Secretario General del PCE, por Radio España Independiente sobre Portugal (27 de abril de 1974). Archivo Histórico del PCE, Sección Dirigentes, Santiago Carrillo, Sig. 6/1.1.2

18 Comunicado de la reunión del pleno ampliado del Comité Central del PCE. "Hacia el Postfranquismo". Introducción (Abril de 1974), Archivo Histórico del PCE, Sección Dirigentes, Santiago Carrillo, Sig. 6/1.1.2. 
"Los acontecimientos de Portugal repercuten profundamente en España; la dictadura de Caetano se hunde cuando la del General Franco se encuentra ya en las últimas. ¿Qué enseña lo sucedido en el país vecino? Enseña que ningún régimen, y menos un régimen fascista, es eterno. A corto plazo, y pese que la sucesión se había realizado con normalidad, la dictadura de Oliveira Salazar no ha sobrevivido a él. Una lección para quienes sueñan con que la dictadura franquista pueda sobrevivir a Franco, entronizando en la jefatura del Estado a Don Juan Carlos."19

El paso de una dictadura a una democracia de forma rupturista, como proponía el PCE, contaba con serias dudas y miedos entre amplios sectores de la población. El temor a una nueva Guerra Civil, todavía presente en el imaginario colectivo, llevaba a muchos españoles a la desconfianza frente a una opción que implicara el derribo del régimen, aunque éste se produjera pacíficamente y sin derramamiento de sangre. La experiencia del 25 de abril, en donde la ruptura tuvo lugar de una forma incruenta, concedía un importante crédito a la estrategia comunista. Para Carrillo quedaba confirmado que un cambio de esa naturaleza podía realizarse sin enfrentamiento civil, sin prácticamente pérdidas humanas y materiales, casi podría decirse que dentro de un orden perfecto. ${ }^{20}$

Semejante confianza en las debilidades del régimen y en las fortalezas de la oposición suponía sobredimensionar en gran medida tanto lo uno como lo otro. El régimen evidentemente se encontraba en crisis; en palabras de Carme Molinero y Pere Ysás, "la dictadura estaba tan deteriorada como la salud física del dictador", pero no lo suficientemente como para perder el control de la situación con unas fuerzas del orden y un ejército leales. La oposición (y principalmente el PCE) controlaba la calle e importantes segmentos de la sociedad que comenzaron a enfrentarse al Estado como ya hemos explicado, llegando incluso a desbordar la situación, pero no contaban con los poderes fácticos como para llevarlo a cabo como había ocurrido en Portugal. En el partido, aunque confiaban en sus posibilidades, eran conscientes de esta relativa inferioridad. De hecho no desconocían la imposibilidad de que el ejército fuera el desencadenante último del cambio en España, de ahí que pensaran en la conflictividad laboral como punta de lanza, algo que ya había sido formulado con anterioridad a través del concepto de la Huelga General Nacional.

Por lo pronto, un año después, en julio de 1975 , en un contexto de agudización de la represión franquista ante la incontrolable contestación -pero al mismo tiempo de creciente crisis del régimen- el PCE celebró la llamada II Conferencia, donde se aprobó el Manifiesto-Programa de partido. Democracia, unidad antifranquista y Huelga Nacional eran las piezas esenciales de la misma. En palabras de Molinero e Ysás, "democracia como objetivo, amplia unidad antifranquista como condición para hacerla posible y huelga nacional como instrumento para alcanzarla".21

Los pilares básicos de la formulación opositora del PCE continuaban intactos. La Huelga Nacional seguía siendo por tanto, años después de ser planteada, la vía para la ruptura democrática. La fuerte implantación de CCOO sobre el fracasado modelo sindical franquista hacía de la lucha obrera y su principal herramienta -la huelga-, el esperado desencadenante para alcanzar el final de la dictadura española. Sin embargo, a pesar de que en 1975 el PCE mantenía el mismo esquema de actuación ante el inminente deceso del general Franco, ¿continuaba siendo Portugal el espejo rupturista donde mirarse y donde justificar su praxis?

19 Declaración de Santiago Carrillo, Secretario General.

20 Comunicado de la reunión del pleno ampliado

21 Carme MOLINERO y Pere YSÁS: “El Partido del antifranquismo (1956-1977)", en Manuel BUENO,

José HINOJOSA, Carmen GARCÍA (Coord.): Historia del PCE. I Congreso 1920-1977, Volumen II, s.I.

Fundación de Investigaciones Marxistas, 2007, p. 29.
El distanciamiento del modelo luso

Como algunos autores han señalado en monografías genéricas sobre el tema, tras la radicalización vivida en Lisboa después de la dimisión del General Spínola en septiembre de 1974, el modelo político que se comenzó a implantar en la república portuguesa fue interpretado unánimemente por toda la derecha, el centro e incluso la izquierda moderada, como un proceso que no se debía importar a España. ${ }^{22}$ Daba así fin el periodo que Sánchez Cervelló denomina como de "influencia positiva" de Portugal, comenzando uno de "influencia negativa" ante el dominio de la situación del sector más cercano al comunismo del MFA, apoyado obviamente por el PCP, tras el fracaso del pronunciamiento de signo moderado liderado por el mencionado Spínola.

Aunque la gran mayoría de la izquierda española valoró positivamente el fracaso contrarrevolucionario espinolista del 28 de septiembre del 74 , muchos acabaron discrepando sobre el sentido último de la revolución. Así el PSOE se mostró contrario a las declaraciones maximalistas de Cunhal ${ }^{23}$-que rechazó la democracia burguesa occidental-, y al papel del MFA y su proyecto de democracia popular prescindiendo de los partidos. Mientras, según Sánchez Cervelló, el PCE sólo se mostró contrario a partir de las elecciones portuguesas de abril del 75 , al observar cómo el papel del PCP en la deriva revolucionaria era utilizado por la derecha española para desacreditar al comunismo en nuestro país, y de paso, la opción rupturista que éstos planteaban.

Éste último hecho será fundamental para entender el alejamiento consciente del PCE del modelo luso, y más concretamente de sus camaradas del PCP. Como señala Andrade Blanco, la misma apuesta pública del PCE por una estrategia democrática y de moderación, tenía mucho que ver con el deseo de contrarrestar la imagen de partido agresivo que sus adversarios se afanaban, con bastante éxito, en subrayar. ${ }^{24}$ Algo que se potenció más tarde tras los decepcionantes resultados obtenidos en las primeras elecciones de 1977, que según la tesis del referido autor, motivó una profundización en las posturas eurocomunistas, llegando incluso a prescindir de la denominación "leninista" en el IX Congreso del partido en abril de 1978.

Los comunistas portugueses en cambio nunca se caracterizaron por ser partícipes del revisionismo eurocomunista, de hecho, estaban ampliamente considerados como uno de los partidos más ortodoxos de Europa occidental. A pesar de este aspecto, las relaciones del PCE con sus homólogos fueron satisfactorias en un principio, llevados por la euforia desatada tras el derrumbe de la dictadura; como demuestra el encuentro entre Santiago Álvarez ${ }^{25}$ y miembros del PCP en Lisboa en mayo del 74 en donde se habló de una serie de encuentros bilaterales entre ambos. ${ }^{26}$ Sin embargo, las relaciones se fueron tornando un tanto frías y distantes ante la susodicha diferencia de matiz ideológico que les separaba.

Sin embargo, esa frialdad con sus correligionarios portugueses acabó por tornarse en crítica directa al llegar la primavera de 1975, escuchándose las primeras objeciones dentro del PCE hacia el proceso revolucionario luso. La deriva política en el país vecino anteriormente comentada y los intereses particulares del partido teniendo en cuenta la situación que se estaba viviendo en España, rompieron en gran medida el espejo rupturista portugués. Portugal pasaba asi de ser un preciado referente de cara a conseguir los objetivos de cambio, a ser un ejemplo perjudicial para el mismo, gracias a la analogía que la propaganda franquista realizaba entre el "desorden" portugués y la hoja de ruta del PCE.

22 Josep SÁNCHEZ CERVELLÓ: La revolución portuguesa y su influencia..., p. 289

23 Secretario General del PCP.

24 José Antonio ANDRADE BLANCO: EI PCE y el PSOE en (la) transición..., p. 106.

25 Miembro del Comité Central del PCE.

26 Carta de Santiago Carrillo a Alejandro (Jaime Ballesteros) (21 de mayo de 1974), Archivo Histórico

del PCE, Sección Activistas España en general, Caja 93, Carp. 49/15. 
El Vicesecretario General del PCE, Jaime Ballesteros, se percató de esta situación, afirmando que lo que acontecía en Portugal era sujeto de especulación de los reaccionarios, y que por lo tanto, las características del proceso luso en general y la política del PCP en particular "no nos ayudan". En su opinión, el PCE debía "desmarcarse prudentemente de la orientación de PCP" ya que sus camaradas portugueses pensaban que estaban haciendo poco menos que la revolución socialista. ${ }^{27}$ Esta postura era compartida por el mismo Secretario General, que en una carta dirigida a su homólogo italiano Enrico Berlinguer, reconocía que "lo sucedido en Portugal ha venido a reforzar las objeciones (hacia el PCE), con la añadidura de que Portugal es como la banlieue de Madrid y cuanto allí sucede nos golpea a nosotros en plena frente" ${ }^{28}$

Las declaraciones públicas en donde miembros destacados del partido se pretendían desmarcar de cualquier similitud con el país vecino no se hicieron esperar, ya fuera en declaraciones a "Le Nouvel Obervateur" criticando el papel del MFA al arrogarse la única legitimidad y de limitar la democracia, ${ }^{29}$ como en la famosa entrevista que la periodista italiana Oriana Fallaci realizó a Carrillo para la revista “'E'Europeo", en donde el Secretario General declaró que el hecho de que el PCP no respete los resultados de las primeras elecciones portuguesas ganadas por los socialistas, "nos ha afectado mucho, ya que las derechas han dicho en seguida que eso es lo que haríamos los comunistas en España", por lo que pretendió que quedara bien claro que "España no es Portugal". ${ }^{30}$ Esta postura contrasta con la mantenida tan solo un año antes, en la que el propio Carrillo deseaba la "potugalización de España",31 muestra más que evidente del diferente contexto político que rodeó ambas declaraciones y que las condicionaba en un sentido u otro.

Las críticas vertidas por parte de miembros destacados del PCE tanto al PCP como al MFA enemistaron a las dos centrales comunistas ibéricas. De hecho, el propio PCUS quiso mediar entre ambos durante el verano del 75 ante la grave situación política por la que estaba atravesando Portugal, al borde de un enfrentamiento civil por la fuerte presión internacional en contra del gobierno del filo-comunista Vasco Goncalves, apoyada desde dentro del país por toda la oposición -desde el PS a la derecha- y que al final contó con el soporte del sector moderado del MFA que el 25 de noviembre del 75, mediante un golpe de Estado dirigido por Ramalho Eanes, acabaron por reconducir la situación en sentido pro-occidental.

En esa difícil coyuntura por la que pasó el comunismo luso, las declaraciones surgidas en el seno del PCE fueron consideradas como un ataque inoportuno. Diplomáticos soviéticos afearon a los comunistas españoles las críticas públicas hacia el PCP en un momento tan agudo de su lucha política, ya que causaba perjuicio al partido y a otras fuerzas democráticas del país. De esta manera reclamaron al PCE hacer prueba de solidaridad, de un apoyo eficaz hacia sus compañeros portugueses que se encontraban en una difícil prueba contra las fuerzas de la reacción. ${ }^{32}$

Ciertamente, en lo que se refiere a las relaciones con los partidos políticos portugueses, el PCE venía contando con una mayor sintonía con el PS (Partido Socialista) que con sus homólogos comunistas. Incidiendo en esta idea, Juan Carlos Jiménez afirma que el interlocutor habitual de Carrillo nunca fue Álvaro Cunhal sino Mario Soares. Por lo que a pesar de la corrección

7 Jaime BALLESTEROS: Apuntes manuscritos (1975), Archivo Histórico del PCE, Dirigentes, Caja 2/1.2.2. 28 Carta de Santiago Carrillo al Secretario General del PCI, Enrico Berlinguer (Sin fecha exacta, 1975), Archivo Histórico del PCE,. Relaciones Internacionales, Caja 142, Carpeta 3

29 "Elecciones italianas y otros temas", Mundo Obrero, 1 de julio de 1975. En donde se recogen las declaraciones de Santiago Carrillo al Le Nouvel Observateur.

30 Entrevista de Oriana Fallaci a Santiago Carrillo del 10 de octubre de 1975. En Oriana FALLACI: Entrevista con la historia, Barcelona, Editorial Noguer, 1986, p. 526.

31 Rueda de prensa mantenida por Santiago Carrillo con los corresponsales españoles en París (16 de mayo de 1974), Archivo Histórico del PCE, Dirigentes, Santiago Carrillo, Escritos, Sig 6/1.1.2.

32 Carta del consejero de la embajada de la URSS en París Anatoli Slussar (19 de agosto de 1975). Archivo Histórico del PCE, Relaciones Internacionales, Caja 142, Carpeta 26. formal que se desarrolló entre ambas directivas en un principio, resulta plausible aseverar una fría relación entre los comunismos ibéricos al poco de transcurrir el proceso revolucionario luso.

A pesar de que el proceso de construcción democrática que se estaba acometiendo en Portugal dejara de servir de modelo al PCE a partir de la primavera del 75; ya que, como hemos dicho, no le resultaba de utilidad de cara a conseguir la "ruptura" en España sino que más bien la perjudicaba, algunos elementos de la política lusa siguieron estando muy presentes en el argumentario del partido, sobre todo los concernientes al fin del Estado Novo y el fracaso de caetanismo, esgrimidos como ariete contra el pretendido reformismo gubernamental.

La muerte del general Franco en noviembre de 1975 y la fracasada experiencia del primer gobierno de la monarquía dirigido por Arias Navarro, no hicieron sino reforzar los ataques contra la opción reformista y el recién estrenado monarca. Para Carrillo, por más planes y declaraciones que hiciera el Gobierno no lograría convencer al país de su autenticidad democrática. "El ejecutivo se encuentra encerrado en el carcavón estrecho de las instituciones y leyes fundamentales de la dictadura, aunque intenten contar con otra fisonomía y se muestren más tolerantes con la oposición, llevan el sello inequívoco del reformismo." ${ }_{33}$

Ante este análisis de la situación, el PCE defendía que para conseguir auténticas libertades democráticas, había que cambiar la política imperante, había que establecer otro poder. Po eso, a la hora de contraponer su alternativa política, los comunistas insistían igualmente en el ejemplo portugués, no tanto en la praxis desarrollada tras el golpe como en la caída de la dictadura reformada. Esperar a que la democracia fuera una concesión del poder y no una conquista, era repetir el caso de los vecinos ibéricos: “Después de Salazar, Caetano. ¿Y luego?"34

La llegada de Suárez en el verano del 76 no presentó variación alguna en los planteamientos de identificación de la reforma con el fracaso caetanista. Sin embargo el partido se percató de que el antiguo Secretario General del Movimiento contaba con mayor determinación que su predecesor, ya que el nuevo Gobierno había pasado de hablar de "reforma" a hablar de transformación democrática, algo que se aproximaba más a los postulados rupturistas de la oposición. ${ }^{35}$

El último intento del PCE de tumbar a los herederos del franquismo, invalidar la reforma e imponer la ruptura a través de la presión social, tuvo lugar con la huelga del 12 de noviembre de 1976. Según Andrade Blanco, esa movilización fue la última y más parecida iniciativa de Huelga Nacional llevada a cabo hasta el momento. El partido destinó sus mayores esfuerzos a la preparación de dicha convocatoria, pero el Gobierno, consciente de semejante desafío, desplegó su intacto aparato represivo para restablecer el orden al día siguiente. En definitiva la huelga tuvo un respaldo social muy importante pero no logró imponer su objetivo último..$^{36}$ Paralelamente, la Ley para la Reforma Política había superado su trámite parlamentario, y se disponía a ser votada en referéndum el 15 de diciembre del mismo año. Un referéndum en el que el PCE defendió la abstención, opción que sólo cosechó un $30 \%$ de apoyo, aunque lógicamente, en opinión de Andrade Blanco, la convocatoria estuvo organizada desde el poder y sin garantías democráticas. Sin embargo, el camino de treinta años de estrategia opositora parecía que tocaba a su fin tras el éxito de la misma.

Desde ese momento, la dirección comunista llegó a la conclusión de que una ruptura por la vía del conflicto social directo era inviable, que la negociación era insalvable y que las movilizaciones ya no serían un instrumento de oposición para derribar al gobierno, sino una herra-

33 Santiago CARRILLO: "Sobre la sedicente impaciencia", Mundo Obrero, 20 de enero de 1976. 34 Ibid.

35 "De la clandestinidad a la legalidad". Informe presentado por el pleno del Comité Central del PCE. Roma, (del 28 al 31 de julio de 1976), Archivo Histórico del PCE. Carpeta 57. Subcarpeta Julio 1976.

36 Álvaro SOTO CARMONA: “Comisiones Obreras en la Transición y consolidación democrática. De Al Asa Comisiones Obreras (1958-1988), pp. 466 y 467 , s.l., s.n., s.a. 
mienta de presión en las transacciones que tendrian lugar con el Ejecutivo. ${ }^{37}$ Así las cosas, la transición por reforma había comenzado y el PCE participaría finalmente en la misma.

Otras influencias lusas: Organismos unitarios de oposición

En el periodo temporal descrito en los apartados anteriores; que discurre entre la caída de la dictadura portuguesa y el referéndum de la Ley para la Reforma Política, la influencia portuguesa no sólo afectó de lleno al debate entre ruptura y reforma del franquismo, o entre las anteriores opciones y el inmovilismo, sino que de forma transversal, la praxis política desarrollada en la incipiente democracia portuguesa empezó a servir de guía para las opciones partidarias que propugnaban un acceso similar a las libertades -o por el contrario a los que pretendían evitar ese modelo y asegurar un acceso distinto y ordenado a la democracia.

En el caso concreto que nos ocupa, la revolución portuguesa actuó -entre otros aspectoscomo dinamizador de la histórica búsqueda del PCE en pos de la unidad de la oposición, gracias al inmediato ejemplo de la Junta de Salvación Nacional -en donde participaban socialistas, comunistas y centristas portugueses

Algunos autores ya se han encargado de señalar la importancia de la influencia portuguesa en la consecución del primer gran intento de unidad de la oposición española (a nivel nacional) a través de la llamada Junta Democrática. Un intento finalmente frustrado pues no pudo agrupar a toda la oposición como se pretendió en un principio, pero el hecho de que el PCE pudiera sentarse en una misma plataforma con monárquicos juanistas, el PSP de Tierno Galván, otras personalidades independientes e incluso el Partido Carlista, tras tantas décadas de intentos por parte del comunismo español, nos indica que algo había cambiado en el contexto político del país.

La Junta Democrática, nacida el 29 de julio de 1974, surgió de una dura gestación en la que el PCE intentó denodadamente la adhesión del PSOE tras la fracasada experiencia unitaria de las Mesas Democráticas. Pero ante la imposibilidad de lograr dicho acuerdo por el veto anticomunista de los socialistas, desde mediados de 1973 Santiago Carrillo inició una serie de contactos con diversas personalidades que en un futuro pudieran presentarse como exponentes de la oposición moderada de cara a materializar el Pacto por la libertad del partido. Comenzaron entonces a entablar negociaciones con los monárquicos de Calvo Serer y García-Trevijano, configurando un plan para la creación de una instancia alternativa de poder para sustituir al franquismo. ${ }^{38}$

La primera reunión de la todavía embrionaria Junta Democrática se realizó el 22 de marzo de 1974, es decir, antes de que se desencadenara el proceso revolucionario luso, por lo que los primeros intentos de organización de la misma corresponden a las propias estrategias unitarias del PCE que venían de tiempo atrás. Sin embargo, la mayoría de autores consideran que la inmediata Revolución de los Claveles, junto al aumento de sensación de crisis del régimen, llevó a Santiago Carrillo a acelerar la maduración de la plataforma opositora, que no por casualidad acabaría adoptando el nombre de "Junta", al estilo de la Junta de Salvación Nacional portuguesa.

A la hora de diseñar este acuerdo entre diferentes, el Secretario General del partido apelaba directamente a seguir las mismas bases que la Junta portuguesa, "es decir, amnistía para unos y para otros, libertades para unos y para otros -los que acepten el juego democrático- libertad sindical, y que el pueblo decida la forma del régimen político". 39 No es de extrañar por tanto que gran parte de los doce puntos que proclamó la Junta Democrática en su presentación en París hubieran sido aplicados ya en Portugal por la Junta de Salvación Nacional.

La sustitución del Gobierno franquista por un Gobierno provisional decantaba a esta organi-

37 José Antonio ANDRADE BLANCO: El PCE y el PSOE en (la) transición..., p. 67.

38 Sergio GALVEZ y Gustavo SALMERON: "Historia de una colaboración . p. 56.

39 Rueda de prensa mantenida por Santiago Carrillo con los corresponsales españoles en París ( $16 \mathrm{de}$

mayo de 1974), Archivo Histórico del PCE, Dirigentes, Santiago Carrillo, Escritos, Sig. 6/1.1.2 zación opositora y a sus miembros, alejados de cualquier extremismo o radicalidad, hacia el rupturismo propugnado por el PCE. Ésa era la gran baza de la Junta Democrática. Este hecho llevó a la propaganda del régimen a ensañarse contra esta plataforma, a la que acusaba de favorecer a comunismo y la anarquía, algo que la Junta negó al declarar que lo que proponían no tenía nada que ver con el comunismo, sino con el "orden democrático". Y es que, para la Junta:

“...quien se pronuncie hoy por las reformas legales en contra de la conquista del poder político de la sociedad por las fuerzas activas de la democracia, no está eligiendo en realidad, una vía más tranquila, más segura y más lenta que conduzca al mismo fin, sino un fin diferente: la continuidad del mismo Estado reaccionario" $4^{\circ}$

Éste éxito inicial del PCE llevó al PSOE, y al resto de siglas y grupos de la oposición que todavía no se habían integrado en la Junta, a rechazar de primeras su adhesión para no favorece los intereses políticos del principal partido del antifranquismo. En ese contexto, durante la primera etapa del proceso revolucionario luso, el ejemplo de la Junta de Salvación Nacional sirvió para intentar convencer a estos grupos que sólo a través de la más amplia unidad se podía conseguir acabar con la dictadura. De ahí que el partido pretendiera ampliar su influencia hacia los más diversos sectores, tales como los democristianos, socialistas, liberales, Fuerzas Armadas, sectores de la derecha social o instituciones socio-políticas como los Colegios Profesionales. Careciendo de interés cualquier acercamiento hacia los grupos izquierdistas ya que con ello se temía la pérdida de contacto con los sectores moderados. Por lo tanto, resultaba de vital importancia la conquista de esos grupos "para competir, pública y abiertamente, con el intento continuista de Arias y Juan Carlos".41

El periodo de la transición portuguesa que dio comienzo tras el golpe del 28 de septiembre del 74 también afectó a esa búsqueda de unidad. Jiménez Redondo incide en que en el partido empezaron a ser más críticos con sus homólogos portugueses tras observar que lo realizado por los lusos afectaba enormemente, no sólo a la imagen moderada del mismo, sino también a la credibilidad democrática de su proyecto de unidad de oposición, debido a las malísimas relaciones que el PCP mantenía en aquel momento con el PS o el centro-derecha luso.

Quizás por este motivo el PCE se mostró incluso dispuesto a mediar entre el Partido Comunista de Portugal y el Partido Socialista -mediación que se dio durante la primavera de $1975-, 42$ quizás porque entendían que un acuerdo entre la izquierda lusa les beneficiaría indirectamente de cara a contrarrestar la feroz propaganda anticomunista en España, y sobre todo de cara a lograr igualmente la unidad con los socialistas españoles. Sin embargo, la iniciativa contó con escasos resultados pues la enemistad entre Cunhal y Soares se mantuvo en el tiempo.

En cambio, la tan ansiada unión de todas las fuerzas políticas democráticas españolas sólo se terminó por conseguir en la primavera de 1976, tras las numerosas contradicciones al respecto vividas por los grupos minoritarios de la oposición. Vencidos los temores relativos a la competencia con el principal partido de la clandestinidad y el miedo a que el aislamiento hacia el mismo les llevara paradójicamente a la irrelevancia, surgió Coordinación Democrática, ${ }^{43}$ eso sí, con una sensible rebaja de las aspiraciones previas de la Junta.

40 Manifiesto de la Reconciliación. Junta Democrática de España (1 de abril de 1975), Archivo Histórico del PCE, Carpeta 56.

41 Carta de Santiago Carrillo (7 de mayo de 1974), Archivo Histórico del PCE, Activistas España en general, Caja 93, Carp. 49/13.

42 Notas manuscritas de la entrevista de Santiago Carrillo con Mario Soares (Marzo de 1975), Archivo Histórico del PCE, Relaciones Internacionales, Caja 142, Carpeta 3.

43 Fruto de la unión de la Junta Democrática y de la Plataforma de Convergencia Democrática, Ilamada popularmente como Platajunta. 
Con la "Platajunta" desapareció la apuesta por un Gobierno de concentración, la alusión a la actividad de masas que debía dinamitar a la dictadura y al mismo tiempo se dejaba una puerta abierta a una posible negociación con el gobierno si éste demostraba su voluntad democratizadora. ${ }^{44}$ Por lo tanto, las posturas rupturistas del PCE quedaron tamizadas ante la búsqueda de la unidad, lo que demuestra la ausencia de maximalismos por parte del partido durante el periodo y la primacía que éste concedió a la consecución de dicho objetivo, a pesar de que este factor tampoco pudo favorecer finalmente el cambio deseado por los comunistas.

Si nos planteamos por qué la Junta Democrática fracasó, algunos de sus artífices, como García-Trevijano, han culpado del mismo al contexto revolucionario del "verano rojo" de 1975 ya que motivó que EEUU y otros países europeos apoyaran al PSOE ante el temor de que el PCE acabara repitiendo lo acaecido en Portugal, consiguiendo de esta manera que el primer gran intento unitario no se llegara a producir.45 Así las cosas, el espejo portugués no sólo estuvo presente en la génesis de la Junta, sino que también fue fundamental para entender su final.

44 José Antonio ANDRADE BLANCO: El PCE y el PSOE en (la) transición..., p. 64.

45 Antonio García-Trevijano, 06 de diciembre de 2012, entrevista realizada por Federico Utrera en el marco de los Diálogos de Somosaguas: España y Portugal cultura y política (y II). Libertad Constituyente TV, recuperado de internet (http://www.diariorc.com/2012/12/o6/dialogos-de-somosaguas-espana-y-portugal-cultura-y-politica-yii-lctv-06-dic-2012/). 
